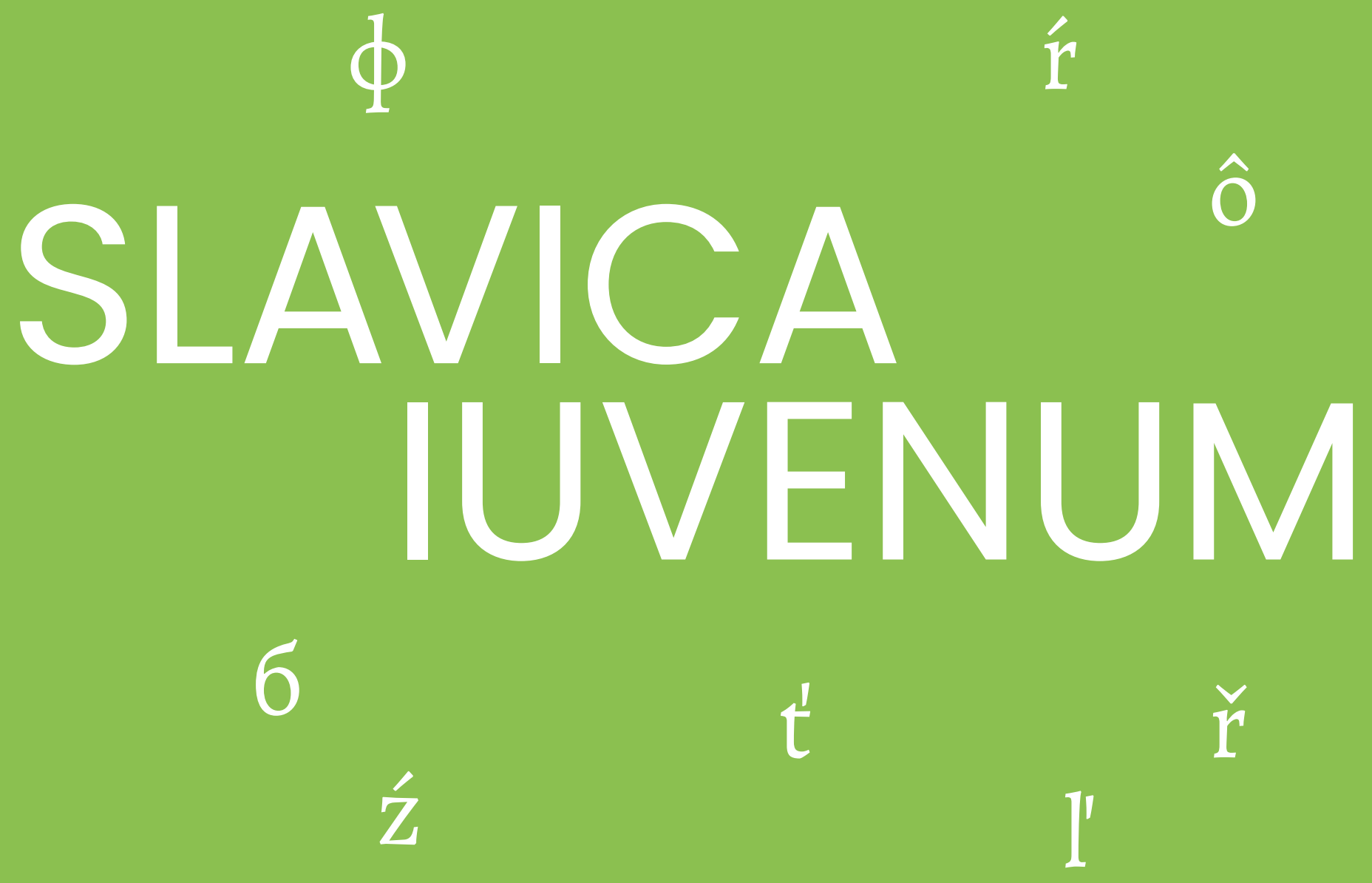

1

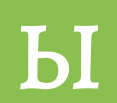

SBORNÍK PŘÍSPĚVKU゚

Z MEZINÁRODNÍ VĚDECKÉ KONFERENCE SLAVICA IUVENUM 2021

$\ddot{a}$ a

EDS

SIMONA MIZEROVÁ LUKÁŠ PLESNÍK

Ж
Л

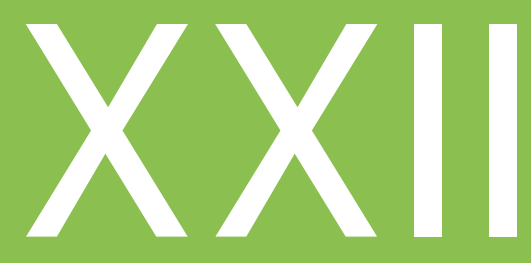

$d^{\prime}$ 
Ostravská univerzita

Filozofická fakulta
Universitas Ostraviensis

Facultas Philosophica

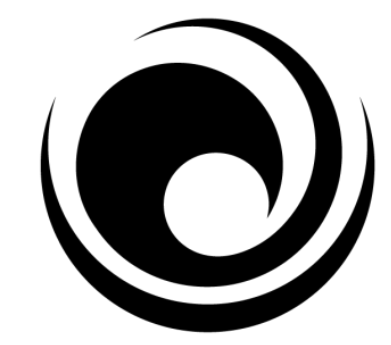

OSTRAVSKÁ

UN IVERZITA

SLAVICA IUVENUM XXII

\author{
Sborník př́íspěvků \\ z mezinárodní vědecké konference \\ Slavica iuvenum 2021
}

30. a 31. 3. 2021

Ostrava

2021 
Redakční rada:

PhDr. Simona Mizerová, Ph.D.

Mgr. Lukáš Plesník, Ph.D.

Recenzovali:

dr hab. prof. UŚ Dariusz Tkaczewski, Uniwersytet Śląsi w Katowicach doc. PhDr. Jan Vorel, Ph.D., Ostravská univerzita

KATALOGIZACE V KNIZE - NÁRODNÍ KNIHOVNA ČR

Slavica iuvenum (konference) (22. : 2021 : online)

Slavica iuvenum XXII : sborník příspěvků z mezinárodní vědecké konference Slavica iuvenum 2021 :

30. a 31.3.2021. -- Vydání: první. -- Ostrava : Ostravská univerzita, 2021. -- 1 online zdroj

Český, polský, ruský a slovenský text, česká, anglická a ruské resumé

Nad názvem: Ostravská univerzita, Filozofická fakulta. -- Obsahuje bibliografie a bibliografické odkazy

ISBN 978-80-7599-245-1 (online ; pdf)

$* 80(=16)+908(4) *(062.534)$

- slavistika

- sborníky konferencí

80 - Filologie [11]

(C) Simona Mizerová, Lukáš Plesník (eds.), 2021

(C) Ostravská univerzita, Filozofická fakulta, 2021

Cover (C) Helena Hankeová, 2021

(c) $\$($ Publikace je př́ístupná v režimu open access pod licencí CC BY-NC-ND BY NC ND Creative Commons Attribution-NonCommercial-NoDerivatives 4.0

\section{ISBN 978-80-7599-244-4 (print)}

ISBN 978-80-7599-245-1 (online) 
OBSAH / STRESZCZENIE / СОДЕРЖАНИЕ

ÚVOD / WSTĘP / ВВEДЕНИЕ

LINGVISTIKA / JĘZYKOZNAWSTWO / ЛИНГВИСТИКА

Наталья БАРИНОВА

ЭТНОЛИНГВИСТИЧЕСКИЙ ОБЗОР ЛЕКСЕМ РЯБИНА И КАЛИНА

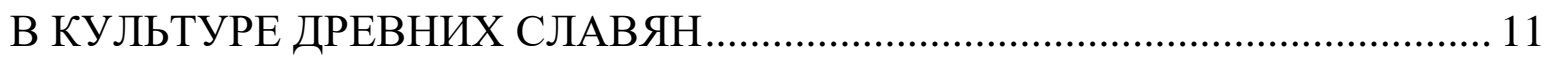

Ангелика БОГОЧОВА

ФУНКЦИОНИРОВАНИЕ МЕДИЦИНСКОГО СОЦИОЛЕКТА В ЧЕШСКОМ

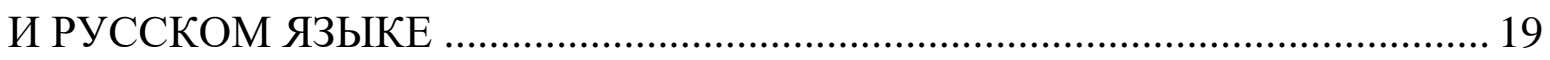

Piotr CZAJKOWSKI

WARSZTAT TŁUMACZA SĄDOWEGO W TRANSLACJI CHORWACKO-

POLSKICH TERMINÓW PRAWNYCH.

Jana DEMELOVÁ

TERMÍNY OZNAČUJÚCE SÚRODENCOV RODIČOV A ICH PARTNEROV

V ZÁPADOSLOVANSKÝCH A JUŽNOSLOVANSKÝCH JAZYKOCH. 37

Дарья ГАЛЬЦОВА

СИНОНИМИЧЕСКИЕ СООТВЕТСТВИЯ В ТЕМАТИЧЕСКОЙ ГРУППЕ «НАЗВАНИЯ ПИЩИ» (НА ПРИМЕРЕ ВОРОНЕЖСКИХ ГОВОРОВ)

Елена ИЩЕНКО

ОБЗОР СИМВОЛИЧЕСКОГО ЗНАЧЕНИЯ ЛЕКСЕМЫ КУКУШКА

В СИНХРОНИЧЕСКОМ И ДИАХРОНИЧЕСКОМ АСПЕКТЕ .53

\section{Ewa KOZIK}

DYSKURS POLSKICH MEDIÓW ALTERNATYWNYCH JAKO SPOSÓB TWORZENIA POSTPRAWDY

АнНа КОЗЛОВА, Софья КОЛГУШКИНА, Дарья ПЕТРОПАВЛОВА

ПОГОДНЫЕ ЯВЛЕНИЯ В ПРИРОДЕ В РУССКОЙ ЯЗЫКОВОЙ КАРТИНЕ МИРА 


\section{Dominika KUBIŠOVÁ}

JAZYKOVÝ OBRAZ ZEMETRASENIA V PRÍSPEVKOCH CHORVÁTSKYCH POLITIKOV NA FACEBOOKU

\section{Daria OGON}

GATUNKI CHARAKTERYSTYCZNE DLA JĘZYKA TURYSTYKI 93

Jana PIKULOVÁ

VYBRANÉ PROBLÉMY ČESKO-POLSKÉ TERMINOLOGIE SPORTU 99

\section{Моника СТЕНХЛАКОВА}

К ПРОБЛЕМАТИКЕ СЛОВОИЗМЕНИТЕЛЬНОЙ СИСТЕМЫ ИМЕНИ СУЩЕСТВИТЕЛЬНОГО В РУССКОМ, ПОЛЬСКОМ И СЛОВАЦКОМ ЯЗЫКАХ

\section{Dominika VINCEJOVÁ}

SLOVENSKÉ A POL'SKÉ LINGVISTICKÉ TERMÍNY MORFOLOGICKEJ ROVINY Z ASPEKTU VYBRANÝCH TYPOV LEXIKÁLNEJ MOTIVÁCIE . 119

Татьяна ВОЕВОДИНА, Александра РУСИНОВА

ФОРМИРОВАНИЕ ПРЕДСТАВЛЕНИЙ О НАРОДНОЙ ЭТИКЕ В ЯЗЫКОВОЙ КАРТИНЕ МИРА МЛАДШЕГО ШКОЛЬНИКА

\section{Aleksandra WOJNAROWSKA}

STATUS SŁOWOTWÓRCZYCH ELEMENTÓW KLASYCZNYCH W WYBRANYCH UJĘCIACH JĘZYKOZNAWCÓW SŁOWIAŃSKICH

\section{Александра ЗЕМБА}

ИСПОЛЬЗОВАНИЕ ПРОГРАММЫ ТRЕQ В ПОЛЬСКО-РУССКОМ ПЕРЕВОДЕ

\section{LITERÁRNÍ VĚDA / LITERATUROZNAWSTWO / ЛИТЕРАТУРОВЕДЕНИЕ}

\section{Anna BRZEZIŃSKA-WINKIEL, Anna GAŃKO}

MIASTOKSZTAETY - POEZJA KONKRETNA W PRZESTRZENI MIEJSKIEJ WROCŁAWIA NA PRZYKŁADZIE REALIZACJI UTWORÓW STANISŁAWA DRÓŻDŻA 


\section{Anna BRZEZIŃSKA-WINKIEL}

FILM OTESÁNEK JANA ŠVANKMAJERA JAKO INTERTEKST

\section{Kamila BYRTEK}

FIGURY MATKI I DZIECKA W POEZJI IRENY WYCZÓŁKOWSKIEJ

\section{Zuzana DUPALOVÁ}

ODKAZ MUSORGSKÉHO BORISE GODUNOVA V DRAMATU SMUTA

ARSENIJE A. GOLENIŠČEVA-KUTUZOVA

Gabriela EIBENOVÁ

HRANIČNÉ ŽIVOTNÉ SITUÁCIE A ICH STVÁRNENIE V PRÓZE PRE DETI A MLÁDEŽ.

\section{Jolanta GREŃ}

KOMUNIZM JAKO RELIGIA. ODZWIERCIEDLENIE MYŚLI MIKOŁAJA BIERDIAJEWA W UTWORZE SWIETŁANY ALEKSIJEWICZ „CZASY SECONDHAND. KONIEC CZERWONEGO CZLOWIEKA"

Gabriela HOMOLOVÁ

ŠPECIFIKÁ SERIÁLOVÝCH ADAPTÁCIÍ ROMÁNU ...

\section{L'udmila HORKÁ}

TELO A EMÓCIE V KRÁTKEJ PRÓZE MARGITY FIGULI 243

Алена ИВАНОВА, Анна ГОРОХОВЦЕВА, Татьяна ТИТОВА

ВОСПИТАТЕЛЬНЫЕ СЮЖЕТЫ В РУССКИХ И ЧЕШСКИХ БЫТОВЫХ

СКАЗКАХ

\section{Klaudia JEZNACH}

PIĘKNO SŁOWA. O PROBLEMACH ESTETYCZNYCH W TWÓRCZOŚCI

C. K. NORWIDA

\section{Agnieszka KUNDA}

„PISMO JEST JAK OBRAZ” - ZAPISKI MARII WIĘCKOWSKIEJ.

INTERPRETACJA WYBRANYCH FRAGMENTÓW Z ELEMENTAMI

GRAFOLOGICZNEJ ANALIZY PISMA

\section{Gabriela ONUŠKOVÁ}

STATUS HISTORICKÉHO ROMÁNU V DIELE ČARODEJNICA Z FLORENCIE OD SALMANA RUSHDIEHO 


\section{Barbora PETROVÁ}

CHARAKTER A POSTAVENIE KOMIKSU V LITERATÚRE A VO FILME.. 293 Mária STANKOVÁ

RECENZIA V 21. STOROČÍ 301

\section{TRANSLATOLOGIE / TRANSLATOLOGIA / ПЕРЕВОДОВЕДЕНИЕ}

\section{Dawid ADAMCZYK}

OBRAZ ROSJANINA W REPORTAŻU JACKA HUGO-BADERA „BIAŁA GORĄCZKA” I JEGO ROSYJSKIM PRZEKŁADZIE..

\section{Szymon BRYZEK}

ARANŻACJA PIOSENKI A JEJ WPŁYW TŁUMACZENIE I JEGO RECEPCJĘ (NA MATERIALE UTWORÓW WŁODZIMIERZA WYSOCKIEGO W PRZEKŁADACH MACIEJA MALEŃCZUKA).

\section{Lukasz GECBOREK}

O PRZEKŁADZIE OPISÓW ILUSTRACJI W CYKLU „BRUDERSZAFT ZE ŚMIERCIĄ" BORISA AKUNINA

\section{Каролина ЗЕЛИНЬСКА}

К ВОПРОСУ О ПЕРЕВОДЕ НАЗВАНИЙ КВЕСТОВ В КОМПЬЮТЕРНЫХ ИГРАХ (НА ПРИМЕРЕ ИГРЫ «DRAGON AGE: INQUISITION») 


\section{ÚVOD / WSTĘP / ВВEДЕНИЕ}

Sborník SLAVICA IUVENUM XXII je publikačním výstupem mezinárodní vědecké konference Slavica iuvenum 2021. Konferenci již tradičně organizuje katedra slavistiky Filozofické fakulty Ostravské univerzity. V pořadí 22. ročník se uskutečnil ve dnech 30. a 31. března $2021 \mathrm{v}$ on-line podobě. Konference se zúčastnili mladí slavisté s př́spěvky z oblasti lingvistiky, literární vědy a translatologie z univerzit v Polsku, Rusku, na Slovensku a v České republice.

Sborník tvoří 34 odborných článků, které jsou setříděny do tř́i tematických oddílů (lingvistika, literární věda, translatologie). Část lingvistická je tvořena 16 odbornými pracemi. Články tohoto bloku jsou věnovány problematice morfologicko-lexikální roviny jazyka (Ангелика Богочова; Piotr Czajkowski; Jana Demelová; Daria Ogon; Jana Pikulová; Моника Стенхлакова; Dominika Vincejová; Aleksandra Wojnarowska; Александра Земба), otázkám etnolingvistiky a etymologie (Наталья Баринова; Дарья Гальцова; Елена Ищенко), jazykového obrazu světa (Анна Козлова, Софья Колгушкина, Дарья Петропавлова; Dominika Kubišová; Татьяна Воеводина, Алексадра Русинова) а diskurzu (Ewa Kozik). Část literárněvědnou tvoří 14 odborných prací, které jsou zaměřeny na problematiku v oblasti prózy (Gabriela Eibenová; Jolanta Greń; L’udmila Horká; Алена Иванова, Анна Гороховцева, Татьяна Титова; Gabriela Onušková), poezie (Anna Brzezińska-Winkiel, Anna Gańko; Kamila Byrtek; Klaudia Jeznach) i dramatu (Zuzana Dupalová). Své zastoupení zde mají rovněž př́spěvky nacházející se tematicky na hranici literatury a filmového umění (Anna Brzezińska-Winkiel; Gabriela Homol’ová; Barbora Petrová) či dotýkající se problematiky ostatních literárních útvarů (Agnieszka Kunda; Mária Stanková). Část translatologická je zastoupena 4 odbornými pracemi. Autoři těchto článkủ (Dawid Adamczyk, Szymon Bryzek, Łukasz Gęborek, Каролина Зелиньска) analyzují vybrané otázky překladu děl beletristické literatury i textů v oblasti virtuálního prostoru.

Představený sborník nabízí prưřrez vybraných témat mladých lingvistů, literárních vědců a translatologů z široké oblasti komparativní slavistiky. Věříme, že jednotlivé publikační výstupy čtenáře zaujmou a stanou se tak inspirací pro konferenční jednání $\mathrm{v}$ roce 2022.

Editoři sborníku 

LINGVISTIKA

/ JEZZYKOZNAWSTWO

/ ЛИНГВИСТИКА 



\title{
ЭТНОЛИНГВИСТИЧЕСКИЙ ОБЗОР ЛЕКСЕМ РЯБИНА И КАЛИНА В КУЛЬТУРЕ ДРЕВНИХ СЛАВЯН
}

\author{
Ethnolinguistic Review of Lexem Sorbus and Viburnum \\ in the Culture of Ancient Slavs
}

Keywords: concept, ethnolinguistic, symbol, sorbus, viburnum, slavs

Contact: МГОУ; lolkuro@mail.ru

Развитие языка в обществе невозможно представить без развития культуры ведь: «язык как зеркало народной культуры, народной психологии и философии, во многих случаях как единственный источник истории народа и его духа давно воспринимался таковым и использовался культурологами, мифологами в их разысканиях» (Толстой, Толстая 2013: 7). Эту пару стоит рассматривать не только как совокупность. По мнению Н.И. Толстого, одним из вариантов отношений данных явлений может быть и частное (язык) - общее (культура) (Толстой, Толстая 2013: 7). Но в тоже время язык достаточно автономен и может рассматриваться учеными-лингвистами сам по себе. Из того можно сделать вывод, что подходы к данной проблеме различаются, одного решения по вопросу общности элементов, на данный момент не существует.

Последующий анализ будет представлен в избирательной репрезентации этнолингвистическом повествования о двух лексемах, относящихся к категории живой природы: куста калины и дерева рябины. Они вызывают наибольший интерес, поскольку данные растения, так или иначе часто встречаются в обрядах, традициях и верованиях славянских народов. Полноценных исследовательских работ, обобщающих информацию по данной теме не было обнаружено, что дает право признать необходимость их изучения. Предметом исследования являются словесно-действенные тексты с участием калины и рябины, которые в работе были описаны с помощью сравнительно-аналитического метода.

Исследованию славянского культурного наследия, среди которого есть и рассматриваемые объекты, было посвящено большое количество трудов. Были рассмотрены некоторые из них. В трудах русского писателя, этнографа 
и лексикографа, собирателя фольклора В.И. Даля дается определение более 200 000 слов (Даль 2004: 5), среди которых есть и рябина, и калина. Приведу пример: рябина дается через определение прилагательного 'рябый': 'южн. рябой сев. пестрый, крапчатый, чубарый, пятнастый’. Здесь стоит отметить единое этимологическое гнездо с рябчиком: 'небольшой лесной курочкой, покрытой пятнами'. Калина имеет следующее обозначение: 'ж. в припевке калинка, калиночка, калинушка, дерево и плод Viburnum opulus...'. Так же словарь предлагает обратиться к глаголу 'калить': 'каливать что, раскалять, накалять, разжигать, сильно нагревать твердое тело в огне’.

В 1862 году В. Даль опубликовал «Пословицы русского народа. Сборник пословиц, поговорок, речений, присловий, чистоговорок, загадок, поверий и проч.». Сборник содержит около 32000 фраз, представляющих малые жанры фольклора. Это один из важнейших источников по бытовой стороне жизни и философии русского народа, что для моей этнолингвистической работы особенно интересно. Стоит отметить, что труд построен весьма необычным способом: он был разбит на главы, в которых пословицы и поговорки были собраны по общей тематике (бог - вера, богатство - достаток и т.д.). Рябина обнаруживается в категориях земледелие, месяцеслов, растение; калина земледелие, пища, припевы и человек.

Следующий автор - это Л.А. Тульцева, советский и российский этнограф, (Тульцева 1985: 20) кандидат исторических наук и одна из авторов «Атеистического словаря». Ее труд «Рябина в народных поверьях» актуален при этнолингвистических исследованиях в качестве пособия для учеников и студентов. К сожалению, калину Людмила Александровна не рассматривала, но рябина предоставлена полно и развернуто.

Этнолингвистический анализ невозможно представить без понятий верования, религия и обряды. Одним из выдающихся этнолингвистических трудов можно считать «Восточнославянский этнографический сборник» под редакцией С.А. Токарева (Токарев (ред.) 1956: 42), где были рассмотрены культура восточных славян и фундаментальное исследование А.Н. Афанасьева по славянской мифологии «Поэтические воззрения славян на природу», где были отражены различные явления природы

Для перечисленных исследователей общим является заинтересованность тематикой культуры древних славян, что было обусловлено бережным отношением к своему прошлому и предкам: славянская народная культура оставила огромное наследство, большая часть которого не была изучена. 
Этимология названий калина и рябина. Рябина (лат. Sorbus) является родом древесных растений, а растение рябина обыкновенная, или красная (лат. Sorbus aucuparia) - плодовое дерево, вид рода Рябина, широко распространенный почти по всей Европе, в Передней Азии и на Кавказе. Родовое название sorbus происходит из кельтского языка, переводится, как 'терпкий, горький' и характеризует вкус плодов рябины. Видовое название происходит от латинских слов, в переводе означающих 'птица' и 'ловить': плоды рябины привлекали птиц и использовались для их приманки. С давних пор рябина являлась частью культуры славян, скандинавов и кельтов, которые наделяли ее магической силой: считалось, что она покровительствовала воинам в боях, защищала от мира мертвых и от колдовства. Ягода рябины с нижней стороны выглядит как равносторонняя пятиконечная звезда - один из древнейших языческих символов защиты (Даль 2004: 125). Калина - древесное цветковое растение, представляющее семейство Адоксовые. Латинское название рода - Viburnum согласно одной из версий связывают с глаголом 'viere', обозначающим 'вязать', 'плести'. Таким образом, происхождение слова обусловлено одним из непосредственных использований калины: из молодых ветвей кустарника вязали корзины (Даль 2004: 91). Однако название 'калина' было дано славянами из-за схожести цвета ягод с раскаленным добела железом.

Калина (Viburnum opulus) - это «растение, наделяемое в народной культуре символикой девственности; из-за ярко-красных ягод ассоциируется с кровью; в некоторых традициях считается несчастливым деревом, в других, наоборот, относится к святым» ${ }^{1}$. Интересно сравнение цвета ягод калины с кровью, чего не наблюдается в описании ягод рябины, которые, как по мне, более насыщенного красного цвета. Рябина (Sorbus aucuparia) - это «дерево, используемое в лечебной и апотропеической магии, а также фигурирующее в ряде легенд и этимологических преданий (...). Для символики и мифологии рябины существенны еe связь с женским началом, апотропеическая функция, мотивируемая красным цветом ягод и горьким вкусом $(\ldots)^{2}$. Стоит отметить связь обоих рассматриваемых объектов с женским полом и медициной, но более подробно рассмотрим это чуть позже.

Для определения происхождения названий куста калины и дерева рябины обратимся к этнолингвистическому словарю «Славянские древности». Этот словарь представляет собой по сути российскую фундаментальную научную

\footnotetext{
${ }^{1}$ Режим доступа: https://floristics.info/ru/stati/sad/2667-kalina-posadka-i-ukhod-obrezka-i-razmnozhenie.html (2021-03-25).

2 Режим доступа: https://floristics.info/ru/stati/sad/3900-ryabina-posadka-i-ukhod-vidy-i-sorta.html (2021-0325).
} 
энциклопедию по тематике славистики, культуры и славянской мифологии. Словарь подводит итог более чем полуторавековому изучению славянских языков, фольклора, мифологии, этнографии, народного искусства, традиций. Именно он послужил главным источником обзора калины (Толстой (ред.) 1995: 437) и обзора рябины (Толстой (ред.) 1995: 821). В словаре информация размещается по рубрикам. Перечислим некоторые из них.

Внешние общие и различные признаки. Очень часто незнающий и невнимательный человек может спутать калину и рябину, если увидит их рядом. И это имеет объяснение: несмотря на видовое различие, представители флоры имеют достаточное много общего. Для славян, восприятие признаков выраженно в следующих знаках качественного характера: небольшие ягоды, гроздью свисающие с ветки, несладкий вкус плодов, яркий цвет, привлекающий птиц. Каждый человек, а следовательно, и народ, воспринимал окружающий мир и его признаки по-своему, в зависимости от его подхода к понимаю мира.

Легенды и обряды. Рябина и калина достаточно широко представлены в славянском фольклоре и участие их в различных обрядах, праздниках и преданиях обнаруживается практически у всех славянских народов. В работе выделены своеобразные группы, где фигурируют и калина, и рябина, и проведен их сравнительный анализ, потому что каждый из элементов несет на себе определенную коннотацию, закрепившуюся за ним испокон веков.

Первая группа - это легенды и предания, связанные с женским началом.

Как уже говорилось ранее, и калина, и рябина неразрывно связаны с женским началом, но из-за кардинально разных трактовок и культурных смыслов, представители флоры имели различные характеристики.

Рябина представлена как отрицательный и негативный славянский образ. Именно на ее стволе был распят Христос (по верованию сербов), а у белорусов красный цвет ягод рябины связан с эпизодом грехопадения, когда Бог изгнал Еву из Рая и из ее глаз стали капать кровавые слезы, из которых позже выросла рябина (Толстой (ред.) 1995: 822). Также существует и другая группа этимологических преданий, которая связывает происхождение рябины с женщиной, благодаря грамматическому роду названий рябины. Но даже в этом случае, рябина - это страдающая девушка, которую прокляли (возможно, с этим связано одно из поверий, что рябина у дома к несчастливой женской судьбе, о чем говорят баллады восточных славян). Однако дерево может рассматриваться и в сочетании с прилагательными 'тонкая, кучерявая, кудрявая', что часто ассоциируется с молодостью и красотой. 
Калина же у большинства славянских народов была именно положительным кустарником. В большей степени ее связывали с невестой или юной девушкой. В родинной обрядности украинцев она - символ красоты, чистоты, продолжения рода (Калина роду род давала).

Вторая группа - связь со свадебными (и не только) обрядами.

Практически половину статьи (Толстой (ред.) 1995: 438) занимает текст о связи кустарника со свадьбой и невестой. В свадебном обряде калина является главным украшением венка, деревца, каравая и других атрибутов свадьбы. На Украине ее ветку вывешивали на доме как знак, что в этом доме девушку выдают замуж. Так же, калиной называлась красная лента, 'красота' невесты (Волынь), девушка, невеста. В Воронежской губернии на третий день свадьбы совершался обряд распивать калинку: все присутствующие поочередно подходили к молодым и клали в рюмку с водкой несколько ягод, выпивали водку и съедали калиновые ягоды. В Краснодарском крае после брачной ночи, если невеста была 'честной', совершался обряд ходить с калиной: обходили станицу с веткой, наряженной лентами, куклами, монетами. Брачная символика кустарника отражена в обрядовой поэзии украинцев, поляков, белорусов.

Но также стоит отметить участие калины в похоронных и календарных обрядах. Ее сажали на могиле в головах или в ногах покойника. При похоронах девушки делали свадебное деревце из сосны, украшенное цветами и калиной, и бросали его в могилу. Из-за красных ягод, напоминающих капли крови, у украинцев стала символом пролитой казацкой крови. В их песнях казак, умерший (погибший) на чужбине, просит, чтобы птицы, прилетая, ели калиноньку и приносили вести с Украины.

В обряде «полазник» животное, которое на Новый год вводили в дом, украшали калиной, барвинком, лентами, колосьями 'на счастье' (гуцулы). В день Крещения женщины и девушки на реке освящали по три свечи, связанные с пучками веток калины и засушенными цветами (Правобережная Украина и Карпаты), умывались водой, в которую клали ягоды, чтобы лицо было румяное (укр. Тернополь).

Связь рябины со свадебным обрядом выражается только в том, что по преданиям некоторых славянских групп рябиной была проклятая мамой жениха невеста. Однако дерево участвовало в других обрядовых мероприятиях, а именно в русской лечебной магии, выступало как мифологический ритуальный центр в восточнославянских заговорах, например, «Есть святое море окиян, на море окияне есть белои камень, на белом камени есть две рябины, две кудрявые, есть 
межу двемя рябинами кудрявыми золота колыбель (...)» (Толстой (ред.) 1995: 831).

Третья группа - связь с медициной.

В народной медицине использовали ягоды, листья, кору, корень калины как общеукрепляющее средство, при простудных заболеваниях, для лечения кашля, сердечных болей, как профилактическое средство от раковых заболеваний, даже при зубной боли обращались к калине. В заговорах на калиновом мосту (переход через болото, межу, границу на место встречи человека и потусторонней магической силы) три сестры (девица) останавливают кровь и выгоняют сглаз.

У восточных славян рябина тоже связана с излечением зубной боли. Для того, чтобы выздороветь, человеку нужно подойти к дереву и попросить у него, стоя на коленях, излечения. При этом человек давал клятву, что не будет рубить, ломать или обирать дерево. Так же, как говорилось выше, рябина была неразрывно связана с лечебной магией, и это проявлялась во множестве заговоров.

Заключение. Проведенный этнолингвистический обзор показывает, что схожие по определенным признакам рябина и калина в культуре славян имели различные коннотации, но общим для них является связь с легендами и преданиями, с тематикой о женском начале, связь со свадебными (и не только) обрядами, связь с медициной, основанные на символике ягод и цветов. На основании приведенных примеров можно сделать вывод о том, что выбранные представители флоры имели широкий спектр применения в различных культурных областях, а также сыграли важную роль в антропоморфизации растений при формировании этих концептов русского языка.

\section{Summary}

The review allows us to state the importance of the studied plants in Slavic cultures and languages, the variability of rituals and the stability of lexemes. The wide geographic prevalence of the image makes it possible to conduct research on the basis of not only folklore, but also modern linguistic material. Common to all textual and ritual examples is the connection with the berries of these plants, the predominance of the berry sign in the concept in different periods among the Slavs, the preservation of the mythological meaning of the image today in amulets and healing and cuisine. 


\section{Резюме}

Проведений огляд дозволяє заявити про значимість досліджуваних рослин в слов'янських культурах і мовах, варіативності обрядів і стійкості лексем. Широка географічна поширеність образу дозволяє проводити дослідження на основі не тільки фольклорного, а й сучасного мовного матеріалу. Загальна для всіх текстових і обрядових прикладів є зв'язок з ягодами цих рослин, переважання знаку ягоди в концепті в різні періоди у слов'ян, збереження міфологічного значення образу сьогодні в оберегах і лечітельстві і кухні.

\section{Литература}

Афанасьев, А.Н. Поэтические воззрения славян на природу. Москва: Индрик, 1994.

Даль, В.И. Пословищь русского народа: сборник В.И. Даля. Москва: Русский язык. Медиа, 2009.

Даль, В.И. Толковый словарь живого великорусского языка. Москва: Олма-Пресс, 2004.

Токарев, С.А. (отв. ред.) Восточнославянский этнографический сборник: Очерки народной материальной культуры русских, украинцев и белорусов в XIXначале XX в. Москва: Издательство АН СССР, 1956.

Толстой, Н.И. (ред.) Славянские древности: этнолингвистический словарь в 5ти томах. Москва: Институт славяноведения РАН, 1995.

Толстой, Н.И., Толстая, С.М. Славянская этнолингвистика: вопросы теории. Москва: Институт славяноведения РАН, 2013.

Тульцева, Л.А. Рябина в народных поверьях. In: Новиков, М.П. (общ. ред.) Атеистический словарь. Москва: Политиздат, 1985.

Калина. Режим доступа: https://floristics.info/ru/stati/sad/2667-kalina-posadka-iukhod-obrezka-i-razmnozhenie.html (2021-03-25).

Рябина. Режим доступа: https://floristics.info/ru/stati/sad/3900-ryabina-posadka-iukhod-vidy-i-sorta.html (2021-03-25). 



\section{ФУНКЦИОНИРОВАНИЕ МЕДИЦИНСКОГО СОЦИОЛЕКТА В ЧЕШСКОМ И РУССКОМ ЯЗЫКЕ}

\section{Functioning of Medical Sociolect in Czech and Russian Language}

Keywords: sociolect, Medical, terms, develop, language, the science, words

Contact: Ostravská univerzita; angelikabogoczova@gmail.com

...социолект включает

в себя систему речевых средств определенной группы, детерминированную рядом факторов, имеющих не только социальный, но и биологический, и психологический характер (Ерофеева 2002: 118).

В данной статье представлены результаты исследования неофициального, «тайного» языка медработников. Исследуя медицинскую лексику, невозможно не обратить внимание на особенности функционирования ее неэтичного слоя, затрагивающего профессиональную речь специалистов в области медицины. Предметом моего исследования в общем, является медицинская терминология, которая, как я упомянула выше, имеет кодифицированные эквиваленты и их невозможно проигнорировать.

Целью исследования является рассмотрение доступного лишь для узкого круга специалистов языка. Какие причины лежат в основе возникновения социолекта в области медицины и какая роль данного словарного состава? Почему тенденция заменять культурное речевое поведение просторечием столь актуальна среди молодых профессионалов? Толчком к данному феномену является не только экономия времени и слов, но и другие социальнопсихологические составляющие, на которые обратим внимание дальше.

Стоит заметить, что пока существует очень маленький объем научной литературы в области медицинского социолекта, и данный феномен нуждается в описании, систематизации и унификации. Наше мелкое погружение 
в проблематику социолекта может вызвать у лингвистов интерес и побудить к более тщательным исследованиям.

И так, научная терминология является необходимым атрибутом языка медицинского персонала, однако имеется параллельная лексика, скрытая от посторонних. Она не существует ни в одном словаре и учебнике на свете. Принято считать, что такую отрасль как медицина должна обслуживать лишь терминология, которая обеспечит точный и неискаженный перенос информации. Практически весь речевой арсенал медицинского работника составляют термины, значение которых ограничено в строгие научные рамки. Термины не примут экспрессивных или неоднозначных оттенков, термины строги, точны и профессиональны. В особенности идет ли речь именно о медицинской терминологии, которая как никакая другая нуждается в однозначности высказываний.

Как отмечает М.Н. Чернявский, медицинская терминология - это «система систем». Она состоит из множества отдельных терминологических подсистем медицинских, медико-биологических и некоторых других наук и областей знания, связанных с медициной (Чернявский 1989: 15).

Данная терминологическая система охватывает широкий пласт языка медицины, сюда можно отнести: наименование заболеваний, наименование возбудителей заболеваний, анатомические особенности, методы лечения, также фармацевтические термины и в не последнюю очередь весь объем терминов недавно возникших на базе новых научных достижений: наномедицина, космическая медищина и т.д.

О.Д. Митрофанова указывает, что ученые лингвисты разработали следующие пласты медицинской лексики, на основании которых возникает нелитературная медицинская речь. К ним относятся: общеупотребительная лексика, общеспециальная лексика, общемедицинская терминология, детерминологизированные термины и терминология частных отраслей (Митрофанова 1985: 198).

Медицинский текст, как любой другой научный текст, содержит общеупотребительную лексику. Именно вышеупомянутая лексика мотивирует трансформацию в социолект. Данный языковой состав применяется в основном в общении медперсонала и пациента. К примеру: анализ крови, насморк, кишечная палочка, пищевое отравление, инфекция, размножаться и т.д. (Митрофанова 1985: 198). 
Итак, несмотря на то что непрофессионалы считают нормой этичное и отчужденное построение речи специалиста в области медицины, существует менее социально пригодный слой лексики, который может использовать медицинский персонал. Вышеупомянутые категории имеют параллельные закодированные наименования, так как зачастую врачи прибегают к разговорной, даже ненормативной лексике. К данной разновидности медицинской устной речи, как упоминалось выше относится «медицинский социолект»- медицинский профессиональный жаргон, сленг, медицинское просторечие и арго. Как ученые относятся к вышеупомянутым слоям социолекта? Общая оценка скорее негативная, но категории нелитературных пластов языка вызывают интерес и необходимость в их исследованиях.

Т.И. Ерофеева объясняет, что термин социолект понимается в условнорасширительном значении. Строго говоря, феномен речевая общность того или иного коллектива следует обозначить как биосоцио-психолект, но для краткости лучше обратиться к термину социолект. В понятие социолект включается понятие социального типа, который проявляется у человека под влиянием черт, свойственных данной расе, этнической группе, национальности, социальному классу. С этой стороны, социолект - это речь «среднего индивида», представляющего свою социальную группу, культуру; иными словами, социолект - инвариантная социально-маркированная подсистема языка (Ерофеева 2010: 21).

Социальный диалект или социолект состоит из жаргона, сленга и арго. Все три части социолекта играют роль ключа, который закрывает, тем изолирует профессиональные, социальные, возрастные и др. группы людей и обобщает в независимый от посторонних круг пользователей.

Е.В. Дворак описывает данное взаимодействие и отличия всех трех слоев социолекта следующим образом, жаргон обычно имеет профессиональную принадлежность, арго же может употребляться вне зависимости от профессии. Часто под арго понимается язык деклассированных групп общества - язык воров, бродяг и нищих. Арго не выделяется в самостоятельную языковую систему и сводится лишь к специфическому употреблению языковых единиц в пределах существующего языка. Арго взаимодействует с жаргоном и просторечием, образуя специальный лексический пласт - сленг (Дворак 2018: 21).

В зависимости от природы, назначения, языковых признаков и условий функционирования В.Д. Бондалетов в свою очередь предлагает следующие виды социолектов: «собственно профессиональные «языки» (лексические системы), например, рыболовов, охотников, гончаров, сапожников, а также представителей 
других промыслов и занятий; групповые, или корпоративные жаргоны, например, учащихся, студентов, спортсменов и других, главным образом молодежных коллективов; условные языки (арго) ремесленников и торговцев, и близких к ним социальных групп; жаргон (арго) деклассированных, которые представляют собой лексические системы, вызванные к жизни разными социальными причинами (Бондалетов 1987: 68). Согласно данной схеме, медицинский социолект относится к первой группе, которая объединяет собственно профессиональные «языки».

В своей статье, посвященной профессиональному социолекту, Е.В. Дворак считает, что вышеупомянутый лексический слой представляет собой особый язык конкретной социальной группы, развившийся на основе национального языка, имеющий в своем составе единицы, обусловленные рядом территориальных, социальных (в том числе профессиональных) факторов. Сосуществуя и пересекаясь с литературными нормами родного языка, каждый из профессиональных социолектов сохраняет свою специфику, оставаясь обособленной, достаточно закрытой языковой системой, предназначенной для социальной идентификации ее представителей в узкоспециальном социуме.

Т.П. Соломенникова в своей работе, посвященной медицинскому социолекту, объясняет, что медицинский социолект - иерархически структурированная микросистема лексического просторечия, составляющая определенную часть языкового репертуара медицинского социума, элементы которого - слова и устойчивые словосочетания - характеризуются сниженной коннотацией и относительно эзотерической функцией и понятийнофункциональной закрепленностью за профессионально-корпоративной областью медицинского дела конкретного общества и соответствующей медицинской сферой функционирования национального языка (Соломенникова 2011: 76).

Медицинский социолект можно рассматривать как «профессиональный язык», что мы уже и упоминали выше, где термины заменяются неспецифическими речевыми системами. Данные образования абстрагированы от привычных норм лексического поведения языка. Тенденция расширения социолекта заключается в культурной картине времени. Свобода мышления мотивирует менее стандартное речевое поведение. Социолект является куда большей модой, чем использование литературного языка во всех сферах жизнедеятельности. 
В.П. Коровушкин дает следующую дефиницию, и объясняет, что профессиональный социолект исторически сложившаяся, относительно устойчивая для данного периода автономная экзистенциальная форма национального языка, представляющая собой совокупность некоторых фонетических, грамматических психологических и, преимущественно, специфических лексических средств общенародного языка, обслуживающих речевое общение определенного социума, характеризующегося единством профессионально-корпоративной деятельности своих индивидов и соответствующей системой социальных понятий (Коровушки 2005: 15).

Главный вопрос все же заключается в том, зачем же при наличии огромного объема терминов специалисты-медики используют столь отдаленный от эталона и речевой культуры лексический пласт?

Ответ на этот вопрос предлагают в своей статье сотрудники Тверской государственной медицинской академии Минздрава России М.И. Волович, В.М. Мирзоева, Н.В. Рюмшина, рассматривая данную проблематику не как негативное явление, а именно как аспект речи, который имеет место быть и является мало изученным. В статье Л.Ф. Ельцовой упоминается, что медицинский социолект относится к лишь устной коммуникации медперсонала и не все специалисты данный слой лексики активно употребляют. Напротив, данное явление вызывает негодование и неприятие у многих врачей, которые чуть-ли не отказываются от существования таких слов и словосочетаний. Если специалист в области медицины использует социолект или нет это связано с личностными особенностями каждого врача и медперсонала. Принято считать, что социолект снижает культуру речи и особенно данный феномен заметен и неприятен в научных отраслях.

Назовем несколько причин, по которым речевое поведение медиков прибегает к ее менее этической форме. Как в русской, так и в чешской неконсервативной речи медиков имеется схожая мотивация. М.И. Волович, В.М. Мирзоева, Н.В. Рюмшина выделяют около трех наиболее заметных тенденций, которые также описывает А. Долежал касательно чешской медицинского социолекта:

Во-первых, причиной возникновения нелитературных выражений является речевая экономия, в частности речь идет о сокращении и упрощении сложных терминологических и труднопроизносимых словосочетаний. Сокращения не имеют четких правил и структур, чаще всего к созданию таких слов приводят ассоциации, богатое воображение, схожесть предметов и явлений и т.д. 
Рассмотрим несколько примеров, которые приводят в данной категории для русского языка авторы М.И. Волович, В.М. Мирзоева, Н.В. Рюмшина (2013). Для чешского языка берем примеры А. Долежала (2007): детство - 'детское отделение (в речи медперсонала больниц для взрослых)'; непроход 'непроходимость кишечника (в речи хирурга)'; патан - 'патологическая анатомия (в речи студентов и преподавателей медицинского вуза)'; biolka 'биология (в речи студентов и преподавателей медицинского вуза)'; depka 'депрессия'; kapačka - 'инфузионная терапия'.

Во-вторых, терминология из области, которая связана с самым важным аспектом жизни человека, с его здоровьем может звучать пугающе, неприятно или жестоко. Возникает необходимость слова немного смягчать, считают ученые М.И. Волович, В.М. Мирзоева, Н.В. Рюмшина, поэтому возникает особенный социолект, образованный от научных терминов при помощи суффиксов эмоциональной оценки, уменьшительно-ласкательных. Рассмотрим несколько примеров, которые приводят ко второй категории для русского языка авторы М.И. Волович, В.М. Мирзоева, Н.В. Рюмшина. Для чешского языка рассмотрим примеры А. Долежала. Вышеупомянутая группа ученых упоминает также несколько разновидностей мотиваций:

- в отношении диагноза (такие термины выступают в функции средства смягчения стресса от страшного заболевания): aденомка, adenomek 'аденома, adenom (доброкачественная опухоль)'; миомка, myomek 'миома, myom (доброкачественное образование, которое развивается в мышечном слое матки)' и др.;

- уменьшительно-ласкательные суффиксы прибавляются к сокращенным элементам терминологических сочетаний ассоциативного характера: шарик - 'шаровидный бор'; алмазик - 'алмазный бор (в речи стоматологов)'; москитик - 'зажим типа «москит» (в речи хирургов)';

- в чешском языке появляется тенденция, когда часть слова, имеющего греко-латинское основание -logie сокращается на -olka:fyziologie -fyziolka; biologie - biolka;

- иногда также на -ačka: farmakologie - farmačka;

- исходя из наших данных использование уменьшительно-ласкательных форм эпонимических терминов не являются весьма плодородными в медицинском социолекте: алиска - 'зажим Алиса'; бульротик - 'зажим Бульрота (в речи хирургов)'; 
- в чешском языке также как и в русском, количество медицинской не культурной лексики, которая берет свое начало именно в эпонимических конструкциях также не велико: oidipák (oidipáček) - 'человек с Эдиповым комплексом (психология, психиатрия)'.

В-третьих, коммуникация врачей хирургов, онкологов и патологоанатомов, и других специалистов, имеющих дело со смертью, может нести следы черного юмора: аппендюк - 'острый приступ аппендицита'; твикс - 'удаление яичек'. За основу номинации положена парность органа, по аналогии с известной шоколадкой (Твикс - сладкая парочка); t’uhýk - 'покойник'; záškrt 'повешенный'. Последний пример ссылается на название заболевания, которое проявляется опуханием дыхательных путей.

И в последнюю очередь, к сожалению, профессия врачей и медперсонала связана с болью, страданиями, абсцессами, пролежнями и всевозможными выделениями. Использование социолекта здесь можно объяснить попыткой снять напряжение и стресс, но и в этом случае невозможно забывать о вопросах этики, ведь не все выражения безобидны. Рассмотрим примеры авторов М.И. Волович, В.М. Мирзоевой, Н.В. Рюмшиной (2013), Т.П. Соломенниковой (2011) и А. Долежала (2007): колбаса - 'повторные ампутации нижних конечностей по поводу их критической ишемии'; тубик - 'туберкулез или больной туберкулезом'; загрузиться - 'впасть в кому'; размочить (кого-то) - 'дать мочегонные лекарственные препараты (диуретики)'; чехол - 'летальный исход'; консервы - 'больные, находящиеся в отделении (как правило хирургическом) на консервативном лечении'; зачехлить, похоронить - 'участвовать в ведении скончавшегося больного'; отnyстиmь - 'не препятствовать активно смерти терминального безнадежного больного'; скоблежка - 'абразия (выскабливание) матки'; рецидивист - 'больной с рецидивом (повторением) болезни'; Robert 'мертвый детский плод'; Čínské ghetto - 'большое количество детей с новорожденной желтухой'; encka - 'encefalitida (воспаление мозга)'; frigida 'frigidita (отсутствие или потеря полового влечения)'; gramofon - 'сидение с унитазом для кала'; hadrák - 'ослабленная мускулатура'; halter 'фиксирующий временный шов (от нем. halten - держать)'; krvák - 'клинический анализ крови'; Líza a Róza - '(paralýza) паралич и (skleróza) склероз’; ос̆i jako tenisáky - ‘смещение глазного яблока вперед (выпученные глаза)'.

Т.П. Соломенникова замечает, что «к особенностям медицинского социолекта относятся также активное использование ласкательной и уменьшительной лексики с целью подбодрить и успокоить пациента и употребление личных местоимений и глаголов в форме первого лица 
множественного числа как указание на сотрудничество, взаимодействие врача и больного. Например, типичны в обращении к больному формулы: «откроем ротик, сейчас мы осмотрим зубик, сестричка сделает нам укольчик, жсивотик у нас хорочий, мягкий, давайте послуиаем сердечко» и т.П. (Соломенникова 2011: 77).

Благодаря тому, что медицинская терминология основана на греколатинских наименованиях, а теперь в ее состав входят также англицизмы, возникает на их основе социолект, который А. Долежал в своей публикации называет «гибридными словами». К данному слою можно отнести слова, содержащие компоненты не только из одного, ни и из нескольких иностранных языков: гиперденсные зоны - 'зоны повышенной плотности, в случае опухоли в головном мозге, ткань самой опухоли плотнее, чем окружающая'; нейровидение - 'от англ. neurovision, техника, которая позволяет картировать мозг' (Соломенникова 2011: 77); biochemka - 'biochemie (наука о химическом составе живых организмов)'; cytolka - 'cytologie (раздел биологии, изучающий живые клетки)' (Doležal 2007: 42-49).

Разговорная и просторечная лексика, не обошла стороной медицинские реалии, и составляет большой пласт в русском и чешском языках. Т.П. Соломенникова описывает данное явление следующим образом: «Ей присущи сниженная экспрессивная окраска, а главное, установка на языковую экономию. Например, составные наименования сокращаются, лексикализируются» (Соломенникова 2011: 77) и приводит следующие примеры: Склиф - 'институт им. Склифосовского’; Кащенка - 'больница им. Кащенко’; глазной центр 'Центр микрохирургии глаза им. Федорова'; диагностика - 'диагностический центр, краевая, городская больница'; мануалка - 'мануальная терапия'; мануальщик - 'мануальный терапевт'; kоžárna - 'kožní oddělení (дерматология)'; Kúnzácká nemocnice - 'krajský ústav národního zdraví (областное учреждение народной медицины)'; obvod'ak - 'obvodní lékař (врач терапевт)'; ped'aček 'pediatr (врач педиатр (уважительно))' (Doležal, 2007: 89-115).

Наше исследование показывает пытливость и находчивость умов как русских, так и чешских специалистов в области медицины. Даже приблизительное количество лексических единиц покрывающих социолект не будет легко установить, так как каждая больница, оздоровительный центр, научное медицинское учреждение и другие, будут иметь свои собственные «засекреченные» наименования. С одной стороны, социолект ярок, интересен и изобретателен, даже в такой сфере науки 
как медицина. С другой стороны, данная область нуждается в точности и адекватности наименований, социолект в свою очередь может сбивать с толку и не ограничивать смысл таких выражений. И в не последнюю очередь, наличие международной медицинской системы, когда обмен научных работников проходит беспрерывно, нельзя забывать о том, что иностранному специалисту социолект будет абсолютно не понятен и данная проблема может подвергать опасности здоровье и даже жизнь человека. Выходя из моего анализа, следует, что медицинский социолект заслуживает внимания специалистов из области лингвистики.

Итак, по итогам краткого обзора медицинского социолекта русского и чешского языков стоит заметить, что разнообразие языковых средств присуще также языку медицины. Несмотря на то что многие лингвисты и сами медицинские работники видят негативное влияние социолекта на культуру речи, данный процесс можно назвать тенденцией в общении медицинских работников. Для одних медиков социолект является разгрузкой, психологическим вентилем, для других он экономит время и речевые ресурсы, но иногда он стирает границы между тем, что такое хорошо, а что такое плохо, заставляет черстветь характер и обесценивает лингвистические нормы. Все же, именно временем диктуется речевое поведение, язык в свою очередь живой организм, иногда он развивается, растет и богатеет, порой чахнет и приостанавливает положительную динамику. Изучение негативных языковых явлений помогает понимать их мотивацию и функционирование. Социолект - это неотъемлемая часть речевой культуры, поражающая не только эмоционально-экспрессивные наименования, но также являющаяся ядром для широкого пласта языковых новообразований.

\section{Summary}

Sociolect is an integral part of the speech culture of individual branches of life. For physicians, sociolect is a relief, it saves time. the medical workers themselves see the negative influence of the sociolect on the culture of speech, this process can be called a trend in the communication of medical workers. Studying negative language phenomena helps to understand their motivation and functioning. This type of emotionally expressive words are interesting, but not always acceptable.

\section{Литература}

Бондалетов, В.Д. Соцчиальная лингвистика. Москва: Просвещение, 1987. 
Волович, М.И., Мирзоева В.М., Рюмшина Н.В. Ассоциативная терминология подъязыка медицины и профессиональный жаргон. In: Голубева, А.B. Тезисы международной конференции «Стратификация наџионального языка в современном российском обществе». Санкт-Петербург: Златоуст, 2013, c. 43-46.

Дворак, Е.В. К вопросу исследования профессионального социолекта как языковой универсалии. Профессиональный сленг как основа языковой специфики профессионального соииолекта. 2018, с. 10-15.

Ерофеева, Т.И. Понятие «социолект» в истории лингвистики XX века. Изменяюшийся языковой мир. 2002. Режим доступа: http://www.philology.ru/linguistics2/erofeeva-02.htm (2021-03-25).

Ерофеева, Т.И. Социолект как инструмент описания языковой ситуации региона. Вестник Пермского университета. 2010 (7/1), с. 21-25.

Казарина, С.Г. Типологические характеристики отраслевой терминологии. Автореферат диссертации. 1999.

Коровушкин, В.П. Язык в современных общественных структурах (соииальные варианты языка - IV): Материалы международной научной конференщии. Нижний Новгород: НГЛУ, 2005.

Митрофанова, О.Д. Научный стиль речи: проблемы обучения. Москва: Русский язык, 1985.

Соломенникова, Т.П. Социально-психологические и лингвистические аспекты функционирования профессиональной медицинской лексики. Вестник НГПУ. 2011 (3), с. 74-81.

Чернявский, М.Н. Язык и основы медицинской терминологии. Минск: Вышэйшая школа, 1989.

Doležal, A. Lékařský slang a úsloví. Praha: Galen, 2007. 


\title{
WARSZTAT TŁUMACZA SĄDOWEGO W TRANSLACJI CHORWACKO-POLSKICH TERMINÓW PRAWNYCH
}

\author{
A Sworn Translator's Skills in Croatian-Polish Translation of Legal Terminology
}

Keywords: translation, lexicography, Polish language, Croatian language, law

Contact: Uniwersytet Jana Kochanowskiegow Kielcach; piotrczajkowski@poczta.onet.pl

\section{Zasady wykonywania zawodu tlumacza sądowego w Polsce i Chorwacji.}

W Polsce wykonywanie zawodu tłumacza przysięgłego reguluje Ustawa z dnia 25 listopada 2004 roku, wg której tłumacz przysięgły jest uprawniony do:

1) sporządzania i poświadczania tłumaczeń z języka obcego na język polski, z języka polskiego na język obcy, a także do sprawdzania i poświadczania tłumaczeń w tym zakresie, sporządzonych przez inne osoby;

2) sporządzania poświadczonych odpisów pism w języku obcym, sprawdzania i poświadczania odpisów pism, sporządzonych w danym języku obcym przez inne osoby;

3) dokonywania tłumaczenia ustnego.

W dalszej części ustawy czytamy o tym, że do poświadczania tłumaczeń oraz poświadczania odpisów pism wydawanych w formie pisemnej tłumacz przysięgły używa pieczęci, zawierającej w otoku jego imię i nazwisko, a w środku wskazanie języka, w zakresie którego ma uprawnienia, oraz pozycję na liście tłumaczy przysięgłych.

W prawie chorwackim zawód tłumacza reguluje Pravilnik o stalnim sudskim tumačima wydany przez Ministra Sprawiedliwości Republiki Chorwackiej i ogłoszony w Dzienniku Ustaw pod Nr 150/05 i 16/07. W odróżnieniu od tłumaczy polskich, tłumacze chorwaccy powoływani są na czteroletnią kadencję $\mathrm{z}$ możliwością wnioskowania o jej przedłużenie. Na liście tłumaczy sądowych w Chorwacji może znaleźć się osoba która posiada wykształcenie wyższe, zna biegle język obcy w obszarze sądu którego językiem urzędowym jest język chorwacki. Musi posiadać 
również wiedzę $\mathrm{z}$ zakresu sądownictwa, administracji państwowej oraz znać terminologię prawną. Postępowanie w sprawie powołania tłumacza sądowego rozpoczyna się od wniosku zainteresowanego, skierowanym do prezesa sądu okręgowego lub sądu gospodarczego właściwego ze względu na miejsce zamieszkania. Do wniosku dołącza się życiorys, dokumenty potwierdzające narodowość, wykształcenie i znajomość języka obcego. Potwierdzeniem znajomości języka, który kandydat deklaruje, jest dyplom ukończenia studiów wyższych filologicznych lub certyfikat językowy (poziom C2). Przed rozpatrzeniem wniosku prezes właściwego sądu kieruje kandydata na test $z$ wiedzy o strukturze sądownictwa i administracji państwowej oraz znajomości terminologii prawniczej. Testu nie musi zdawać absolwent prawa. Przed wydaniem decyzji kandydaci odbywają również aplikacje pod czujnym okiem doświadczonych tłumaczy przysięgłych. Po wydaniu decyzji tłumacz otrzymuje podobnie jak w Polsce repertorium i okrągłą pieczęć imienną z informacją o języku, dla którego został ustanowiony.

\section{Specyfika tłumaczeń prawnych.}

Tłumacze sądowi mają do czynienia z tłumaczeniami mającymi cechy wspólne z każdym innym tłumaczeniem. Te jednak łączą ze sobą nie tylko wiedzę językową, ale także szerszą wiedzę z zakresu prawa, historii, legislacji itp. Definiując przekład prawny Barak stwierdził, że jest to ,racjonalne działanie, nadające znaczenie tekstowi prawnemu” oraz „działalność intelektualną, która zajmuje się określeniem normatywnego przesłania, jakie wyłania się z tekstu” (Barak 2005: 3). Tłumaczenie prawne musi zatem posiadać charakterystyczne cechy. Mam tu na myśli strukturę gramatyczną zdań, specyficzne słownictwo i wzorce leksykalne. Aby zrozumieć zdanie, potrzebna jest wiedza kognitywna. Składniki zdaniowe (jawne i niejawne) budują złożoną propozycję, znajdując się w pewnych relacjach i tworząc jasną hierarchię. Zdanie o strukturze logicznej to wyraźnie wyrażona propozycja, która jest uzupełniona ukrytym znaczeniem zawartym w zdaniu. Zgodnie z opracowaną przez Europejski Komitet Normalizacyjny w 2006 r. Europejską Normą EN 15038 „Usługi tłumaczeniowe. Wymagania dotyczące świadczenia usług" Artur Kubacki wymienia elementy, na jakie powinien zwrócić uwagę tłumacz podczas przekładu pisemnego. Rozróżnia on siedem elementów: „1. Terminologię: zgodność z terminologią specjalistyczną danej dziedziny i terminologią stosowaną przez klienta lub inną dostarczoną terminologią, jak również zachowanie spójności terminologicznej w całym tłumaczeniu; 2. Gramatykę: składnię, ortografię, interpunkcję, typografię, znaki diakrytyczne; 3. Leksykę: spójność leksykalną i frazeologię; 4. Styl: zgodność z własnymi lub otrzymanymi od klienta wytycznymi dotyczącymi stylu, w tym 
odnoszącymi się do rejestru językowego i wariantu języka; 5. Aspekty kulturowe: zwyczaje lokalne i normy regionalne; 6. Formatowanie; 7. Grupę docelową i cel tłumaczenia" (Kubacki 2008: 155).

Tłumaczenie przysięgłe musi ponadto być wierne, przejrzyste i rzetelne. Użyte $\mathrm{w}$ nim terminy muszą być zastosowane jednakowo w całym dokumencie. Nie ma znaczenia, czy tekst jest tłumaczony z jednego języka na inny oparty na tych samych czy innych systemach prawnych. Musi zawierać kod języka docelowego, a nie tylko przeniesienie słów z tekstu źródłowego do tekstu docelowego. Tłumaczenie prawne zakłada nie tylko interpretację semantyczną, ale uwzględnia też czynniki pragmatyczne. Tłumacz musi trzymać się pojęcia równoważnego pojęciu języka docelowego, w tym kontekstu w tekście źródłowym i kontekstu w tekście docelowym. Nie może też zapomnieć o pragmatyzmie międzykulturowym (zob. Wierzbicka 2003), ponieważ tłumaczenie tekstu prawnego sporządzonego w danym kraju jest głęboko zakorzenione w jego kulturze i nie powinno być postrzegane jako zjawisko odosobnione. Współczesna nauka zmierza dziś w kierunku interdyscyplinarności. W ten sposób tłumaczenie prawne łączy ze sobą wiedzę z zakresu nauk prawnych i językoznawstwa.

\section{Terminologia prawna jako podstawa kształtowaniu warsztatu thumacza.}

Terminologia prawna używana jest nie tylko przez prawników lingwistów, leksykologów, ale także tłumaczy przysięgłych. Ci ostatni w swojej pracy często spotykają się $\mathrm{z}$ tekstami $\mathrm{z}$ zakresu postępowania karnego, cywilnego, administracyjnego, rodzinnego i opiekuńczego, rzadziej z prawa konstytucyjnego. „Można uznać, iż w tłumaczeniu na język polski przede wszystkim należy zwracać uwagę na to, z jaką gałęzią prawa mamy do czynienia i przy uwzględnieniu tej wiedzy dokonywać wyboru odpowiednich ekwiwalentów funkcjonalnych" (Juszkiewicz 2012: 8). Terminologiczna interpretacja tekstu prawnego jest z natury bardzo wysublimowana, a tłumacz musi wziąć pod uwagę szerszy kontekst oryginału, który w tłumaczeniu prawnym (zarówno pisemnym, jak i ustnym) jest od dawna uznawany za bardzo ważny, niestety często z różnych przyczyn bywa zapominany i zaniedbywany. Konceptualna strona systemu terminologicznego odzwierciedla relacje, jakie istnieją między pojęciami w ramach określonego pola semantycznego. „Mając na myśli tłumaczenie tekstów prawniczych mówimy o tłumaczeniu z jednego języka prawniczego na drugi, przy czym nie stosuje się w języku docelowym terminologii potocznej, czy jakiejkolwiek terminologii pośredniej” (Groot 2002: 223). Szeroko rozumiane tłumaczenia sądowe, oparte muszą być na doświadczeniu, kompetencjach $\mathrm{i}$ interdyscyplinarnej wiedzy tłumacza. „Tłumacz sądowy jest zatem ekspertem 
w zakresie komunikacji transkulturowej, odpowiedzialnym za zapewnienie rozumienia i bycia zrozumianym (...)" (Kadrić 2009: 26). Szczególnie ważne przy porównawczej analizie terminologicznej języka polskiego i chorwackiego jest zwrócenie uwagi na stronę pojęciową. Podobnie jak w języku polskim również $\mathrm{w}$ języku chorwackim występuje wiele różnic między terminologią prawa cywilnego i karnego. Powód i pozwany to pojęcia prawa cywilnego, a podejrzany i oskarżony terminy z zakresu prawa karnego.

„W postępowaniu karnym dobór terminów jest uzależniony od etapu postępowania, a więc od tego czy chodzi o postępowanie przygotowawcze (śledztwo, dochodzenie) czy o postępowanie przed sądem oraz od rodzaju postępowania" (JopekBosiacka 2009: 213). Jak trafnie zauważa Pieńkos: „Tekst specjalistyczny wymaga od tłumacza znajomości danej dziedziny oraz zasad, rządzących sztuką przekładu. Znajomość terminologii zastosowanej $\mathrm{w}$ danej dziedzinie wiedzy lub tłumaczonym dziele naukowym jest - obok gruntownej znajomości języka oryginału i języka przekładu - jednym z podstawowych warunków osiągnięcia równowartościowego i pełnowartościowego przekładu dzieła (...) (Pieńkos 2003: 234). Należy wziąć pod uwagę, że tłumacz wykorzystuje w języku ojczystym wiedzę kognitywną w sposób nieświadomy wręcz automatyczny. Aby kształtować kompetencje społecznokulturowe, powinien więc stale pracować nad poszerzaniem wiedzy pojęciowej w języku docelowym. W tym celu niezwykle ważne jest poznanie systemów prawnoustrojowych funkcjonujących zarówno w Polsce, jak i w Chorwacji. Jest to bardzo ciekawe w szczególnie w drugim przypadku. System prawny w Chorwacji ewaluował na przestrzeni wieków kilkukrotnie. „Przeobrażenia prawno-ustrojowe w Jugosławii pod koniec lat osiemdziesiątych znalazły swój wyraz obok konstytucji federalnej w ustawach zasadniczych poszczególnych republik" (Wojnicki 2014: 14). Na problem ten należy również spojrzeć z aspektu języka. W Chorwacji forma državni odvjetnik (prokurator) tożsama z tą do 1929 roku. W Królestwie Serbów, Chorwatów i Słoweńców do 1941 roku używano terminu državni tužilac a po II wojnie światowej w Socjalistycznej Republice Jugosławii był to javni tužilac. W funkcjonującej dziś w Chorwacji terminologii prawnej powrócono zdecydowanie do form sprzed 1929 roku i zrezygnowano z form funkcjonujących dziś w języku serbskim.

\section{Rodzaje tlumaczeń prawnych jako narzędzia warsztatu translatorskiego.}

Tłumaczenia ustne występują w pracy tłumacza sądowego równie często jak pisemne a nawet uzupełniają się wzajemnie. Ma to miejsce podczas przesłuchań, z których następnie sporządzane są protokoły $\mathrm{i}$ inne dokumenty wykorzystywane $\mathrm{w}$ dalszym 
postępowaniu. Najpopularniejszym typem przekładu, wyróżnionym przez współczesnych specjalistów z zakresu translatoryki, jest przekład automatyczny, zwany też maszynowym. Realizowany głównie za pomocą programów komputerowych. W praktyce sądowej, ze zrozumiałych powodów nie stosuje się jednak podobnej strategii, która nie zapewnia w odpowiedni sposób przekazania informacji. Chociaż teoretycznie możliwy, jest sposób takiego tłumaczenia, to w praktyce podobnie jak tłumaczenie interesmiotyczne (transmutacyjne) - nie znajduje zastosowania w tłumaczeniach $\mathrm{z}$ dziedzin prawa. Tłumacz często musi zmierzyć się za to z innym typem tłumaczeń. Najczęstszym z nich jest wspomniany już przez mnie wcześniej przekład konsekutywny, sekwencyjny, polegający na wysłuchaniu kilku zdań, zapamiętaniu ich (lub odnotowaniu), a następnie wypowiedzeniu przetłumaczonego tekstu. Tłumaczenia takie wykonywane są na potrzeby organów wymiaru sprawiedliwości. Zlecają je sądy, prokuratura czy policja. Mniej popularne, ale także mające miejsce w pracy tłumaczy sądowych, są tłumaczenia symultaniczne i konferencyjne wykorzystywane przy organizacji konferencji lub prezentacji dla dużej liczby osób. Uważa się, że takie tłumaczenia są najtrudniejsze ze względu na liczbę decyzji, jakie musi podjąć tłumacz w określonym czasie, szukając odpowiedniego słowa do przekazania informacji w języku docelowym. „Tłumacze sądowi są aktywnymi uczestnikami procesu karnego, mogącymi poprzez swoje działania bezpośrednio wpływać na jego przebieg, a nawet wynik" (Nartowska 2013: 125).

Należy tu zaznaczyć, że do przeprowadzenia tłumaczenia symultanicznego musi zostać zapewnione odpowiednie wyposażenie techniczne. Ze względu na sposób przekazywania informacji można wyróżnić tłumaczenia autorskie, wewnątrzjęzykowe, swobodne czy też diachroniczne. Ja chciałbym skupić się głównie na tłumaczeniach dokumentów urzędowych, sporządzanych przez tłumaczy przysięgłych, które mają taką samą moc prawną jak oryginał.

Interpretacja semantyczna implikuje znaczenie słów lub wyrażeń, które uważamy za najpowszechniej występujące w słownikach (najczęściej określane jako znaczenie podstawowe) lub znaczene niezależnie od kontekstu. Lessig podkreślał (Lessig 1993: 1178), że ,znaczenie składa się z czegoś na pierwszym planie (tekst) i czegoś w tle (kontekst). Aby zachować znaczenie (zarówno językowe, jak i pozajęzykowe), oba plany muszą być możliwe do analizy. W słownikach terminologicznych często więcej uwagi poświęca się tylko językowej stronie, co prowadzi do błędów translatorskich. Podejście konceptualne jest ważne w przypadku tłumaczenia prawnego, ponieważ opiera się na specjalistycznej wiedzy z określonej dziedziny, tworzy podstawę dla wyważonej i znormalizowanej terminologii, ułatwia analizę porównawczą pojęć i znaków językowych między językami. Dobrze 
przygotowany thumacz nie będzie tłumaczył terminu podejrzany jako oskarżony, w przypadku jeśli postępowanie nadal się toczy. W praktyce jednak organy sądowe często traktują podejrzanego jako oskarżonego ze względu na szybkość toczącego się postępowania, które jest nieprawidłowo określone pod kątem językowym a co gorsza prawnym. Należy zatem wziąć pod uwagę tego typu niuanse i nieścisłości.

\section{Problemy z translacją tlumaczeń prawnych $w$ języku polskim i chorwackim.}

Odnosząc się do wyszukiwania, selekcji i wykorzystania terminów prawniczych w procesie thumaczenia prawnego, należy podkreślić, że tłumacz zarówno w Polsce jak i w Chorwacji znajduje się w dość trudnej sytuacji, ponieważ do tej pory nie wydano specjalistycznych słowników polsko-chorwackich i chorwacko- polskich poświęconych terminom prawnym. Tłumaczenia są możliwe jedynie przy przy wykorzystaniu jednojęzycznych słowników terminów prawniczych polskich lub chorwackich. Wymienię tu Polski stownik terminów i pojęć prawniczych Zofiii KrzysztoforskiejWeisswasser wydany we Wiedniu w 1998 roku. W Chorwacji w Zagrzebiu w 2006 roku został opublikowany Opći pravni rjecnik autorstwa Marti Vidaković-Mucić a rok później ukazał się Pravni Leksikon Vladimira Pezo. Z dwujęzycznych słowników na uwagę zasługuje Stownik polsko-chorwacki wydany w Zagrzebiu w 2002 roku pod redakcją Milana Moguša i Nedi Pentarić oraz starszy wydany w Warszawie w roku 1987 dwutomowy Stownik serbsko-chorwacko polski Vilima Frančicia. Ze względu na różne koncepcje terminologiczne przedstawione $\mathrm{w}$ słownikach ogólnych terminologia prawnicza może być interpretowana w różny sposób, co budzi wiele niejasności.

Dla tłumaczy ze znajomością języka angielskiego dobrym rozwiązaniem będzie Engelsko-hrvatski rječnik prava, međunardnih odnosa, kriminalistike i forenzičnih znanosti, kriminologije $i$ sigurnosti wydany w Zagrzebiu w 2004 autorstwa Milici Gačić.

Z powyższych przykładów widać, że słowników jest niewiele i często nie odpowiadają potrzebom prawników lingwistów czy thumaczy sądowych. Często zdarza się, że jest w nich zawartych zbyt mało haseł a terminy są potoczne lub zbieżne ze sobą. Tak jest w przypadku terminów skarga i zażalenie, które w słowniku Moguša brzmią identycznie jako tužba. Dlatego słowniki tylko częściowo pomagają $\mathrm{w}$ pracy translatorskiej. W tym przypadku tłumacz musi skorzystać z pomocy wyszukiwarek internetowych. Zawarte w nich dane są bardziej wiarygodne i częściej modyfikowane, ponieważ tłumacz może sprawdzić termin, jego częstotliwość oraz liczbę wystąpień na stronie. Główną zaletą internetu są też fora dyskusyjne dla tłumaczy czy bazy terminologiczne, dzięki którym można znacznie skrócić czas na odnalezienie 
wyszukiwanego terminu. Ponadto funkcjonalność tłumaczenia jest zwiększona, ponieważ tłumacz uzyskuje wgląd w to, jak na przykład inni tłumacze rozwiązali podobne problemy terminologiczne i czy istnieje $\mathrm{w}$ bazach odzwierciedlenie określonego terminu. Różnego rodzaju proste internetowe translatory online, wykorzystywane często przez osoby o różnych profesjach - od inżynierów, prawników, lekarzy po studentów bez wiedzy lingwistycznej, często pozostają bezużyteczne przy translacji prawnej.

\section{Podsumowanie.}

Jak powszechnie wiadomo sama znajomość języków nie jest wystarczająca do wykonania poprawnego przekładu. Proces ten jest bowiem czynnością złożoną, opartą przede wszystkim na gruntownym i wszechstronnym warsztacie opartym na zrozumieniu tekstu oryginału począwszy a skończywszy na gotowym produkcie. Jak trafnie zauważyła Karolina Nartowska: „Tłumacz sądowy musi (...) nabyć i rozwinąć specyficzne kompetencje i umiejętności, których programy studiów translatorycznych obecnie nie obejmują, a moduły dotyczące kształcenia tłumaczy sądowych, przede wszystkim w zakresie tłumaczenia ustnego, praktycznie nie istnieją (Nartowska 2018: 178).

Jak widać, bardzo ważną kwestią w podnoszeniu warsztatu tłumaczy są specjalistyczne szkolenia. W Polsce prowadzą je różnego rodzaju stowarzyszenia. Wiodącą rolę odgrywa tu jednak Towarzystwo Tłumaczy Przysięgłych i Specjalistycznych TEPIS $\mathrm{z}$ siedzibą w Warszawie. Niestety w zakresie języka chorwackiego szkoleniom i webinariom poświęca się nadal zbyt mało miejsca i uwagi. Warsztaty takie muszą obejmować nie tylko zakres wiedzy ogólnej, ale również specjalistycznej, mającej kluczowy czynnik na wartość tłumaczonego tekstu czy dokumentu. Kolejnym i chyba kluczowym problemem jest brak fachowych słowników, które niewątpliwie skróciłyby czas i ułatwiłyby pracę tłumaczom przysięgłym zarówno w Polsce, jak i Chorwacji.

\section{Summary}

The above article is devoted to the role of a sworn translator and translation, with particular attention to the specificity of a legal terminology rendering. It was based on personal competence, translation experience, and interdisciplinary knowledge. A process of translation begins with an understanding of the original source text and ends in achieving a final result, that is committing a diligent translation. A legal 
translation bears similarity to any other rendering but is very specific in the way that it brings together not only lingual but also a broader understanding as far as legal knowledge and that of history is concerned. A translator has to bear in mind the fact that combined knowledge both of law and history is required to be applied in the most appropriate manner.

\section{Literatura}

Barak, A. Purposive Interpretation of Law. Princeton: Princeton University Press, 2005.

Groot, de G. R. Rechtsvergleichung als Kerntätigkeit bei der Übersetzung juristischer Terminologie. In: Sprache und Recht. Berlin-New York, 2005.

Jopek-Bosiacka, A. Przekład prawny i sadowy. Warszawa: PWN, 2009.

Juszkiewicz, H. Małoletni, młodociani, nieletni ... czyli polska terminologia prawna związana z wiekiem w kontekście tłumaczeń angielsko-polskich. Biuletyn Koła Naukowego Ttumaczeń Specjalistycznych Uniwersytetu Gdańskiego. Linguana, nr 4. Wydanie specjalne: Ttumaczenia prawne i prawnicze. 2012.

Kadrić, M. Dolmetschen bei Gericht. Erwartungen - Anforderungen - Kompetenzen. Wien: facultas, 2009.

Kubacki, A. D. Odpowiedzialność zawodowa tłumaczy przysięgłych. Język. Komunikacja. Informacja. Tom 3, 2008, s. 149-161.

Nartowska, K. Tłumacz i działanie translatorskie w sądzie. Comparative Legilinguistics International Journal for Legal Communication vol. 13, 2013.

Nartowska, K. Ustawa o zawodzie tłumacza przysięgłego a tłumaczenie sądowe w Polsce. Rocznik przekładoznawczy. 2018 (3/13), s. 171-193.

Pieńkos, J. Podstawy przekładoznawstwa. Od teorii do praktyki. Kraków. Kantor Wydawniczy Zakamycze, 2003.

Wojnicki, J. Dylematy przeobrażeń ustrojowych w Republice Chorwacji. Republika Chorwacji. Polityka wewnętrzna i międzynarodowa. 2014, s. 13-26. 


\title{
TERMÍNY OZNAČUJÚCE SÚRODENCOV RODIČOV A ICH PARTNEROV V ZÁPADOSLOVANSKÝCH A JUŽNOSLOVANSKÝCH JAZYKOCH
}

\author{
Terms for Parent's Siblings and Their Partners \\ in West and South Slavic Languages
}

Keywords: kinship terminology, aunt, uncle, West Slavic languages, East Slavic languages

Contact: Masarykova univerzita; demelova@phil.muni.cz

\section{Úvod}

Ciel'om tejto práce je poskytnút' podobný prehl'ad o súčasnej situácii v oblasti označovania súrodenca rodiča a jeho partnera $v$ západoslovanských a južnoslovanských jazykoch (konkrétne v slovenčine, češtine, pol’štine, slovinčine, chorvátčine, srbčine, bulharčine a macedónčine). Na základe podrobného skúmania etymológie i situácie v týchto jazykoch ponúkame podrobný prehl'ad o vývoji tejto časti terminológie, pričom situáciu zároveň overujeme $\mathrm{v}$ národných jazykových korpusoch. Na základe dát z korpusov potom môžeme potvrdit' či vyvrátit' predpoklady o využívaní určitých termínov, a zachytit’ aktuálny stav terminológie (ktorý je v slovníkoch často zastaraný).

Hlavným predpokladom tejto práce je, že terminológia označujúca príbuzných v nepriamej (teda o. i. súrodencov rodičov) a nepokrvnej línii (o. i. partnerov súrodencov rodičov) sa z dôvodu zmeny štruktúry spoločnosti a nárokov na príbuzenstvo výrazne mení, a to smerom $\mathrm{k}$ nižšej potrebe rozlišovania jednotlivých príbuzných. Predpokladáme teda, že termíny označujúce jednotlivých príbuzných, či už matrilineárnych či patrilineárnych, pokrvných či nepokrvných, sa budú v skúmaných jazykoch približovat', zamieňat' a zjednodušovat'. Pôvodné odlíšenie matrilineárnych a patrilineárnych, pokrvných a nepokrvných príbuzných totiž - podla našich predpokladov - nie je pre hovorcov jazyka nijak dôležité, čo sa musí prejavit' aj v jazyku. 


\section{Pôvod termínov}

Termíny označujúce súrodencov rodičov možno jednoducho rozdelit' podl'a pohlavia a čiastočne linearity. Pre mužských príbuzných $\mathrm{v}$ tomto vzt’ahu fungovalo už v praslovančine odlíšenie matrilineárneho $\left({ }^{*} \mathbf{u j} \mathbf{b}\right)$ a patrilineárneho $\left({ }^{*}\right.$ stryjb) brata rodiča, pričom toto rozdelenie sa do istej miery zachováva $\mathrm{v}$ niektorých zo skúmaných jazykov dodnes. V prípade ženského príbuzného je situácia jednoduchšia, ked’že už v praslovanských dobách (a možno i praindoeurópskych) bol termín pre matrilineárnu a patrilineárnu tetu spoločný (psl. *teta). Niektoré zo skúmaných jazykov sa však pod vplyvom iných jazykov od tohto prístupu odkláňajú, ako bude ukázané nižšie.

Ako sme už naznačili, pôvod termínov označujúcich súrodenca rodiča možno hl'adat' už v dobách praslovanských, prípadne praindoeurópskych. Patrilineárny mužský termín zrejme pochádza z pie. *ptrū-jo-s, čo sa spája s pie. *patēr (ide teda o priamy odkaz na otcovskú líniu). Trochu problematickou čast'ou etymológie je v tomto prípade zmena *pst- > st-, ked’že takáto zmena je pomerne zriedkavá (Machek 2010: 584). Na druhej strane stojí matrilineárny mužský príbuzný, ktorého označenie pochádza z pie. *auo- ,starý otec z matkinej strany“ (Králik 2015: 640). Význam „matkin brat“ pre preto zrejme až druhotný.

Označenie matkinej i otcovej sestry zrejme napodobuje lalický pôvod iných príbuzenských termínov, pričom skutočnost', že ide o dospelými vytvorený a detom až vnútený termín, dokazuje skutočnost', že obsahuje vokál $e$ (a nie očakávané $a$ ).

I ked’ sa väčšina jazykov drží aspoň do istej miery (s prípustnou mierou zjednodušenia) uvedenej pôvodnej terminológie, objavujú sa lokálne aj inovácie. Najvýraznejšou je zrejme temer plné nahradenie termínu pre ženskú príbuznú v tomto vzt’ahu v Bulharčine termínom леля, ktoré ale zrejme vzniklo podobne ako vyššie uvedené teta. Druhou, i ked' menej výraznou výnimkou, je prijímanie termínov s pôvodom $\mathrm{v}$ iných, neslovanských jazykoch, $\mathrm{v}$ južnoslovanskej vetve - uved'me chorvátske barba či dondo (z taliančiny), srbské amidža (z turečtiny), prípadne širšie rozšírené bulharské a macedónske (a čiastočne aj srbské) чичо, rovnako z turečtiny. $\mathrm{Z}$ neslovanských jazykov, konkrétne mad’arčiny, čerpá aj slovenská inovácia vo forme báčik/báči.

Nepokrvné príbuzenstvo sa následne označuje termínmi odvodenými od označenia pokrvných príbuzných, a to najmä pri pomenovávaní ženských príbuzných (napr. slk. stryná, srb. strina). Čiastočne to platí aj pri pomenovávaní mužských príbuzných (pol. pociot, slo. tetak), i ked’ variabilita je v tejto oblasti výrazne väčšia. V zásade možno povedat', že termíny $\mathrm{v}$ tejto oblasti, teda oblasti pomenovávania priženených mužov, narážajú na výrazné odchýlky a nejednotnost', a to nie len pri 
porovnaní jednotlivých jazykov navzájom, ale i regionálne. V jednom jazyku sa preto môžeme stretnút' s viacerými termínmi, často nejednoznačného charakteru, ktoré sa aplikujú na viacero rôznych príbuzných (priženených mužov - teda manželov sestier, tiet, dcér a podobne). Najčastejšie sú tieto termíny odvodené od skutočnosti sobáša (slk. svák, bulh. свако).

\section{Termíny označujúce súrodencov rodičov a ich partnerov}

$\mathrm{Na}$ základe korpusového skúmania a získaných dát môžeme stav $\mathrm{v}$ jednotlivých jazykoch preskúmat' podrobnejšie. $\mathrm{V}$ západoslovanských jazykoch vidíme všeobecnú tendenciu $\mathrm{k}$ preferencii jedného $\mathrm{z}$ dostupných termínov pre mužského príbuzného. V prípade češtiny je situácia jednoznačná, ked’že výskyt termínu pôvodne určeného pre matkinho brata (ujec) je oproti termínu pre otcovho brata (strýc, strejda, strýček) je len $0,5 \%$. Pol'ština naproti tomu preferuje termín pôvodne vyhradený pre matkinho brata (wujek, wuj, wujaszek), jeho dominancia nie je ale absolútna, ked’že termíny pôvodne vyhradené pre otcovho brata (stryj, stryjek, stryk) dosahujú výskytu až $16,5 \%{ }^{1}$ Slovenčina sa javí byt' v tomto súboji najviac vyrovnanou, i ked' rovnako ako pol'ština preferuje termín pôvodne určený matkinmu bratovi (ujo, ujec, ujko). Termín strýko (strýčko, strýc) však dosahuje až $61 \%$ z výskytu dominantného termínu. Uvedené naznačuje, že všetky západoslovanské jazyky sa vydali cestou k zjednodušeniu terminológie a upúšt’ajú od rozlišovania patrilineárnych a matrilineárnych príbuzných. Najmenej zrejmá je táto skutočnost' v slovenčine, avšak i tu je dominancia jedného z termínov zrejmá. Zmätenie pôvodného významu potom dokladajú slovníky, ktoré uvádzajú termíny ujec a strýc ako synonymá (Ujo. Slovníkový portál Jazykovedného ústavu L. Štúra SAV). Práca Jozefa kohúta z roku 1883 však dokladá, že pred vyše storočím boli termíny ešte významovo odlišné (Kohút 1883: 200-201).

Termíny určené nepokrvným príbuzným v mužskej línii sa v západoslovanských jazykoch ukazujú byt' málo využívanými, pričom čeština je opät' najviac vyhraneným z jazykov - v korpusoch sa neukázali ani stopy pôvodných termínov. Situácia v slovenčine a pol'štine nie je vel'mi odlišná, i ked' v týchto jazykoch termíny sváko (v slovenčine) a pociotek (v pol’štine) zaujímajú hodnoty nad 0,3 i. p. m. ${ }^{2}$

\footnotetext{
${ }^{1}$ Uplatňujú sa najmä v rurálnych oblastiach (Parkin 1995: 144).

${ }^{2}$ Jednotiek na milión výskytov. Ide o jednotku, ktorá vyjadruje, ako často sa priemerne termín nachádza v jednom milióne jednotiek jazyka. Toto vyjadrenie považujeme za účelné najmä pre možnost' porovnatel'nosti medzi rôzne vel'kými korpusmi. Všetky grafy v tejto práci vyjadrujú hodnoty i. p. m.
} 


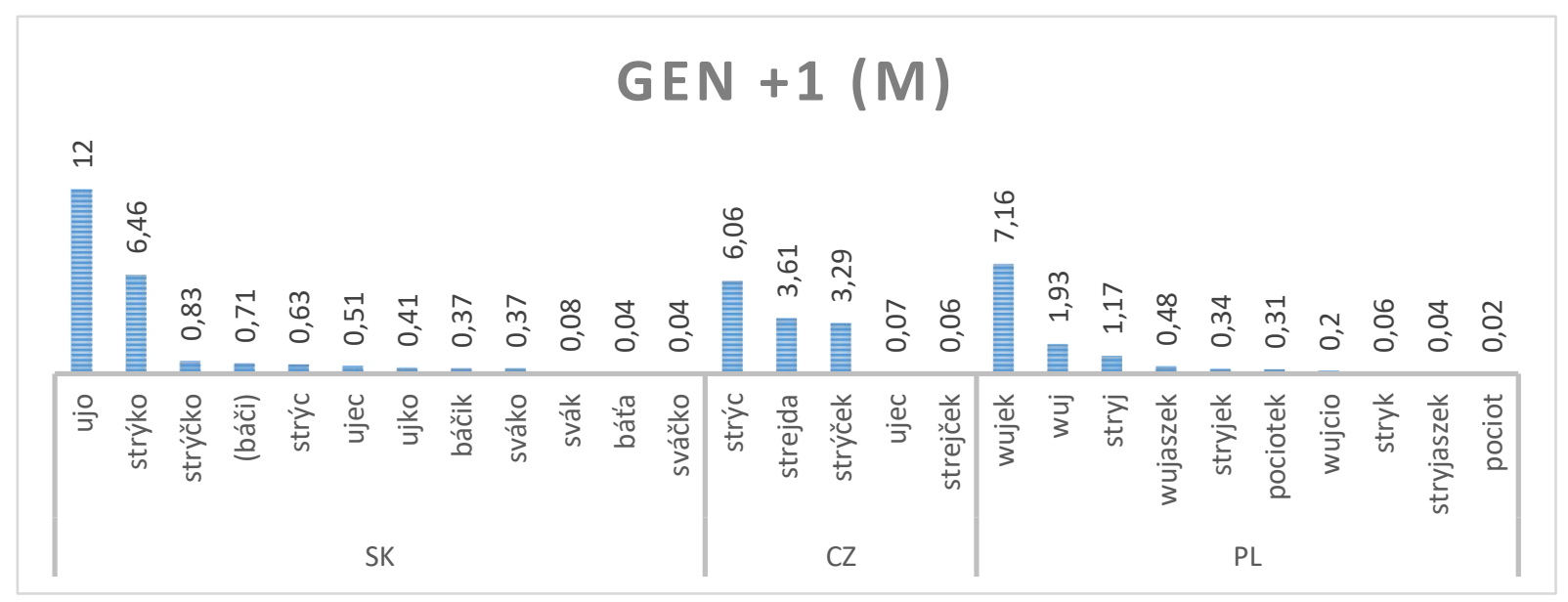

Pomenovávanie ženských príbuzných v tejto kategórii je výrazne jednoduchšie, pričom evidujeme vyšší výskyt deminutívnych variant. Jediným výkyvom oproti očakávaniu sú pol'ské opisné formy siostra matki či siostra ojca, ktoré ale nie sú príliš časté (s hodnotami 0,21 i. p. m., resp. 0,07 i. p. m.).

V západoslovanských jazykoch sa rovnako neprejavili nijak výraznejšie pôvodné termíny pre manželku otcovho či matkinho brata. Čeština nevykazuje ani stopy týchto termínov, výskyt v slovenčine a pol’štine je na úrovni stotín i. p. m., teda v jednotkách výskytov. Jednoznačne môžeme potvrdit', že pôvodné termíny sú vo všetkých západoslovanských jazykoch eliminované v prospech pokrvných termínov (pôvodne vyčlenených matkinej či otcovej sestre), prípadne v prospech opisných pomenovaní, ak je nutné rozlíšenie zachovat'.

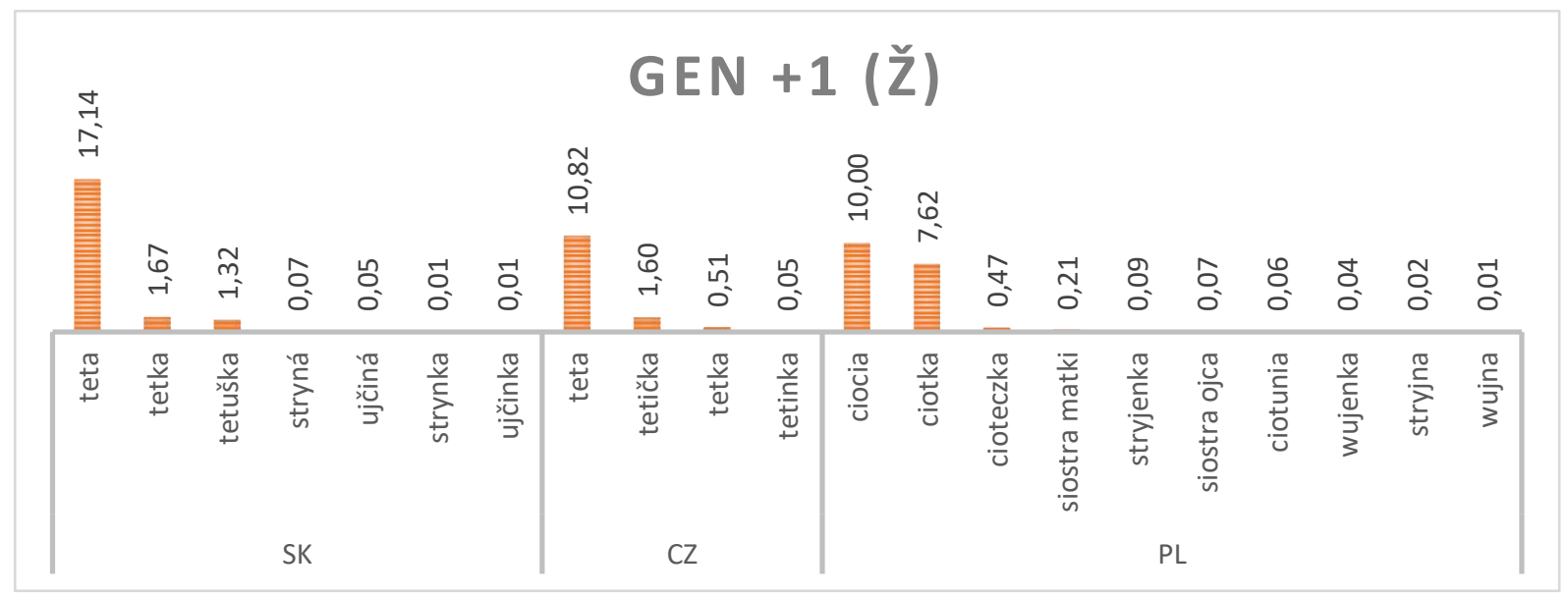

V oblasti južnoslovanských jazykov je situácia mierne odlišná. Okrem slovinčiny, ktorá jednoznačne preferuje termín stric (striček) existujú vo všetkých skúmaných jazykoch deliace línie medzi viacerými termínmi. V prípade srbčiny 
a chorvátčiny ide o termíny stric (striko, strika) a ujak (ujac). V srbčine i chorvátčine sú pomery týchto termínov temer vyrovnané, s miernou preferenciou termínu stric, ktorá však môže byt' spôsobená ako štatistickou chybou, tak mimojazykovými vplyvmi. Srbčina a chorvátčina, ako sme už spomínali vyššie, využívajú aj široký fond d'alších termínov, najčastejšie prebraných z iných jazykov. ${ }^{3}$ Ich výskyt sa v korpusoch však neukázal byt' významným. Najviac využívaným sa javí byt' termín barba, zachytený v chorvátčine, ktorý má ale primárne iný význam, preto ho uvádzame v zátvorke.

$\mathrm{Na}$ označovanie nepokrvných príbuzných využíva táto západná vetva južnoslovanských jazykov najmä termíny odvodené od označenia pokrvnej príbuznej (matkinej či otcovej sestry) - v srbčine a slovinčine ide o termíny teča či tetak, i ked' v slovinčine je ich výskyt minimálny, v chorvátčine opät tetak a tetac (druhý variant však marginálne). Výskyt týchto termínov je síce nižší ako v prípade označenia pokrvných príbuzných, to však môže byt' spôsobené aj mimojazykovými skutočnost'ami (menší kontakt, menší počet týchto príbuzných - nie všetky tety sa vydávajú, a podobne).

Východná vetva južnoslovanských jazykov, na druhej strane, využíva v značnej miere termíny чичо (bulh.) а чичко (mac.). V bulharčine tento termín plne nahradil pôvodné označenie otcovho brata (Чичо. Речник на българския език). Vzhl'adom na výrazne nižší výskyt termínu вуйчо (24 \% oproti termínu чичо) však možno uvažovat' o rozšírení jeho významu aj na matkinho brata. Obdobne je tomu aj v macedónčine, i ked' poradie i pomery sú mierne odlišné. Macedónčina tiež do istej miery zachováva pôvodný termín pre otcovho brata, стрико. Najčastejší, avšak polysémantický termín бaj uvádzame opät’ v zátvorke.

$\mathrm{V}$ prípade nepokrvných príbuzných disponuje bulharčina plejádou termínov označujúcich partnera matkinej či otcovej sestry - свако, лелично, калеко, лелин, тетин, okrem prvého menovaného je ich výskyt však minimálny. Hovorovo je prípustný význam „Мъж на лелята“ aj v prípade termínu вуйчо (Вуйчо. Речник на българския език), dokladá to tak už vyššie spomínané stieranie rozdielu medzi pokrvnými a nepokrvnými príbuznými. Macedónčina potom vôbec nedisponuje termínmi špecificky určenými nepokrvným príbuzným.

\footnotetext{
${ }^{3}$ Tento vplyv je najvýraznejšie badat' v čakavských a kajkavských nárečiach, z očividných geografických dôvodov (Hraste 1956: 1-2).
} 

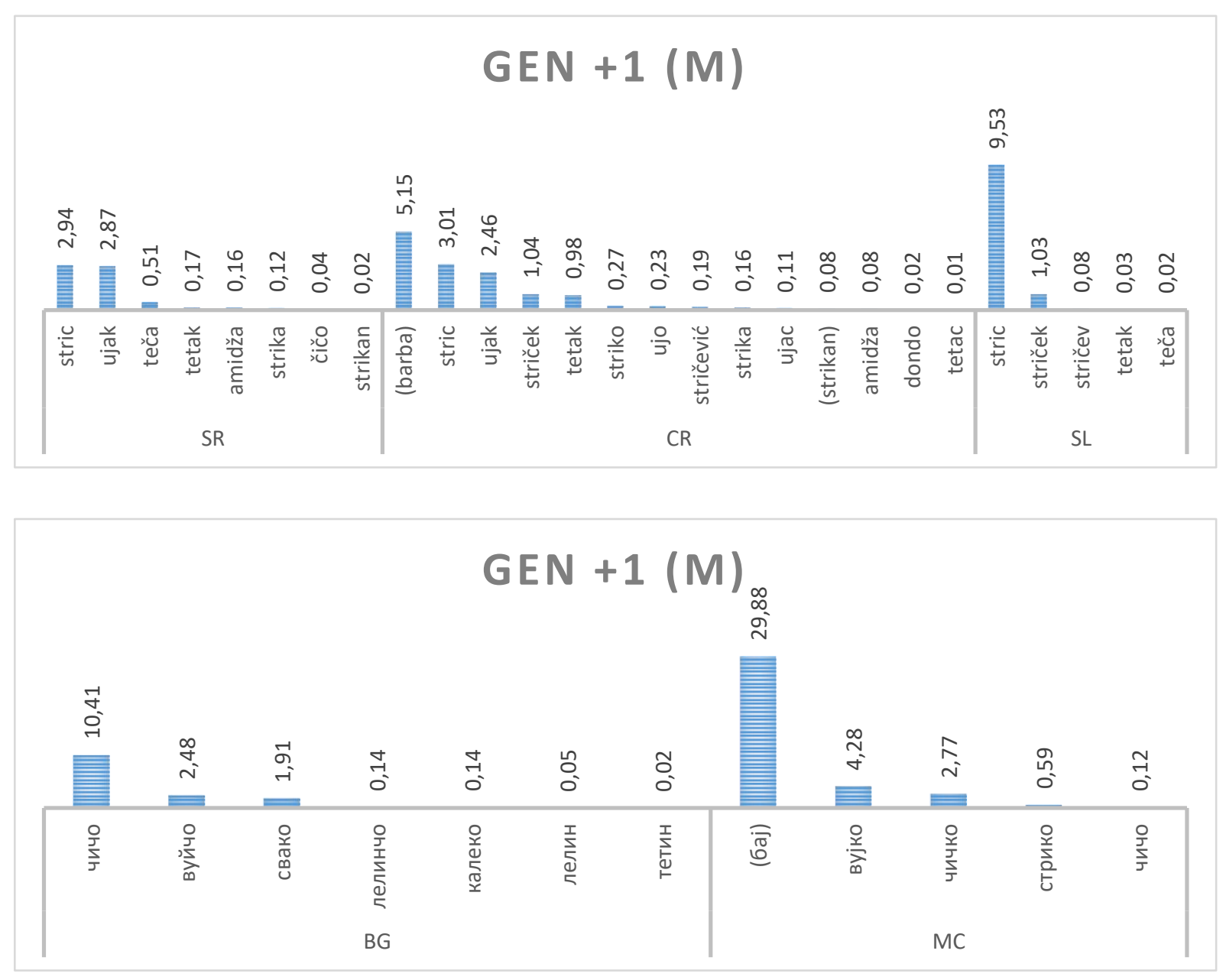

Južnoslovanské jazyky si vo všeobecnosti zachovávajú v prípade označovania ženských príbuzných v skúmanej kategórii rozdelenie na pokrvnú a nepokrvnú líniu, i ked' malé výskyty práve nepokrvných označení v niektorých jazykoch napovedajú, že i tu dochádza k ich nahradeniu termínmi určenými pre pokrvné príbuzné. Najvýraznejší je podiel týchto termínov (strina, ujna) vidiet’ v prípade srbčiny, kde spolu dosahujú asi $25 \%$ podiel (oproti termínom tetka, teta). ${ }^{4}$ Chorvátčina, bulharčina a macedónčina využívajú tieto termíny výrazne menej (pomer nepokrvných termínov je 7-10 \%), a slovinčina ich temer vyradila zo svojej slovnej zásoby $(2,7 \%)$.

Pokrvné príbuzné sú označované v skúmaných jazykoch bez prekvapení, s výnimkou bulharského леля a macedónskeho нина, ktoré ale vedú čo do používanosti, v prípade bulharčiny absolútne. V západnej vetve sa opät’ stretávame so širokým využitím deminutívnych foriem, v prípade srbčiny dokonca dominantným. Dodajme ešte, že bosenské, kosovské a čiernohorské dialekty disponujú rozlišovaním aj medzi

\footnotetext{
${ }^{4}$ Termíny strina a ujna sme sa rozhodli porovnávat' spolu, a to oproti ostatným termínom určeným pokrvným príbuzným. Výsledkom je teda pomer termínov pre nepokrvné príbuzné v pomere k termínom pre pokrvné.
} 
matkinou a otcovou sestrou, prebraným z neslovanských jazykov, napr. v Čiernej Hore v podobe teza a hala (Бјелетић 1994: 202).

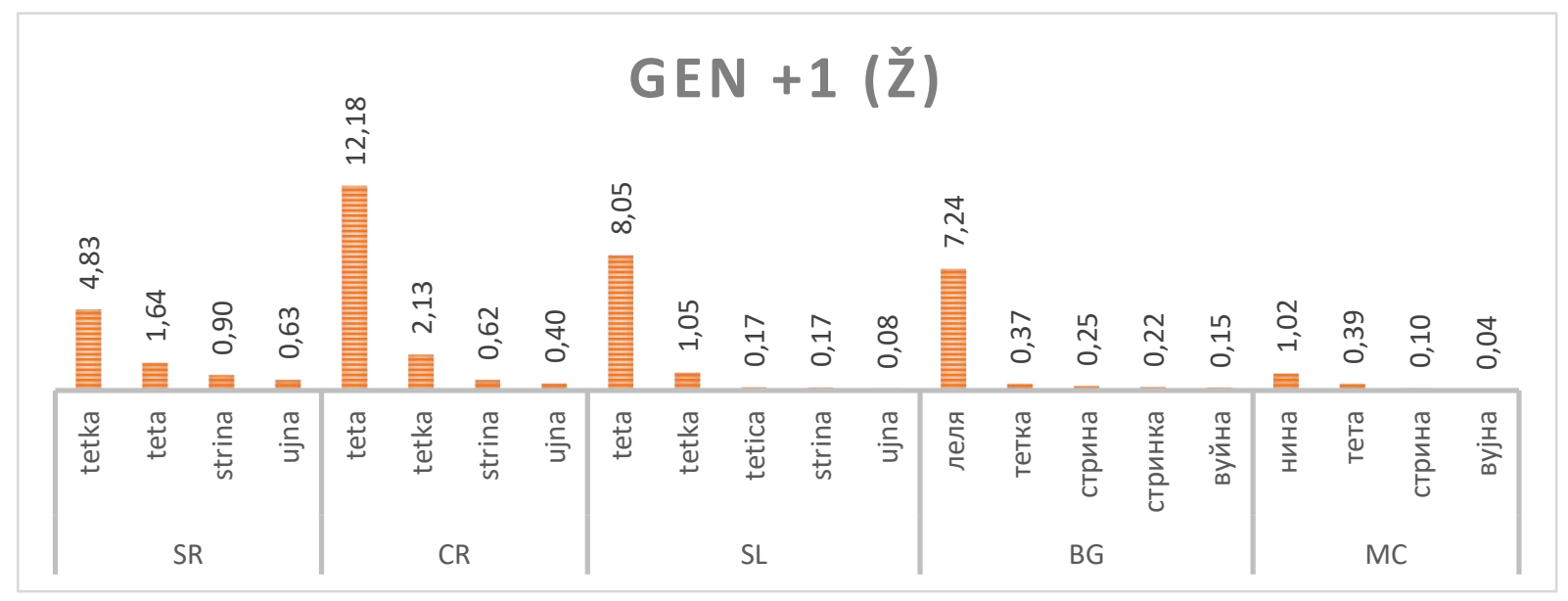

Ako sme ukázali vyššie, skúmané jazyky vykazujú výraznú tendenciu k zjednodušeniu. $\mathrm{V}$ prípade západoslovanských jazykov a slovinčiny sa rozdiel medzi pokrvným a nepokrvným, rovnako ako matrilineárnym a patrilineárnym príbuzenstvom plne stiera (i ked' v slovenčine ešte nie je definovaný jediný používaný termín pre označenie brata jedného z rodičov). Na druhej strane, rozdiel medzi patrilineárnymi a matrilienárnymi príbuznými stále do istej miery zachovávajú južnoslovanské jazyky (okrem slovinčiny). I v nich ale badat' výrazne menší výskyt termínov pre nepokrvných príbuzných (čo ale môže byt' spôsobené mimojazykovými vplyvmi). Možno sa domnievat', že pokým bude zachovaný rozdiel medzi otcovým a matkiným bratom, nebude možné ani zotriet' rozdiel medzi takýmto pokrvným príbuzným a tým nepokrvným (hovorca jazyka by narazil na problém ku ktorému z termínov sa v prípade nepokrvného príbuzného priklonit'). ${ }^{5}$ Toto do istej miery potvrdzuje aj situácia v prípade označovania ženských príbuzných, kde rozdiel medzi matrilineárnou a patrilineárnou tetou neexistuje, a výskyt termínov pre nepokrvnú príbuznú je výrazne menší ako v prípade mužských príbuzných.

$\mathrm{Na}$ záver ešte dodajme, že vplyv iných jazykov sa ukázal byt' minimálnym, a to s výnimkou bulharčiny a macedónčiny (чичo, чичко). Rovnako lokálne inovácie sa prejavili len v týchto jazykoch (леля, нина), čo môže súvisiet’ s ich analytickým charakterom.

\footnotetext{
${ }^{5}$ Možno predpokladat', že v južnoslovanských jazykoch, ak budú postupovat' smerom k zjednodušeniu, prevládne rovnako ako $\mathrm{v}$ západoslovanských jazykoch pôvodne termín určený pokrvnému príbuznému. Aj z oblasti príbuzenskej terminológie sú však známe prípady, kedy bol celý systém plne nahradený termínom prevzatým z iného jazyka namiesto toho, aby bol využitý jeden z existujúcich termínov (napr. slk. či čes. švagor / švagr).
} 


\section{Závery}

Na základe vyššie uvedeného môžeme potvrdit', že zmeny v oblasti nepriameho a nepokrvného príbuzenstva $v$ generácii +1 (od ega) jednoznačne prebiehajú, i ked' v každej zo skúmaných vetiev iným spôsobom. Západoslovanské jazyky (a slovinčina) sa vydali smerom $\mathrm{k}$ výraznému zjednodušeniu terminológie, pričom južnoslovanské jazyky zachovávajú rozdiely medzi matrilineárnymi a patrilineárnymi, rovnako ako pokrvnými a nepokrvnými príbuznými. Najmä v druhej kategórii však môžeme na základe výsledkov z korpusového skúmania predpokladat' určité zjednodušenie, najmä v prípade označovania ženských príbuzných.

Rozlišovanie matkinho a otcovho brata $v$ jazyku môže súvisiet' so špecifickou pozíciou matkinho brata v živote jej detí. Alexander Pashos vysvetl'uje túto špecifickú pozíciu výraznejšími väzbami žien na svoju orientačnú rodinu. V posledných desat'ročiach sa však stretávame so zmenšovaním významu príbuzenských väzieb, ktoré sú nahrádzané alternatívnymi štruktúrami, najčastejšie inštitucionálneho charakteru. To znamená, že v prípade posilňovania či udržovania inštitucionálnych nástrojov, ktoré rodinu zabezpečujú a nahrádzajú tak pôvodne príbuzenstvu vyhradené úlohy (opatera detí či starých, sociálne zabezpečenie a pod.), bude zrejme pokračovat' aj stieranie rozdielov medzi jednotlivými príbuznými, a tým aj rozdielov v jazyku.

\section{Summary}

This paper discusses kinship terminology of West and South Slavic languages, more precisely its part naming parent's siblings and their partners (husbands and wives). First part of the paper is devoted to the origin of the terms in question, while the second one is presenting outcomes of our research, based mainly on corpus data. This paper points out the main tendencies, as well as minor deviations and changes that are taking place in these languages. In the concluding part, it also discusses possible reasons of the mentioned changes.

\section{Literatura}

Bremmer, J. The Importance of the Maternal Uncle and Grandfather in Archaic and Classical Greece and Early Byzantium. Zeitschrift für Papyrologie und Epigraphik. 1983 (17/50), s. 173-186.

Hraste, M. Nazivi za rodbinu i svojtu. Časopis za kulturu hrvatskoga knjiženog jezika. $1956(5 / 1)$, s. 1-4. 
Kohút, J. Rodinné názvy. Slovenské pohl'ady. 1883 (3/1), s. 200-201.

Králik, L. Stručný etymologický slovník slovenčiny. Bratislava: Veda, 2015.

Machek, V. Etymologický slovník jazyka českého. Praha: Lidové noviny, 2010.

Možný, I. O rodině - hrubý koncept elementárního přehledu. In: Socialistický způsob života jako sociální realita: Pracovní texty sympozia. Brno: UJEP, 1982, s. 2031.

Pashos, A. Asymmetric Caregiving by Grandparents, Aunts, and Uncles and the Theories of Kin Selection and Paternity Certainty: How Does Evolution Explain Human Behavior Toward Close Relatives? Cross-Cultural Research. 2017 (51/3), s. 263-284.

Parkin, R. The Contemporary Evolution of Polish Kinship Terminology. Sociologus. 1995 (45/2), s. 140-152.

Ujo. Slovnikový portál Jazykovedného ústavu L. Štúra SAV. Bratislava: Jazykovedný ústav L'udovíta Štúra SAV. Dostupné z: https://slovnik.juls.savba.sk/?w=ujo (2021-02-09).

Бјелетић, М. Терминологија крвног сродства у српскохрватском језику. Јужнословенски филолог. 1994 (50), s. 199-207.

Вуйчо. Речник на българския език. Sofia: Институт за български език. Dostupné z: https://ibl.bas.bg/rbe/lang/bg/вуйчо (2021-02-09).

Чичо. Речник на българския език. Sofia: Институт за български език. Dostupné z: https://ibl.bas.bg/rbe/lang/bg/чичо (2021-02-09).

Korpusové dáta boli získané prostredníctvom aplikácie SketchEngine. Dostupné z: https://www.sketchengine.eu. 



\title{
СИНОНИМИЧЕСКИЕ СООТВЕТСТВИЯ В ТЕМАТИЧЕСКОЙ ГРУППЕ «НАЗВАНИЯ ПИЩИ» (НА ПРИМЕРЕ ВОРОНЕЖСКИХ ГОВОРОВ)
}

\author{
Synonymous Matches in the "Food Names" Topic Group \\ (on the Example of Voronezh Dialects)
}

Keywords: synonymous matches, food names, nomination principles, vocabulary, Voronezh dialects

Contact: ВГУ; Darij98@yandex.ru

Одним из самых древних компонентов материальной культуры всех народов является пища. Она отличается устойчивостью и традиционностью, несмотря на определенные изменения во времени под влиянием различных факторов. Комплекс основных блюд дает представление о том, какие продукты растительного и животного происхождения окружали представителей того или иного народа в древности. Кроме того, способы приготовления и употребления пищи отражают старинные обычаи и исконное мировоззрение людей.

На русской территории особенности пищи были рассмотрены в трудах историков и этнографов Т.А. Ворониной, С.А. Арутюнова, В.В. Похлебкина, В.К. Соколовой, Л.Н. Чижиковой, М.Н. Шмелевой и др. На территории Воронежской области о блюдах и связанных с ними обрядах частично писали П. Малыхин, Д. Зеленин, А. Путинцев. С лингвистической точки зрения пища Воронежского края анализировалась в статьях И.К. Зайцевой (1977), а также в масштабном диссертационном исследовании Т.В. Карасевой (2004).

В нашей работе мы обратились к тому аспекту, который ранее не был рассмотрен на материале данной тематической группы воронежских говоров: синонимические соответствия и особенности их функционирования. Отметим, что «слова, обозначающие одну и ту же реалию и принадлежащие разным говорам, образуют ряд синонимических соответствий (параллелей)» (Блинова 1975: 168). Исследование лексики определенной тематической группы через призму синонимических соответствий способствует созданию более полной 
и систематизированной картины лексического состава какой-либо диалектной макросистемы.

В рамках нашего исследования был собран пласт лексики воронежских говоров, относящийся к названиям пищи; проведена систематизация выявленных лексем; построены синонимические ряды; обозначены принципы номинации синонимических соответствий; рассмотрены словообразовательные процессы.

Материалом нашего исследования послужили: 1. картотека «Словаря воронежских говоров»; 2. «Словарь воронежских говоров», вып. 1-3, 2004, 2007 , 2019 гг.; 3. персональная картотека автора.

В построенных рядах синонимических соответствий четко прослеживаются два основных источника возникновения диалектной синонимии: 1. различные принципы номинации вследствие неодинакового восприятия мира коллективом диалектоносителей; 2. словообразовательные процессы. Рассмотрим указанные источники на конкретных примерах.

Примером синонимического ряда, состоящего из лексем с различными принципами номинации, может служить ряд со значением 'картофельное пюре': бухо'ня - ду'тики - карто'шка мя'тая - карто'шная ка'ша - карто'шник-мя'тка - мяту'ха - толкани'цуа - толкано'к - толченка - топту'н. В данном ряду выделяются следующие номинации:

1. По основному продукту: карто'иник.

2. По способу приготовления:

- с мотивирующей основой мя-: мя'тка, мяту'ха;

- с мотивирующей основой топm-: топту'н;

- с корнем -толк- (-толч-): толкани'и̧а, толкано'к, толченка.

3. По консистенции:

- с мотивирующей основой бухон-: бухо'ня. Связано с мягкостью приготовляемого блюда. В русских говорах бухо'нить 'делать что-либо мягким, пышным’ (Курск.), бухо'нный ‘пышный, мягкий’ (Новг.), бухо'ный 'пышный, хорошо испеченный' (Волог., Яросл., Новг.Север., Твер., Курск) (СРНГ 1968: 324).

- с мотивирующей основой $\partial y m-:$ ду'тики. Связано с мягкостью, воздушностью, «дутостью» блюда. У В.И. Даля дутик 'раздутая вещь, пузырь', а также 'человек полный в лице или вообще плотный коротыш, толстячок' (Даль 1935: 518). В русских говорах бытует лексема $\partial y^{\prime} т н и к$ 
в значении 'пресная ржаная лепешка, облитая сверху раствором гороховой муки' (СРНГ 1972: 274).

В названиях, которые представляют собой словосочетания, соединяются два способа номинации: по основному продукту и способу приготовления: карто'шка мя'тая; по основному продукту и консистенции: карто'шная ка'ша.

Таким образом, в ряду синонимических соответствий со значением 'картофельное пюре' в воронежских говорах самым распространенным принципом номинации является способ приготовления (картофель мнут, толкут, mопчуm - это является определяющим признаком данного блюда).

Проанализировав все выявленные синонимические соответствия в тематической группе «Названия пищи», мы выделили самые частотные принципы номинации (приводятся фрагменты синонимических рядов):

1. Номинации по способу приготовления: дра'нки - дра'нчики - каварду'шки 'картофельные оладьи'. Происхождение слов дра'нки, дра'нчики связано с диалектным глаголом драть в значении 'измельчать, дробить', ‘тереть на терке (картофель)' (смоленское) (СРНГ 1972: 175). Слово кавардушки связано с глаголами кавардать, кавырдать, которые в воронежских говорах имеют значение 'ворочить, переворачивать', т.е. оладьи в процессе жарки переворачивают на сковороде, кавардают.

2. Номинации по основному продукту: костри'чник - крапи'вник - суп с жи'гой 'суп из крапивы'. Отметим, что костри'ка и жи'га - это названия крапивы в воронежских говорах.

3. Номинации по консистенции: дрожа'чка - дры'га - дря'зга'ло 'холодец'.

4. Номинации по форме: кола'бух - ко'лоб - кругля'к 'круглый хлеб; каравай'. Слова колабух и колоб восходят к древнерусскому коло 'круг' (Черных 1999: 411).

5. Номинации по вкусу: солоду'ха - солоду'шки 'свекольный суп'. Известно, что солод и продукты из солода имеют приятный, сладкий вкус.

Необходимо ответить, что самыми многочисленными рядами синонимических соответствий являются ряды, в которых представлены лексемы со значением: 'оладьи' - 14 синонимических соответствий, 'картофельные оладьи' - 12; ‘картофельное пюре' - 11; ‘холодец' - 10; ‘круглый хлеб; каравай’ - 7, 'картофель, сваренный в кожуре' - 7. 
Из приведенных рядов видно, что наибольшее количество синонимических соответствий называет блюда из картофеля (картофельные оладьи; картофель пюре; картофель, сваренный в кожуре), холодец, а также хлебобулочные изделия (оладьи, каравай). Следовательно, можно сделать вывод, что названные блюда являются одними из самых распространенными среди воронежских диалектоносителей.

Нельзя не отметить связь синонимии с многозначностью. Некоторые выявленные лексемы являются многозначными, т.е. входят в различные ряды синонимических соответствий данной тематической группы. Это может быть связано:

a) со сходством способа приготовления: сливуха 'картофельный суп' и 'каша из пшена и картофеля'. Отличительным признаком приготовления обоих блюд является сливание воды;

б) со сходством формы номинируемого блюда: колобышки 'пышки' и 'оладьи' (оба изделия имеют форму круга);

в) со сходством вкуса номинируемого кушанья: кислица 'каша из заваренной муки с добавлением различных ягод и фруктов' и 'щи с кислой капустой' (их объединяет кислый вкус);

г) с широким и размытым значением корня, который может отражать свойства различных блюд: дрочена 'кушанье из запеченной каши, молока и яиц', 'картофельные оладьи', 'яичница' .

Другим источником диалектной синонимии являются словообразовательные процессы. Большинство представленных лексем имеют общеславянские корни (варенуха, крошенка, мятка), являющиеся системными для русского национального языка. Активное функционирование исконных для исследуемой нами диалектной макросистемы корней обусловило образование новых слов с помощью аффиксов.

В тематической группе «Названия пищи» самым частотным способом образования является суффиксальный: гороховииа, грибник, солодуха и др. Зафиксированные синонимические соответствия являются именами существительными, которые могут образовываться от 1. существительных (караваеи $\leftarrow$ каравай); 2. прилагательных (грибник $\leftarrow$ грибной); 3. глаголов (крошенка $\leftarrow$ крошить). Среди суффиксов можно отметить следующие: $-y x$ (солодуха ‘свекольный суп', ‘блюдо из заваренной муки с добавлением 
свекольного сока'; затируха 'суп из затертой ржаной муки'; мятуха 'картофельное пюре'; глазуха 'яичница'), -ик- (ушник 'гречневый суп', 'гречневая каша' (от ушное); грибник 'грибной суп'), -'ак- (крутяк 'густая часть супа'; молошняк 'молочный суп'), -ок- (кулешок 'пшенный суп'; зварок 'компот'), -иц(щербциа 'уха'; кислица 'каша из заваренной муки с добавлением различных ягод и фруктов', ‘щи с кислой капустой').

Отметим, что выделяются ряды синонимических соответствий, которые состоят только из однокоренных слов, различия в словах обеспечиваются лишь аффиксами: кали'на - кали'нка - кали'нник 'каша из заваренной муки с добавлением различных ягод и фруктов (калины, яблок, вишен)'; тыл'квенник тылве'шник - тыквя'нка 'тыквенная каша'; варену'ха - зава'p - звар - зваро'к изва'р-изва'рчик-узва'р 'компот'.

Таким образом, наличие разнообразных блюд из определенного набора ингредиентов в воронежских говорах способствовало появлению богатства лексики, связанной с обозначением пищи. Выявленные синонимические соответствия отражают детализацию названий сходных явлений по каким-либо признакам, кажущимся важными носителям говора. Основными принципами номинации являются следующие: по способу приготовления, по основному продукту, по консистенции, по вкусу и по форме. Самым распространенным способом образования является суффиксальный, отмечается определенный набор суффиксов, которые участвуют в образовании слов в данной тематической группе. Проанализированный нами материал свидетельствует о большом количестве и активном функционировании названий пищи в воронежских говорах.

\section{Summary}

The article deals with synonymous correspondences in Voronezh food names. The paper presents the constructed synonymic series, describes the various principles of nomination, analyzes the word-forming processes. Therefore, a conclusion is made about the frequency of certain motivational signs, as well as about the features of the functioning of the identified synonymic correspondences. 
Дарья ГАЛЬЦОВА

Синонимические соответствия в тематической группе «Названия пищи»

(на примере воронежских говоров)

\section{Литература}

Блинова, О.И. Введение в современную региональную лексикологию. Томск: Издательство Томского университета, 1975.

Даль, В.И. Толковый словарь живого великорусского языка. В 4 m. Москва: Русский язык, 1935.

Карасева, Т.В. Названия пищуи в воронежских говорах (этнолингвистический аспект). Диссертаџия канд. филол. наук. Воронеж, 2004.

Ковалев, Г.Ф. (ред.) Словарь воронежских говоров. Bыn. 1-3. Воронеж: Издательский дом ВГУ, 2004-2019-.

Филин, Ф.П., Сороколетов, Ф.П., Мызников, С.А. (ред.) Словарь русских народных говоров. Bыл. 1-49-. Москва-Ленинград: Наука, 1965-2016-.

Черных, П.Я. Историко-этимологический словарь современного русского языка. I том. Москва: Русский язык, 1999. 


\title{
ОБЗОР СИМВОЛИЧЕСКОГО ЗНАЧЕНИЯ ЛЕКСЕМЫ КУКУШКА В СИНХРОНИЧЕСКОМ И ДИАХРОНИЧЕСКОМ АCПЕКТЕ
}

\author{
Overview of the Symbolic Meaning of the Cuckoo Lexeme \\ in the Synchronic and Diachronic Aspects
}

Keywords: concept, cuckoo, symbol, dominant feature, polysemy

Contact: МГОУ; lisenkobk@gmail.com

Среди всех восточноевропейских птиц кукушка - одна из немногих, для которой русский язык сохраняет мифологическую ассоциацию. Многие птицы в славянской культуре имели образно-символические значения, однако в современном языке связанные с ними фигуры речи чаще всего архаичны. Кукушка - элемент фразеологизмов и устойчивых выражений, активно используемых в современном языке, более того - с кукушкой связаны до сих пор широко известные ритуальные действия (например, подсчет количества «ку-ку» во время прогулки по лесу). В связи с этим интересно проследить взаимосвязь современных и древних элементов образа кукушки, а также определить, какие из ассоциативных элементов были утрачены, какие - сохранились в виде традиций и имеют тенденцию к утрате, а какие - надежно сохраняются в русском языке.

Цель работы - на основе анализа фольклорных материалов и современных текстов выявить особенности образа кукушки у восточных славян и в современной русской культуре. При подготовке к работе изучены труды А.В. Никитиной, А.В. Гуры, Т.В. Ковалевой, Т.А. Бернштам, Т.А. Голиковой и др., толковые, этимологические, этнолингвистические словари. Проанализированы фольклорные и текстовые источники (1706 текстов с упоминанием кукушки из НКРЯ, материалы словаря славянских древностей, сборников фольклорных материалов П.В. Шейна, А.В. Овсянникова и др., результаты запросов в поисковых системах «Яндекс» и «Google», статистика постинга в социальных сетях, материалы порталов «Стихи.ру» и «Проза.ру»). Архив примеров, 
иллюстрирующих различные символические значения образа кукушки, в статье атрибутирован в сносках (указаны автор, название произведения и год).

В методологическом отношении использован сравнительно-исторический анализ, типологический и семантический анализ материала, текстологический метод.

Наличие у кукушки мифологических черт отмечено во всех изученных научных работах. А.В. Никитина результаты исследований символики кукушки представляет в книге «Образ кукушки в славянском фольклоре» и в ряде статей, акцентирует внимание на исключительно женской символике кукушки в общеславянской традиции, при наличии андрогинных и мужских черт в западноевропейском фольклоре, обращает внимание на общеславянскую принадлежность сакральных функций кукушки, предполагает их индоевропейское происхождение, основой для формирования верований считает кукование, связываемое с функциями негативного предсказательства и вестничества (Никитина 2014). Кукушка предсказывает переходные моменты в жизни человека: смерть, брак, рекрутство, т.е. мотив потери другого человека, актуальный в первую очередь для женщины. Поэтому с птицей связана символика плача, женского горя, несложившейся судьбы. Кукушка в славянской культуре реализуется как сугубо женский образ «недоли»; плачеи и освобождения от горя, а также реализует контакты между мирами живых и мертвых.

А.В. Гура посвящает кукушке один из параграфов своей книги «Символика животных в славянской народной традиции» (Гура 1997: 682-709), упоминает о птице в разделах, посвященных ужу и ястребу. Отмечает, что кукушка в народном сознании наделена способностью к превращению (в ужа, ястреба, лягушку и т.д.), большинство связанных с кукушкой календарных примет предвещают неудачи, кукушка имеет символов-двойников, образ многократно используется в фольклоре. Выделяется женский весенний обряд крещения (похорон) кукушки. О нем подробно рассказывают Т.А. Бернштам, Л.И. Виноградова, Т.А. Зимина, Р.Е. Кедрина, В.А. Смирнов и др.

Выделим характеристики кукушки, на основе которых складывались мифологизированные представления о птице.

\section{Кукушка - плохая мать}

Одна из самых очевидных для современного человека характеристик в фольклорном тексте выражена слабо, хотя и развилась из биологической 
приметы кукушки - подкидывания своих яиц в чужие гнезда. Фиксируется в «Толковом словаре живого великорусского языка» В.И. Даля: «Кукушка беззаботная мать, покидающая детей», в тексте XIX века: «Какая-нибудь кукушка, вертихвостка, наплодит ребят и с легким сердцем подбрасывает к вам»1, в советских текстах, актуализируется в беллетристике к XX-началу XXI вв. «Словарь русского арго» (2002) дает определение кукушке: «Мать, бросившая или подбросившая кому-либо своего ребенка». В 2010-х гг. «кукушка» в этом значении часто встречается в записанной разговорной речи (блоги, форумы). По запросу «Мать-кукушка» в «Яндекс» находится три тыс. совпадений, в «Google» - 47 тыс.; преимущественно - новостные сюжеты о подброшенных или оставленных детях, личные истории. В современном русском языке выражение «мать-кукушка» имеет тенденцию к превращению в штамп публицистического стиля с резко отрицательной коннотацией. В социальных сетях хештег \#матькукушка используется с саркастическим оттенком - употребляется в первом лице авторами-матерями в значении 'неидеальная мать' без негативной коннотации, часто сопровождается смайлами, шутливыми подписями (около четырех тыс. публикаций в «Инстаграм»).

\section{Кукушка - несчастная мать, мать неблагодарных детей}

Мотив встречается в болгарских, полесских, южнорусских легендах, служит основой фольклорных песен. В варианте болгарской легенды в филина и кукушку превращаются брат и сестра, проклятые матерью за то, что не принесли воды; в Полесье - сама мать. В художественной литературе (по данным НКРЯ) сюжет встречается единожды, со ссылкой на предположительно фольклорный источник: «Ей было три года, я спела ей песенку про кукушку, которая потеряла детей» ${ }^{2}$. В современном русском языке мотив сохраняется через культуру не славянского, а ненецкого народа: ненецкая сказка «Кукушка» включена в хрестоматии для учеников начальной школы, на ее основе создан мультфильм, на ненецкую сказку находим ссылку у Л.К. Чуковской. Характеристика в современном русском языке проявляется слабо - вероятно, связано это с тем, что легенды бытовали на балканских и южнорусских территориях, общеславянского распространения не получили.

\footnotetext{
${ }^{1}$ Ср. Андреев, Л.Н. Валя. (1899).

${ }^{2}$ Ср. Чуковский, К.И. От двух до пяти. (1933-1965).
} 


\section{Кукушка - предсказательница}

В «Пословицах русского народа» В.И. Даля зафиксировано шесть пословиц с символом кукушки-предсказательницы, пять имеют негативный оттенок (кукует не к добру, горе вещует, к пожару, к неудаче, кукушка обманула, накуковав долгую жизнь). Ограниченная сфера предсказаний кукушки описана в XVIII веке у А.П. Сумарокова: кукушка, в отличие от хиромантика, «знает только то, сколько кому лет жить, а хиромантик знает то все, что кому ни будет» ${ }^{3}$. В дореволюционной литературе образ встречается редко («Вещеванью сердца верить - все равно что у кукушки о годах спрашивать» ${ }^{4}$, «ььи-то годы считала кукушка, и все сбивалась со счета, и опять начинала» ${ }^{5}$, «Кукушка, кукушка, через сколько лет я буду знаменитостью?» ${ }^{6}$ ).

\section{Кукушка - опасная, чужая}

Характеристика связана с одним из биологических отличий кукушки подбрасыванием яиц в гнезда других птиц, через эту особенность описывают понятие «кукушка» толковые словари С.И. Ожегова, Д.Н. Ушакова, Т.Ф. Ефремовой. Характеристику фиксирует словарь русского арго с двумя значениями - «агент милиции, подсаживаемый в камеру к преступникам под видом преступника, заключенного» и «человек, подсаженный в какую-л. компанию для сбора информации; доносчик». Агрессия в адрес кукушки чаще является не первичной, исходящей от других птиц, а реакцией на враждебные действия самой кукушки (бьют, мстя за то, что она не сама высиживала птенцов, а подкидывала яйца в чужие гнезда). Связана с «оборотничеством»кукушки одна и та же птица может быть кукушкой и ястребом, кукушкой и коршуном, кукушкой и удодом, т.е. маскировать свою сущность.

\section{Кукушка - «календарная» птица}

Характеристика не уникальна - большинство птиц были «календарными». Приметы делятся на две группы: связанные с прилетом и связанные с кукованием. Прилет кукушки в различных регионах был приурочен к различным датам церковного календаря: Благовещению, Лазаревой субботе, Чистому четвергу, Пасхе, моменту пасха. У А.В. Гуры (Гура 1997: 697) встречается наблюдение, что

\footnotetext{
${ }^{3}$ Ср. Сумароков, А.П. Приданое обманом. (1769).

${ }^{4}$ Cp. Полевой, Н.А. Клятва при гробе Господнем. (1832).

${ }^{5}$ Ср. Айхенвальд, Ю.И. Чехов. (1910).

${ }^{6}$ Ср. Будищев, А.Н. Молодой друг. (1901). 
ранний прилет кукушки предвещал плохой год и голод. В.И. Далем зафиксированы пословицы: «Кукушка до Егорья - к неурожаю и падежу скота», «Ранняя кукушка до опушки дерева - к голоду». Образ первой кукушки до сих пор сохраняется в фольклорной сфере.

\section{Кукушка - плакальщица; оплакивает мужа или брата}

У южных славян с кукушкой обычно ассоциируют сестру умершего, на российских территориях кукушкой чаще выступала вдова; в некоторых регионах во время обряда крещения / похорон кукушки обрядовую фигурку повязывали вдовьим платком. И.Ю. Попович-Липовац в 1879 г. пишет, что «въ народной поэзіи и обычађ женщинамъ и особенно вдовамъ дается названіе кукавицы (кукушки)»; Ф.И. Буслаев называет обыкновенным представление горюющей женщины в образе кукушки в южнорусской поэзии; В.И. Даль фиксирует пословицу «Не кукушка кукует, а жена горюет». Кукование символизировало поминальный плач. Восточные славяне голосили с кукушкой - уходили в лес и выплакивали боль. В XIX-начале XX века происходит актуализация мотива («Погибъ ты, родной, оставилъ кукушку, Оставилъ меня, черную вдову, И еще родныхъ четверо дњтей» $\left.{ }^{7}\right)$.

\section{Кукушка - символ женщины}

По мнению ряда исследователей, основная характеристика кукушки в славянской культуре. Само слово «кукуша», согласно «Словарю славянских древностей», использовалось как ласковое обращение к женщине; в польских загадках с ответом «кукушка» птица зашифрована под словом «рапі» - «женщина». Ф.И. Буслаев в 1861 г. отмечал всеобщность славянских преданий о превращении несчастных женщин в кукушек. Женская символика сохранилась в пословицах: «Кукушка соловушку журит», где кукушка - свекровь, а соловей - сноха (используется до сих пор - девять тыс. результатов в «Google», фиксация в словаре С.И. Ожегова); «Ночная кукушка дневную перекукует», где кукушки жена и мать одного мужчины. Женские образы отражает кукушка в свадебных обрядах и песнях. Широко распространенный географически обряд крещения (иногда - похорон) кукушки совершался девушками и женщинами. В обряде использовалась кукла-кукушка в женском обличии. Обряд сохранился в художественной литературе XIX века («Березка моя! Тут же и «кукушку

\footnotetext{
${ }^{7}$ Ср. Попович-Липовац, И.Ю. Черногорские женщины. (1897).
} 
крестят» $^{8}$ ), и в одной из версий сказки «Царевна-лягушка», где Василиса Премудрая обращается в кукушку.

\section{Кукушка - наказанная, согрешившая, порочная}

Мотив прослеживается во множестве легенд, преимущественно украинских и белорусских. Причины наказания связаны либо с любовно-брачной тематикой (в кукушку превращается дочь, проклятая матерью за отказ выйти замуж, распутная девка, королевна, отвергавшая всех сватов и т.д.), либо с религиозной (наказана за отказ накормить бога, подшучивание над Христом и святыми, работу на Пасху или Благовещение и т.д.). Словарь славянских древностей фиксирует наказание за подбрасывание яиц в чужие гнезда. Мотив встречается в текстах: «Она прежде человеком была и согрешила. Ее мать прокляла, вот она с тех пор и кукует» ${ }^{9}$, «Отчего же кукушка грђшная птица? - Оттого, что озорница, воръптица» ${ }^{10}$, «За то кукушку Бог наказал, навек без гнезда оставил, что в Благовещенье гнездо завила» ${ }^{11}$. Интересно трансформируется образ в художественной литературе, превращая кукушку в оскорбительное наименование или обращение («За делом воровал, кукушка ты этакая!» ${ }^{12}$ ).

\section{Кукушка - несчастная, одинокая, бездомная}

В обрядах и верованиях мотив выражен слабо, сохраняется в пословицах («О том и кукушка кукует, что своего гнезда нет», «Кукушка кукует, по бездомью горюет»). В языке реализован на лексическом уровне через глагол «куковать», который «Толковый словарь русского языка» С.И. Ожегова определяет как «испытывать лишения, бедствовать», с пометой (прост.), «Современный толковый словарь русского языка» Т.Ф. Ефремовой одним из значений называет «жить одиноко, без семьи», а «Словарь синонимов русского языка» «бедствовать». Помимо словарной фиксации лексем - через народную этимологию цветка «кукушкины слезки» («Старая кукушка летала, детей своих искала по опушкам, когда они куковали, и слезы на опушках теряла» ${ }^{13}$ ).

\footnotetext{
${ }^{8}$ Ср. Мельников-Печерский, П.И. В лесах. Книга вторая. (1871-1874).

${ }^{9}$ Ср. Краснова, Е. Груша. Из деревенских портретов. (1897).

${ }^{10}$ Ср. Лейкин, Н.А. Рыболовы. (1898).

${ }^{11}$ Ср. Бакланов, Г.Я. Дурень. (2002).

${ }^{12}$ Ср. Салиас, Е.А. На Москве. (1880).

${ }^{13}$ Сp. Зуров, Л. Иван-да-марья. (1969). 
Сохраняется в литературной традиции мотив бездомности («Пора мне завести гнездо, будет жить кукушкой!» ${ }^{14}$, «Племяннички как кукушки у меня: своего гнезда не вьют» ${ }^{15}$, «Плакалась на свою бездомную долю одинокая кукушка» ${ }^{16}$, «Может, как кукушки, и гнезд не вьете?» ${ }^{17}$ ) и одиночества («Во зеленой, темной роще кукушка кукует: одинокой сиротою девица тоскует» ${ }^{18}$, «Тоскливо надрывается лесная сирота, кукушка» ${ }^{19}$, «Остался дневальный посередке за столиком одинокой кукушкой» ${ }^{20}$ ).

Ярче остальных выражен мотив грусти - кукушка плачет, кукует жалобно, тоскливо («Кукушки нежный плач в глуши лесной звучит мольбой тоскующей и странной» ${ }^{21}$, «Тоскливо и призывно куковала кукушка» ${ }^{22}$, «Грустно и редко, будто не доверяя самой себе, куковала кукушка» ${ }^{23}$ ). В текстах XXI века не встречается.

На протяжении XX века образ терял негативную семантику. Если в 1913 году в книге «Эпитеты литературной русской речи» к слову «кукушка» подобраны примеры с резко негативным либо пренебрежительным значением: «Бестолковая (Пушкин); зловещая (Порфиров); игривая (Шмелев); «Кукушкабездомница» (В.Каменский); рябая (Аксаков, Мей); «Самолюбивая болтушка» (Пушкин); сиротливая (Фофанов)» ${ }^{24}$, то в текстах XX века встречаются и положительные коннотации («Есть ли вообще голос птицы прелестней, грустней, нежней и юней голоса кукушки!» ${ }^{25}$, «От реки напевно и нежно доносилось кукование последней кукушки» ${ }^{26}$, «Я видел кукушку. Говорят, это к счастью» $\left.{ }^{27}\right)$.

Анализ символа кукушки в диахронии демонстрирует, что как в славянской, так и в современной русской культуре символ многозначен, в различные исторические периоды одно или несколько значений актуализируются, остальные переходят в пассивный запас языка. Так, распространенная у древних славян

\footnotetext{
${ }^{14}$ Ср. Горький, М. Старуха Изергиль. (1895).

${ }^{15}$ Ср. Евдокимов, И.В. Колокола. (1925).

${ }^{16}$ Ср. Зуев-Ордынец, М. Сказание о граде Ново-Китеже. (1930).

${ }^{17}$ Ср. Руднев, Е. Рассказ об одном утре. (1959).

${ }^{18}$ Ср. Шевченко, Т. Во зеленой, темной роще... (1845).

${ }^{19}$ Ср. Мамин-Сибиряк, Д.Н. Золотуха. (1883).

${ }^{20}$ Ср. Черный, С. Солдатские сказки / Лебединая прохлада. (1932).

${ }^{21}$ Ср. Бальмонт, К. Зарождаюшаяся жизнь. (1894).

${ }^{22}$ Ср. Зензинов, В.М. Пережитое. (1953).

${ }^{23}$ Ср. Нагибин, Ю.М. Беглеи. (1977).

${ }^{24}$ Ср. Левенсон, А.А., Зеленецкий, А.Л. Эпитеть литературной русской речи. (1913).

${ }^{25}$ Ср. Бунин, И.А. Дневники. (1931-1939).

${ }^{26}$ Ср. Наживин, И.Ф. Евангилие от Фомы. (1933).

${ }^{27}$ Ср. Нагибин, Ю.М. Дневник. (1975).
} 
ассоциация с кукушкой как с женским и вдовьим символом в советские годы ослабевает, однако сильнее проявляется в культуре мотив «кукушкапредсказательница». В первой половине XX века на первый план выходит отождествление кукушки с одинокой, всюду гонимой несчастливицей. Доминирующую ассоциацию символ кукушки меняет и сейчас, превращаясь в русском языке из предсказательницы в непутевую мать. Ассоциация «кукушкавестник календаря» практически исчезла, а ассоциации «кукушка - опасная, чужая» и «кукушка - наказанная, согрешившая» используются в метафорическом значении 'доносчик, шпион' и 'нехороший, порицаемый человек'. Образы «кукушка - предсказательница», «кукушка - календарная птица», «кукушка плакальщица» и «кукушка - согрешившая, порочная» заслуживают подробного рассмотрения.

\section{Summary}

The analysis allows us to state the ambiguity of the image of the cuckoo in Slavic symbolism, its wide geographical distribution and variability, diachronic stability, the motif of an unhappy female fate common to all meanings of the image, the predominance of one or more characteristics over others in different periods of language development, and the preservation of the mythological meaning of the image today. The dynamic nature of the image allows us to conduct research based not only on folklore but also on modern language material.

\section{Резюме}

Проведенный анализ позволяет заявить о многозначности образа кукушки в славянской символике, его широкой географической распространенности и вариативности, диахронической устойчивости, общем для всех значений образа мотиве несчастливой женской судьбы, преобладании одной или нескольких характеристик над другими в разные периоды развития языка, сохранении мифологического значения образа сегодня. Динамичность образа позволяет проводить исследования на основе не только фольклорного, но и современного языкового материала. 


\section{Литература}

Бернштам, Т.А. Обряд «крещение и похороны кукушки». In: Путилов, Б.Н. (отв. ред.) Материальная культура и мифология. Ленинград, 1981, с. 179-203.

Гура, А.В. Символика животных в славянской народной традиции. Москва: Издательство «Индрик», 1997.

Даль, В.И. Толковый словарь живого великорусского языка: в 4-х т. Т. 2: И-О. Санкт-Петербург, Москва: Типография М.О. Вольфа, 1881.

Елистратов, В.С. Словарь русского арго (материальл 1980-1990 г2.). Режим доступа: http://gramota.ru/slovari/argo (2021-03-20).

Ковалева, Т.В. О чем вещает кукушка. Новости этнокультуры. 2004 (16), с. 233243.

Никитина, А.В. Образ кукушки в славянском фольклоре. Москва: ФЛИНТА, 2014.

Толстой, Н.И. (ред.) Славянские древности: этнолингвистический словарь в 5ти томах. Москва: Институт славяноведения РАН, 1995.

Национальный корпус русского языка. Режим доступа: https://ruscorpora.ru/ (202103-20). 



\section{DYSKURS POLSKICH MEDIÓW ALTERNATYWNYCH JAKO SPOSÓB TWORZENIA POSTPRAWDY}

\section{The Language of Polish Alternative Media as a Way of Creating Post-truth}

Keywords: media, post-truth, language, information, discourse

Contact: Uniwersytet Śląki w Katowicach; ewa.a.kozik@us.edu.pl

\section{Postprawda w nowych mediach}

Termin ,postprawda“ został pierwszy raz użyty przez Steva Tesicha w 1992, następnie w 2004 wykorzystał go Ralph Keyes w swojej książce The Post-Truth Era: Dishonesty and Deception in Contemporary Life, gdzie zwrócił uwagę moment, gdy w latach 50. $\mathrm{XX}$ wieku pojawiła się telewizja. Wtedy przekazywane przez media informacje zaczęły być konstruowane w taki sposób, by odbiorcy nie musieli podejmować racjonalnej analizy przekazywanych treści, których z racji szybszego tempa przekazu, pojawiało się znacznie więcej niż wcześniej. Media masowego przekazu oferowały uproszczone, schematyczne informacje, które w rezultacie w mniejszym bądź większym stopniu zniekształcały rzeczywistość społeczną. Już nie racjonalność i wiedza stanowiły podstawę decyzji odbiorcy o tym, której informacji może on zaufać i za kim podążyć (na przykład podczas wyborów prezydenckich), ale sam sposób przekazywania danej treści. Odwoływał się on nie tylko do doświadczenia odbiorcy, ale również do jego przekonań, wyznawanych przez niego wartości oraz nierzadko również odczuć i emocji (Pawełczyk, Jakubowski 2017: 198). Postprawda w tym ujęciu występuje jako wykreowany przez media wyobrażenie o stanie życia społeczno-politycznego, który powstaje w wyniku określonego sposobu przekazywania informacji w mediach.

Sposób ten uzależniony jest od języka, jakim posługuje się dane medium. Inaczej będzie wyglądało to w przypadku krajowej, publicznej telewizji, inaczej zaś w przestrzeni wirtualnej, gdzie etnolingwiści mają szansę zaobserwować charakterystyczny dyskurs medialny, powstały w wyniku interakcji pomiędzy nadawcą a odbiorcą komunikatu. Dyskurs, będący zjawiskiem językowym, to inaczej „rozbudowane akty mowy i teksty pisane w relacji do ich kontekstów społecznych“ (Faiclough, Duszak 2008: 7), zaś jego analiza pozwala zbadać i określić, w jaki sposób 
dyskurs odzwierciedla postawy, ogólne nastroje oraz tendencje swoich użytkowników. Umożliwia to koncepcja dyskursywnego obrazu świata opracowana przez Waldemara Czachura bazująca na wcześniejszej teorii językowego obrazu świata, według której język, myśl i rzeczywistość tworzą wzajemnie oddziałującą na siebie triadę, która oddaje nie tylko językowy sposób opisu rzeczywistości, ale również sposób postrzegania i myślenia członków danej społeczności (Grzegorczykowa 2015: 7-10). Waldemar Czachur pisze o powszechnie akceptowanej wiedzy dystrybuowanej przez media oraz struktury władzy panujące w danej społeczności (Czachur 2011: 81). Przekazy medialne tworzą zbudowany przez różne rodzaje znaków, środki retoryczne oraz niewerbalne dyskurs, który konstruuje obraz świata.

Celem niniejszego tekstu jest opis sposobu przekazywania informacji dystrybuowanych w polskich mediach alternatywnych oraz wskazanie wpływu tychże przekazów na powstawanie stanu postprawdy wśród użytkowników omawianego dyskursu. Definicja mediów alternatywnych nastręcza tutaj niejakich trudności ze względu na to, że są one zawsze alternatywne względem czegoś. W tym przypadku krytycznej analizie dyskursu zostały poddane polskie media funkcjonujące w przestrzeni wirtualnej, będące alternatywą wobec mediów głównego nurtu, przekazujących oficjalnie przyjęte narracje, dystrybuowane przez państwowych ekspertów oraz systemy władzy. Analizie poddane zostały dane zebrane podczas badań netograficznych przeprowadzonych od 11 marca 2020 do 10 marca 2021 roku. Dane te dotyczą przede wszystkim wątków okołomedycznych, które ze względu na wybuch pandemii koronawirusa SARS-CoV-2 w 2019 roku, stały się dominującym tematem w dyskursie polskich mediów alternatywnych.

\section{Polskie media alternatywne}

Jak zostało już zasygnalizowane, podstawowym celem mediów alternatywnych jest produkcja treści konkurencyjnych względem mediów głównego nurtu. Wszak nie jest to ich najważniejsza cecha, ponieważ w świetle niniejszych rozważań ważniejsza jest ich funkcja komunikacyjna. Komunikacja może być rozumiana jako siła sprawcza pomiędzy jednostkami a różnymi organizacjami społecznymi (Pielużek 2006: 215). Jednostki te, czyli odbiorcy alternatywnych mediów należą często do ściśle określonych subkultur, których członkowie podzielają określone wartości, a ich światopogląd jest do siebie co najmniej zbliżony. Jest to jedna z cech, która odróżnia media alternatywne głównego nurtu informacyjnego, który z reguły przekazuje zróżnicowane tematycznie treści bliżej nieokreślonemu odbiorcy, w ten sposób starając się dotrzeć do ogółu społeczeństwa. Celem oficjalnego, telewizyjnego programu informacyjnego jest 
dotarcie do jak największego grona, bez względu na osobiste poglądy, wyznanie lub orientację polityczną potencjalnych odbiorców. Natomiast media alternatywne konstruują informacje z myślą o konkretnym profilu odbiorcy. Komunikują o problemach społecznych pozostając ponad wszelkimi partiami oraz organizacjami, funkcjonują jako niezależne, niskobudżetowe inicjatywy oddolne, tworzone przez nieprofesjonalnych dziennikarzy i reporterów (Pielużek 2006: 215-216). Tym, co dodatkowo je wyróżnia jest konkretny, ideologiczny cel ich powstania i funkcjonowania. Motywacją twórców mediów alternatywnych jest nie tylko przekazywanie informacji odbiorcom o określonym profilu światopoglądowym, ale również (a czasem przede wszystkim) potwierdzanie słuszności podzielanych poglądów i wartości, dążenie do ich wzmocnienia oraz poszerzania zasięgu w celu uzyskania nowych odbiorców, a co za tym idzie wzmocnienia i potwierdzenia słuszności postulowanych postaw, norm i wartości. Media alternatywne często mają charakter radykalny, gromadząc wśród swoich twórców i odbiorców osoby bardzo mocno przywiązane do określonych wartości i poglądów, jak i do wyznawanej religii oraz nieoficjalnej wersji niektórych wydarzeń historycznych. Według Helmutha Plessnera radykalizm „oznacza unicestwienie zastanej rzeczywistości w imię idei, która może być racjonalna lub irracjonalna, ale zawsze jest nieskończona (...). Wszystko, co konkretne pozwala jedynie przeczuć, jakie są jego części składowe; radykalizm chce je natomiast odseparować i z jednej uczynić twórczą zasadę tego, co konkretne“" (Plessner 2008: 12).

Niniejsza analiza opiera się na danych zebranych $w$ jednym z najpopularniejszych polskich mediów alternatywnych, którym jest internetowa telewizja „wRealu24“1. Swój przekaz kieruje ona do konkretnego odbiorcy, którym jest Polak-patriota, katolik, otwarcie sprzeciwiający się aktualnie rządzącemu ugrupowaniu politycznemu, wykluczający wszelkie laickie nurty myślowe oraz lewicowe ugrupowania polityczne. Telewizja „wRealu24“ powstała w 2014 roku w odpowiedzi na informacje pochodzące $\mathrm{z}$ mediów głównego nurtu dotyczące tzw. kryzysu uchodźczego. Jej celem było zwalczenie narracji zachęcającej polskie społeczeństwo do pomocy migrantom z Bliskiego Wschodu i Afryki Północnej. Na bazie tych wydarzeń telewizja ta zyskała szerokie grono odbiorców ${ }^{2}$, które systematycznie się mnoży. Tworzone i wyświetlane tam programy (głównie informacyjne oraz o charakterze talkshow) $\mathrm{z}$ biegiem czasu stają się coraz bardziej profesjonalne pod względem technicznym i coraz mocniej przypominają programy znane odbiorcy z oficjalnych kanów telewizyjnych. Poruszana w nich tematyka zawsze dotyczy aktualnych

1 Źródło: https://wrealu24.tv/; https://www.youtube.com/channel/UCiwsDgj8mJnsGOr6oN-2OVQ (dostęp: 2021-02-13).

${ }^{2}$ „,wRealu24“ nie udostępnia statystyk dotyczących ilości odbiorców przekazywanych treści, jednak na podstawie liczby wyświetleń na „YouTube“ można szacować, że jest ich około miliona. 
problemów społecznych, informacje przekazywane są z perspektywy Polaka-patrioty, pragnącego chronić swój kraj, swoją rodzinę oraz zdrowie przed szkodliwymi zewnętrznymi wpływami ${ }^{3}$, którymi według przyjętej wersji twórców „wRealu24“ w czasie pandemii koronawirusa okazują się być przede wszystkim medycy, wirusolodzy, epidemiolodzy oraz producenci szczepionek ${ }^{4}$.

\section{Retoryka mediów alternatywnych}

Niemal od początku trwania pandemii SARS-CoV-2 telewizja „wRealu24“ wyrażała w swoich licznych programach wątpliwość $\mathrm{w}$ istnienie nowo powstałego wirusa wywołującego chorobę Covid-19. Narracja dziennikarzy tworzących owe medium przechodziła przez wiele etapów: od negacji jego występowania (od stycznia do kwietnia 2020 roku), poprzez bagatelizowanie niebezpieczeństwa epidemiologicznego (przez cały czas trwania badań) aż po kwestionowanie decyzji rządzących dotyczących konieczności noszenia masek ochronnych $\mathrm{w}$ miejscach publicznych, ograniczenia kontaktów społecznych oraz zalecenia zastosowania szczepionki przeciwko koronawirusowi (przede wszystkim od czerwca 2020 do marca 2021 roku). Pomimo braku konsekwencji dotyczącej sposobu informowania o pandemii w Polsce i na świecie (najpierw negowano istnienie wirusa, po czym zmieniono nastawienie wobec niego, głosząc, że koronawirus SARS-CoV-2 istnieje, jednak nie jest tak groźny, jak głoszą to media głównego nurtu), wszystkie wyróżnione etapy łączy nieufność względem informacji podawanych przez oficjalne media oraz struktury władzy, a także niemal całkowita negacja autorytetu nauki oraz samych naukowców, w szczególności zaś medyków, epidemiologów, wirusologów i producentów szczepionek.

Twórcy telewizji „wRealu24“ zdecydowali się szerzyć pogląd o ukrytym celu wybuchu „rzekomej“ ich zdaniem pandemii, natomiast model jej zwalczania oparty o reżim sanitarny, dystans społeczny oraz stosowanie szczepionek zinterpretowali jako strategię przejęcia kontroli nad społeczeństwem. Odpowiedzialnymi za obecny stan rzeczy uczyniono w ich wypowiedziach bliżej nieokreślone światowe elity, do których zaliczono między innymi decydentów państwowych (prezydentów, premierów, ministrów). W tym świetle telewizja „wRealu24“ wpisuje się w nurt teorii spiskowych, których głównym wyznacznikiem jest taka interpretacja zjawisk i zastanej sytuacji społecznej, która zakłada, że za wszelkimi wydarzeniami kryje się podstęp osób pragnących zdobyć władzę i kontrolę nad światem (Czech 2015: 13). Telewizja ta

\footnotetext{
${ }^{3}$,wRealu24“ wskazuje na różne ugrupowania, instytucje oraz osoby, mogą nimi być ugupowania rządzące, Unia Europejska, Federacja Rosyjska, muzułmanie, społeczność LGBT itp.

${ }^{4}$ Źródło: https://www.youtube.com/watch?v=MDOSMTM_74s, (dostęp: 2021-01-25).
} 
przekazuje takie informacje, które mają obudzić czujność widzów, skłonić do podważenia oficjalnie przyjętej narracji o pandemii oraz zachęcić do otwartego sprzeciwu wobec rządowych decyzji. W rezultacie odbiorcy „wRealu24“ stanowią społeczność o charakterze kontestującym. W nurcie idei przekazywanej na tym kanale, czują się oni zobowiązani do kontynuowania misji uświadamiania społeczeństwa o kłamstwach naukowców i ekspertów, dla których walka z pandemią jest płaszczem przykrywającym szkodliwe społecznie zamiary.

Chcąc przekonać licznych odbiorców do danej wersji bieżących wydarzeń oraz swojej własnej opinii na ich temat, dziennikarze i reporterzy tworzący treści dla „wRealu24“ używają specjalnej retoryki. Retoryka jest sztuką przekonywania o tym, co dana osoba uważa za prawdziwe, posługuje się znakami wyrażającymi emocje i sądy o rzeczywistości (Pisarek 2000: 214). Naturalnym wydaje się stosowanie retoryki w codziennych sytuacjach, takich jak na przykład targowanie się ze sprzedawcą jabłek, który żąda wygórowanej ceny za małe i kwaśne owoce, chcąc przekonać go, że cena powinna odpowiadać jakości. Retoryka stanowi na tyle ważny aspekt posługiwania się systemem językowym, że nie raz trudno jest przekazać jakikolwiek komunikat lub wyrazić sąd na temat danego zjawiska bez stosowania środków retorycznych. Przykładowo, targując się ze sprzedawcą jabłek pomocne będzie wspomnienie mu o niższej cenie widzianej u innego sprzedawcy za ten sam rodzaj owoców.

Czy stosowanie podobnych środków retorycznych, a więc mających przekonać do prezentowanego przez nas stanowiska, powinno być powszechne w dziennikarstwie? Najprawdopodobniej bez ich stosowania dziennikarstwo nie mogłoby w ogóle istnieć. Warunkiem istnienia każdego medium jest jego popularność wśród odbiorców, dlatego twórcy wszelkich programów informacyjnych, artykułów prasowych lub audycji radiowych muszą stale zastanawiać się, jak przekazać informacje, by odbiorca zwrócił uwagę na określone medium, poświęcił mu swój czas, by wysłuchać, przeczytać lub obejrzeć, a dodatkowo zrozumiał przekazywaną mu treść, zgodził się z nią i zapamiętał (Pisarek 2000: 218). Media głównego nurtu, o ile nie są kontrolowane przez struktury władzy, a istnieją jako mniej lub bardziej niezależne instytucje, ograniczają swoją retorykę do stosowania takich środków retorycznych, by możliwie uatrakcyjnić przekazywane treści, mające trafić do licznego i zróżnicowanego grona odbiorców. Retoryka dziennikarska oscyluje w tym przypadku wokół takiej selekcji informacji, która narzuca wybór tego, o czym społeczeństwo chce słuchać, przy czym stara się przekazywać treści zgodne z obiektywnymi faktami. Retoryka dziennikarska powinna więc przekonywać głównie do tego, by odbiorca chciał poświęcić swoją uwagę danemu medium. 
Natomiast retoryka mediów alternatywnych jest zgoła odmienna, staje się retoryką per se, której celem jest przekonanie do tej wersji wydarzeń, którą głoszą niezależni, oddolni dziennikarze. W rezultacie środki retoryczne stosowane przez telewizję „wRealu24“ są liczniejsze, bardziej dosadne, a ich stosowanie nie jest dyskretne ani subtelne. To oznacza, że odbiorca niezrzeszony ze wspólnotą, jaka utworzyła się wśród odbiorców tego kanału, bardzo szybko jest w stanie zrozumieć, że przekazywane mu treści mają funkcję kształtowania i uzasadniania poglądów, niejako narzucają pewien sposób bycia w świecie i nie są dedykowane każdemu.

$\mathrm{Na}$ początku każdego programu dziennikarze tworzący tą telewizję witają odbiorców słowami: „Dzień dobry, witamy w «wRealu24», propolskiej, oddolnej, niezależnej telewizji dla prawdziwych patriotów“"5, co można odebrać jako komunikat, że osoby nie czujące się polskimi patriotami, nie muszą, a być może nawet nie powinni oglądać danego programu. Na temat samego sformułowania „prawdziwy patriota“ i innych używanych w „wRealu24“ określeń należy napisać osoby artykuł, dlatego nie będę rozwijać typu kwestii, zaznaczam jedynie, że tego rodzaju nawyki językowe i środki stylistyczne (w tym wypadku epitety stałe) stosowane przez dziennikarzy „wRealu24“ są dowodem na instnienie wspomnianego wcześniej konkretnego profilu odbiorcy kanału ,wRealu24“.

Jednym z najczęściej stosowanych środków retorycznych tego medium jest używanie języka potocznego, co oznacza, że poprawność językowa, prawidłowe stosowanie nazw własnych oraz specjalistycznych określeń nie jest priorytetem. Zamiast dyscypliny językowej oraz stylistycznej, dziennikarze „wRealu24“ obficie stosują neologizmy, takie jak przykładowo: „covidioci“ i „plandemia““6. Nie unikają również wulgaryzmów, używając ich z zamiarem wzmocnienia wypowiedzi. Znacznie częściej niż w mediach głównego nurtu decydują się na bezpośredni zwrot do odbiorcy, mieszając przy tym oficjalny styl wypowiedzi z poufałym, przykładowo: „Szanowni Państwo, to od was zależy, czy prawda wygra“"7. Te i wiele innych środków językowych sprawiają, że przekazywane informacje odwołują się nie tylko do wiedzy, poglądów i codziennego doświadczenia odbiorców, ale również do emocji, które pełnią istotną rolę w procesie przetwarzania, akceptacji i utożsamiania się z otrzymywanymi danymi. W rezultacie odbiorcy słysząc wezwanie do „walki o wolnośćc, „sprzeciwienia się

\footnotetext{
${ }^{5}$ Zob. np.: https://www.facebook.com/TelewizjawRealu24/videos/158809489471395, (dostęp: 2021-12-14).

${ }^{6}$ Zob. np.: https://www.youtube.com/watch?v=eskujCTH0mE, (dostęp: 2020-04-04).

7 Zob. np.: https://wrealu24.tv/na-zywo/szokujace-info-lekarzy-ws-testow-na-covid-jest-falszywa-s-i-r-opandemicznym-bezprawiu, (dostęp: 2020-08-07).
} 
nakazowi noszenia kagańców ${ }^{8}$ oraz zachowania dystansu społecznego“9 czują się jeszcze mocniej zaangażowani w realizację misji inicjowanej przez twórców „wRealu24“

Według koncepcji językowego i dyskursywnego obrazu świata taki sposób przekazywania komunikatów kształtuje pewną rzeczywistość społeczną i narzuca jej odbiorcom obraz konstruowany według przesłania płynącego $\mathrm{z}$ informacji dystrybuowanych przez media. Kiedy do niniejszego dyskursu dodajemy retorykę odwołującą się do poglądów, wartości i emocji, z analizy wyłania się wizja kanału telewizji internetowej, który posiada potencjał i charakter oddolnego ruchu kontestującego ogólnie przyjętą, oficjalną narrację dotyczącą walki z pandemią. Tym samym wzywa on do walki z systemem, równocześnie podważając przyjęte normy zachowania i etyki dziennikarskiej.

Telewizja „wRealu24“ neguje autorytet nauki oraz naukowców, którzy w mediach głównego nurtu występują $\mathrm{w}$ roli ekspertów, a ich wiedza i doświadczenie mają stanowić dla ogółu społeczeństwa swoistą gwarancję bezpieczeństwa. Opiera się ona na zaufaniu do ekspertów z różnych dziedzin. Zaufanie to powinno polegać na przekonaniu, że eksperci wiedzą, co robią, a swoją wiedzę chcą wykorzystać dla dobra ogółu (Giddens 2012: 182-186). Dyskurs „wRealu24“ zdradza utratę zaufania do ekspertów i ich wiedzy. Poprzez podważenie nauki jako takiej i uznanie jej za systemową, odgórną metodę manipulacji społeczeństwem ${ }^{10}$, podważona zostaje również wiarygodność osób reprezentujących naukę, w tym przede wszystkim medycynę konwencjonalną. Dyskurs ten absolutyzuje wrażenia dotyczące jednej osoby lub jednego zjawiska na całokształt grupy, do której ona należy, dlatego w wyniku sukcesywnego zaprzeczania postanowieniom medyków i wirusologów, neguje się zasadność twierdzeń całego środowiska naukowego związanego z medycyną.

\section{Dyskursywne tworzenie wspólnoty}

Ta krótka analiza niektórych elementów retoryki polskich mediów alternatywnych pozwala sformułować kilka wniosków, które zasługują na dalsze rozwinięcie w innych tekstach naukowych poświęconych niniejszej tematyce. Dyskurs zawsze wpływa na obraz świata swoich użytkowników, a w przypadku polskich mediów alternatywnych, w tym przypadku telewizji „wRealu24“ oddziaływanie to jest wzmacniane poprzez

\footnotetext{
${ }^{8}$ Czyli noszenia maseczek ochronnych, hamujących rozprzestrzenianie się wirusów.

9 Zob. np.: https://wrealu24.tv/film/pilne-czy-pis-wprowadzi-stan-wyjatkowy-czy-to-juz-dyktatura-smichalkiewicz-wrealu (dostęp: 2021-01-25).

${ }^{10}$ Źródło: https://www.youtube.com/watch?v=68M8fMys7IQ, (dostęp: 2021-01-25).
} 
stosowanie specyficznych środków retorycznych. Wśród nich najmocniej na odbiorcę wpływa stosowanie prostego, powszechnie zrozumiałego języka potocznego oraz odwoływanie się do doświadczenia i wiedzy potocznej odbiorcy zamiast do skomplikowanych twierdzeń naukowych. Ogromne znaczenie zdaje się mieć również nawiązywanie psychicznej i emocjonalnej więzi zodbiorcą poprzez regularne odwoływanie się do podzielanych przez niego wartości i poglądów.

Wszystkie te elementy retoryki dziennikarzy „wRealu24“ przyczyniają się do zaistnienia wśród odbiorców tej telewizji stanu postprawdy, świata informacji akceptowanych i przyjmowanych według własnego uznania, a nie w wyniku ścisłej analizy faktów. Stan postprawdy gwarantuje odbiorcom „wRealu24“ poczucie orientacji $\mathrm{w}$ świecie, który podczas trwania pandemii koronawirusa SARS-CoV-2 diametralnie się zmienił.

Dodatkowo, stan postprawdy zawiera w sobie element, który dla współczesnego odbiorcy może wydawać się szczególnie atrakcyjny. Skoro postprawda zawiera w sobie komponenty odwołujące się do wspólnych wartości i generuje powstawanie określonych postaw społecznych, można założyć, że sprzyja ona tworzeniu się wspólnoty. Zapośredniczony przez internetowe komunikatory kontakt dziennikarzy „wRealu24“ z widzami oraz stale powtarzające się zwroty do adresatów budują poczucie więzi oparte dodatkowo o poczucie wspólnoty doświadczania tych samych przeżyć, niepokojów, niesprawiedliwości oraz nadziei i radości. W tym świetle należy zadać pytanie: czy zgodnie $\mathrm{z}$ teorią dyskursywnego obrazu świata radykalne medium tworzy radykalną wspólnotę?

\section{Summary}

This article presents a critical analysis of the discourse of Polish alternative media in the context of the SARS-CoV-2 coronavirus pandemic lasting from 2020. Materials taken from the Internet TV "wRealu24" were analyzed, on the basis of which it was shown how the rhetoric of alternative media contributes to the formation of the state of posttruth. In order to analyze the data collected in 2020 and 2021, the concept of the discursive worldview and the postmodern theory of Anthony Giddens were used. Issues such as the loss of confidence in medical specialists and scientists were raised. Linguistic mechanisms contributing to the creation and strengthening of the community of recipients of "wRealu24" were also indicated. 


\section{Literatura}

Fairclough, N., Duszak, A. Krytyczna analiza dyskursu - nowy obszar badawczy dla lingwistyki i nauk społecznych. In: Duszak, A. Fairclough N. (eds.) Krytyczna analiza dyskursu. Interdyscyplinarne podejście do komunikacji społecznej. Kraków: Universitas, 2008.

Czachur, W. Dyskursywny obraz świata. Kilka refleksji. „Tekst i dyskurs”. 2011 (4), s. 79-97.

Czech, F. Spiskowe narracje i metanarracje. Kraków: Nomos, 2015.

Giddens, A. Nowocześność i tożsamość. Warszawa: Wydawnictwo Naukowe PWN SA, 2001.

Grzegorczykowa, R. Co to jest językowy obraz swiata i dlaczego warto go badać. In: Dubisz, S. (ed.) Poradnik językowy. Warszawa: Elipsa, 2015, s. 7-13.

Pawełczyk, P., Jakubowski, J. Postprawda i nowe media. Czy potrzebujemy postprawdy? Środkowoeuropejskie Studia Polityczne, 2017 (1/197). Dostęp z: https://doi.org/10.14746/ssp.2017.1.11 (2020-12-13).

Pielużek, M. Teorie radykalnych mediów alternatywnych Radykalne media alternatywne - modele Downinga i Attona. In. Graszewicz, M. Jastrzebski J. (ed.) Teorie komunikacji i mediów. Tom 3, Wrocław: Wrocławskie Wydawnictwo Oświatowe, 2010, s. 215-228.

Pisarek, W. Podstawy retoryki dziennikarskiej. In: Bauer, Z. Chudzińsk, E. (eds.) Dziennikarstwo i świat mediów. Kraków: Universitas, 2000, s. 214-231.

Plessner, H. Granice wspólnoty. Krytyka radykalizmu społecznego. Warszawa: Oficyna Naukowa, 2008.

\section{Źródła internetowe}

Dostępne z: https://wrealu24.tv/; https://www.youtube.com/channel/UCiwsDgj8mJns GOr6oN-2OVQ (2021-02-13).

Dostępne z: https://www.youtube.com/watch?v=MDOSMTM_74s (2021-01-25).

Dostępne z https://www.facebook.com/TelewizjawRealu24/videos/158809489471395 (2020-12-14).

Dostępne z https://www.youtube.com/watch?v=eskujCTH0mE (2020-04-04). 
Dostępne z https://wrealu24.tv/na-zywo/szokujace-info-lekarzy-ws-testow-na-covidjest-falszywa-s-i-r-o-pandemicznym-bezprawiu (2020-08-07).

Dostępne z.: https:/wrealu24.tv/film/pilne-czy-pis-wprowadzi-stan-wyjatkowy-czy-tojuz-dyktatura-s-michalkiewicz-wrealu (2021-01-25).

Dostępne z: https://www.youtube.com/watch?v=68M8fMys7IQ (2021-01-25). 


\title{
ПОГОДНЫЕ ЯВЛЕНИЯ В ПРИРОДЕ В РУССКОЙ ЯЗЫКОВОЙ КАРТИНЕ МИРА
}

\author{
Weather Phenomena in Nature \\ in the Russian Language Picture of the World
}

Keywords: weather phenomena, linguistic picture of the world, folklore, omens, proverbs, riddles

Contact: МГПУ; annaandreevna99@yandex.ru, kolgsonya@gmail.com, Petropavlova.darya@yandex.ru

Каждый народ характеризуется своей культурой. Народное творчество отражает результаты художественной деятельности народа, оно выстраивается сквозь года, из поколения в поколение. Устное народное творчество вбирает в себя всю мудрость народа, его отношение к жизни.

Фольклор подразделяется на разные жанры, такие как: загадки, пословицы и поговорки, приметы, сказки, легенды, былины и другие. Каждый жанр имел свои черты и особенности, но все они отражали опыт наблюдения народа за окружающей действительностью. Фольклор служил в том числе источником просвещения: через народное творчество передавались научные знания о природе.

Одним из самых распространенных жанров устного народного творчества являются приметы. Обратимся к «Толковому словарю русского языка» С.И. Ожегова, в котором отмечается: 1. Отличительное свойство, признак, по которому можно узнать, кого-что-нибудь. Приметы весныл. Особые приметы (характерные индивидуальные признаки). 2. Явление, случай, которые в народе считаются предвестием чего-нибудь. Верить в приметьл. Дурная примета. Есть приметы: просыпанная соль - к ссоре. Сбылась старая примета. ${ }^{1}$

\footnotetext{
${ }^{1}$ Режим доступа: https://slovarozhegova.ru/word.php?wordid=23881 (2021-03-22).
} 
Народные приметы - жанр, который отличается своим содержанием и объемом, структурой. С древности приметы носили бытовой характер, они подразумевали совет или наставление, которое давалось человеку с целью предотвратить или обозначить какое-либо явление или событие. Приметы также отражают причинно-следственные связи в природе.

Приведем в пример примету, которую достаточно часто можно услышать в речи людей: Ласточки низко летают $-\kappa$ дождю. В данной примете описывается такое погодное явление как дождь. Если рассматривать данную примету с научной точки зрения, то можно объяснить истинную причину этого явления.

Примету изучали орнитологи и энтомологи. Научное обоснование заключается в уровне влажности накануне дождя. Уровень влажности воздуха это количество влаги, которая содержится в одном кубометре воздуха. Уровень влажности зависит от температуры воздуха и атмосферного давления. Распределение влажности также зависит от местоположения, рода поверхности и рельефа земли, характера растительного покрова. По мере возрастания широты и убывания температуры абсолютная влажность понижается. В преддверии дождя атмосферное давление падает, а влажность повышается, тем самым оказывается влияние на полет насекомых. Во время полета на них оседает небольшое количество капель воды, которые скапливаются на крыльях. Это делает их массу больше. При изменении массы тела меняется масса крыльев, что приводит к затруднению полета. Именно поэтому насекомые «спускаются» ниже к земле. Вслед за насекомыми меняют свою траекторию полета и сами птицы, так как ласточки питаются в основном летающими насекомыми.

Если рассматривать данную примету с языковой точки зрения, то можно сделать выводы, что люди во время наблюдения за погодными явлениями обратили внимание на определенную закономерность: как только траектория полета ласточек меняется с одного уровня на другой, спустя небольшое количество времени, начинаются осадки. Люди определяли погоду исходя из наблюдения за птицами, не задумываясь об истинной причине данного явления.

Также существует и мистическая сторона этой приметы: многие народы России считают, что ласточки - это птицы, которые могут общаться с душами умерших людей. Люди связывали явление с этим фактом и были уверены, что, спускаясь ближе к земле, ласточки передают весточку родственникам. В следствие чего люди плакали, что и считалось причиной изменения погодных явлений. 
Приведем в пример еще одну примету, которую можно отнести к теме дождя: Воробьи купаются в пьли - к дождю. Рассмотрим примету с научной точки зрения. Ключ к разгадке данного явления также кроется в изменении влажности и атмосферного давления. При понижении атмосферного давления повышается активность паразитов, которые живут в перьях у птиц. Высокая активность вызывает у воробьев зуд, и для того, чтобы от него избавиться, они купаются в песке, тем самым очищая перья. Народ, наблюдая за данным явлением, видел определенную логику: птицы купались в песке - следом шел дождь.

В фольклоре существует множество разнообразных примет, которые раскрывают сущность погодных явлений. Большинству примет можно дать научное объяснение: Красный закат - летом к ветреной погоде, зимой-кморозу; Лягушки громко квакают - кясной погоде, тихо - к дождю; Перед стихией становится тихо; Сильная роса на траве - дождя не будет; Солнце село в облаках - жди дождя; Кузнечики стрекочут к хорошей погоде; Черемуха изветет к холодам; Паук плетет паутину - к ясному дню; Чайки сидят на воде к ясной погоде, и многие другие.

Таким образом, можно сделать вывод, что приметы имеют большое значение в устном народном творчестве. В них содержится мудрость и представления о мире, о явлениях природы. Анализ примет с разных точек зрения и поиск научного объяснения помогают узнать причину событий, а также взглянуть на привычный мир людей их глазами.

Одним из жанров народного творчества является загадка. В «Толковом словаре русского языка» С.И. Ожегова загадка определяется как изображение или выражение, нуждающееся в разгадке или истолковании. ${ }^{2}$ Иными словами загадка подразумевает под собой вопрос или задание, которое необходимо разгадать. С древнерусского языка «гадать»- означает 'размышлять', 'думать'

Возникновение загадки приходится на древние времена и имеет тесную связь с обрядами и ритуалами, которые имели важное значение для людей, а также сопровождали все значимые события. Изначально люди использовали иносказательную (тайную) речь для обмана растений и животных. В те времена люди боялись природы и верили, что повсюду злые и добрые существа, которые их слышат. Таким образом, с помощью загадок люди пытались воздействовать на природу.

\footnotetext{
${ }^{2}$ Режим доступа: https://slovarozhegova.ru/word.php?wordid=8022 (2021-03-22).
} 
На ранних этапах развития человеческого общества через загадки передавался житейский опыт и сведения о природе от старших поколений к младшим. Разгадки народной загадки, являясь общим достоянием, передаются как знание из поколения в поколение, и тот, кто не знает загадки, не сможет ее отгадать (Сендерович 2008).

Через загадки люди пытались постичь тайны природы. Затем загадки становились частью общественной жизни людей, использовались как средство для испытания мудрости и смекалки. И только спустя долгое время загадки стали использоваться в целях воспитания и развлечения. В Древней Руси загадки также связывают с тайной речью охотников. Древнерусские загадки прослеживаются в сказках, былинах, баснях и славянских мифах.

Рассмотрим более подробно русские народные загадки. Так как загадки, в частности, представляли собой сведения о природе, то многие из них можно объяснить с помощью научных знаний. Так, наблюдая за погодой, люди отмечали особенности и характерные признаки того или иного природного явления. Люди описывали их через загадку и пытались дать им объяснение. Например, рассмотрим следующую загадку: Вечером наземь слетает, ночь на земле пребывает, утром опять улетает. В данной загадке описано такое погодное явление как роса. С помощью наблюдений люди заметили, что существует такое явление природы, при котором мелкие капли влаги оседают на землю в результате утренней либо вечерней прохлады. С научной точки зрения образование росы связано с тем, что насыщенный влагой воздух преобразуется в жидкое состояние при понижении температуры. Появление капелек воды на земле связано с тем, что теплый воздух оседает на более холодную поверхность. А утром при повышении температуры воздуха влага выпаривается, и роса пропадает.

К загадкам, которые объяснимы с научной точки зрения, можно отнести следующие: Летом греет, зимой холодит (солнце); И в огне не горит, и в воде не тонет (лед, сосульки); Сперва блеск, за блеском треск, за треском плеск (молния); Зимой греет, весной тлеет. Летом умирает, осенью оживает (снег); Не огонь, а жжется (мороз) (Макшанов 2018).

Однако не все загадки имеют научное описание природных явлений. Погодные явления в таких загадках люди сравнивали с привычными им предметами быта, домашними животными и птицами, частями тела. Для описания природного явления люди проводили аналогию между тем или иным образом, который возникал в сознании. Например, часто погодные условия описываются с характеристиками, присущими определенным животным: Конь бежит, земля 
дрожит (гром). Ударную волну и звук, вызванные громом, народ сопоставлял со звуками, возникающими при передвижении коней. Конь в древние времена считался атрибутом высших языческих богов, был связан с культом плодородия, а также считался проводником на «тот свет». Люди боялись грома и считали, что это посланец неба, именно поэтому не делали никаких работ во время данного погодного явления, чтобы не привлечь нечистую силу. В погодном календаре гром показывал будущую погоду и определял урожай.

К загадкам, в которых погодные явления сравниваются с характеристиками животных и птиц, можно отнести следующие: Летит птица орел, несет в зубах огонь, посередине его человечья смерть (молния); В избе баран ревет (холод); Беленька собачка в подворотню глядит (сугроб); Сивые кабаны все поле облегли (туман); Гуляет в поле, да не конь. Летает на воле, да не птица. (метель). Загадки, в которых погодные явления сравниваются с частями тела: Без рук, без ног, а стучит (ветер); Стучит без рук, бег огня горит (гроза); Без рук, без ног, а рисовать умеет (мороз). Загадки, в которых погодные явления сравниваются с предметами быта: Крашенное коромысло через реку повисло (радуга); Скатерть бела весь свет одела (снег); Старо лукошко, новый покрой (пруд).

Таким образом, мы можем сделать вывод, что загадки несли в себе большой смысл для народа, именно с их помощью люди передавали знания об окружающей действительности. Так, многие народные загадки о погодных явлениях в современном мире можно объяснить с научной точки зрения. Однако если рассматривать народные загадки с точки зрения языковой картины мира, то можно проследить тенденцию описания погодных явлений с помощью предметов и животных, которые присутствовали в повседневной жизни людей.

Далее рассмотрим погодные явления в русской языковой картине мира, отраженные в пословицах. В «Толковом словаре русского языка» Д.Н. Ушакова пословица - это «краткое образное законченное изречение, обычно ритмичное по форме, с назидательным смыслом» ${ }^{3}$. В народном творчестве существует большое количество пословиц и о воле, и о счастье, и о добре и зле, о любви, о здоровье, о правде и лжи, об уме, о трудолюбии, богатстве и бедности и т.д. Так или иначе, через это жанр устного народного творчества передавалась человеческая мудрость из поколения в поколение.

Языковая особенность пословиц состоит в том, что в кратком изречении отражается прожитый опыт людей, содержится поучительный смысл через образ, в частности, через образ погодных явлений. Если проанализировать пословицы,

\footnotetext{
${ }^{3}$ Режим доступа: https://biblioclub.ru/?page=dict\&dict_id=117 (2021-03-22).
} 
связанные с погодой, можно увидеть связь: между ней и человеческой жизнью, испытаниями и радостью.

Почему же люди отражали свои жизненные невзгоды или счастье в пословицах через погодные явления? Дело в том, что большая часть жизни русского народа была связана с сельскохозяйственной деятельностью, а она неотъемлемо зависела от погоды. Например, если в сезоне были сильные дожди или засуха, то урожай погибал, соответственно, наступал голод. Поэтому русский народ часто сравнивал негативные жизненные испытания с дождем, тучами, ветром и морозом, ср. Поднимутся тучи - дождь будет, пойдут речи - ссора будет. Рассмотрим данную пословицу с научной точки зрения. Туча - это темное, густое облако. Как она образуется? Высоко в небе намного холоднее, нежели на поверхности земли. Пар, поднимающийся высоко в воздух, превращается в капельки. Эти капельки образуют облако. Нижний край тучи становится тяжелее, поскольку сама туча состоит из «толстых» капелек воды, в следствие чего капли не могут держаться в воздухе и начинают падать на землю. Это явление называется дождем (Тарасов 2016). В пословице слово «речи»как споры, выяснение отношений отображает образ тучи, которая поднимается, а «ссора»дождь, т.е. следствие тучи. Иными словами, когда люди начинают спорить, доказывать что-то сильнее и сильнее, начинается ссора. Примеры подобных пословиц: Сбежались тучи в одну кучу - быть ненастью; Из тучи все в грозу выйдет; Ветер и море кольшет. Вместе с тем стоит отметить другую пословицу: Не все тучи с собой дождь несут. Она несет в себе мудрую мысль, что даже в сложных жизненных ситуациях не всегда будет печальный исход.

Пословицы с подобным смыслом: Из большой тучи да малая капля; Om большой тучи не всегда много дождя. С научной точки зрения, объяснение содержится в следующем: все зависит от облаков. Существует четыре вида облаков, по виду которых можно понять, будет ли дождь, гроза или нет. Первый вид облаков - кучевые. В солнечный день лучи греют землю, которая греет воздух, расположенный прямо над ней. Нагретый воздух поднимается наверх и образует небольшие пушистые облака. Они похожи на вату и являются признаком «хорошей погоды». Второй вид облаков - кучево-дождевые. Если кучевые облака увеличиваются и растут по высоте, то это признак того, что будет сильный дождь. От кучевых они отличаются тем, что недалеко от земли кучеводождевые облака четко оформлены, однако с высотой начинают становиться более дымчатыми по краям. Такой переход свидетельствует на то, что облако состоит уже не из капель воды, а из кристаллов льда. Чаще всего их можно увидеть летом: когда утренние кучевые облака днем превращаются в кучево- 
дождевые. Третий вид - перистые облака. Они формируются в высоких слоях атмосферы, являются дымчатыми, поскольку состоят полностью из кристаллов льда, падающих в атмосфере. Если перистые облака начинают покрывать большую площадь неба, становятся ниже и толще, то, скорее всего, в ближайшие 12 часов пойдет дождь. Четвертый вид - слоистые облака. Это низко расположенная, непрерывная облачная простын, покрывающая небо. Формируются такие облака медленно восходящим воздухом и несильным ветром, который покрывает влажным воздухом холодную землю или поверхность моря. Эти облака достаточно тонкие, что дождь из них вряд ли пойдет. ${ }^{4}$ Таким образом, приближение дождя зависит от вида облаков, а каждую пословицу можно рассмотреть с разных точек зрения.

Как уже отмечалось ранее, русский народ часто использовал в пословицах образ погодных явлений. Пословицы о дожде, о тучах, о ветре по большей части отражают жизненные невзгоды людей, однако существуют и те, которые описывают урожайный или неурожайный сезон, сравнивая его с таким природным явлением, как снег. Возьмем к примеру пословицу: Больше снега на полях, больше хлеба в закромах. Аналогами ее являются также: Задержишь снег на полях зимой-будешь с хлебом осенью; Снег глубок-год хорош; Зима без снега - лето без хлеба.

Русский народ ожидал появление снега, поскольку считал, что он помогает зимовать посевам зерновых. Стоит отметить, что зерновые культуры, в свою очередь, являются важной группой в хозяйственной деятельности человека, так как дают зерно, сырье для многих отраслей промышленности и корм для животных. С научной точки зрения, если в пословице речь идет об озимой пшенице, тогда снежный покров действительно защищает ее от сильных морозов и ветра. Она вымерзает при низкой температуре, а значит, при отсутствии снега хорошего урожая может не быть. В обратном случае - при формировании глубокого снежного покрова, пшеница способна выдержать (Клещенко 2013). Наряду с этим, важно отметить, что снег хоть и важен для того, чтобы пшеница благополучно перезимовала, однако существуют и другие факторы, влияющие на урожай, а именно: качественны ли семена, плодородна ли почва, какие были сроки посева, как ухаживали за посевами и т.д. Отсюда следует, что в пословицах, отражающих урожайный или неурожайный сезон, нельзя сказать однозначно, необходимо учитывать многие факторы.

\footnotetext{
${ }^{4}$ Режим доступа: https://habr.com/ru/post/374459/ (2021-03-14).
} 
В заключение следует отметить особое значение устного народного творчества в описании погодных явлений. Как мы уже сказали ранее, каждый народ является олицетворением своей собственной культуры, а отражением народа является его устное народное творчество. Во многом благодаря ему люди накапливали мудрость и жизненный опыт, познавали окружающую действительность, сохраняя и передавая их из поколения в поколение. Люди формировали представления о природе и природных явлениях, фольклор являлся одним из главных источников получения информации.

\section{Summary}

The article is devoted to the study of weather phenomena in the Russian linguistic picture of the world reflected in folklore. For example, in signs, riddles and proverbs. The analysis of the signs showed that the signs help to find out the cause of events as well as look at the familiar world of people through their eyes. If we consider folk riddles from the point of view of the linguistic picture of the world, we can trace the tendency to describe weather phenomena with the help of objects and animals that were present in the daily life of people. The linguistic peculiarity of proverbs is that through the image of weather phenomena we can see the connection between them and human life, trials and joy.

\section{Литература}

Астахова, А.М., Базанова, А.М., Путилова, Б.Н. Загадки. Ленинград: Наука, 1968.

Ирлык, А. Народные приметы, пословицы и поговорки о погоде. Nauka.Club. 2021. Режим доступа: https://nauka.club/literatura/stikhi/narodnye-primety-opogode.html (2021-03-23).

Клещенко, А. «Много снега - много хлеба»: правдива ли пословица? Аргументы и фактыл. 26.03.2013.

Макшанов, С. Русские народнье загадки. Москва: АСТ, 2018.

Ожегов, С.И. Толковый словарь русского языка. Режим доступа: https://slovarozhegova.ru/ (2021-03-22).

Орлова, О.С. Происхождение загадки. Вестник ММА. 2017 (1), с. 192-197. 
Селянгина, К.Н. (сост.) Календарь народных примет погоды на все дни года. Режим доступа: https://royallib.com/book/selyangina_klara/kalendar_narodnih _primet_pogodi_na_vse_dni_goda.html (2021-03-23).

Сендерович, С.Я. Морфология загадки. Москва: Языки славянской культуры, 2008.

Тарасов, Л. Почему образуются облака? Наука и жизнь. 2016 (7). Режим доступа: https://elementy.ru/nauchno-populyarnaya_biblioteka/433212/Pochemu _obrazuyutsya_oblaka (2021-03-24).

Ушаков, Д.Н. Толковый словарь русского языка. Режим доступа: https://biblioclub.ru/?page=dict\&dict_id=117 (2021-03-22).

От примет к научному подходу. Режим доступа: https://www.culture.ru/materials/ 163222/ot-primet-k-nauchnomu-podkhodu (2021-03-23).

Шесть типов облаков, которые нужно знать - и что они рассказывают о погоде. Режим доступа: https://habr.com/ru/post/374459/ (2021-03-14). 



\title{
JAZYKOVÝ OBRAZ ZEMETRASENIA V PRÍSPEVKOCH CHORVÁTSKYCH POLITIKOV NA FACEBOOKU
}

\author{
Linguistic Reflection of the Earthquake in the Posts \\ of Croatian Politicians on Facebook
}

Keywords: Facebook, earthquake, Croatia, politicians, language, help, gratitude, manipulation

Contact: Masarykova univerzita; domcakubisova@gmail.com

\section{Úvod}

V roku 2020 otriasla Chorvátskom séria zemetrasení. Začalo sa to v marci v hlavnom meste Záhrebe. Seizmológovia sa zhodli, že nasledovat' bude mnoho d'alších zemetrasení, ktoré skutočne počas roka pokračovali. Vyvrcholili na konci roka, kedy d'alšia vlna, 28. a 29. decembra, zničila mestá Petrinja, Sisak, Glina a okolie. Táto prírodná katastrofa vyvolala ohlas širokej verejnosti aj zahraničia. Museli reagovat' aj chorvátske politické špičky, ktorých príspevky na Facebooku boli predmetom skúmania. Zozbierané údaje pochádzajú z verejných účtov v časovom rozpätí od 28. decembra 2020 do 16. januára 2021. Prvým skúmaným bol súčasný prezident Zoran Milanović, druhým premiér Andrej Plenković, jeho domácou stranou je pravicová HDZ (Chorvátske demokratické spoločenstvo). Ďalej Peđa Grbin predseda opozičnej l'avicovej SDP (Sociálne-demokratická strana) a posledným bol Miroslav Škoro (Vlastenecké hnutie Miroslava Škora), predseda populistickej a ultrapravicovej strany. Príspevky teda pokrývajú širokú škálu politického spektra. Ciel'om pozorovania bolo zistit' aké slová volili, či je prírodná katastrofa dôvodom, ktorý by mohol zjednotit' politikov naprieč svetonázormi, a v neposlednom rade, aké emócie svojimi textami vyvolávali v l’ud'och, ktorí ich čítali.

\section{Sociálne siete a politická komunikácia}

Na sociálnych siet'ach trávime čoraz viac času. Za rok 2020 je podl'a portálu Statista svetový priemer približne 145 minút za deň (Statista 2021a). Podl’a inštitúcie HootSuite, 
ktorá monitoruje používanie internetu a sociálnych sietí v množstve krajín, je v Chorvátsku na Facebooku 1,7 milióna l'ud, čo je skoro polovica obyvatel'ov (HootSuite 2020). Vybraných politikov sledujú desat'tisíce l'udí, ${ }^{1}$ ktorí môžu neskôr preberat' ich naratív, ale (a to je signifikantné pre používanie sociálnych sietí) aj reagovat' na ich príspevky a rôzne s nimi interagovat' (zdiel'at' alebo označit' emotikonami). Počet l’udí, ktorí si vyberajú sociálne siete ako zdroj informácií každým rokom rastie. V krajinách EU je to od $25 \%$ v Nemecku po $71 \%$ v Grécku (Statista 2021b). Zároveň sa internet, a s ním aj sociálne siete, stali priestorom, kde sú informácie l'ahko dostupné a poskytujú možnost' získavat' ich z mnohých zdrojov. To v praxi znamená, že umožňujú sledovanie ako tradičných spravodajských agentúr, tak vyhl'adávanie alternatív. Sociálne siete umožňujú l'ud'om vybrat' si informácie, ktoré chcú dostávat' (Mackova 2017: 23). S tým počíta aj politická komunikácia, ktorá sa snaží svojim poslucháčom poskytnút' práve tie informácie, o ktoré majú záujem. A táto druhá strana veci bude sledovaná na nasledujúcich riadkoch, pretože prístup politických aktérov a politických inštitúcií $\mathrm{k}$ novým formám komunikácie je jedným z klúčových perspektív v rozvoji politickej komunikácie na internete (Mackova 2017: 37). V prípade sociálnych sietí je jednou zo zmien na poli policajnej komunikácie personalizácia politiky, ktorá posilnila spojenie osobnej charakteristiky (politika) a jeho politických činov. Ďalším je presun pozornosti od strán smerom $\mathrm{k}$ jednotlivcom a d’alej $\mathrm{k}$ ich osobným črtám (Mackova 2017: 23). Koniec koncov aj tento text sa zaoberá profilmi predstavitel'ov strán / štátu. Ich vplyv v priestore sociálnych sietí rastie, a preto je dôležité sledovat' čo a ako hovoria.

\section{Jazyk zemetrasenia}

Označovanie zemetrasenia v prejavoch sa väčšinou obmedzilo na slová ako „razoran“‘2 (ničivý) alebo „strašan“3. Pri pohl'ade do korpusu (Hrvatska jezična riznica) zistujeme, že tieto slovné spojenia sú v pri zemetraseniach v chorvátčine vlastne ustálené a objavujú sa aj v súvislosti s inými zemetraseniami. Ked’že zoznam zasiahnutých oblastí je vel'ký, ich presný výpočet sa vyskytuje málokedy (robí tak napr. Škoro). Inak sa na ne odkazuje ako na trojicu najväčších miest: Petrinja, Sisak, Glina ${ }^{4}$ alebo sa objavujú d’alšie administratívne názvy ako „Bánovina“ resp. sisačko-moslavačka

\footnotetext{
${ }^{1}$ Zoran Milanović - 118 249, Andrej Plenković - 80 428, Peđa Grbin - 20 035, Miroslav Škoro - 145944 (údaje z jednotlivých facebookových profilov ku dňu 28. apríla 2021).

2 „U mislima smo s obiteljima stradalih u razornom potresu“ (Plenković, 30. januára 2020).

3 ",...duboko suosjećanje sa stradalnicima strašnog potresa.“ (Škoro, 30. januára 2020).

",....prikupljanje pomoći stradalima u potřesu u Petrinji, Sisku i Glini.“ (Škoro, 29. decembra). 
županija“55 alebo úplne obecne „zemetrasením zasiahnuté oblasti“6. V prípade ich názvov sa mestá samotné stávajú symbolmi. S Petrinjou, Siskom aj Glinou sa bude zemetrasenie roku 2020 spájat' ešte dlho.

\section{Vd'ačnost'}

Pod'akovania sú druhým najčastejším javom v sledovaných príspevkoch. Politici, ako to býva zvykom, d'akujú všetkým zložkám, ale aj dobrovol'níkom, ,,velika zahvala svima koji pomažu i rade, i onima kojima je to posao i onima koji su se javili kao dragovoljci“‘ (Milanović, 30. decembra 2020). Vedia, že týmto l'ud'om vd'aka patrí, pretože vlna solidarity, ktorá sa zdvihla už v prvých hodinách po druhom zemetrasení bola neuveritel'ná. Napriek tomu existujú medzi politikmi rozdiely. Grbin zo skupiny dobrovol'níkov vydelil tých, ktorí sú členmi jeho strany ${ }^{7}$ a jej mládeže (SDP), Škoro spomína aj chorvátsku diasporu, Plenković d'akuje najdlhšie, ešte aj dva týždne po udalosti. Vd'ačnost' je teda forma, ktorá ich spája naprieč politickým spektrom. Pomáhajúci sú označovaní ako l’udia s „,vel'kým srdcom“, dobrovol'níci na mieste sú „usilovni““ (Grbin, 9. januára ). Z podobných prejavov má príjemca dobrý pocit. Síce sa stalo niečo nepredstavitel'ne šokujúce a zlé, ale správa je, že spolu to zvládneme.

\section{Pomoc}

Pomoc je jednoznačne najpoužívanejším slovom v príspevkoch v sledovanom období. Spája s d'alšími slovami, tesne po zemetrasení sa objavovali žiadosti o pomoc, a d'akovanie za ňu. Neskôr za začala pomoc sl'ubovat' a aj zhromažd'ovat'. „Na razini cijele Hrvatske organiziramo prikupljanje pomoći stradalima“ (Škoro, 29. decembra). $\mathrm{Na}$ volanie odpovedalo mnoho občanov Chorvátska, ale aj zahraničie a zaostávat' nemohli ani politické špičky. Určitou zvláštnost'ou je pomerne neskorá reakcia prezidenta Milanovića, ktorý sa na svojom profile vyjadril až 30. decembra, čo je pri rýchlosti fungovania sociálnych sietí pozde.

\footnotetext{
5 „,...potresu koji je pogodio Sisačko-moslavačku županiju i nadamo se brzom oporavku.“ (Plenković, 30. januára 2020).

${ }^{6}$,Iako je u ovom trenutku primarno raditi na tome da se ljudima s potresom pogođenih područja osiguraju krov nad glavom i osnovne životne potrepštine.“

${ }^{7}$ Grbin samozrejme d'akuje aj ostatným občanom a zložkám, ktoré pomáhali, ale v jednom momente z nich vydelil svojich „Hvala svim vrijednim volonterima koji marljivo svaki dan pomažu građnima koji čiji su domovi stradali u potresu, među kojim su i naši članovi Forum mladih SDP Hrvatskee. Hrvatska je još jednom pokazala da ima velko srce." (Grbin, 9. januára).
} 


\section{Spoluobčania}

Katastrofa zmobilizovala masu l'udí a ich pomoc bola vel'ká a spontánna a vôbec nemusela súvisiet' s výzvami politikov, pretože nepomáhali im, ale svojim spoluobčanom, l'ud'om ako sú oni sami. Na túto tému jazykovo nasadli aj sledovaní politici. Slovo „sugrađanin“ (spoluobčan) sa objavuje naprieč politickým spektrom, často v spoločnosti slova pomoc, ,hvala...svima drugima koji su pritekli u pomoć našim prijateljima, susjedima i sugrađanima“ (Grbin, 28. december). V normálnej komunikácií nie je také bežné, ale v politickom príspevku má v čitatel’ovi vyvolat' pocit súnáležitosti, ,pomoći ćemo našim sugrađanima u saniranju šteta“ (Plenković, 28. decembra). Politik aj dobrovol'níci, či obyvatelia zasiahnutí zemetrasením, všetci sú $\mathrm{v}$ tom spolu.

\section{Jednota a nádej}

S tým súvisí aj jazykový a emocionálny apel na jednotu a katastrofické udalosti l’udí spájajú akosi automaticky. Apel na jednotu má často persuazívny charakter, mieri na emócie, kde prebúdza v prijímatel'ovi pocit hrdosti a solidarity, ale aj snahu byt' súčast'ou väčšieho celku (Čulenová 2013: 112). Jednota a solidarita sa v sledovaných príspevkoch objavujú v dvoch prípadoch: bud' k nim politici vyzývajú, alebo za ne d'akujú. Plenković zdôrazňuje, že aj v čase pandémie sa ukázala jednota a solidarita: „Pokazali smo jedinstvo i solidarnost nacije“ (Plenković, 31. decembra 2020). a publikum (alebo celý národ) môže mat' pocit výnimočnosti a nezdolatel'nosti napriek situácií, ktorá nastala. Nie je ničím výnimočným najprv vyvolat' pocit jednoty a solidarity a potom ich prepojit' so snahou získat' finančné prostriedky „da pokažu solidarnost i sukladno sa svojim mogućnostima uplate donaciju za pomoć stradalima na području Siska i Petrinje. Upute za uplatu donacije možete pronaći na ovom linku“ (Grbin, 29. decembra 2020). Tak to skúša Peđa Grbin a vyzýva, aby „ukázali solidaritu v rámci svojich možností.“ Tento druh kampane však často vyvoláva nedôveru, hlavne, ked' je spojený s politickou stranou, a preto ho politik šikovne nadväzuje na obecnejšiu inštitúciu s apolitickým renomé, v tomto prípade s Červeným krížom. Najsilnejšie sa vyjadruje prezident Milanović. Vzhl'adom na úrad prezidenta je to aj na mieste, pretože on má byt' ten, kto zjednocuje, napriek tomu, že sa mu to inak nedarí, ${ }^{8}$ tu si svoju politickú povinnost' splnil. „U ovom trenutku moraju znati da ne samo da smo uz njih... postojimo svi zajedno s jednakim pravom na novi početak“ (Milanović, 30. decembra 2020).

\footnotetext{
${ }^{8}$ Aj počas pandémie a kríze v Bánovine sa s premiérom na Facebooku ostrel’ovali vel'mi nepríjemným slovníkom, založeným na ich príklone k rozdielnym straníckym líniám. (Jutarnji List 2021).
} 
Aj Grbin v jednom svojom výroku sl’ubuje znovuvybudovanie regiónu na ešte lepší než bol pred zemetrasením, konkrétne kroky však nespomína. Čo je ešte zaujímavejšie, sl’uby svetlej budúcnosti, ktoré sú pri podobných udalostiach očakávané, sú minimálne. V tomto prípade je teda dôležité sledovat' nielen to, čo je povedané, ale aj to čo je zamlčané.

\section{Frázy}

Zatial' čo prvé zemetrasenie sa zaobišlo bez obetí, druhé si vyžiadalo sedem životov. Skúmaní politici teda stáli pred nel'ahkou úlohou, ako je vyjadrenie sústrasti a v ich príspevkoch sa objavuje spojenie úprimnú sústrast' rodinám pozostalých: „Prvenstveno, izražavam sućut obitelji stradalih i želje za brz oporavak svima ozlijeđenima“ (Grbin, 29. decembra). Ustálené slovné spojenia, pokial' sa nevyprázdnia, môžu byt' vel'mi nápomocné práve pri takýchto príležitostiach. Nie je nutné vymýšl'at' a hl'adat' slová, máme ich po ruke a netreba ich vnímat' ako neosobné, práve naopak.

Ďalšou opakujúcou sa frázou je „mat'vel'ké srdce“9. Obyvatelia majú vel'ké srdce, celý štát ma vel'ké srdce. Odkazujú nás tým na láskavost' a to najlepšie v nás. Objavuje sa však aj iný spôsob, ktorý ukázal Miroslav Škoro. Do svojich príspevkov zakomponoval tzv. human interest story ${ }^{10}$ a rozpovedal príbeh neznámeho pána, ktorý jednej rodine s diet'at'om prenechal auto. „Veliko srce pokazao je i jedan gospodin ponudivši svoj automobil na trajno korištenje oblitelji s djecom. Ganuti smo velikodušnošču hrvatskog naroda i zahvalni na toplim srcima i nesebičnosti““ (Škoro, 1. januára). Miroslav Škoro takto pracuje často, pretože ho to stavia do pozície politika, ktorý sa stretáva a cení si „obyčajných“ l’udí a ich malé láskavosti sú hodné zverejnenia. Odrazu je to vel'ké srdce ovel'a menšie, ale aj osobnejšie, než ked' má rozmery štátu. Zároveň túto vel'kodušnost' pripisuje celému národu, malé srdcia tak tvoria vel'ký celok.

Druhou opakovanou frázou bolo „,mat' strechu nad hlavou“, napr. „ljudi moraju dobiti krov nad glavom“ (Grbin, 14. januára 2021). V tomto prípade je to odôvodnená figúra, pretože vel'a l'udí prišlo o strechu nad hlavou doslova, nielen metaforicky a je na politikoch, aby sa postarali, aby im bola prinavrátená.

\footnotetext{
${ }^{9}$ Hrvatska je još jednom pokazala da ima velko srce.“(Grbin, 9. januára) „Još jednom zahvaljujem...na iznimnoj solidarnosti i humanosti te na velikom srcu i zajedništvu koj esu pokazali!“ (Plenković, 14. januára).

${ }^{10}$ Human interests story je v publicistike článok, ktorý má vo svojom strede l'udí a rozpráva ich jedinečný príbeh. Poukazuje na nepriazeň osudu, zvyšuje povedomie o nejakej veci alebo dáva príklad. Hlavnou úlohou je emočné pohnutie čitatel'a. (Community Journalism).
} 


\section{Kritika}

Katastrofy by mali spájat', ale zároveň sa stávajú živnou pôdou pre spory a kritiku, a napokon aj rozdiely. „Nadamo se da će/takva/ odluka dovesti do organiziranijeg i boljeg odgovora na krizu, nego što smo svjedočili u zadnjih tjedan dana“ (Grbin, 4. januára). Predseda druhej najsilnejšej strany sa nemohol vyhnút' kritike vlády, ktorej pomoc označil za zle zorganizovanú a nedostatočnú. ${ }^{11}$ Zároveň sa jedná o druh negatívnej kampane (Welch 2013: 152), hoci je vedená vel'mi jemne a prekvapivo neadresne. Grbin neoznačuje presne vinníka (len dúfa $\mathrm{v}$ lepšie pokračovanie), pritom by si ako šéf opozičnej strany mohol dovolit' menovat'.

Naopak populista Škoro priamo menuje dve najsilnejšie chorvátske politické strany, naznačujúc, že medzi ich vládami nie je nijaký rozdiel a obidve ${ }^{12}$ sú zodpovedné za to, že o pomoc sa starajú obyvatelia a nie štát. „Pitanje je i gdje su robne rezerve? Zašto je došlo do toga da deke i hranu skupljaju građani? Sve ovo dokaz je da država ne funkcionira, i to nema nikakve veze s koronakrizom. Ima veze s mandatima predstavnika duopola HDZ-a i SDP-a na čelu države“" (Škoro, 31. decembra). Označením obidvoch strán zároveň naznačuje, že on by bol lepšia vol’ba, nehovoriac o tom, že tým cieli na emócie rámovaním situácie, ktorá je tak zlá nielen kvôli katastrofe, ale aj kvôli neschopnosti politických špičiek naprieč vládami. Zároveň používa syntaktickú figúru, rečnícku otázku, na ktorú si odpovedá iba čiastočne, čím vyvoláva určitý persuazívny efekt - núti čitatel’a, aby si na ňu odpovedal sám a zároveň upozorňuje na žiadaný obsah (Čulenová 2013: 141-142).

V politických príspevkoch, ale aj prejavoch, sa často stáva, že politici sa vyjadrujú namiesto neznámych l'udí: „Na temelju brojnih upita građana koje dobivamo, pozivamo Stožer...“ (Grbin, 4. januára). Hovoria o častých otázkach od voličov alebo sa neznáme osoby niečoho dožadujú. Meno, prieskum či zdroj sa nespomínajú. Môžeme len odhadovat' či sa im l'udia ozývajú naozaj alebo je to len spôsob nastavovania debaty, ale je to vynikajúca možnost' ako dat' svetu najavo, že politik je občanom blízko, že načúva ich požiadavkám a potrebám.

Na populistickej strane spektra je to jazykovo zaujímavejšie. Miroslav Škoro žiadal zrušit' záhrebské ženské lyžiarske preteky a presunút' peniaze na opravy zemetrasením zasiahnutých miest. „Nadalje pozivam Grad Zagreb i gradonačelnika Milana Bandića da odmah odkažu Snježnu kraljicu. Neka se taj novac preusmejri u obnovu i pomoć stradalima u potresu“ (Škoro, 31. decembra 2020). Používa celkom ostrý slovník ,žiadam primátora, aby okamžite odvolal“ a vyvoláva obraz, ktorom má

11 Rozbroje a vzájomná kritika sa viac vyostrila po sledovanom období. Čiastočne je to spôsobené aj nadchádzajúcimi lokálnymi vol'bami, ktoré sa odohrajú 16. mája 2021.

${ }^{12}$ Od vzniku samostatného Chorvátska sa pri zostavovaní vlády striedalo len HDZ a SDP. 
hlavné mesto čas a prostriedky na šport a zemetrasením zasiahnuté oblasti ho netrápia. Zatial' čo Andrej Plenković ${ }^{13}$ hovoril o prostriedkoch získaných z vel'kého EU rozpočtu, Škoro tu siaha na peniaze mesta, ktorého ani nie je primátorom. ${ }^{14}$

\section{U populistu}

Populistickej scéna sa budem venovat' ešte trochu dlhšie, pretože poskytuje viac jazykového materiálu. Miroslav Škoro zdiel'al až patetický príspevok, ktorý vel'a napovedá o hodnotách strany, ktorá nesie jeho meno. Hovorí o panej, ktorá zo svojho rúcajúceho sa domu vyniesla dva vel'mi dôležité predmety: chorvátsky znak a kríž. „Đurđica je sve izgubila ali je zahvalna što je iz kuće izvukla raspelo i hrvatski grb. Bogu hvala je preživjela“ (Škoro, 6. januára). V tomto prípade hovoríme naraz o slovách aj o predmetoch a sú to vel'mi silné a často používané symboly. Podl'a Welcha sú dvomi najdôležitejšími symbolmi štátna hymna a vlajka (znak). Na jednej strane je príkladom akceptovatel'ného patriotizmu, prostého výrazu národnej identity, no na druhej strane môže byt' aj nebezpečným nástrojom. V krajných prípadoch dochádza až k tzv. kultu vlajky (Welch 2013: 45-48), čo môžeme pozorovat' pri krajných politických uskupeniach. V Chorvátsku sa dá hovorit' až o nadužívaní štátnej symboliky v porovnaní napríklad so slovenským či českým prostredím. Ak sa na tento príbeh pozrieme bližšie, zistíme, že pomocou symbolov odovzdáva posolstvo, že štát a viera sú dôležité, tak dôležité, že stojí za to pre ne riskovat' vlastný život.

Aby však ukázal aj jemnejšiu stránku, nahral video so svojím psom, kde upozorňuje na to, že okrem l'udí sa treba postarat' aj o domácich miláčikov a podpísal seba aj svojho psa. „Dragi prijatelji, svi vi ljubitelji životinja, udruge, Na području pogođenom potresom, u našoj Banovini, ima jako puno životinja koje su nezbrinute i u teškim uvjetima...Vaši, Frida i Miro" (Škoro, 11. januára). Aj bez fotografie ${ }^{15}$ by tento text zapôsobil podobne, ako ked' sa politici ${ }^{16}$ nechávajú vyfotit's malými det'mi. Je to jednoznačný apel na emócie, vytvára tak dojem láskavého a starostlivého človeka, ktorý pôsobí vierohodne.

\footnotetext{
13 „Vodimo razgovore kako bismo relocirali više of 100 milijuna $€$ iz @EUBudget“" (4. januára).

${ }^{14}$ Miroslav Škoro sa d'alej téme zemetrasenia nevenuje. Momentálne kandiduje za primátora hlavného mesta Záhreb, pretože predchádzajúci primátor nečakane zomrel na infarkt.

15 Škoro sedí so svojím bielym psom v náručí.

${ }^{16}$ Mimochodom aj iní politici majú podobné zábery. Putin má svoje šteniatka, královná corgiho, Boris Johnson jacka-russela a Miroslav Škoro svoju Fridu.
} 


\section{Záver}

Zemetrasenie v decembri 2020 v Chorvátsku prinieslo vel'ké materiálne škody, prekvapilo obyvatel'ov Bánoviny a vyvolalo obrovskú vlnu solidarity. Článok sa zameral na rekcie štyroch chorvátskych politikov na Facebooku: prezidenta Zorana Milanovića, premiéra Andreja Plenkovića, šéfa opozičnej strany Peđa Grbina a populistu v opozícií Miroslava Škora. Vplyv sociálnych médií rastie a politické špičky ho využívajú na komunikáciu s verejnost’ou. Z pozorovaných príspevkov vyplynulo niekol'ko vecí.

Objavujú sa prvky, ktoré sú aj jazykovo ustálené. Politici opisujú zemetrasenie ako strašné či ničivé, zároveň sa opakuje aj fráza mat' vel'ké srdce a mat' strechu nad hlavou. Naprieč politickým spektrom sa objavovalo volane o pomoc, samotné slovo pomoc sa stalo najpoužívanejším vo všetkých profiloch. Všetci politici venovali svoje príspevky aj pod'akovaniam občanom aj záchranným zložkám a vyzývali k jednote. Často skloňovaným bolo aj slovo spoluobčan, práve $\mathrm{v}$ kontexte vytvárania pocitu jednoty a súnáležitosti a zároveň zmenšovania vzdialenosti medzi politikom a občanom. Rozdiely v komunikácií sa objavili tiež napr. v prípade populistu sa častejšie nachádzali príspevky, ktoré mali silnejší apel na emócie, využívali rečnícku otázku a pracovali so silnou (nielen verbálnou) symbolikou. Spätný pohl'ad na tieto udalosti a využitie jazyka na Facebooku nám ukazuje ucelený obraz reakcie politikov na katastrofu. Preniesli sa od šoku a mobilizácie pomoci cez vd'ačnost' až po kritiku.

Monitorovanie aktivít politikov na Facebooku je dôležitou činnost'ou, ktorá nám vel'a napovie o svetonázore politických špičiek, l’ahšie tak odhalíme jazykové manipulácie, ktorým sú sledovatelia vystavení. Poskytne nám to potrebný odstup od náhl'ad do fungovania politickej komunikácie, ktorá je de facto stále nová.

\section{Summary}

The text deals with the posts of chosen Croatian politicians on Facebook that were written soon after earthquake hit the region of Banovina. It is focused on the used language, the expressions that politicians have in common or the one that are different, it also analyses some of the most used words and phrases, and the emotions posts evoke in a reader. The aim of the article is to draw attention to the problematics of new political communication via social media as well as the content of their posts that are read by thousands of people. 


\section{Literatura}

Čulenová, E. Verbálna manipulácia. Banská Bystrica: Belianum, 2013.

Macková, A. Nová média v politické komunikaci. Brno: Muni Press, 2017.

Welch, D. Propaganda. Power and Persuasion. London: British Library, 2013.

Andrej Plenković. Dostupné z: https://www.facebook.com/andrej.plenkovic.rh (202103-20).

Community Journalism. Dostupné z: https://www.communityjournalism.co.uk/ resources/writing-human-interest-s (2021-04-16).

HootSuit 2020. Dostupné z: https://datareportal.com/reports/digital-2020-croatia (202103-18).

Hrvatska jezična riznica. Dostupné z: http://riznica.ihjj.hr/philocgi-bin/search3t? dbname $=$ Cijelihr\&word $=$ potres $(2021-03-21)$.

Jutarnji List. Dostupné z: https://www.jutarnji.hr/vijesti/hrvatska/htio-sam-dakrenemo-cistiti-ribetinu-a-plenkovic-to-ne-da-ja-sam-orao-a-on-nilski-konj15062188 (2021-04-3).

Miroslav Škoro. Dostupné z: https://www.facebook.com/MiroslavSkoroofficial (202103-20).

Peđa Grbin. Dostupné z: https://www.facebook.com/GrbinPedja (2021-03-20).

Statista. 2021a. Dostupné z: https:/www.statista.com/statistics/433871/daily-socialmedia-usage-worldwide/ (2021-04-05).

Statista. 2021b. Dostupné z: https:/www.statista.com/statistics/718019/social-medianews-source/ (2021-04-05).

Zoran Milanović. Dostupné z: https://www.facebook.com/ZoranMilanovic (2021-0320). 



\section{GATUNKI CHARAKTERYSTYCZNE DLA JĘZYKA TURYSTYKI}

\section{Genres Specific to the Language of Tourism}

Keywords: genres, tourism language for specific purposes, tourism discourse

Contact: Uniwersytet Opolski; daria.ogon@uni.opole.pl

W szeroko pojętej turystyce, będącej bardzo ważną dziedziną życia dla coraz większej rzeszy ludzi (zarówno zatrudnionych w tej branży oraz uprawiających aktywnie turystykę poprzez liczne podróże) wykształcił się jak i w innych obszarach komunikacji specjalistyczny język turystyki / język turystyczny. Stanowi funkcjonalną odmianą języka ogólnego „posiadającą bogaty repertuar odmian pisanych oraz mówionych” (Wilkoń 2007: 13). Uważam, że można go pełnoprawnie wyróżnić obok innych języków specjalistycznych takich jak język religii, medycyny, architektury, muzyki i wielu innych. Stwierdzenie to potwierdzają m.in. charakterystyczna leksyka oraz liczne gatunki związane z turystyką i obszarami jej komunikacji, których szeroki wachlarz zostanie przedstawiony w niniejszym artykule.

Pojęcia język specjalistyczny / language for specific purposes / cneųuaльный язык / язык для специиальных ичелей zwykle używa się go w odniesieniu do funkcjonalnej odmiany języka, która umożliwia odpowiednią i skuteczną komunikację pomiędzy specjalistami w danej dziedzinie. O funkcjonowaniu specjalistycznych języków w polskim językoznawstwie pisał w 1956 r. już Zenon Klemensiewicz, że „różne realizacje polskiego języka narodowego nazywa się ,językami”, natomiast różnego typu przydawki zacieśniają je gatunkowo. Mówiąc np. język artystyczny, język naukowy, język żeglarski, traktuje się pierwszy człon tych terminów jako skrót wyrażenia ,język polski”. Podaje on geneus proximum. W drugim członie wskazuje się na cechę różniącą, diferentia specifica, polegającą zwykle na istnieniu odrębnej grupy słownictwa typowej dla danej dziedziny" (Klemensiewicz 1956: 179). Swoją klasyfikację pisanych odmian funkcjonalnych języka polskiego zaproponował Aleksander Wilkoń, wśród nich wymienił język oficjalny jak urzędowy (administracyjny), publicystyczny, artystyczny, naukowy, religijny oraz język biznesu (Wilkoń 2007: 13). Teoretycznie język turystyki wpisuje się przede wszystkim 
w ostatnią z propozycji, a jednocześnie również poza niego wykracza, dlatego warto opisać go jako osobny byt, zawierający w sobie również elementy z innych odmian.

Poza tym, obszar komunikacji w turystyce można mianować również dyskursem turystycznym, będącym przykładem przede wszystkim dyskursu instytucjonalnego, stanowiącego pole komunikacji ludzi, należących do jakiejś grupy społecznej w typowej dla nich sytuacji komunikacyjnej. Badacz analizy dyskursu John Swales opisał społeczności dyskursywne, jako grupy ludzi posiadających wspólne cele komunikacyjne, skupione na ich realizacji poprzez określone gatunki mowy i specyficzną leksykę (Swales 1990: 24).

Natomiast zależność między językiem, a turystyką jako jedni z pierwszych zauważyli badacze Dean MacCannell oraz później Urry i Graham Dann. Dwaj pierwsi chociaż opierali się na innych argumentach doszli do wniosku, że „turystyka” poprzez używany język buduje i determinuje doświadczenie turystów i ich wyobrażenia o odwiedzanym miejscu, bierze udział w kreowaniu rzeczywistości. Spełnia więc zarówno impresywną i magiczną funkcję języka. Myśli te rozwinął później Graham Dann w swoich badaniach, gdzie dokonał socjolingwistyczej analizy języka turystyki i podkreślił jego ścisły związek z językiem reklamy, charakteryzując jako język kontroli społecznej. We wstępie do swojej publikacji The language of tourism wspomniał, że w procesie promocji turystyka ma swój własny język. Tym samym sugerując, że elementy werbalne i wizualne w materiałach promocyjnych turystyki, które głównie badał, stanowią szczególny rodzaj języka różniący się od innych form komunikacji. Zaś za Julią Murrmann można zauważyć, że język turystyki nie jest oparty tylko na języku reklamy, bo jest on dużo bardziej wielowymiarowy, zróżnicowany i zależy od danej sytuacji komunikacyjnej. Nie jest też wyłącznie profesjolektem, służącym do wewnętrznej komunikacji pracowników branży turystycznej, gdyż wchodzi on w ich kontakty z turystami, czy też komunikację samych turystów oraz pojawia się w literaturze podróżniczej i publikacjach dla nich przeznaczonych. Badaczka zaproponowała ciekawą klasyfikację języka turystyki. Poza komercyjnym językiem reklamy i żargonem specjalistów wyróżniła m.in. prawniczy, literacki i dydaktyczny aspekt języka turystyki oraz język porozumiewania się pracowników branży z klientami, a także kontaktów samych klientów między sobą dotyczące ich podróży (Murrmann 2014: 47-57). Podkreśliła, że język turystyki ma wiele oblicz, jest zróżnicowany wewnętrznie i zasilany przez inne odmiany języka (m.in. język dziennikarski, reklamy czy prawniczy).

Usankcjonowanie języka turystyki, jako osobny język specjalistyczny jest możliwe poprzez przypisanie mu wielu charakterystycznych gatunków, tworzących powiązany wzajemnie system. 
Wiąże się to $\mathrm{z}$ teorią Bachtina, według której wszystkie nasze wypowiedzi składają się z konkretnych typowych form konstruowania całości, stanowiących gatunki mowy, czyli stałe pod względem tematycznym, kompozycyjnym i stylistycznym typy wypowiedzi, których kształt zależy od pełnionych funkcji i warunków występowania. Rosyjski badacz podkreślał, że „we wszystkich dziedzinach swojej działalności człowiek posługuje się językiem. Naturalnie charakter i formy wykorzystania języka są tak różnorodne, jak różnorodne są sfery ludzkiej działalności. W żadnej mierze nie przeczy to ogólnonarodowej jedności językowej” (Bachtin 1986: 348). Można przytoczyć również zdecydowane stwierdzenie Wilkonia, iż „nie ma odmiany funkcjonalnej języka bez gatunków (i wyższych form genologicznych) i na odwrót każdy gatunek tekstu realizuje się w określonej odmianie językowej” (Wilkoń 2007: 14).

W polskich badaniach o gatunkach wyszczególnić możemy kilka definicji pojęcia. Gajda postrzega gatunek jako „kulturowo i historycznie ukształtowany, ujęty w społeczne konwencje sposób językowego komunikowania się, wzorzec organizacji tekstu” (Gajda 1990: 67). Podobnie konstatuje go Maria Wojtak, jako „utrwalony w świadomości twórców schemat określonego typu wypowiedzi” (Wojtak 2004: 16) czy też przykładowy rosyjski wariant definicji - „werbalny przekaz typowej sytuacji komunikacyjnej między ludźmi” (Шмелева 1991: 90).

Czym są gatunki turystyczne? Analogicznie do innych gatunków przypisanych wybranym odmianom, językom specjalistycznym są to wszelkie formy wypowiedzi tworzone, upowszechniane, komunikowane przez branżę turystyczną, ale także przez jej klientów-turystów.

Próbę klasyfikacji gatunków turystycznych podjęła rosyjska badaczka turystycznego dyskursu Natalia Filatova. Podziału dokonuje na podstawie specyfiki realizowanego celu, sposobu przedstawienia zawartości, cech kompozycji i charakterystycznych elementów językowych. Przede wszystkim pogrupowała teksty ze względu na rodzaj przekazu komunikatów na pisemne - drukowane oraz funkcjonujące w przestrzeni Internetu i ustne - mówione, które dzieli na bezpośrednie oraz pośrednie.

Wśród pisemnych wymienia:

- przewodnik turystyczny;

- prospekt turystyczny;

- katalog;

- broszurę oraz ulotkę. 
Warto by do nich dodać gatunki z pogranicza dziedzin, związanych również z pracą w branży turystycznej, jak np. prawa i reklamy. Sa one niezwykle istotne dla dyskursu i specjalistycznego języka turystyki, czyli wszelkie umowy o udziale w imprezie turystycznej oraz ustawy np. o usługach turystycznych. Dalej w nawiązaniu do klasyfikacji Murrmann o wymiarach języka turystyki, warto by wyszczególnić również literackie formy, jak wydawane reportaże podróżnicze. Poza tym, sądzę, że do tego spisu należałoby dopisać również gatunek reklamacji turystów, który także rządzi się charakterystycznymi regułami, sformułowaniami i kompozycją oraz ma jasno określony cel - otrzymanie jakiejś formy rekompensaty za różnego rodzaju szkody.

Za gatunki turystyczne pojawiające się głównie w przestrzeni wirtualnej w formie multimedialnej Filatova uważa:

- strony internetowe biur podróży;

- wirtualne wycieczki;

- artykuły związane z tematyką turystyczną;

- opinie turystów na forach internetowych;

- teksty na blogach turystów i podróżników, będące często jednocześnie ich subiektywnymi opiniami.

Do tego zbioru klasyfikuje również korespondencję mailową zarówno wewnętrzną pracowników branży jak i specjalistów z klientami-turystami. Można by pokusić się o przypisanie konkretnych nazw gatunkowych najbardziej powszechnym celom w komunikacji elektronicznej. W obu tych przypadkach bardzo częstą formułą są zapytania ofertowe i prośby o rezerwację oraz zwrotnie ze strony usługodawcy przygotowane oferty i potwierdzenia rezerwacji, także w formie dokumentu - vouchera turystycznego (później drukowanego). Jako gatunki ustne bezpośrednie przedstawia:

- wycieczkę (oprowadzanie turystów przez przewodnika turystycznego);

- rozmowę handlową pracownika z klientem (w biurze lub poza nim);

- negocjacje handlowe pracownika z kontrahentem w celu uzyskania ofert, zawarcia umów o współpracy np. na specjalistycznych targach i spotkaniach branżowych.

Wymienia także, że na peryferiach pola gatunkowego mogą się znaleźć również oficjalne rozmowy z urzędnikami konsulatu, dotyczące załatwienia np. niezbędnych formalności wizowych dla turystów. 
Można je uzupełnić o formułę istotną szczególnie w życiu pilotów i przewodników, czyli spotkania informacyjne rezydentów, pilotów dla klientów oraz komunikaty informujące.

Wśród gatunków mówionych pośrednich wyszczególnia:

- wideoprzewodniki;

- nagrane audioprzewodniki, często dostępne w muzeach do odsłuchania przez zwiedzających wyposażonych w specjalny sprzęt słuchawkowy.

Czasem trudno o jednoznaczny synkretyzm w typologii gatunków i zdarza się, iż dany gatunek występuję w kilku odmianach/językach specjalistycznych, jak np. forma umowy czy modyfikowana na potrzeby turystyczne reklama w postaci wymienionych powyżej katalogów, broszur, ulotek. Maria Wojtak określiła je jako gatunki wędrujące. W języku turystyki one również występują, nie mniej jednak są one nieodłącznymi wobec tej dziedziny działalności człowieka.

Mam nadzieję, że mnogość możliwych form wyszczególnionych przez Filatovą oraz sugestie poszerzenia tego spisu o kolejne gatunki w tym artykule, potwierdza istnienie osobnego specjalistycznego języka turystyki oraz bogatego instytucjonalnego dyskursu turystycznego.

\section{Summary}

The purpose of this article is to raise awareness of the existence of a specialised language of tourism alongside other specialised languages and, even more broadly, of tourism discourse. It is evidenced by specific lexis and used genres related to this sphere of communication of both tourism specialists and their clients-tourists. We present a sample typology of genres characteristic for the language of tourism.

\section{Literatura}

Bachtin, M. Estetyka twórczości stownej. Warszawa: Państwowy Instytut Wydawniczy, 1986.

Gajda, S. Wprowadzenie do teorii terminu. Opole: Wyższa Szkoła Pedagogiczna im. Powstańców Śląskich, 1990.

Murrmann, J. Profesjolekt branży turystycznej, czyli o specyficznych cechach języka zawodowego turystyki. In: Pawłucki, A. (ed.) Rozprawy Naukowe Akademii 
Wychowania Fizycznego we Wrocławiu. Wrocław: Akademia Wychowania Fizycznego we Wrocławiu, 2014, s. 47-57.

Swales, J.M. Genre. analysis: English in academic and research settings. Cambridge: Cambridge Univ Ed., 1990.

Wilkoń, A. Typologia odmian językowych współczesnej polszczyzny. Katowice: Wydawnictwo Uniwersytetu Śląskiego, 2000.

Wojtak, M. Gatunki prasowe. Lublin: Wydawnictwo Uniwersytetu Marii CurieSkłodowskiej, 2004.

Wojtak, M. Wprowadzenie do genologii. Lublin: Wydawnictwo Uniwersytetu Marii Curie-Skłodowskiej, 2019.

Филатова, Н.В. Жанровое пространство туристического дискурса. Филологические науки. 2012 (2), с. 76-82.

Шмелева, Т.В. Речевые жанры. Культура русской речи: Энциклопедический словарь-справочник: проспект. Красноярск: Издательствово Красноярского государственного университета, 1991. 


\title{
VYBRANÉ PROBLÉMY ČESKO-POLSKÉ TERMINOLOGIE SPORTU ${ }^{1}$
}

\author{
Representative Problems of Czech-Polish Sport Terminology
}

Keywords: sport, Czech language, Polish language, terminology, etymology, semantics Contact: Masarykova univerzita; pikulova.jana@gmail.com

\section{1 Úvod}

Tématem příspěvku je představení analýzy vybraných lexémů sportovní terminologie, která je součástí zkoumání rozdílnosti v pojmenovávání v českém a polském sportu. Prvotní myšlenka vychází z pozorování, že v obou výše zmíněných jazycích existují malé i velké rozdíly v označení částí hřišt', hráčů, pravidel, výstroje a výzbroje aj. $\mathrm{V}$ jednom jazyce se pro konkrétní předmět užije domácí výraz, kdežto na straně druhé výpůjčka. Kromě toho označující výrazy nemají vždy stejnou šíři významu.

\section{Tvorba slovní zásoby}

Tvorba slovní zásoby je založena na sběru výrazů, které jsou vloženy do tabulek podle sportů. V jednom sloupci se nachází české výrazy a v druhém jejich polský překlad.

\section{Způsob výběru dvojic k další analýze}

Po sebrání vyčerpávajícího množství výrazů týkajících se jednoho sportu, následuje výběr těch dvojic jednotek, které budou podrobeny hlubší analýze. Mimo náš zájem se dostávají páry, které mají na obou stranách bud’ domácí pojmy, nebo výpůjčky, ale ze stejných jazyků, tedy stejného původu. Naopak se do popředí dostávají následující dvojice: ty, které mají na jedné straně domácí výraz a na druhé straně výpůjčku; ty, které mají na obou stranách výpůjčku, ale jedná se o výpůjčky z dvou různých jazyků; ty,

\footnotetext{
1 Tento text vznikl v rámci řešení projektu Specifického výzkumu MUNI/A/1348/2020 Teoreticko-aplikační a lexikografická podpora překladu ve slovanských jazycích (Ústav slavistiky FF MU).
} 
které mají sice na obou stranách výpůjčky stejného původu nebo domácí výrazy, avšak šíre jejich významu není stejná.

\section{Rozbor jednotek}

Níže představujeme způsob detailního rozboru jednotek na př́íkladu termínů z fotbalu a hokeje. Každý výraz obsahuje původ, vysvětlení významu a př́iklad užití z českého ${ }^{23}$ nebo polského ${ }^{4}$ korpusu.

\section{Fotbal}

\section{polsky PILKA NOŻNa, FUTBOL}

piłka nożna - původ: $\mathrm{z}$ angl. football

= sportovní soutěž, které se účastní dvě družstva o jedenácti hráčích, která se snaží $\mathrm{v}$ určitém čase získat, co nejvíce bodů za vstřelení míče do soupeřovy branky ${ }^{5}$

„Po raz pierwszy w historii mistrzostwa świata w pitce nożnej zorganizuja dwa kraje."

futbol - původ: $\mathrm{z}$ angl. football

„Goeteborg musi rozpoczać ofensywnie $i$ uważać na polskie kontry. Dlugie pitki do szybkich napastników zawsze wyróżniaty polski futbol. Lech Poznań opanowat tę sztukę dobrze i będzie z pewnościa czekat na bład Szwedów."

\section{česky FOTBAL, KOPANÁ}

fotbal - původ: $\mathrm{z}$ angl. football

„Kariéru Baroš naštěstí zatím ještě neukončil, někdejši vitěz Ligy mistrů zastává nyní, už ve svých třiatřiceti letech, roli náhradníka v Mladé Boleslavi. Vypjaté emoce fotbal každopádně neopouštějí, kvůli nim se vlastně hraje. "

\footnotetext{
${ }^{2}$ Křen, M., Cvrček, V., Čapka, T., Čermáková, A., Hnátková, M., Chlumská, L., Jelínek, T., Kováríková, D., Petkevič, V., Procházka, P., Skoumalová, H., Škrabal, M., Truneček, P., Vondřička, P., Zasina, A. SYN2015: reprezentativni korpus psané češtiny. Dostupné z: http://www.korpus.cz (2021-04-25).

${ }^{3}$ Kř̌en, M., Cvrček, V., Henyš, J., Hnátková, M., Jelínek, T., Kocek, J., Kováŕíková, D., Křivan, J., Miličcka, J., Petkevič, V., Procházka, P., Skoumalová, H., Šindlerová, J., Škrabal, M. SYN2020: reprezentativní korpus psané češtiny. Dostupné z: http://www.korpus.cz (2021-04-20).

${ }^{4}$ Pęzik, P., Przepiórkowski, A., Bańko, M., Górski, R. L., Lewandowska-Tomaszczyk B. (ed.) Wyszukiwarka PELCRA dla danych NKJP: Narodowy Korpus Języka Polskiego. Dostupné z: http://www.nkjp.uni.lodz.pl/ (20213-28).

${ }^{5}$ Piłka nożna. Dostupné z: https://sjp.pwn.pl/szukaj/pi\%C5\%82ka\%20no\%C5\%BCna.html (2021-04-21). 
kopaná - od českého kopat

„Dvacet osm firemnich týmů změř́ dnes své sily na Strahově v benefičním fotbalovém turnaji v malé kopané. Koná se totiž 7. ročník Sue Ryder Charity Cupu. Touto jedinečnou formou podpoři fotbalisté Domov Sue Ryder a jeho poslání - disstojnou péči o seniory. Turnaj se koná ve Fotbalovém centru mládeže Strahov. “

Označení piłka nożna je lexikální kalk neboli doslovný překlad původního anglického výrazu football. Můžeme se také setkat s často používanou zkráceninou „piłka“, Idziemy zagrać w piłkę. V tomto př́padě je ale nutné znát kontext, protože samotné označení piłka nemusí odkazovat pouze na fotbal, ale také na futsal (pl. piłka halowa) nebo házenou (pl. piłka ręczna). Kromě označení piłka nożna se používá také výraz futbol, ale méně často. Ovšem přesnější informace k frekvenci užití těchto dvou výrazů nám nejsou známy, protože se nám zatím nepodařilo najít dostupný frekvenční slovník polského jazyka, tak jak je pro češtinu dostupný v rámci korpusu na př́slušných internetových stránkách. Stejně jako u lexému piłka, tak i u jednotky futbol je třeba znát kontext, i když ve velké většině př́ípadů jde v polském prostředí o fotbal, může však jít rovněž o rugby, americký fotbal a další.

V českém prostředí jednoznačně převažuje pro označení tohoto sportu výraz fotbal, pocházející také z anglického football, zde jde však pouze o výpůjčku nikoliv o překlad původního názvu. Naproti tomu existuje ještě výraz kopaná, který se neužívá $\mathrm{v}$ až tak vysoké míře jako fotbal. Najdeme ho spíše v projevech sportovních komentátorů jako vhodné synonymum nebo také v menší míře u fanoušků, avšak u osob, které fotbal př́lišs nezajímá, se s tímto termínem setkáváme spíše zř́ídka, protože kromě jiného působí i archaicky. Podle frekvenčního slovníku se od dvacátých let 20. století užíval téměř výhradně výraz kopaná, kdežto v šedesátých letech se trend obrátil a od té doby se v 95 \% př́ípadů užívá termín fotbal. ${ }^{6}$ Stejně jako v př́padě polského futbolu bychom i zde mohli požadovat bližší specifikaci, jestli snad nejde o americký fotbal, ale vzhledem k oblíbenosti, to není nutné. Ještě je třeba podotknout, že výraz kopaná se zachoval v názvu halového sportu malá kopaná, který je teda také označován jako malý fotbal.

Z hlediska použití tedy není možné říct, že výraz futbol je přesným ekvivalentem českého výrazu fotbal, naopak českému fotbalu odpovídá polské piłka nożna. Zároveň také nemůžeme říct, že by futbol byl nějak spjatý s českou kopanou, nebot' česká kopaná jako označení fotbalu je výraz méně užívaný a spíše archaický, kdežto polský výraz futbol toto zabarvení nemá.

\footnotetext{
${ }^{6}$ Cvrček, V., Vondřička, P. SyD. Dostupné z: http://syd.korpus.cz (2021-04-20).
} 


\section{polsky POZYCJA SPALONA, SPALONY}

- polský výraz vycházející ze staršího významu „pokažený, zničený“7

\section{I. spálený, popálený8}

„Pierwsza historyczna wzmianka o Brodnicy (nazwa od brodu) pochodzi z XIII w. Istniejacy tu zamek krzyżacki, spalony w 1298 przez Litwinów, potem odbudowany, stanowit siedzibę komtura."

\section{II. vyzrazený (vyzvědač); zkompromitovaný ${ }^{9}$}

,,- Dokad wrócisz, oszalateś? Jesteś spalony.

- Nie - powiedziat. - Spalony zostat agent udajacy Hansa Klossa."

III. v hokeji, fotbale, ragby - porušení pravidel, kdy při prrihrávce míče druhému hráči stejného týmu se mezi druhým hráčem a soupeřovou brankou nenachází žádný ze soupeřova týmu ${ }^{10}$

„Bramka nie powinna być uznana. Piłka odbiła się od ręki Haesslera, a Klinsmann byt chyba na spalonym - powiedziat trener Boliwii, Bask Xabier Azkargorta."

\section{polsky OFSAJD, OFSAJDOWA PULAPKA}

$=$ ofsajdová past

„Zagranie to rodzi wiele kontrowersji, podobnie jak sam ofsajd, gdyż zdarzaja sie sytuacje, kiedy to ewidentny spalony zostaje nieodgwizdany przez sędziego, bądź też kiedy zostaje odgwizdany gdy faktycznie go nie $m a . " 11$

„Pułapka ofsajdowa (ang. offside trap) - zagranie wpiłce nożnejpolegajace na wyjściu linii obrony do przodu i pozostawieniu napastnika (bądź innego zawodnika / zawodników) drużyny przeciwnej na pozycji spalonej, co kończy się odgwizdaniem

\footnotetext{
${ }^{7}$ „Znacznie ciekawszy jest przymiotnik (imiesłów) spalony, powiązany z czasownikami palić, spalić. Jako termin (czasem w wyrażeniu pozycja spalona) funkcjonuje on nie tylko w piłce nożnej, ale też w rugby i hokeju. Co więcej, także w innych dyscyplinach sportu znane są sfrazeologizowane połączenia typu spalić bój (rwanie, podrzut) w podnoszeniu ciężarów, spalić skok (w dal, w trójskoku), spalić rzut (dyskiem, młotem, oszczepem). Wygląda więc na to, że spalony to 'zepsuty, nieudany', por. w Uniwersalnym stowniku języka polskiego: „,spalić, położyć dowcip”. Sięgając głębiej w przeszłość, należałoby wziąć pod uwagę frazeologizm coś spaliło na panewce 'coś się nie udało, zakończyło się niepowodzeniem, zawiodło'.“ Bańko, M. Polska terminologia piłkarska. Dostupné z: https://sjp.pwn.pl/poradnia/haslo/polska-terminologia-pilkarska;11960.html (2021-04-21).

${ }^{8}$ Oliva, K., Balowski, M. Polsko-český slovnik. Voznice: Leda, 2012.

${ }^{9}$ Spalony I. Dostupné z: https://wsjp.pl/index.php?id_hasla=17066\&ind=0\&w_szukaj=spalony\# (2021-03-13).

${ }^{10}$ Spalony. Dostupné z: https://sjp.pwn.pl/szukaj/spalony.html (2021-03-13).

${ }^{11}$ Pułapka ofsajdowa. Dostupné z: https://juventus.fandom.com/pl/wiki/Pu\%C5\%82apka_ofsajdowa\# (2021-03$13)$.
} 
przewinienia $i$ przerwaniem akcji ofensywnej, lub przynajmniej koniecznościa rozegrania akcji innym wariantem." 12

\section{česky OFSAJDOVÁ POZICE, OFSAJD}

původ: $\mathrm{z}$ angl. offside

- používá se také česká varianta postavení mimo hru, ale ne ve fotbalu, ale např̀. u hokeje ano

„Před koncem sice Wágner srovnal, ovšem kvůli ofsajdu Františka Rajtorala sudí Miroslav Zelinka uznaný gól po delši konzultaci s pomezním Jiřim Jiřikem zrušil. "13

Pozycja spalona označuje ofsajdovou pozici čili situaci, kdy se některý hráč nachází na polovině soupeře, blíže k soupeřově brance než míč i než předposlední hráč soupeře. Takováto situace sama o sobě není porušením pravidel, pokud se však hráč v ofsajdové pozici zapojí do hry ve chvíli, kdy se jeden z jeho spoluhráčů dotkne míče, jedná se o ofsajd a hra je přerušena. ${ }^{14}$ Pokud se zaměříme na výraz spalony, tak ten má mnoho významů i mimo sportovní oblast. Jde o něco, co se spálilo, osobu, která byla vyzrazena nebo nějak zkompromitována, nebo také o osobu pod vlivem marihuany. Použití ve sportu odkazuje na dřívější význam, který označoval něco pokaženého, nepodařeného viz např. spalić dowcip.

Český výraz ofsajd pochází z anglického offside čili postavení mimo hru. Je zajímavé, že ve fotbale se užívá výhradně termínu ofsajd, naproti tomu např. v hokeji už se užívá obou termínů rovnocenně, tedy ofsajd i postavení mimo hru.

Můžeme říci, že pozycja spalona, spalony a ofsajdová pozice, ofsajd jsou ideálními ekvivalenty a není důvod, aby zde při překladech docházelo k nějakým problémům. Je třeba ale zmínit, že v polštině se objevuje výraz ofsajd, ale to jen marginálně. Běžně se však užívá ve slovním spojení pułapka ofsajdowa (č. ofsajdová past) a není možné říci pułapka spalona.

\footnotetext{
12 Op. cit. Pulapka ofsajdowa.

${ }^{13}$ Ofsajd. Dostupné z: https://www.korpus.cz/slovo-v-kostce/search/cs/ofsajd?lemma=\&pos= (2021-04-22).

${ }^{14}$ Ofsajd. Dostupné z: https://cs.wikipedia.org/wiki/Ofsajd (2021-04-22).
} 


\section{Hokej}

\section{polsky KIJ}

původ: z psl. *kyjь 'kladivo, kyj'15

\section{I dlouhý, tlustý, jednoduchý klacek ${ }^{16}$}

„,W mroku trudno już było dostrzec cokolwiek, ale poczuła, że coś dotyka jej twarzy, siegnęła tam ręka i chwyciła kij, trzymała mocno, a Konus wyciagat ja z bagna, już jest na brzegu, poczuła pod brzuchem twardy grunt, puściła kij, już była bezpieczna."

bambusowy $\sim$, drewiany $\sim$, krzywy

$\sim$ od łopaty, $\sim$ od miotły, $\sim$ od siekiery

\section{II dřevěná nebo kovová tyč speciálního tvaru používaná ve sportu ${ }^{17}$}

$\sim$ baseballowy, $\sim$ bilardowy, e golfowy, $\sim$ hokejowy; e narciarskie, $\sim$ do bilarda, $\sim$ e do golfa, e do krykieta ${ }^{18}$

„,- Poproszę kij do hokeja, ten za dwieście.

Już widziatem siebie mknacego po lodzie z moim nowym kijem, ale, jak na razie, znajdowatem sie jeszcze na Pradze, wśród budek i kramów. ”

\section{česky HOKEJKA}

původ: $\mathrm{z}$ angl. hockey

= sportovní náčiní v podobě hole, kterou hráči strkají puk (popřr. míček) do soupeřovy branky $^{19}$

„Adam byl skvělý brankár̆ - nepochybně by byl jedním ze žhavých kandidátư na vysokoškolský tým -, pak ale pred šesti měsíci prestal. Prostě zničehonic. Odložil hokejku, lapačku i masku a prohlásil, že konči.."

\section{česky HŮL}

původ: z psl. *golъ ,holý‘ ${ }^{* 20}$

\footnotetext{
${ }^{15} \mathrm{Kij}$. Dostupné z: https://wsjp.pl/index.php?id_hasla=24442\&id_znaczenia=2945423\&l=13\&ind=0 (2021-0325).

${ }^{16}$ Op. cit. Kij.

${ }^{17}$ Drabik, L., Sobol, E. Stownik języka polskiego PWN. Warszawa: Wydawnictwo naukowe PWN, 2007.

${ }^{18}$ Op. cit. Kij.

${ }^{19}$ Nechybujte.cz. Dostupné z: nechybujte.cz (2021-03-26).

${ }^{20} \mathrm{H}$ ůl. Dostupné z: https://en.wiktionary.org/w/index.php?title=h\%C5\%AFl\&oldid=54704079 (2021-03-26). 
= obvykle rovná tyč, sloužící jako opora při chůzi, módní doplněk či zbraň hokejová , florbalová , baseballová , golfové e, slepecká , francouzské e

„Bílá slepecká hůl většinu lidí pohne $k$ nezištné pomoci nevidomému člověku. “

„Ve 22. minutě už diváci ve slušně zaplněné hale aplaudovali vstřelené brance, té ale predcházela vysoká hůl Jakuba Nakládala, zkoumání u videa proviněni proti regulím potvrdilo. “

Polský výraz kij vychází z praslovanského výrazu pro kladivo, kyj a označuje jakoukoliv dlouhou, jednoduchou tyč. Používá se i ve významu násady k zahradnímu nebo stavebnímu náčiní, nebo jako topor k sekeře. Druhý význam výrazu kij jen více specifikuje význam první a zaměřuje se pouze na sport. Ovšem ani v tomto př́padě okruh označovaných předmětů není tak úzký jako v př́ípadě české hokejky.

Český výraz hưl už nemá tak úzký význam, pochází z praslovanského výrazu holý a neoznačuje čistě jednu věc, naopak můžeme tento výraz najít v souvislosti se sportem hokejová hưl, golfové hole, jako pomůcku pro nevidové slepecká hůl nebo jako pomůcku pro zraněného člověka francouzské hole. U výrazu hůl je ve velké většině př́padů, pokud to není jasné z kontextu, nutné doplnit adjektivum, které výraz bliže specifikuje.

V českém prostředí se pro náčiní, které používají hráči ledního hokeje, užívají dva výrazy, avšak výraz hokejka je rozšířenější, a to především mezi laiky a fanoušky sportu, kdežto mezi sportovními komentátory a lidmi více spjatými s hokejem jsou oba výrazy rovnocenné. Zajímavostí je, že ač se tyto dva významy mohou zaměňovat, v př́ípadě překročení pravidel, kdy hráč hraje s vysoko zdviženou hokejkou, užívá se pro tuto situaci ustálené spojení hra vysokou holi, nikoli hokejkou.

Pro shrnutí tedy můžeme ř́íci, že polský výraz kij má ve vztahu ke sportu v češtině dva protějšky. Výraz hůl, který je obecnějšího charakteru a dá se užít i mimo oblast sportu, a hokejka, která už úzce odkazuje na sport, konkrétně na lední nebo pozemní hokej a na florbal.

\section{polsky KRĄżEK}

původ: z psl. *krǫgъ 'něco zakrouceného, svinutého, svitek, kolo, kruh, předmět ve tvaru kola, koule ${ }^{21}$ = zdrobnělina od „kruh“

\footnotetext{
${ }^{21} \mathrm{Krag}$. Dostupné z: https://wsjp.pl/index.php?id_hasla=33986\&ind=0\&w_szukaj=kr\%C4\%85g (2021-03-27).
} 
Ia krążek światła - povrch vyznačený kruhovitou linií

Ib krążek np. sera - plochý předmět

„Biszkopty przekroić na trzy krążi, każdy krążek nasaczyć sokiem ananasowym i przełożyć kremem. W krem wcisnać osaczone i pokrojone ananasy."

Ic płyta - deska z umělé hmoty, na kterou se zapisuje zvuk, abychom jej později mohli přehrát

„Testy odczytu z plyt $C D-R$ rozłożyliśmy na trzy osobne pomiary, uwzględniajace kolor powierzchni odblaskowej płyty. Jako nośnik $R W$ wykorzystaliśmy krążek Hawlett Packarda $z$ nagrana kopia wspomnianego wcześniej Nortona."

\section{Id krążek do hokeja}

„Niespetna pięć minut później rozegrat doskonata akcje z obrońca Kelly Buchbergerem i jeszcze raz posłat krążek do bramki rywali.'

IIa krążek znajomych - okruh známých

IIb krążek zainteresowań - okruh zájmů

\section{česky Puk}

\section{I sportovní náčiní ve tvaru disku z černé gumy, používané v ledním hokeji ${ }^{22}$}

„Z angl. puck, jež přišlo z Kanady kolem r. 1900. Původ nejasný - snad z angl. poke ,št'ouchnout, strčit (holí)‘, či snad žertovně podle homonymního puck «čertík, skřítek, šotek»" “23

„Sám jel na prázdnou branku, když hosté ve snaze vyrovnat odvolali brankárée. Protihráči ho faulovali, takže nemohl vystřelit a puk těsně minul branku."

\section{II záhyb na kalhotách ${ }^{24}$}

původ: z něm. Bug od slovesa biegen - ohýbat ${ }^{25}$

„Lehce zachmuřený pohled a precizně vypilované detaily nenechávají nikoho na pochybách, že Audi A8, ten rezervovaný perfekcionalista, si nechal opět ušit oblek podle posledni módy. Nic na nèm netrčí, nohavice mají správnou délku a puky jsou pěkně zažehlené. "

\footnotetext{
${ }^{22}$ Puk. Dostupné z: https://cs.wiktionary.org/wiki/puk (2021-03-27).

${ }^{23}$ Rejzek, J. Český etymologický slovník. Praha: Leda, 2015.

${ }^{24}$ Op. cit. Krag.

${ }^{25}$ Op. cit. Rejzek, J. 


\section{III rostlinný pupen ${ }^{26}$}

„Pro 4 osoby si pripravíme: $500 \mathrm{~g}$ hovězi roštěné kousek čerstvého zázvoru asi 5 lžic sójové omáčky 1 velkou cibuli 2 velké mrkve $200 \mathrm{~g}$ mražených fazolových lusků (převařených) 2 puky bílé čekanky asi 4 lžice oleje asi $150 \mathrm{ml}$ hovězího vývaru sưl mletý černý pepř. “

\section{česky KOTOUČ}

původ: „Jen č. a slk. (kotúč), úzce spojeno s kotoul, přesný způsob tvoření však není jasný. “27

\section{Ia plochý předmět kulatého tvaru}

„Využití vody snižuje teplotu broušeného povrchu a minimalizuje prašnost. Pracuje se s brusnými kotouči různé hrubosti, nakonec se povrch doleští lešticím kotoučem."

„Maximální fáze zatměni nastane ve 22:12, kdy bude měsični kotouč procházet nejtemnějši částí zemského stínu, a skonči tři minuty po třiadvacáté hodině. “

\section{Ib protáhlá věc svinutá do kulatého tvaru}

„,Mandžiró a jeho druhové se usadili na přidi za velkým kotoučem lodního lana a vyménili Džúsukemu obvaz na noze."

\section{Ib hokejový puk}

„Síla a zkušenosti, to jsou hlavní rozdíly v porovnání s juniorkou. Hráči si umí kotouč ohlídat. Vědí, kdy mají vystřelit, a kdy puk naopak podržet."

Krążek, zdrobnělina od výrazu krąg, pochází z praslovanského výrazu *krogъ, kterým se nazývá předmět kulatého tvaru, kolo, kruh. Zde označení hokejového puku odkazuje na jeho kruhový tvar, podobně jako je tomu u českého výrazu kotouč. Slovo krążek má však mnoho významů a je-li vytrženo z kontextu, neodkazuje pouze na sportovní předmět, ale např́klad na kruh světla, kruh sýra, $C D$, nebo v přeneseném slova smyslu na okruh známých nebo okruh zájmů.

V češtině se pro kulatý předmět z černé gumy používá výraz puk, který vychází ze stejného předmětu z angličtiny z výrazu puck. Slovo puk má zároveň i jiné významy, které ale nesouvisí se sportem a ani nijak svým tvarem hokejový puk nepřipomínají. Máme tedy puk ve významu záhyb na kalhotech nebo také jako pupen na rostlině.

\footnotetext{
${ }^{26}$ Op. cit. Krąg.

${ }^{27}$ Op. cit. Rejzek, J.
} 
Dalším označením černého předmětu v hokeji je výraz kotouč. Běžní mluvčí častěji užívají termín puk, ale mezi komentátory a osobami pohybující se $\mathrm{v}$ hokeji je i kotouč rozšířen, ale není zastoupen $\mathrm{v}$ tak velké míře. Výraz kotouč je ale používán i mimo sport. Jedná se o plochý předmět kulatého tvaru, jako např. brusný kotouč, kotouč pily, kotoučové brzdy, kde je pokaždé odkazováno na tvar předmětu.

Můžeme tedy říct, že v obecném slova smyslu by polský krążek lépe odpovídal českému kotouči, ale pro vhodný překlad tuto dvojici nemůžeme spojit, protože kotouč je vhokejovém prostředí méně užívaný než dominantní puk. Proto vhodnými ekvivalenty jsou krążek-puk.

\section{Závěr}

Na základě výrazů, které do této chvíle prošly naší analýzou, není možné říci, že by v některém z jazyků převažovaly výpůjčky. Avšak je zde patrné, že pokud je termínem výraz domácí, je zde větší pravděpodobnost, že šiřre jeho významu bude větší než u výpůjčky.

Př́klady představené $\mathrm{v}$ tomto př́spěvku jsou jen zlomkem $\mathrm{z}$ výzkumu, který bude dále pokračovat $\mathrm{v}$ dalších sportech analýzou podobně charakteristických jednotek. Jestliže se podaři sesbírat velké množství slov, bez ohledu na to, jestli budou dále analyzována, jako vedlejší produkt by mohl vzniknout česko-polský slovníček sportovních pojmů. Podle našeho zjištění v posledních letech žádný takový slovník $\mathrm{v}$ této jazykové kombinaci nevznikl a jeho vznik by tedy mohl pomoci nejen sportovním fanouškům, ale také např. sportovním komentátorům.

\section{Summary}

The article focuses on introducing representative problems of Czech-Polish sport terminology. The aim is to show that in these two languages, there is a different extent of representation of domestic expressions and borrowed expressions from other languages. Moreover, as demonstrated with examples of football and ice hockey terminology, there is also a different scope of meaning of these expressions which can complicate the choice of appropriate equivalent while translating. 


\section{Literatura}

Drabik, L., Sobol, E. Słownik języka polskiego PWN. Warszawa: Wydawnictwo naukowe PWN, 2007.

Oliva, K., Balowski, M. Polsko-český slovník. Voznice: Leda, 2012.

Rejzek, J. Český etymologický slovník. Praha: Leda, 2015.

\section{Elektronické zdroje}

Bańko, M. Polska terminologia piłkarska. Dostupné z: https://sjp.pwn.pl/poradnia/ haslo/polska-terminologia-pilkarska;11960.html (2021-04-21).

Cvrček, V., Vondřička, P. SyD. Dostupné z: http://syd.korpus.cz (2021-04-20).

Hůl. Dostupné z: https://en.wiktionary.org/w/index.php?title=h\%C5\%AFl\&oldid $=54704079$ (2021-03-26).

Kij. Dostupné z: https://wsjp.pl/index.php?id_hasla=24442\&id_znaczenia= 2945423\&l=13\&ind=0 (2021-03-25).

Krą. Dostupné z: https://wsjp.pl/index.php?id_hasla=33986\&ind=0\&w_szukaj $=\mathrm{kr} \% \mathrm{C} 4 \% 85 \mathrm{~g}(2021-03-27)$.

Křen, M., Cvrček, V., Čapka, T., Čermáková, A., Hnátková, M., Chlumská, L., Jelínek, T., Kováŕíková, D., Petkevič, V., Procházka, P., Skoumalová, H., Škrabal, M., Truneček, P., Vondřička, P., Zasina, A. SYN2015: reprezentativní korpus psané češtiny. Dostupné z: http://www.korpus.cz (202104-25).

Křen, M., Cvrček, V., Henyš, J., Hnátková, M., Jelínek, T., Kocek, J., Kováříková, D., Křivan, J., Milička, J., Petkevič, V., Procházka, P., Skoumalová, H., Šindlerová, J., Škrabal, M. SYN2020: reprezentativní korpus psané češtiny. Dostupné z: http://www.korpus.cz (2021-04-20).

Nechybujte.cz. Dostupné z: nechybujte.cz (2021-03-26).

Není kibic jako kibic. Dostupné z: http://www.akcr.cz/txt/neni-kibic-jako-kibic (202104-20).

Ofsajd. Dostupné z: https://cs.wikipedia.org/wiki/Ofsajd (2021-04-22).

Ofsajd. Dostupné z: https://www.korpus.cz/slovo-v-kostce/search/cs/ofsajd?lemma $=\&$ pos $=(2021-04-22)$. 
Pęzik, P., Przepiórkowski, A., Bańko, M., Górski, R. L., LewandowskaTomaszczyk B. (ed.) Wyszukiwarka PELCRA dla danych NKJP: Narodowy Korpus Języka Polskiego. Dostupné z: http://www.nkjp.uni.lodz.p1/ (2021-3-28).

Pitka nożna. Dostupné z: https://sjp.pwn.pl/szukaj/pi\%C5\%82ka\%20no\%C5\%BC na.html (2021-04-21).

Puk. Dostupné z: https://cs.wiktionary.org/wiki/puk (2021-03-27).

Pułapka ofsajdowa. Dostupné z: https://juventus.fandom.com/p1/wiki/Pu\%C5\%82apka _ofsajdowa\# (2021-03-13).

Spalony. Dostupné z: https://sjp.pwn.pl/szukaj/spalony.html (2021-03-13).

Spalony I. Dostupné z: https://wsjp.pl/index.php?id_hasla=17066\&ind=0\&w _szukaj=spalony\# (2021-03-13). 


\section{К ПРОБЛЕМАТИКЕ СЛОВОИЗМЕНИТЕЛЬНОЙ СИСТЕМЫ ИМЕНИ СУЩЕСТВИТЕЛЬНОГО В РУССКОМ, ПОЛЬСКОМ И СЛОВАЦКОМ ЯЗЫКАХ}

\section{The Problem of Declension of a Noun in Russian, Polish and Slovak Language}

Keywords: noun, declension, Russian language, Polish language, Slovak language

Contact: Ostravská univerzita; mon.stenchlakova@gmail.com

\section{К актуальности проблематики}

Проблематика сравнения словоизменительных систем частей речи является актуальной и по сей день. Разные подходы лингвистов к проблематике помогают лучше понять современное состояние языков, структуру их функционирования и взаимное влияние языков из одной языковой семьи.

Сравнение славянских языков также помогает понять актуальные тенденции, происходящие в данных языках, и одновременно является вспомогательным элементом в улучшении коммуникации среди носителей славянских языков.

Основной целью статьи является сравнение словоизменительной системы имени существительного в русском, польском и словацком языках, прежде всего отдельных систем в данных языках, сходств и отличий относительно морфологического подхода к данной проблематике. Статья представляет собой обзор основных морфологических структур в склонении имени существительного в выбранных языках.

\section{Основные понятия статьи}

В начале статьи следует определить ключевой термин «имя существительное». «Русская грамматика» Н.Ю. Шведовой определяет имя существительное как самостоятельную часть речи, которая обозначает названия лиц, вещей, веществ, организмов и живых существ, культурных, политических, исторических и других 
событий, фактов и явлений. Имя существительное выражает это значение в категориях числа, падежа и в категории рода (Шведова 1980: 458).

Вместе с глаголом существительные являются наиболее часто употребляемыми частями речи. Для человеческой коммуникации и для языка никакая из частей речи не является абсолютно необходимой, кроме существительных и глаголов (Сепир 1993: 116).

Следующим из основных понятий является термин «словоизменение». Это образование форм одного и того же слова. При словоизменении происходят такие изменения отдельного слова, при которых сохраняется полностью его лексическое значение.

«Парадигма»- у этого термина есть два определения. Во-первых, это то же самое что образец, во-вторых, это совокупность всех отдельных форм одного и того же слова (Шведова 1980: 453).

В русском языке выделяются три типа парадигм у имен существительных - полная, неполная и избыточная. Полная парадигма - включает всю систему форм изменяемого слова (12 падежных форм - 6 единственного числа и 6 множественного числа). Неполная парадигма - некоторые формы системы изменения конкретного слова отсутствуют по разным морфологическим причинам (характерно для singularia tantum i pluralia tantum). Избыточная парадигма - содержит большее количество форм данного слова нежели полная парадигма (Колесникова 2017: 50).

Также следует обратить внимание на термин «склонение», которое можно определить как класс слов, объединенных общностью словоизменения и образец, по которому изменяются слова данного класса. Итак, склонение - это изменение слова по падежам (Шведова 1980: 481).

\section{Обзор склонения имен существительных в русском языке}

Современный русский язык выделяет 3 основных типа склонения - I, II, III. Различия между типами склонения более конкретно и заметно указаны в падежных формах единственного числа, нежели в формах множественного числа. Происходит так наз. нейтрализация типов склонения, отчего большинство типов склонения имеют те же самые окончания в падежных формах множественного числа (Колесникова 2017: 50).

В группу I склонения входят существительные мужского рода с нулевым окончанием в форме именительного падежа единственного числа, как, например: 
нож, конь, стол. К первому склонению также относятся и существительные мужского и среднего родов с окончанием -o, -e, -ё; в форме именительного падежа единственного числа - окно, ружьё, поле (Шведова 1980: 481).

В зависимости от конечного звука основы существительных мужского рода можно выделить несколько типов образцов склонения. Зависит от того, оканчивается ли основа на твердый согласный (завод, ученик), на мягкий согласный (автомобиль, словарь, учитель), на -IJ (санаторий, планетарий), на -Ј (трамвай, край, герой), на ж, ш, щ, ч, ц (нож, товарищ, плач, месяи, отец).

В зависимости от конечного звука основы существительных среднего рода также можно выделить несколько типов I склонения. В таком случае основа оканчивается на -IJ (собрание), на твердый согласный (государство), на -Ј (ружьё), на ж, ш, щ, ч, ц (училище), на мягкий согласный (поле, море, горе) (Plesník 2019: 53, 58).

В группу II склонения входят существительные мужского, женского и общего родов с окончанием - $a$, -я в форме именительного падежа единственного числа, как, например: мужчина, судья, икола.

Как в I, так и во II склонении можно выделить несколько типов в зависимости от характера окончания основы. Основа может быть закончена на твердый согласный (школа), на -IJ (армия), на ц, щ, ш, ч, ж (овца), на мягкий соглачный (неделя), на -J без предшествующего -I- (статья) (Plesník 2019: 63).

В группу III склонения входят существительные женского рода с нулевым окончанием в форме именительного падежа единственного числа с основой на парно-мягкий согласный типа тетрадь или на шипящий (вещь, мылшь, ткань) (Шведова 1980: 481). В отличие от I и II склонений, существительные, которые входят в группу III склонения, относятся к типу тетрадь.

В этот состав входят также отвлеченные существительные с суффиксом -ость / -есть (молодость, радость, свежесть), географические названия

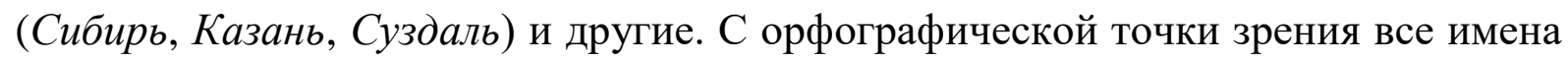
существительные, которые входят в группу III склонения, оканчиваются на -b (Plesník 2019: 66).

Вне системы склонения находятся существительные путь и группа существительных типа время. Это замкнутая группа слов, в которую входят только слова - бремя, время, вымя, знамя, имя, пламя, племя, стремя, семья, темя. Некоторые грамматические пособия зачисляют данные слова к системе третьего склонения. 
В русском языке довольно часто встречаются имена существительные, которые не подвергаются склонению, речь идет о так наз. несклоняемых именах существительных. Их можно определить как слова, у которых для всех 12 форм парадигм (6 падежей единнственного и 6 падежей множественного чисел) имеется только одна форма. В данный состав входят: аббревиатуры (CHГ), иноязычные географические наименования (Сочи), заимствованные слова (кофе), украинские фамилии на -о (Шевченко), русские фамилиии на -аго и -ых (Живаго, Черных) и другие (Колесникова 2017: 54).

\section{Обзор склонения имен существительных в польском языке}

Основным критерием, который влияет на разделение имен существительных по типам склонения в польском языке, является грамматический род. Система основана на других правилах и отличается от системы русского и словацкого языков. Можно выделить 5 типов склонения: склонение мужского рода личное, склонение мужского рода одушевленное, склонение мужского рода неодушевленное, склонение существительных женского рода и склонение существительных среднего рода. Наиболее сложно разработана система склонения в мужском роде.

Склонение мужского рода личное - в группу этого склонения входят имена существительные, которые называют лица мужского рода, у которых основа твердого или мягкого типа окончания обладает в именительном падеже флексией -о или -O (student, chłop, wujcio). Отличительной чертой или своего рода особенностью можно считать синкретизм форм родительного и винительного падежей в единственном и во множественном числах.

Склонение мужского рода одушевленное - в группу этого типа склонения входят одушевленные существительные мужского рода, у которых основа твердого или мягкого типа окончания обладает в именительном падеже флексией -о или -O (kot, wilk, piesio). В данную группу входят также существительные, называющие мертвые лица (nieboszczyk), марки машин (Fiat), названия танцев (kujawiak), названия монет (grosz), названия грибов (borowik). Особенностью является синкретизм форм родительного и винительного падежей в единственном числе и именительного и винительного во множественном числе.

Склонение мужского рода неодушевленное - в группу данного склонения входят имена существительные, которые называют не личностей, а вещи и абстрактные предметы мужского рода, у которых основа твердого или 
мягкого типа окончания обладает в именительном падеже флексией -о или -O (las, $a k t, m \nmid o t e k)$. Тут синкретизм именительного и винительного падежей.

Склонение существительных женского рода - в группу данного склонения входят существительные женского рода, у которых основа твердого типа окончания обладает в именительном падеже флексией - (żona, kasza, głowa) или основа мягкого типа окончания, которая обладает в именительном падеже флексией -a, -i, -0 (pani, kość, tania). В зависимости от формы в именительном падеже единственного числа, склонение имен существительных женского рода можно разделить на две группы - склонение существительных, окончивающихся на гласные (żona, waga, pani), склонение существительных, окончивающихся на согласные (gęś, mysz, noc).

Склонение существительных среднего рода - в группу данного склонения входят существительные среднего рода, у которых основа твердого типа окончания и последующая флексия в именительном падеже ед. числа -о (biodro, błoto, miasto); существительные, у которых основа мягкого типа окончания и последующая флексия в именительном падеже единственного числа -e, -e (pole, zboże, ciele). Можно выделить две группы склонения: существительные, у которых окончание -o, -е в именительном, винительном и звательном падежах (jajko, pole); существительные, у которых окончание -e в именительном, винительном и звательном падежах (imię, ciele) (Strutyński 2009: 140-152).

\section{Обзор склонения имен существительных в словацком языке}

Система склонения имен существительных в словацком языке хорошо и систематично разработана. Для каждого грамматического рода существительных выделены парадигмы, на основе которых склоняются почти все имена существительные.

Во-первых, следует обратить внимание на склонение имен существительных мужского рода. В мужском роде выделяются 4 основных парадигмы (chlap, hrdina, dub, stroj). Склонение имен существительных мужского рода зависит от одушевленности и окончаний. Одушевленные имена существительные мужского рода склоняются при помощи парадигм - chlap, hrdina. При помощи парадигмы $d u b$ склоняются неодушевленные имена существительные, окончивающиеся на твердые согласные или двоякие согласные (prst, hrad, most). Также данная парадигма служит примером склонения заимствованных слов, оканчивающихся на -um / -on / -ón (múzeum, protón, 
gymnázium). При помощи парадигмы stroj склоняются имена существительные, окончивающиеся на мягкий согласный (žalud’, kmeň, ciel). Кроме 4 основных, существует еще и образец Kuli, на основе которого склоняются некоторые заимствованые имена существительные (Dvonč, Horák, Miko 1966: 73-96).

Во-вторых, следует объяснить парадигмы и особенности имен существительных женского рода. У данного типа склонения уже не надо учитывать фактор одушевленности. Выделяется 5 основных парадигм и два слова, у которых особый тип склонения. Это парадигмы: žena, ulica, dlă̌, kost’, gazdiná и слова особого склонения mat' и pani.

Парадигма gazdiná служит примером склонения только закрытой группе слов, связанной прежде всего с эпохой феодализма. Эти слова, как правило, образованы на почве мужских названий (královná, šlachtičná, cárovná). Слова mat' и pani имеют особый тип склонения. При помощи образца žеna склоняются те имена существительные, основа которых оканчивается на твердый или двоякий согласный и окончание этих существительных -a (sloboda, malina, budova). При помощи парадигмы ulica склоняются те имена существительные, основа которых оканчивается на мягкий согласный и окончание этих существительных также, как в предыдущем случае - $a$ (cibul’a, knižnica, dielňa). При помощи образца dlan̆ склоняются те имена существительные женского рода, у которых основа именительного падежа единственного числа оканчивается на согласные -d', -с̌,

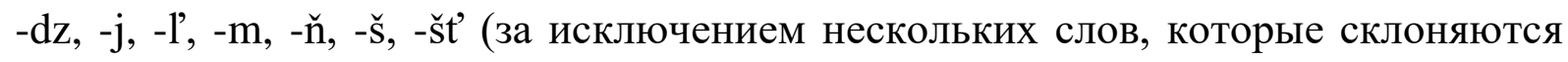
по парадигме kost' - sol', myš, Budapešt'). При помощи образца kost' склоняются те имена существительные женского рода, у которых основа именительного падежа единственного числа окончена на согласные -c, -p, -s, -v, -st', -r (за исключением нескольких слов, которые склоняются при парадигме dlắ obec, pec, čelust') (Dvonč, Horák, Miko 1966: 101-110).

В-третьих, следует назвать имена существительные среднего рода, изменяющиеся в соответствии с образцами mesto, srdce, vysvedčenie и dievča. По образцу mesto склоняются имена существительные среднего рода, которые в именительном падеже единственного числа оканчиваются на -о (meno, slovo, zrno). По образцу srdce склоняются имена существительные среднего рода, которые в именительном падеже единственного числа оканчиваются на -e, и их основа оканчиваются на мягкий или двоякий согласный (c, t', j, l, r, p) (more, pole, vajce). По образцу vysvedčenie склоняются собирательные существительные среднего рода, которые в форме именительного падежа оканчиваются на дифтонг -ie (prútie, údolie, pohorie) (Dvonč, Horák, Miko 1966: 112-120). 
В заключение можно констатировать, что данная статья представила в сжатом виде обзор систем склонения имен существительных в трех выбранных славянских языках - русском, польском и словацком. Показаны как отдельные системы, так и подходы лингвистов к данной проблематике. Все системы выглядят на первый взгляд по-разному, у них разная структура, но если вникнуть глубже в, то можно отметить, что они основаны на схожих принципах. Важную роль играют грамматический род существительных, характер их основы и система окончаний. Проблематика сравнения словоизменительных систем частей речи помогает лучше понять современное состояние языков и их взаимное влияние.

\section{Summary}

The main goal of this work was to present the system of declension of nouns in three Slavic languages - Russian, Polish, and Slovak. The work presents concrete systems and their specifics that work in the given languages. At first, the topicality of the issue was explained. At second, basic terms of the article were introduced, and then the specific systems of the Russian, Polish, and Slovak declension of nouns were presented. At first glance, these systems look different, but many similarities can be found if we look deeper into the issue. Among the main determinants of the above classifications are the grammatical genders of nouns, their bases, and suffixes. It should be noted that in each of the selected languages, there are exceptions that are not included in the declension system.

\section{Литература}

Колесникова, С.М. Современный русский язык. Морфология. Москва: Юрайт, 2017.

Сепир, Э. Избранные труды по языкознанию и культурологии. Москва: «Прогресс», «Универс», 1993.

Сидоренко, Е.Н. Морфология современного русского языка. Части речи и контаминантыл. Москва: ФЛИНТА «Наука», 2017.

Шведова, Н.Ю. (ред.) Русская грамматика. Москва: Наука, 1980.

Dvonč, L., Horák, G., Miko, F., Mistrík, J., Oravec, J., Ružička, J., Urbančok, M. Morfológia slovenského jazyka. Bratislava: Vydavatel'stvo SAV, 1966. 
Моника СТЕНХЛАКОВА

К проблематике словоизменительной системы имени существительного в русском,

польском и словацком языках

Grzegorczykowa, R., Laskowski, R., Wróbel, H. Gramatyka współczesnego języka polskiego. Morfologia. Warszawa: Wydawnictwo Naukowe PWN, 1999.

Plesník, L. Gramatika ruštiny - morfologie 1. Ostrava: Ostravská univerzita, 2019.

Strutyński, J. Gramatyka polska. Kraków: Wydawnictwo Tomasz Strutyński, 2009. 


\title{
SLOVENSKÉ A POLSKÉ LINGVISTICKÉ TERMÍNY MORFOLOGICKEJ ROVINY Z ASPEKTU VYBRANÝCH TYPOV LEXIKÁLNEJ MOTIVÁCIE
}

\author{
Slovak and Polish Linguistic Terms of Morphology in the View \\ of Selected Lexical Motivation Types
}

Keywords: Slovak language, Polish language, linguistic terms, lexikal motivation

Contact: Prešovská univerzita v Prešove; dominika.vincejova@smail.unipo.sk

\section{0 Úvod}

Jazykovedná terminológia je základným pilierom lingvistiky a odráža súčasný stav spracovania vedeckých poznatkov, metód a smerov lingvistického výskumu v danom jazyku, ako aj vo svetovej jazykovede. Lingvistickú terminológiu tvorí súbor pomenovaní jednotlivých javov v oblasti lingvistiky a zohráva významnú úlohu pri štúdiu materinského či cudzieho jazyka.

Ciel'om našej komparatívnej práce je poukázat' na zhody, ale aj rozdiely medzi terminologickými jednotkami morfologickej roviny porovnávaných jazykových systémov slovenčiny a pol’štiny. V prekladanej práci sa zameriame na dva typy lexikálnej motivácie - interlingválnu motiváciu a abreviačnú motiváciu. Interlingválne motivácia predstavuje lexikálnej jednotky, ktoré boli prevzaté z cudzích jazykov a tvoria početnú zložku v lexikálnej zásobe slovenčiny a pol’štiny, nevynímajúc jazykovednú terminológiu, v ktorej interlingválne motivované termíny (prevzaté termíny) kvantitatívne prevažujú nad interlingválne nemotivovanými termínmi (termíny domáceho pôvodu). Abreviačná motivácia predstavuje abreviačne motivované jednotky, t. j. skratky, ktoré si v posledných desat'ročiach našli svoje významné uplatnenie nielen v spoločenskom živote, ale aj jazykovedná terminologická sústava slovenčiny a pol'štiny si čoraz častejšie osvojuje skracovanie lingvistických termínov (najmä $\mathrm{v}$ písomnej podobe). Vychádzat' budeme $\mathrm{z}$ teórie lexikálnej motivácie, z prvotnej typológie lexikálnej motivácie a pojmovo-terminologického vymedzenia jednotlivých motivačných typov J. Furdíka (2008), a viacerých prác M. Ološtiaka, ktorý teóriu lexikálnej motivácie rozvinul. 


\section{Morfologické termíny $\mathrm{z}$ aspektu interlingválnej motivácie}

Rovnako ako v terminológii iných odborov vedy a techniky (napr. medicína, botanika, informatika), aj v jazykovednej terminológii sa stretávame s vel'kým množstvom lexém prevzatých z cudzích jazykov. Takéto lexémy sa nazývajú interlingválne motivované a tvoria početnú zložku nielen $\mathrm{v}$ odbornej terminológii, ale aj v lexikálnej zásobe ako celku. Preberanie lexém je v posledných desat'ročiach jedným z najproduktívnejších spôsobov obohacovania lexiky, vrátane lingvistickej terminológie, v ktorej prevzaté termíny kvantitatívne prevažujú nad domácimi termínmi. Z tohto dôvodu sme sa rozhodli venovat' pozornost' práve týmto interlingválne motivovaným lexémam v slovenskej a pol'skej jazykovednej terminológii, ktoré opíšeme a porovnáme na základe interlingválnej motivácie, ktorá je jedným z typov lexikálnej motivácie. Ciel’om nášho príspevku je zistit', $\mathrm{z}$ akých jazykov boli prevzaté lingvistické termíny $\mathrm{v}$ slovenčine a pol'štine $\mathrm{v}$ rámci morfologickej roviny a percentuálne ich vyčíslit' analýzou lexikografického spracovania slovenskej a pol'skej jazykovednej terminológie. Prostredníctvom našej analýzy opíšeme a porovnáme slovenské a pol'ské lingvistické termíny ako interlingválne motivované jednotky; zdôrazníme medzijazykové diferencie a upozorníme na zhody. Budeme vychádzat' z prvotnej typológie lexikálnej motivácie a pojmovo-terminologického vymedzenia jednotlivých motivačných typov J. Furdíka (2008), a viacerých prác M. Ološtiaka (porov. d’alej), ktorý túto teóriu rozvinul.

V našej štúdii vychádzame z teórie lexikálnej motivácie, ktorá vznikla v slovenskom lingvistickom prostredí. Ide o jedinečnú koncepciu slovenského jazykovedca Juraja Furdíka (2008), ktorá predstavuje jeden z možných celkových prístupov $\mathrm{k}$ skúmaniu lexikálnej zásoby. V tejto koncepcii sa lexika považuje za súbor lexikálnych jednotiek navzájom spätých siet’ami rôznych vzt’ahov. J. Furdík vyčlenil celkovo 17 typov lexikálnej motivácie. Na Furdíkovu prácu nadviazal Martin Ološtiak (2011), ktorý túto teóriu značne rozšíril. Rovnako ako J. Furdík, aj M. Ološtiak vyčleňuje 17 typov lexikálnej motivácie, vrátane interlingválnej motivácie, ktorá je predmetom prvej časti našej štúdie. Interlingválnej motivácii sa venuje M. Ološtiak najmä v monografii Aspekty teórie lexikálnej motivácie (2011) a v d’alších čiastkových štúdiách (2012, 2015a, 2017b). Pred ním koncepciu interlingválnej motivácie načrtol J. Furdík (2008), ktorý však túto motiváciu nazval ako akceptačná motivácia (porov. Furdík 2008: 68-70; Ološtiak 2011: 195-228). Podl’a J. Furdíka aktívnu úlohu v procese preberania lexém z jedného jazyka do druhého hrá preberajúci jazyk. M. Ološtiak uvádza, že „termín akceptačná motivácia nezahŕňa všetky možné kontaktové prípady“ a prikláňa sa k termínu interlingválna motivácia (2011: 196).

Interlingválna motivácia, teda preberanie lexém z východiskového jazyka $\mathrm{L}_{1}$ do ciel’ového jazyka $\mathrm{L}_{2}$ je jedným z najproduktívnejších spôsobov obohacovania lexikálnej 
zásoby $\mathrm{v}$ jazyku $\mathrm{L}_{2}$. Rovnaká situácia je aj $\mathrm{v}$ odbornej jazykovednej terminológii. Jednotlivé termíny, prebraté najmä $\mathrm{z}$ latinčiny a gréčtiny, $\mathrm{v}$ mnohých prípadoch majú internacionálny charakter, napr. morféma (slov.) - morfem (pol.) - morpheme (angl.) das Morphem (nem.) - morphème (franc.); singulár (slov.) - singularis (pol'.) - singular (angl.) - der Singular (nem.) - singulier (franc.); infinitiv (slov.) - infinitivus (pol'.) infinitive (angl.) - der Infinitiv (nem.) - infinitif (franc.). Ciel'om internacionálnej terminologickej lexiky je ul'ahčit' profesijnú komunikáciu na medzinárodnej úrovni, dochádza tak $\mathrm{k}$ zharmonizovaniu terminologických sústav na formálnej i pojmovej úrovni. Podl'a niektorých autorov termíny prevzaté z klasických jazykov (latinčina, gréčtina) si zachovávajú status internacionalizmu dokonca aj vtedy, ak vystupujú len v jednom jazyku $\mathrm{L}_{2}$, a to vd'aka ich zrozumitel'nosti pre cudzojazyčné profesijné prostredie (porov. Lukszyn-Zmarzer 2006: 71-72). „Lingvistické internacionalizmy zohrávajú pozitívnu úlohu aj v procese učenia sa cudzích jazykov a vo všeobecnosti ul'ahčujú medzijazykové porozumenie,“ čo je aj dôvodom toho, prečo mnohí autori jazykovedných slovníkov a encyklopédií cielene používajú na pomenovanie lingvistických javov práve internacionálne termíny (Vojteková 2018: 22). Napr. autori Encyklopedie językoznawstwa ogólnego (Polański et al. 1999) uprednostňujú ako hlavné heslo prevzatý termín accusativus, pričom domáce pomenovanie tohto pádu biernik je v encyklopédii zaznamenané s odkazom na internacionálny termín (biernik zob. accusativus; podobne aj czynna strona zob. activum a i.).

V slovenskej a pol'skej jazykovednej terminológii sa možno stretnút' aj s ojedinelými prípadmi tzv. zdanlivej medzinárodnosti (Vojteková 2018: 25), kde sa na pomenovanie jedného denotátu používajú termíny prevzaté z rozličných jazykov, napr. slov. modus (lat.) - pol'. tryb (nem.). Podl’a Slovníka slovanské lingvistické terminologie možno považovat' slovenský termín modus za internacionálny, ked’že sa vyskytuje vo viacerých slovanských jazykoch (napr. čeština, slovinčina, macedónčina), naopak pol'ský termín tryb sa nevyskytuje v žiadnom zo zohl'adnených jazykov (porov. Jedlička et al. 1977: 384-385).

Interlingválne motivované (prevzaté) a interlingválne nemotivované (domáce) termíny môžu v oboch jazykoch navzájom vstupovat' aj do vzt’ahu synonymie (napr. slov. flexia / ohýbanie, interjekcie / citoslovcia, imperatív / rozkazovaci spôsob; pol'. positivus / stopień równy, interiekcja / wykrzyknik, dualis / liczba podwójna) alebo sa vyskytujú ako jediné pomenovanie termínu: prevzaté termíny (napr. slov. morféma, supletivizmus, nominativ; pol'. morfem, supletywizm, reflexiva tantum) a domáce termíny (napr. slov. slovné druhy, dvojtvar, vôlové citoslovcia; pol'. części mowy, bezokolicznik, liczebnik). Tejto problematike sme sa venovali v našom 
predchádzajúcom výskume (porov. Vincejová 2019), v ktorom sme predstavili synonymiu na osi domáci - prevzatý termín na medzijazykovej úrovni.

V d'alšej časti štúdie sa zameriame na jazykovednú terminológiu konkrétnej jazykovej roviny - morfologickej roviny. Pri uvádzaní výsledkov budeme vychádzat’ zo slovníka Slovensko-pol'sko-ruský slovník jazykovedných termínov II. Morfológia, ktorý sme podrobili detailnej analýze z hl’adiska interlingválnej motivácie. Ide o slovník, ktorý vychádza $z$ jestvujúceho a súčasného stavu jazykov a ich terminologických opisov, všetky termíny uvedené v tomto slovníku možno považovat' za prijaté, akceptované a používané v súčasnej slovenskej, pol'skej i ruskej jazykovede. V slovníku je dôsledne zachovaná synonymia na osi domáci - prevzatý termín, ked’že $\mathrm{v}$ rámci jedného hesla vystupujú synonymické termíny.

$\mathrm{Na}$ základe uskutočneného výskumu v Slovensko-pol'sko-ruskom slovníku jazykovedných termínov II. Morfológia, môžeme konštatovat', že v morfologickej rovine slovenského jazyka je výskyt prevzatých termínov nasledovný1: v latinčine má pôvod 87,5 \% termínov (napr. abtraktá, akuzatív, deklinácia, flexia, futúrum, gradácia, infinitív, infix, komparativ, kondicionál, konjugácia, modus, préteritum, reflexíva, singulár, supletivizmus, transgresív); v gréčtine 12,5\% (napr. alomorfémy, graméma, morfológia, morféma, paradigma, synkretizmus, onomatopoje) z celkového počtu prevzatých termínov. V rámci morfologickej roviny sa v slovenčine nevyskytujú lexémy iného cudzieho pôvodu ako latinského a gréckeho.

V pol'skej terminológii sa objavujú termíny ${ }^{2}$ pochádzajúce z latinčiny $74 \%$ (napr. apellativa, comparativus, deklinacja, imperfektywizacja, koniugacja, partykuła, pluralia tantum, supletywizm, walencja), z gréčtiny $22 \%$ (napr. morfem, morfologia, onomatopeje, synkretyzm), z iných jazykov 4 \% (z francúzštiny (apel), z nemčiny (tryb) $\mathrm{z}$ celkového počtu prevzatých termínov.

\section{Morfologické termíny $z$ aspektu abreviačnej motivácie}

Abreviácia si v poslednom období našla svoje významné uplatnenie nielen v spoločenskom živote, ktorý sa snaží o úspornú jazykovú komunikáciu (predovšetkým v písanej podobe), ale aj odborné terminologické sústavy si čoraz častejšie osvojujú

\footnotetext{
1 Pôvod slovenských termínov uvádzame na základe lexikografických publikácií: Slovník cudzích slov (akademický) (Petráčová-Kraus et al. 2006), Slovník súčasného slovenského jazyka. A-G (Buzássyová-Jarošová et al. 2006), Slovník súčasného slovenského jazyka. H-L (Jarošová-Buzássyová et al. 2011), Slovník súčasného slovenského jazyka. M-N (Jarošová et al. 2015).

2 Pôvod pol'ských termínov uvádzame na základe lexikografických publikácií: Słownik wyrazów obcych i zwrotów obcojęzycznych z almanachem (Kopaliński 2007), Uniwersalny słownik języka polskiego (Dubisz et al. 2003), Wielki słownik języka polskiego (Żmigrodzki et al., dostupné na internete).
} 
skracovanie. Potreba skracovania sa spája predovšetkým s rýchlym životným tempom posledných desat'ročí a snahou úsporne a vecne popísat' jednotlivé javy. So skratkami sa stretávame aj v odborných terminológiách mnohých vedných odborov, predovšetkým však v technických odboroch (napr. informatika, mechanika) a prírodných vedách (napr. matematika, fyzika, chémia). Skratky sa stali dôležitou súčastou aj mnohých lingvistických publikácií, prevažne lexikografického a encyklopedického charakteru a „,...bez abreviačného aparátu sa nezaobíde žiadne lexikografické dielo“ (Ološtiak 2011: 259). S abreviáciou sa v pomerne vel'kom počte stretávame aj v rôznych odborných jazykovedne zameraných monografiách a vedeckých prácach, kde sa zvyknú skracovat' najmä klúčové a často sa opakujúce lingvistické termíny.

Teoretickým východiskom našej štúdie je koncepcia lexikálnej motivácie, ktorú načrtol Juraj Furdík (2008), a ktorú vo viacerých prácach komplexne rozvinul Martin Ološtiak (2011, 2015a, 2015b, 2017). Konkrétne abreviačnej motivácii (AM) sa osobitne venovala Miroslava Gavurová (2013), ktorá sa opierala o Furdíkovu a Ološtiakovu teóriu lexikálnej motivácie.

Predmetom predkladanej kapitoly sú abreviačne motivované lexémy, teda skratky, v slovenskej a pol'skej lingvistickej terminológii. Prinesieme prehl'ad jednotlivých skratiek ako abreviačne motivovaných lexém, ktoré budeme analyzovat' z hladiska ich výskytu, formy a zapojenosti do paradigmatických vztahov, pričom upozorníme na zhody a rozdiely $\mathrm{v}$ tejto odbornej lexike.

Podla J. Furdíka pri abreviačnej motivácii ,ide o kontakt prirodzeného jazyka s jeho graficky špecifikovanou podobou“ (Furdík 2008: 68). Samotné skracovanie je pritom podl'a neho „prechodom do iného subkódu“ (Furdík, 2008: 68). Skratky sa považujú za plnohodnotné lexémy a samotné ,skracovanie je dôsledkom snahy o jazykovú ekonómiu“, ktorého hlavným účelom je „aby sme na čo najmenšej ploche vyjadrili čo najviac sémantických príznakov" (Ološtiak 2011:240). Nie je ničím výnimočným, že o takúto jazykovú úsporu (prevažne v písanej podobe) majú záujem aj autori rôznych typov slovníkov a encyklopédií, jazykových príručiek i lingvisticky zameraných monografií, ktorí sa v rozsiahlych publikáciách snažia o ul'ahčenie, zefektívnenie a urýchlenie jazykovej komunikácie medzi expedientom a percipientom. Najčastejšie sa prejavuje potreba skracovat' viacslovné pomenovania ako formálne nákladnejšie jednotky a často sa opakujúce lingvistické termíny.

Pri procese abreviácie vzniká medzi abreviačným motivantom (neskratkou) a abreviačným motivátom (skratkou) abreviačný motivačný vzt’ah. Abreviačným motivantom je každá lexéma, syntagma alebo vol'né spojenie lexém, ktoré sú pri procese abreviačnej motivácie východiskom pre utvorenie abreviačného motivátu, teda sktratky. 
Výsledkom abreviačného procesu je abreviačný motivát, ktorým je každá abreviačne motivovaná lexéma (Gavurová 2013: 15-17). Pri samotnej abreviácii je však dôležité, aby skratka nestratila zrozumitel'nost' a komunikačnú efektívnost' (Furdík, 2008: 71).

Abreviačne motivované lexémy ul’ahčujú jazykovú komunikáciu medzi expedientom a percipientom, kde najmä pre expedienta ide o jednoduchšie a ekonomickejšie opísanie javu, avšak pre percipienta môže íst' o neporozumenie skratky, čím sa komunikačný akt stáva neprehl'adným a t’ažko dekódujúcim, preto „expedient komunikátu musí zhodnotit' komunikačný štatút skratky, jej frekventovanost', schopnost' percipienta dekódovat' skratku, priradit' jej adekvátny abreviačný motivant a sémantický obsah“ (Gavurová 2013: 25). Aj z tohto dôvodu v každom jazykovednom slovníku (výkladovom i prekladovom), encyklopédii či monografii nájdeme zoznam použitých skratiek, ktoré používatel’ovi danej publikácie ozrejmujú priradenie jednotlivých abreviačných motivátov (skratiek) k ich abreviačným motivantom (neskratkám). Platí pritom aj skutočnost', že „poznanie sémantiky abreviatúry je podmienené poznaním sémantiky východiskového pomenovania“ (Furdík 2008: 71).

\subsection{Abreviácia v slovenskej a pol'skej lingvistickej terminológii}

S abreviačnou motiváciou sa stretávame aj v odbornej terminológii, „tým sa naplńa predpoklad, že AM je dôležitým identifikačným a spoluorganizačným faktorom vplývajúcim na fungovanie odbornej terminológie“ (Ološtiak 2011: 259). Tak ako v lexikálnej zásobe ako celku, tak aj v odbornej terminológii sú skratky „výsledkom úsilia o úsporné, ekonomické zachytenie lexém alebo časti jazykového prejavu“ (Furdík 2008: 70).

V lingvistickej terminológii sa so skratkami primárne stretávame v jazykových slovníkoch (výkladových i prekladových) ako aj v odborných lingvistických slovníkoch a encyklopédiách. V našej analýze sme sa zamerali na nasledovné jestvujúce slovenské výkladové slovníky, jazykovedné príručky a odborné lingvistické slovníky a encyklopédie obsahujúce skratky lingvistických termínov: Krátky slovník slovenského jazyka (Kačala-Pisárčiková-Považaj et al. 2003), Slovník súčasného slovenského jazyka. A-G (Buzássyová-Jarošová et al. 2006), Slovník súčasného slovenského jazyka. H-L (Jarošová-Buzássyová et al. 2011), Slovník súčasného slovenského jazyka. M-N (Jarošová et al. 2015), Slovník slovenského jazyka I-VI (Peciar et al. 1959-1968), Slovník cudzích slov (akademický) (Petráčková-Kraus et al. 2005), Synonymický slovník slovenčiny (Písárčiková et al. 2004), Pravidlá slovenského pravopisu (Považaj et al. 2013), Encyklopédia jazykovedy (Mistrík et al. 1993). 
Z jestvujúcich pol'ských lingvistických slovníkov a odborných jazykovedných slovníkov a encyklopédií sme analyzovali: Inny słownik języka polskiego PWN. A-Ó, P-Ż (Bańko et al. 2000), Uniwersalny słownik języka polskigo. A-J, K-O, P-Ś, T-Ż (Dubisz et al. 2006), Słownik poprawnej polszczyzny (Szober 1968), Słownik języka polskiego PWN. A-K (Szymczak et al. 1978), Slownik języka polskiego PWN. L-P (Szymczak et al. 1982), Słownik języka polskiego PWN. R-Ż (Szymczak et al. 1981), Slownik języka polskiego PWN. A-K, L-P, R-Z (Szymczak et al. 2002), Encyklopedia językoznawstwa ogólnego (Polański et al. 2003), Encyklopedia języka polskiego (Urbańczyk-Kucała et al. 1999) a prekladový slovník Słownik slowacko-polski A-Ô, P-Ž (Jurczak-Trojan-Mieczkowska-Orwińska-Papierz 2010). Abreviačne motivované termíny $\mathrm{v}$ týchto publikácia sme podrobili analýze z hl'adiska typu jednotlivých skratiek, ich výskytu, formy a zapojenosti do paradigmatických vzt’ahov.

$\mathrm{Z}$ uskutočneného výskumu skratiek $\mathrm{v}$ uvedených publikáciách vyplýva, že $\mathrm{v}$ lingvistickej terminológii sa stretávame predovšetkým s ustálenými grafickými typmi skratiek $^{3}$. V slovenskej jazykovednej terminológii sa objavujú najmä jednoduché iniciálové skratky, napr. m. (podstatné meno mužského rodu), ž. (podstatné meno ženského rodu), $n$. (podstatné meno stredného rodu); jednoduché lineárne skratky, napr. neurč. (neurčitok), prísl. (príslovka), spoj. (spojka), zám. (zámeno), príč. (príčastie), čast. (častica); zriedkavejšie sa objavujú zložené iniciálové skratky, napr.j. č. (jednotné čislo), skeletové skratky, napr. sg. (singulár) a kombinované skratky, napr. min. $\check{c}$. (minulý čas), mn. č. (množné číslo).

Podobná situácia ako v slovenskej jazykovednej terminológii je aj v pol'skej jazykovede. Aj tu sa možno stretnút' prevažne s ustálenými grafickými typmi skratiek ${ }^{4}$. Medzi najčastejšie sa vyskytujúce patria jednoduché iniciálové skratky, napr. $c z$. (czasownik), r. (rodzaj), f. (femininum); jednoduché lineárne skratky, napr. mian. (mianownik), miejsc. (miejscownik), imiest. (imiesłów), przym. (przymiotnik), rzecz. (rzeczownik), bezok. (bezokolicznik), part. (partykuła) a kombinované skratky, napr. l. mn. (liczba mnoga), l. podw. (liczba podwójna), rodz. m. (rodzaj męski), rodz. n. (rodzaj nijaki), cz. przysz. (czas przyszty). V pol'skej lingvistickej terminológii sa v menšej miere možno stretnút' aj so zloženými iniciálovými skratkami, napr. $l \mathrm{~m}$. / lm (liczba mnoga), lp. I lp (liczba pojedyncza), zloženými lineárnymi skratkami, napr. imwsp (imiestów przystówkowy wspótczesny) a skeletovými skratkami, napr. Msc. (miejscownik), ndk. (niedokonany), ndm (nieodmienny).

\footnotetext{
${ }^{3}$ V našej analýze sme sa orientovali na typológiu skratiek v publikácii Skratka ako lexéma (abreviačná motivácia v lexike) (Gavurová 2013: 25-27).

${ }^{4} \mathrm{Na}$ analýzu a typológiu pol'ských abreviatúr sme použili slovenské terminologické pomenovania skratiek (Gavurová 2013: 25-27).
} 
Typickým znakom grafických skratiek je, že sa pri abreviácii ponecháva začiatok slova ako informačne relevantnejšia čast' a vypúšt’a sa koniec slova, napr. slov. predl. (predložka); pol'. bezok. (bezokolicznik). Pravidlo, že významnejšími nositel’mi informácie sú konsonanty, potvrdzujú skeletové a kombinované značky, napr. slov. sg. (singulár); pol'. Msc. (miejscownik). Pre pravopis slovenských grafických značiek je kl'účovým pravidlom písanie bodky za grafickou skratkou, napr. cit. (citoslovce). V pol'skom pravopise je pravidlo písania grafických skratiek sčasti odlišné. Hoci sa za grafickými skratkami píše bodka, v prípadoch, kedy skratka obsahuje aj poslednú grafému abreviačného motivantu, sa bodka nepíše. Medzi abreviačnými motivátmi pol'ských lingvistických termínov sa však objavujú prípady porušenia tejto normy, napr. $d k$ (dokonany), ger (gerundium), Im (liczba mnoga), $n$ (rodzaj nikaki), os (osoba) a i.

Graficko-fónické skratky lingvistických termínov sa v slovenských a pol’ských (výkladových ako aj prekladových) slovníkoch a príručkách vyskytujú v minimálnej miere, napr. slov. I (inštrumentál), VM (vlastné meno), pol'. CZ (czasownik), LM (liczba mnoga). Tento typ skratiek je ovel’a produktívnejší v monografiách a vedeckých prácach lingvistického charakteru.

\subsection{Abreviačná synonymia, paronymia a homonymia}

Skratka „sa môže vyznačovat' inou zapojenost’ou do lexikálnoparadigmatických vzt'ahov“ (paronymia, polysémia, homonymia, slovotvorné vzt’ahy) ako neskratka (Ološtiak 2011: 233). Ide o spoluprácu abreviačnej motivácie a paradigmatickej motivácie. Pri terminologickej lexike možno hovorit’ o kooperácii troch motivácii terminologickej, abreviačnej a paradigmatickej, ktoré sa prejavujú v začleňovaní skratiek odborných termínov do rozličných lexikálnych paradigiem. V prípade jazykovednej terminológie ide o realizáciu paradigmatických vzt’ahov na úrovni skratka - neskratka, kde ide najmä o homonymickú, paronymickú, synonymickú paradigmu. M. Ološtiak hovorí o abreviačnej homonymii, paronymii a synonymii ${ }^{5}$ (2011: 246249).

\subsubsection{Abreviačná synonymia}

Mnohé skratky slovenských a pol'ských lingvistických termínov sú ustálené, čo dokazuje aj ich opakujúci sa výskyt v rôznych typoch slovníkov, encyklopédí a jazykovedných príručiek. Medzi takéto ustálené skratky patria napr. slov. bud. (budúci

\footnotetext{
${ }^{5}$ M. Ološtiak hovorí aj o abreviačnej antonymii, hyperonymii, hyponymii, meronymii a abreviačných lexikálnoonomaziologických paradigmách, ale ked’že $v$ jazykovednej terminológii ide o ojedinelé javy, $v$ našej práci im nebudeme venovat' pozornost'.
} 
čas), čast. (častica), m. (podstatné meno mužského rodu), os. (osoba); pol. bezok. (bezokolicznik), imiest. (imiestów), part. (partykuła), przym. (przymiotnik). Početné množstvo lingvistických termínov sa však skracuje do rôznych podôb, napr. slov. akuzatív - A / akuz. / 4. p., citoslovce - cit. / citosl., jednotné čislo - j. č. / jedn. / j., minulý čas - min. / min. č.; pol'. biernik - B / B. / biern., liczba mnoga - lm / lm. / l. mn., miejscownik-Ms. / Msc. / miejsc., rodzaj żeński $-\dot{z}$ / ż. / rż. / rodz. ż. Pri takýchto obmenách skratiek však podl'a M. Ološtiaka nejde o synonymiu, ale považuje ich za varianty (2011: 248). V lingvistickej terminológii sa však možno stretnút' aj s abreviačnou synonymiou, ktorú zapríčiňujú skratky interlingválne motivovaných a interlingválne nemotivovaných termínov, ktoré sú v synonymickom vzt’ahu, napr. slov. neurč. (neučitok) - inf. (infinitív), j. č. / jedn. / j. (jednotné číslo) - sg. / sing. (singulár), mn. č. / mn. (množné čislo) - pl. (plurál), str. / s. (podstatné meno stredného rodu) - n. / neutr. (neutrum), príd. (prídavné meno) - adj. (adjektívum); pol'. l. poj. I lp / lp. (liczba pojedyncza) - sg. / sing. (singularis), cz. przysz. / przysz. (czas przyszły) fut. (futurum), imiest. (imiesłów) - part. (participium), rodz. m. / rm. / m. (rodzaj męski) - m. I masc. I masc (masculinum), tr. rozk. I rozk. (tryb rozkazujacy) - Imp. (imperativus).

\subsubsection{Abreviačná paronymia}

Medzi skratkami slovenských a pol'ských lingvistických termínov možno nájst' aj abreviačné paronymá. Ide o formálne podobné skratky, ktorých abreviačné motivanty však nemusia byt' paronymami, napr. slov. min. č. (minulý čas), mn. č. (množné č́slo); os. (osoba), osob. (osobné zámeno), morfol. (morfológia), morfonol. (morfonológia); pol'. $m$ / m. (rodzaj męski), M / M. (mianownik), Ms. / Msc. (miejscownik); $N$. (narzędnik), n. (rodzaj nijaki); cz. (czas), czas. (czasownik). M. Ološtiak pri skratkách uvažuje o špecifickom prejave poronymie, tzv. ortografickej paronymii prejavujúcej sa viacerými spôsobmi, ktoré M. Gavurová doplnila o d’alšie prípady (porov. Ološtiak 2011: 247-248; Gavurová 2013: 72-73). Pri lingvistickej terminológii sa objavujú najmä: a) odlišnosti v písaní majuskúl a minuskúl, napr. slov. $N$ (nominatív), $n$ (neutrum); pol'. $M /$ M. (mianownik), $m / m$. (rodzaj męski); b) odlišnost' v nealfabetickom znaku, napr. slov. $\langle>:\langle g\rangle$ (z gréčtiny), G (genitív); ( ): prísl. (prislovka), (prísl.) (príslovie). Pri analýze uvedených lexikografických zdrojom sme navyše zaznamenali aj odlišnost' $\mathrm{v}$ dolnom indexe, napr. slov. $L_{1}$ (východiskový I zdrojový jazyk), $L_{2}$ (preberajúci / cielový jazyk); pol'. Vintr (czasownik nieprzechodni), $V_{t r}$ (czasownik przechodni) a odlišnost' v numerickom znaku, napr. slov. 1. p. (1. pád I nominatív), 2. p. (2. pád / genitív) a pod., pol'. os 1 (osoba pierwsza), os2 (osoba druga), os3 (osoba trzecia). 


\subsubsection{Abreviačná homonymia}

Pri abreviačnej homonymia ide o formálne identické skratky, ktoré však majú rozdielne abreviačné motivanty (Ološtiak 2011: 246). V slovenskej a pol'skej lingvistickej terminológii ide o ojedinelý jav, avšak možno nájst' prípady, kedy dochádza k abreviačnej homonymii medzi jednotlivými abreviačne motivovanými termínmi, napr. slov. neurč. - 1. neučité (zámeno), neurčitá (čislovka); 2. neurčitok; pol'. jęz. - 1 . język; 2. językoznawstwo, $L$ - 1. w fonetyce i fonologii - spółgłoska plynna; 2. w językoznawstwie algebraicznym - język (łac. lingua); 3. zmienna lokatywa. O niečo častejšie sú príklady, kedy pri homonymných skratkách iba jeden $\mathrm{z}$ abreviačných motivantov je lingvistický termín, napr. slov. str. - 1. stredný rod; 2. strana; s. -1 . podstatné meno stredného rodu; 2. strana; VM-1. vlastné meno; 2. Velká Morava; MŠ - 1. morfematická štruktúra; 2. materská škola; pol'. cz. - 1. czas; 2. część; lp. - 1. liczba pojedyncza; 2. liczba porzadkowa; $n$. - 1. rodzaj nijaki; 2 . nad; gen. - 1. genetivus; 2. generał; rż. - rodzaj żeński; 2. rok życia.

\subsection{NeúpIné skratky}

Väčšina skratiek utvorených z viacslovných pomenovaní si zachováva všetky relevantné sémantické príznaky abreviačného motivantu zohl'adnením všetkých autosémantických lexém prítomných v motivante, teda sú skracované všetky komponenty viacslovného pomenovania, napr. slov. min. ̌̌. (minulý čas), j. č. (jednotné čislo), podst. m. (podstatné meno); pol'. lp. I lp (liczba pojedyncza), cz. ter. (czas teraźniejszy), tr. ozn. (tryb oznajmujacy). Tak ako medzi skratkami v bežnej komunikácii, tak aj v lingvistickej terminológii sa možno stretnút' so skratkami, v ktorých nemajú zastúpenie všetky komponenty viacslovného pomenovania, napr. slov. dok. (sloveso dokonavého vidu), hromad. (hromadné podstatné meno), pomn. (pomnožné podstatné meno), m. (mužský rod), bud. (budúci čas), podst. (podstatné meno), podm. (podmieňovací spôsob); pol'. m. / m (rodzaj męski), $\dot{z}$. I z (rodzaj żeński), rozk. (tryb rozkazujacy), OZN (tryb oznajmujacy), przesz. (czas przeszyy), TER (czas teraźniejszy), imb (imiestów przymiotnikowy bierny), imuprz (imiestów przysłówkowy uprzedni). Takéto skratky označujeme termínom neúplné skratky. Ide o snahu jazykovej ekonómie vynechaním sémanticky „menej dôležitých“ komponentov viacslovného pomenovania. M Gavurová hovorí o vynechávaní synsémantických komponentov, v odbornej lingvistickej terminológii však dochádza aj $\mathrm{k}$ vynechaniu autosémantických komponentov (2013: 57-60). Zachovávajú sa však vždy komponenty viacslovného pomenovania, ktoré obsahujú relevantnejšiu informáciu a vypúštajú sa tie, ktoré nesú sémanticky menej dôležitú informáciu. 


\section{Záver}

V predkladanom príspevku sme predstavili slovenské a pol’ské lingvistické termíny z aspektu dvoch vybraných typov lexikálnej motivácie - interlingválnej motivácie a abreviačnej motivácie, na základe ktorých sme predstavili početné zhody a podobnosti, ale aj rozdiely $\mathrm{v}$ tejto špecifickej časti lexiky. Zhody sú výrazným ukazovatel’om genetickej príbuznosti a areálovej blízkosti slovenčiny a pol'štiny. Prícinami rozdielov v lexike týchto dvoch západoslovanských jazykov sú samostatné vývinové procesy, ako aj odlišné kultúrne a mentálne vlastnosti ich nositelov, geomorfologické vlastnosti obidvoch krajín, vnútropolitické rozdiely a pod.

Slovenskú a pol'skú lingvistickú terminológiu tvoria termíny domáceho pôvodu (interlingválne nemotivované) i cudzieho pôvodu (intelingválne motivované). Z uskutočneného výskumu jazykovednej terminológie vyplýva, že slovenská a pol'ská jazykovedná terminológia je vo výraznej miere latinského a gréckeho pôvodu. Vel'ká skupina termínov cudzieho pôvodu bola prevzatá aj do iných jazykov, vd’aka čomu nadobúda internacionálny charakter. Jednotlivé lexikografické a encyklopedické zdroje zhŕňajúce lingvistickú terminológiu pri synonymii domácich - prevzatých termínov zohl'adňujú jeden alebo druhy typ v rozličnej miere. Autori slovenských i pol'ských publikácií sa často prikláňajú len k jednému pomenovaniu - domácemu alebo prevzatému $\mathrm{v}$ závislosti od percipienta, ktorému je publikácia primárne určená alebo v závislosti od toho, či ide o populárno-náučné alebo striktné vedecké spracovanie.

V slovenskej a pol'skej lingvistickej terminológii sa objavujú skratky odborných termínov, ktoré sa stali dôležitou súčastou mnohých publikácií, prevažne lexikografického charakteru, kde sa zvyknú skracovat' najmä kl'účové a často sa opakujúce lingvistické termíny. Skratky jazykovedných termínov slúžia na ul'ahčenie, zefektívnenie a urýchlenie jazykovej komunikácie medzi expedientom a percipientom, kde najmä pre expedienta ide o jednoduchšie a ekonomickejšie opísanie javu, avšak pre percipienta môže íst' o neporozumenie skratky, čím sa komunikačný akt stáva neprehl'adným a t’ažko dekódujúcim, preto $\mathrm{v}$ každom slovníku (výkladovom i prekladovom), encyklopédii, jazykovej príručke či monografii možno nájst' zoznam použitých skratiek, ktoré používatel'ovi danej publikácie ozrejmujú priradenie jednotlivých abreviačných motivátov $\mathrm{k}$ ich abreviačným motivantom.

\section{Summary}

The paper describes and compares Slovak and Polish linguistic terms as terminologically motivated units from the perspective of selected lexical motivation types (interlingual and abbreviation). The paper is based on the theory of lexical 
motivation, the primary typology of lexical motivation and notional-terminological specification of particular motivation types by J. Furdík (2008) as well as on various publications by M. Ološtiak who has significantly developed the theory of lexical motivation.

\section{Literatúra}

Bańko, M. (ed.) Inny słownik języka polskiego PWN. Warszawa: Wydawnictwo Naukowe PWN, 2000.

Buzássyová, K., Jarošová, A. (eds.) Slovník súčasného slovenského jazyka. A-G. Bratislava: Veda, 2006.

Dubisz, S. (ed.) Uniwersalny stownik języka polskiego. Warszawa: Wydawnictwo Naukowe PWN, 2003.

Furdík, J. Teória motivácie v lexikálnej zásobe. Košice: Vydavatel'stvo LG, 2008.

Gavurová, M. Skratka ako lexéma (abreviačná motivácia v lexike). Prešov: Filozofická fakulta Prešovskej univerzity v Prešove, 2013.

Jarošová, A, Buzássyová, K. (eds.) Slovnik súčasného slovenského jazyka. $H-L$. Bratislava: Veda, 2011.

Jarošová, A. (ed.) Slovník súčasného slovenského jazyka. M-N. Bratislava: Veda, 2015.

Jedlička, A. (ed.) Slovnik slovanské lingvistické terminologie 1. Praha: Academia, 1977.

Jurczak-Trojan, Z., H. Mieczkowska, E. Orwińska, Papierz, M. Stownik stowackopolski. Kraków: Universitas, 2010.

Kačala, J., Pisárčiková, M., Považaj, M. (eds.). Krátky slovník slovenského jazyka. Bratislava: Veda, 2003.

Kopaliński, W. Stownik wyrazów obcych i zwrotów obcojęzycznych z almanachem. Warszawa: Oficyna Wydawnicza RYTM, 2007.

Lukszyn, J., Zmarzer, A. Teoretyczne podstawy terminologii. Warszawa: Uniwersytet Warszawski, 2006.

Mistrík, J. (ed.) Encyklopédia jazykovedy. Bratislava: Vydavatel'stvo Obzor, 1993.

Ološtiak, M. Aspekty teórie lexikálnej motivácie. Prešov: Filozofická fakulta Prešovskej univerzity v Prešove, 2011. 
Ološtiak, M. Poznámky ku koncepcii interlingválnej demotivácie. In: Buhunická, A. (ed.) Jazykoveda v pohybe. Bratislava: Univerzita Komenského, 2012, s. 148157.

Ološtiak, M. (ed.) Kvalitatívne a kvantitatívne aspekty tvorenia slov v slovenčine. Prešov: Filozofická fakulta Prešovskej univerzity v Prešove, 2015a.

Ološtiak, M. O terminologickej motivácii v lexike. In: Mislovičová, S. (ed.) Jazyková kultúra a terminológia: zborník štúdií venovaný Matejovi Považajovi. Bratislava: Veda, 2015b, s. 56-84.

Ološtiak, M. Lexikálna paradigmatika, sémantika a kombinatorika. Prešov: Prešovská univerzita v Prešove, 2017a.

Ološtiak, M. Slovotvorba, slovnodruhové prechody, preberanie a skracovanie lexém. Prešov: Prešovská univerzita v Prešove, $2017 \mathrm{~b}$.

Peciar, Š. (ed.) Slovník slovenského jazyka I-VI. Bratislava: Vydavatel'stvo SAV, 1959-1968.

Petráčková, V, Kraus, J. (eds.) Slovník cudzích slov (akademický). Bratislava: Slovenské pedagogické nakladatel'stvo - Mladé letá, 2005.

Pisárčiková, M. (ed.) Synonymický slovník slovenčiny. Bratislava: Veda, 2004.

Polański, K. (ed.) Encyklopedia językoznawstwa ogólnego. Wrocław: Ossolineum, 1999.

Považaj, M. (ed.) Pravidlá slovenského pravopisu. Bratislava: Veda, 2013.

Szober, S. Słownik poprawnej polszczyzny. Warszawa: Państwowy Instytut Wydawniczy, 1968.

Szymczak, M. (ed.) Stownik języka polskiego PWN. A-K. Warszawa: Państwowe Wydawnictwo Naukowe, 1978.

Szymczak, M (ed.) Słownik języka polskiego PWN. A-K. Warszawa: Państwowe Wydawnictwo Naukowe, 2002.

Urbańczyk, S., Kucała, M. (eds.) Encyklopedia języka polskiego. Wrocław: Ossolineum, 1999.

Vincejová, D. Slovenská a pol’ská lingvistická terminológia. In: Mikulášková, G. (ed.) 15. študentská vedecká a umelecká konferencia. Zborník príspevkov. Prešov: Filozofická fakulta Prešovskej univerzity v Prešove, 2019, s. 191-197. 
Vincejová, D. Slovenské a pol’ské lingvistické termíny z aspektu abreviačnej motivácie. In: Pachomovová, S. (ed.) Studia slovakistica 20. Užhorod: Vydavnyctvo Oleksandry Harkuši, 2020a (v tlači).

Vincejová, D. Slovenské a pol'ské lingvistické termíny z aspektu interlingválnej motivácie. In: Blaho, M. (ed.) 16. študentská vedecká a umelecká konferencia. Zbornik príspevkov. Prešov: Filozofická fakulta Prešovskej univerzity v Prešove, $2020 \mathrm{~b}$ (v tlači).

Vojteková, M. Slovenské a pol'ské jazykovedné termíny z aspektu vybraných typov lexikálnej motivácie. In: Vojteková, M. (ed.) Jazykovedná terminológia $v$ slovanskom kontexte. Prešov: Filozofická fakulta Prešovskej univerzity v Prešove, 2018, s. 7-37.

Vojteková, M. (ed.) Slovensko-pol'sko-ruský slovnik jazykovedných termínov II. Morfológia. Prešov: Filozofická fakulta Prešovskej univerzity v Prešove, 2019.

Żmigrodzki, P. (ed.) Wielki słownik języka polskiego. Dostupné z: http://www.wsjp.p1/ (2021-04-15). 


\title{
ФОРМИРОВАНИЕ ПРЕДСТАВЛЕНИЙ О НАРОДНОЙ ЭТИКЕ В ЯЗЫКОВОЙ КАРТИНЕ МИРА МЛАДШЕГО ШКОЛЬНИКА
}

\author{
Forming Perceptions of Ethics in the Linguistic Worldview \\ of Primary Schoolchildren
}

Keywords: primary schoolchildren, paremia, proverb, Russian ethics, linguistic worldview

Contact: МГПУ; tatiana.voevodina.2017@mail.ru,rusinova_aleksandra@mail.ru

Каждый этнос приобретал опыт и знания в труде, наблюдениях за природой, окружающей средой и за взаимоотношениями людей. Словесным выражением этого стали пословицы, в которых отражен и закреплен многовековой социальноисторический опыт именно того или иного народа. В пословицах и поговорках нашла свое отражение вся многогранная жизнь народа, все сферы деятельности человека, его бытийного состояния. Пословичные выражения - сгусток трудового, нравственного и эстетического опыта этноса, сжатого в мудрые изречения. Именно поэтому с помощью пословиц можно приобщиться к образу мыслей народа, приблизиться к постижению своеобразия национального характера, национальной системы ценностей (Замалетдинов, Замалетдинова 2010: 73-78).

Термин «паремия» можно рассматривать как синоним пословичнопоговорных образований. В филологии паремии (пословицы и поговорки) трактуются как особый вид устойчивых высказываний, носящих образный характер, которые в сжатой форме выражают моральные нормы. В паремиях содержится житейский опыт, народная мудрость народа. Следовательно, через рассмотрение паремий познается не только язык, но и культура народа. Одним из свойств паремий является то, что они способны как отражать, так и порождать правила и нормы поведения человека в реалиях окружающего его мира.

Среди основных характеристик паремий можно выделить их краткость, цельнооформленность, наличие той или иной прагматической установки, 
жесткость структуры. Оценочный характер паремий, в основе которого лежит образ, является их неотъемлемой чертой (Гетман 2013: 316-320).

Отражая народную мудрость и ценностную картину мира русского народа, пословицы и поговорки отличаются высокой метафоричностью, образностью, чему способствует их двуплановость, наличие буквального и переносного смыслов; они способны выражать как авторитарную, так и гуманистическую этические системы (Буянова 2014: 60-62).

Пословицы и поговорки играют особую роль в создании языковой картины мира. Языковая картина мира - это фиксация отраженной действительности в языке, которая влияет на становление языковой личности. Природа значения пословиц тесно связана с фоновыми знаниями носителя языка, с его практическим опытом, а также с культурно-историческими традициями народа, говорящего на данном языке (Лобанова, Афонина 2019: 227-233).

Отметим, что в пословицах и поговорках в большей мере, чем в других языковых единицах, проявляется субъективный человеческий фактор, отражающий лингвокреативный потенциал человеческого мышления, и огромный потенциал особого типа коммуникации - межпоколенной (Буянова 2014: 60-62).

Современное общество ставит перед школой актуальные задачи в области нравственного воспитания - формирование у детей доброжелательности, уважительного отношения к истории и культуре своего и других народов, развитие эстетических потребностей, способности к самостоятельным поступкам и действиям, совершаемым на основе морального выбора, что также отражено в новых образовательных стандартах. Вместе с тем учителя отмечают, что испытывают затруднения в воспитании у детей нравственно-этических качеств: доброты, отзывчивости, искренности, сострадания, умения сопереживать и сочувствовать, т.е. тех качеств личности, которые имеют глубинную природную основу и слабо компенсируются другими качествами. В связи с этим необходимо эффективное использование воспитательного потенциала всех видов образовательной деятельности, объединение усилий школы, семьи и всего общества.

В период начальной школы развиваются формы мышления, обеспечивающие в дальнейшем усвоение системы научных знаний, развитие научного, теоретического мышления. Известно, что научные понятия становятся доступными ребенку не сразу. В частности, они могут быть долго непостижимы в системе, хотя каждое из них порознь и понятно ребенку. Именно в начальной 
школе необходимо специально формировать у младших школьников представления о языковой картине мира, т.е. комплекс знаний о мире, отражающих мировоззрение народа и заключенных в языке, в значениях слов. Чем глубже познает ребенок родной язык, тем шире и разнообразнее картина мира в его сознании. Поскольку проблема формирования представления о языковой картине сложна и многогранна, то мы в своей статье останавливаемся на одном аспекте данной проблемы, а именно на формировании представлений о народной этике в языковой картине мира младшего школьника посредством паремий.

По мнению ведущих отечественных лингвистов, в русской языковой картине мира ключевыми оказываются идеи ценности семьи, важности родины, сущности добра, значимости человеческих отношений, справедливости. С этими идеями связано множество пословиц, имеющих различную смысловую нагрузку. Именно с них можно начать работу над формированием представлений о языковой картине мира у младшего школьника. Разберем на примерах те взгляды, которые вкладывались русским народом не одну сотню лет.

Семья - один из концептов, которому следует уделить внимание.

Сила семьи отражается в следующих пословицах: Вся семья вместе, так и душа на месте.; Где семья дружна, не страшна беда.; Человек семьею крепок.; В недружной семье добра не бьвает.; В семье дружат - живут не тужат.; В семье разлад, так и дому не рад.; Когда семья вместе, и сердие на месте. Такими паремиями иллюстрируется значимость семьи для каждого человека - это залог счастливой жизни, ведь стабильность, спокойствие, любовь поддерживает всех членов семьи, вот почему люди могут вместе справиться со всеми невзгодами и быть по-настоящему счастливыми.

Прощение и понимание в семье: В семье не без урода.; В семье все бывает.; В одной суме - да разные денежки; в одной семье - да разные детушки.; Намеки да попреки - семейные пороки.; На что и клад, когда в семье лад.; Семейное согласие всего дороже. Как уже упоминалось, семья - это важная составляющая жизни любого человека, но самое первостепенное - наличие понимания у членов семьи, умения прощать друг друга и принимать такими, какими есть.

Следующий концепт, который не обладает такой большой моральной составляющей, но являющийся частью русского менталитета - богатство.

В русском менталитете заложено довольствоваться меньшим: Не думалось жить богато, да пришлось.; Не жили богато, нечего и начинать. Бедность народа - это естественное состояние. И если человек вдруг разбогател, а затем 
потерял все свое богатство, то считается, что это знак, что ему привычнее жить небогато.

Богатство - счастье: Богатый как хочет, а бедный как может.; Богатство открывает и двери, и замки.; Богатому везде рады. В русском языке сложно найти пословицы, где богатство представляется как положительный аспект жизни, потому что, как уже упоминалось ранее, большинство людей к этому не склонны. Говоря о приведенных выше единицах, их главное значение в том, что богатство дает свободу в выборе, даря возможность заниматься тем, что нравится, не задумываясь о завтрашнем дне.

Перейдем к следующему концепту - дружба: Дружба да братство дороже всякого богатства.; Дружба - дело святое.; Без дружбы нет счастья.; На дружбе мир держится.; Дружба крепка не лестью, а правдой и честью.; Дружба солдатская крепче каменных стен.; Дружбой дорожи, забывать ее не спеши.; Потому хорошо живется, что дружба народов в нашей стране ведется.; Дружба народов увеличивает их силу.; Народная дружба и братство дороже всякого богатства.; Если дружба велика, будет Родина крепка. Большое количество пословиц посвящено именно дружбе, потому что она помогает человеку стать лучше. Каждый из нас обретает в товарище родственную душу и опору. Даже если мы обратимся к истории, именно благодаря дружбе удалось преодолеть все трудности, которые постоянно сопровождали русский народ (революции, войны), поэтому это оставило неизгладимый след в русском менталитете.

Теперь рассмотрим еще один концепт - добро: Добрые слова лучше мягкого пирога.; Жизнь дана на добрые дела.; Про доброе дело говори смело.; Свет не без добрых людей.; Кто любит добрые дела, тому и жизнь мила.; От добра добра не ищут.; Сделав добро, не хвались. Доброта является ценным качеством человека, возвышающим его. Это качество позволяет человеку оставаться человечным.

Воззрения русского народа определяли в себе гуманистические идеи. В себе они несли оптимально сбалансированные соотношения внешнего воздействия через правила социального поведения, норм общества и внутренних психических возможностей, возрастных особенностей, индивидуальности детей. Воспитательные средства народной культуры отражают по своей сути социальноличностный ориентир. И можно сказать, что в современном мире приобщая детей к народным традициям русской культуры, мы формируем постепенно возрастные нормы поведения. Происходит самовоспитание ребенка, так как, осторожно исследуя границы дозволенного, он решает свои эмоциональные проблемы. Ведя 
последовательно работу в познании нравственно-этических норм, опираясь на опыт предков, можно сделать заключение о том, что дети не только теоретически различают понятия добро и зло, любовь и ненависть, правду и ложь, но и в жизни стремятся проявлять положительные качества души (Диденко 2015: 52-54).

С.В. Лихачев отмечает, что в период обучения необходимо «специально формировать у младших школьников представления о языковой картине мира, т.е. комплекс знаний о мире, отражающих мировоззрение народа и заключенных в языке, в значениях слов» (Лихачев 2017: 16-19).

При определении тематических групп для организации работы с паремиями необходимо исходить из «социального заказа» общества о воспитании подрастающего поколения. В настоящее время обществу необходимо молодое поколение, которое будет не только следовать нравственноэтическим нормам, но и сохранит в себе этические нормы русского народа.

При анализе паремий можно выявить особенности русского менталитета. Обращаясь к опыту наших предков, можно увидеть, что оптимизм и жизнелюбие ценилось с давних времен. Они считались основой для положительного поведения людей. В менталитете русского народа заложено милосердие, сотворение добра другим, что нельзя быть счастливым, если рядом беда. Традиции русской народной культуры - вот источник, который поможет решить нравственноэтические задачи с детьми. Эффективность формирования эстетического опыта младших школьников средствами народных пословиц и поговорок в значительной мере зависит от создания оптимальных условий педагогического руководства учебно-воспитательным процессом. Такими условиями следует считать: учет возрастных особенностей младших школьников; определение оптимального объема информации для младших школьников о народных пословицах и поговорках; создание положительной эмоциональной атмосферы в процессе восприятия и изучения младшими школьниками народных пословиц и поговорок; методическое обеспечение процесса их освоения.

Пословицы должны стать для младших школьников образцом речи, передачи мысли кратко и точно, без избытка информации и использования излишнего количества слов. Также видится целесообразным формировать осознанное отношение к пословицам и поговоркам как средствам обогащения собственного жизненного и формирования нового эстетического опыта (Чужа 2016: 136-140). Менталитет русского народа в полной мере находит отражение в паремиях, которые в свою очередь несут в себе морально-нравственные нормы и информацию о жизни предыдущих поколений. Несомненно, знакомясь 
с пословицами, младший школьник познает особенности русского народа и приобретает свою языковую картину мира, в которой так или иначе будут отражены моральные нормы и народная лексика. Таким образом, подтекст, который доносят данные пословицы, оказывает значительное влияние на формировании представлений о народной этике в языковой картине мира младшего школьника.

\section{Summary}

To summarize all of the above, we guess that the study of proverbs in primary school is an integral part of education. The study of paremias really helps to form the linguistic worldview of the younger student. The article discusses concepts such as family, friendship, goodness, etc. Through them, children gain knowledge about the people, culture and morality. Thus, proverbs convey folk ethics and give the child those ideals that are necessary in modern society.

\section{Литература}

Буянова, Л.Ю. Русские пословицы и поговорки как этнокультурные константы: ментально-аксиологический аспект. Вестник Новгородского государственного университета. 2014 (77), с. 60-62.

Гетман, А.А. Паремии как воплощение концепта «Бедность». Мир науки, культуры, образования. 2013 (6/43), с. 316-320.

Диденко, И.А. Традиции русского народа в воспитании нравственно-этических норм поведения. In: Диденко, И.А. (ред.) Актуальные вопросы современной педагогики: материаль VI Международной научной конференции. Уфа, 2015 , с. 52-54.

Замалетдинов, Р.P., Замалетдинова, Г.Ф. О роли пословиц в исследовании национально-культурных особенностей языкового сознания. Филология и культура. 2010 (2/20), с. 73-78.

Лихачев, С.В. Формирование у младших школьников представлений о языковой картине мира. Начальная школа. 2017 (1), с. 16-19.

Лобанова, Т.А., Афонина, Е.О. Роль противительных отношений в раскрытии национального своеобразия языковой картины русского мира (на материале сборника В.И. Даля «Пословицы русского народа»). In: Коптелова Н.Г., Котлов, А.К. (ред.) Духовно-нравственные основы русской 
литературы. Сборник научных статей конференции (Кострома, 19-20 апреля 2019 г.). Кострома: Костромский государственный университет, 2020, c. 227-233.

Чужа, Н.П. Формирование эстетического опыта младших школьников средствами народных пословиц и поговорок. Wschodnioeuropejskie Czasopismo Naukowe. 2016 (10), c. 136-140. 



\section{STATUS SŁOWOTWÓRCZYCH ELEMENTÓW KLASYCZNYCH W WYBRANYCH UJĘCIACH JĘZYKOZNAWCÓW SLOWIAŃSKICH}

\section{Status of Classical Word-formative Elements in Selected Approaches of Slavic Linguists}

Keywords: Bulgarian, Slovak, Polish, prefix, sufix, afixoids, compounds, wordformative element

Contact: Uniwersytet Śląskiw Katowicach; a.wojnarowska93@gmail.com

\section{Wstęp}

Określenie roli obcych komponentów w procesie internacjonalizacji leksyki, a przede wszystkim ich statusu słowotwórczego, stanowią przedmiot badań lingwistów od drugiej połowy XX wieku. Jednocześnie przedstawione badania prezentują różnorodne podejścia względem elementów obcych i wskazują na brak jednomyślności w kwestii ich typologii. Celem tego artykułu jest więc naświetlenie i próba porównania poglądów wybranych językoznawców słowackich, polskich i bułgarskich dotyczących statusu formalno-gramatycznego cząstek obcych (głównie klasycznych) ${ }^{1}$.

Motywacją do przeprowadzenia niniejszej komparacji jest chęć określenia statusu słowotwórczego elementów występujących w terminologii okulistycznej w językach bułgarskim i słowackim. Mowa o cząstkach występujących w terminach klasyfikowanych jako internacjonalne, w których, element obcy (klasyczny) łączy się z obcą podstawą słowotwórczą. Choć opracowania lingwistyczne nie podejmują raczej próby klasyfikacji obcych cząstek w ramach profesjolektu medycznego, rozbieżności pojawiające się $\mathrm{w}$ interpretacji takich cząstek, nawet na gruncie poszczególnych języków narodowych zasługują na uwagę. Cząstki wyekscerpowane podczas badań mają pochodzenia greckie i łacińskie, są to m.in.: $a(H)$ - / $a(n)-$; bio- / бuo-; extra- /

\footnotetext{
${ }^{1}$ Temat statusu słowotwórczego cząstek obcych jest bardzo szeroki. Niniejszy artykuł stanowi ogólny przegląd klasyfikacji takich cząstek w językach, które są analizowane w powstającej rozprawie doktorskiej na temat terminologii okulistycznej w języku słowackim i bułgarskim.
} 
екстра-; суб- / sub-; foto- / фото-; хетеро- / hetero-; хипер- / hiper-; xuno- / hypo-; интер- / inter-; микро- / mikro-; моно- / топо-; nара- / para-; теле- / tele-, itp.

Te i podobne im elementy są zaliczane przez różnych językoznawców do derywacji lub kompozycji. Cząstki o charakterze prepozycjonalnym określane są jako prefiksy, prefiksoidy, poloprefiksy, polomorfemy, prepozitivni afixoidy (por. Waszkowa 2005; Kaproń-Charzyńska 2004; Селимски 2003; Furdík 2004). Inni lingwiści elementy obce (także wygłosowe) uznają za człony złożeń, interpretując struktury z ich udziałem jako złożenia bezinterfiksalne / bezafiksalne, złożenia z członem (nie)samodzielnym, złożenia z członem powtarzalnym czy quasi-złożenia. W badaniach lingwistów bułgarskich, czeskich i słowackich pojawiają się dodatkowo takie określenie obcych cząstek jak: radixoid, лексико-морфема, bázoid, czy też dość ogólnie ujęty internacionálny komponent.

\section{Prefiksy $^{2}$}

Różnice w rozumieniu poszczególnych elementów obcych można zauważyć nie tylko podczas komparacji interlingwalnej, ale również w obrębie jednego języka. Pojęcie prefiks (pl. przedrostek, sk. predpona, bg. представка) ${ }^{3}$ to pojęcie raczej ustabilizowane w polskiej, słowackiej czy bułgarskiej lingwistyce. Charakteryzowane są jako formant słowotwórczy występujący przed rdzeniem (Grzegorczykowa, Puzynina 1999a: 366; Furdík 2004: 93).

K. Waszakowa w swojej monografii (Waszakowa 2005) wydziela nieliczną grupę elementów obcych, którym nadaje status prefiksu; zalicza do nich m. in. $a$-, anty-, de- // dez-, dys-, ekstra-, hiper-, kontr-, sub-, super-. Ta klasyfikacja jest podyktowana włączeniem w zakres prefiksacji takich konstrukcji, których znaczenie (komunikowane przez powtarzalny element obcy, nie mający statusu samodzielnego wyrazu) może być $\mathrm{w}$ pełni oddane lub przybliżone przez odpowiedni rodzimy przyrostek bądź przyimek (Waszakowa 2005: 54-55). Podobne podejście prezentują R. Grzegorczykowa i J. Puzynina przyjmując, że podstawą w typologii cząstek słowotwórczych może być ich rodzimość lub obcość (Grzegorczykowa, Puzynina 1999b: 465-468).

Dosyć szeroki zakres prefiksacji na płaszczyźnie języka bułgarskiego w odniesieniu do obcych morfemów przyjmuje L. Selimski. Jako prefiksy traktuje m.in.,

\footnotetext{
${ }^{2}$ Ze względu na przedmiot badań (cząstki nagłosowe) i szeroki zakres tematyczny z nimi związany w artykule nie wspomina się szczegółowo o sufiksach, a jedynie o cząstkach o przechodnim charakterze, które odnoszą się do kompozycji lub derywacji jak np. formantoidy, afiksoidy (w tym sufikso- i radiksoidy).

${ }^{3}$ Podobnie pojęcie sufiks (pol. przyrostek, sk. prípona, bg. наставка) czy ogólne afiks (formant) również są definiowane $\mathrm{w}$ analizowanych językach jednorodnie.
} 
struktury typu: $а($ (н)-, де- (дез-), дис-, интер-, пара-, супер-, транс-, ултра-, хипер-. Podobne stanowisko na gruncie języka polskiego przyjmuje J. Bartmiński dodając do powyższego zbioru także inne cząstki pochodzenia klasycznego, np. tele-, wideo-, bio-, mini-, maksi (por. Bartmiński 2000: 111).

C. Avramowa (Avramowa 2002: 24) w studium porównawczym bułgarskoczeskim jako prefiksy klasyfikuje paralelne cząstki armu- / anti, de- / de-, nocm- / post-, хипер- / hyper, псевдо- / pseudo-, cynep- / super-, itp. Wymienione przedrostki badaczka uważa za niepodzielną część systemu słowotwórczego języka bułgarskiego i czeskiego, które standardowo łączą się z podstawami rodzimymi.

\section{Prefiksoidy}

O wiele mniejszą zgodność obserwuje się wśród badaczy w kwestii typologii tego, co jest prefiksoidem lub członem złożenia oraz czym te dwie formacje różnią się od prefiksu. Określeniu czym ma być prefiksoid miało służyć na gruncie języka polskiego wprowadzenie przez polskie lingwistki - R. Grzegorczykową i J. Puzyninę, bardziej ogólnego pojęcia formantoid dla wyrazów, które są: podzielne jednostronnie formalnie, nie mają podstaw słowotwórczych i nie są motywowane ${ }^{4}$ (Grzegorczykowa, Puzynina 1979: 24).

Inaczej afiksoidy (prefiksoidy / sufiksoidy) są opisywane w słowackiej i czeskiej lingwistyce. J. Furdík definiuje afixoidy jako człony złożeń, które zostały zdegradowane do poziomu środka derywacyjnego: ,(...) útvary, ktoré spočiatku fungovali ako slovotvorné základy zložených slov, ale pri častejšiom tvorení príslušných kompozít ich vlastná sémantika zoslabla, takže poklesli na úroveň derivačného prostriedku afixoidu" (Furdík 2004: 46-47). Za prefiksoidy J. Fudík uznaje struktury typu: eko-, mini-, maxi-, makro-, tele-, itp. (Furdík 2004: 46-47).

Bardzo podobnie afiksoid jest rozumiany przez C. Avramovą, czerpiąca głównie z założeń Olgi Martincovej i Nikolaja Savickiego. Badaczka rozumie aфиксоидu jako „компоненти заемащи мединно положение по отношение на корените и афиксалните морфем" (Аврамова 2003: 33-34; Martincová, Savický 1987: 125). C. Avramova zaznacza, że afikosoidy nie tworzą grupy homogennej, wskazując w swoich badaniach niejednokrotnie na ich nieustabilizowany i niezdefiniowany w pełni dotąd charakter. Do grupy afiksoidów, oprócz prefiksoidów i sufiksoidów,

\footnotetext{
${ }^{4}$ Mowa o cząstkach -ent i -ant w wyrazach, np. docent i adiutant. Te same cząstki będą jednak sufiksami, jeśli wyraz, w którym występują są motywowane - podzielne słowotwórczo, a ich znaczenie można opisać za pomocą parafrazy słowotwórczej, np. student, konsultant ('ten, kto studiuje' lub 'ten kto konsultuje') (Grzegorczykowa, Puzynina 1979: 24-25).
} 
zalicza również tzw. radiksoidy (czes. radixoidy) czyli cząstki, których status słowotwórczy można umiejscowić pomiędzy afiksem i rdzeniem (radixem), por. еко-, електро-, енерго-, евро-, крими-, моно-, нарко-, профи (2003: 35-42).

Bułgarscy lingwiści w odniesieniu do określenia radiksoid (bułg. paдиксоид) używają również zaczerpniętego z lingwistyki rosyjskiej terminu лексико-морфема, definiowanego jako „своеобразен слой лексико-морфологични елементи, загубили морфологичните връзки със своите източници и служещи за образуване на селии серии сложносъкратени думи, които в действителност нямат зад себс си реално ськращаващи съчетани” (Аврамова 2003: 43).

$\mathrm{Na}$ niestabilność koncepcji i trudność w typologizacji opisywanych cząstek wskazuje także fakt, że sami badacze zmieniają swoje podejścia i kryteria klasyfikacji w trakcie analiz. K. Waszakowa, w odróżnieniu od swojej późniejszej klasyfikacji, w studium komparatystycznym polsko-słowacko-czeskim, człony typu: super-, mega-, hiper / hyper-, mini-, mikro-, maksi- / maxi-, pseudo-, multi-, opisuje jako prefiksoidy, zaznaczając, że część językoznawców traktuje je jako prefiksy oraz, że jako cząstki obce mają zdolność łączyć się z formacjami imiennymi, zarówno obcymi jak i rodzimymi (Waszakowa 2003: 85-100).

\section{Kompozycje}

Struktury obce, poszerzające inwentarz słowotwórczy języków-biorców, nie są badane jedynie przez pryzmat derywacji, ale i kompozycji. Niejednomyślność lingwistów w kwestii członów obcych przejawia się w tym, jak klasyfikują daną jednostkę według ogólnych kryteriów - czy jako samodzielną słowotwórczo albo motywowaną na gruncie właściwego im języka rodzimego. Pluralizm przejawia się także w odniesieniu do kwestii formalnych.

Można przyjąć, że elementy obcego pochodzenia wchodzą w skład złożeń jak czyni to J. Mleczko, zaliczając do internacjonalnych pierwszych członów złożeń segmenty takie jak np: био-, хроно-, хромо-, фото-, гига-, хетеро-, хомо-, хинтер-, мега-, микро-, моно-, теле- ${ }^{6}$ (por. Mleczko 2012: 79). Podobne cząstki są traktowane przez grupę słowackich badaczy jako części złożeń internacjonalnych czy quasi-

\footnotetext{
${ }^{5}$ Jako podstawowe kryterium rozgraniczenia prefiksoidów od radiksoidów autorka przyjmuje opozycję znaczeń przedmiotowe $\neq$ nie przedmiotowe (bg. предметно $\neq$ непредметно) i konkretne $\neq$ abstrakcyjne (bg. конкретно \# абстрактно). Radiksoidy wyrażają znaczenie przedmiotowe, z kolei prefiksoidy nie mają znaczenia przedmiotowego i wyrażają stosunki ogólne (lokalne, temporalne, wartościujące, ilościowe, stosunku przeciwwagi, hierarchię) (Радева 2003: 35-42).

${ }^{6}$ Należy jednak zaznaczyć, że w tym samym zbiorze ukazał się sąsiedni artykuł tej samej autorki, w którym opisuje niejednomyślność poglądów, badaczy czeskich i bułgarskim w kwestii opisanych przez nią struktur (por. Mleczko 2012a).
} 
composit (kvázikompozitá, intarnacionálne kompozitá, internacionálne zloženiny) (Horecký, Buzássyová, Bosák et al. 1989: 251-252).

Oprócz kryteriów semantyczno-morfologicznych brany jest pod uwagę także stopień motywacji słowotwórczej. To podejście wydaje się być wyjściowym na gruncie polskiej i słowackiej lingwistyki (por. Waszakowa 2005 oraz Ološtiak, Vojteková, Oriňáková 2019). Można więc wydzielić trzy rodzaje struktur (jednostek):

- struktury o pełnej motywacji (podstawy słowotwórcze, z których składa się złożenie są samodzielne słowotwórczo);

- struktury o niepełnej motywacji (złożenia z jednym członem związanym niesamodzielnym);

- quasi-złożenia (złożenia o dwóch członach niesamodzielnych - związanych).

K. Waszakowa dodatkowo złożenia z członami samodzielnymi dzieli na złożenia z członami o pełnej postaci oraz na złożenia $\mathrm{z}$ członem o postaci skróconej (zdezintegrowanej). Natomiast złożenia z członem niesamodzielnym grupuje razem z quasi-złożeniami, do których zalicza znaczną większość elementów klasycznych. Niektóre człony, których etymologia jest klasyczna, ale ich obecność w systemie słowotwórczym języka polskiego pozwala na określenie ich motywacji, autorka włącza do grupy złożeń zdezintegrowanych, np. auto- od automatyczny; bio- od biologia, biologiczny (por. Waszakowa 2005: 77-80).

O skróconych wyrazach złożonych (съкратени сложни думи) bułgarscy lingwiści piszą również jako o tzw. групови абревиатури (por. Крумова, Чоролеева 1982: 24). Opisują ten typ złożeń jako oscylujące na pograniczu między nimi a wspominanymi wyżej strukturami określanymi jako лексико-морфеми (albo радиксоиди). Według V. Radevej cząstkę, która traci swój związek z podstawą, do której była przyłączona i zbliża się pod względem funkcji do środka słowotwórczego, można traktować jako wspominane лексико-морфеми (Радева 1991: 50).

W Gramatyce współczesnego języka polskiego (Grzegorczykowa, Puzynina 1999b: 466-467) człony obce klasyfikuje się głównie jako segmenty niesamodzielne, powtarzane $\mathrm{w}$ złożeniach jednostronnie motywowanych, a jako najbardziej produktywne wyróżnia się m. in: mono-, poli-, makro-, mikro-, izo-, bio-, endo-, hetero-, tele-. Badaczki określają strukturę złożeń jednostronnie motywowanych i quasi-złożeń jako niejasną i rezygnują z ich interpretacji semantyczno-składniowej (Grzegorczykowa, Puzynina 1999b: 465).

Opisana niejednomyślność w systematyzacji i niemożność wyznaczenia ostrych granic pomiędzy procesami derywacji i kompozycji, w których uczestniczą klasyczne cząstki obce była bodźcem do stworzenia nowego pojęcia na gruncie słowackiej 
lingwistyki. M. Ološtiak. M. Vojteková, S. Oriňáková (2019: 22) proponują termin nowy dla słowackiego językoznawstwa - bázoidy, o których piszą w następujący sposób „komponenty neslovného charakteru (a so zrejmým lexikálnym významom) v kompozitných lexémach budeme nazývat' bázoidy a jednotky $\mathrm{s}$ takýmito komponentmi bázoidné kompozitné lexémy, resp. semikompozitá”. Za podstawowe kryterium delimitacyjne autorzy założyli semantykę. Pełne znaczenie leksykalne przypisują bazie (podstawie słowotwórczej), formanty są natomiast nosicielami znaczenia „semikategorialnego“(Ološtiak, Vojteková, Oriňáková 2019: 17-18)7.

\section{Podsumowanie}

Jak pokazują powyższe rozważania, dysponując wyekscerpowanymi cząstkami obcymi nie sposób ich jednoznacznie zaklasyfikować w sposób, w jaki pozwalałaby na to logiczna oraz merytoryczna argumentacja. I. Kaproń Charzyńska podejmuje próbę kompleksowej klasyfikacji, biorąc pod uwagę poszczególne wytyczne, proponowane przez innych językoznawców, również rosyjskich i czeskich. Lingwistka uwzględnia formalne i semantyczne relacje słowotwórcze (między derywatami i ich podstawami słowotwórczymi) oraz cechy formalne (miejsce danej cząstki w derywacie - sposób połączenia z innymi członami złożenia, powtarzalność). Wnioski płynące z jej analizy, będące zarazem swoistą klasyfikacją cząstek obcych (nagłosowych i wygłosowych) dzielą elementy obce na afiksy oraz cząstki obce, których afiksami nazwać nie można. $\mathrm{Za}$ afiksy uznane są te elementy, które mogą być wyrażane za pomocą rodzimych również afiksów lub przyimków. Grupa „nie-afiksów” podzielona została na afiksoidy i człony złożeń. Afiksoidy to według autorki te elementy, które w parafrazie słowotwórczej są zastępowane leksemem, który ma związek formalny. Człony złożeń to mianowicie te, które nie są zastępowane leksemem. Klasyfikacja wydaje się być zasadna i pomocna w badaniach, nie ma w niej jednak miejsca na quasi-złożenia czy cząstki typu radiksoidalnego lub bazoidalnego.

Z opisanych, proponowanych przez różnych językoznawców, klasyfikacji wynikałoby bowiem, że prefiksy, prefikso- (ale i afiksoidy) oraz (pierwsze) człony złożeń wykazują cechy, które przenikają się wzajemnie, ale i wykluczają. Określenie statusu słowotwórczego klasycznych elementów obcych, a następnie ich komparacja w innych językach, okazuje się przy wielości wyznaczanych warunków opisu a jednocześnie niekonsekwencji $\mathrm{w}$ ich stosowaniu trudna. Ilość słowiańskich źródeł literatury przedmiotowej, która powstaje, wydaje się niezasadna, uwzględniając fakt, że

\footnotetext{
${ }^{7}$ Dla porównania: w myśl tej tezy bazoidem będzie cząstka inter- w znaczeniu „internacionálny, medzinárodný“, ale inter- występujący w charakterze przyimka „medzi“ przyjmie status afiksu (Ološtiak, Vojteková, Oriňáková 2019: 28).
} 
nie w pełni rozlicza się ona z powstałymi już próbami typologizacji internacjonalnych słowotwórczych elementów obcych.

W przypadku terminologii okulistycznej pomocna może być szeroko rozumiana medyczna literatura, która klasyfikuje cząstki obce - dość zgodnie - jako prefiksy. Taki podział wydaje się być najwygodniejszy i najbardziej uniwersalny - pozwala na określenie statusu obcych cząstek w terminologii, która również jest zinternacjonalizowana i obca na gruncie wielu innych języków.

\section{Summary}

The following paper is an attempt to present diverse linguistic views on international formative elements of classical (i.e. Latin and Greek) origin, excerpted from reaserch of Bulgarian and Slovak ophthalmological terminology. The paper is divided in three main parts, depicting various concepts about affixes, affixoids and compounds. In the end, a summary provides juxtaposition of the most important information about the described structures and aims to adopt one, most universal classification for typology of foreign word formative elements, occurring in medical terminology.

\section{Literatura}

Avramova, C. Slovotvorné tendence u substantiv v bulharštině a češtině v 80. a 90. letech 20. století. Slavia (68/1), s. 23-33.

Bartmiński, J. Pasywne i aktywne paneuropeizmy we współczesnym języku polskim, In: Mazur, J. (ed.) Słownictwo współczesnej polszczyzny w okresie przemian. Lublin: Wydawnictwo Uniwersytetu Marii Curie-Skłodowskiej, 2000, s. 109116.

Ekes, K. Niezbędnik Kleopatry. Greckie i łacińskie korzenie terminologii nie tylko dla kosmetologów. Warszawa: Wydawnictwo Naukowe Sub Lupa, 2016.

Grzegorczykowa, R., Puzynina, J. Słowotwórstwo współczesnego języka polskiego. Rzeczowniki sufiksalne rodzime. Warszawa: Państwowe Wydawnictwo Naukowe, 1979.

Grzegorczykowa, R., Puzynina, J. Problemy ogólne słowotwórstwa. In: Grzegorczykowa. R., Laskowski, R., Wróbel, H. (eds.) Gramatyka współczesnego języka polskiego. Morfologia. Warszawa: Wydawnictwo Naukowe PWN, 1999a, s. 361-389. 
Grzegorczykowa, R., Puzynina, J. Rzeczownik In: Grzegorczykowa. R., Laskowski, R., Wróbel, H. (eds.) Gramatyka współczesnego języka polskiego. Morfologia. Warszawa: Wydawnictwo Naukowe PWN, 1999b, s. 389-469.

Horecký, J. O slovách s predponou gama-. Kultúra slova. 1981 (15/4), s. 97-99.

Horecký, J., Buzássyová, K., Bosák, J. et al. Dynamika slovenej zásoby súčasnej slovenčiny. Bratislava: Veda, 1989.

Kaproń-Charzyńska, I. 2004. Prefiksy, sufiksy, prefiksoidy, sufiksoidy czy człony związane? Język Polski. 2004 (84/1), s. 16-28.

Mleczko, J. Internacjonalizmy we współczesnym języku polskim i bułgarskim (złożenia). Zeszyty Cyrylo-Metodiańskie. 2012 (1), s. 64-81.

Mleczko, J. Status elementów składniowych niektórych internacjonalizmów w języku polskim i bułgarskim. Zeszyty Cyrylo-Metodiańskie. 2012a (1), s. 82-91.

Landesberg, J. Język łaciński dla studentów weterynarii. Warszawa: Państwowe Wydawnictwo Naukowe, 1975.

Waszakowa, K. Przejawy internacjonalizacji w słowotwórstwie wspótczesnej polszczyzny. Warszawa: WUW, 2005.

Waszakowa, K. Przejawy tendencji do internacjonalizacji w systemach słowotwórczych języków zachodniosłowiańskich. In: Ohnheiser, I. (ed.) Komparacja systemów i funkcjonowania współczesnych języków słowiańskich. 1. Stowotwórstwo / Nominacja. Opole: Uniwersytet Opolski - Instytut Filologii Polskiej i Opolskie Towarzystwo Przyjaciół Nauk. 2003, s. 60-78.

Аврамова, Ц. Словообразувателни тенденциии при съществителните имена в българския и чешкия език в края на XX век. Sofia: Hron Press, 2003.

Крумова, Л., Чоролеева, М. Съкращуаването и съкращения в български език, Sofia: БАН, 1982.

Радева, В. Словообразуването в българския книжовен език. София: Университетско издателство „Св. Климент Охридски“, 1991.

Селимски, Л. Прояви на тенденцията към интернацийонализация в южнославянските езици,. In: Ohnheiser, I. (ed.) Koтparacja systemów ifunkcjonowania współczesnych języków słowiańskich. 1. Słowotwórstwo / Nominacja. Opole: Uniwersytet Opolski - Instytut Filologii Polskiej i Opolskie Towarzystwo Przyjaciół Nauk, 2003, s. 103-127. 


\section{Źródła elektroniczne}

Martincová, O., Savický, N. Hybridní slova a některé obecné otázky neologie. Slovo a slovesnost. Dostęp z: http://sas.ujc.cas.cz/archiv.php?art=3164 (2021-02-21).

Ološtiak, M., Vojteková, M., Oriňáková, S. Slovotvorná adaptácia a kompozitnost' $v$ slovenčine. Dostęp z: http://www.pulib.sk/web/kniznica/elpub/dokument/ Olostiak16 (2021-01-15). 



\section{ИСПОЛЬЗОВАНИЕ ПРОГРАММЫ ТRЕQ В ПОЛЬСКО-РУССКОМ ПЕРЕВОДЕ}

\section{Using the Treq Program in Polish-Russian Translation}

Keywords: Treq, InterCorp, translation equivalence, Polish, Russian, Czech

Contact: Uniwersytet Ślaskiw Katowicach; aleksandrazieba33@gmail.com

Программа Treq, использованию которой будет посвящена настоящая статья, представляет собой электронный инструмент, обеспечивающий поиск переводных эквивалентов на базе корпуса InterCorp. Последний подразумевает под собой проект, целью которого является создание обширного параллельного синхронного корпуса текстов, охватывающего как можно больше языков. Это открытый корпус, т.е. он постоянно пополняется новыми текстами. Последняя тринадцатая версия 2020 года включает в себя публицистические тексты и новости с сайтов Project Syndicate и VoxEurop, юридические тексты корпуса Acquis Communautaire, отчеты с заведений Европейского парламента Europarl, субтитры к фильмам из платформы OpenSubtitles, переводы Библии и художественные тексты (так называемые ядро). Упомянутые источники не фиксируют текстов на всех языках, поэтому для каждой отдельной переводной лексикографии InterCorp создает лучшие или худшие условия для работы переводчика. Сама идея зародилась в Праге в Карловом университете в 1994 году. Инструмент Treq относительно молодой, а его исходная версия (альфа 0.1) датируется сентябрем 2014 года и быстро набирает популярность среди пользователей, особенно благодаря своей простоте (Škrabal, Vavř́n 2017: 246). Авторы предположили, что программа адресована не только специалистам (переводчикам, лексикографам), а также для всех тех, кто в средней степени владеет конкретным языком или его изучает (ученики, студенты и т.п.). Несложность и доступность приложения обладает также существенным недостатком - нет возможности провести расширенный многофакторный анализ. До недавнего времени языками интерфейса программы Treq выступали исключительно либо чешский, либо английский, которые считались обязательными из сопоставляемых друг с другом языков. Однако настоящая 
версия базы переводных эквивалентов 2.1, созданная в июле 2020 года, позволяет дополнительно искать доступные переводы и синонимы для испанского языка, что делает Treq надежным инструментом не только для богемистов и англистов, а также тех, кто связан с широко понимаемой испанистикой. Необходимо добавить, что в настоящее время указанное приложение пользуется уже двенадцатой версией корпуса InterCorp, что значительно увеличивает количество доступных текстов и тем самым возможности получения правильного перевода. Для использования данного набора двуязычных словарей, нужен только веббраузер (http://treq.korpus.cz), а поиск эквивалентов возможен без предварительной регистрации для всех пользователей. В первую очередь надо указать желаемую языковую пару, выбрав исходный язык (язык запроса) и целевой язык (язык потенциальных эквивалентов). Потом необходимо ввести в соответствующую колонку языковую единицу, переводной эквивалент которой нам нужен. Затем пользователь может ввести свой запрос (Query) и нажать кнопку Search.

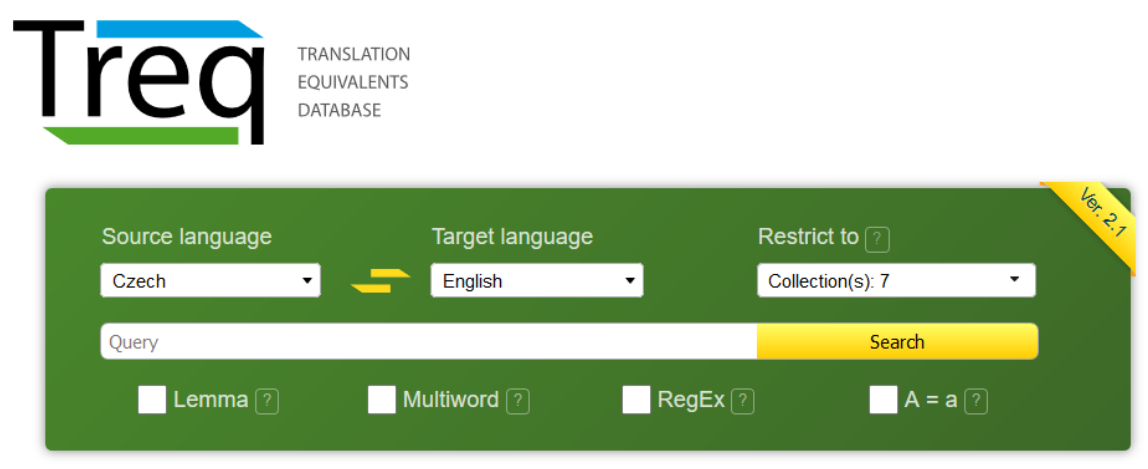

Результатом поиска будут всевозможные эквиваленты перевода данного слова на целевой язык, причем автоматически отсортированные по убыванию частоты и с учетом процентных долей в общем объеме. Кроме вышеуказанных функций, программа Treq предоставляет возможность проверить контексты перевода выбранного нами слова, а также посмотреть его вхождения в InterCorp. Приложение содержит также дополнительные инструменты (функции), облегчающие поиск нужного нам транслята. Функция Lemma обнаружит все словоформы одной и той же лексемы, благодаря чему пользователь получит значительно больше число вхождений. К примеру, приведем вхождения русской лексемы хлеб в следующем порядке: число вхождений, процентная доля, русский транслянд, чешский транслят: 


\section{без функции Lemma}

\begin{tabular}{|c|c|c|c|}
\hline$\Delta$ Frequency $\boldsymbol{\nabla}$ & $\Delta$ Proportion $\boldsymbol{\nabla}$ & $\Delta$ Russian $\boldsymbol{\nabla}$ & $\Delta$ Czech $\nabla$ \\
\hline 166 & 48.7 & хлеб & chléb \\
\hline 159 & 46.6 & хлеб & chleba \\
\hline 6 & 1.8 & хлеб & obili \\
\hline 3 & 0.9 & хлеб & Chleba \\
\hline 1 & 0.3 & хлеб & chlebu \\
\hline 1 & 0.3 & хлеб & zájmem \\
\hline 1 & 0.3 & хлеб & chlebem \\
\hline 1 & 0.3 & хлеб & rušených \\
\hline 1 & 0.3 & хлеб & Obili \\
\hline 1 & 0.3 & хлеб & pečivo \\
\hline 1 & 0.3 & хлеб & houska \\
\hline 341 & & & \\
\hline
\end{tabular}

\section{с функцией Lemma}

\begin{tabular}{|c|c|c|c|}
\hline$\Delta$ Frequency $\boldsymbol{\nabla}$ & $\Delta$ Proportion $\boldsymbol{\nabla}$ & $\Delta$ Russian $\boldsymbol{\nabla}$ & $\Delta$ Czech $\nabla$ \\
\hline 905 & 89.2 & хлеб & chléb \\
\hline 66 & 6.5 & хлеб & obili \\
\hline 11 & 1.1 & хлеб & jídlo \\
\hline 6 & 0.6 & хлеб & Chlebo \\
\hline 3 & 0.3 & хлеб & jist \\
\hline 2 & 0.2 & хлеб & nádraži \\
\hline 1 & 0.1 & хлеб & sedmý. \\
\hline 1 & 0.1 & хлеб & žemle \\
\hline 1 & 0.1 & хлеб & obživa \\
\hline 1 & 0.1 & хлеб & louka \\
\hline 1 & 0.1 & хлеб & jeden \\
\hline 1 & 0.1 & хлеб & dostávat \\
\hline 1 & 0.1 & хлеб & $\underline{\text { věc }}$ \\
\hline 1 & 0.1 & хлеб & nějaký. \\
\hline 1 & 0.1 & хлеб & drobek \\
\hline 1 & 0.1 & хлеб & Bubbie \\
\hline 1 & 0.1 & хлеб & predpisovat \\
\hline 1 & 0.1 & хлеб & $\underline{\text { żvanec }}$ \\
\hline 1 & 0.1 & хлеб & pečivo \\
\hline 1 & 0.1 & хлеб & $\underline{\text { nasytit }}$ \\
\hline 1 & 0.1 & хлеб & koláček \\
\hline 1 & 0.1 & хлеб & $\underline{\text { huba }}$ \\
\hline 1 & 0.1 & хлеб & bochnik \\
\hline 1 & 0.1 & хлеб & $\underline{\text { živobytí }}$ \\
\hline 1 & 0.1 & хлеб & õeá \\
\hline 1 & 0.1 & хлеб & kaše \\
\hline 1 & 0.1 & хлеб & cože \\
\hline 1 & 0.1 & хлеб & rušený. \\
\hline 1015 & & & \\
\hline
\end{tabular}


Не будет особым преувеличением сказать, что существенные различия в количестве чисел очевидны - введение единицы с функцией Lemma обнаруживает почти в 3 раза больше ответов, чем без использования данного инструмента. Помимо этого, запрос может быть введен также как многословная единица (Multiword), либо с использованием регулярных выражений (RegEx). Пользователям также предоставляется возможность введения запроса без различения программой прописных и строчных букв $(\mathrm{A}=\mathrm{a})$. Последним является параметр Restrict to, с помощью которого извлечение результатов может быть нацелено на разные типы текста: основные тексты, ориентированные на художественную литературу, определенные коллекции или весь корпус. Однако, следует учитывать тот факт, что ограничение выбора корпусных ресурсов приведет не только к снижению числа вхождений, а также к меньшей достоверности полученных данных. Все эти факторы несомненно осложняют проведение правильного анализа или делают его невозможным.

Нельзя и не заметить того факта, что в программе осуществляется выравнивание текстов по словам, происходящее автоматически и практически не пересматриваемое. Указанную особенность создатели Treq описывают следующим образом:

Originální a překladové texty jsou nejprve na základě statistických výpočtu zarovnány po slovech pomocí programu GIZA++ (Och-Ney 2003). Zarovnané dvojice slov jsou pak setřídèny a sumarizovány. Výsledek automatické excerpce neni nijak revidován, jako ukazatel relevance překladového ekvivalentu však může posloužit relativní frekvence př́slušné dvojice slov. Čím častěji se ekvivalent zadaného slova vyskytl ve srovnání sostatními ekvivalenty, tím větší je pravděpodobnost, že je funkční (Treq, Nápověda, электронный ресурс).

При подготовке данных для Treq из всего корпуса выбираются только предложения, выровненные методом 1:1, что позволяет в большей степени предотвращать потенциальные ошибки. В более старых версиях программы использовался метод пересечения, который создавал только такие выравнивания, при которых одно слово на исходном языке соответствует одному эквиваленту на целевом языке. Как уже было написано, инструмент Treq предоставляет пользователю дифференцированные условия для поиска эквивалентов, что обусловлено выбором исходного и целевого языков. На это влияют модули конкретных языков, содержащие в параллельном корпусе и отличающиеся друг от друга количеством текстов и определенных жанров. К примеру, двенадцатая версия польского корпуса насчитывает свыше 87 млн. слов, а русского - примерно 19 млн. лексических единиц и выражений. В дополнение к этому польские 
и русские коллекции, содержащиеся в InterCorp v12 полностью не совпадают. Польский InterCorp содержит все коллекции InterCorp за исключением публицистических текстов на сайте Project Syndicate. С другой стороны, имеется русский InterCorp, включающий в себя художественные тексты, публицистические тексты и субтитры на сайте OpenSubtitles.

Совершенно разные условия для перевода и наличие исключительно трех языков запроса могут привести к ощущению, что данная программа не представляет собой пригодного переводческого инструмента для польского русиста или русского полониста. Однако для пользователей, которые знакомы с основами чешского, английского либо испанского языков, Treq может служить вспомогательным инструментом в процессе перевода (напр., польско-чешского, русско-чешского и т.д.). Чтобы доказать полезность программы в процессе польско-русского перевода и описать возможность выступления потенциальных ошибок, выберем конкретные лексические единицы и попробуем получить правильный эквивалент путем сопоставления польско-чешских и чешско-русских результатов перевода. Для иллюстрации будем использовать многозначную польскую лексему paczek, для которой попытаемся найти верный русский транслят посредством чешского перевода. Обращение к печатным или электронным одноязычным и переводным словарям, т.е. к основным источникам материала, приносит следующие ответы.

Объяснение значений лексемы paczek представляет электронный «Wielki słownik języka polskiego», основной материальной базой которого является Национальный корпус польского языка (NKJP). Первое значение подразумевает под собой часть растения, состоящую из зачатков стеблей, листьев и побегов, второе - круглое дрожжевое печенье с начинкой из розового джема, фруктов, ликера, пудинга и т.д., жаренное во фритюре. Более точное толкование данного слова приводит «Słownik języka polskiego PWN», в котором дополнительно узнаем, что paczek - это отдельная часть стволового организма в виде клетки, комплекса клеток или тканей, которая превращается в организм-потомок (выступает у растений и низших животных). В свою очередь, только «Wolny, wielojęzyczny Wikisłownik» (pl.wiktionary.org) отмечает лексему pączek как диминитивную форму слова $p q \varepsilon$. Нельзя не заметить того факта, что никакой из перечисленных источников не фиксирует очень распространенного и разговорного значения этой лексической единицы, т.е. paczek 'толстый мальчик'. Как легко можно догадаться, с точки зрения перевода в центре нашего интереса будет значение данной лексемы как разновидности пищи, которое характеризируется наибольшей употребительностью. 
Обратимся сейчас к переводным словарям, чтобы установить потенциальные трансляты: «Polsko-czeski słownik LINGEA 5» (https://dict.com/czesko-polski/paczek) приводит следующие переводные эквиваленты для лексемы paczek: 1. (на дереве) pupen, (розы и т.п.) роире̌; 2. (печенье) koblih. Проверка семантики данных слов на сайте ssjc.ujc.cas.cz (Slovník spisovného jazyka českého) позволяет частично подтвердить соответствие смыслового значения польских и чешских лексических единиц.

В свою очередь, бумажный «Wielki słownik polsko-rosyjski PWN» рекомендует использование следующих возможных транслятов для слова paczek: 1. почка (в растении); 2. бутон (цветочный на ветке, стебле); 3. пышка (хлебобулочное изделие кольцеобразной формы); 4. пончик (жареная булочка).

С другой стороны, «Польско-русский и русско-польский словарь» Г.В Ковалевой не отмечает лексемы пышка в качестве надежного переводного эквивалента. Необходимо еще подчеркнуть, что слово пончик - польского происхождения, а помимо этого, указанную лексему в русском языке употребляется преимущественно для обозначения печенья с дыркой, которая никак не напоминает польской сладкой булочки. В таком случае, многократно к слову пончик добавляется прилагательное польский или словосочетание с начинкой, чтобы адресат точно сообразил себе печенье, которое автор имеет ввиду. В ходе исследования семантического значения приведенных эквивалентов себя обнаружила несколько неожиданная особенность, состоящая в том, что русские одноязычные словари фиксируют значение слова пончик как пренебрежительное название ребенка с лишним весом. Как уже было отмечено, польские словарные ресурсы не замечают значения данной лексемы в контексте обозначения лица, несмотря на то что они зафиксированы в корпусе. К примеру:

Mówia na niego Psychol. Kiedyś nie wychodził z domu dla gier, ale od kiedy ma internet nic się nie liczy... Wygląda jak paczek. Przed kompem czas szybko leci.

После разъяснения возможных дефиниции слова paczek и определения потенциальных русских и чешских эквивалентов, попытаемся сейчас при помощи программы Treq найти подходящий перевод для обозначения круглого шарика с вареньем внутри. Сначала назначим, что исходным языком будет польский, а целевым чешский с использованием функции Lemma для получения более достоверных ответов. Результаты поиска представляются следующим образом (из-за ограничений в объеме статьи не приводим все вхождения). 
Таблица 1. Treq для запроса paczek.

\begin{tabular}{|c|c|c|c|}
\hline $\begin{array}{c}\text { Число вхождений } \\
\text { (Frequency) }\end{array}$ & $\begin{array}{c}\text { Процентная доля } \\
\text { (Proportion) }\end{array}$ & $\begin{array}{c}\text { Польский } \\
\text { транслянд } \\
\text { (Polish) }\end{array}$ & $\begin{array}{c}\text { Чешский } \\
\text { эквивалент } \\
\text { (Czech) }\end{array}$ \\
\hline 201 & 60,2 & pączek & kobliha \\
\hline 17 & 5,1 & pączek & poupě \\
\hline 10 & 3,0 & pączek & pupen \\
\hline 8 & 2,4 & pączek & koblížek \\
\hline 7 & 2,1 & pączek & kompot \\
\hline
\end{tabular}

Полученные данные являются результатом автоматического корпусного анализа, который безусловно может включать в себя многочисленные ошибки. Они могут вытекать как из неправильной аннотации, так из омонимии. Имея дело с программой Treq, которая не различает значения многозначных единиц, мы должны осознавать, что предложенные эквиваленты на самом деле могут не являться теми, которых мы ищем. В данном случае потенциальные чешские переводы слова pqczek следует считать достоверными согласно с ранее приведенной словарной информацией. Ручной анализ контекстов подтверждает верность перевода, однако число вхождений (201) не совпадает с числом доступных контекстов (280). Внимание еще привлекает различие в грамматической категории рода существительного - словарь «LINGEA» предлагал употребление мужской формы koblih, в то время как Treq фиксирует преимущественное использование слова kobliha (женский род). Как оказывается, первый вариант является диалектизмом, сильно нераспространенным в повседневной речи, в силу чего нельзя считать его правильным эквивалентом (https://czechtongue.cz/kobliha-x-koblih/). Замеченное несоответствие позволило доказать, что программа Treq лучше работает с поиском надежного транслята. Переведем сейчас чешское слово kobliha как эквивалент лексемы paczek на русский язык.

Таблица 2. Treq для запроса kobliha.

\begin{tabular}{|c|c|c|c|}
\hline $\begin{array}{c}\text { Число вхождений } \\
\text { (Frequency) }\end{array}$ & $\begin{array}{c}\text { Процентная доля } \\
\text { (Proportion) }\end{array}$ & $\begin{array}{c}\text { Чешский } \\
\text { транслянд } \\
\text { (Сzech) }\end{array}$ & $\begin{array}{c}\text { Русский } \\
\text { эквивалент } \\
\text { (Russian) }\end{array}$ \\
\hline 14 & 21,5 & kobliha & пончик \\
\hline 8 & 12,3 & kobliha & пончики \\
\hline 6 & 9,2 & kobliha & пирог \\
\hline 6 & 9,2 & kobliha & пончиками \\
\hline 5 & 7,7 & kobliha & пирожок \\
\hline
\end{tabular}


В данном случае предложенный нами способ перевода польской лексемы paczek на русский язык при помощи программы Treq можно считать успешным. Небольшое число вхождений и некоторые замеченные контекстные ошибки не могут полностью отрицать верность полученного эквивалента. Хотя результаты поиска не фиксируют наиболее адекватного перевода, т.е. пончик с начинкой, то нельзя их считать недостоверными. Польско-русские словари рекомендуют тот же эквивалент, что обусловлено высокой степенью применения лексемы пончик на фоне доступных переводов. Чтобы пользователь мог абсолютно убедиться в правильности перевода, лучше верифицировать отдельные вхождения во избежание многочисленных ошибок.

Процесс перевода при помощи программы Treq сильно осложняется в случае поиска многолексемных единиц (Multiword). В данном случае лучше дополнительно использовать функцию регулярные (RegEx), благодаря которой можем формировать более сложные запросы. Регулярные слова включают в себя специальные символа, что позволяет выявить конкретный набор слов. Регулярные слова состоят: 1. из специальных символов; 2 . из специальных и альфанумерических символов; 3. из альфанумерических символов (Charciarek 2020: 126).

Указанная функция дает возможность выявить возможные варианты как трансляндов, так и транслятов. В данном месте попробуем перевести польское наименование очередного сладкого пищевого продукта, т.е. bita śmietana на русский язык посредством чешского перевода. На этот раз проверку доступных эквивалентов, содержащихся в переводных польско-чешских и польско-русских словарях, сделаем после анализа программы Treq.

Таблица 3. Treq для запроса bita śmietana.

\begin{tabular}{|c|c|c|c|}
\hline $\begin{array}{c}\text { Число вхождений } \\
\text { (Frequency) }\end{array}$ & $\begin{array}{c}\text { Процентная доля } \\
\text { (Proportion) }\end{array}$ & $\begin{array}{c}\text { Польский } \\
\text { транслянд } \\
\text { (Polish) }\end{array}$ & $\begin{array}{c}\text { Чешский } \\
\text { эквивалент } \\
\text { (Czech) }\end{array}$ \\
\hline 2 & 50,0 & bita śmietana & šlehačku \\
\hline 1 & 25,0 & Bita śmietana & Šlehačka \\
\hline 1 & 25,0 & bita śmietana & šlehačka \\
\hline
\end{tabular}

Как видно из приведенной таблицы, процентная доля предлагаемых эквивалентов распределяется равномерно. В то время как филолог сразу будет догадываться, что первой транслят представляет собой винительный падеж слова šlehačka, то для тех, кому не вполне знакомы грамматические правила склонений слов, нужно будет дополнительно проверить ту информацию, чтобы выбрать правильный эквивалент. Помимо этого, у некоторых еще может вызвать сомнения 
тот факт, что многолексемная польская единица имеет однословный эквивалент в чешском языке. Не проверяя в словарях адекватности предлагаемого программой перевода, попытаемся найти русский эквивалент при использовании лексемы šlehačka.

Таблица 4. Treq для запроса šlehačka.

\begin{tabular}{|c|c|c|c|}
\hline $\begin{array}{c}\text { Число вхождений } \\
\text { (Frequency) }\end{array}$ & $\begin{array}{c}\text { Процентная доля } \\
\text { (Proportion) }\end{array}$ & $\begin{array}{c}\text { Чешский } \\
\text { транслянд } \\
\text { (Czech) }\end{array}$ & $\begin{array}{c}\text { Русский } \\
\text { эквивалент } \\
\text { (Russian) }\end{array}$ \\
\hline 1 & 33,3 & Šlehačka & Сливки \\
\hline 1 & 33,3 & Šlehačka & Взбитые сливки \\
\hline 1 & 33,3 & šlehačka & $\begin{array}{c}\text { Клочья сливок } \\
\text { заляпали }\end{array}$ \\
\hline
\end{tabular}

Такие результаты запроса заставляют пользователя проверить возможные эквиваленты в достоверных словарных источниках, потому что обнаруженные программой переводы обладают той же частотностью выступления в корпусных текстах. Такая ситуация нередко делает невозможным сразу выбрать адекватный перевод. В упомянутом уже словаре Г.В. Ковалевой имеется информация, что в качестве эквивалента для многолексемной единицы bita śmietana применяется русский перевод взбитые сливки. Данный пример доказал, что программе в конечном итоге удалось найти подходящий эквивалент, однако необходима предварительная проверка возможных транслятов в бумажных и электронных словарях. Чтобы полезность программы не подвергалась дальнейшим сомнениям, необходимо еще проверить, как Treq устанавливает эквиваленты для определенных фразеологизмов, часто употребляемых в повседневной речи. Наша цель - установить русский эквивалент распространенного польского фразеологизма butka z mastem 'разг. что-то очень простое для исполнения'. Электронный словарь «GLOSBE», в котором есть возможность ввести многолексемный запрос, в качестве чешского эквивалента рекомендует употребление слова hračka вместе со вспомогательным глаголом быть (напр. Byla to hračka) или без него (напр. úplná hračka). В свою очередь, для русского языка предлагаются три эквивалента: 1. проще пареной репь; 2. раз плюнуть; 3. как два пальца обоссать, которые несомненно сильно отличаются друг от друга разными стилистическими оттенками: проще пареной репь принадлежит к разговорной речи, раз плюнуть к просторечию, а фразеологизм как два пальца обоссать считается вульгаризмом. После проверки возможных переводов обратимся к программе с целью установления верного русского транслята посредством чешского перевода: 
Таблица 5. Treq для запроса butka z mastem.

\begin{tabular}{|c|c|c|c|}
\hline $\begin{array}{c}\text { Число вхождений } \\
\text { (Frequency) }\end{array}$ & $\begin{array}{c}\text { Процентная доля } \\
\text { (Proportion) }\end{array}$ & $\begin{array}{c}\text { Польский } \\
\text { транслянд } \\
\text { (Polish) }\end{array}$ & $\begin{array}{c}\text { Чешский } \\
\text { эквивалент } \\
\text { (Сzech) }\end{array}$ \\
\hline 13 & 15,7 & Bułka z masłem & hračka \\
\hline 5 & 6,0 & Bułka z masłem & Je to hračka \\
\hline 5 & 6,0 & Bułka z masłem & Hračka \\
\hline 4 & 4,8 & Bułka z masłem & Byla to hračka \\
\hline 4 & 4,8 & bułka z masłem & hračka \\
\hline
\end{tabular}

Дополнительная проверка отдельных вхождений позволяет доказать, что эквивалентом польского фразеологизма является употребление слова hračka с разными формами вспомогательного глагола, к примеру: A jak u Ciebie? - Butka z mastem. I A co ty? - Opravdu to byla hračka. Сравнивая указанные результаты поиска и найденный в электронном словаре чешский эквивалент, можно прийти к выводу, что Treq безусловно предлагает пользователю правильный транслят. Последним этапом нашей работы будет установление подходящего русского перевода при использовании чешского выражения Je to hračka.

Таблица 6. Treq для запроса Je to hračka.

\begin{tabular}{|c|c|c|c|}
\hline $\begin{array}{c}\text { Число вхождений } \\
\text { (Frequency) }\end{array}$ & $\begin{array}{c}\text { Процентная доля } \\
\text { (Proportion) }\end{array}$ & $\begin{array}{c}\text { Чешский } \\
\text { транслянд } \\
\text { (Сzech) }\end{array}$ & $\begin{array}{c}\text { Русский } \\
\text { эквивалент } \\
\text { (Russian) }\end{array}$ \\
\hline 1 & 16,7 & Je to hračka & Проще простого \\
\hline 1 & 16,7 & Je to hračka & пофиг \\
\hline 1 & 16,7 & Je to hračka & Кусок торта \\
\hline 1 & 16,7 & Je to hračka & Проще \\
\hline 1 & 16,7 & Je to hračka & Легко \\
\hline
\end{tabular}

В данном случае уже на первый план выдвигаются проблемы, связанные не только с небольшим числом выступлений указанных единиц в корпусе, а также с тем, что они никаким образом не совпадают с ранее отмеченными возможными переводами. С целью решения данного вопроса мы прибегли к НКРЯ, чтобы проверить частотность употребления каждого предлагаемого программой и словарем транслята. К нашему удивлению оказалось, что самым распространенным русским выражением для определения чего-то очень простого является первый эквивалент из программы Treq, т.е. Проще простого (246 вхождений). Интересно получилось, что одинаковое число вхождений всех транслятов и их малое количество не показались препятствием для инструмента, который все-таки зафиксировал наиболее подходящий перевод. Однако 
недостатком в этом случае может быть тот факт, что программа не предложила перевода выражения butka z mastem в его буквальном значении (вид пищи).

На фоне проведенного анализа выбранных нами слов можно подытожить, что приложение Treq лучше применяется при поиске перевода однолексемных единиц исходного языка. Весь процесс осуществляется достаточно быстро и эффективно, а пользователь не должен обязательно обладать одним из трех языков интерфейса программы, чтобы найти нужный ему эквивалент. В подавляющем большинстве случаев инструмент предлагает достоверный перевод, но исследование контекстов их употребления только поможет убедиться в правильности эквивалента. Полезность программы Treq для польско-русского перевода - несомненна, о чем свидетельствуют указанные в статье примеры найденных транслатов и способы их поиска. Несложно решить разные переводческие задачи, благодаря обширному списку текстовых эквивалентов, которые делают Treq одним из самых достоверных электронных словарей.

Однако не следует забывать о том, что представленный корпусной материал содержит большое количество существенных ошибок, которые в первую очередь относятся к эквивалентам многолексемных единиц. В этом случае начинающий переводчик может извлечь из списка несоответствующий перевод, поэтому необходима высокая степень опытности пользователя, чтобы решить неоднозначные вопросы. Большие сомнения может вызывать и малое число вхождений, которое заставляет сделать детальное исследование предлагаемых транслятов, как получилось в случае проанализированного нами фразеологизма butka z mastem. Необходимо еще напомнить, что большая разница в числе доступных польских и русских коллекций значительно влияет на репрезентативность и достоверность полученных корпусных данных. Увеличение ресурсов InterCorp несомненно повысило бы вероятность выступления искомого эквивалента. Надеемся, что большой объем польского корпуса позволит в будущем включить тот язык в ряд доступных языков интерфейса программы Treq, благодаря чему процесс польско-русского перевода безусловно облегчится.

\section{Summary}

The purpose of this article is to present the Treq program and to describe how to use this electronic tool in the Polish-Russian translation process. The author shows the available functions of the program that make it easier to find the needed equivalent. The author provides information on the number of the collections included in the InterCorp corpus. In addition, the article contains specific examples illustrating the usage of the Treq 
application in the lexicography of the Polish-Czech and the Czech-Russian translations. The analysis of one-word and multi-word lexemes, as well as translation of phraseological expressions allowed us to draw concrete conclusions referring to the advantages and disadvantages of the application. The usefulness of the program in the process of the Polish-Russian translation is emphasized. At the same time the article shows the ways of avoiding the potential mistakes.

\section{Literatura}

Škrabal, M., Vavř́n, M. Databáze překladových ekvivalentů Treq. Časopis pro moderní filologii. 2017 (99), s. 245-260.

Charciarek, А. Программа для установления переводных эквивалентов Treq: преимущества и недостатки. Studia Rossica Posnaniensia. 2020 (45/1), с. 121132.

Vavř́n, M., Rosen, A. Treq. FF UK. Praha, 2015. Режим доступа: http://treq.korpus.cz. 


\section{LITERÁRNÍ VĚDA}

/ LITERATUROZNAWSTWO

/ ЛИТЕРАТУРОВЕДЕНИЕ 



\title{
MIASTOKSZTALTY - POEZJA KONKRETNA W PRZESTRZENI MIEJSKIEJ WROCŁAWIA NA PRZYKLADZIE REALIZACJI UTWORÓW STANISŁAWA DRÓŻDŻA
}

\author{
City-shapes - Concrete Poetry in Wroctaw Urban Space \\ on the Example of Implementation of Works by Stanisław Dróżdż
}

Keywords: Stanisław Dróżḋ, Barbara Kozłowska, concept-shapes, city-shapes, concrete poetry, palimpsest, loneliness

Contact: Anna Brzezińska-Winkiel, Uniwersytet Wrocławski, brzezinska.ann@gmail.com, anna.brzezinska@uwr.edu.pl; Anna Gańko,Uniwersytet Warszawski,anna.ganko@uw.edu.pl

\section{Wrocław - miasto konkretne}

Stanisław Dróżdż (1939-2009) to jeden z najbardziej rozpoznawalnych polskich poetów-konkretystów i teoretyków tego ruchu. Sam artysta był mocno związany z Wrocławiem, studiował na wrocławskiej polonistyce, gdzie obronił dyplom magisterski z poezji konkretnej. Zaczynał tworzyć już we wczesnych latach sześćdziesiątych XX w. zwracając się w stronę poezji lingwistycznej. W latach siedemdziesiątych rozwinął swój nowy projekt w ramach ruchu konkretystycznego poetycko-artystycznego nurtu łączącego w sobie obraz i słowo dzięki materialnej funkcji tekstu. Przyjaźnił się z Barbarą Kozłowską i Zbigniewem Makarewiczem. Prace Stanisława Dróżdża na stałe wpisały się we wrocławską biografię i geografię.

Tadeusz Sławek - związany z Wrocławiem literaturoznawca - słusznie pisze o tym mieście jako o pierwszym i głównym ośrodku poezji konkretnej w Polsce. Chodzi nie o cechy dystynktywne Wrocławia, ale o fakt, że jest to miejsce, które sprzyjało artystom bardziej niż inne. To tutaj działało najwięcej konkretystów: Barbara Kozłowska, Marianna Bocian, Marzenna Kosińska i Michał Bieganowski. Wrocław, jako miasto gospodarowane od nowa po drugiej wojnie światowej, wskutek przesiedleń na ziemie zachodnie i napływania ludności z różnych części kraju stało się w jakiś sposób egalitarne - każdy był w nim przybyszem, cechował go swego rodzaju dystans 
do tego miejsca, nie był powiązany z tym obszarem historycznie, kulturowo czy językowo. Postawa dystansu w miejsce utożsamienia się jest zgodna z przesłaniem poezji konkretnej, zarówno tej funkcjonującej na papierze, jak i w przestrzeni (Sławek 1989: 92). Warto także zaznaczyć, że Wrocław stał się w latach siedemdziesiątych i osiemdziesiątych przestrzenią dla wielu innych neoawangardowych, artystycznych czy społecznych akcji, między innymi działał tutaj Teatr Jerzego Grotowskiego, Grupa Luxus czy Pomarańczowa Alternatywa.

Ważnym wydarzeniem w artystycznej biografii Wrocławia było Sympozjum Plastyczne Wrocław '70 zorganizowane oficjalnie w związku z 25. rocznicą Powrotu Ziem Zachodnich i Północnych do Macierzy’. Podczas sympozjum od początku dominowały dwa wątki: sztuki konceptualnej oraz sztuki w przestrzeni publicznej. Jak zapowiadali organizatorzy, Sympozjum miało być „próbą konfrontacji różnych sposobów współczesnego myślenia plastycznego, mającego w konsekwencji doprowadzić do powstania w tkance miejskiej wybitnych dzieł sztuki" (Lisowski 2020: online).

W ramach sympozjum powstał szereg projektów artystycznych, z których tylko nieliczne udało się zrealizować. Jednym z nich była instalacja przestrzenna stworzona przez Barbarę Kozłowską na podstawie wiersza Stanisława Dróżdża pt. Samotność, który pojawił się w przestrzeni miejskiej w nieco zmienionej niż oryginalna formie dopiero w 2016 roku w ramach projektu Ścieżki tekstu realizowanego we Wrocławiu w ramach działań Europejskiej Stolicy Kultury. Inicjatywa miała na celu przeniesienie prac Dróżdża do przestrzeni publicznej; powstały murale (optimum, Zapominanie, Czasoprzestrzennie), na nośnikach reklamowych na przystankach linii tramwajowej nr 33 zostały powieszone plakaty z wierszami Stanisława Dróżdża z tomu pt. Pozasłowne śródsłów międzysłowia, niepublikowanego wcześniej, a wydanego właśnie w ramach Ścieżek tekstu. Do tej książki dodawany był przewodnik z mapą Wrocławia, która ujęła wszystkie ślady poezji konkretnej w przestrzeni miejskiej (Dawidek 2016: online).

Ścieżki tekstu nie były jednak pierwszą taką inicjatywą w mieście, a stały się raczej kontynuacją i rozbudowaniem idei, które podjęto jeszcze przed rokiem 2016. Na pl. Nowy Targ umieszczono instalację trójwymiarową Stanisława Dróżdża pt. Koło złożoną z 16 betonowych kwadratów, na każdym z nich widnieje właśnie napis KOŁO. Muzeum Współczesne we Wrocławiu na pl. Strzegomskim, które mieści się w budynku dawnego schronu, na swojej elewacji ma namalowany wiersz konkretny pt. Klepsydra (wrocławianie kojarzą go jako Było-Jest-Będzie). W muzeum tym można odwiedzić stałą wystawę prac Dróżdża. 
Dzisiejszy Wrocław staje się więc przestrzenią wielowymiarową. Na jego mapę nakładają się murale i instalacje przekładające poezję z papieru do rzeczywistego świata. Spełnia się to, o czym Sławek pisał w Między literami, mianowicie myślenie geograficzne nie odnosi się tylko do przestrzeni, ale szerzej - przede wszystkim do osobistej „geografii wewnętrznej”: miejsc mojego działania, które wyznacza horyzont mojego myślenia, świadomości artystycznej i estetycznej (Sławek 1989: 89). Umiejscowienie utworów poezji konkretnej Stanisława Dróżdża to kolejny metapoziom tej refleksji ponieważ „geografia wewnętrzna”, ścieżki myślenia i rozwoju artysty, nie są pozbawione kontekstu, którym jest samo miasto, co w sposób rzeczywisty przekłada się do przestrzeni dostępnej wszystkim mieszkańcom Wrocławia. Dzięki temu poeta uobecnia się nie tylko w otoczeniu, ale w świadomości przechodniów. Poezja konkretna staje się miejscem dzięki praktykom użytkowników, którzy ją konkretyzują oraz odnoszą do swojego miejsca w świecie, a dzięki formie murali i instalacji staje się jeszcze szerzej dostępna.

\section{Pojęcioksztalty i Miastoksztalty}

Poezja konkretna - zwracająca uwagę na materialność słowa będącego tworzywem poezji - polega na przywróceniu słowu jego pierwotnego znaczenia, wyłączenia z kontekstów, zautonomizowaniu i nadaniu mu takiej postaci, w której zintegruje się treść i forma. Stanisław Dróżdż dla wytworów poezji konkretnej opracował określenie - „pojęciokształty”. Jak wskazuje sam poeta są one „materializacją języka i myślenia; podkreślona tu zostaje materialność tych obszarów pojęć. Chodzi tu o integralność języka. Kształty pojęć jak sama nazwa wskazuje, integralne myślowo-tekstowowizualnie-przestrzennie" (Dróżdż 2007: online). Termin ten oznacza utwór, który integruje w sobie nie tylko tekst i znak wizualny, ale często i matematyczny. Pojęciokształt łączy w sobie poezję, logikę oraz sztuki wizualne, chociaż sam istnieje na pograniczu tych dziedzin. Dróżdż w swoich pojęciokształtach operował dodatkowo znakami interpunkcyjnymi oraz brakiem (spacją, pustą przestrzenią kartki, przerwami, dystansem). Poezja konkretna ma na celu ukazać odbiorcy konkret autora (znak tekstowy oraz znak wizualny powinny nawzajem się uzupełniać), skracając w ten sposób proces percepcyjny, wymykając się niejednoznacznościom interpretacji. W tym kontekście najważniejsza stała się dla Dróżdża autentyczność, inkluzywność, minimalizm (Dróżdż 1969: online).

Dróżdż zawsze stanowczo twierdził, że jego sztuka jest poezją a nie sztuką wizualną. Podstawą jego twórczości jest język a cały proces obcowania z jego utworami opiera się na semantyce, chodzi o sensy zawarte w słowach realizujące się w wizualnych 
aranżacjach. Nie czysta estetyka, a znaczenie odgrywa tu pierwszorzędna rolę. W rozmowie z Małgorzatą Dawidek Gryglicką stanowczo jej poleca: „Musi Pani wyraźnie zaznaczyć w swoim tekście, że Dróżdż powiada, że nie ma nic wspólnego ze sztuką, tylko z poezją" (Dróżdż 2009: online).

Jak pisze Elżbieta Łubowicz, ,prace Stanisława Dróżdża ze swojej zasady zbudowane są z dwóch nieoddzielnych od siebie wzajemnie aspektów: językowego i wizualnego. Koncepcja pracy musi zakładać od razu oba te aspekty - wynika to z istoty zasady poezji konkretnej, jaką przyjął Dróżdż. Językowy materiał pracy (który zawsze jest pierwotny) zostaje wyjęty z kontekstu reguł języka i wstawiony w nowy kontekst wizualny" (Łubowicz 2009: online).

Umieszczenie tak rozumianych pojęciokształów w przestrzeni miejskiej dodaje trzeci: przestrzenny i zarazem społeczny aspekt całej koncepcji. Stąd tytuł naszego projektu: „miastokształty” - chciałyśmy zwrócić uwagę na to, jak opracowywane przez Dróżdża pojęcia konkretyzują się w przestrzeni miasta.

Zanim poezja konkretna przeniosła się na ściany kamienic, już na papierze utożsamiano ją z miejscem. Tadeusz Sławek stwierdził: „Poezja to miejsce” (Sławek 1989: 95), a myśl ta realizuje się w kolejnych trzech aspektach: 1. jako lokalność miejsca, sprzężenie historii i geografii, 2. jako świadomość cielesna artysty oraz 3. jako lokalność gestu artysty, odkrywania semantyki danego znaku poprzez jego uwarunkowania geograficzne. Poezja konkretna prowadzi od słowa do rzeczywistości, przeobraża słowa w rzecz. Proces ten jest więc warunkowany przez geografie w skali mikro - artysty, uczestników i samego miasta (Sławek 1989: 95).

\section{Palimpsest}

Jakiś czas temu w humanistyce karierę zrobiło porównanie miasta do palimpsestu. Oryginalnie palimpsest to ponownie zapisany kawałek papieru. To, co było zapisane na nim wcześniej, zostaje wymazane po to, żeby można było napisać na nim coś nowego. Ta metafora została spopularyzowana głównie przez tekst Jeffreya Kroesslera (2015), który zwraca uwagę na to, że miasto składa się z czasowo nakładających się na siebie warstw i stale się zmienia.

Umieszczenie murali na ścianach budynków z jednej strony wykorzystuje tę zmianę - uwidacznia ślepe ściany kamienic odsłonięte przez zmianę układu urbanistycznego a zdrugiej strony jest swego rodzaju zapiskiem na marginesie korzysta $\mathrm{z}$ pozornie niefunkcjonalnych przestrzeni przekształcając je w przestrzeń artystycznego wyrazu. W niektórych realizacjach - jak w przypadku wierszy Samotność 
i Koło - poezja zyskuje bardzo konkretny materialny wymiar. Tym samym poezja staje się częścią miejskiego środowiska i zyskuje całkiem nowe konteksty odczytywania.

Sam Dróźdż mówiąc o języku stwierdza, że opiera się on na wyborze odpowiednich części i kombinowaniu z nich całości - to „kombinatoryka prawideł” mówi. Wskazuje: „Język jest grą, ale nie w potocznym tego słowa znaczeniu, jak gra w brydża, czy w pokera, czy w szachy, albo w siatkówkę. W grze, proszę Pani, nie ma żartów. To jest rosyjska ruletka" (Dróżdż 2009: online).

Tak rozumiana gra bliska jest grze językowej takiej, jak rozumie ją Wittgenstein (1972). Jest to gra, która polega na kombinowaniu ze sobą poszczególnych elementów, jednak, co najważniejsze, nie ma w niej z góry ustalonych zasad. Reguły tej gry tworzą się na bieżąco - już w trakcie gry. Nie ma kogoś, kto ustala zasady i czuwa nad ich przestrzeganiem. Wytwarzają się one $\mathrm{w}$ interakcji pomiędzy uczestnikami i ewoluują $\mathrm{w}$ trakcie. Takie gry językowe wyjęte $\mathrm{z}$ wyłącznie semantycznego kontekstu i przeniesione $\mathrm{w}$ rzeczywistość ludzkich działań przyjmują formę praktyk, które uwzględniając kreatywność działających osób podlegają jednocześnie pewnym społecznym ramom. Literacki utwór wpisany w przestrzeń miejską wkracza jednocześnie w nurt miejskiego życia stając się zarazem jednym z jego elementów.

To oznacza, że miasto-palimpsest, o którym była mowa wcześniej, tym różni się od palimpsestu-papieru, ze nie jest dane wyłącznie do czytania, ale do działania w nim. Interpretacja wiersza w przestrzeni miejskiej nie polega wyłącznie na przywoływaniu w umyśle znaczeń, ale opiera się przede wszystkim na sposobach interakcji z przestrzenią, w której umieszczony jest wiersz.

Poezja konkretna staje się więc szczególną formą artystycznego wyrazu, ponieważ angażuje odbiorcę niezależnie od tego, czy przyjmuje postać pojęcio- czy miastokształtu. Jej potencjał do odczytywania jej jako przestrzeni, płaszczyzny lub integracji przestrzeni i płaszczyzny, co omówimy poniżej na przykładzie utworu Samotność.

\section{Samotność}

Utwór Samotność Stanisława Dróżdża składa się z cyfr jedynek (1), które stoją w równych odstępach, oddzielone są od siebie spacją (brakiem), nie dobiegają do krawędzi strony, ale wychodzą poza kartę. Nie wiemy, czy to, na co patrzymy jest środkiem utworu, jego krańcem czy może wylewa się on dalej w przestrzeń, czy mówimy o jakiejś nieskończonej ilości jedynek, zbiorze liczb 1, 11 a może 111, czy po prostu o cyfrach stojących $\mathrm{w}$ równych odstępach? Przyjmując, że są to jedynki 
ustawione obok siebie, dzięki zabiegowi „wychodzenia” ich poza stronę, mamy wrażenie, że chodzi o pewien nieskończony zbiór.

Pojęciokształty matematyczne Dróżdża uderzają swoją prostotą po to, aby za chwilę się skomplikować w procesie interpretacji. Teksty są jasne, ascetyczne, monotonne w doborze znaków, ale poprzez doświadczanie ich i praktykowanie, paradoksalnie stają się skomplikowane, ponieważ zestawiane są z doświadczeniem. W zamierzeniu poezji konkretnej to właśnie praktyka i doświadczenie mają decydować o interpretacji utworu, dlatego konkret uwidacznia się dzięki słowu, które jest kluczem - tytułowi utworu (Dawidek Gryglicka 2012: 158).

Dróżdż pracuje ze znakami, które przekładają się na postawę człowieka względem świata. Obcując z poezją konkretną czytelnik nie musi zastanawiać się nad sensem wiersza, jak to się dzieje w tradycyjnej poezji, ponieważ utwór konkretny uderza swoją jednoznacznością (Sławek 1989: 98). Odbiorca nie przejmuje uczuć i nastrojów artysty - są one niewidoczne, z tego powodu, że znak tekstowy i wizualny, sam się prezentuje i jest obiektywny - nie traktuje się go jako czyjejś wypowiedzi albo wyrazu osobistych przeżyć. W utworze konkretnym znak jest i mówi sam za siebie, sam się prezentuje, przez to podmiot liryczny jest właściwie niewidoczny.

\section{Interpretacja przestrzenna poezji strukturalnej Stanisława Dróżdża Samotność (1970)}

Barbara Kozłowska - jedna z najważniejszych wrocławskich artystek konceptualnych w ramach Sympozjum Plastycznego Wrocław '70 przygotowała projekt będący przestrzenną interpretacją omawianego utworu Dróżdża. Projekt pt. Jedynka składał się z 25 metalowych słupków o wymiarach: $50 \mathrm{~cm}$ x $10 \mathrm{~cm}$, x $10 \mathrm{~cm}$ ustawionych w równych szeregach (Dawidek Gryglicka 2012: 314). Projekt doczekał się realizacji dopiero w 2016 roku w ramach opisywanego wcześniej projektu Ścieżki tekstu. Samotność została umieszczona w parku Popowickim w postaci 45 betonowych bloków, stojących pionowo jedynek rozmiarem przewyższających dorosłego człowieka. Projekt jest w formie dwukrotnie wyższy i szerszy, niż w pierwotnym zamyśle artystki, inne jest także jego umiejscowienie. Należy pamiętać, że wrocławskie miastokształty są właściwie interpretacjami, ponieważ znalazły się w przestrzeni miejskiej po śmierci Dróżdża i Kozłowskiej i projektowane były w innych celach. Pojęciokształty możemy więc scharakteryzować jako autorskie; miastokształtom bliżej do reprodukcji.

Warto wspomnieć o tym, że sam Dróżdż eksperymentował wcześniej z przestrzenną formą wierszy. Przykładem może być wiersz Między zaprezentowany pierwszy raz w warszawskiej galerii Foksal w 1977 roku. Wiersz przybrał formę pokoju, 
w którym każda ze ścian pokryta była literami składającymi się na napis „między”. Co ważne, wyraz nigdzie nie pojawia się bezpośrednio - daje się odczytać, ale zawisa gdzieś pomiędzy literami, tak samo jak znajdujący się w pokoju odbiorca wiersza. Dróżdż sprawdza tutaj, na ile daje się naruszyć tożsamość jakiej rzeczy-pojęcia, żeby wciąż było zrozumiałe i rozpoznawalne. Jednocześnie wprowadza czytelnika do środku wiersza. Już nie tylko sens tekstu znajduje się „między” słowami, ale także sam odbiorca jest między nimi.

W ,papierowej” wersji Samotności Dróżdż niejako powtarza ten zabieg, ale w nieco inny sposób. Nie wprowadza czytelnika do środka, ale za to rozszerza pole samego tekstu. Jedynki, z których składa się wiersz wylewają się poza obręb kartki nie wiadomo, gdzie wiersz się zaczyna a gdzie kończy.

Widoczna tutaj interpretacja Samotności nie podąża za zastosowanym przez Dróżdża rozszerzeniem. Wiersz w tej wersji stanowi wyraźnie zarysowany kwadrat składający się $\mathrm{z}$ szeregu betonowych brył. Jednak wprowadzając tekst w miasto i nadając mu przestrzenną formę reprodukuje się poniekąd gest Dróżdża $\mathrm{z}$ wiersza Między - zaprasza czytelnika do środka.

Tym samym diametralnie zmienia się perspektywa. Jedynki na papierze siłą rzeczy widziane są $\mathrm{z}$ góry. Jedynki w mieście stoją na baczność i tylko w drodze konceptualizacji odtworzyć można ich ułożenie. Odbiorca dzieła nie patrzy na nie z lotu ptaka, ma dwie możliwości - patrzeć z dystansu, albo wejść do środka. Kozłowska przenosi tekst Dróżdża z poziomu mapy - zdystansowanego, uporządkowanego oglądu - na poziom ścieżki - doświadczenia i uczestnictwa. Pozycja odbiorcy wobec dzieła wydaje się kluczowa w tak skonstruowanej poezji. Tadeusz Sławek w „Zestawie pierwszej pomocy dla ofiary zderzenia z poezją konkretną (użyć w chwili zwątpienia)" pisze: „Nie przerażaj się tym, że to dzieło cię nie wciąga, nie urzeka, nie czaruje. Tak ma być: jego zadaniem nie jest wzbudzać twoje zainteresowanie (co go to może obchodzić?), lecz refleksję nad miejscem, które zajmujesz”' (Sławek 1989: 147).

Jednak pomiędzy tym, co wydarza się w Między i tym, co dzieje się w Samotności w parku Popowickim jest jeszcze jedna znacząca różnica. W obu przypadkach zaprasza się odbiorcę do środka utworu, jednak w drugim przypadku dzieło zostaje całkowicie wyjęte z wystawienniczego kontekstu. Gdyby nie tabliczka informująca o tym, czym jest instalacja i skąd wzięła się w parku, można byłoby ją uznać za jedno z urządzeń parkowych. Estetyka instalacji nie odbiega zbytnio od estetyki miejskiej siłowni na wolnym powietrzu i placu zabaw dla dzieci - bezpośrednio z nią sąsiadujących. Cechują się podobną kolorystyką opartą na barwach podstawowych a ich forma bazuje na prostych bryłach i geometrycznych kształtach. Takie usytuowanie wyjmuje dzieło 
z muzealnego kontekstu i pozbawia go typowego dla tradycyjnie traktowanego dzieła sztuki dystansu. Zachęca do tego, żeby do niego podejść i coś z nim robić.

$\mathrm{Na}$ instalacji w parku Popowickim można zauważyć niewielkie napisy pojawiające się na ścianach ,jedynek". Nie odnoszą się one bezpośrednio do samego dzieła i jego sensów, wynikają raczej z tego, do jakich działań skłania instalacja traktuje się jak jak inne urządzenia parkowe, które też są nośnikami tego rodzaju napisów. Niezależnie jednak od intencji ich autorów, takie ingerencje, przekształcając formę instalacji mogą dodawać do niej kolejnych znaczeń.

To pokazuje, że w ramach takiej realizacji, wiersz zyskuje konkretny wymiar również $\mathrm{w}$ innym sensie. Tekst $\mathrm{w}$ takiej formie przestaje też być reprodukowaną w różnych wersjach konfiguracją znaków a staje się unikatowym zespołem przedmiotów. Przedstawienie wiersza $\mathrm{w}$ formie instalacji i pozostawienie w przestrzeni publicznej sprawia, że relacja tekst-odbiorca przestaje być jednokierunkowa. Ten, kto czyta (postrzega) wiersz może nie tylko współtworzyć wywodzące się z niego sensy, ale też ingerować $\mathrm{w}$ jego formę. Ponadto ingerencje poszczególnych odbiorców kumulują się i mogą generować nowe sensy w interakcji ze sobą nawzajem.

Co więcej, samo działanie z instalacją (wobec niej, w niej), bez pozostawiania widocznych śladów, staje się też interpretacją wiersza. Dobrym przykładem jest mężczyzna z dwiema dziewczynkami, którzy wykorzystali instalację do zabawy w berka. Biegali między betonowymi ,jedynkami” próbując się wzajemnie dosięgnąć. Instalacja funkcjonuje tutaj jako labirynt, w którym można się ukryć. Dodaje to znaczeń do szeregów równo ustawionych jedynek, które, mimo że stoją razem, nigdy się ze sobą nie spotykają. W przestrzennej wersji wiersza same stają się przestrzenią, w której można się zgubić lub ukryć - albo paradoksalnie spotkać i spędzać razem czas. W ten sposób interpretacja wierszy, które stały się częścią miasta, nie polega na ich czytaniu (patrzeniu na nie), ale na działaniach z nimi związanych.

\section{Pandemia}

W realizacji Kozłowskiej wiersz konkretny zyskuje dodatkowy przestrzenny wymiar działa już nie tylko na płaszczyźnie, na którą można patrzeć i odczytywać jej znaczenia, ale staje się trójwymiarowym przedmiotem, z którym można wchodzić w fizyczne interakcje. Jednak dopiero umieszczenie $\mathrm{w}$ przestrzeni publicznej pozwoliło odczytywać go w szerszym - społecznym - kontekście.

Ucieleśniony wymiar interpretacji występujący w ramach projektów obecnych w przestrzeni publicznej odgrywa bardzo ważną rolę w społecznym kontekście 
funkcjonowania takich obiektów. To, w jaki sposób są traktowane - jak się z nimi postępuje - może być probierzem społecznej zmiany. Interpretacja tak rozumianych utworów odbywa się nie na poziomie idei a na poziomie dających się wprost zaobserwować praktyk codzienności.

$\mathrm{Na}$ wiosnę 2020 roku w pierwszej fali pandemii w sieci krążyły fotografie przedstawiające place zabaw i siłownie plenerowe zgodnie z obostrzeniami owinięte czarną folią na znak zakazu korzystania z nich. Urządzenia przeznaczone do aktywności fizycznej przekształciły się w geometryczne, nieużyteczne bryły w przestrzeni miejskiej.

Sytuacja, utrwalona na tych fotografiach, jest odwrotna do tej opisanej powyżej, dotyczącej instalacji w parku Popowickim. Plac zabaw i siłownie, których założeniem jest interakcja z nimi ze względu na sytuację epidemiczną stały się obiektem, którego nie można dotykać. W gruncie rzeczy stały się nośnikami znaczeń, które można odczytywać z dystansu - tak jak to ma miejsce w przypadku dzieł sztuki w galeriach lub eksponatów w muzeach. Puste, nie-dotykalne place zabaw stały się przede wszystkim nośnikami sensów związanych z zmianą społecznych aktywności w czasie pandemii.

Pandemia zmieniła też nasze sposoby obcowania ze sztuką, w szczególności tą związaną z przestrzeniami publicznymi. Znaczna część działań związanych z Sympozjum 70/20 - przedsięwzięcia związanego z obchodami rocznicy wspomnianego wcześniej Sympozjum Plastycznego Wrocław '70 - ze względu na sytuację epidemiczną musiała zostać przeniesiona do sieci: w tym również działania skupione wprost wokół instalacji Kozłowskiej znajdującej się w parku Popowickim.

Biorąc pod uwagę również takie konteksty można też przyjrzeć się funkcjonowaniu Samotności. Dzieło umieszczone w przestrzeni publicznej zostaje jednocześnie wprzęgnięte w mechanizmy, którymi ta przestrzeń się łączy: czasami są to długotrwałe lub tymczasowe regulacje prawne, czasami społecznie wytwarzane sensy.

Idąc tym tropem i przyglądając się Samotności zastanawiamy się, jakie znaczenie może zyskać ta instalacja w dobie pandemii. Najprostszą, najszybciej nasuwającą się interpretacją omawianego utworu jest, wypływająca z tytułu, samotność. Jedynki stoją w pewnych odstępach, nigdy się nie dotkną, w zależności od naszych doświadczeń możemy zadawać pytania na temat obcości w tłumie, osamotnienia w mieście, doświadczeń związanych z komunikacją międzyludzką, a w czasach współczesnych z pandemią Covid-19. Jedynki mogą być odzwierciedleniem tego, że każdy człowiek jest indywidualną jednostką, a jednak identycznie jesteśmy zintegrowani $w$ tej odmienności (Dawidek Gryglicka 2012: 158). W związku z tym głównymi tematami, do których prowadzą nas betonowe szeregi jedynek jest nasza relacja $\mathrm{z}$ drugim 
człowiekiem, czym jest solidarność międzyludzka czy komunikacja. W jaki sposób możemy być z innymi ludźmi. A w dobie pandemii - pytania na to, jak funkcjonujemy w pandemicznej rzeczywistości, to pytania o nasze doświadczenia i sposoby radzenia sobie z samotnością.

Takie rozumienie instalacji w przestrzeni publicznej, mimo że może wydawać się dalekie od poezji konkretnej prezentowanej przez Dróżdża, w gruncie rzeczy podąża tym samym tropem. Wychodząc od prostego znaku - w przypadku poezji jest to litera, liczba albo pusta przestrzeń - rozszerza namysł ku znacznie szerszym sensom generowanym przez proste znaki i konstytuującym się w napięciom między nimi. Podobnie wychodząc od konfiguracji betonowych bloków możemy dojść do refleksji na temat samotności w tłumie oraz konieczności i konsekwencji społecznego dystansu.

\section{Wnioski}

Wiersze konkretne umieszczone w przestrzeni miejskiej wrastają w miasto a miasto jako aktywna strona interakcji nadaje im nowe znaczenia. Poezja konkretna ma znaczny potencjał do traktowania swoich utworów jako przestrzeni i jako płaszczyzny. Konkretność poezji ukonkretnia się $\mathrm{W}$ materialności miejsca a praktykowanie przestrzeni miejskiej staje się jednocześnie interpretacją tekstu.

Projekt Ścieżki tekstu mapuje różne geografie: osobiste, literackie, rzeczywiste (biograficzne, instytucjonalne), które to stają się zderzeniem dwóch rzeczywistości: literackiej (artystycznej) z topografią miasta (Rybicka 2014: 45). Refleksją można objąć wiele czynników, które znajdują się między tymi dwoma zagadnieniami: doświadczenie, praktykę codzienną i kulturową czy geografie osobiste mieszkańców.

Poezja konkretna stając się częścią przestrzeni miejskiej zostaje wprzęgnięta w procesy, które tę przestrzeń kształtują. Wyjęta z kontekstu funkcjonowania sztuki staje się częścią codziennego doświadczenia i obszarem codziennego działania. Znaczenia, które generuje, stają się też wrażliwe na społeczne procesy zachodzące w mieście i formujące je jako przestrzeń życia i działania mieszkańców, przechodniów i turystów. W ten sposób Samotność Dróżdża po raz pierwszy opublikowana w 1969 roku a w 2016 roku jako przestrzenna instalacja umieszczona w miejskim parku przez to jak zmienia się sposób jej używania i zmienia się kontekst, w jakim funkcjonuje, może stać się opowieścią o współczesnym dam doświadczeniu pandemii w mieście. 


\section{Summary}

Concept-shapes is an original term developed by Stanisław Dróżdż - Wrocław concretist. City-shapes are those concept-shapes which placed in the urban space become part of it - they interact with the surroundings and generate new meanings based on the context of the place, its materiality and practices of the city dwellers. The concretness of poetry becomes concrete in materiality of the place and the practice of urban space becomes the interpretation of the text. The aim of the article is to analyze the functioning of the poem "Loneliness" by Stanisław Dróżdż in its original version and in the form of instalation created on the basis of a design by Barbara Kozłowska in the context of their functioning in Wrocław formed on the reflection on the citz as a palimpsest, consisting of the authrąs and usersą internal geography, as wełł as the place itself, practices and experiences of residents, the Covid-19 pandemic.

\section{Resumé}

Pojmotvary je autorský pojem opracovaný vratislavským konkrétistou Stanisławem Dróżdżem. Městotvary jsou ty pojmotvary, které byly umístěny v městském prostoru, a které se staly jeho součástí - vstupují do interakcí s prostředím, vytváří nové významy vznikající z kontextu místa, jeho materiální povahy a činnosti uživatelů. Konkret poezie je konkretizovaný v materialitě místa a praxi, což se stává zároveň interpretací textu. Cílem článku je rozbor verše Samotność (Samota) Stanisława Dróżdże a srovnání s uměleckou instalací provedenou na základě návrhu Barbary Kozłowské, a to $\mathrm{v}$ kontextech jejich uplatnění ve Vratislavi $\mathrm{s}$ přemýšlením nad městem jako palimpsestem složeným z vnitřní autorovy geografie, uživatelů tohoto místa, praxe a zkušenosti obyvatelů a pandemie Covid-19. 
Miastokształty - poezja konkretna w przestrzeni miejskiej Wrocławia na przykładzie realizacji utworów

\section{Fotografie}

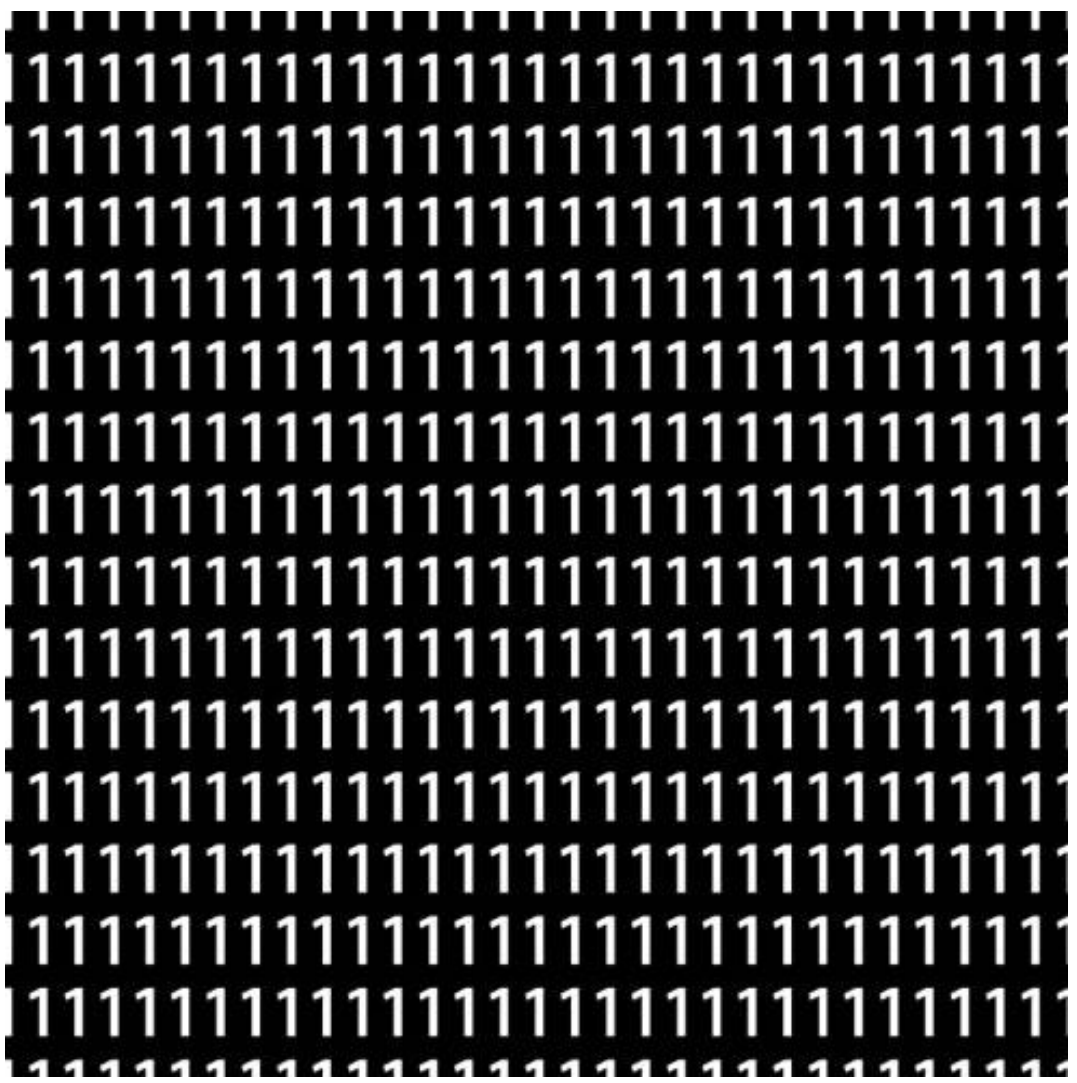

Stanisław Dróżdż, Samotność, 1967

(źródło: https://drozdz.art.pl/galeria-pojecioksztalty/)

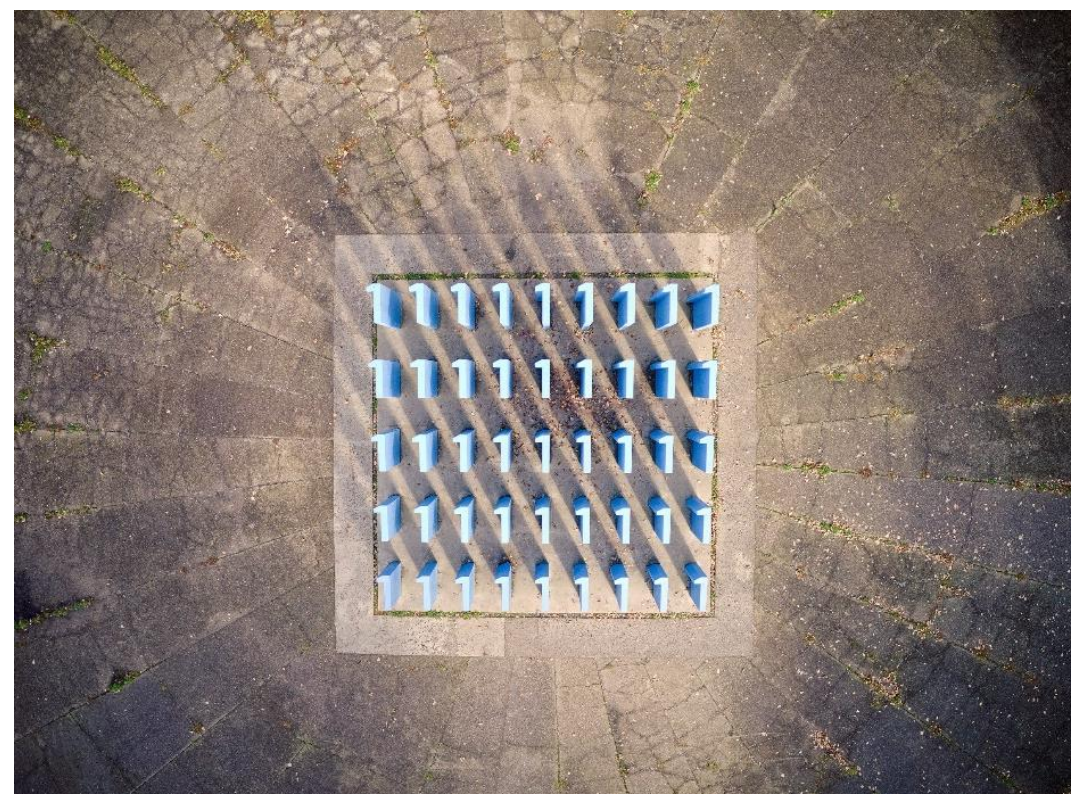

Interpretacja przestrzenna poezji strukturalnej Stanisława Dróżdża Samotność, 1970, zdjęcie lotnicze (źródło: https://fotopolska.eu/1477018,foto.html) 


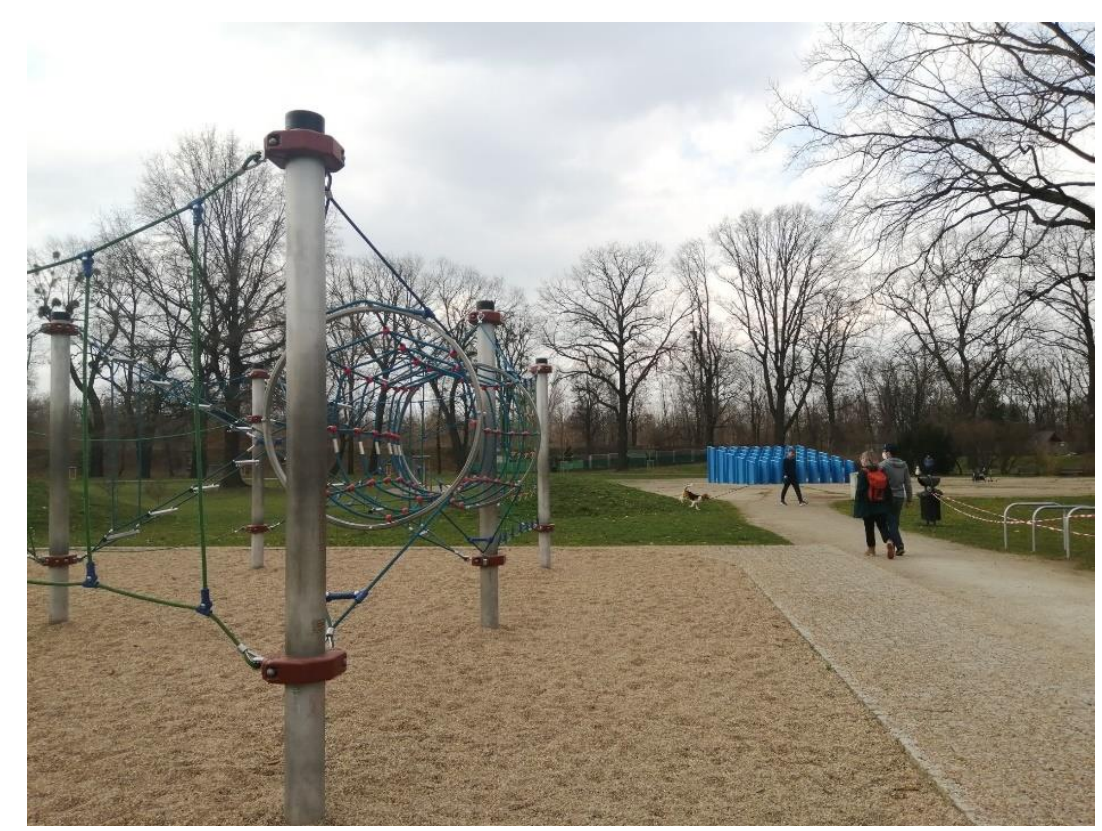

Samotność w parku Popowickim w otoczeniu innych urządzeń parkowych, fot. własna

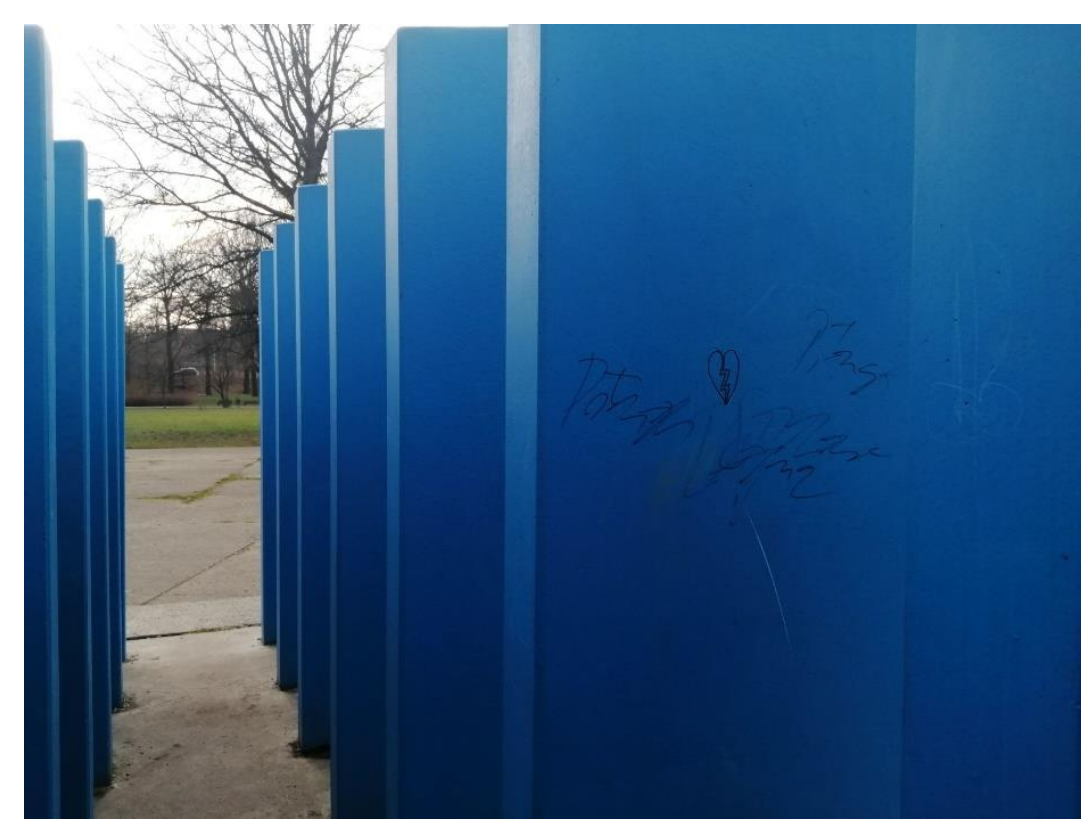

Napisy w Samotności, fot. własna 
Anna BRZEZIŃSKA-WINKIEL, Anna GAŃKO

Miastokształty - poezja konkretna w przestrzeni miejskiej Wrocławia na przykładzie realizacji utworów Stanisława Dróżdża

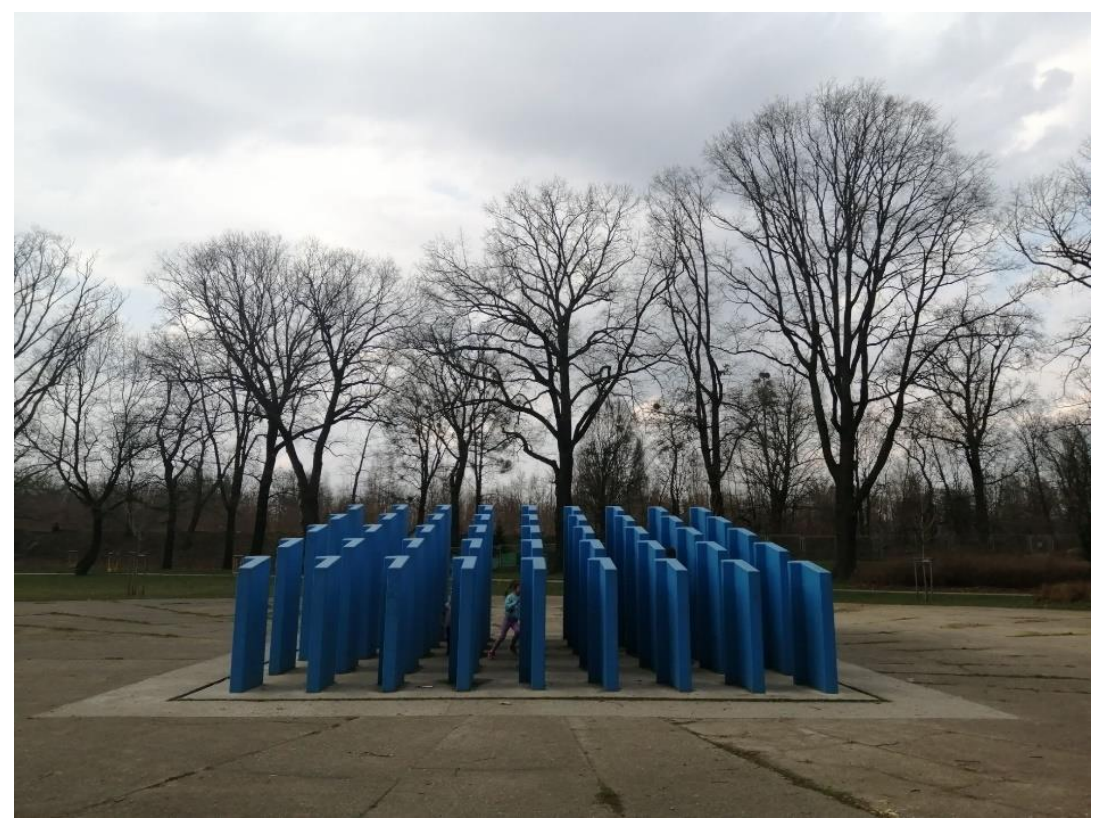

Samotność, gra w berka, fot. własna

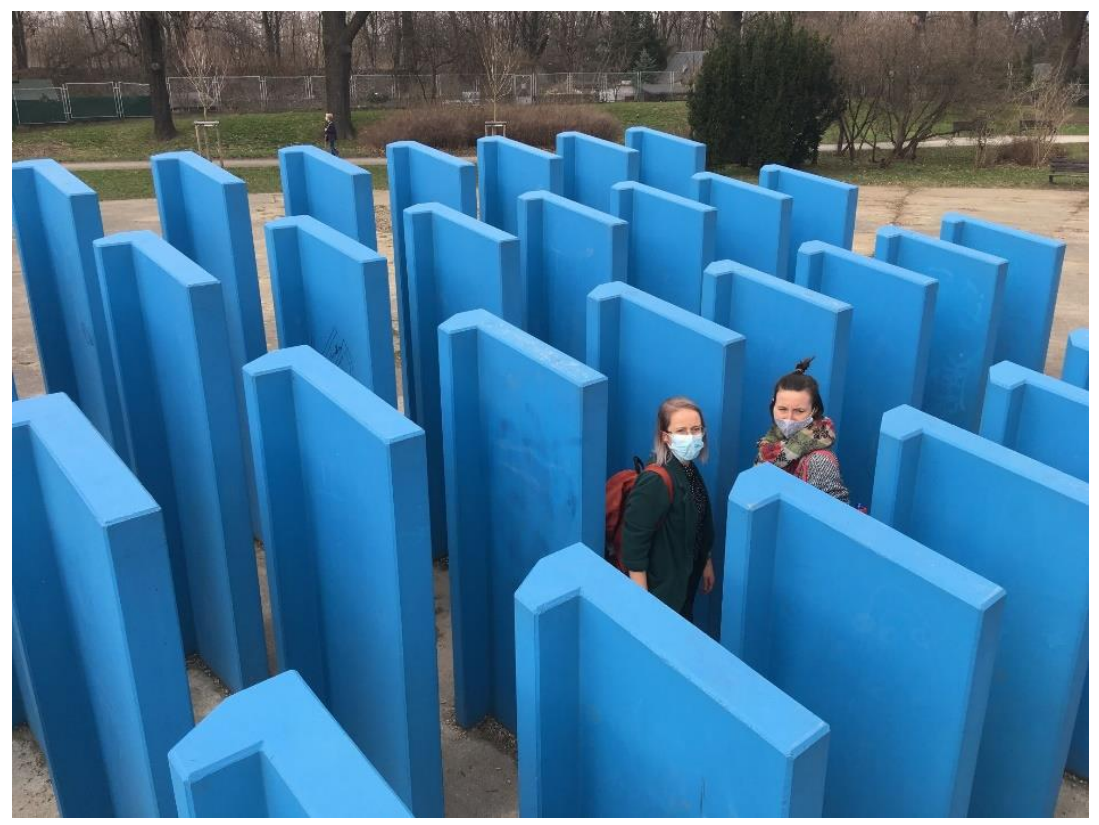

Samotność, labirynt, fot. własna 


\section{Literatura}

Dawidek, M. Ścieżki tekstu. Wrocław: Fundacja ART TRANSPARENT, 2016.

Dawidek Gryglicka, M. Historia tekstu wizualnego. Polska po 1967 roku. KrakówWrocław: Korporacja Ha!art, 2012.

Dróżdż, S. Fragmenty rozmowy, rozm. przepr. Małgorzata Dawidek Gryglicka. In: Stanisław Dróżḋ̇, początekoniec. Pojęciokształty. Poezja konkretna. Prace z lat 1967-2007. Wrocław: Ośrodek Kultury i Sztuki we Wrocławiu, 2009. Dostęp z: https://drozdz.art.pl/02050100-2/ (2021-04-18).

Dróżdż, S. Pojęciokształty. Odra. 1968 (12).

Dróżdż, S. rozm przepr. Jedliński, J. In: Dróżdż S., Język to gra (katalog wystawy), Poznań: Galeria Muzalewska, 2007. Dostęp z: https://drozdz.art.pl/02050300-2/ (2021-04-18).

Kroessler, J. A. The city as a Palimpsest, New York: CUNY Academic Works, 2015.

Lisowski, P. Sympozjum Plastyczne Wrocław '70 - historia. Dostęp z: https://www.sympozjum7020.pl/sympozjum-plastyczne-wroclaw-70-historia (2021-04-18).

Lubowicz, E. Stanisław Dróżdz. Pojęciokształty. Poezja konkretna. Prace z lat 19672007. Wrocław: Ośrodek Kultury i Sztuki we Wrocławiu, 2009.

Rybicka, E. Geopoetyka. Przestrzeń i miejsce we współczesnych teoriach i praktykach literackich. Kraków: Universitas, 2014.

Sławek, T. Między literami. Szkice o poezji konkretnej. Wrocław: Wyd. Dolnośląskie, 1989.

Wittgenstein, L. Dociekania filozoficzne. Przeł. B. Wolniewicz, Warszawa: PWN, 1972.

\section{Źródła elektroniczne:}

Dostęp z: https://drozdz.art.pl/galeria-pojecioksztalty/ (2021-04-18).

Dostęp z: https://fotopolska.eu/1477018,foto.html (2021-04-18). 



\section{FILM OTESÁNEK JANA ŠVANKMAJERA JAKO INTERTEKST}

\section{The Movie Otesánek by Jan Švankmajer as an Intertext}

Keywords: Jan Švankmajer, Otesánek, surrealism, archetypes, myths, psychoanalysis

Contact: Uniwersytet Wroctawski; brzezinska.ann@gmail.com,anna.brzezinska@uwr.edu.pl

\section{Wstęp}

„Pewnego poranka mężczyzna wykopał w lesie pieniek, który wyglądał jak małe dziecko. Wystarczyło tylko ociosać korzonki, żeby stworzyć rączki i nóżki” (Erben 1863, Švankmajer 2000) - tak zaczyna się opowieść o Otesánku, kawałku korzenia drzewa ożywionym dzięki pragnieniu rodziców o posiadaniu potomstwa. Opowiadanie to wywodzi się z ludowej tradycji, zostało spisane przez romantycznego poetę Karela Jaromíra Erbena w ramach jego etnograficznych badań przeprowadzonych wśród czeskiej ludności w XIX w. W roku 2000 Jan Švankmajer, czeski surrealista zajmujący się przede wszystkim filmem, zarówno długo, jak i krótkometrażowym, nakręcił adaptację tej opowieści, rozszerzając $\mathrm{w}$ ten sposób projekt swojej żony Evy Švankmajerovej, która wcześniej pracowała nad ilustracjami oraz animacją tej bajki. ${ }^{1}$

Bajka spisana przez Erbena opowiada o małżeństwie, które było zbyt biedne, aby mieć dzieci. Pewnego dnia mężczyzna znalazł w lesie pieniek, przypominający niemowlę. Przyniósł znalezisko do domu i podarował kobiecie, która to włożyła pieniek do kołyski, ten ożył i od razu zaczął domagać się jedzenia. Rodzice ustępowali mu we wszystkich zachciankach. Kiedy zjadł wszystko, co miał w zasięgu domostwa, rzucił się na swoich rodziców, dalej na sąsiadów. Za każdym razem wyliczając:

Jedl jsem - snědl jsem: kaši z rendlíka, krajáč mlíka, pecen chleba, mámu, tátu ... a tebe taky sním.

Jadłem - zjadłem: kaszę z rondelka, dzbanek mleka, bochen chleba, mamę, tatę... i ciebie też zjem! (Erben 1863: 118).

W końcu zechciał pożreć pewną babcię, która uprawiała pole kapusty. Ta była jednak szybsza i rozciachała motyką brzuch Otesánka. Wszyscy wyskoczyli z niego

\footnotetext{
${ }^{1}$ Schmitt, B., Leclerc, M. Chimery Jana Švankmajera (videozáznam na DVD). Francja, Czechy: 24images, TV 10 Angers, Canal 8 (Le Mans), 2001.
} 
i podziękowali babci za ratunek. Filmowa adaptacja Švankmajera ma fabułę rozbudowaną o kilka dodatkowych wątków, reżyser przeniósł akcję do współczesnych nam czasów, podstawowa historia pozostaje jednak taka sama. Najważniejszą dodaną postacią jest Alžbietka, mała sąsiadka głównych bohaterów Horáków (którzy są bezpłodni) - rodziców Otesánka. Ona jako jedyna rozumie bieg historii, a to dzięki lekturze książki Erbena, przez co wie, jak się skończy opowieść o Otesánku. Jej działania jako dziecka są bardziej dojrzałe niż samych dorosłych, a prowadzą do tego, aby uratować nieświadomego swego losu Otíka przed ostatecznym ciachnięciem motyki.

\section{Otesánek Švankmajera jako intertekst}

Film można rozpatrywać jako intertekst, szczególnie w szerszym rozumieniu tego terminu, zaproponowanym przez Ryszarda Nycza, gdzie intertekst pełni tutaj funkcję intersemiotyczną, włączając nie tylko literaturę, ale także pozadyskursywne media sztuki i komunikacji, jak film. W szerokim rozumieniu intertekstualności jako kategorii obejmującej aspekt ogółu własności i relacji tekstu Nycz wskazuje na uzależnienie jego wytwarzania i odbioru od znajomości innych tekstów oraz „architekstów” (reguł gatunkowych, norm stylistyczno-wypowiedzeniowych) przez uczestników procesu komunikacyjnego. Jego rozumienie zależy od tego, czy znamy inne teksty kultury oraz od naszych kompetencji kulturowych i dociekliwości. Sam tekst nie ukrywa swoich powiązań z innymi tekstami (Nycz 1993: 62). W przypadku omawianego filmu nawiązanie do opowieści ludowych jest oczywiste, podpowiedzią stają się sceny, podczas których Alžbietka czyta bogato ilustrowaną książkę - zbiór bajek Erbena, która zawiera opowieść Otesánek.

Film Švankmajera określić można jako intertekst, o licznych powiązaniach intertekstualnych, mających źródło w szczególności w literaturze. Celem artykułu jest ukazać sieć relacji zbudowaną przez artystę poprzez mity i archetypy z uwzględnieniem bajek magicznych i czeskich opowiadań ludowych (szczególne nawiązanie do dzieł Karela Jaromíra Erbena), psychoanalizy Zygmunta Freuda (obsesji, zróżnicowania kultura versus natura) oraz funkcji przedmiotów i obiektów znalezionych w kontekście poezji czeskiego surrealizmu.

\section{Archetypy w przekazach ludowych}

Švankmajer pracuje z tematem mitów i archetypów przekazywanymi w społeczeństwie przede wszystkim w formie bajek. Wydaje się, że Otesánek stworzony jest jako mozaika 
innych mitów, a jednak reżyser próbuje udowodnić, iż podanie to ma autonomiczne, odrębne korzenie. Švankmajer źródeł opowieści o ożywającym miłością matki pieńku upatrywał się nie w tradycji judeochrześcijańskiej, ale w mitach pierwotnych, animistycznych. Korzeń-dziecko, postać hybrydowa z granicy dwóch światów, które jest przyjęte przez ludzką rodzinę nawiązuje do nierozerwalnej więzi człowieka i natury oraz wiary w nadprzyrodzoną moc przyrody. Otesánek prowokuje odbiorców do zadawania sobie pytań o relacje ludzi z przyrodą, zwłaszcza w kontekście współczesnej cywilizacji oraz kryzysów klimatycznych i ekologicznych (Schmitt 2012: 383).

Odpowiedzi na pytanie o mit Otesánka mogą nam udzielić źródła dotyczące bajek i podań wywodzących się z tradycji słowiańskiej. Świat przedstawiony w filmie oraz ten z przekazów ustnych w ludowej tradycji jest dualistyczny i uproszczony, dzieli się na dobro i zło, dzień i noc, Boga i Diabła, świat ludzki oraz świat duchów. Otesánek Erbena należy do gatunku bajek magicznych, których fabuła jest z założenia wymyślona, w przeciwieństwie do mitów, legend i niektórych bajek ajtiologicznych (Niebrzegowska-Bartmińska 2018: online). Celem opowiadania jest odkrycie pewnych prawd ludowych lub przestroga, ukazanie problemów egzystencjalnych czy etycznych oraz odpowiedź na nie (Bettelheim 1985: 43). Za jedne z najważniejszych przesłań dydaktycznych w słowiańskich przekazach możemy uznać następujące: za czynienie zła spotka cię kara (jeśli nie za życia, to po śmierci); wszystko jest zdeterminowane przez los; wszystko co piękne, jest dobre, a co złe - brzydkie; niepełnosprawność, obcość, inność, choroba są karą; to co złego spotyka człowieka w życiu jest karą za grzechy; należy uważać, czego sobie człowiek życzy; słowo ma wielką moc sprawczą. W najbardziej znanym zbiorze ludowych opowieści Kytice, które Erben skomponował w formie ballad, przesłaniem, które występuje najczęściej, a można nawet powiedzieć, że tematycznie spina ten zbiór, są obowiązki kobiety jako matki. Zaniechanie tej roli nie tylko w sposób fizyczny (pozostawienie dziecka pod opieką innych osób), ale przede wszystkim symboliczny (wypowiedzenie pewnych słów - wyrzeknięcie się dziecka, przedłożenie potrzeb swoich) niesie skutki tragiczne, najczęściej jest to śmierć potomka, której nie można odwrócić w żaden sposób, choćby się modliło i błagało boga o litość. Ciekawą funkcję pełnią też $\mathrm{w}$ tych opowieściach kobiety starsze, które są matkami młodych matek czy dziewcząt wchodzących w dorosłość. Pełnią rolę doradczą, jednak kiedy ich pouczenia odzwierciedlają ich chciwy charakter lub egoistyczne pobudki to działanie zawsze obróci się przeciwko nim i ich córkom.

Morał wypływający z Otesánka dotyczy nie tylko roli rodziców w wychowaniu dziecka, w szczególności potrzebie mówienia „nie” zachłanności i łakomstwu najmłodszych, ale sięga głębiej, ponieważ mówi o pragnieniu rodziców i ich nieracjonalnej, niepohamowanej chciwości w kwestii posiadania potomstwa, a co za 
tym idzie, sprzeciwieniu się woli losu, co w opowiadaniach ludowych zawsze niesie najsurowsze konsekwencje. „Pewnego razu byli sobie kobieta i mężyczyzna i byli bardzo biedni. A mimo to ciągle mówili »gdybyśmy tylko mieli jakieś dziecko«" (Erben 1863: 117). Władimir Propp tworząc narzędzia do badania struktury bajki magicznej uwzględnił brak, jako główną motywację działań bohaterów. Filmowe małżeństwo Horáków jest wręcz zafiksowane na punkcie posiadania potomstwa, nie zważając na racjonalne argumenty są gotowi poświęcić wszystko i wszystkich (nawet siebie), żeby tylko spełnić swoje pragnienie (Marlicka-Robert 2013: 165).

Rodzice Otíka sprzeniewierzyli się fatum, chcieli zostać rodzicami wbrew naturze, za co spotyka ich kara: wszystkie działania, które podejmują, żeby wydostać się, z sytuacji tylko pogarszają ich położenie. Ich strategie rozwiązywania problemów krążą wokół półśrodków, żadne postanowienie nie narzuca Otíkowi zasad czy granic, nic nie uczy go funkcjonowania w społeczeństwie. Szczególnie Karel przedkłada swój status społeczny nad dobro dziecka - „co ludzie powiedzą”. W momencie, kiedy tracą kontrolę, pozbywają się problemu - chowają Otíka do skrzyni i zamykają w piwnicy, gdzie ten płacze z głodu. Racjonalizują sobie swoje postępowanie i zachowanie dziecka. Švankmajer w ten sposób komentował działanie rodziców:

Zdecydowanie Otesánek przedstawia coś, co nas przerasta, czego chętnie byśmy się pozbyli, albo chociaż kontrolowali, ale i coś, w czym trwamy, ponieważ jest to i nasze dzieło. Otesánek jest irracjonalną częścią naszego życia, którą na marne staramy się spacyfikować. I tak właśnie Otesánek ciągle nas pożera. Może jest to kara za popapraną cywilizację ( ̌̌vankmajer 2001: 199).

W szerszym kontekście mit o Otesánku dotyczy nas wszystkich. Dorośli ludzie, racjonalni, pragmatyczni, utracili swoje relacje $z$ naturą. Staje się ona dla nas niebezpieczna, zepchnięta na margines naszego życia i myślenia, nie potrafimy się z nią komunikować (Švankmajer 2001: 199-200). Švankmajer przekazuje swój własny morał poprzez film: jako społeczeństwo nie jesteśmy w stanie spacyfikować natury, a zamiast z nią walczyć powinniśmy ją uznać za ważną część naszego życia i zacząć ją szanować. Fraza Otesánka; „I ciebie też zjem”, którą jego ofiary usłyszą jako ostatnie swoje zdanie w życiu, jest wyzwaniem stawianym nam przez naturę, które staje się jednocześnie przestrogą.

Film Švankmajera ukazuje nam także ważną rolę komunikacji i jej jakości. Alžbietka jako jedyna bohaterka rozumie, dzięki wcześniejszej lekturze baśni Erbena, co dalej się wydarzy. Pełni funkcję narratorki całej opowieści (Marlicka-Robert 2013: 167). Chwilami rozumie, czym jest nieuchronność losu i nie działa przeciw niemu - 
kiedy trzeba nakarmić Otíka losuje krótką zapałkę, jako przepowiednię, kogo teraz rzucić na pożarcie zachłannemu dziecku. Ma jednak nadzieję i całą swoją energię wkłada w uratowanie Otíka, chociaż wie, że nie może się to udać - chowa motykę, próbuje odciągnąć babcię-sąsiadkę od ostatecznego rozprawienia się z ożywionym korzeniem. Działania obrazują jej niewinność, czystość intencji, ale także naiwność człowieka, który wierzy, że może kogoś ocalić przed nieuchronnym losem. Jednocześnie Alžbietka to jedyna osoba, która jest w stanie nawiązać porozumienie i zrozumieć Otesánka, a pieniek słucha się tylko jej; po części dlatego, że jako pierwsza wprowadziła kilka prostych zasad w jego życie: dziewczynka uczy go myć ręce przed posiłkiem, czekać spokojnie na jedzenie, przede wszystkim, że ona nie jest pożywieniem. Alžbietka odkrywa tajemnicę Otíka i staje się pośredniczką jego komunikacji: tłumaczy mu świat, jako jedyna akceptuje i rozumie to małe dziecko. Kiedy ojciec zamyka Otíka w skrzyni wyłącznie mała sąsiadka współczuje mu: „Biedaczku, ale masz rodziców! Zasługują na karę"2. Alžbietkę i Otíka łączy to, że są jedynymi dziećmi w sąsiedztwie, a co za tym idzie, tylko oni przejawiają przynależność do świata dziecięcego. Obydwoje działają na poziomie myślenia magicznego, nieracjonalnego, nawet podświadomego. Dziwne rzeczy dziejące się wokół dziewczynki nie są przez nią racjonalizowane tak jak przez dorosłych; ona przyjmuje je takimi, jakimi są.

Monika Marlicka-Robert opisała szczegółowo występujące w przekazie o Otesánku archetypy: Boženy Horák jako matki, Karela Horáka jako ojca oraz mity: o Adamie i Ewie, Golemie, Fauście. W micie o Adamie i Ewie rodzice stają się ofiarami zakazanego owocu: kiedy dostają to, czego pragnęli, okazuje się, że wcale nie spełnia to ich wyobrażenia o raju. Ponadto cierpią oni nie tylko osobno, ale i jako małżeństwo. Rozmawiają tylko o dziecku, ostatecznie wspólnie się mobilizują do jakiegoś działania, ale właściwie nic ich emocjonalnie ze sobą nie łączy. Podobnie jak w micie o Golemie i Fauście na rodziców Otíka spadła kara nie tylko dlatego, ponieważ sprzeciwili się woli fatum, ale także dlatego, że sprzeniewierzyli się prawu boskiej kreacji. Mężczyzna przyniósł pieniek z lasu, został odpowiedzialny za nadanie mu antropomorficznego kształtu, zaś kobieta dokonała cudu - ożywiła go swoją miłością. Kiedy Karel wchodzi do ich domu na działce widzi, jak Božena karmi Otíka piersią, akt ten jest obcowaniem z sacrum - nie bez powodu kobieta ubrana jest jak Matka Boska (Marlicka-Robert 2013: 167-168). Pyszny człowiek zapomniał jednak, że nie może równać się z bogiem, może być wytwórcą, ale nigdy stworzycielem, a więc jego dzieła będą przypominać człowieka, ale nigdy się nim nie staną. Horákowie dotkliwie to odczuwają. Ich dziecko właściwie nie jest dzieckiem. Nie należy ani do świata ludzi, ani też do natury, nie mogą

\footnotetext{
2 Švankmajer, J. Otesánek (videozáznam na DVD). Česko: Zeitgeist Films, 2000.
} 
go nikomu pokazać, muszą tuszować jego ludożercze akty, podporządkowują całe życie walce z obżarstwem Otíka. Kara jednak polega na tym, że im więcej energii wkładają $\mathrm{w}$ te działania, tym bardziej wszystko obraca się przeciwko nim. W końcu Otík zjada własnych rodziców, co przypomina poniekąd mit o Kronosie, a który jest przestrogą przed wysysaniem z rodziców energii życiowej (Marlicka-Robert 2013: 167-172). Na samym końcu filmu, kiedy Horák postanawia ostatecznie rozprawić z Otíkiem i schodzi z piłą mechaniczną do piwnicy, aby go porąbać, staje przed pieńkiem, po czym rzuca siekierę i woła: synu! Następnie zostaje zjedzony przez własne dziecko. W micie o Kronosie to ojciec, który spłodził syna odbiera mu życie (podobnie jak w biblijnej przypowieści o Abrahamie i Izaaku), jednak tutaj Horák nie jest prawowitym ojcem Otíka, ostatecznie więc życia nie może mu odebrać. Matka również zostaje zjedzona, co jest dla niej najwyższą formą poświęcenia.

Bajka Otesánek może być także nawiązaniem do jeszcze innej opowieści o Pinokiu. Te przekazy łączą dwa elementy: twory z ich wytwórcami nie wiążą więzy krwi oraz obaj bohaterowie pochodzą z tego samego materiału - drewna. W ludowych bajkach ajtiologicznych drzewo pełni dwie, zupełnie ambiwalentne funkcje. Jest jednocześnie nośnikiem życia, wigoru, ale może stać się pułapką posiadającą nadprzyrodzone siły, często śmiercionośną (Smyk 2018). Otík i Pinokio mają obydwie te właściwości: są żywi, ale z tym sobie nie radzą, przez co wpadają w pułapkę: chcą żyć, ale nie mogą zrobić tego po swojemu, muszą się podporządkować regułom społecznym, co jest sprzeczne z ich naturą. Ciało zarówno Pinokia i Otesánka zmienia się w sposób nienaturalny dla człowieka, kiedy czynią zło, ponieważ są w tej kwestii bardziej ludzcy, nie potrafią sobie poradzić z własnym ciałem.

Bajka o Otesánku jest właśnie poniekąd bajką etiologiczną w tym sensie, że tłumaczy, skąd się biorą ludzie z niepełnosprawnościami ruchowymi i umysłowymi. Świat ludowych opowieści jest bardzo dualistyczny: w mitologii słowiańskiej istnieje przekonanie, że bóg stworzył ciało człowieka na swoje podobieństwo, po czym zostało ono pokłute przez zazdrosnego diabła. Aby ich nie było widać, bóg wywinął rany do środka ciała, stąd wzięły się wszelkie choroby i ułomności (Zadurska 2018: online). Odstępstwa w kwestii wyglądu były uznawane więc jako kara z zaświatów, pokuta za zachowanie rodziców. Osoby z niepełnosprawnością były nieakceptowane przez środowisko, a nawet samych domowników. Uroda została zarezerwowana dla ludzi dobrych. Wszystkie odstępstwa od normy w kwestii wyglądu ciała oraz zachowania były wskazówką, że ktoś nie pochodził z świata ludzkiego lub posiadał podejrzany status ontologiczny. Inność i odmienność dzieci próbowano sobie racjonalizować przekonaniem, że zostały one podłożone przez dziwożony, kiedy nikt ich nie pilnował (Zadurska 2018: online). 


\section{Psychoanaliza a kwestia natury i kultury}

Badacze reprezentujący nurt psychoanalityczny wskazują, że ludowe opowieści odwołują się zarówno do ukrytych i jawnych sensów, do wszystkich warstw zarówno dorosłego, jak i dziecka. Poruszają problemy etyczne i podają odpowiedzi na nurtujące człowieka pytania lub tłumaczą mu świat (Bettelheim 1985: 43). Język symboliczny, który przekazuje znaczenia czy symbole jest podobny do języka mitów oraz snów (Fromm 1972 za: Niebrzegowska-Bartmińska 2018). Jako surrealista Jan Švankmajer często operuje właśnie pojęciami psychoanalizy.

W filmie Otesánek można zauważyć jasną granicę pomiędzy kulturą i naturą. Otík jest przykładem na to, jak kończą się próby wtłoczenia istoty pochodzącej od natury w kulturę. Przejawia się to głównie w ukazanym w filmie jedzeniu. Reżyser wielokrotnie prezentuje zbliżenia na sceny jedzenia, bohaterowie siorbią, ciumkają, ich obiady są najczęściej w formie płynnej (zupy, sosy) oraz nawiązują do czeskiej kultury (knedle). Jedzenie jest też okraszone wszelkimi rytuałami, takimi jak wspólne jedzenie przy stole, mycie rąk przed posiłkiem, posługiwanie się sztućcami, przekazywanie uwag dotyczących zachowania: jedz z zamkniętymi ustami, jedz pomału. Mały Otík jako jedyny ma przywilej jedzenia mięsa, przy czym na jego przynależność do natury wskazuje fakt, że nie musi wypełniać żadnych rytuałów. Jego posiłek ma zawsze makabryczną oprawę: krew tryska, a chłopiec rzuca wnętrzności o szybę.

Dla Švankmajera motyw jedzenia jest obecny w prawie wszystkich jego filmach. W wywiadach wspominał o swoich doświadczeniach z dzieciństwa, kiedy to wmuszane było w niego pożywienie. Później przez wiele lat nie mógł sobie z tym poradzić, a sztuka stała się dla niego formą autoterapii. ${ }^{3}$ Reżyser pokazuje poprzez Otesánka, że ludzie mają przeróżne obsesje i budują różne strategie radzenia sobie z nimi. Otík ma także inny przywilej, może traktować jedzenie, tak jak chce i jeść to, co chce, jest niezwiązany kulturowymi zasadami, co oddaje kolejny surrealistyczny postulat: wyzwolenie człowieka ze społecznych konwencji.

Film ukazuje dualistyczny świat ludowych przekazów oraz to, jak natura i kultura odwiecznie ścierają się ze sobą. To, że Otík należy do świata natury wiedzą doskonale jego rodzice, dlatego też ukrywają go przed światem ludzi i kultury. Horákowie są podzieleni, można powiedzieć stereotypowo, iż mężczyzna przedstawia kulturę (postawa „,co ludzie powiedzą”), kobieta naturę (kontra postawa „to jest nasze dziecko, musimy z nim być na dobre i złe"). Ojciec wielokrotnie dyscyplinuje matkę, o synu wypowiada się jako o czymś wstydliwym: „Jeśli ludzie się dowiedzą staniemy się

\footnotetext{
${ }^{3}$ Schmitt, B., Leclerc, M. Chimery Jana Švankmajera (videozáznam na DVD). Francja, Czechy: 24images, TV 10 Angers, Canal 8 (Le Mans), 2001.
} 
pośmiewiskiem", matka zawsze broni dziecka odwołując się do prawa natury i obowiązków rodzica. Kiedy ojciec mówi „Czemu cię posłuchałem, powinienem go porąbać.” matka odpowiada: „Proszę cię uspokój się. To nasze dziecko, musimy z nim być na dobre i na złe". ${ }^{4}$

Švankmajer odwołuje się także do jednych $\mathrm{z}$ kluczowych twierdzeń psychoanalizy, która ukazuje kulturę jako tłumiciela naturalnych popędów. Otík nieskrępowany kulturą, jako jedyna postać nie ogranicza się, niejednokrotnie przekraczając normę społeczną i zostając ludożercą (lub kanibalem zakładając, że według swoich rodziców jest dzieckiem i człowiekiem). Pozostali bohaterowie uwikłani są w siatkę kulturowych norm i przekonań tego, co wypada, dyscyplinują się nawzajem, ukrywają swoje pragnienia czy obsesje. Dlatego też, na pytanie: Kim jest Ociosanek? reżyser odpowiada:

Personifikacją natury, która nie ma żadnych zahamowań, która jest naszą miłością, przyjacielem i wrogiem? Czy jest to nasza mroczna podświadomość, która nas kontroluje i niszczy, i z którą mogą się komunikować tylko dzieci i szaleńcy? Możliwe, że tym i tym (Švankmajer 2001: 199).

Horákowie mają obsesję na punkcie posiadania potomstwa. W scenie otwierającej film widzimy Karela obserwującego sprzedaż uliczną ryb: karpie wykładane z balii wody na ladę, na której zmieniają się w niemowlaki, pakowane i gotowe do kupna przez wszystkich chętnych. Następnie, wracając od lekarza, który przekazał Horákom, że nie doczekają się potomstwa do domu prowadzący auto Karel wszędzie widzi wózki z małymi dziećmi.

Zachowanie Boženy i Karela to klasyczny przykład funkcjonowania mechanizmów obronnych, w szczególności wyparcia i racjonalizacji. Traktują Otíka jak człowieka, chociaż niewątpliwie nim nie jest. Budują strategie tuszowania aktów ludożerczych swojego syna w sposób absurdalny. Kiedy Otík zjada listonosza, matka wpada na plan i tak zwraca się do swojego męża: „Pozbieramy wszystkie listy i wieczorem, kiedy już się ściemni dostarczysz je wszystkie, i nikt się nie zorientuje, zobaczysz”. Kiedy żarłoczny korzeń pochłonął kota matka racjonalizuje: „Przecież to tylko zwierzę. I tak już miał z czternaście lat. A koty rzadko kiedy dożywają piętnastu!" ". Postać Karela jest szczególnie ciekawa, przez cały film jego podejście do syna rozwija się od negacji i niechęci do akceptacji i miłości. W ostateczności zgadza się na pożarcie przez własne dziecko.

\footnotetext{
${ }^{4}$ Švankmajer, J. Otesánek (videozáznam na DVD). Česko: Zeitgeist Films, 2000.

5 Švankmajer, J. Otesánek (videozáznam na DVD). Česko: Zeitgeist Films, 2000. 
Proces socjalizacji Alžbietki jest ukazany na przykładzie funkcjonowania tabu o seksualności człowieka. Kiedy się pyta mamy, o panią Horákową i o to, dlaczego nie ma w brzuchu dziecka, ta odpowiada, że dziewczynka nie powinna się tym interesować. Kiedy Alžbietka czyta książkę o seksualności i chce rozmawiać o tym z rodzicami, ci ją karcą. Co więcej, kiedy staje się obiektem pożądania pana Žlabka, starego pedofila, rodzice nie uważają tego za zagrożenie, co więcej znów pojawia się dyscyplinowanie dziecka, matka Alžbietki mówi: „Nie zmyślaj Alžbietko, on jest bardzo słaby, ledwo się trzyma na nogach biedaczek.”“ Sytuacja z czytaniem „nieodpowiednich rzeczy” przez dziewczynkę to przykład na to, jak bystre są dzieci oraz jak ich ciekawość świata jest „zabijana” przez normy społeczne. Alžbietka wykorzystując swoją wiedzę jako pierwsza domyśla się, że to, co Horákowa wyprowadza na spacer w wózku, to wcale nie jest niemowlę.

\section{Surrealizm - obiekt znaleziony}

O Švankmajerze trudno powiedzieć, że jest artystą, kiedy on sam wielokrotnie przyznawał, że właściwie traktuje surrealizm jako postawę względem życia, a pojęcie sztuki jest zbyt mało pojemne, aby zdefiniować całokształt działalności człowieka (Solař́k 2018: 44). Surrealizm to praca ze swoimi lękami, obsesjami, fetyszami, uświadomienie swoich pragnień, snów, poszukiwanie odpowiedzi na to, jakim jestem człowiekiem w okresie dzieciństwa. Właściwie wszystko to, co surrealizmowi przyniosły związki z psychoanalizą, opiera się na dialektyce doświadczenia przeszłości, a często nawet obsesji na jej punkcie. W tym przejawia się także koncepcja obiektów znalezionych, postulat surrealistów z czasów pomiędzy pierwszą a drugą wojną światową.

Postać Otesánka jest o tyle ciekawa w kontekście przedstawiania ciała w surrealizmie, że w czeskiej poezji z czasów międzywojnia, groza konfliktu zbrojnego wywołała u surrealistów głęboki kryzys postrzegania człowieka; dlatego w ich poezji, fotografiach i malarstwie zastępuje się człowieka przedmiotami, które na pierwszy rzut oka jego ciało przypominają: manekiny, odbicia w lustrze, kukły, lalki, złudzenia, obrazy (Vojvodík 2007: 50-53). Metamorfozy ciała stały się szczególnie obecnym środkiem wyrazu w estetyce kolażu. Co więcej, przedmioty te pełnią funkcję podmiotu, ożywają, stają się aktorami akcji w rzeczywistości ogarniętej absurdem wojny, migoczą pomiędzy byciem podmiotem a przedmiotem. W obecnych czasach Švankmajer mówi o innych kryzysach cywilizacyjnych: konsumpcjonizmie i kapitalizmie oraz wynikających z nich problemach, jak kondycja społeczeństwa, przerwanie więzi

\footnotetext{
${ }^{6}$ Švankmajer, J. Otesánek (videozáznam na DVD). Česko: Zeitgeist Films, 2000.
} 
człowieka z naturą (katastrofy ekologiczne), przemysł i nowe technologie, bezstresowe wychowanie.

Odpowiedzią na lęki wywołane współczesną sytuacją oraz pochodzące z osobistych doświadczeń człowieka jest przedmiot znaleziony (obiekt znaleziony). Jest to koncepcja, która konstytuowana jest poprzez dwie elementarne cechy: przedmiot przejmujący rolę podmiotu (cz. vnitřni model) oraz odchodzenie od realności na rzecz podświadomości i wyobraźni autora (cz. princip imaginace), co staje się elementarnymi właściwościami surrealistycznego eksperymentu (Kornhauser 2015: 12). Obiekty znalezione, jak sama nazwa wskazuje, są to (najczęściej) przedmioty, które zostały wybrane spośród innych rzeczy w celu umieszczenia ich w jakimś wytworze ludzkiej działalności, najczęściej artystycznej - w rzeźbach, instalacjach, filmach, ale także w poezji i malarstwie. Wybranym obiektom została nadana rola podmiotu, dzięki temu, że artysta utożsamił się z ich znaczeniem i na odwrót.

Można powiedzieć, że działanie z przedmiotami znalezionymi pełni poniekąd funkcje autoterapeutyczne, zwłaszcza kiedy surrealista tworzy pracując ze swoimi skojarzeniami, przeżyciami, snami i przekłada to na rzeczywiste wytwory traktując je jako surrealistyczne eksperymenty. Švankmajer tak wypowiadał się na temat obiektów znalezionych:

(...) jestem kolekcjonerem (uczuć), choć nie systematycznym. Z moich chaotycznych uczuć zbieram wrażenia, które odnajduję w konkretnych obiektach - dziełach sztuki, wytworach natury czy innych przypadkowo znalezionych. Te przedmioty nie są dla mnie martwymi artefaktami. $\mathrm{Z}$ radością powierzam im główne role swoich filmach (Hames 2008: 116 za: Maciejewska 2014: 119).

Ripostą Švankmajera na pytania o kondycję współczesnej cywilizacji są w obiekty, które dostają od niego drugie życie. Od lat sześćdziesiątych XX w. surrealista tworzy Kunkstkammerę, jest to projekt całożyciowy zakładający stworzenie osobistej encyklopedii składającej się z obiektów znalezionych lub przedmiotów-kolaży, przedmiotów-mozaik, które poddane recyklingowi tymi obiektami się stają. Praca z rekwizytami do filmów jest dla Švankmajera pracą z obiektem znalezionym:

Objaw twórczej metody Švankmajera uchwycił jeden z filmów dokumentalnych, który nakręcił artystę w momencie znalezienia korzenia, z którego następnie stworzył głównego bohatera swojej bajki-horroru Otesánek. Do momentu, kiedy go nie dotknęła ręka Švankmajera był to nieciekawy kawał drewna, jakich w lesie jest tysiące. Kiedy Švankmajer podniósł kawałek z ziemi, stała się z niego groźna marionetka z apetytem 
alchemicznego uniwersalnego rozpuszczalnika, która, jeśli nie zostałaby powstrzymana, pożarłaby cały świat (Purš 2012: 216).

Švankmajer jest nie tylko reżyserem, ale i rekwizytorem, podejmuje decyzje odnośnie występujących w jego filmach przedmiotów-aktorów. Sama technika poklatkowej animacji, dzięki której kukła Otíka ożywa, ma wartość dla artysty jako klasyczna, czasochłonna praca z materiałem. Metoda ta ma dać odbiorcy wrażenie, że jest to realistyczna opowieść, mogąca się przydarzyć każdemu z nas. Gdyby jej obraz był zbyt gładki i doskonały, mogłoby to dać oglądającemu odczucie, że jest to fantastyczny film, podczas gdy ma w nas budzić grozę. Švankmajer w swoich zasadach dotyczących pracy przy filmie jako jedną z nich wymienia: „Im dalej zmierzasz ku fantastycznej fabule, tym bardziej realistyczny musisz być w szczególe" (Švankmajer 2012: 462-463).

Ożywanie obiektów dzieje się nie tylko dzięki technice animacji poklatkowej, ale także dzięki powszechnemu przekonaniu dotyczącego tego, jak powinno wyglądać ciało człowieka. Otík wygląda jak dziecko, zachowuje się jak dziecko, ale ludzkim dzieckiem nie jest. Ma typowe dziecięce ruchy i zachowanie, kwili, płacze, ssie pierś matki, butelkę, płacze burczy mu w brzuchu, kiedy jest głodny, bawi się jedzeniem. Posiada zantropomorfizowany kształt: ma rączki i nóżki, pępek, buzię i nawet małego penisa. Zamiast palców u rączek ma małe gałązki, które mama mu podcina, tak jak dzieciom podcina się paznokcie. Posiada zęby (co jest nienaturalne dla niemowląt, ale podkreśla żarłoczność ożywionego korzenia) oraz jedno oko, które znajduje się w otworze gębowym. Rośnie w nienaturalnie szybkim tempie. Otík nie ma odbytu, ma tylko jeden otwór - gębowy. Gęba jest odpowiedzialna za jego istnienie i jest cechą konstytuującą Otíka. Nie ma więc też innej drogi, jest tylko jedna - do brzucha Otíka. Jego ciało jest worem, do którego można włożyć wszystko i dlatego pieniek cały czas rośnie i rośnie. Jedynym ratunkiem, i to tylko w bajce jest wyjście przez rozciachany brzuch. Końcowa scena w filmie sugeruje, że babcia z motyką zabija Otesánka, z jego brzucha jednak nikt nie wyjdzie, ponieważ wszyscy zostali rozszarpani przed trafieniem do środka Otíka lub strawieni w jego sokach żołądkowych.

\section{Wnioski}

Surrealistyczna estetyka posługuje się narzędziami psychoanalizy do pracy nad samym sobą przy pomocy obiektów znalezionych. Oglądając ten horror-bajkę, makabryczną w środkach wyrazu, odbiorca może zadać sobie pytania o własną postawę względem współczesnego świata, ale także wglądnąć w głąb siebie i odkryć to, co go pożera. Każdy ma swoje obsesje i lęki, przyjemności, które można sobie uświadomić. 
Švankmajer w filmie Otesánek ukazał uniwersalność pewnych przekonań ludowych funkcjonujących i pozostających $\mathrm{w}$ społeczeństwie za pomocą mitów i archetypów. Opowieść jest komentarzem do współczesnej cywilizacji, destrukcyjnych zachowań człowieka, szczególnie w sytuacji, kiedy brnie on w coś, z czego najchętniej by się uwolnił, nie ma jednak na tyle siły psychicznej, żeby podjąć działanie. Destrukcja jest także mocą Otíka, jest on w stanie unicestwiać kolejne byty bez szczególnych wyrzutów sumienia.

Oglądając ten film możemy zadać pytanie - komu współczujemy? W perspektywie posthumanistycznej, którą reprezentuje postać Alžbietki, współczuć powinniśmy Otíkowi, który został powołany do życia wbrew swojej woli, żyje w obcym mu środowisku, a jego zachowanie tłumaczy instynkt przetrwania. Jego inność rozumie właśnie mała sąsiadka, posiadająca niesamowite pokłady empatii i zrozumienia, których pozbawieni zostali wszyscy dorośli. Švankmajer poniekąd lawiruje z uczuciem empatii: kiedy Otík zjada starego erotomana, pana Žlabka, który narzucał się Alžbietce, czy nie odkrywamy lepszego świata bez kolejnego zagrożenia (wcześniej bagatelizowanego przez dorosłych) dla małej dziewczynki? Kiedy Otík zjada swoich rodziców trudno nie dostrzec pewnej sprawiedliwości - rodzice powołali dziecko do życia, a ono to życie zabrało im, życie za życie. Bruno Latour w Nigdy nie byliśmy nowocześni zauważył, że człowiek w swoich dążeniach chciał rozgraniczyć sferę natury i kultury, i przyporządkować się tej drugiej, podczas gdy nigdy tej pierwszej sfery nie opuścił. Społeczna rzeczywistość to dla Latoura kultura i natura w jednym. Co więcej, natury i kultury nie można w społecznym dyskursie oddzielić, ponieważ właściwie każde zagadnienie czy problem rozpatrywane są także pod kątem działania środowiska naturalnego, a nie tylko czynności człowieka. To właśnie nowe wyzwania stojące przed człowiekiem, szczególnie postęp technologiczny, prowokują do zadawania pytań o to, czy nie powinniśmy stworzyć nowej definicji słowa humanizm. Otík jest przykładem na to, że nieudolne działania rodziców spowodowane były przede wszystkim tym, że negowali jego inność. Posthumanizm mierzy się z kwestią innego, postuluje koegzystencję ludzi, zwierząt i roślin, zaakceptowanie praw przyrody jako równoważnych z ludzkimi (Zawojski 2017: 61). Być może właśnie to próbuje nam przekazać ten stary, animistyczny mit: szacunek i uznanie równości człowieka i przyrody.

\section{Summary}

The movie Little Otik (2000) by Jan Švankmajer can be described as an intertext, with numerous intertextual connections, rooted in particular in literature. The aim of the 
article is to present this network of relations built by the artist through myths and archetypes, including fairy tales and Czech folk tales (especially with references to the works of Karel Jaromír Erben), the psychoanalysis of Sigmund Freud (obsession, diversity, culture versus nature) and the functions of things and found objects in the context of poetry of Czech surrealism.

\section{Resumé}

Švankmajerův film Otesánek (2000) je možné popsat jako intertext s četnými intertextuálními souvislostmi, které zakořeněné jsou především v literatuře. Cílem článku je představit sít' vztahů, které umělec vybudoval prostřednictvím mýtů a archetypů, s přihlédnutím pohádek a českých lidových vyprávění (zvlášt' s odkazem na díla Karla Jaromíra Erbena), psychoanalýze Sigmunda Freuda (posedlost, rozmanitost, kultura versus př́roda) a funkce předmětů a nalezených objektů v kontextu poezie českého surrealismu.

\section{Literatura}

Bettelheim, B. Cudowne i pożyteczne. O znaczeniach $i$ wartościach baśni. T. 1-2. Warszawa: Państwowy Instytut Wydawniczy, 1985.

Erben, K. J. Sto prostonárodních pohádek a pověstí slovanských v nářečích původních. Praha, 1863-1865.

Fromm, E. Zapomniany język. Wstęp do rozumienia snów, baśni i mitów. Warszawa: Państwowy Instytut Wydawniczy, 1972.

Hames, P. Interview with Jan Švankmajer. In: Hames, P. (ed.) The Cinema of Jan Švankmajer: Dark Alchemy. Wallflower Press, 2008, s. 104-139.

Kornhauser, J. Całkowita rewolucja. Status przedmiotów w poezji surrealizmu. Kraków: Wydawnictwo Uniwersytetu Jagiellońskiego, 2015.

Latour, B. We have never been modern. Cambridge: Harvard University Press, 1993.

Maciejewska, M. Ludzkie marionetki w krwistym teatrze: mięso w filmach pełnometrażowych Jana. Švankmajera. Kultura Popularna. 2014 (4/42), s. 118127.

Marlicka-Robert, M. Okrutna bajka, czyli Otík Karela Jaromíra Erbena i Jana Švankmajera. In: Ciszewska, E., Nurczyńska-Fidelska, E. (eds.) Hrabal i inni. 
Adaptacje czeskiej literatury. Łódź: Wydawnictwo Uniwersytetu Łódzkiego. Wydawnictwo Biblioteki PWSFTviT, 2013, s. 159-173.

Niebrzegowska-Bartmińska, S. Bajka ludowa. In: Wróblewska, V. (ed.) Słownik polskiej bajki ludowej. T. 1-3. Toruń: Wydawnictwo Naukowe UMK, 2018. Dostęp z: https://bajka.umk.pl/slownik/lista-hasel/haslo/?id=218 (2021-04-30).

Nycz, R. Tekstowy świat. Poststrukturalizm a wiedza o literaturze. Warszawa: Instytut Badań Literackich, 1993.

Purš, I. Kunstkamera jako Švankmajerův mikrokosmos. In: Dryje, F., Schmitt, F. (eds.) Možnosti dialogu - Mezi filmem a volnou tvorbou. Praha: Arbor vitae, 2012, s. $195-218$.

Schmitt, B. Podrobný komentovaný životopis (III) 1990-2012. In: Dryje, F., Schmitt, B. (eds.) Možnosti dialogu - Mezi filmem a volnou tvorbou. Praha: Arbor vitae, 2012, s. 195-218.

Schmitt, B., Leclerc, M. Chiméry Jana Švankmajera (videozáznam na DVD). Francie, Česko: 24images, TV 10 Angers, Canal 8 (Le Mans), 2001.

Smyk, K. Drzewo. In: Wróblewska, V. (ed.) Stownik polskiej bajki ludowej. T. 1-3. Torun: Wydawnictwo Naukowe UMK, 2018. Dostęp z: https://bajka.umk.pl/slownik/lista-hasel/haslo/?id=52 (2021-04-30).

Solařík, B. Hmyz. Praha: Academia, 2018.

Švankmajer, J. Otesánek (videozáznam na DVD). Česko: Zeitgeist Films, 2000.

Švankmajer, J. Síla imaginace, režisér o své filmové tvorbě. Praha: Dauphin, 2001.

Švankmajer, J. Desatero. In: Dryje, F., Schmitt, F. (eds.) Možnosti dialogu - Mezi filmem a volnou tvorbou. Praha: Arbor vitae, 2012, s. 462-463.

Vojvodík, J. Świat strachu i strach przed światem w czeskim surrealizmie lat 30. i 40. Teksty Drugie. 2007 (6), s. 50-77.

Zadurska, O. Ciało. In: Wróblewska, V. (ed.) Stownik polskiej bajki ludowej. T. 1-3. Toruń: Wydawnictwo Naukowe UMK, 2018. Dostęp z: https://bajka.umk.pl/slownik/lista-hasel/haslo/?id=40 (2021-04-30).

Zawojski, P. Posthumanizm, czyli humanizm naszych czasów. Kultura i Historia. 2017 (32), s. 68-76. 
Kamila BYRTEK

\section{FIGURY MATKI I DZIECKA W POEZJI IRENY WYCZÓLKOWSKIEJ}

\section{Figures of a Mother and a Child in the Poetry of Irena Wyczótkowska}

Keywords: poetry, Polish poetry, contemporary poetry, a child in literature, a mother in literature

Contact: Uniwersytet Opolski; kamila.byrtek@gmail.com

Figury matki i dziecka pojawiają się w poezji Wyczółkowskiej głównie w odniesieniu do doświadczeń egzystencjalnych poetki. W związku z tym uzasadnione jest traktowanie podmiotu w tej poezji - za Ryszardem Nyczem - jako sylleptycznego, co oznacza, że ,ja” należy rozumieć na dwa odmienne sposoby jednocześnie: ,jako prawdziwe i jako zmyślone, jako empiryczne i jako tekstowe, jako autentyczne" i jako fikcyjne, poetyckie ${ }^{1}$ (Nycz 1997: 108). Wybór kategorii syllepsis umożliwia bowiem traktowanie biografii i twórczości poety nierozłącznie oraz zawiesza wszelkie kwestie sporne dotyczące traktowania ich w sposób rozłączny. „Słowo literackie” staje się w koncepcji tej ,zespolone z życiem” (Nycz 1996: 49). Literatura natomiast jest tropem rzeczywistości, sztuką „wypowiadania ludzkiego doświadczenia” (zob. Nycz 2012). Samą zaś kategorię doświadczenia można potraktować jako centralną w poezji Ireny Wyczółkowskiej. Zarówno doświadczenia spisywane z perspektywy Ireny jako córki, jak i refleksje Ireny jako matki odnoszą się do egzystencji jednostkowej. Jest to liryka intymna, posiłkująca się słowem prywatnym - ,wykorzystywanie osobistych asocjacji”, o którym pisze Teresa Dobrzyńska w swoim studium o metaforze (Dobrzyńska 2012: 86), uwidacznia się w tej poezji bardzo wyraźnie. Światy (wewnętrzne i zewnętrzne) Ireny Wyczółkowskiej zostają ujęte w „wiersze-zwierzenia”, „wiersze intymne"2 (Dąbrowska 2006: 72) (w zależności od tego, jaki jest charakter (tonacja) przekazu),

\footnotetext{
${ }^{1}$ Nycz mówi o ,ja fikcyjno-powieściowym".

2 „Świadectwa autentyku - zwraca uwagę Dąbrowska - wpisane w poetycką strukturę zdają się potwierdzać kierunki poszukiwań nowych środków wyrazu i korzystania przy tym z możliwości semantycznych, jakie daje organizacja wierszowa (dlatego mówienie wierszem właśnie). Przejście od jednoznacznej historii własnej do formy lirycznej decyduje bowiem o przekształcaniu danych wyjściowych i sprawia, że tekst osobisty nabiera owej wartości dodatkowej, jaką niesie semantyzacja słowa w tekście poetyckim. Prywatne światy poety organizują sytuację liryczną i typ wiersza, który z kolei - w zależności od charakteru (tonacji) przekazu jest: «wierszemdokumentalnym», «wierszem zwierzeniem» czy «wierszem intymnym»" (Dąbrowska 2006: 72).
} 
które stają się płaszczyzną wyrażania jej doświadczenia (do-świadczenie (o) rzeczywistości).

W poezji tej wyraźnie uwidacznia się czas indywidualny, którego rytm wyznaczają zdarzenia z życia, w tym - w dużym stopniu - narodziny i śmierć, będące elementami należącymi w tym mikroświecie do egzystencji (śmierć - zarówno Innego, jak i własną - trzeba u Wyczółkowskiej ,jakoś przetrzymać" - *** (Jakoś śmierć przetrzymać...), zob. (Wyczółkowska 2016: 276). Figury matki i dziecka służą wyrażaniu doświadczeń, co uwidacznia się silnie w sposobie opisu - przedstawione zostają różne sytuacje (rzeczywiste - takie jak wspomnienia, i nierzeczywiste - jak sny), w których matka i dziecko uczestniczą, nie pojawiają się natomiast bezpośrednie informacje na temat samych cech fizycznych, a nawet psychicznych przedstawianych osób. Substytutem opisu wyglądu osób (szczególnie matki lub ojca) staje się obecność fotografii, która, jak pisał Roland Barthes, „(...) stanowi: Dotykalne, (...) Napotkane, Rzeczywiste, w ich niewyczerpalnym wyrazie” (Barthes 2008: 14). Zdjęcia „ocalają konkret”, pozwalają „trwać na przekór upływowi czasu”, i na swój sposób zachować „nieustannie trwająca bliskość osoby” (Morzyńska-Wrzosek 2012-2013: 122). Jak pisał Barthes w Świetle obrazu, „To, co Fotografia powiela w nieskończoność, nastąpiło tylko jeden raz; powtarza więc mechanicznie to, co już nigdy nie będzie się mogło egzystencjalnie powtórzyć" (Barthes 2008: 13) - tak też u Wyczółkowskiej przywoływane są obrazy, które zatrzymują chwile, rozciągając ich istnienie do nieskończoności. W jednej z fraz wiersza Fotografia (Wyczółkowska 2016: 169) - „Mama z żółknącej fotografii / uśmiechała się rozbawiona” - poetka przywołuje postać matki, zatrzymaną na zawsze w określonej pozie z uśmiechem, którego obecność wydaje się jeszcze bardziej podkreślać uczucia tej osoby i relacje z nią. „Zatrzymane obrazy domagają się uważnego patrzenia, zastanowienia, niekiedy zjednoczenia z postrzeganym obiektem. Każdy akt przypominania nasycony zostaje wewnętrznym wyobrażeniem, jednostkowym przeżyciem. W sytuacji, gdy oglądający odnajduje na fotografiach znane miejsca lub postacie, napięcie wzrasta, a dystans uczuciowy maleje" (Morzyńska-Wrzosek 2012-2013: 122). Podobnie jak fotografie, także poezja staje się przestrzenią ocalenia bliskich osób, siebie i minionych wydarzeń, a także uważnego przyglądania się rzeczywistości.

Figura matki pojawia się $\mathrm{w}$ wierszach Wyczółkowskiej najczęściej w postaci matki poetki. Wyczółkowska jest związana $\mathrm{z}$ nią $\mathrm{w}$ szczególnie silny sposób. Doświadcza jej starości i utraty sprawności z nią powiązanej:

Otwierasz drzwi powoli

skrzydełko klucza trzepocze w twej dłoni 
wchodzisz pochylona

każdy gest i krok drobiąc jak okruchy

Przestań - myślę - co ty wyprawiasz

Jak pies

co się dziwi nowej zabawie

gdy pan się poślizgnął i pada

nie mogę pojąć twej starości mamo (Wyczółkowska 2016: 33).

Brak zgody na starzenie się matki, jej postępującą niesprawność fizyczną, powolne gaśnięcie przywodzi na myśl Różewiczowskie wyznania zawarte w tomie Matka odchodzi, wyrażające głębokie wewnętrzne rozdarcie syna: „Nie chcę zgodzić się z jej chorobą. Nie chcę zgodzić się i wiem, że jestem śmieszny - nie chcę zgodzić się z jej śmiercią. Jestem jak nierozumne zwierzę, które karmi swoje małe martwe. Wpycha mu jedzenie do ust" (Różewicz 1999: 89). Matka Wyczółkowskiej portretowana jest za pomocą wydarzeń, w których uczestniczy. Przede wszystkim zaś ukazywana jest jako uczestnicząca w przemijaniu i przemijająca. Odchodzi z niej życie i ona odchodzi z życia. Także dziecko ukazuje poetka w tej perspektywie. W jednym $\mathrm{z}$ wierszy $\mathrm{z}$ tomu Portret $z$ dusza na ramieniu (Wyczółkowska 2016: 223) - opublikowanych w 2013 roku, a więc dwa lata przed śmiercią poetki - postać dziecka zobrazowana zostaje w kolejnych etapach: etap pierwszy - wczesne dzieciństwo, pełne ciekawości i niewinności spojrzenia („dziecko staje na palcach przed lustrem”); etap drugi, podczas którego dziecko dorasta, nabywa świadomość o procesie przemijania i nieubłagalnym upływie czasu („,dziecko przymierza starość”), i w końcu dwa kolejne etapy - śmierć matki oraz doświadczanie własnej starości:

Potem śmierć: synku wyrzuć listy fotografie

oczyść świat z moich śladów

zmień w nim sprężyny

niech nie będzie wysiedziany

Dziecko się postarzało

idzie na strych szukać matki wśród rupieci

Powietrze jest tam gęste ciężkie

smuga światła z małego okienka (Wyczółkowska 2016: 223). 
Zaiste, świat rzeczywisty zbiega się tu z poetyckim, gdyż Irena Wyczółkowska faktycznie prosiła swojego syna, by wyrzucił jej listy i fotografie, czego wyraz dał on sam, komentując jeden z wpisów na blogu jednej z polskich pisarek - Marty Fox (Fox 2015). Postać dziecka odnosi się zatem w niniejszym wierszu jednocześnie zarówno do syna Wyczółkowskiej, jak i do figury dziecka jako takiej - poezja mocą swej niejednoznaczności przekazuje uniwersalny obraz nas wszystkich, przechodzących od etapu do etapu, mierzących się z upływem czasu i przemijaniem, szukających śladów minionego, naznaczonych śmiercią od początku istnienia, do niej zmierzających.

Doświadczenie graniczne, jakim jest śmierć, w sposób najbardziej oczywisty uzmysławia kruchość życia i jego przemijanie. Jak to twierdził Karl Jaspers, „subiektywny aspekt [sytuacji granicznych - K.B.] charakteryzuje się tym, że są one przez każdego człowieka zawsze przeżywane w pryzmacie osobistego cierpienia" (za: Piszkalski 1978: 103). Cierpienie to jest niepowtarzalne i powtarzalne zarazem - każde przeżycie jest indywidualne, ale też każde wpisuje się w naturalny porządek rzeczy, którego nic nie jest w stanie naruszyć. Próby uwieczniania tego, co mija, są wyrazem swoistej walki z nieuniknionym.

Przestrzenią służącą ocaleniu matki (podobnie jak innych zmarłych) staje się - oprócz wiersza - także sen. W snach matka wraca zdrowa ze szpitala i nie może się doczekać domu (np. w wierszu Powrót ze szpitala z tomu Smocza samotność (1997) - zob. Wyczółkowska 2016: 142), pozostaje żywa, pojawia się w obrazach codzienności (wiersz Konfitury):

Raz jeszcze ten sen: mama żyje. A dalej śnię, że się obudziłam i chociaż wiem, jakie to głupie szukam starego klucza. Schodzę piętro niżej, w koszuli nocnej, szczęście, że śpią sąsiedzi, do jej mieszkania.

Cóż tam mogę zobaczyć poza pustką i kurzem, nawet pamięć staje się podobna do ściany ze śladami po meblach i obrazach, a nie - z nimi samymi.

A jednak otwieram drzwi, klucz się obraca wolno, z takim trudem, jakbym to świat miała obrócić. 
Wchodzę. Jakiż zapach - mama smaży konfitury.

Zdejmuje drewnianą łyżką białe szumowiny, spróbuj, mówi, wiśnie w tym roku wyjątkowe, słowo daję, nigdy nie będą już takie dobre (Wyczółkowska 2016: 181).

Sen staje się zatem przestrzenią, w której spotyka się zmarłych, rozmawia się z nimi, współuczestniczy w życiu. „Jako fenomen zakorzeniony tyleż w pamięci, co w wyobraźni, marzenie senne sytuuje śniącego poza jakimkolwiek stałym, dającym się jasno zdefiniować porządkiem ontologicznym" (Owczarski 2014: 10). Sen jest zatem przestrzenią szczególną, nierzeczywistą, jednak w rzeczywistości zakorzenioną. W snach świat rozrasta się i zniekształca, powracają zmarli, powtarzać mogą się chwile minione, nie istnieje niemożliwe, więc istnieć może wszystko. I każdy. Jak to ujmuje Bartosz Suwiński, „Sen dawkuje niezbędną ilość zapomnienia, odwodzi od procederu życia ze śmiercią, jest momentem zawieszenia. Staje się przestrzenią, która daje namiastkę wytchnienia po wytężonej drodze od świtu do zmierzchu" (Suwiński 2017: 41). Sen może przynieść chwilową ulgę, zamalować swoimi obrazami tęsknotę za kimś, kto odszedł z życia doczesnego. Przywoływanie snów staje się też sposobem na zatrzymywanie czasu - ,powtórzenia, nawroty tych samych tematów. (...) Powroty do punktu wyjścia i powielanie przebytej drogi prowadzą do «zapętlenia»: przekształcają ruch postępowy w ruch kolisty" (Dobrzyńska 2015: 89). Podobnie rolę snu określała w swojej poezji Szymborska (,W snach żyje jeszcze / nasz niedawno zmarły, / cieszy się nawet zdrowiem i odzyskaną młodością") - sny pozwalają więc także zachowywać obraz zmarłych, pamiętać o nich. U Wyczółkowskiej jednakże granica między obydwoma światami nie jest tak wyraźna - w wierszach następuje ,ppoetyckie wiązanie światów równoległych" (żywych i umarłych) (Dąbrowska 2018: 64). Stają się one także przestrzenią służącą komunikacji ze zmarłymi. Wyczółkowska w jednym ze swoich utworów (Rozmowa z matka z tomu Wstep do teorii jawy (2000)) notuje:

Piszę, żeby z tobą rozmawiać, choć nie znam języka, którym teraz mówisz, a wiersz, jak cień, nie przestaje być ziemski, choć się oddziela od ciała.

Komuż innemu mogłabym powiedzieć, że śniła mi się Zosia S., pamiętasz, zawsze pierwsza uczennica, historia sztuki 
z najlepszym dyplomem.

(...)

wyskoczyła z okna (Wyczółkowska 2016: 166).

Poetka nie tylko wyraża swą tęsknotę za możliwością kontaktowania się z matką, ale także podejmuje próbę podzielenia się z nią dalszymi ciągami historii z życia prywatnego (nawet jeśli dopowiedzenia te dotyczą opowieści i obrazów powstałych w snach), jakimi tylko z matką podzielić by się mogła. Podkreślona zostaje intymność ich relacji, wspólnota duchowa ukształtowana przez doświadczenia dzielonej z matką rzeczywistości.

Co również warte podkreślenia, „poezja uwiecznia”, stanowi literacką grę motywem „unieśmiertelnienia” (Dąbrowska 2018: 64). Jak to trafnie syntezuje Elżbieta Dąbrowska, „Irena Wyczółkowska konceptualnie powtarza zaklęcie nieśmiertelności, by choć na moment zatrzymać czas w «wiecznej chwili»" (Dąbrowska 2018: 63). To ciągłe przepracowywanie żałoby, mierzenie się ze śmiercią matki cyklicznie powraca w różnych konfiguracjach w twórczości poetki. „Całych pięć lat ma już Twoja śmierć” - wyzna w jednym z wierszy, zastanawiając się - „Jak to będzie po latach - oddali się / zacznie żyć własnym życiem? / Niemożliwe żebyśmy umiały obejść się bez siebie" (Pięć lat, z tomu Ulica równoległa (2005) - Wyczółkowska 2016: 178). W owej powtarzalności, w powrotach do śmierci matki jest klucz do zrozumienia siebie jako człowieka $^{3}$. Wyczółkowska jako córka jest silnie związana z rodzicielką, a więzy te okazują się dużo mocniejsze niż śmierć.

W ostatnim wierszu pojawiającym się na kartach Wierszy wybranych opracowanych przez Krzysztofa Lisowskiego i Michała Nowika (jej syna) ukazała ona śmierć jako zdarzenie przejściowe, inicjujące przejście do innego świata:

Jakoś śmierć przetrzymać.

A potem się podnieść, otrzepać sukienkę.

Mamo tęskniłam za tobą.

Czy to jest mój ojciec, który zginął tak młodo?

Jesteś jeszcze przystojniejszy niż na zdjęciu

obok mamy w welonie!

(...) (Wyczółkowska 2016: 276).

\footnotetext{
${ }^{3}$ „Najwięcej tropów wiodących w stronę rozumienia ludzkiego losu wiąże się z rozpamiętywaniem. Człowiek, który zapomina, niewiele rozumie z historii własnej i wspólnej” - mówi Karol Maliszewski (Maliszewski 2011). 
Powraca tu rekwizyt, jakim jest fotografia, przywołujące dawne czasy (ojciec Wyczółkowskiej był żołnierzem Armii Krajowej i zginął w Powstaniu Warszawskim (1944)), gdy Irena miała zaledwie 3 lata, dlatego też większość wspomnień dotyczących jego wizerunku kształtować musiała się między innymi poprzez obcowanie $z$ detalami zawartymi na fotografii). Matka Ireny zmarła ponad pół wieku później (około 2000 roku), gdy poetka miała niemal 60 lat. To również z tego powodu pojawia się ona na kartach jej tomików znacznie częściej niż ojciec. To starości matki nie mogła pojąć Wyczółkowska i w niej dostrzegała dramatyzm upływu czasu. W innym świecie matka ma być znów młoda (,będziesz wtedy Mamo taka młoda / w niepoważnej charlestonowej sukience / a ja jeszcze stara - / pewnie przyjdę później / i nie zdążę od razu / zetrzeć z siebie życia" - *** (Wszystkie psy mojej matki...), z tomu Ptaszysko - Wyczółkowska 2016: 53). Starość fizyczna jest zatem atrybutem istniejącym wyłącznie na ziemi, w życiu doczesnym.

Warto też wspomnieć o wizerunku Matki Boskiej (w wierszu Matka Boska z tomu Skóra węża (1990)), który - przez pryzmat doświadczeń poetki - jest w jej wizji odmienny niż w wyobrażeniach upowszechnionych w społeczeństwie:

Wolą Cię piękną

w błękitnej sukience

białym motylem aureoli

tak delikatną

że lukrowany rogalik

nie pęka pod Twymi stopami

Czy to grzech

widzieć Cię pochyloną

z posiwiałymi włosami

$\mathrm{z}$ cierniami zmarszczek

na bledziutkim czole (Wyczółkowska 2016: 11).

Ludzie częściej wolą postrzegać Matkę Boską jak boginię - idealną, bez skaz, zastygłą w posągowo perfekcyjnej formie, Wyczółkowska zaś przywraca jej atrybuty człowieczeństwa - „ciernie zmarszczek” określają trudy i cierpienia, jakich doświadczała, bladość i pochylona postawa wiązane są często $z$ fizycznym wyczerpaniem. Jako matka - podobna do innych matek - zmagała się z trudnościami dnia codziennego, jako człowiek podlegała niszczącej sile czasu, przez którą przybywa 
siwych włosów i zmarszczek na twarzy. W myśl tę wpisana zostaje refleksja, iż macierzyństwo nie wiąże się wyłącznie z radością życia - to także noszenie jego ciężaru.

W poezji Wyczółkowskiej figury matki i dziecka służą także ukazaniu siły miłości i więzów pomiędzy nimi. Wyrazić ową miłość może chociażby „wierszwyznanie” dziecka „kołyszącego się w wodach płodowych”, zjednoczonego z matką, zadomowionego w łożysku tak mocno, iż nie chce się urodzić - zob. *** (Kocham cię kocham...) z tomu Gdzie piołun rośnie (1991) - Wyczółkowska 2016: 40). Poczucie jedności z matką jest tak silne, że trudno o rozdzielenie - wyjście na świat dziecka (może być tu mowa zarówno o Irenie jako dziecku, Irenie jako matce, jak i o uniwersalnym ujęciu więzów matki i dziecka). Refrenicznie powtarzane wyznanie „kocham cię kocham" nadaje rytm owemu kołysaniu w wodach płodowych. To wiersz pisany z czułością, z perspektywy bezbronnego i delikatnego dziecka, znajdującego się - po raz ostatni zapewne - w bezpiecznej przestrzeni. W rytm egzystencji wpisane jest odchodzenie rodziców (ich umieranie), ale także odchodzenie dziecka. Dziecko najpierw opuszcza ciało matki, następnie zaś dom rodzinny. Dom po odejściu dzieci staje się zimny i pusty, a rodzicom trudno się pogodzić z nieobecnością potomków - pojawiają się rekwizyty z dzieciństwa: ubranka lalek, książki z obrazkami, zeszyty, części roweru, by zniknąć w ciągle rozrastającej się przestrzeni, dystansie, jaki pogłębia się z każdą chwilą, gdy „czas prószy i prószy” (wiersz Rodzice, z tomu Smocza samotność (1997) - Wyczółkowska 2016: 130). Również w innym wierszu pojawia się podobny obraz:

Dzieci dorastają

odchodzą zabierając swoje rzeczy

I zabierają rzekę

Dom osiada na piaskach

Kruszy się droga i sypie

na cztery wiatry (Wyczółkowska 2016: 54).

Erozja, czy - jak we wcześniej przywołanym wierszu - rozrastanie się przestrzeni - wyrażają coraz bardziej pogłębiające się spustoszenie, wpisane w naturalny porządek rzeczy. Powrót do wspomnień, do obrazu dzieciństwa - podobnie jak powroty w wierszach-snach do obrazu matki - ma moc ocalającą i w melancholijnych tonach przywołuje to, co kiedyś było trzonem egzystencji (z wiersza Dawniej to byty zimy): 
(...)

Miało się na sznurku wełniane rękawiczki

ale kule należało lepić gołymi dłońmi

z tego co przed chwilą było żywiołem

I nawet gdy śnieg topniał

nikt nie mówił o jakimś tam przemijaniu

czy nicości

a sens był tuż pod powierzchnią (Wyczółkowska 2016: 251).

Poezja Wyczółkowskiej tętni różnymi obrazami rzeczywistości (w obliczu śmierci jeszcze lepiej uwidaczniają się jej wrażliwość na świat, uważne przyglądanie się, „światoodczuwanie” (zob. Dąbrowska 2018: 64), epifanie codzienności), a jednocześnie wygasa stopniowo wraz z postępującą chorobą autorki. Powracające figury matki i dziecka wyraziście odznaczają się w rytmach tej egzystencji i - choć podlegają niszczącej sile czasu - zostają ocalone od unicestwienia.

\section{Summary}

This article presents how Irena Wyczółkowska constructs figures of a mother and a child in her poetry. These figures will be shown in the context of themes evoked by the poet (including poems about her mother and mother's poems; also poems related to the subject of passing away, experiencing illness and death). I am particularly interested in the direction of discovering the humanistic dimension of Irena Wyczółkowska's poetry (the poetic word between the self and the world, experience of the world). I am considering the relation between contemporary poem and the experience of existence. My main research focus on the poetry of Irena Wyczółkowska is determined by literary anthropology.

\section{Literatura}

Barthes, R. Światto obrazu. Uwagi o fotografii. Warszawa: Aletheia, 2008.

Dąbrowska, E. Ireny Wyczółkowskiej „wiersze otwarte na oścież” (sztuka patrzenia widzenia - światoodczuwania). Kwartalnik Opolski. 2018 (4). 
Dąbrowska, E. Tekst artystyczny między stylami i gatunkami (genologiczne „silva rerum" nowej i najnowszej literatury polskiej). Przestrzenie Teorii. 2006 (6).

Dobrzyńska, T. Od stowa do sensu. Studia o metaforze. Warszawa: Wydawnictwo IBL, 2012.

Dobrzyńska, T. Tekst poetycki i jego konteksty. Warszawa: Instytut Badań Literackich PAN, 2015.

Fox, M. Siódme niebo Ireny Wyczótkowskiej, 2015. Dostęp z: https://martafox.pl/ 2015/05/05/siodme-niebo-ireny-wyczolkowskiej/ (2021-02-25).

Maliszewski, K. Wobec umarłych, wobec siebie - recenzja tomu „Bilet na wodolot” Ireny Wyczółkowskiej, 2011. Dostęp: http://www.poezja-polska.pl/fusion/ viewpage.php?page_id=167 (2020-12-12).

Morzyńska-Wrzosek, B. Pamięć, intymność, ocalenie. Wokół Matka odchodzi Tadeusza Różewicza. Spotkania Humanistyczne. Międzynarodowy Interdyscyplinarny Periodyk Naukowy. International Interdisciplinary Scientific Journal. 2012-2013.

Nycz, R. Język modernizmu. Prolegomena historycznoliterackie. Wrocław: Wydawnictwo Leopoldinum Fundacji dla Uniwersytetu Wrocławskiego, 1997.

Nycz, R. Poetyka doświadczenia. Teoria - nowoczesność - literatura. Warszawa: Wydawnictwo IBL, 2012.

Nycz, R. Tropy „JA”. Koncepcje podmiotowości w literaturze polskiej ostatniego stulecia. In: Śnieżko, D. (ed.) Ja, autor. Sytuacja podmiotu w polskiej literaturze wspótczesnej. Warszawa: Wydawnictwo Naukowe Semper, 1996.

Owczarski, W. Sennik polski. Literatura, wyobraźnia i pamięć. Gdańsk: Słowo/obraz terytoria, 2014.

Piszkalski, H. Problem „sytuacji granicznych” w ujęciu Karla Jaspersa. Analecta Cracoviensia. 1978 (10). Dostęp z: https://core.ac.uk/download/pdf/ 299330303.pdf (2021-03-12).

Różewicz, T. Matka odchodzi. Wrocław: Wydawnictwo Dolnośląskie, 1999.

Suwiński, B. Okna zwrócone w tamtą stronę (Irena Wyczółkowska). In: Suwiński, B. Po tej stronie rzeki. Szkice o poetach znad Odry. Opole: Nowik, 2017.

Wyczólkowska, I. Wiersze wybrane. Opole: Rudy Kot, 2016. 


\title{
ODKAZ MUSORGSKÉHO BORISE GODUNOVA V DRAMATU SMUTA ARSENIJE A. GOLENIŠČEVA-KUTUZOVA
}

\author{
The Influence of Mussorgsky's Boris Godunov on the Play \\ Smuta by Arseny A. Golenishchev-Kutuzov
}

Keywords: Boris Godunov, Mussorgsky, drama Smuta, Arseny Arkadyevich Golenishchev-Kutuzov, Russian drama

Contact: Masarykova univerzita; dupalova.zuzana@email.cz

Opera Boris Godunov Modesta Petroviče Musorgského (1839-1881) je dnes již světoznámým hudebním dílem, jehož význam tkví nejen v tom, že představuje jedinou operu, kterou tento geniální skladatel Mocné hrstky kompletně dokončil, ale především ve faktu, že se jedná o první operu napsanou na čistě prozaické libreto, jež si pro své dílo si napsal Musorgskij sám. ${ }^{1}$ Právě pod vlivem této opery napsal Musorgského přítel Arsenij Arkad’jevič Goleniščev-Kutuzov svou dramatickou kroniku Smuta (1879). Následující stránky zachycují spojitosti mezi hlavními postavami dramatických děl Musorgského a Goleniščeva-Kutuzova, tj. mezi Borisem Godunovem a Vasilijem Šujským, a nahlíženy jsou také rozdíly v pojetí role národa s cílem dokázat, že opera Boris Godunov měla vedle vlivu hudebního i vliv literární.

Arsenij Arkad’jevič Goleniščev-Kutuzov (1848-1913) byl ruský básník, prozaik, dramatik a publicista, vystudoval práva a v sedmdesátých letech publikoval své básně

\footnotetext{
${ }^{1}$ Inspirací mu byla dvě významná ruská literární díla - Dějiny ruského státu Nikolaje M. Karamzina a Puškinovo drama Boris Godunov (1825). První verze opery (1869) byla komisí Mariinského divadla odmítnuta, údajně pro nedostatek výrazných ženských postav, Musorgskij pak Godunova přepracoval a druhá verze již byla přijata. Premiéra díla se konala pod taktovkou Eduarda Nápravníka v petrohradském Mariinském divadle 27. ledna / 8. února 1874. Puškin a Musorgskij nebyli však jedinými, kdo se chopil historické látky doby Smuty. Lžidimitrijovská tematika byla především v 19. století v Rusku dramatiky velmi oblíbená a často zpracovávaná. Události z počátku 17. století, kdy se mladý dobrodruh s nejasným původem vydává za dávno mrtvého syna Ivana Hrozného Dimitrije, aby dosáhl ruského trůnu a sesadil nezákonného cara Borise Godunova, a který nakonec sám skončil zabit, poskytovaly vše potřebné pro poutavý příběh, včetně milostné zápletky. Kromě Puškina svá dramata na toto téma napsali např. Alexandr Ostrovskij (Дмитрий Самозванец и Василий Шуйский, 1867) Alexej Tolstoj (Царь Борис, 1870) nebo Alexej Chomjakov (Дмитрий Самозванец, 1833), ještě před Puškinem např́íklad Alexandr Sumarokov (Димитрий Самозванец, 1771), věhlasu Musorgského opery a Puškinova dramatu se však žádné z ruských děl nevyrovnalo. Téma se v dlouhém 19. století výrazně projevilo i v Německu, kde se významnou inspirací pro ostatní tamní spisovatele stala nedokončená dramata Friedricha Schillera a Christiana Friedricha Hebbela.
} 
v žurnálech Дело а Вестник Европы. Přátelil se s hudebním kritikem Vladimirem V. Stasovem a s jeho pomocí roku 1875 vydal poemu Гашиш, která pronikla do širšího povědomí. Jeho vrcholné básnické umění představují např́íklad sbírky Затишье и буря (1878), Стихотворения (1884, 1901, 1912) а На закате (1912), které v mnohém souzněly s díly ruských symbolistů. Jeho básně se dočkaly častého zhudebnění (jeho texty podložili hudbou např. Kjuj, Ljapunov, Nápravník, Rachmaninov), osudovým se mu však stalo přátelství s Modestem P. Musorgským, který na jeho básně napsal dva písňové cykly (Bez slunce 1874, Písně a tance smrti 1875-77), baladu Забытый (1874) nebo romans Видение (1877). Goleniščev-Kutuzov se stal také autorem libreta Musorgského nedokončené opery Soročinský jarmark. Dramatickou kroniku Smuta (1879), která je předmětem zájmu tohoto příspěvku a kterou, jak již bylo zmíněno, napsal básník pod vlivem Borise Godunova, tomuto skladateli dedikoval (Николаев 1989: 603-604).

\section{Pojetí hlavních postav}

Drama Smuta v pěti jednáních Arsenije A. Goleniščeva-Kutuzova nepatří mezi nejslavnější díla zabývající se tímto tématem (Lžidimitrij navíc vystupuje pouze v prvních dvou jednáních), ovšem svou návazností na Musorgského operu je poměrně zajímavé. Děj začíná chvíli poté, kde Musorgského (i Puškinovo) dílo končí, hostinou na oslavu Samozvance, poslední scéna pak zobrazuje př́ichod zajatce Vasilije Šujského na dvůr polského krále. ${ }^{2}$ V Musorgského opeře hlavní úloha připadá Godunovovi, v Kutuzovově dramatu stojí v popředí díla ctižádostivý Šujskij, kterého s operním Borisem mnoho nespojuje. Boris je váhavý a důstojný státník zkroušený nečistým svědomím s krví careviče Dimitrije na svých rukách, Šujskij využije každé příležitosti, aby posílil svou moc, a neštítí se úskoků a lží, intrik se vzdává až přijetím koruny.

\footnotetext{
${ }^{2}$ Samozvanec Dimitrij je upozorněn na Šujského komploty proti němu, Šujskij je zatčen a poslán do vyhnanství do Galiče, po nějaké době ho ale Dimitrij povolává zpět do Moskvy, Šujskij s návratem neváhá a chystá se carovi zasadit konečnou ránu. Po svém návratu si Šujskij obratným jednáním s Marfou, matkou mrtvého careviče Dimitrije, která nyní předstírá, že je i matkou samozvancovou, zajistí Marfin př́slib, že po chystaném převratu před lidem dosvědčí, že car Dimitrij nebyl jejím skutečným synem. Na začátku třetího jednání se kupec Fjodor Koněv chystá s druhy na povstání vedené Šujským, je zachyceno škorpení a nedočkavost tlupy, začátek bouře je odstartován zvoněním zvonů. Po úspěšném povstání se Šujskij chystá, že se stane novým carem. Za nového cara je skutečně zvolen on. Další děj se odehrává až na sklonku Šujského vlády, skrze konverzaci šlechtičny s mladou cařicí se dozvídáme o nepokojích na Rusi i o novém, již druhém samozvanci se jménem Dimitrije. Šujskij po svém prríchodu vyjevuje, že nechápe vývoj událostí, přichází jeho bratr s varováním, že se lid srocuje a bouří, Šujskij odchází povstalcủm hrdě vstř́ic. Je nucen vzdát se koruny. Ctižádostivá Marina, manželka prvního Lžidimitrije, nyní předstírá, že svého manžela poznala v novém samozvanci, ale náhle se dozvídá, že její muž byl na lovu zabit, a Marina je tím ztracena. Poslední scéna dramatu se odehrává v Polsku na královském dvoře, kam je přiveden jako zajatec Šujskij, ten je stále hrdý, král se smiluje a nechává starého Rusa v klidu dožít v domácím vězení na panství. Jak je vidět, děj je podobně jako i u Musorgského opery velmi roztř́štěný a je nutná obeznámenost čtenáře nebo publika s historickými událostmi.
} 
Hned první Šujského monolog v dramatu (1. akt, 1. scéna) připomíná Borisův první monolog opery (prolog, 2. scéna). ${ }^{3}$ Zatímco u Borise jde o korunovační řeč, Šujskij po hostině se samozvancem přemýšlí o budoucnosti:

Musorgskij

БОРИС ГОДУНОВ

Скорбит душа.

Какой-то страх невольный

зловещим предчувствием

сковал мне сердце.

О праведник, о мой отец державный!

Воззри с небес на слезы верных слуг

и ниспошли ты мне

священное на власть благословенье.

Да буду благ и праведен, как ты, да в славе правлю свой народ!

Теперь поклонимся почиющим властителям Русии.

А там сзывать народ на пир, всех, от бояр до нищего слепца!

всем вольный вход, все гости дорогие!

Goleniščev-Kutuzov

ШУЙСКІЙ

Сбираются надъ головою тучи,

Быть, быть грозъ!.. Посмотримъ, чья возьметъ!

Сдается мнъ, до сей поры не даромъ

Господь меня храниль святой десницей,

Въ годину бъдъ, и милостью своей

Запечатльль главу мою сьдую.

(...)

Исчезнеть лживый призракъ, аки дымъ,

И свято мъсто снова пусто станетъ!

Ктожь мъсто то заиметь? Господь всесильный!

Не помяни гръховъ моихъ великихъ,

Дай силу мнъ на подвигъ многотрудный,

Змъиную мнъ мудрость дай, чтобъ могъ

Враговъ моихъ я сокрушить злодьйство!

(...)

Oba monology, či spíše jejich začátky (u Borise první čtyři řádky, u Šujského první dva), spojuje pocit blížícího se nebezpečí - Borise svírá zlá předtucha, Šujskij tuší

\footnotetext{
${ }^{3}$ Texty z opery jsou převzaty z edice Borise Godunova od Davida Lloyda-Jonese z r. 1975 (Mussorgsky 1975), texty dramatu z vydání z roku 1879 (Голенищев-Кутузов 1879).
} 
nějakou převratnou událost, „bouřri“, u které si ale není jist, na čí hlavu se snese. Boris následně prosí o Boží požehnání pro svou vládu - oproti tomu Šujskij je si vědom jakési ochrany, kterou mu Bůh do té doby poskytoval. Šujskij si je jist, že po úspěšném převratu se uvolní místo na trůnu a již si na něj myslí sám. Boris pak Boha prosí o vlastnosti jako je dobrota a spravedlnost, Šujskij o sílu na „hrdinství" a lstivou moudrost. $V$ těchto monolozích je již poznat základní rozdíl mezi oběma postavami: je třeba zde zmínit, že tato část Borisova monologu je niterná, není určena pro uši ostatních, což jí dodává na pravdivosti. Musorgskij se sice při psaní tohoto monologu nechal inspirovat Puškinovým Borisem a jeho korunovačním monologem, ten ale působí mnohem formálněji a strojeněji právě díky tomu, že je celý adresován patriarchovi a bojarům. Zatímco Godunov se obává budoucnosti, Šujskij ji očekává s netrpělivostí, zatímco Boris chce být spravedlivým vládcem, Šujskij se snaží přemoci své nepřátele, kteř́ jsou v jeho očích zároveň nepřáteli Rusi.

Zároveň je nasnadě, pokud mluvíme o Godunovově korunovačním monologu, jej porovnat s korunovační řečí Šujského v dramatu (3. obraz 3. dějství):

Musorgskij

БОРИС ГОДУНОВ

Скорбит душа.

Какой-то страх невольный

зловещим предчувствием

сковал мне сердце.

О праведник, о мой отец державный!

Воззри с небес на слезы верных слуг

и ниспошли ты мне

священное на власть благословенье.

Да буду благ и праведен, как ты, да в славе правлю свой народ!

Теперь поклонимся почиющим властителям Русии.

А там сзывать народ на пир, всех, от бояр до нищего слепца!

всем вольный вход, все гости дорогие!

\section{Goleniščev-Kutuzov}

ШУЙСКІЙ

Народъ московскій! Возблагодаримъ

Царя Небеснаго за избавленье

Отъ смутъ и бъдъ, ниспосланныхъ на насъ.

Свидьтельп Богъ - я не искаль престола.

Служа Руси, себя я забывалъ.

Въ тяжелую годину испытаній 
Я слезы лиль сь народомъ, и молитвы

Ко Господу смиренно возносиль,

Да отвратить Онъ бъдствія отчизны,

Да дасть ей миръ, и счастіе, и славу,

И мудраго правителя. Теперь

Хотите вы. чтобъ я пріяль державу,

И на престолъ царей московскихъ сьль?

Противиться и спорить не дерзаю,

Склоняюся предъ божьимъ повельньемъ

И волей всей Руси. - Да будетъ такъ!

Jedním z hlavních rozdílů mezi monology je ten, že Šujského proslov je určen lidu. Na rozdíl od Godunova, který má zlé tušení, zde Šujskij děkuje za konec těžkých časů, čehož, jak víme, se Rus ještě několik let nedočkala. Zároveň se zapř́ísahá, že trůn nechtěl a vždy trpěl společně s Rusí. Nyní, když si ho lid vyvolil, se neopovažuje protivit jeho a Boží vưli a svůj úkol pokorně přijímá. Tento proslov by mohl působit upřímně, pokud bychom však $\mathrm{v}$ jeho monologu přímo předcházejícím korunovační scéně nebyli svědky toho, jak dychtivě očekává, že novým vládcem bude zvolen právě on, a jak se snaží ještě naposledy působit skromně a pokorně, aby si nezprotivil bojary a Boha.

Největší podobnost mezi Smutou a Musorgského operou ale nacházíme v jedné celé scéně, a to v prvním obraze čtvrtého dějství dramatu, které se silně podobá pátému obrazu opery. V opeře na začátku pláče Borisova dcera Xenie nad mrtvým snoubencem, vchází Godunov a nachází potěšení v rozpravě se synem Fjodorem, přichází ovšem Šujskij, který mu sdělí zprávu o osobě samozvance vydávajícího se za careviče Dimitrije, na konci scény se Borisovi v šílenství zjevuje př́zrak mrtvého Dimitrije. Tato scéna byla výrazně dotčena přepracováním opery, vyličený základní děj však zůstává stejný. Začátek čtvrtého dějství dramatu se odehrává na sklonku Šujského vlády. Ve své komnatě si jeho žena povídá se starou šlechtičnou, která jí informuje o nepokojích na Rusi, kde se zjevil druhý Lžidimitrij, který se vydává za svého předchůdce, navíc je lid nespokojen s Šujského vládnutím. Přichází podrážděný car, jeho žena ho uklidní, vchází ovšem jeho bratr, který velel výpravě proti Lžidimitriji II., a zpravuje ho, že zrádci začali ve velkém přecházet na stranu samozvance, lid se srocuje a bouří se. Manželce se sice podaří cara znovu uklidnit, ale vzápětí si Šujskij uvědomí nebezpečí vzpoury a skutečně je slyšet zvonění zvonů (které jako znamení začátku vzpoury použil i on sám proti Lžidimitriji I.). Přichází bojaři, aby mu dali zprávu o povstání vedené bojarem Ljapunovem a car vychází vzbouřenému lidu hrdě vstř́íc.

V obou dílech tyto scény začínají bez prítomnosti cara v pokoji jejich milovaných, následně přichází car, který právě se svými blízkými (synem nebo nevěstou) nachází útěchu, $\mathrm{v}$ obou dílech mají carové monolog (viz dále) vyjevující jejich 
strasti s vládou. V dramatu i v opeře je z rozhovoru vyruší Šujskij - v opeře jde o bojara Vasilije, budoucího cara, v dramatu o jeho bratra. V opeře Šujskij předá Godunovovi zprávu o tažení samozvance pod jménem Dimitrije, v dramatu carův bratr promluví o zradách a přeběhlících ke Lžidimitriji II. a bouření lidu. V obou dílech se car k narušiteli chová s opovržením a nedůvěrou. Ke konci obou scén mají oba carové záchvat paranoii, Boris vidí ducha mrtvého chlapce, Šujskij si uvědomí nebezpečí vzpoury a slyší neexistující křik, poté ale skutečně zazvoní zvon jako znamení povstání. Co se týče monologů obou carů, jejich podobnost je zjevná - ani jeden z carů nevládne v klidu, Boris si úpadek Rusi vysvětluje jako trest za své hř́chy, Šujskij ale nechápe, proč ho Bůh trestá. V obou monolozích je $\mathrm{v}$ závěru též naznačena nespokojenost s chováním lidu, který se od svých carů odvrací:

\section{Musorgskij \\ БОРИС \\ Достиг я высшей власти, шестой уж год я царствую спокойно; но счастья нет моей измученной душе. Напрасно мне кудесники сулят дни долгие, дни власти безмятежной.}

Ни жизнь, ни власть, ни славы обольщенье, ни клики толпы меня не веселят;

В семье своей я мнил найти отраду, Готовил дочери веселый брачный пир, Моей царевне, голубке чистой. Как буря, смерть уносит жениха... Тяжка десница грозного судии, Ужасен приговор душе преступной...

Окрест лишь тьма и мрак непроглядны! Хотя мелькнул бы луч отрады!

И скорбью сердце полно, Тоскует, томится дух усталый. Какой-то трепет тайный... Все ждешь чего-то... Молитвой теплой, к угодникам Божьим, я мнил заглушить души страданья...

В величьу и блеске власти безграничной, Руси владыка, я слез просил мне в утешенье...

А там донос: бояр крамола, Козни Литвы, и тайные подкопы, Глад и мор, и трус, и разоренье... Словно дикий зверь рыщет зачумленный; Голодная, бедная стонет Русь...

И в лютом горе, ниспосланном Богом, За тяжкий наш грех в испытанье, Виной всех зол меня нарекают, 
Клянут на площадях имя Бориса!

И даже сон бежит, и в сумраке ночи

Дитя окровавленное встает... (...)

\section{Goleniščev-Kutuzov}

ШУЙСКІЙ

Покоя нътъ! Мнъ не даютъ

Покоя. Думалъ я, вступивъ на царство:

Теперь конецъ иевзгодамъ, треволненьямъ!

Я счастьемъ наслажусь... и позабыль, Что отнимать враги то счастье стануть! Казалось мнъ: смятенье, звонъ набата, Мятежъ бояръ, народа буйный кликъ,Все это я творю своею волей.

Все такъ и быть должно, пока на царствђ Сидитъ татаринъ, злой цареубійца, Иль мной-же впущенный въ Москву, бродяга

Безъ племени и рода... Я ошибся!

Потомокъ Рюрика, Москвы любимецъ, Народомъ избраиный, пріялъ вьнецъ И властвуетъ, - а Русь объята смутой! Кого еще ей надо? Или мало Лилася кровь? Иль Богомъ предназначенъ Иной Руси владыка! Гдъже онъ? Пусть явится, помърится со мною Заслугой, доблестью, иль честнымъ родомъ. Кто выше насъ, царица, покажи?! (...)

Чего имъ надо?

Разстрига смерть пріяль! Предъ всей Москвой Лежало тъло. Всъ надъ нимъ ругались, Благословляя Бога и меня...

И вдругъ молва: опять возсталь изъ мертвыхъ Димитрій! И толпой къ нему бъгутъ, Надъ вымысломъ нелЂпымъ потъшаясь! БЪгутъ... Зачъмъ? Куда? На зло кому? Никто не въдаетъ. А царь одинъ, Что щепка на волнахъ!...

\section{Pojetí národa}

Problematika národa bývá obecně v mnoha lžidimitrijovských dílech výrazná např́íklad Puškin právě národ a obavu z jeho náhlého povstání přesunul do hlavního 
motivu svého dramatu Boris Godunov. Musorgskij ve své opeře roli národa oproti Puškinovi ještě posílil, nejvíce skličujícím okamžikem celé opery je závěrečná kromská scéna, kde se lid chová jako neúprosná lítá zvěř, která se krutě vysmívá polapenému carskému bojarovi. Právě tato scéna ale měla být předmět zklamání samotného skladatele. Podle vzpomínek Goleniščeva-Kutuzova se mu Musorgskij svěřil, že si vyčítá, že ruský lid zde vylíčil nepravdivě. Národ zabíjí a trestá, ale nikdy se svým obětem nevysmívá: «В этом акте, - ответил мне Мусоргский, - я, и притом единственный раз в своей жизни налгал на русский народ. Издевательства народа над боярином - это неправда, это нерусская черта. Рассвирепевший народ убивает и казнит, но не издевается над своей жертвой» (cit. dle Тюлин 1970: 93). Tato vzpomínka však byla mnohokrát, i v citovaném textu, napadnuta jako neprůkazná a tendenční. Její věrohodnost však nyní můžeme nechat stranou, jelikož zásadní je pro tento př́ispěvek způsob, jakým sám Goleniščev-Kutuzov s postavením národa ve své dramatické kronice nakládal a nakolik se držel vzoru Musorgského. Dramatik zařadil hned několik scén, kde hrají výraznou roli představitelé lidu. ${ }^{4}$

Nejvíce se i na základě zobrazených událostí sobě podobají scény korunovační, (1. scéna prologu opery a 3. obraz 3. dějství dramatu), v obou dílech je dění komentováno členy lidu, avšak zatímco v opeře lid řeší své osobní problémy a neprojevuje o politiku velký zájem, ve Smutě se lidé baví o politických záležitostech:

\author{
Musorgskij \\ ПЕРВАЯ ГРУППА \\ Митюх, а Митюх, чево орем? \\ МИТЮХА \\ Вона! Почем я знаю! \\ ВТОРАЯ ГРУППА \\ Царя на Руси хотим поставить! \\ ЧАСТЬ ЖЕНЩИН \\ Ой, лихонько! Совсем охрипла! \\ Голубка, соседушка, \\ не припасла ль водицы? \\ ДРУГАЯ ЧАСТЬ ЖЕНЩИН \\ Вишь, боярыня какая! \\ Орала пуще всех, сама б и припасала!
}

\footnotetext{
${ }^{4}$ První scéna druhého jednání se odehrává v domě kupce Soloda, který se dozvídá, že jeho přátelství se sousedem Šujským není politicky vhodné, Šujskij pak toká se Solodovou dcerou, dovídá se ale náhle o milosti od cara a chvátá zpět do Moskvy. První scéna třetího jednání zobrazuje kupce Fjodora a jeho tlupu, která se chystá k povstání pod vedením Šujského, její členové mezi sebou vtipkují i se sváří a scéna končí pobodáním jednoho z nich. Třetí scéna tohoto jednání se odehrává během oznámení, že se carem stává Šujskij, někteří jsou ale z této volby nadšeni o poznání méně než jiní. Druhá scéna pátého jednání nás zavádí k domu Lžidimitrije II., popisuje znesvářené skupinky osob a zlovůli kozáků, poslední scéna dramatu se potom odehrává v polském královském paláci, kde se polští šlechtici a šlechtičny mezi sebou různě škorpí, tato scéna tedy nezobrazuje ruský lid, ale má lidový charakter.
} 


\section{МУЖЧНИЫ}

Ну вы, бабы, не гуторить!

ЖЕНЩИНЫ

А ты что за указчик!

Вишь пристав навязался!

МИТЮХА

Ой, вы, ведьмы, не бушуйте!

Goleniščev-Kutuzov

ПЕРВЫЙ

Чего здъсь ждуть?

ВТОРОЙ

Аль сь неба, брать, свалился?

Сейчась царя Москва провозгласить!

Въ палатахъ думу думають бояре...

Ръшенья ждемъ.

ТРЕТІЙ

Когото изберуть?

ВТОРОЙ

Въстимо, князя Шуйскаго!

Нъсколько голосов

Когоже, Какъ не его!

ЧЕТВЕРТЫЙ

Эхъ, братцы, право, любо!

Гляди, опять почнутъ въ колокола

Звонить на всю Москву, и пиръ горой

Пойдетъ, какъ въ день Борисова избранья.

ТРЕТІЙ

Теперь не до пировг!

ЧЕТВЕРТЫЙ

А что?

ТРТЕТІЙ

Да смута!

Какъ съ ляхамито справимся, Богъ въсть!

Немало ихъ намедни положили!

Войны не миновать...

Krvelačné vyznění Musorgského kromské scény zde nechybí - touha po prolití nenáviděné polské krve se objevuje ve scéně z domu kupce Fjodora, avšak např́klad právě onen „problematický“ výsměch můžeme nalézt v závěrečné polské scéně, kde se šlechtici vysmívají Mniszkovi kvůli jeho dceři Marině, manželce samozvanců, Goleniščev-Kutuzov se tedy tímto neprovinil proti ruskému prostému lidu, ale tuto krutost přiřkl polské šlechtě, která je $\mathrm{v}$ jeho podání povrchní, znuděná a hašteřivá. 


\section{Závěr}

Rozdíl mezi Borisem a Šujským je znatelný hned od počátku, kdy první jejich monology jsou v podstatě kontrastní. Zatímco Musorgskij v opeře podtrhl Godunovovo lidství (i v porovnání s Puškinovým dramatem), Šujského život jako by byl až do okamžiku jeho zvolení spjat pouze s politikou, což je i naznačeno napr. ve scéně z vyhnanství, kdy ve chvíli, kdy je mu nabídnuto vrátit se zpět do Moskvy, se naprosto odvrací od počínajícího milostného vztahu i od svých předešlých slov, podle kterých by nově nabytý klid už nevyměnil za labyrint politického centra. Jeho povaha $\mathrm{v}$ dramatu do okamžiku korunovace je tedy shodná s negativní lstivou povahou Šujského, kterou nám předkládá Musorgskij ve své opeře. Po jeho korunovaci nastává v Šujského životě obrat - podle svých slov se vzdal úskoků, aby důstojně vládl svému lidu, a právě scéna z komnat jeho ženy naznačuje, že se povahově mnohem více přiblížil Borisovi, možná tímto autor naznačil i svůj pohled na charakter Borise před začátkem jeho vlády. V závěru je pro Šujského ale zásadní jeho nezlomná hrdost a důstojnost, kterou Boris svým šílenstvím i smrtí na scéně ztratil. Šujského postava tedy není zdaleka tolik rozervaná jako Godunov v opeře, vždy u něj dominuje jediný povahový rys. V tomto ohledu je více než s Musorgského Godunovem srovnatelný s Borisem z Puškinova dramatu. Po Puškinově vzoru Musorgskij udělal z lidu ústřední subjekt a hlavní konflikt postavil mezi lid a šlechtu s panovníkem, lid v jeho pojetí prochází vývojem z bezduché masy do revoluční síly. Významná role lidu v dějinách je naznačena i GoleniščevemKutuzovem - jak víme, byl to lid, díky kterému mohl Lžidimitrij I. usednout na trůn, vylíčeno je zde, jak právě i kvůli lidu padl, Šujskij se stává carem s podporou lidu, nespokojenost lidu je ale zároveň to, co zapřičiní konec i jeho vlády a vzestup Lžidimitrije II., lid je tedy př́tomen v každé scéně, kde se odehrávají zlomové okamžiky dramatu. Goleniščev-Kutuzov tímto ukazuje, že úspěch vlády závisí právě na podpoře lidu, který je ale vrtkavý a divoký. Paradoxem je, že Šujskij v jeho podání využíval právě těchto vlastností lidu při svržení Lžidimitrije, neuvědomil si ale, že se může lid obrátit i proti němu, zákonnému carovi, což je patrné v jeho citovaném monologu. V pojetí lidu i v zobrazení hlavních postav tedy lze nalézt shody, a to ve sfére ideové i v rovině textové, jak bylo dokázáno na doložených ukázkách. Podrobnější srovnání či komparace dalších jednajících postav by byla jistě zajímavá, avšak již toto relativně zběžné porovnání dokázalo, že Goleniščev-Kutuzov byl Borisem Godunovem ovlivněn nejen v oblasti výběru tématu svého dramatu, ale také v jeho naplnění. 


\section{Summary}

This paper deals with the theme of the influence of the opera Boris Godunov by M. P. Mussorgky on the drama Smuta by A. A. Golenishchev-Kutuzov, Mussorgsky's friend. In the paper the connections between the main characters (Godunov and Vasili Shuisky) and in the conception of the nation are analysed. Golenishchev-Kutuzov was clearly influenced by the opera and some moments of his play bear a strong resemblance to the scenes of Boris Godunov, the role of the people in the history as outlined in the drama is similar to the role of the nation in the opera.

\section{Literatura}

Mussorgsky, M. P. Boris Godunov: Opera in four Acts with a Prologue. Lloyd-Jones, D. (ed.), 2 vols. London: Oxford University Press, 1975.

Голенищев-Кутузов, А.А. Смута. Драматическая хроника в пяти действиях. Санкт-Петербург, 1879.

Николаева, Л.А. Голенищев-Кутузов, Арсений Аркадяевич. In: Николаев, Л.А. (ред.) Русские писатели 1800-1919. Биографический словарь. Том 1. Москва: Советская энциклопедия, 1989, с. 603-604.

Тюлин, Ю. К изучению наследия М.П. Мусоргского. Сцена под Кромами в драматургии Бориса Годунова. In: Тюлин, Ю., Фрид, Э., Ярустовский, Б., Кандинский, А., Аравон, П. К изучению наследия М.П. Мусоргского. Сцена под Кромами в драматургии Бориса Годунова. Советская музыка. 1970 (34/3), c. 90-98. 



\section{HRANIČNÉ ŽIVOTNÉ SITUÁCIE A ICH STVÁRNENIE V PRÓZE PRE DETI A MLÁDEŽ}

\section{Extreme Life Situations and their Depiction in the Prose for Children and Youth}

Keywords: children prose, youth prose, environmental problems, ecological problems

Contact: Univerzita Pavla Jozefa Šafárika v Košiciach; gabriela.eibenova@student.upjs.sk

\section{Interpretácia diela Lišiak Pax}

Dielo americkej autorky Sary Pennypackerovej Lišiak Pax $^{1}$ patrí medzi diela, ktoré detskému percipientovi citlivo a nenásilne približujú viacero eticko-ekologických otázok a problémov. Zároveň je to príbeh vzácneho priatel'stva a pevnej citovej väzby medzi malým chlapcom Petrom a jeho lišiakom, ktorého nazýva Pax.

Už prostredníctvom kompozičných postupov vo vstupnej časti diela, incipitu ${ }^{2}$ a introdukcie ${ }^{3}$, je naznačený hlboký vzt'ah chlapca a lišiaka, ktorý v podstate otvára príbeh a tvorí prvú kapitolu diela. V incipite: „Lišiak postrehol, že auto spomal’uje, skôr ako chlapec.“ (Pennypackerová 2017: 11) sa percipient zoznamuje s dvomi ústrednými postavami diela, a to chlapcom a lišiakom.

Príbeh sa začína cestou chlapca a lišiaka v aute. Rozprávanie môžeme označit' ako chronologické, pričom je doplnené niekol'kými retrospektívnymi odbočeniami. Dielo je v podstate postavené na dôvere a výnimočne blízkom vzt'ahu medzi Petrom a Paxom. Ich vzt’ah zároveň posilňuje emocionálnu stránku diela a citový zážitok, ktorý príbeh ponúka detskému percipientovi. Vel'mi emotívne pôsobí úvodná scéna, ked' je chlapec donútený nechat' lišiaka $\mathrm{v}$ lese. Táto scéna otvára dej príbehu, možno ju považovat' za akýsi odrazový mostík, od ktorého sa odvíjajú aj d’alšie dôležité udalosti.

Po odlúčení Petra a Paxa sa Peter dostáva k starému otcovi. Postupne sa dozvedáme o dôvodoch, pre ktoré bol Peter nútený opustit' Paxa, ale aj svoj domov:

\footnotetext{
${ }^{1}$ Ikar, a.s., 2017, prel. Michal Jedinák.

2 „Incipit (z lat. incipere = začínat') je sémanticky zat’ažená vstupná veta textu, ktorá dáva kl'úč alebo aspoň čiastočný kl'úč k nasledujúcemu dianiu.“ (Všetička 1986: 49).

3 „Introdukcia je vstupná situácia v texte, je to prvopočiatok diela a začiatok expozície.“(Všetička 1986: 50).
} 
„Blíži sa vojna. Každý prinesie nejakú obet'. Ja musím nastúpit' do služby - je to moja povinnost'. A ty musíš odíst'““ (Pennypackerová 2017: 19). Petrov život teda začínajú ovplyvňovat' spoločenské udalosti - vojna, ktorá síce nepriamo, ale výrazne narušila jeho komfort a istotu, na ktorú bol zvyknutý.

Neskôr sa dozvedáme aj o d’alších dôležitých udalostiach a momentoch, ktoré značne ovplyvnili Petrovo detstvo. Po príchode k starému otcovi sa protagonista v spomienkach vracia do minulosti. Zážitky s Paxom striedajú spomienky na Petrovu mamu. Jej smrt' je percipientovi sprostredkovaná len implicitne, dotvára však celkový obraz o živote a situácii hlavného hrdinu. Percipient tak postupne dostáva odpovede na otázky, ktoré sa vynárajú počas čítania. Retrospektívny obraz Petrovho života je podaný vel'mi zaujímavo a originálne. Ako sme už spomenuli, veselé zážitky s Paxom striedajú bolestivé spomienky na mamu, čo môže miestami pôsobit' mierne chaoticky. Na druhej strane však vd’aka tomuto spôsobu rozprávania príbeh v tejto časti pôsobí dynamickejšie a môžeme ho považovat' za akýsi obraz situácie, ktorá sa odohráva v Petrovej hlave. Zároveň je náznakom neistoty a zmätku $\mathrm{v}$ jeho živote a obrazom okolností, $\mathrm{s}$ ktorými nie je zmierený.

Pri retrospektívnom pohl'ade do minulosti si Peter vybaví nepríjemný zážitok ako v pasci našiel mítveho zajaca, ktorého zrejme na smrt' vystrašili kojoty. Tento zážitok v protagonistovi vyvolá negatívne pocity, kladie si za vinu, že zviera nezachránil. Práve tieto spomienky sú pre hlavného hrdinu podnetom a silnou motiváciou k nájdeniu Paxa. Zbalí si najnutnejšie veci, rozhodne sa opustit' dom starého otca a vydat' sa na riskantnú a na prvý pohl'ad takmer neuskutočnitel'nú cestu s ciel’om nájst' svojho lišiaka.

Za vel'mi originálny považujeme autorkin spôsob práce s napätím. V niekol'kých častiach diela je prítomný motív tajomstva. Tento premyslený kompozičný postup dodáva dielu dynamiku, príbeh vd’aka nemu pôsobí prítažlivejšie, ale hlavne napínavejšie. V priebehu deja sú postupne odkryté mnohé odpovede na otázky o Petrovej minulosti, nie sú však vypovedané priamo. Tvoria súčast' spomienok protagonistu a postupne dopíňajú predstavu o jeho minulosti a jej následkoch na súčasné konanie a citové rozpoloženie.

Príbeh je tvorený dvomi dejovými líniami, pričom jedna sprostredkúva osud chlapca a druhá osud lišiaka. Tieto dejové línie sú po formálnej stránke rozlíšené pravidelne sa striedajúcimi kapitolami - jedna sa venuje Petrovi a jeho neutíchajúcej túžbe nájst' svojho priatel'a zo zvieracej ríše, druhú dejovú líniu tvorí príbeh lišiaka, ktorý sa snaží prežit' bez svojho pána v prostredí, ktoré je mu v podstate cudzie. Čo sa týka rozprávača, môžeme tu hovorit’ o personálnom rozprávačovi, ktorý sa sústredí striedavo na Paxa a na Petra. 
Život lišiaka Paxa po tom, ako ho hlavný hrdina spolu otcom vypustil v lese, možno charakterizovat' ako ustavičný boj o prežitie. $\mathrm{V}$ tomto prípade by sme mohli hovorit' o istom rozpore. Pax sa síce ocitá v lese, prostredí, ktoré je preňho ako pre šelmu prirodzené, adaptácia na novú situáciu a prostredie však preňho predstavuje značný problém: „Pax bol hladný, uzimený a zobudil sa na to, že potrebuje prikrývku.“ (Pennypackerová 2017: 30). Tomuto faktu sa rozprávač venuje podrobnejšie. Pax sa $\mathrm{v}$ lese dostáva do blízkosti líšky, ktorá je v príbehu nazývaná Ježatá, a jej brata, malého lišiaka, či starého lišiaka menom Sivý a jeho družky. Môžeme tak sledovat' rozdiel medzi životom líšok zvyknutých na ich prirodzené prostredie a teritórium a lišiaka, ktorý sa snaží prežit'v doteraz neznámom prostredí a učí sa od skúsenejších rovnakého druhu. Pax pôsobí medzi ostatnými líškami vel'mi placho, nesmelo a osamotene. Tento fakt je umocnený nepriatel'ským a spočiatku vel'mi odmeraným prístupom Ježatej, ktorá len s vel'kou nevôlou vpúšt’a neznámeho na svoje územie. ${ }^{4}$ Autorka tak premyslene prepája fiktívny príbeh s reálnym životom a správaním zvierat. Líšky skutočne patria k zvieratám, ktoré si poctivo strážia svoje teritórium. ${ }^{5}$ Čitatel'sky atraktívne pôsobí spôsob dorozumievania medzi líškami, ktorý má v príbehu dôležité miesto. Líšky medzi sebou komunikujú rečou, ktorá je po formálnej stránke odlíšená kurzívou. Prehovory zvieracích postáv sú odkazom na ničenie ich prirodzeného prostredia l’ud’mi. Načrtáva sa nám tu teda aktuálna a pomerne vážna téma ochrany životného prostredia. Príbeh detskému percipientovi nenásilným spôsobom ukazuje súčasné environmentálne problémy, ktoré sú $\mathrm{v}$ tomto prípade zobrazené cez prizmu zvierat. Nejde tu teda o explicitný výklad a explicitné vymenovanie problémov, ktoré v súčasnosti trápia našu biosféru, čo je, vzhl'adom na vek potencionálneho percipienta, vel'mi vhodne zvolený spôsob. Na druhej strane je však dôležité poznamenat', že spôsob, akým sú tieto problémy det'om približené, je vel'mi ohl'aduplný vzhl'adom k nevinnému detskému svetu, nenásilný, ale za to vel'mi originálny a presvedčivý.

Vel'kú hrozbou pre líšky, ktoré v príbehu vystupujú, prestavuje vojna. Vojna sa v príbehu kladie do vel'mi úzkej súvislosti s l’ud’mi, ktorí sú z pohl'adu zvierat chápaní negatívne. Cítia z nich strach a nebezpečenstvo, čo súvisí s nepríjemnými zážitkami a spomienkami: „Ešte vždy sú bezohl'adní? Boli takí, ked’ som s nimi žil.“ (Pennypackerová 2017: 63). Vojna je v diele vysvetlená cez prizmu zvierat: „Existuje choroba, ktorou sa občas nakazia lišky. Vtedy sa správajú inak a útočia na cudzích. Vojna je zas l'udská choroba.“ (Pennypackerová 2017: 63). Chápanie vojny ako l’udskej choroby svojím spôsobom ospravedlňuje konanie tých, ktorí sú za vojnu zodpovední.

\footnotetext{
${ }^{4}$ „Každá líška má vyhradené svoje lovecké územie, ktoré si bráni pred inými líškami. Pravidelne ho obchádza a značkuje trusom alebo močom. Tým dáva signál iným líškam, že územie je už obsadené.“ (Čačko, L. Osamelý lovec. Dostupné na: https://www.quark.sk/osamely-lovec/ (2021-02-24)).

${ }^{5}$ Informácie dostupné na: https://ekolist.cz/cz/publicistika/priroda/liska-obecna-skryte-zijici-lovec (2021-02-24).
} 
Ďalšou postavou, ktorá v príbehu vystupuje, je postava samotárky Voly, ktorú Peter stretáva na ceste za Paxom po tom, ako si nešt’astnou náhodou zlomí nohu. Vola pôsobí pomerne odmeraným dojmom. Táto postava je dokonalým príkladom preživšej vojny, ktorú jej následky, fyzické, ale aj psychické, nezvratným spôsobom ovplyvnili v konaní, správaní, ale aj myslení. Vola sama priznáva, že trpela posttraumatickou stresovou poruchou. Zabudla, aký život žila pred vojnou, čo ju naplńalo a robilo št’astnou. Zvrátený a bezcitný charakter vojny autorka zvýrazňuje aj porovnaním Voly ako nevinného diet’at’a a neskôr človeka, ktorý bol schopný zabit'. Trpí výčitkami svedomia, nedokáže si odpustit' smrt' vojaka, ktorú zavinila. Ako spomienka na mítveho vojaka a strašný čin, ktorý spáchala, jej ostáva knižka s názvom Sedem ciest Sindibáda námorníka, ktorú si vojak vzal so sebou na front. Do hry tu teda v podobe odkazu na iné dielo vstupuje intertextualita.

Príbeh sa uzatvára stretnutím Petra a Paxa. Možno tu hovorit' o otvorenom konci. Petrovi sa síce podarí dosiahnut' svoj ciel', nájst' Paxa, pochopí však, že odteraz už lišiak patrí do lesa, svojho prirodzeného prostredia, medzi ostatné líšky a zvieratá: „Peter pochopil. Jeho lišiak patrí im. A oni patria Paxovi. Sú nerozluční.“ (Pennypackerová 2017: 243). V diele môžeme pozorovat' prerod Paxa z nesmelého lišst'at'a, ktoré sa ocitlo v neznámom prostredí, na statočného a odvážneho lišiaka. Stará sa o Ježatú a raneného Drobca, ktorý prišiel o nohu pri výbuchu, je svedkom smrti lišiaka Starého, ktorého privalil strom. Tieto udalosti sú zároveň asociáciou na častú sebeckost' a ignorantstvo l'udstva a absurdnost' vojny.

\section{Interpretácia diela Vlčie oko}

Novela Vlčie oko $^{6}$, dielo jedného z najprekladanejších francúzskych autorov Daniela Pennaca, autora niekol'kých diel pre detského, ale aj dospelého čitatel'a ${ }^{7}$, je síce primárne určené pre detského percipienta, svojím poučným príbehom si však určite nájde miesto aj v literatúre pre dospelých.

Čo sa týka kompozičnej výstavby, dielo pozostáva zo štyroch kapitol. V prvej kapitole s názvom Stretnutie sa percipient zoznamuje s dvomi ústrednými postavami diela, chlapcom a vlkom. Ich tajomné stretnutie otvára príbeh a uvádza čitatel’a do deja. Incipit diela: „Pred vlčou klietkou nehybne stál chlapec.“ (Pennac 2016: 9) vel’mi výstižne naznačuje situáciu a bariéru, ktorá je medzi vlkom a chlapcom. Klietka, v ktorej sa nachádza vlk sledujúci chlapca ako sa naňho trpezlivo pozerá. Táto situácia je zároveň zobrazená aj graficky, na obrázku. Medzi chlapcom a vlkom sa nachádza

\footnotetext{
${ }^{6}$ NM CODE \& Asociácia Corpus, 2016, prel. Beata Panáková.

${ }^{7}$ Informácie dostupné na: https://www.walker.co.uk/contributors/Daniel-Pennac-5717.aspx (2021-02-24). 
biela čiara symbolizujúca klietku, a teda bariéru, ktorá ich oddel’uje. Vizuálna stránka však $\mathrm{v}$ tomto prípade úplne nekorešponduje s verbálnou, ked’že na ilustrácii stoja chlapec a vlk vo vol'nej prírode obklopení otvoreným priestranstvom, ktoré môžeme chápat' ako symbol slobody a vol'nosti. Vizuálna stránka teda predstavuje obraz slobody a nezávislosti, kým verbálna stránka je odrazom väznenia a obmedzovania pohybu, ktorý je pre vlka prirodzený.

Koniec prvej kapitoly symbolizuje zblíženie a spriatelenie sa chlapca a vlka: „Vlkovi však niečo prekáža. Je to hlúpe. Má len jedno oko a chlapec má dve oči.“ (...) Vtedy chlapec urobí niečo zvláštne. Čosi, čo vlka upokojí a uistí. Chlapec zavrie jedno oko.“ (Pennac 2016: 15). V tejto časti sa teda dozvedáme o hendikepe vlka, ktorý má len jedno oko. Za znak a symbol istého spojenectva a priatel'stva medzi chlapcom a vlkom možno považovat' práve to, že chlapec jedno oko zatvára. Je to empatický prejav diet'at'a voči zvierat'u.

Čo sa týka rozprávača, v tomto prípade môžeme hovorit' o vševediacom rozprávačovi. Kompozícia, ktorú autor volí, pôsobí vel’mi originálne. Máme tu dočinenia s príbehom, ktorý je v podstate vsadený do d’alšieho príbehu. Pri pohl'ade chlapca do vlčieho oka sa nám otvára d'alší príbeh - príbeh vlka pred jeho zajatím v ZOO. Zrenička oka predstavuje vlčicu skrútenú do klbka a dúhovka okolo zreničky sedem víčat, okolo ktorých vlčica leží. Tento príbeh symbolicky začína v momente, ked' chlapec jedno oko zatvára. Tento akt naznačuje vcit’ovanie, vžívanie sa do príbehu uväzneného zvierat’a.

Práve tu sa začína rozvíjat' rozprávanie o rodine Modrého vlka - vlka zo zoologickej záhrady. Autor tu vel'mi zaujímavo pracuje s motivovanost'ou mien vlčej rodiny. Možno tu hovorit' o tzv. nomen omen, ked’že vlastné mená niektorých vlkov sú motivované ich najtypickejšími vonkajšími znameniami. Srst' Modrého vlka je sfarbená do modra, Čierna iskra, matka víčat, je jednak sfarbená do čierna, táto farba je však zároveň alúziou na čiernu zreničku Modrého vlka: „Najvýraznejšia je však zrenička. Čierna zrenička!“‘ (Pennac 2016: 17). Rovnako sa zoznamujeme aj s Čačkou, víčat’om so zlatou kožušinou, sestrou Modrého vlka. Jej meno možno chápat’ ako alúziu na zlatú farbu, resp. ozdôbku, pričom zlatú farbu môžeme považovat' za farbu niečoho hodnotného či cenného. Čačka je tiež považovaná za najkrajšiu vlčicu s vel'mi dobre vyvinutými zmyslami.

Rodina Modrého vlka reprezentuje zvieratá a ich život, ktorý je neustále ohrozovaný l'ud'mi. Človek predstavuje pre zviera hrozbu, je stelesnením strachu: „Nie, ja chcem počut' o l'ud’och, ozajstný strašidelný príbeh.“ (Pennac 2016: 20). Vlci musia neustále utekat' pred pol'ovníkmi túžiacimi po vlčej kožušine, a tak žijú v ustavičnom 
strachu a napätí. Ich život, vol'nost' a sloboda, ktorá je pre zvieratá prirodzená a nevyhnutná, l'udia neustále ohrozujú. Táto skutočnost' vrcholí scénou, v ktorej je Čačka uväznená v sieti v pol'ovníckom tábore. Pol'ovníci Čačku chytili, vd'aka Modrému vlkovi sa jej však podarí vyslobodit'. Jeho obetavost' Čačku zachránila, on sa však dostáva do zajatia, do zoologickej záhrady. Práve po záchrane Čačky ostáva jedno oko vlka zatvorené.

Tretiu kapitolu s názvom L’udské oko tvorí príbeh chlapca zo ZOO. Rovnako ako vlk ukazoval svoje spomienky chlapcovi, ukazuje teraz chlapec svoje spomienky Modrému vlkovi: „A teraz sa premieňa chlapcovo oko. Ako vyhasnuté svetlo.“ (Pennac 2016: 43). Chlapca a vlka spája podobný životný príbeh. Obaja sú nútení odíst' zo svojho prirodzeného prostredia d'aleko od svojich blízkych. Chlapec zrejme v dôsledku vojny prichádza o svoju matku. Strata životnej istoty a bezpečného prostredia je v diele vyjadrená neustálymi zmenami, ktorými chlapec prechádza. L’udia v jeho blízkosti sa menia, prichádzajú a odchádzajú, a nedokážu chlapcovi poskytnút' oporu, ktorú potrebuje. Jedinou istotou a priatel'mi chlapca sú zvieratá, ktoré sa dostávajú do jeho blízkosti. Najprv je to Hrkálka, t’ava sebeckého obchodníka Tou, s ktorým chlapec strávi istý čas, neskôr je to gepard, ktorého stretáva pri práci u Kozieho král'a. Práve tu sa ukazuje chlapcovo bystré, dôvtipné a vel'mi múdre uvažovanie.

Vel'mi dôležitou súčast'ou života malého chlapca sú príbehy „o Žltej Afrike, o Sahare, o piesočnej krajine, o slnku, o samote, o škorpiónoch, o tichu.“ (Pennac 2016: 49), ktoré l'ud'om rozpráva. Ked’že chlapec je pre všetkých l'udí vôkol seba neznámy a nikto, ani on sám, nepozná jeho skutočné meno, dostáva meno podl'a príbehov o Afrike: „Toa, budeme tohto chlapca volat' Afrika.“ (Pennac 2016: 50). Rozprávaním a svojimi vedomost’ami chlapec pripomína múdreho a rozvážneho starca, ktorého rady majú skutočný význam a zmysel. Ani Toa, ani Kozí král' však nedokážu, ale predovšetkým nechcú dat' chlapcovi to, čo naozaj potrebuje - lásku a skutočný domov. Ten nachádza až u Papu a Mamy Biovcov, ku ktorým sa dostáva po autonehode: „A tak sa z neho stal Afrika N’Bia, najmladšie diet’a Papu a Mamy Biovcov.“ (Pennac 2016: 67). V tomto bode do deja vstupuje otázka ochrany životného prostredia a environmentálnych problémov. Neohl'aduplné zásahy človeka do prirodzeného prostredia zvierat, vyrúbané lesy či vel'ké sucho, nútia opustit' rodinu N'Bia svoj domov a odíst' do tzv. Inakšieho sveta. Autor tak detskému percipientovi opät' vel'mi jemne a nenútene vysvetl'uje problémy, ktoré trápia súčasný svet a ekológiu. Spôsob rozprávania, ktorý autor volí, pôsobí poučne, zároveň však vel'mi emotívne a dojímavo. Rovnako tu je naznačený problém migrácie $\mathrm{z}$ environmentálnych dôvodov.

Posledná kapitola diela s názvom Inakší svet je v podstate vysvetlením otázok, ktoré si počas čítania čitatel' kladie. Papa Bia sa zamestnáva v mestskej zoologickej 
záhrade, práve v tej, v ktorej sa Afrika zoznamuje s Modrým vlkom. Práve tu opät' stretáva stratené zvieratá - t’avu Hrkálku, Hyenu, Geparda či kozl’atá Kozieho krála. Táto skutočnost' pôsobí optimistickým dojmom štastného konca, zároveň však v sebe skrýva vel'mi silný odkaz s poučným charakterom. Kontrast slobody, vol’nej prírody a neobmedzeného pohybu s múrmi zoologickej záhrady je jasnou alúziou na utrpenie zvierat, ktorému sú vystavené. Detský percipient vd’aka vel'mi citlivo a pokojne podanému problému dokáže vnímat' a pochopit' alegoricky zakódované posolstvo $\mathrm{v}$ diele, ktoré vyznieva emotívne, nie však prehnane sentimentálne.

Záverečná kapitola diela je opät' venovaná vzt’ahu chlapca a Modrého vlka a ich vzácnemu putu. V podstate tu možno hovorit' o istom zarámovaní príbehu ${ }^{8}$. Prvá a posledná kapitola sa odohrávajú $\mathrm{v}$ rovnakom priestore - v zoologickej záhrade, pričom záverečná kapitola je akoby pokračovaním prvej. V súvislosti s týmito dvoma rámcujúcimi kapitolami je dôležité spomenút, že obe sa vpodstate odohrávajú v súčasnosti, zatial' čo pri ostatných kapitolách ide o retrospektívne rozprávanie chlapca a vlka. Ako sme spomenuli na začiatku, chlapec pri pohl'ade na vlka zatvára jedno oko, pričom následne mu vlk akoby dovolí vidiet' jeho životný príbeh. Na konci rozprávania má chlapec oko stále zatvorené. Každé ráno, už celé mesiace, otvára len jedno oko, čo si jeho noví rodičia, a dokonca ani lekár, nedokážu vysvetlit'. Nikto okrem Modrého vlka netuší, že zatvorené oko nesúvisí so žiadnou chorobou. V úplnom finále príbehu chlapec oko otvorí, ale až po tom, ako ho otvorí vlk. Chlapec tak svojím spôsobom donúti vlka otvorit' oko a presvedčí ho, že aj v zoologickej záhrade, mimo svojho prirodzeného prostredia má zmysel pozerat' sa na svet okolo seba oboma očami. Otvorené oči možno zároveň považovat' za akýsi symbol zahojenia starých rán, nový začiatok a pohlad vpred, do budúcna.

\section{Zhrnutie}

Obe analyzované diela sú určené pre detského, resp. adolescentného percipienta a zaoberajú sa pomerne vážnymi a aktuálnymi ekologicko-etickými témami a problémami. Predovšetkým je to problém ohrozenia životného prostredia, narúšanie prírodných biotopov človekom či zásahy človeka do prirodzeného prostredia živočíchov, ale aj vojna, hlavne v diele Lišiak Pax. Všetky tieto témy sú síce náročné a ich spracovanie si vyžaduje vel'mi opatrný a citlivý prístup vzhl'adom na ich adresnost', považujeme však za dôležité, aby sa s nimi postupne oboznamoval aj detský

\footnotetext{
8 „Zarámovanie je v podstate založené na paralelnom princípe, na paralelizmoch medzi začiatkom a koncom literárneho diela.“(Všetička 1986: 55).
} 
percipient. Zároveň však musíme podotknút, že tieto témy sú v oboch interpretovaných dielach spracované naozaj vel'mi jemne a taktne s ohl'adom na citlivý detský svet.

Čo sa týka protagonistov oboch príbehov, aj v diele Lišiak Pax, aj v diele Vlčie oko sa protagonisti nachádzajú mimo svojho bezpečného domáceho prostredia. Aj Peter, aj Afrika sú v podstate siroty. Obaja prichádzajú o svoju životnú istotu, pocit bezpečia a ochranu svojich rodičov. Môžeme teda konštatovat', že sa nachádzajú v hraničnej životnej situácii mimo svojho domova a svojich blízkych. To isté platí aj pri zvieracích protagonistoch oboch diel. Lišiak aj vlk sú nútení opustit' prostredie, na ktoré sú zvyknutí, je medzi nimi však zásadný rozdiel. Lišiak Pax sa síce dostáva do lesa, prirodzeného prostredia líšok, ked’že však nikdy nežil vo vol'nej prírode, predstavuje preňho značný problém prispôsobit' sa životu vo vol’nej krajine medzi ostatnými zvieratami. Postupne si však zvyká a finále príbehu je dôkazom, že zviera ako líška naozaj patrí do vol'nej prírody. Domovom Modrého vlka je Aljaška, vol’ný pohyb a sloboda preňho teda predstavujú nevyhnutnú a prirodzenú súčast’ života, čo ostro kontrastuje s výrazne obmedzeným pohybom v zoologickej záhrade. Môžeme konštatovat', že práve prostredníctvom zoologickej záhrady autor poukazuje na bezohl'adnost' človeka, ktorý často ignoruje právo zvierat na ich slobodu a vol'ný pohyb.

Ďalším spoločným znakom diel, ktorý súvisí so zásahom do prirodzeného prostredia zvierat, ale aj l’udí, je vojna. V diele Lišiak Pax hrá vojna pomerne dôležitú úlohu, pričom v diele Vlčie oko je spomenutá len vel'mi nepriamo. Vojna zásadným spôsobom zasahuje do života Petra, protagonistu diela Lišiak Pax. Ani v tomto diele však nemožno o vojne hovorit' ako o leitmotíve príbehu. Vojna v diele nie je zobrazená priamo (nejde o konkrétny vojnový konflikt naviazaný na konkrétny priestor), je potrebné chápat' ju v širšom kontexte, ako súčast' globálnych problémov sveta, ktoré majú nezvratné následky jednak na prírodu, prírodné biotopy, ale aj l'udské osudy. Aj vd’aka takejto koncepcii sa autorovi podarilo ešte viac zdôraznit' dôsledky, hrôzostrašné javy, ktoré s vojnou súvisia, jej dopad na bežného človeka, deti, osudy l'udí, zvierat a prírody.

V diele Vlčie oko možno v súvislosti s vojnou hovorit' o akejsi kulise, ktorá je tiež súčast'ou väčšieho problému. Aj tu sa poukazuje predovšetkým na jej následky.

Zaujímavo zobrazené sú zároveň aj vzt’ahy medzi postavami. Medzil’udské vzt’ahy a vzt'ahy v rodine tvoria pomerne dôležitú súčast' diela Lišiak Pax. Komplikovaný vzt’ah s otcom, ktorý uprednostní odchod na front pred svojím synom, či nie práve vrúcny vzt'ah so starým otcom, sú v diele príkladom narušených rodinných väzieb. Tieto zložité vzt’ahy s dospelými si Peter kompenzuje svojím neobyčajne 
blízkym vzt'ahom s lišiakom, ktorý preňho predstavuje jedinú istotu. Do popredia tu teda vystupuje vzt'ah človeka a zvierat'a, na ktorom je v podstate dielo vybudované.

O podobnej situácii môžeme hovorit' aj v diele Vlčie oko. Tu máme opät’ dočinenia so vzt'ahom človeka a zvierat'a. Chlapec si svojím blízkym spojením so zvieratami tiež v podstate kompenzuje absenciu dospelých vo svojom živote, nahrádzajú mu blízkost' a starostlivost' rodičov. Výnimočný je predovšetkým jeho vzt'ah s Modrým vlkom. Spojenie, ktoré medzi nimi vzniká, im obom pomáha zabudnút' na útrapy minulosti a vnímat' krásy, ktoré život ponúka. Vzt’ah človek - zviera je však v týchto dvoch spomínaných dielach zobrazený odlišne. V diele Vlčie oko by sme mohli hovorit' o istom tajomnom, magickom a rozprávkovom stvárnení tohto vzt'ahu, kdežto v diele Lišiak Pax puto medzi lišiakom a Paxom pôsobí reálnejšie, aj ked' má v sebe tiež istý náznak rozprávkovosti. V súvislosti s dielom Vlčie oko môžeme celkovo hovorit' o magickejšom vyznení diela. $V$ tomto diele sú použité fantastické a rozprávkové prvky, a to predovšetkým v súvislosti s okom vlka a chlapca, prostredníctvom ktorého je ich príbeh vyrozprávaný.

\section{Summary}

Our work describes extreme life situations and their depictions in prose for children and youth. We will focus on extreme life situations like war, death, loss of the close person, isolation and also environmental and ecological problems. On the basis of the interpretation of proses from American writer Sara Pennypacker Pax and French writer Daniel Pennac The Eye of the Wolf we will show, what kind of serious topics and motives can appear in the literature for children and youth and also how the world of people and the world of animals intertwine in these stories.

\section{Literatúra}

Dorul'a, J. et al. Krátky slovník slovenského jazyka. Bratislava: Veda, 2013.

Pennac, D. Vlčie oko. Bratislava: NM CODE \& Asociácia Corpus, 2016.

Pennypackerová, S. Lišiak Pax. Bratislava: Ikar, a. s. - Stonožka, 2017.

Všetička, F. Kompoziciána: o kompozičnej výstavbe prozaického diela. Bratislava: Slovenský spisovatel', 1986. 


\section{Internetové zdroje}

Čačko, L. Osamelý lovec. Dostupné na: https://www.quark.sk/osamely-lovec/ (202102-24).

Danniel Pennac. Dostupné na: https://www.databazeknih.cz/zivotopis/daniel-pennac1598 (2021-02-24).

Danniel Pennac. Dostupné na: https://www.walker.co.uk/contributors/Daniel-Pennac5717.aspx (2021-02-24).

Liška obecná - skrytě žijicí lovec. Dostupné na: https://ekolist.cz/cz/publicistika/ priroda/liska-obecna-skryte-zijici-lovec (2021-02-24). 


\section{KOMUNIZM JAKO RELIGIA. ODZWIERCIEDLENIE MYŚLI MIKOLAJA BIERDIAJEWA W UTWORZE SWIETLANY ALEKSIJEWICZ „CZASY SECONDHAND. KONIEC CZERWONEGO CZLOWIEKA"}

\section{Communism as a Religion. The Reflection of Nicolai Berdyaev's Thoughts in the Piece Svetlana Alexievich's "Secondhand Time. The Last of the Soviet"}

Keywords: communism, Russian philosophy, religion, perestroika, homo sovieticus, faith, atheism

Contact: Ostravská univerzita; jolagren@interia.pl

„, Człowiek jest zwierzęciem religijnym i kiedy neguje istnienie prawdziwego Boga, wówczas tworzy sobie fałszywych bożków, idoli, którym oddaje pokłon."

M. Bierdiajew

Mikołaj Bierdiajew jest najbardziej znanym (Łosski 2000: 262) i jednym z najwybitniejszych współczesnych filozofów rosyjskich (Smaga 2002: 57). Myśl filozoficzna Bierdiajewa została ukształtowana przez ufundowaną na prawosławiu kulturę rosyjską, która za życia myśliciela rozpadła się, została wyparta przez idee rewolucji 1917 roku i komunizm, który zaczęto budować tuż po niej. Bierdiajew, będąc już na emigracji ${ }^{1}$, uważnie śledził rozwój wypadków w Rosji i komentował je w swoich pracach. W Źródłach i sensie rosyjskiego komunizmu $(1937)^{2}$ dokładnie przeanalizował historyczne, społeczne i kulturowe uwarunkowania, które uczyniły możliwym „przeszczepienie” idei komunistycznej na rosyjski grunt. We wspomnianej książce przekonywał, że problem socjalizmu i komunizmu w stosunku do chrześcijaństwa

\footnotetext{
${ }^{1}$ Budując nowy ustrój polityczny konstruktorzy Związku Radzieckiego wprowadzili w 1929 roku drakońskie prawo ograniczające działalność Cerkwi. Nieco wcześniej, bo w 1922 r. wypędzono za granicę najwybitniejszych rosyjskich myślicieli religijnych, w tym właśnie Bierdiajewa, Siemiona Franka czy Siergieja Bułhakowa (Smaga 2002: 56-57).

${ }^{2}$ Tytuł oryginału: Истоки и смысл русского коммунизма (1937). Cytaty w niniejszej pracy pochodzą z polskiego wydania książki: Źródła i sens rosyjskiego komunizmu. Kęty: wydawnictwo ANTYK 2005.
} 
rugowanego z porewolucyjnej rzeczywistości wymaga szczegółowego omówienia (Bierdiajew 2005: 116). Myśliciel uważał, że „wrogi stosunek komunizmu do każdej religii nie jest przypadkowym zjawiskiem, wrogość ta należy do samej istoty światopoglądu komunistycznego. Państwo komunistyczne jest dyktaturą światopoglądu (...)" (Bierdiajew 2005: 116). Filozof był przekonany - i, jak pokazuje historia XX wieku, słusznie - że komunizm nie reprezentuje sobą tylko idei proponującej rozwiązania dla życia społecznego; okazał się on fanatycznym przeciwnikiem wszelkiej innej, zwłaszcza religijnej, wizji świata. Bierdiajew pisze, że „komunizm sam chce być religią i zastąpić chrześcijaństwo, pretenduje do tego, by dać odpowiedź na problemy o charakterze religijnym, nadać sens życiu" (Bierdiajew 2005: 116). Rosyjski uczony uważa zatem komunizm za zjawisko integralne, chcące ogarnąć wszystkie dziedziny życia oraz ekskluzywne, dlatego jego walka $\mathrm{z}$ innymi wierzeniami religijnymi była nieunikniona ${ }^{3}$. Komuniści nie uważali religii za kwestię prywatną czy sprawę wyboru sumienia, lecz za sprawę społeczną. Bierdiajew pisze, że komunizm przyjął charakter totalitarny, traktując religię jako sprawę partii, państwa i komunistycznego społeczeństwa: autentyczny komunista nie może być człowiekiem religijnym, nie może być chrześcijaninem - jego światopoglądem powinien być materializm i wojujący ateizm, bowiem wyznawanie określonego programu społecznego to za mało, komunizm oznacza bowiem wyznawanie określonej wiary, przeciwstawnej chrześcijaństwu (Bierdiajew 2005: 118-120). Komuniści lubili podkreślać, że są przeciwnikami moralności chrześcijańskiej i takie rozumienie porewolucyjnego systemu dominuje w sowieckiej literaturze. Bierdiajew pisze, że ów silny sprzeciw wobec moralności chrześcijańskiej, ewangelicznej miłości i współczucia jest najstraszniejszym elementem myśli komunistycznej, zaś sama partia stała się ,rodzajem sekty ateistycznej, religijnej sekty ateistycznej” (Bierdiajew 2005: 122). Rosyjski myśliciel podkreśla, że wszelkie rozważania (teoretyczne, ideowe, społeczne, polityczne czy ekonomiczne) mają w porewolucyjnej Rosji charakter ortodoksyjny i heretycki, „tymczasem rozróżnienie pomiędzy ortodoksją a herezją ma charakter religijny, teologiczny, a nie filozoficzny i polityczny. Kiedy polityka występuje pod sztandarem ortodoksji, to państwo traktowane jest jako Kościół i nieuniknione są prześladowania za wierzenia i poglądy. Tak się działo w średniowiecznej teokracji chrześcijańskiej, tak samo dzieje się w teokracji komunistycznej, sowieckiej, jak również w Trzeciej Rzeszy Hitlera,

\footnotetext{
3 Warto zaznaczyć, że ideologowie porewolucyjnej Rosji korzystali z myśli Marksa, jednak bardzo ją zniekształcili, a nawet - szczególnie W. Lenin - zwulgaryzowali. Bierdiajew pisze o Leninie, że był „geniuszem wulgarności” (Bierdiajew 2005: 118), który zwulgaryzował i sprymitywizował idee Marksa, dla którego problem religijności był kwestią zmiany świadomości, podczas gdy dla wodza rewolucji październikowej problem religii był wyłącznie kwestią walki rewolucyjnej i jej był podporządkowany. Nienawidzący religii Lenin stał się w opinii Bierdiajewa „klechą bez sutanny”, głosicielem „wiary w ateizm” (Bierdiajew 2005: 119).
} 
i w każdym państwie, które pretenduje do tego, by być państwem totalitarnym" (Bierdiajew 2005: 124).

Funkcje Kościoła przeniósł na państwo Iwan Groźny, wyznający ideę prawosławnego królestwa, w którym władca jest odpowiedzialny za zbawienie dusz poddanych. Podobne zadanie stawia przed sobą, jak pisze Bierdiajew, władza komunistyczna, która chce swą ludność „wychować w jednej zbawiającej prawdzie, jaką jest prawda materializmu dialektycznego" (Bierdiajew 2005: 124). Nic więc dziwnego, że nienawiść komunistów skierowana ku chrześcijaństwu zawiera w sobie sprzeczność, której nie są w stanie dojrzeć sami komuniści: „najlepszy typ komunisty, czyli człowieka całkowicie oddanego służbie dla idei, zdolnego do ponoszenia ofiar i do bezinteresownego entuzjazmu jest możliwy wyłącznie dzięki chrześcijańskiemu wychowaniu" (Bierdiajew 2005: 125). Trzeba podkreślić, że rosyjski myśliciel uważa ów wpływ na dusze ludzkie za ukryty, często niezauważalny, jednak pozostający w ludziach nawet gdy świadomie rezygnują z chrześcijaństwa i zajmują wobec niego wrogie pozycje ${ }^{4}$. Filozof twierdzi, że w przypadku całkowitego wykluczenia chrześcijaństwa i jego wpływów z życia duchowego i społecznego zrealizowanie komunizmu w Rosji nie byłoby możliwe - któż bowiem chciałby ponosić ofiary w imię służenia metaosobowemu celowi? ${ }^{5}$ (Bierdiajew 2005: 125).

Postrzegając komunizm jako ideę chcącą urzeczywistnić sprawiedliwość społeczną i braterstwo drogą przymusu i musztry, Bierdiajew akcentuje w tym procesie fakt odmawiania człowiekowi prawa do osobowości i indywidualności ${ }^{6}$, „Cała ograniczoność i fałsz filozofii komunistycznej wiążą się z niezrozumieniem problemu osoby, co przekształca komunizm w siłę dehumanizującą, wrogą człowiekowi. Ze

\footnotetext{
${ }^{4}$ To przekonanie wiąże się z myślą Aarona Guriewicza o kategoriach kulturowych oraz ich przechodzeniu z pokolenia na pokolenie. Kategorie kulturowe postrzegał Guriewicz jako ,pojęcia i formy postrzegania rzeczywistości, jak czas, przestrzeń, zmiana, przyczyna, los, liczba, stosunek części do całości (...)” (Guriewicz 1976: 17). Każda kultura splata te uniwersalne pojęcia w swoisty „układ współrzędnych”, „model świata”, za pośrednictwem którego ludzie postrzegają świat i konstruują swój jego obraz. Percepcja tych wartości uczestniczy w kształtowaniu wartości zgodnie $\mathrm{z}$ wewnętrznym doświadczeniem, a same kategorie występują jako „poprzedniczki idei i światopoglądu kształtującego się u członków społeczeństwa lub poszczególnych jego grup” (Guriewicz 1976: 18). Badacz podkreśla, że stwierdzenie, iż pewne pojęcia są obowiązujące dla całego społeczeństwa nie oznacza żadnej formy przymusu - mowa tu o nieświadomym narzucaniu przez społeczeństwo i równie nieświadomej percepcji tych kategorii i wyobrażeń przez członków danej grupy społecznej (Guriewicz 1976: 18). Do kategorii kulturowych należą m.in. cierpienie i ofiara, soborowość, kolektywizm czy los.

${ }^{5}$ Efektem takiej postawy, zdaniem Bierdiajewa, byłoby zwycięstwo typu egoisty myślącego wyłącznie o swoim dobru - co, jak wiemy z historii, przydarzyło się partii komunistycznej i jej członkom: z biegiem lat ideowcówkomunistów zastapili pragmatycznie myślący sekretarze (Smaga 2002: 195-233).

${ }^{6} \mathrm{~W}$ przekonaniu Bierdiajewa niedostrzeganie dwuwymiarowości oddziaływania Kościoła na ludzi (duchowego i społecznego) i akcentowanie wyłącznie wpływu społecznego sprawiło, że komuniści zatracili zdolność do rozróżniania tego, co indywidualne. Fakt ten znacząco wpływa na kierunek i dynamikę rozwoju idei totalitarnej w ZSRR (Bierdiajew 2005: 129-130).
} 
społeczeństwa, społeczeństwa socjalistycznego, z klasy społecznej, proletariatu, czyni się bożka, idola, neguje się natomiast realnego człowieka" (Bierdiajew 2005: 130).

Dehumanizacja i traktowanie człowieka jako środka do osiągnięcia celu to wyraźne cechy komunizmu - Bierdiajew wskazuje tu demoniczny element myśli marksistowskiej obecny w poglądach komunistów, nazywany dialektyką: „zło dialektycznie przechodzi w dobro, ciemność w światłość" (Bierdiajew 2005: 134). Lenin za moralne uważał bowiem wszystko, co sprzyjało rewolucji proletariackiej, dla niego celem nie była ani pełnia życia społecznego, ani człowieczeństwa, lecz organizacja społeczeństwa, dlatego to, co stare (burżuazyjne, prawosławne) - musiało zostać zniszczone. Bierdiajew, rozważając zagadnienie fanatyzmu, braku tolerancji, okrucieństwa i przemocy komunistów oraz ich stosunku do przeszłości wysnuwa wniosek, że burżuazja, prawosławie czy kapitalizm musiały się stać naczelnymi wrogami socjalizmu, bo „komunista nie może żyć bez wroga”, bez negatywnych uczuć do niego ,traci patos. (...) Jeśli wroga nie ma to trzeba go wymyślić” (Bierdiajew 2005: 135).

Jak wiadomo z historii ZSRR, komuniści postawili sobie za cel nie tylko budowę nowego typu społeczeństwa, ale również konstrukcję nowego człowieka ${ }^{7}$, który do dziś określany jest mianem 'homo sovieticus ${ }^{9}$. Bierdiajew również na ten problem zwraca uwagę i podkreśla, że komunizm nie dysponuje dostateczną siłą duchową, by móc ukształtować wartościową jednostkę. Jednocześnie - co może wydawać się zaskakujące - myśliciel uważa, że „komunizm rosyjski jest bardziej tradycyjny, niż się zazwyczaj sądzi, jest transformacją i deformacją dawnej rosyjskiej idei mesjanistycznej”". (Bierdiajew 2005: 137) Właśnie tradycje płynące z kultury, historii i duchowości rosyjskiej uwarunkowały totalność pojmowania i determinację we wprowadzaniu idei w życie - idei, mającej pokazać kierunek całemu światu; idei, pretendującej na to, aby dać odpowiedź na wszystkie ludzkie pytania - w tym o sens życia i cierpienia. Zdaniem Bierdiajewa to właśnie tradycja rosyjska predestynowała komunizm do roli religii, jaką stał się w ZSRR ${ }^{10}$.

Problem wpływu idei komunistycznej na życie ludzkie podjęła w swej książce Swietłana Aleksijewicz, białoruska pisarka nagrodzona w 2015 roku Literacką Nagrodą

\footnotetext{
${ }^{7}$ Za pierwszego ,inżyniera dusz” uchodził Maksym Gorki.

8 Pojęcie to wprowadził Aleksander Zinowjew w swoim studium mentalności sowieckiego człowieka zatytułowanym Homo sovieticus (1982).

${ }^{9}$ Bierdiajew uważa, że w Europie Zachodniej komunizm będzie nieco innym zjawiskiem, niż w Rosji - jego charakter może być mniej despotyczny i mniej integralny, a nieco bardziej zsekularyzowany (Bierdiajew 2005: 135).

${ }^{10}$ Zagadnienie jest dużo szersze i złożone, na potrzeby tej pracy pewne zjawiska są tylko sygnalizowane. Bierdiajew szczegółowo wyjaśnia je również w książce Idea rosyjska (Warszawa 1999); ros. Русская идея (Париж 1946).
} 
Nobla. W powieści Czasy secondhand. Koniec czerwonego człowieka (2018) zawarła dziesiątki opowieści ludzi urodzonych, wychowanych i ukształtowanych przez ZSRR. Krach państwa i jego wartości dotknął wszystkich rozmówców pisarki, a ich relacje układają się w spójny obraz państwa, które z idei uczyniło religię, a z obywateli - jej wyznawców. Aleksijewicz przyjmuje ciekawą perspektywę spotkań ze swymi rozmówcami: „Cywilizacja radziecka... Spiszę się, by utrwalić jej ślady. Znajome twarze. Wypytuję nie o socjalizm, ale o miłość, zazdrość, dzieciństwo, starość. O muzykę, tańce, fryzury. O tysiące szczegółów życia, które zniknęło. To jedyny sposób, żeby zapędzić katastrofę w ramy czegoś zwykłego i spróbować coś opowiedzieć" (Aleksijewicz 2018: 11).

Z tej tkanki codzienności, o jakiej opowiadają bohaterowie wyłaniają się zręby funkcjonowania państwa totalitarnego i systemu antywartości, w odniesieniu do których sowiecki człowiek definiował siebie, cel swojego życia, plany i pragnienia. Warto podkreślić, że noblistka celowo oddaje głos ludziom, na oczach których zawalił się ZSRR, a oni sami - zostali postawieni wobec konieczności odnalezienia się w trudnym okresie pieriestrojki. Dlatego wypowiedzi, które czytamy w Czasach secondhand są pełne emocji - rozgoryczenia, żalu, buntu wobec dynamicznych zmian, poczucia sieroctwa i klęski.

Przez cały tekst Aleksijewicz (liczy on 508 stron) jak mantra przewijają się płynące z ust wielu rozmówców zapewnienia, że wierzyli w komunizm: „kiedy wierzyłem w komunizm, nie potrzebowałem cerkwi” (Aleksijewicz 2018: 43), „nasza babcia nie wierzyła w Boga, wierzyła w komunizm” (Aleksijewicz 2018: 49), „nasza wiara była szczera i ...naiwna” (Aleksijewicz 2018: 68), zaś sama partia - „wydawała się wieczna" (Aleksijewicz 2018: 66). To partia organizowała życie, odpowiadała za system wartości, jakimi powinni się kierować komuniści. Lenin i Stalin postrzegani są przez opowiadających jak bogowie - dla Boga nie było miejsca w ZSRR: „O Bogu wiedzieliśmy jedno: że go nie ma. Śmialiśmy się z popów, w domu rąbaliśmy ikony (...) Marksizm stał się naszą religią." (Aleksijewicz 2018: 186) W innym miejscu 87-letni komunista powie: „Byłem szczęśliwy, że żyłem w tym samym czasie co Lenin (...) Lenin był ikoną, Bogiem!” (Aleksijewicz 2018: 187) Wierzono nie tylko w Lenina i Stalina, ale również w partię - tak początki walki rewolucyjnej wspomina zasłużony jej członek: „Dla nas słowo 'miłosierdzie' pasowało do popów. Bij białą gadzinę! Zaprowadzimy rewolucyjny porządek! Hasło pierwszych lat rewolucji: żelazną dłonią zapędzimy ludzkość do szczęścia! Skoro partia mówi, to ja wierzę partii! Wierzę" (Aleksijewicz 2018: 189) .

Portrety uznanych za bogów przywódców otaczano w ZSRR kultem, ich imiona - czcią, a doktrynę uznawano za świętość, wobec której i rodzicielska miłość okazywała 
się bez wartości. Jedna z bohaterek wspomina: „Pewna moja znajoma tak się pożarła z synem i synową o Lenina, że wypędziła ich na ulicę, mieszkali więc za miastem w nieogrzewanej daczy" (Aleksijewicz 2018: 67). Sakralny charakter zyskały pieśni rewolucyjne, pionierskie i komsomolskie, a pośród nich najważniejszy był radziecki hymn. Przysięgano na „największe świętości”: „słowo pioniera”, „na Lenina”, największą rangę miało jednak "słowo stalinowskie” (Aleksijewicz 2018: 53). Do przedmiotów sacrum zaliczano też czerwony sztandar, pionierską chustę i znaczek oraz, oczywiście, legitymację partyjną, zaś sierp i młot wykuwano na nagrobkach. Słowo, mające moc kreacji, należało do partii reprezentującej władzę radziecką, która „wydawała się wieczna” (Aleksijewicz 2018: 66), a jej dyrektywy miały porządkujący i ukierunkowujący myślenie charakter. Dzięki hasłu: „Partia kieruje!” wierzono, że „dzieło Lenina przetrwa na wieki” (Aleksijewicz 2018: 65).

Szczególną rangę dla rozmówców Aleksijewicz mają socjalistyczne święta, dające okazję do uniesień i zachwytu. Jedna $\mathrm{z}$ bohaterek z rozrzewnieniem wspomina „olśniewające parady gimnastyków, splecione z żywych ciał i kwiatów nazwiska na placu Czerwonym: Lenin i Stalin.” (Aleksijewicz 2018: 108) Sam plac Czerwony - serce sacrum, do którego należało się udać „i pokłonić” (Aleksijewicz 2018: 101).

Powinności obywatela radzieckiego wyznaczała nie tylko partia, ale również radzieccy bohaterowie - komunistyczni ,święci”. W przytoczonych przez pisarkę opowieściach pojawia się nazwisko Pawlika Morozowa, którego postawa wyznaczała standardy moralne w ZSRR: „Tak! Jak Pawlik Morozow... Byłam w stanie donieść na własnego ojca... na matkę... Mogłam... Tak! Byłam gotowa!” - powie jedna z rozmówczyń Aleksijewicz.

Z wypowiedzi bohaterów wyłania się obraz komunizmu, o jakim mówił Bierdiajew - integralny, będący nie tylko propozycją ułożenia stosunków społecznych, ale pretendujący do tego, by stać się jedynym światopoglądem i jednocześnie przedmiotem wiary, a nie racjonalnych dociekań czy dyskusji. Prawdziwą okazała się również refleksja myśliciela o tym, że bez chrześcijańskiego pojmowania idei ofiary urzeczywistnienie komunistycznej wizji nie byłoby możliwe. Jak wynika z wypowiedzi bohaterów, są oni świadomi ofiar, jakie poniósł naród (głód na Ukrainie, łagry, Wielka Wojna Ojczyźniana), zdają sobie również sprawę z ich konieczności: „wielka idea potrzebuje krwi” - stwierdzi jedna z rozmówczyń Aleksijewicz. Poświęcenie, cierpienie, heroiczna praca i oczekiwanie nagrody w przyszłości - oto pobudki działań radzieckich ludzi: „Myśmy tak wierzyli! Wierzyli, że kiedyś będzie nam się dobrze żyło. Poczekaj, pocierp... Całe życie po koszarach, po hotelach robotniczych, po barakach" (Aleksijewicz 2018: 97) - wspomina bohaterka, która całą młodość spędziła na największych budowach radzieckich. Poświęcenie i altruizm były ukierunkowane nie 
tylko na partię i jej cele, ale również na zwykłych obywateli, którzy - pamiętając nomenklaturę religijną - tak werbalizowali swoje marzenia i działania: „Pragnęliśmy zbudować Królestwo Boże na ziemi. (...) od Pugaczowa po Lenina wszyscy marzyli o równości i braterstwie" (Aleksijewicz 2018: 183). Wartością w ZSRR była idea komunizmu i walka o jej urzeczywistnienie oraz zasada braterstwa i jedności. Jak jednak czytamy w powieści Aleksijewicz, oddanie idei przy jednoczesnym odmówieniu jednostce prawa do osobowości i indywidualności, o którym pisze Bierdiajew, skutkuje powstaniem dehumanizujących i niszczących człowieka zjawisk. Jeden z bohaterów mówi tak: „Socjalizm to nie tylko łagry, donosy i żelazna kurtyna, ale także sprawiedliwy, jasny świat: ze wszystkimi się dzielić, litować się nad słabszymi, współczuć, nie garnąć wszystkiego dla siebie” (Aleksijewicz 2018: 57) .

Wspomniana przez Bierdiajewa droga przymusu i musztry uwidoczniała się w realizacji idei komunistycznej przez ponad 70 lat trwania ZSRR. Trafność spostrzeżeń myśliciela na temat komunizmu jako religii wyłania się ze wszystkich zebranych przez Swietłanę Aleksijewicz opowieści. Wynika z nich jasno, że traktowali oni komunizm jak religię, która po rewolucji w 1917 roku winna była zastąpić chrześcijaństwo. Myśl Lenina i jego kontynuatorów pretendowała do tego, by dawać sowieckim ludziom odpowiedzi nie tylko na pytania o porządek społeczny, ale rozstrzygała problemy o charakterze religijnym i decydowała o tym, jak nadać życiu sens.

\section{Summary}

Nikolai Berdyaev in The Origin of Russian Communism (1937) analyzed the historical, social and cultural conditions that made it possible to "transplant" the communist idea into Russian basis. The philosopher understands communism as a kind of "atheistic religious sect", which is at the same time a transformation and deformation of the old Russian Messianic idea. In the novel Seconhand Times. The End of the Red Man Svetlana Alexievich presented the implementation of the idea of communism and its impact on human's life and spirituality. It shows that communism not only controlled the social order, but also settled the problems of morality and faith.

\section{Literatura}

Aleksijewicz, S. Czasy secondhand. Koniec czerwonego człowieka. Wołowiec: Czarne, 2018.

Bierdiajew, M. Źródła i sens komunizmu rosyjskiego. Kęty: ANTYK, 2005. 
Jolanta GREŃ

Komunizm jako religija. Odzwierciedlenie myśli Mikołaja Bierdiajewa w utworze Swietłany Aleksijewicz „Czasy secondhand. Koniec czerwonego człowieka”

Bierdiajew, M. Rosyjska idea. Warszawa: Fronda 1999.

Billington, J. Ikona i topór. Historia kultury rosyjskiej. Kraków: Wydawnictwo Uniwersytetu Jagiellońskiego 2008.

Guriewicz, A. Kategorie kultury średniowiecznej. Warszawa: Państwowy Instytut Wydawniczy 1976.

Losski, M. Historia filozofii rosyjskiej. Kęty: ANTYK, 2000.

Smaga, J. Rosja w 20. stuleciu. Kraków: Znak 2002. 


\section{ŠPECIFIKÁ SERIÁLOVÝCH ADAPTÁCIÍ ROMÁNU ${ }^{1}$}

\section{Specifics of Serial Adaptation of the Novel}

Keywords: serial adaptation, classic novel adaptations, serie, novel, Anna Karenina

Contact: Univerzita Pavla Jozefa Šafárika v Košiciach; gabi.homolova@gmail.com

Literatúra zohrala dôležitú úlohu nielen pri zrode kinematografie, ale aj televízie. Adaptácie literárnych diel sa podiel'ali na formovaní televízneho vysielania, v ktorom sa ako jeden zo základných televíznych programov udomácnil aj seriál, ktorý bol bud’ pôvodný, napísaný priamo pre televíziu, alebo podobne ako film čerpal námety $\mathrm{z}$ literatúry. $\mathrm{V}$ druhom prípade seriál predstavuje osobitý priestor najmä pre adaptovanie rozsiahlejšej literárnej predlohy, akou je napríklad románové dielo, ked’že v porovnaní s filmom sú časové možnosti seriálu na prvý pohl’ad neobmedzené.

Seriál ako ,viacčast'ové dielo vytvárajúce uzavretý celok, zverejňované alebo vysielané v istých časových intervaloch“ (Mrlian 1990: 308) nie je novinkou, ktorá sa objavila so vznikom televízie. Jeho predchodcov nájdeme napríklad v románoch na pokračovanie uverejňovaných v novinách v 2. polovici 18. storočia, ale aj v starovekej či stredovekej epike (prednes dlhého eposu po častiach). Po rozšírení televízie do domácností po 2. svetovej vojne sa seriál stal jedným z dominantných naratívnych žánrov televíznej masmediálnej produkcie. Postupne sa prispôsobil aj jeho vysielací čas a periodicita: ,„popri každodenných (či obdenných) soap operách sa objavujú aj seriály s týždennou periodicitou a ich hlavný vysielací čas sa presúva do najsledovanejších častí dňa, tzv. prime-timu, teda do podvečerných a večerných hodín.“ (Rusnák 2010: 223). Napriek tomu, že staršia literatúra za seriál považuje „dielo pozostávajúce najmenej zo šiestich častí (ostatné sú ako troj, štvor, či pät’dielne inscenácie, hry alebo filmy“ (Mrlian 1990: 380), uprednostňujeme terminológiu, ktorú používa Kokeš, ktorý ho definuje ako „fikční audiovizuální dílo složené z více než dvou epizod (seriálových dílů), které mají

\footnotetext{
${ }^{1}$ Príspevok je súčast'ou riešenia grantového projektu APVV-19-0244 Metodologické postupy v literárnovednom výskume s presahom do mediálneho prostredia. Zodpovedný riešitel': prof. PhDr. Ján Gbúr, CSc. Doba riešenia: 2020-2024.
} 
společné znaky a tvoří makrostrukturu seriálu - a to nezávisle na tom, jestli epizody na sebe navazují nebo sa vzájemně variují.“" (Kokeš 2011: 228).

Je dôležité spomenút', že seriál v súčasnosti už nie je iba výsadou televízneho vysielania. V posledných rokoch sa začínajú stierat' hranice medzi televíznou a filmovou produkciou a pri sledovaní seriálu niekedy nadobúdame pocit sledovania viacdielneho filmu. Vznikajú rôzne streamovacie platformy ako Netflix, Amazon Prime, HBO GO a pod., ktoré bud' prinášajú podobne ako televízia v pravidelnom čase novú epizódu, alebo vydávajú všetky epizódy celej série naraz. Staré princípy uvažovania o seriáloch preto nemôžeme v súčasnosti považovat' za stopercentne platné. Zmenili sa totiž nielen technologické možnosti, ale aj vkus mediálneho publika. Vplyv spoločenských trendov sa odráža najmä na tvorbe mediálnych produktov určených pre široké publikum, a teda ho môžeme pozorovat' aj v súčasných seriáloch, medzi ktorými majú špecifické miesto aj seriálové adaptácie.

Pod termínom seriálová adaptácia máme na mysli audiovizuálne dielo seriálového typu, ktoré vzniklo na základe literárnej predlohy, pričom informácia, že ide o adaptáciu, nemusí byt' divákovi explicitne podaná vo forme úvodných titulkov. Najmä tvorcovia súčasných seriálových adaptácií nie vždy upozorňujú na vzt’ah s iným dielom a v prípade úspechu prvej série vytvárajú série, ktoré s prototextom už zvyčajne nesúvisia, prípadne z neho preberajú iba niektoré prvky, napríklad postavy. Opačne je to pri tzv. klasických románových adaptáciách, pri ktorých sa podl’a Zatloukalovej (2011) najzretel'nejšie prejavujú špecifické znaky seriálových adaptácí́. Ide o označenie seriálových adaptácií klasických románov 19. a začiatku 20. storočia. Informácia, že ide o adaptáciu, je v prípade klasických románových adaptácií priznaná hned’ na začiatku v úvodných titulkoch a počas celého trvania diela môže divák pozorovat' výraznú spätost' s literárnou predlohou. Pri tomto type seriálových adaptácií zostáva dôležitý verbálny aspekt diela, pričom dialógy postáv sú často prevzaté s minimálnymi zmenami. Dôraz je kladený na postupné vykreslenie vzt'ahov medzi postavami. (Cardwell 2007) Vzhl'adom na kultúrny a technologický vývoj sa postupne upúšt’a od snahy dodržat' čo najväčšiu vernost' voči predlohe, avšak aj nad’alej si tento typ adaptácií zachováva svoju žánrovú identitu, a to aj napriek tomu, že: „nově vznikající adaptace vycházejí poměrně radikálními změnami ve formátu a stylu seriálu vstř́c požadavkům publika ovlivněného ostatními televizními žánry i filmovou tvorbou.“ (Zatloukalová 2011: 221).

So seriálom úzko súvisí aj termín séria, ktorá má podobné črty, a taktiež sa používa na označenie viacdielneho textu. Na rozdiel od seriálu jej jednotlivé časti vytvárajú autonómny celok, pričom každú čast' možno uvádzat’ aj samostatne. Častým dôvodom pre vznik série je úspech diela, ktoré sa stalo inšpiráciou na vytvorenie pokračovania (Mrlian 1990: 380). Pod termínom séria však môžeme chápat’ aj seriálový 
rad, teda súbor viacerých epizód vytvárajúcich uzavretý celok, ktorý môže, ale nemusí navodzovat' potrebu pokračovania deja. Aj v tomto prípade vznik d’alšej série (seriálového radu) často súvisí s ekonomickou situáciou, sledovanost'ou a úspechom u publika. Ďalším seriálovým typom, ktorý sa teší obl'ube divákov, je miniséria. Miniséria predstavuje naratívnu formu, ktorú môžeme prirovnat' k viacdielneho filmu. Jednotlivé časti na seba priamo nadväzujú a nasledujúca epizóda pokračuje tam, kde predchádzajúca skončila. V epizódach sa nezvyknú prezentovat' samostatné príbehy, ale dejová línia prekračuje hranice jednotlivých epizód. Pre potreby tohto príspevku budeme seriálovými adaptáciami označovat' viacdielne audiovizuálne diela ako seriál, tak aj minisériu, ktoré vznikli na základe literárnej predlohy.

\section{K adaptáciám románu Anna Kareninová}

Lev Nikolajevič Tolstoj je známy predovšetkým ako tvorca vel'kých epických foriem, a ked’že sa seriál svojím charakterom približuje rozmernej epickej próze, vybrali sme si na analýzu práve jeden z románov tohto autora. Anna Kareninová patrí medzi diela, ktorých počet adaptácií (filmových, seriálových, divadelných a pod.) sa pohybuje $\mathrm{v}$ desiatkach. Vychádzajúc z terminológie Aujezdského (2006), ktorý adaptácie rozdel'uje na základe vzt’ahu k predlohe na 3 typy: adaptácie verné predlohe, adaptácie s tvorivým vkladom scenáristu a adaptácie na motívy, by sme mohli väčšinu filmových adaptácií románu Anna Kareninová označit’ ako adaptácie verné predlohe, v ktorých je však najväčší priestor venovaný dejovej línii súvisiacej s Annou. Druhá dominantná línia opisujúca život Levina je zvyčajne zobrazená iba niekol'kými scénami, ktoré by sme v prototexte mohli označit' za tzv. jadrové udalosti príbehu. Aby sme podl'a Pašteku správne pochopili tento román musíme ho chápat' „, celej zložitosti tematickopersonálnej výstavby, ako kompozične jednotný útvar s niekol'kými tematickosujetovými plánmi. Tieto plány nie sú od seba oddelené, naopak, navzájom mnohonásobne pospájané, mnohostranne poprepletané.“ (Pašteka 2005: 136). Pre súčasného čitatel'a sa však niektoré pasáže súvisiace s Levinom opisujúce najmä jeho filozofovanie nad životom, hospodárske projekty, pol'ovačky či vol'by môžu zdat' retardačné a nezaujímavé, preto sú vo väčšine adaptácií tieto scény oklieštené alebo úplne eliminované.

V príspevku sa detailnejšie zameriame na štyri seriálové adaptácie tohto románu, všetky s rovnomenným názvom Anna Kareninová. Zhodnotíme, či rovnako ako pri filmových adaptáciách, sa snažili tvorcovia o čo najvernejšie dodržanie predlohy a či sa im podarilo preniest' dielo na obrazovky bez výraznejších zásahov do pôvodného príbehu, zároveň si budeme všímat', do akej miery využili režiséri výhody seriálového 
spracovania vzhl’adom na priblíženie druhej dominantnej línie súvisiacej s Levinom, a ked’že v prototexte Anna umiera v závere 7. časti románu a román pokračuje bez nej 8. čast'ou, vktorej čitatel' nachádza ideové vyústenie diela skrz postavu Levina, pozornost' upriamime taktiež na záverečné scény seriálových spracovaní.

\section{Anna Kareninová, 1977, réžia: Basil Coleman}

10-dielne britské seriálové spracovanie románu z roku 1997, ktorého režisérom bol Basil Coleman, môžeme označit ako klasickú románovú adaptáciu vd’aka svojím špecifickým znakom: informácia, že ide o adaptáciu je uvedená už v úvodných titulkoch a pozornejšiemu divákovi neujdú takmer identické dialógy s prototextom. Vzhl'adom na obdobie, v ktorom táto seriálová adaptácia vznikla sú pre ňu príznačné dlhé zábery súvisiace aj s technologickými možnosti a strihová skladba charakteristická pre vtedajšiu seriálovú tvorbu (Giddings 2001). Jednotlivé epizódy síce na seba priamo nadväzujú, avšak v ich závere nemôžeme hovorit' o akomsi dramatickom napätí, ktoré by malo navodit' $\mathrm{v}$ divákovi potrebu pokračovania, tzv. cliff-hanger „označujúci záverečné anotácie, ktoré tvorcovia umiestňujú na záver častí televízneho seriálu s ciel’om poistit' záujem diváka o d’alšiu čast' televízneho seriálu, prípadne série.“ (Rusnák 2010: 22). V porovnaní s filmovými adaptáciami je $\mathrm{v}$ tomto seriálovom spracovaní daný väčší priestor postave Levina, iba v 4. časti sa neobjaví ani raz, inak sa scény zobrazujúce líniu Anny a Levina navzájom striedajú. Zaujímavé je, že v porovnaní s prototextom, je Levinova línia uzavretá skôr ako Annina. V závere vidíme, ako sa Kitty narodí diet’a a Levin sa teší zo svojej rodiny a až po tejto scéne je zobrazená Anna prichádzajúca na železničnú stanicu. Divák má však pocit, že dej negraduje ani pár minút pred koncom. Posledné scény zobrazujú Annu, ktorá sa hádže pod vlak a neskôr Vronského, ktorý drží jej kabelku v rukách a seriál končí, ked' sa Vronskij pozrie smerom hore smerom $\mathrm{k}$ oblohe. Po tomto zábere nasledujú záverečné titulky. Celý seriál teda rámcuje príbeh Anny, ktorým sa začína aj prvá čast' (vidíme vlak počas snehovej víchrice). Pri tomto type ide o čo najdôveryhodnejšie spracovanie klasického románu, preto sa tempo celého seriálu môže dnešnému divákovi, ktorý je zvyknutý na rýchly strih, zdat' pomalé až retardačné.

\section{Anna Kareninová, 2000, réžia: David Blair}

4-dielna miniséria z Vel'kej Británie prináša už v úvode pohl’ad na cvičiaceho nahého Levina a v celom spracovaní sa neskôr objaví niekol'ko explicitnejšie zobrazených sexuálnych scén. Podobne ako v predchádzajúcej seriálovej adaptácii, aj tu je priznaná informácia, že ide o adaptáciu Tolstého diela už v úvodných titulkoch a odhliadnuc od 
nevyhnutnej kompresie románovej predlohy, adaptáciu by sme mohli označit' ako vernú predlohe. Oproti predchádzajúcej však pozorujeme ,modernejšie tendencie“ či už čo sa týka rýchlejšieho strihu alebo práce s kamerou. Aj závery jednotlivých častí končia v dramatickom momente, ked' divák nevie, čo bude nasledovat'. Napríklad v závere prvej časti sa Anna prizná manželovi Kareninovi, že je Vronského milenka, v závere druhej časti sa Vronský pokúsi zastrelit’, divák, ktorý nepozná predlohu, nevie, či sa mu to podarí, alebo nie, v závere tretej časti si Anna uvedomí, aký život vedie a obviňuje Vronského, že sa vzdala syna kvôli nemu, v závere štvrtej časti síce Anna zomiera, ale touto scénou nekončí celá miniséria. Príbeh pokračuje d’alšími zábermi po určitej dobe - Stiva a Doly sa objímajú, Levin sa rozpráva s Vronským o Anne, ale i jeho dcére a v úplne poslednom zábere vidíme spokojnú Levinovu rodinu, Kitty a syna, ktorí sa pozerajú na dlho očakávaný dážd', ktorý nielenže vyrieši problém sucha, ale môžeme ho chápat' aj symbolicky, zmyje všetky ich životné problémy. Celý príbeh tejto série je teda rámcovaný líniou Levina.

\section{Anna Kareninová, 2009, réžia: Jurij Klimenko}

Tvorcovia 5-dielnej ruskej minisérie si dali záležat' na detailnom vykreslení ruského prostredia od začiatku do konca. V jedinej spomedzi nami analyzovaných seriálových adaptácií je už od prvej scény opisujúcej situáciu u Oblonských prítomný rozprávač, ktorý nielen posúva dej, ale taktiež komentuje dianie a približuje vnútorný svet postáv, aby divák náhodou nepochopil Tolstého dielo nesprávne. Každá epizóda má svoj vlastný názov (1. Metelica, 2. Dôstojnícke preteky, 3. Svadba, 4. Ona nie som ja, 5. Ja odplatím), ktorý divákovi, ktorý pozná predlohu, naznačí ich obsah. Iba jedna z častí je pomenovaná podl'a Levinovej línie - svadba, a to aj napriek tomu, že jeho línia je v porovnaní s Anninou v celom seriáli rovnomerne zastúpená. Podobne ako v adaptácii z 1977 - miniséria končí najprv uzatvorením Levinovej línie. Levin počas búrky hl'adá Kitty so synom a ked' ich nájde, jeho strach sa mení na radost' z rodiny. Aj Anninu líniu uzatvára búrka. Anna ukončí svoj život pod kolesami vlaku a následne na stanicu prichádza Vronskij. Nasleduje dlhý záber na mŕtvolu a ked’ odkryje Anninu tvár, v tom momente vidíme blesk a začína búrka. Aj v tomto prípade si môžeme tento dážd' vysvetlit' tak, že má zmyt' a odplavit' všetko zlé, čo sa stalo. Posledný záber je vel'mi špecifický, žiadna zo seriálových (ani filmových) adaptácií nekončí podobne. Vidíme manžela Anny - Karenina, ktorý drží na rukách Anninu dcéru a spoločne cez okno pozerajú na Seriožu, ako sa korčul'uje. Ten v istom momente na l'ade spadne, avšak po chvíli sa postaví a korčul'uje d'alej. Môžeme si to vysvetlit' aj tak, že tvorcovia tejto adaptácie sa v závere rozhodli poukázat' na deti, ktoré zostali bez matky. Aj ked’ Anna 
chcela svojou smrt'ou potrestat' Vronského, najviac trpia jej deti, ich život však nekončí, možno sa na chvíl'u zastavil, ale musia vstat' a pokračovat' d'alej.

\section{Anna Kareninová, 2017, réžia: Karen Šachnazarov}

Fakt, že sa Tolstému podarilo vytvorit’ a spojit' dva životné príbehy, ktoré sú síce prepojené, ale môžu vystupovat' aj samostatne, potvrdzuje aj najnovšie seriálové spracovanie tohto románu, kde pozorujeme úplné eliminovanie postavy Levina. Vzt'ah Levina a Kitty v tomto prípade nie je vykreslený vôbec a Kitty vidíme v celom diele iba raz na úvodnom plese a o jej živote sa neskôr dozvedáme iba z rozprávania Dolly. Predlohou tejto adaptácie však nebol len Tolstého román, ale aj román ruského autora Vinkentija Veresajeva Zápisky z Japonskej vojny, o ktorých sa dozvedáme hned' z úvodných titulkov. Z hl'adiska vernosti by sme túto adaptáciu neoznačili ako adaptáciu vernú predlohe, ale ako adaptáciu s tvorivým vkladom scenáristu. Rozprávačom príbehu je Vronskij a na priblíženie Anninej línie je využitá retrospektíva. Svoju históriu rozpovedá 30 rokov po Anninej smrti jej synovi Sergejovi, ktorý je velitel’om vojenskej nemocnice počas rusko-japonskej vojny. Tento 8-dielny seriál existuje aj v skrátenej kinoverzii s názvom Anna Kareninová. Príbeh Vronského.

\section{Záver}

Aj ked' seriál podl'a Kokeša (2011) predstavuje amébovú naratívnu formu, ktorá sa môže rozvíjat' a menit' donekonečna vytváraním stále d'alších seriálových radov, v prípade seriálovej adaptácie môže byt' táto naratívna forma kvôli korelácii s literárnou predlohou obmedzená, najmä ked’ ide o adaptáciu diela ako je román Anna Kareninová, ktorého dej je definitívne ukončený smrtou hlavnej postavy. Analyzované adaptácie môžeme označit' ako verné predlohe, no zároveň v najnovšom seriálovom spracovaní vidíme tendenciu posunút' príbeh za hranicu prototextu. V porovnaní s filmovými spracovaniami tohto románu, síce tvorcovia detailnejšie zobrazili Levinovu líniu, ale väčšinou len v prípade, ked' touto postavou rámcovali príbeh, avšak smerom k rozvíjaniu vedl'ajších línií z prototextu sa neuberali. Naopak poslednú adaptáciu Tolstého románu doplnili o iný príbeh a úplne eliminovali líniu s Levinom. Všeobecne platí, že „šírka románovej plochy núti dramaturgiu selektovat' jednotlivé motívy románového príbehu, naopak poviedkový útvar umožňuje dramaturgii rozvádzat' jednotlivé motívy literárneho prototextu“ (Sabol 2021: 9), ale v najnovšom seriálovom spracovaní môžeme vidiet' doplnenie dejových línií (aj z iných textov), ktoré sa môžu javit' pre súčasného diváka lákavejšie ako tie, o ktorých píše autor v prototexte. A tak si v závere kladieme otázku, či by bolo možné preniest' Annin príbeh do viac než desiatich 
častí, prípadne niekol'kých sérií, aj v prípade, že tragický osud Anny zostane nezmenený.

\section{Summary}

The influence of social trends affects also on serial production, where we can difference between serial adaptations and original series. Modern serial adaptations do not used to refer to prototext, but the second type - classic novel adaptations always point to a relationship with a literary text. The paper focuses on four classic serial adaptations of the novel by L. N. Tolstoy - Anna Kareninová. Although they adhere to the relationship to the original, in the latest serial processing we observe the tendency of the creators to move the story beyond the limits of the prototext.

\section{Literatúra}

Aujezdský, P. Od knížky k televíznímu filmu. Brno: Janáčkova akademie múzických umění v Brně, 2009.

Cardwell, S. Literature on the small screen: television adaptations. 2007. Dostupné z: /https://www.academia.edu/657528/Literature_on_the_small_screen_television _adaptations/ (2021-03-15).

Giddings, R. The Classic Serial on Television and Radio. New York: Palgrave Macmillan, 2001.

Kokeš, R. Teorie seriálové fikce. Možné cesty naratologické analýzy televízního seriálu. In: Fedrová, S., Jedličková, A. (eds.) Intermediální poetika přiběhu. Praha: Akropolis, 2011, s. 228-257.

Mrlian, R. Encyklopédia dramatických umení Slovenska. Bratislava: VEDA, 1989.

Pašteka, J. Svet literatúry, literatúra sveta. Analýzy a interpretácie II. zväzok. Bratislava: Petrus Publishers, 2005.

Rusnák, J. et al. Texty elektronických médií: Stručný výkladový slovník. Prešov: Prešovská univerzita v Prešove, 2010.

Sabol, J. S. Interpretácia filmového diela. Košice: Univerzita Pavla Jozefa Šafárika v Košiciach, 2021.

Tolstoj, L. N. Anna Kareninová. Preklad N. Szabová. Bratislava: Slovart, 2019. 
Zatloukalová, A. Specifika seriálové adaptace (od počátků až po současnost). In: Fedrová, S., Jedličková, A. (eds.) Intermediálni poetika př́běhu. Praha: Akropolis, 2011, s. 210-227.

\section{Audiovizuálne zdroje}

Blair, D. Anna Kareninová (televízna miniséria). Vel'ká Británia: Company Television Production, 2000.

Coleman, B. Anna Kareninová (televízny seriál). Vel’ká Británia: BBC, 1977.

Klimenko, J. Anna Kareninová (televízna miniséria). Rusko: Ugra-Film Company, 2009.

Šachnazarov, K. Anna Kareninová (televízny seriál). Rusko: Mosfilm Company, 2017. 


\section{TELO A EMÓCIE V KRÁTKEJ PRÓZE MARGITY FIGULI ${ }^{1}$}

\section{Body and Emotions in Short Prose of Margita Figuli}

Keywords: body, emotions, love, metaphor, M. Figuli, Slovak Naturism

Contact: Slovenská akadémia vied; ludmila.horka@gmail.com

\section{Úvod}

V literatúre sa emóciám venuje vel'ký priestor a umelecky zaujímavé sú najmä zobrazenia silných, netypických emócií, často až iracionálnych emočných prejavov. Intenzívne emócie a vypätú citovost' nachádzame aj v próze Margity Figuli, predovšetkým v zbierke krátkych próz Pokušenie (1937).

Knižný debut Margity Figuli - zbierka noviel Pokušenie vyšla v roku 1937 v nakladatel'stve Leopolda Mazáča v Prahe a obsahovala výber 10 prozaických textov. Expresívne názvy noviel (napr. Extáza, Víchor, Príval, Strmina) prezrádzajú, že Figuli sa sústredila na vypäté psychické a existenciálne situácie a narušenú harmónia v živote postáv. Dobová kritika prijala zbierku Pokušenie vel'mi pozitívne (Š́utovec 2011: 470_ 472).

Vo svojich textoch Figuli tematizuje skryté vášne, citové trápenie i sociálne problémy predovšetkým ženských hrdiniek. Dej noviel je lineárny, neobsahuje výraznejšie vonkajšie zvraty a vedl'ajšie línie. Postavy vo väčšine textov riešia reálne či zdanlivé dilemy, ktoré sú zamerané intelektuálne, sociálne alebo mravne. Postavy vo svojich snaženiach, túžbach a snoch narážajú na limity, ktoré vyplývajú z nejakého „zákona“, „tradície“, „rozumu“. Pre tieto texty je typické výrazné používanie lyrizačných techník $\mathrm{v}$ reči rozprávača, prehovoroch postáv a autorskom opise prostredia. Jazyk próz je rytmicky organizovaný, s bohatým využitím metafor a poetickými opismi prostredia.

Vypätá citovost' a senzuálnost' charakteristická pre tieto texty sú vhodným materiálom na skúmanie emócií v literatúre. Dôrazná zmyslovost' a uplatňovanie lyrických postupov a prvkov situujú zbierku Pokušenie do línie podobných próz

\footnotetext{
${ }^{1}$ Príspevok vznikol v rámci projektu VEGA 2/0045/18, Emócie v literatúre: kognitívnovedný pohl’ad.
} 
medzivojnového obdobia, ktorú dobová kritika označila pojmom lyrizovaná próza. (Šútovec 2005: 210-212) Tento všeobecný pojem neskôr prehodnotil Oskár Čepan (1977), ktorý navrhol presnejšiu periodizáciu medzivojnovej slovenskej prózy a vymedzil naturizmus ako vyvrcholenie lyrizačných tendencií v slovenskej próze toho obdobia. Tým sa Figuli zaradila k hlavným predstavitel’om naturizmu (Čepan 1977: 43$54)$.

Emócie opisuje nemecká literárna teoretička Simone Winko (2003) ako komplexný fenomén, v ktorom možno odkryt' viaceré dimenzie: fenomenologickú kvalitu, kognitívnu zložku, fyziologické symptómy a funkciu motivovat' ku konaniu. Emócie patria k biologickej výbave človeka, sú evolučne ukotvené a človek ich vníma bezprostredne ako subjektívnu formu precit'ovania. Zároveň sú však kultúrne podmienené a formované, kultúrne normy ovplyvňujú primeranú formu vyjadrenia emócí́.

K najdôležitejším médiám artikulácie emócií patrí jazyk, ktorý umožňuje emócie intersubjektívne vyjadrit' a tematizovat'. V literárnych textoch sa na sprostredkovanie emócií využívajú jazykové prostriedky na rôznych úrovniach: zvukovej, morfologickej, syntaktickej, lexikálnej či obraznej. Emócie sú teda do jazyka kódované (Winko 2003: 104-109).

Subjektívne emocionálne prežívanie sa niekedy vhodnejšie vyjadrí pomocou metafor. Nie sú to len štylistické prostriedky, ale pomáhajú konceptuálne uchopit' t'ažko opísatel'né vnútorné stavy. Sú ukotvené v základnej skúsenosti človeka, ktorú získal $\mathrm{v}$ tele a prostredí. Konceptuálna metafora ako ju zadefinovali George Lakoff a Mark Johnson (1980) je nástroj myslenia a poznávania. Jej základným princípom je mapovanie, projekcia prvkov zo zdrojovej domény na ciel’ovú doménu, ktorá je zväčša abstraktnejšia. Konceptuálna metafora sa manifestuje v jazyku vo forme metaforických jazykových výrazov, pričom kreatívne metafory majú zložitejšiu štruktúru. Pri emočných kategóriách zohráva dôležitú úlohu metafora nádoby. Emócie sú teda často konceptualizované pomocou schémy EMÓCIE SÚ TEKUTINY V NÁDOBE (Kövecses 2000: 37; Lakoff 2006: 370).

V príspevku sa zameriam na dva texty zo spomínanej zbierky, ktorých témou je láska - rovnomennú novelu Pokušenie a novelu Extáza. V uvedených dielach budem sledovat' spôsoby zobrazenia lásky a d'alších citov a nálad i to, aké hlbšie schémy možno $\mathrm{v}$ texte identifikovat' a ako sa zobrazované emócie $\mathrm{v}$ texte prepájajú $\mathrm{s}$ telom. Láska patrila $\mathrm{k}$ dominantným témam Margity Figuli. V zbierke Pokušenie autorka tento cit „skúma“ z rôznych pozícií a v rôznych kontextoch. Vo vybraných dvoch prózach ide o lásku mladú, o prvé zalúbenie, ktoré vyvolá aj mnoho pochybností a otázok. V zásade 
dochádza v oboch prózach ku konfliktu rozumu a citu, morálky a prirodzeného cítenia, ktoré je úzko prepojené s telesnost'ou.

\section{Pokušenie}

V novele Pokušenie (Figuli 2011: 180-187) autorka zobrazila lásku dvoch mladých l'udí, Aleny a Ondra, ktorí spolu trávia horúci letný deň v prírode, na lúke na okraji lesa. Vzájomná náklonnost' $\mathrm{v}$ atmosfére letnej horúčavy prerastá do pocit’ovania telesnej túžby, čo však hned' zavrhujú, pretože sa boja „trestu z neba“. Telesný aspekt lásky je zat’ažený zákazom a hriechom, zároveň je ale podčiarknutá sila prirodzeného pocit’ovania túžby.

Samotný cit lásky je v texte reflektovaný z viacerých strán. Nespája sa len so strachom z previnenia voči morálke, ale aj so strachom zo straty dôvery (,,potom by som vám už nevidela nebo v očiach“) a s obavami z možného sklamania (kamarátka Ol'ga na základe vlastných zážitkov Alenu varovala pred bolestnou skúsenost’ou v láske). Ďalšia rovina, ktorá Ondrovi v zápale presviedčania unikala, je dôležitost' súhlasu partnerky. Alena odoláva prehováraniu, nepodl'ahne nátlaku, ale sebavedomo vie partnerovi signalizovat', že je dôležité aj to, čo chce ona. To Ondra motivuje k reflexii a na krátkej prechádzke, počas ktorej sa na chvíl'u od Aleny vzdiali, sa pokúša upokojit'. Ked' sa vráti, opät' sa v nich ozve túžba a napokon dôjde aj k telesnému zblíženiu.

V atmosfére leta a slnečnej pál'avy sa vášeň v texte znázorňuje hlavne pomocou domény ohňa a tepla, resp. horúčavy. Nápadný je kontrast medzi Ondrom a Alenou, najmä v momente, ked’ Alena čakajúc na Ondreja zaspí. Ondrovo telo je zobrazené ako živé, prebudené, zohriate („horúci príboj citov a cítenia zobúdza mu telo“), v protiklade s tým, ako je opísaná Alena. Ked' ju Ondro nájde spat' v tráve, jej telo sa javí „bez pohybu, bez znaku života“, ako ,podoba z kameňa vytesanej ženy“ (Figuli 2011: 185). Alena je na viacerých miestach opísaná ako „studenác a „bez citu“, a teda chlad korešponduje s jej váhavost'ou a rezervovanost'ou v prejavoch citu. Ondro ,postrknutýc k úvahe si jej chladné prejavy skúša vysvetlit’ inak, hl'adá pre n̆u nové atribúty zdôrazňujúce jej nedotknutel’nost': zdá sa mu „,svätá“, „krásna“ a „nevinná“. Rozhodne sa obsypat' jej telo kvetmi, ktoré by ju prikryli ako „svieža, zarosená perina“ a zamedzili tak možnost' dotyku. Dar v podobe plného priehrštia kvetov sa však z obavy pred zosmiešnením v krátkosti rozhodne zahodit’ do vody, čím sa ruší aj budovaná atmosféra sakrálnosti.

Ked' Ondro uvidí Alenu po prebudení zo spánku stát' na lúke prežiarenú slnkom, opät' sa v ňom ozvú pocity túžby. I ona je veselá a zvádza ho hrou na naháňačku. Provokujúce pokriky „nechytíte ma“ či „nedočiahnete“ hravo odkazujú na 
nepolapitel'nost' a nedosiahnutel'nost', ktorou Figuli ženskú hrdinku v predchádzajúcich pasážach charakterizovala. Zároveň sa neguje meravost', „mítvost“" a potvrdzuje „Živost'“ Aleninho tela a jej fyzická zdatnost'.

A. Mráz (1937) vo svojej recenzii označil novelu Pokušenie ako „vibráciu nálad a citových záchvevov“ (Šútovec 2011: 410), čím poukázal na jednoduchost' deja, čo ale textu neuberá na bohatosti, pretože ide o text $\mathrm{s}$ výrazným emočným potenciálom. Novelu Figuli komponuje ako hru erotického napätia a uvol'nenia, priblíženia a oddialenia, rozbúrenia a upokojenia, rozohriatia a schladenia, násilia a podvolenia. Postavy sa striedavo približujú k sebe a vzd'al'ujú od seba fyzicky a duševne - Ondro opakovane vystiera ruky a schytáva Alenu do náruče, ona sa bráni, vyslobodzuje. Ondrova prechádzka bola vyústením diskusie o citoch a vášni, ked' sa na dlhšiu chvíl'u vzdialil od Aleny. Mala priniest' čas na upokojenie, premyslenie, ale stretnutie znova rozbúrilo city, rozohrialo telá.

Erotická túžba je v texte znázornená ako pokušenie, ktoré sa spája s niečím nedovoleným, so zákazom a vinou. Výraznejšie je to reflektované cez postavu Ondra, ktorý si spočiatku praje, aby „sa telo pokušenia chcelo zbavit““. V prostredí prírody, kde nie sú sledovaní ostatnými a odbúrali sa vonkajšie „prekážky“ (matka, slúžka), si uvedomuje prirodzenost' a samozrejmost' toho, čo cítia a snaží sa o tom presvedčit’ aj Alenu. Popierat' lásku znamená „,prikazovat' vlastnému srdcu, aby tíklo inak, ako má“ (Figuli 2011: 183) a naliehavost' tejto výpovede je v texte zvýraznená opakovaním. Ondro si uvedomí, že ovládnutie telesnej túžby je len dočasné, že vášeň je silnejšia a dokáže sa presadit' aj ,proti vôli človeka“. Praje si, aby pokušenie „odišlo“, „odtieklo prúdom ako zahodené kvety“, ale cíti, že „náruživost' ožíva“ a celý sa „stráca v prívale, v blaženom omotávaní každého kúska mäsa“. Sila túžby sa ukazuje vo vnútornom zápase. Je znázornená ako ohrozenie, pred ktorým chce „bránit”“ seba aj Alenu, a ako nepriatel', s ktorým chce „bojovat“", ale v skutočnosti z toho vyplynie len „boj proti sebe“. Napokon sa vášeň presadí a prejaví v plnej intenzite, čo Figuli znovu zachytila pomocou konceptu ohňa: „nový oheň žíha Ondrovo vnútro a spaluje mu mozog i srdce“. Aj Alena je po zobudení zohriata slnkom a jej ,pery zdajú sa ako okraje nádobky preplnenej túžbou“ (Figuli 2011: 186). V pozadí tohto obrazu je overená schéma zobrazovania tela ako nádoby pre emócie (Lakoff 2006: 370).

Figuli v novele Pokušenie prostredníctvom ženskej hrdinky nasvecuje lásku $\mathrm{v}$ troch rovinách $-\mathrm{v}$ rovine tela, ale aj $\mathrm{v}$ rovine mozgu/mysle a srdca. Pre Alenu je dôležitá dôvera, hlbší cit a nie nereflektované nasledovanie vášne. V texte je ale zdôraznená sila telesného zážitku, ktorý možno len oddialit'. Túžba má potenciál presadit' sa ako niečo pôvodné, prirodzené a nepotlačitel'né. 
Fyzické zblíženie Ondra a Aleny prináša zmenu, ktorá sa ukazuje aj vo vzájomnom oslovovaní - ak Alena v úvode novely konštatuje: „nebo vám vidím v očiach“, v závere túto vetu vyslovuje v pozmenenej podobe Ondro: „nebo ti vidím v očiach“. Zmena, ktorou postavy v priebehu novely prechádzajú je formou dozrievania a dospievania. $V$ texte je charakterizované ako prebratie, zobudenie či oživenie.

Na dotváranie atmosféry a nálady Figuli využíva pôsobivé poetické opisy prírody. Prírodné prostredie a cítenie postáv sú navzájom prepojené: veselá a idylická atmosféra na začiatku príbehu je badatel'ná v okolí: „žltý ligotavý blyštek pustí sa do smiechu a rozochvieva na okolí trávu“. Zmenu nálady a tenziu, ktorú medzi pár vnieslo telesné pokušenie, reflektuje aj nebo „napäté st’a sval““. Nepokoj a Alenine obavy zrkadlí žalostenie hory, ktorá „hudie t'ahavo, a nevediet', či to ona tak l'udsky narieka, či niekoho vyvoláva, či niekoho oplakáva“" (Figuli 2011: 182).

\section{Extáza}

Aj komorne ladená novela Extáza (Figuli 2011: 65-75) ponúka bohaté opisy emocionálnych stavov postáv. Začína sa pozvaním Evice na narodeninovú oslavu k Pavlovičovcom. Pozvanie je však spojené so zámerom, aby sa spoznala s inžinierom Daňom, ktorý sa javí ako vhodný kandidát na manželstvo. Vytipovaný nádejný partner Evu síce zaujal, ale vnútorne ju takýto spôsob zoznámenia poburuje, takže Daňo u nej nemá šancu na úspech. Toto umelo organizované spoznávanie sa hrdinke pripomína „trh“, čo Figuli podčiarkla aj l’ahkou iróniou: „Najprv len myšlienkami vstupujem naň a morím sa hádankou, či pán si bude žičit’ telo, alebo dušu azda. Či obidvoje v krásnej, ideálnej predstave? Trh! No môj kupec, musím sa priznat', bol na závidenie stvorený človek“" (Figuli 2011: 65). Evica sa dostáva pod tlak. Daňo sa zdá byt' zaujímavým partnerom s mnohými kvalitami, ale celá situácia v nej vyvoláva nepríjemné pocity, pretože sa cíti ako „tovar“. Aj myšlienky na manželstvo sú poznačené nevôl'ou. Budúcich partnerov - Daňa a seba - vníma ako vybrané kone z dobrého chovu: „Vraj môj budúci muž. Jasne som si predstavila tento manželský záprah dobre odchovaných koníčat. Chcelo sa mi zažalostit’ rehotom. Ach!“ (Figuli 2011: 68).

Sebavedomé komentovanie sa však deje len v rámci vnútorných monológov. V spoločnosti pri stole sa musí vyrovnat' s neustálym pozorovaním a hodnotením: „Tichá, bezradná dala som sa olizovat' zvedavost'ou ostatných.“ Na otázku, či je spokojná s výberom partnera, reaguje zahanbene, červenaním sa, čo prerastie do pocitu, že ju zasiahol oheň: „Horela som pod dotieravými pohl'admi prítomných“ (Figuli 2011: 66). 
Z danej situácie ju zachráni stará pani Pavlovičová, hlavná hostitel'ka a oslávenkyňa, ktorá ju pozve, aby jej ukázala dar od syna - obraz visiaci vo vedl’ajšej miestnosti. Do diskusie o obraze sa po čase pripojí aj mladý Pavlovič. Rozhovor o maliarskom umení sa zvrtne k téme, ktorú rozoberá celé mesto, aj pozvaní hostia na oslave. Aféra mladého dievčat'a, ktoré sa zal'úbilo do ženatého nadriadeného, spôsobila rozpad rodiny a stretla sa s vel'kým odsudzovaním. Medzi Pavlovičom a Evicou sa rozvinie debata, ktorá na ňu bude mat' výrazný vplyv - v ten večer sa Evica zal'úbi, no nie do vytipovaného partnera, ale do zadaného mladého spisovatel'a Pavloviča. Debata sa týkala lásky a cti. Pavlovič za čest' považuje prirodzené cítenie človeka a nie to, čo diktuje spoločenská norma, zákon. Evica mu protirečí: „,... akože možno slobodnému dievčat’u milovat' ženatého človeka?“ (Figuli 2011: 68), no už o krátku chvíl'u sama podl'ahne takémuto citu. Láska neskúsenú hrdinku prekvapí svojou nástojčivost'ou, túži sa dotknút' jeho úst: „hoci sa nerada bozkávam, potom som myslela už iba na akýsi požitok, ktorý nepoznám a ktorý naozaj jestvuje“ (Figuli 2011: 69). Zamilovanost’ spustí trýznivé riešenie morálnej dilemy. Evica prežíva drámu len vo svojom vnútri až do chvíle, ked' sa rozhodne svoju lásku priznat' v liste. Ten však nestihne odoslat', pretože Pavlovičovci odchádzajú po zvyšok prázdnin do letoviska mimo mesta.

Dôležitou emóciou textu je extáza, ktorá sa objavuje najprv v súvislosti s darovaným obrazom, na ktorom je zobrazená otrokyňa O-lan pohrúžená do meditatívneho stavu modlitby. Akt modlenia sa je nezvyčajne opísaný cez detail rúk a prstov: „Odovzdane preciedza cez prsty ruženec. Ruky má robustné, rozpl'asnuté st’a žilnatý, prezretý list.“ O-lan sa dostáva do stavu, v ktorom je oslobodená od svetských pokušení, do stavu opojenia modlitbou, extázy: „Priobyčajný tvor, ale v pohlade tajila povýšenost', odpútanie od svetských povol'ností. Akási nábožná extáza“ (Figuli 2011: 67).

Aj Evica sa dostáva do extázy, ale deje sa tak pri opätovnej návšteve, ked' jej Pavlovič číta svoje básne o láske a chce počut' jej názor na ne. Evica je zobrazená ako mladá, sebavedomá a vzdelaná žena s prehl'adom, ktorá dokáže viest' diskusie o umení, no v láske je neskúsená. Zakázané city k Pavlovičovi v nej vyvolávajú rozpor. Svoju extázu zažíva, pretože si mladého básnika vo svojej predstave povýšila, zbožštila: „Boh! Svojho som si vtedy zamenila za Pavloviča“" (Figuli 2011: 70).

Láska vyvolala v hlavnej hrdinke zmätok a rozhádzanie samozrejmých hodnôt: „rozum a cit zavliekli ma do chaosu prirodzenej cti a vymysleného zákona“ (Figuli 2011: 73). Pokúša sa urobit' eticky správne rozhodnutie, ale znamená to pre ňu vnútorný boj. Vzbudené city k Pavlovičovi vníma ako „,nezmyselný prvý vír“, ktorý chce „zdolat‘، a „byt' statočná“. Na viacerých miestach postava reflektuje svoje prežívanie 
ako vnútorný konflikt, ktorý jej nedovolí spat: „Živý rozpor v duši šúlal mi hlavu po vankúšoch“ (Figuli 2011: 70).

Intenzita emócií Evicu prekvapí. City sú opísané ako voda, ktorá predstavuje dravý prúd pretekajúci jej telom: „Nemohla som bez pohnutia tušit’ dravý prúd všetkých tých citov, čo mali za ten čas pretiect’ mojím telom“" (Figuli 2011: 73). Citové pohnutie je v texte zachytené aj cez dynamický obraz „búrky, čo jej rozkolísala srdce“. Objavujú sa aj obrazy spútanosti a obmedzenia, ktoré sa asociujú so zákonom a spoločenskou povinnost’ou: „sputnaná zázračným povojníkom zákonov stojím povedl’a neho“, ale aj obrazy rozpútania, uvol’nenia: „rozbúrené živly duše (...) naraz rozviazali remence.“ Evine zatajené city náklonnosti k Pavlovičovi sú opísané ako „horenie“, ktoré navonok nevidno a sú prirovnané $\mathrm{k}$ jemnému vláknu pavučiny.

Zažívaná láska sa nespája len s pocitmi št’astia vykresleného ako prameň, z ktorého možno pit', ale aj s bolestnými pocitmi: Ale čím tvrdohlavejšie pritkýnam si pery k prameňu tohto št’astia, tým viac sa morím. Trápenie je personifikované ako niekto, kto sa bezciel’ne pohybuje v priestore duše: „od tej chvíle poneviera sa mi trýzeň v duši“ či ako osoba, ktorá Evicu cielene sleduje: „, skutočnosti začala ma prenasledovat' akási bolest““.

Romantická láska hlavnej postavy sa končí náhle odchodom rodiny Pavlovičovcov do letoviska. Tento moment Figuli zobrazuje ako poškodenie krehkého objektu, ktorý sa rozbil: ,zaskučal zmar vo mne a čriepky roztíknutých citov padali ticho na dno mojej duše“ (Figuli 2011: 74).

\section{Záver}

Telo a emócie sú úzko prepojené. Prejavy emócií možno pozorovat'v správaní, gestách, vo vonkajších prejavoch (červenanie sa, zrýchlený dych) alebo vnútorne pocit’ovat'. Súvislosti tela s emóciami sú badatel'né aj v jazyku a v umeleckých textoch sú tvorivo spracované.

Z analýzy vybraných textov M. Figuli vyplýva, že rezonančným priestorom emócií je hlava, ale najmä konkrétnejšie pomenovaná tvár, oči a ústa (pery). S láskou súvisí aj priestor hrudníka, pís a srdca. Z hl’adiska metaforiky je telesná a zmyslová skúsenost' človeka zásadná. S láskou a vášňou sa spája predovšetkým ohnivost', horúčost' a búrlivost'. Na druhej strane nedostatok či slabšia intenzita citov korešponduje s chladom a meravostou. Láska a city majú aj fluidný charakter a v texte sú vyjadrené ako tečenie. 
M. Figuli okrem bohatej obraznosti pracuje s rytmom slov a viet a na zosilnenie emotivity funkčne využíva opakovanie. Poeticky ladené opisy prostredia korešpondujú s citovými stavmi postáv.

\section{Summary}

Two novellas Temptation (Pokušenie) and Ecstasy (Extáza) written by Margita Figuli in 1937 are analysed in the presented article. The focus is on the relationship between the body and emotions and their expression through metaphors. Several such metaphors of emotions (love, passion, weak emotional response, absence of emotional reactions) are identified, linked to the body (head, eyes, mouth, lips, breast, hearth) or natural phenomena (heat, fire, storm, fluid, cold, stiffness), and discussed in detail.

\section{Literatúra}

Čepan, O. Kontúry naturizmu. Bratislava: Slovenský spisovatel', 1977.

Figuli, M. Výber z diela. Bratislava: Kalligram - Ústav slovenskej literatúry SAV, 2011.

Kövecses, Z. Metaphor and Emotion: Language, Culture, and Body in Human Feeling, Cambridge University Press, 2000.

Lakoff, G. Ženy, oheň a nebezpečné věci: co kategorie vypovídají o naší mysli. Praha: Triáda, 2006.

Lakoff, G., Johnson, M. Metafory, kterými žijeme. Brno: Host, 2002.

Šútovec, M. Doslov. In: Figuli, M. Výber $z$ diela. Bratislava: Kalligram - Ústav slovenskej literatúry SAV, 2011, s. 463-479.

Š́tovec, M. Mýtus a dejiny v próze naturizmu. Bratislava: Literárne informačné centrum, 2005.

Winko, S. Kodierte Gefühle. Zu einer Poetik der Emotionen in lyrischen und poetologischen Texten um 1900. Berlin: Erich Schmidt, 2003. 


\section{Алена ИВАНОВА Анна ГОРОХОВЦЕВА Татьяна ТИТОВА}

\section{ВОСПИТАТЕЛЬНЫЕ СЮЖЕТЫ В РУССКИХ И ЧЕШСКИХ БЫТОВЫХ СКАЗКАХ}

\section{Educational Stories in Russian and Czech Household Fairy Tales}

Keywords: education, fairy tales, moral, everyday life, Czech, Russian

Contact: МГПУ; IvanovaAI@mgpu.ru; Gorokhovtsevaaa@mgpu.ru; TitovaT@mgpu.ru

Статья посвящена исследованию воспитательных мотивов русских и чешских бытовых сказках. Целью настоящей статьи было выяснить наличие совпадений в воспитательных взглядах и различий, если таковые имеются.

Основанием для сбора материала послужили представления о том, что в бытовой сказке представлены обычные человеческие отношения, которые решаются не волшебным образом. Если в сказке появляются отдельные элементы волшебной сказки, например, волшебные предметы, но в целом, отношения разрешаются не волшебным образом, то такую сказку мы также отбирали как бытовую.

В задачи настоящей статьи входило: 1. собрать материал сказок, опираясь на электронные достоверные академические сборники; 2. проанализировать сюжеты сказок, выявить воспитательные мотивы, а также возможную воспитательную мораль, т.е. некоторые нравоучения, которые можно извлечь из сказок. На следующем этапе мы планировали систематизировать полученный материал - обобщить нравоучения по темам, например, нравоучение о жадности, доверии, хитрости, дружбе, труде, лени, гордыне, уважении и др. После систематизации мы предполагали сравнить как содержание выявленных нравоучений, так и частотность их представления в сказках. При этом предполагалось, что из чешского и русского фольклора отбирается около 30 сказок для анализа.

Русские сказки были найдены в сборнике А.Н. Афанасьева «Народные русские сказки» (Афанасьев 2014) и на информационном ресурсе сайта «Фригато» 
(https://frigato.ru/); чешские - на информационном pecypce Электронной библиотеки детской литературы (https://skazkibasni.com/).

В результате у нас получилась таблица соотношения моралей в русских и чешских сказках.

\begin{tabular}{|c|c|c|}
\hline Мораль & Русские сказки & Чешские сказки \\
\hline $\begin{array}{l}\text { Из любой ситуашии } \\
\text { можно найти выход, } \\
\text { пользу }\end{array}$ & $\begin{array}{l}\text { «Барин и мужик» } \\
\text { «Дурак и береза» } \\
\text { «Хорошо, да худо» } \\
\text { «Беспамятный зять» } \\
\text { «Барин и собака» } \\
\text { «Каша из Топора» } \\
\text { «Солдат и сало» } \\
\text { «Болтливая баба» }\end{array}$ & \begin{tabular}{|l} 
«Янко и злая королевна» \\
«Кукушка» \\
«Кум Негода» \\
«Пугало» \\
«Глупая жена» \\
«Двое деток» \\
«Заколдованный \\
капеллан» \\
«Михалевы чины» \\
«Гадальщики» \\
«Сапожник Либор»
\end{tabular} \\
\hline $\begin{array}{l}\text { Сначала думай-потом } \\
\text { делай / говори }\end{array}$ & $\begin{array}{l}\text { «За дурной головой - } \\
\text { ногам работа» } \\
\text { «Беззаботная жена» } \\
\text { «Глупый мужик» } \\
\text { «Барин лает в церкви» } \\
\text { «Как барин овцу купил» }\end{array}$ & \begin{tabular}{|l} 
«Про трех торговок» \\
«Сапожник Гицек»
\end{tabular} \\
\hline $\begin{array}{l}\text { Относись к людям так, } \\
\text { как хочешь, чтобы они } \\
\text { относились к тебе }\end{array}$ & $\begin{array}{l}\text { «Сердитая барыня» } \\
\text { «Барин лает в церкви» } \\
\text { «Как старик домовничал» } \\
\text { «Умный работник» } \\
\text { «Ямщик и купец» }\end{array}$ & $\begin{array}{l}\text { «Янко и злая королевна» } \\
\text { «Кукушка» } \\
\text { «Кум Негода } \\
\text { «Сапожник Гицек» }\end{array}$ \\
\hline Доверяй, но проверяй & $\begin{array}{l}\text { «Горшечник» } \\
\text { «Как барин овцу купил» } \\
\text { «Болтливая баба» }\end{array}$ & «Крестьянин и купцы» \\
\hline $\begin{array}{l}\text { Бесплатный сыр } \\
\text { бывает только в } \\
\text { мышеловке }\end{array}$ & $\begin{array}{l}\text { «Как мужик гусей делил» } \\
\text { «Как поп работницу } \\
\text { нанимал» } \\
\text { «Ленивая Арина» }\end{array}$ & $\begin{array}{l}\text { «Вареные яйца» } \\
\text { «Лекарь-самозванец } \\
\text { и его ученик» }\end{array}$ \\
\hline $\begin{array}{l}\text { Гордыня до добра не } \\
\text { доведет }\end{array}$ & $\begin{array}{l}\text { «Чего на свете не бывает» } \\
\text { «Брито» }\end{array}$ & $\begin{array}{l}\text { «Янко и злая королевна» } \\
\text { «Бедняк и богач» }\end{array}$ \\
\hline
\end{tabular}


Алена ИВАНОВА, Анна ГОРОХОВЦЕВА, Татьяна ТИТОВА Воспитательные сюжеты в русских и чешских бытовых сказках

\begin{tabular}{|c|c|c|}
\hline Без ума жить тяжело & «Глупый мужик» & «Глупая жена» \\
\hline $\begin{array}{l}\text { Лень до добра не } \\
\text { доведет }\end{array}$ & «Горшок» & $\begin{array}{l}\text { «Лекарь-самозванец } \\
\text { и его ученик» }\end{array}$ \\
\hline $\begin{array}{l}\text { Без труда не вытащчишь } \\
\text { и рыбку из пруда }\end{array}$ & «Солдатская шинель» & «Горошек и Золушка» \\
\hline $\begin{array}{l}\text { Честный труд всегда } \\
\text { вознаграждается }\end{array}$ & & $\begin{array}{l}\text { «Бедный кузнец» } \\
\text { «Сильвент и цыганка» }\end{array}$ \\
\hline Нужно верить в себя & & $\begin{array}{l}\text { «Сон» } \\
\text { «Не ищи там, где не } \\
\text { положил» }\end{array}$ \\
\hline $\begin{array}{l}\text { Жадность до добра не } \\
\text { доводит }\end{array}$ & & $\begin{array}{l}\text { «Жадность к деньгам» } \\
\text { «Серебряные сосульки } \\
\text { в Радгощи» } \\
\text { «Невеста разбойника» }\end{array}$ \\
\hline $\begin{array}{l}\text { На чужсое добро рот не } \\
\text { разевай }\end{array}$ & & $\begin{array}{l}\text { «Волшебные рыбы» } \\
\text { «Не ищи там, где не } \\
\text { положил» }\end{array}$ \\
\hline $\begin{array}{l}\text { В доме должна быть } \\
\text { хозяйка }\end{array}$ & & «Горошек и Золушка» \\
\hline $\begin{array}{l}\text { Настоящчий друг всегда } \\
\text { поможет }\end{array}$ & & «Добрый совет» \\
\hline $\begin{array}{l}\text { Все тайное становится } \\
\text { явным }\end{array}$ & & $\begin{array}{l}\text { «Лекарь-самозванец } \\
\text { и его ученик» } \\
\text { «Невеста разбойника» }\end{array}$ \\
\hline $\begin{array}{l}\text { Обешуания нужно } \\
\text { выполнять }\end{array}$ & & «Крестьянин и купцы» \\
\hline Сила в единстве & «Репка» & \\
\hline $\begin{array}{l}\text { Одно и то же каждый } \\
\text { человек понимает по- } \\
\text { своему }\end{array}$ & $\begin{array}{l}\text { «Завещание» } \\
\text { «Как Иван-дурак дверь } \\
\text { стерег» }\end{array}$ & \\
\hline
\end{tabular}


Проанализировав таблицу, мы пришли к выводу, что: 1. русских сказок об отсутствии безвыходных ситуаций - 8, чешских сказок об отсутствии безвыходных ситуаций - 10; 2. русских сказок о важности обдумывания последствий своих действий - 5, чешских сказок о важности обдумывания последствий своих действий - 2; 3. русских сказок об уважительном отношении людей друг к другу -5 , чешских сказок об уважительном отношении людей друг к другу - 4; 4. русских сказок о доверии - 3, чешских сказок о доверии - 1 ; 5. русских сказок о том, что ничего просто так не достается - 3, чешских сказок о том, что ничего просто так не достается - 2; 6. русских сказок о гордыне -2 , чешских сказок о гордыне - 2; 7. русских сказок об уме -1 , чешских сказок об уме -1 ; 8 . русских сказок о трудолюбии -1 , чешских сказок о трудолюбии -1 ; 9. русских сказок о лени - 1, чешских сказок о лени $-1 ; 10$. русских сказок о пользе честного труда - 0 , чешских сказок о пользе честного труда $-2 ; 11$. русских сказок о важности веры в себя - 0, чешских сказок о важности веры в себя $-2 ; 12$. русских сказок о жадности - 0 , чешских сказок о жадности - 3; 13 . русских сказок о желании владеть чужим - 0, чешских сказок о желании владеть чужим 2 ; 14. русских сказок о важности хозяйки в доме - 0, чешских сказок о важности хозяйки в доме - 1 ; 15 . русских сказок о настоящей дружбе - 0, чешских сказок о настоящей дружбе - 1; 16. русских сказок о тайнах - 0, чешских сказок о тайнах - 2; 17. русских сказок о важности выполнения обещаний - 0 , чешских сказок о важности выполнения обещаний $-1 ; 18$. русских сказок о групповом труде -1 , чешских сказок о групповом труде - $0 ; 19$. русских сказок о восприятии людьми одной и той же информации - 2, чешских сказок о восприятии людьми одной и той же информации - 0 .

Из нашей таблицы, можно увидеть, что морали совпали у русских и чешских сказок в 9 случаях. Это следующие морали: Из любой ситуации можно найти выход, пользу; Сначала думай - потом делай / говори; Относись к людям так, как хочешь, чтобы они относились к тебе; Доверяй, но проверяй; Бесплатный сыр бывает только в мышеловке; Гордыня до добра не доведет; Без ума жить тяжело; Лень до добра не доведет; Трудолюбие.

Также можно обратить внимание, что есть морали, к которым подошли либо только русские сказки, либо только чешские. Морали с чешскими сказками: Честный труд всегда вознаграждается; Нужно верить в себя; Жадность до добра не доводит; На чужое добро рот не разевай; В доме должна быть хозяйка; Настоящий друг всегда поможет; Все тайное становится явным; Обещзания нужно выполнять. И также есть морали, которые встречаются только в русских сила в единстве; Одно и то же каждый человек понимает по-своему. 
В сборнике с чешскими сказками мы обнаружили две очень похожие друг на друга сказки - это «Сон» и «Не ищи там, где не положил». Сюжет этих двух произведений идентичен. Мужчине приснился сон о том, что на мосту Праги лежит клад. Жена отговаривала его туда ехать, но он не послушал и отправился в путь на поиски заветного клада. По приезде на мосту ничего не оказалось. Однако вскоре мужчина встретил охранника, который рассказал, что раньше ему тоже снился сон про клад. По рассказу наш герой понял, что этот сон про его дом и клад спрятан под печкой. Приехав домой, мужчина решил разломать ее, хотя жена снова была против и долго упрашивала мужа этого не делать.

Отличительными особенностями этих двух сказок будут их концовки и морали. Сказка «Сон» заканчивается тем, что главный герой все-таки находит заветный клад в самом низу под камнем. Соответственно мораль сказки будет следующая: добивайся своей цели, даже если остальные против и не поддерживают тебя, нужно верить в себя несмотря ни на что.

Сказка «Не ищи там, где не положил» имеет противоположенную концовку, где мужик ничего не нашел и остался со сломанной печкой. Мораль будет соответствовать названию сказки: не ищи там, где не положил, - или же может быть сформулирована следующим образом: не гоняйся за чужим добром.

Таким образом мы видим, что две сказки с одинаковым сюжетом, но разной концовкой имеют совершенно противоположенные воспитательные мотивы. При анализе русской литературы нами не были обнаружены сказки со схожим сюжетом, но разными концовками и моралями.

Довольно много сказок, которые учат нас тому, что из любой ситуации можно найти выход. Данная мораль присутствует как в русских, так и в чешских сказках. Герои решают практически безвыходные ситуации с помощью своей смекалки. Рассмотрим следующие сказки: «Кум Негода», «Солдат и сало».

Сказка «Кум Негода» рассказывает о том, что в одном селе жил мужик по имени Негода, а по-уличному прозвали его негодяем. Выбрали Негоду старостой, стали звать «кум Негодяй» не понравилось это Негоде, попытался имя сменить. Решил для этого всех задобрить и устроил пир, попросил, чтобы по-другому называли, но никто не послушал. Все деньги на пиры спустил, а результата нет. Расстроился Негода, пошел на базар шкуры продавать да денег заработать. Устал Негода в дороге прилег отдохнуть пока спал шкуры в мешке испортились. Казалось бы, безвыходная ситуация, но наш герой нашел решение. Он сумел провести всех жителей и заработать много денег, однако никто не знал где и на чем. И тут Негода не растерялся и рассказал небылицу, всех обманул. Люди 
взбунтовались, решили отомстить негодяю. Но он опять их провел, собрал побольше денег и уехал.

Вторая сказка «Солдат и сало» повествует нам о Солдате и его находчивости. Как-то раз заметил солдат, что припасены в сенях у его зажиточного хозяина большие мешки с салом. Решил он среди ночи пробраться к нему через крышу, и забрать себе один мешок. Но он поскользнулся, и рухнул прямо на пол. Хозяин задал ему вопрос, зачем он явился. Солдат стал предлагать ему сала. Хозяин ответил, что этого богатства у него полно. Тогда солдат говорит, чтобы в таком случае навесил ему на спину мешок. Хозяин послушался, и солдат пошел своей дорогой.

Таким образом мы видим, что совершенно разные герои, попадая в трудные для них ситуации смогли выбраться из них с помощью своей смекалки и вовремя принятых решений.

В чешских сказках наиболее ярко показано разграничение гендерных ролей и отношения в семье.

Рассмотрим сказку «Горошек и Золушка». Речь пойдет об отце Горошке и сыне его Гонзе. Горошек женился на богатой женщине, но в скором времени они обнищали. Было у них 6 детей, но только Гонза остался, остальные ушли. Мужики каждый день трудились, но тяжело им было. Однажды к ним в дом пришла девушка и звали ее Золушка. Она начала все делать по дому. Потом в дом пришла бабушка Золушки. В конце они разбогатели, и Золушка с Гонзой поженились. Перед этим Золушку крестили и дали ей имя Кристина.

Как мы видим в сказке повествуется об обычных событиях из жизни крестьян. На их примере показан быт и устройство семьи. Четко прослеживается следующий воспитательный мотив: в доме всегда должна быть трудолюбивая женщина.

Анализируя наличие в русских сказках таких моралей, как из любой ситуации можно найти выход, пользу; без ума жить тяжело; бесплатный сыр бывает только в мышеловке, - и отсутствие таких моралей, как честный труд всегда вознаграждается; на чужое добро рот не разевай; жадность до добра не доводит, - выстраивается следующий образ русского народа: находчивые, сплоченные люди, способные найти выход из любой ситуации, готовые использовать при этом все возможные методы. Тогда как образ чешского человека представляется нам следующим образом трудолюбивый, ответственный, но в то же время больше сконцентрированный на своей личности, а не на коллективе. 
Таким образом мы видим, что морально-нравственных нормы, отраженные в русских и чешских бытовых сказках, имеют больше сходств чем различий, что говорит об общности двух культур.

\section{Summary}

The article is devoted to the analysis of moral norms reflected in Russian and Czech household fairy tales. The authors aim to identify the ethical guidelines of the peoples reflected in the plot of everyday fairy tales. The objectives of the article included the study of the culture of the peoples, based on the material under study, as well as the search for common ideas and differences in folk wisdom. The immediate interest of the study is the study of the features of educational motives.

\section{Литература}

Афанасьев, А.Н. Народные русские сказки. Москва: «Альфа-книга», 2014.

Фригато: развлекательный образовательный портал для детей и родителей. Режим доступа: https://frigato.ru/ (2021-03-20).

Электронная библиотека детской литературы. Режим доступа: https://skazkibasni.com/ (2021-03-25). 



\section{PIĘKNO SŁOWA. O PROBLEMACH ESTETYCZNYCH W TWÓRCZOŚCI C. K. NORWIDA}

\section{The Beauty of the Word. On Aesthetic Problems in the Work of C. K. Norwid}

Keywords: discourse, source, truth, person, transcendence

Contact: Uniwerytet Humanistyczno-PrzyrodniczywCzęstochowie; klaudia.pompa@gmail.com

Cyprian Kamil Norwid - XIX wieczny poeta, którego twórczość ukazał światu na początku ubiegłego wieku Zenon Przesmycki. Nie ulega wątpliwości, że jest to jeden z najgłębszych i najtrudniejszych polskich poetów - wieszczów. Jego twórczość jest połączeniem słowa, dźwięku i obrazu. To epifania piękna, która dąży do wzbogacenia człowieka i doskonalenia go w swoim jestestwie.

\section{Dyskurs początku - poezja źródła.}

Na twórczość Norwida można by spojrzeć przez pryzmat dyskursów konstytuujących Dominique'a Maingeueneau, ponieważ kategoria ta ,pozwala lepiej uchwycić związki między literaturą i filozofią, literaturą i religią, literaturą i mitem, literaturą i nauką" (Maingueneau 2009: 160). Samo wyrażenie „dyskursu konstytuującego” odnosi się do dyskursów, które ,prezentują się jako «dyskursy Początku»” (Maingueneau 2009: 160), a więc mogące istnieć samodzielnie bez konieczności wspierania się o inne dyskursy. „To właśnie przynależność literatury i filozofii do wspólnej kategorii dyskursów konstytuujących pozwala na istnienie połączeń między nimi, stref ich wzajemnego przenikania" (Maingueneau 2009: 166). Charakterystyczną cechą twórczości Cypriana Norwida jest także dążenie do uchwycenia rzeczywistości w całej jej złożoności przy jednoczesnym zatajeniu istotnych elementów w taki sposób, by wymusić na czytelniku aktywność intelektualną, a nie bierne towarzyszenie. Autor Promethidiona, jako alchemik słowa balansuje na granicy pól semantycznych, wykorzystując siłę językowej ewokacji. Jego literatura jest rzeczywistością głębi, pozwala dotrzeć do istoty rzeczy, a za sprawą ewokacji kontemplować je i unaoczniać. Poszukiwanie doskonałości i uchwycenie w języku tego, co dla poety najistotniejsze, a więc prawdy, dobra i piękna, jest możliwe dzięki zbliżeniu literatury i religii. „Poezja, przekraczając to, co zmysłowo 
oczywiste, pojęciowo ujmowalne, przekraczając wszelkie granice: słowa i tego, na co słowo wskazuje, zmierza do rzeczywistości, która żywi religię" (Sawicki 2007: 15) przekonuje Stefan Sawicki. To właśnie teksty, na które wskazywał Maingueneau „aspirują do wizji globalnej, do tego, by mówić coś istotnego o społeczeństwie, prawdzie, pięknie, egzystencji..." (Maingueneau 2009: 167).

Nie ulega wątpliwości, że Norwid był twórcą przekraczającym pewne zastałe schematy, wpisującym w literaturę własny traktat o historii, narodzie, religii. Nie bojąc się polemizować $\mathrm{z}$ polską martyrologią, dawał świadectwo swojej odrębności $\mathrm{i}$ indywidualności. Jego uczestnictwo w dialogu kultur, wyjście poza określone horyzonty myślowe, poza europocentryzm, umożliwiło mu uniwersalne spojrzenie na naród i człowieka, a przy tym pozwoliło na wydobycie esencji jaką jest tożsamość narodowa. Literatura stała się dla poety „chrześcijańską interpretacją dziejów” wartości ludzkich, w której człowiek poprzez świadome uczestnictwo buduje siebie i innych jako osoby, a dzięki relacji praxis do Boga, człowieka, natury i kultury wyraża sens własnej egzystencji, prawdę o człowieku (wymiar indywidualny i powszechny). S. Kołaczkowski pisał: „Nie znam pisarza, który by u nas lepiej od Norwida wychował ludzi do dojrzałości, który by głębiej i szczytniej pojmował zadania człowieka, jako twórcy historii" (Kołaczkowski 1934: 74).

„Dokonać «zapisu» to nie tyle przemawiać we własnym imieniu, ile iść po śladach Innego, niewidzialnego, skupiającego w sobie wypowiadających, którzy spełniają model jego postawy, więcej, mieszczącego w sobie Źródło, które funduje dyskurs konstytuujący: Tradycję, Prawdę, Piękno..." (Maingueneau 2009: 162).

W twórczości Norwida horyzontem niezbędnym do głębokiego widzenia dziejów i rozwoju człowieka w kierunku transcendencji jest sfera wartości absolutnych. Podążanie zgodne z triadą prawda - dobro - piękno jest warunkiem sine qua non drogi do doskonałości. W tradycji filozoficznej pojęcie doskonałości rozumiane jest przede wszystkim jako „najwyższy akt bytu, bytowanie bez braku (...) działanie zgodne z naturą lub zamiarem Stwórcy lub twórcy", w estetyce natomiast, pojęcie doskonałości związane jest z kategorią piękna i stanowi, ,jeden z trzech elementów piękna, jest wyrazem wykończenia, nieposiadania braku"2. W języku polskim pojęcie to jest wyrazem dwuznacznym, bowiem spełnia jednocześnie funkcję konkretną (rzeczy pięknej) i abstrakcyjną (cechy piękna), łącząc się tym samym z ,prawdą” i „dobrem”3. Norwidowskie rozumienie sztuki i piękna jest związane z zasadą egzystencjalnego

\footnotetext{
${ }^{1}$ Zob. ks. Dunajski, A. Chrześcijańska interpretacja dziejów w pismach Cypriana Norwida. Lublin, 1985.

${ }^{2}$ Robaczewski, A. Doskonałość. In: Powszechna Encyklopedia Filozofii T. 2. Lublin, 2001, s. 669.

${ }^{3}$ Zob. Tatarkiewicz, W. Dzieje szczęściu pojęć. Warszawa, 1975, s. 136-137.
} 
wysiłku, która łączy się także ,z chrześcijańskim pojmowaniem zmartwychwstania (...) Sztuka, miejsce wydarzania się piękna, jest dla poety obszarem wyzwalania się ducha. Rzeczywistość sztuki jest dziedziną materii (tego co martwe) przemienianej w życie" (Kuczera-Chachulska 2008: 20).

Bo nie jest światło, by pod korcem stało,

Ani sól ziemi do przypraw kuchennych,

Bo piękno na to jest, by zachwycało

Do pracy - praca, by się zmartwychwstało (PWsz 3: 439-4404).

Doskonalenie się człowieka odbywa się poprzez trud i wysiłek, który ulepsza człowieka, podnosi go i uszlachetnia. Już sam Platon umieszczając piękno w sferze tego, co transcendentne, utożsamiał je z doskonałością, bowiem „piękno jest właściwością dusz i idei” (Gołaszewska 1984: 353). Podobnie myślał Plotyn, dla którego „pięknem jest objawienie się ducha w materii” (Gołaszewska 1984: 354), a więc lśnienie piękna duchowego. Zbliżony do nich okazał się także Hegel ,piękno (wartość estetyczna) jest wyrazem ducha absolutnego (...) jest przejawem tego, co idealne" (Gołaszewska 1984: 378-379). W „przypowieści o pięknem” Norwida piękno jest kategorią ruchu, działaniem ,połączonym ściśle z dojrzewającą przemianą” (Kuczera-Chachulska 2008: 37), miejscem przebywania Boga. Sztuka jako „wieczna tęcza Jeruzalem” jednoczy, godzi historię i społeczeństwa, jest harmonią, która ma wartość katartyczną, tłumiąc fałsz i wydobywając prawdę, ,aż się sumienie kształtem wymarmurzy”.

- Co piękne, nie jest to - mówił Maurycy -

Co się podoba dziś lub podobało,

Lecz co się winno podobać; jak niemniej

I to, co dobre, nie jest, z czym przyjemniej,

Lecz co ulepsza... (PWsz: 434-435).

Relacja twórcy do tworzenia, analogicznie do kreacyjnej figury Boga, ukazuje swoją pełnię w „kształcie Miłości”, stąd też poeta „wskazywał Polsce drogę postępu moralnego opartą na chrześcijańskiej miłości do Boga i bliźniego" (Merdas 1983: 187). Norwid głosił epifanię piękna, wyrastającą z biblijnego: „I spojrzał Bóg na wszystko, co stworzył, i uznał, że jest bardzo dobre i piękne" (Rdz 1: 31). Artysta jest nikim innym

\footnotetext{
${ }^{4}$ Wszystkie utwory Cypriana Norwida cytowane są według wydania: Cyprian Norwid, Pisma wszystkie, zebrał, tekst ustalił, wstępem i uwagami krytycznymi opatrzył J. W. Gomulicki, t. 1-12, Warszawa 1971-1976. W sąsiedztwie przytaczanych fragmentów w nawiasach podawane są tom oraz numer strony.
} 
jak kapłanem w służbie piękna, estetą wcielającym sztukę w życie, twórcą przekazującym słowo doskonałe, wysublimowane, niejednoznaczne - słowo mające moc sprawczą i działające na wnętrze człowieka.

Relacja miedzy dobrem a pięknem skłania do refleksji. Piękno jest bowiem poniekąd widzialnością dobra, tak jak dobro jest metafizycznym warunkiem piękna. Rozumieli to dobrze Grecy, którzy zespalając te pojęcia ukuli wspólny termin dla obydwu: «kalokagathía», czyli «piękno-dobroć». Tak pisze o tym Platon: «Potęga Dobra schroniła się w naturze Piękna» (Jan Paweł II 2004: 563).

Jan Paweł II uważał autora Promethidiona za ,jednego z największych poetów i myślicieli, jakich wydała chrześcijańska Europa”, doceniał jego metafizyczną twórczość, a także doskonale rozumiał jego przesłanie. Nie ulega wątpliwości, że to właśnie papież stał się prekursorem norwidowskich dzieł, a słowa Norwida były najczęściej cytowanymi frazami jego pontyfikatu.

\section{Poezja światla i wieczności.}

„Każda autentyczna forma sztuki jest swoistą drogą dostępu do głębszej rzeczywistości człowieka i świata" (Jan Paweł II 2004: 565). Optyka ewangelicznego spojrzenia na świat, pomaga otworzyć się człowiekowi na wieczność, a poezja to narzędzie, które umożliwia głębokie przeżywanie i wyrażanie tego, co z pozoru niewyrażalne, jest światłem, prowadzącym w kierunku transcendencji. Pisarzem, który czuł się człowiekiem świata i wieczności jest niewątpliwie Cyprian Norwid, jako poeta „pozostawił dzieło, z którego emanuje światło pozwalające wejść głębiej w prawdę naszego bycia człowiekiem, chrześcijaninem, Europejczykiem, Polakiem" (Jan Paweł II, 1 VII 2001 - Audiencja papieska dla przedstawicieli Instytutu Dziedzictwa Narodowego). Jego język, ubogacony w treści własnej wyobraźni religijnej, nakazuje czytelnikowi patrzeć na twórczość jak na wielką całość, przepełnioną poszukiwaniem praw wiecznych, dążącą do odnalezienia ostatecznej Prawdy i ostatecznego Sensu, poezję, która wydobywa zagubioną prawdę o człowieku i scala ją z nieśmiertelnością. Zamysł ten reprezentują słowa, wykraczające poza sferę temporalną, ograniczoność i cząstkowość: „wszech-sztuka”, „,cało-żywot”, „wszech-doskonałość”, „cało-piękno”

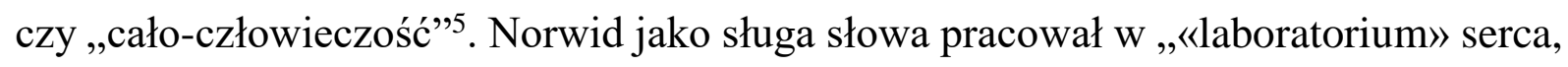
wyobraźni i umysłu zarazem, w którym poddawał próbom to, czego w inny sposób się nie wyrazi” (Skwarnicki 1998: 8). Jego celem była sztuka pozwalająca na pełniejszą realizację człowieczeństwa, twórczość pełna chrześcijańskich wartości.

\footnotetext{
${ }^{5}$ Por. Sawicki, S. Wstęp. In: Cyprian Norwid. Nie sq nasze - pieśni nasze. Wiersze religijne. Wybór, wstęp, komentarz - S. Sawicki. Kielce, 2021, s. 16.
} 
Miejscem pomagającym wzrastać człowiekowi w swoim osobowym bycie jest naród, a praca (praktyczność) winna być traktowana jako ta, która doprowadza do zharmonizowania się uniwersaliów. Autor Promethidiona traktował naród jako organizm, osobę, obywatela świata, którego narzędziem jest słowo, a celem - prawda: „Ale Naród - Ziomkowie! - jest to najstarszy po Kościele obywatel na świecie (...) Głosem tego Narodu jest harmonia ojczysta, mieczem - jedność i zgoda, celem - prawda (...) Bo Ojczyzna - Ziomkowie! - jest to moralne zjednoczenie (...)" (PWsz 7: 7). Naród jako jedno z ogniw relacji, staje się bardzo ważną częścią dla osoby ludzkiej, ponieważ pomaga mu poznać i zrozumieć samego siebie. Norwid dysponuje określonym językiem symbolicznym i metaforycznym, w którym naród utożsamiany ze zbiorowym człowiekiem, dąży do szczęścia Ludzkości, jest udziałem w „dziejów ludzkości rozwoju" (PWsz 9: 265), a kultura narodowa musi niejako wykraczać poza naród, być kulturą sensu largo, niezależną od terytorium czy warunków politycznych, winną realizować się wszędzie tam, gdzie jesteśmy.

Naród jest więc częścią Ojczyzny - przestrzeni ludzkości, w którą wpisana jest tradycja kulturowa i religijna, jest częścią duchowego rozwoju człowieka.

Kto mi powiada, że moja ojczyzna:

Pola, zieloność, okopy,

Chaty i kwiaty, i sioła - niech wyzna,

$\dot{\mathrm{Z}} \mathrm{e}-$ to jej stopy.

(...)

Ojczyzna moja nie stąd wstawa czołem;

Ja ciałem zza Eufratu,

A duchem sponad Chaosu się wziąłem:

Czynsz płacę światu.

Naród mię żaden nie zbawił ni stworzył;

Wieczność pamiętam przed wiekiem;

Klucz Dawidowy usta mi otworzył,

Rzym nazwał człekiem. (PWsz 1: 336, strofy: 1, 3, 4)

Ojczyzna dla Norwida jest wielką rodziną ludzką, wspólnotą połączoną poprzez Biblię i Rzym. 
Historia każdego człowieka wyraża się poprzez naród i jego kulturę, jest niejako centrum świata, z którego wyrasta byt osobowy, jest też „«księgą żywota», pełną ciężaru, ale i blasku ludzkiej egzystencji” (Sawicki 2007: 121). „Człowiek i naród stają się sobą do końca przez «tajemnicę dziejów» (Bartnik 1987: 190), a tradycja jawi się jako fundamentalny element istnienia narodu. Podkreśla to S. Sawicki, gdy pisze o Norwidowej tradycji pełnej wartości, w której kultura „nabiera wyjątkowego znaczenia zarówno dla trwania narodu, jak i dla egzystencji «wiecznego człowieka»" (Sawicki 2007: 174). Osobotwórczym wymiarem, pomagającym człowiekowi stawać się osobą, jest niezaprzeczalnie praca, która jak pisał Norwid w Promethidionie „Bo piękno na to jest, by zachwycało / Do pracy, praca - by się zmartwychwstało" (PWsz 3: 440, podkr. K. J.) Jest to praca, która wydobywa na powierzchnię światło ludzkiej wspólnoty, pomaga wytworzyć wspólne dobro, dąży do uczestnictwa. Norwid pragnął, aby ludzkość, za sprawą pracy „rozgorzała jak lampa na globie”. Dojrzewający wewnętrznie za sprawą Pisma Świętego poeta, traktował pracę jako pokutę, pozwalającą odnowić utracone przez grzech pierworodny przymierze z Bogiem, wysiłek rozwijający człowieka duchowo oraz podnoszący godność człowieka. Autor Asunty zwracał uwagę także na fakt, że praca musi odnosić się do wolności „gdzie więcej wolności, tam i pracy więcej, i o ile wolniejszym społeczeństwo, o tyle dzielniejszą jest praca" (PWsz 6: 641), jest to także dar, który uszlachetnił swoim Wcieleniem Bóg:

„Zaprawdę powiadam, że Rodzic ludzkości, skazanym będąc na pracę $\mathrm{z}$ potem CZOŁA, miał sobie dane $\mathrm{w}$ tymże samym ukazie zapewnienie, iż żona jego da początek potomstwu, z którego narodzi się Zbawca. Dlatego to praca człowieka, lubo z pokutnego źródła pochodząca, nie tylko że się na smętnościach pokutnych nie ogranicza, ale owszem, byłaby niecałą rzeczą, gdyby nie obejmowała Zbawstwa - czyli byłaby bez-celną ilotów pańszczyzną!” (Kubiak 2019: 57).

Praca jest więc czymś, co pomaga człowiekowi w osiągnięciu własnego człowieczeństwa, jest dobrem, które uszlachetnia, a zatem jest także sztuką właściwą każdemu człowiekowi. Jak dowodzi Zofia Trojanowiczowa koncepcję «sztuki-pracy» wyprowadził Norwid „,z etosu pracy ludu polskiego, który to etos miał za swoisty i samorodny" (Trojanowiczowa 1983: 30). Tym samym ludowość, za sprawą doskonalenia wewnętrznego i pracy nad własnym jestestwem zyskuje miano „ludzkości”. Zakorzenienie w ludowości, służy rozwojowi ludzkości i jest spoiwem łączącym kulturę, religię i doskonalenie człowieka. „Podnoszenie ludowych natchnień do potęgi przenikającej i ogarniającej Ludzkość całą podnoszenie ludowego do Ludzkości nie przez stosowania zewnętrzne i koncesje formalne, ale przez wewnętrzny rozwój dojrzałości... " (PWsz 3: Promethidion, Epilog). 
Źródłem stale wypływającym z twórczości C. K. Norwida jest Pismo Święte i Prawda, która pomaga człowiekowi wzrastać w człowieczeństwie, otwiera drzwi do światła. Swoją myślą i twórczością autor Quidama udowodnił, że najwyższy stopień poetyckiej doskonałości osiąga się dzięki zakorzenieniu Słowa w Miłości, Wierze i Prawdzie. Jako pasterz ludzkości, swoją ,,pracą” zbliżył niebo do ziemi, łączył rozbite społeczeństwa i jednoczył narody w uniwersalnej koncepcji obejmującej przeszłość i przyszłość.

\section{Summary}

A source constantly flowing from the work of C.K. Norwid is the Holy Bible and the Truth that helps man to grow in humanity, opens the door to light. With his thought and work, the author of Quidam proved that the highest degree of poetic perfection is achieved by rooting the Word in Love, Faith and Truth. As the shepherd of mankind, with his "work" he brought heaven closer to earth, united shattered societies and united nations in a universal concept embracing the past and the future.

\section{Literatura}

Buś, M. Idee i formy. Studia i szkice o Norwidzie. Lublin: Towarzystwo Naukowe Katolickiego Uniwersytetu Lubelskiego, 2014.

Chlebowski, P. Cypriana Norwida „Rzecz o wolności słowa”. Ku epopei chrześcijańskiej. Lublin: Towarzystwo Naukowe Katolickiego Uniwersytetu Lubelskiego, 2000.

Styczeń, T. SDS Człowiek $w$ poszukiwaniu zagubionej tożsamości. „,Gdzie jesteś, Adamie?". Lublin: Towarzystwo Naukowe Katolickiego Uniwersytetu Lubelskiego, 1987.

Dunajski, A. Chrześcijańska interpretacja dziejów $w$ pismach Cypriana Norwida. Lublin: Towarzystwo Naukowe Katolickiego Uniwersytetu Lubelskiego, 1985

Dybciak, K. Pisarstwo Karola Wojtyły - Jana Pawła II w oczach krytyków i uczonych. Warszawa: PIW, 2019.

Gołaszewska, G. Zarys estetyki. Warszawa: PWN, 1984.

Kołaczkowski, S. Dwa studia: Fredro, Norwid. Warszawa: Wydawnictwo Droga, 1934.

Kuczera-Chachulska, B. Norwida „,przypowieść o pięknem” $i$ inne szkice z pogranicza genologii i estetyki. Warszawa: Wydawnictwo Uniwersytetu Kardynała Stefana Wyszyńskiego, 2008. 
Maingueneau, M. Dyskurs literacki jako dyskurs konstytuujacy. Tłum. H. Konicka. „Teksty Drugie”, 2009 (4).

Merdas, A. RSCJ (ed.) Inspiracje religijne $w$ literaturze. Warszawa: Akademia Teologii Katolickiej, 1983.

Norwid, C. Nie sq nasze - pieśni nasze. Wiersze religijne. Wybór, wstęp, komentarz S. Sawicki. Kielce: Wydawnictwo Pewne, 2021.

Norwid, C. Pisma wszystkie. Zebrał, tekst ustalił, wstępem i uwagami krytycznymi opatrzył J. W. Gomulicki. T. 1-12. Warszawa: PIW, 1971-1976.

Powszechna Encyklopedia Filozofii (praca zbiorowa). T. 2. Lublin: Polskie Towarzystwo Tomasza z Akwinu SITA, 2001.

Sawicki, S., Gotfryd, J. (eds.) Biblia a literatura. Lublin: Towarzystwo Naukowe Katolickiego Uniwersytetu Lubelskiego, 1986.

Sawicki, S. Wartość - Sacrum - Norwid 2. Studia i szkice aksjologicznoliterackie Lublin: Towarzystwo Naukowe Katolickiego Uniwersytetu Lubelskiego, 2007.

Tatarkiewicz, W. Dzieje szczęściu pojęć. Warszawa: PWN, 1975.

Trojanowiczowa, Z. Norwid o pracy ludzkiej. W drodze. 1983 (10).

Wojtyła, K. (Jan Pawel II) Poezje, dramaty, szkice, Tryptyk rzymski. Kraków: ZNAK, 2004. 


\section{„PISMO JEST JAK OBRAZ” - ZAPISKI MARII WIECCKOWSKIEJ. INTERPRETACJA WYBRANYCH FRAGMENTÓW Z ELEMENTAMI GRAFOLOGICZNEJ ANALIZY PISMA}

\section{"Writing is Like a Picture" - Writes Maria Więckowska. Interpret Selected Fragments with Elements Graphological Analysis of the Handwriting}

Keywords: graphology, manuscripts, multimodality, typography, Więckowska

Contact: Uniwersytet Warszawski; ilp.polon@uw.edu.pl

„Mowa jest stara jak sama ludzkość” (Kuckenburd 2006: 103) - natomiast historia pisma to zaledwie 5000 lat. Przekaz historyczny miał charakter oralny, stąd też przypisywanie szczególnie ważnej roli starcom, jako skarbnicom wiedzy, a ich śmierć była porównywana do płonącej biblioteki (Klaffke 1983: 222). Próby poszukiwań najlepszych sposobów porozumiewania się i utrwalania komunikatów prawdopodobnie rozpoczęły się od kija karbowanego, a więc nacięć w postaci prostych, krzyżujących się, czy pochyłych kresek. Informacje najczęściej dotyczyły życia codziennego myśliwych, pasterzy, robotników: ilości upolowanej zwierzyny, zebranych kiści winogron, czy wiązek chrustu. Zapiski te przypominały formułę księgi rachunkowej, a ich znaczenie dla rozwoju pisma podkreśla fakt, iż w chińskim piśmie znak karbowanego kija zachował się do dziś. Warto zwrócić uwagę, że badacze przy interpretacjach nacięć na kiju, czy też na kości zwracali uwagę na ich jakość odnośnie chociażby głębokości. W takim podejściu zamyka się istota specjalistycznych badań grafologicznych, dla których najmniej istotna jest treść, „Grafolog patrzy na rękopis jak na obraz" (Hill 1992: 44).

\section{Grafologia na drodze ku naukowości}

Historia pisma sięga czasów starożytnych, nie dziwi, zatem że równie zamierzchłych dziejów dotyczy grafologia. Konfucjusz już zauważył, by strzec się człowieka, którego „pismo kołysze się jak trzcina na wietrze” (Hill 1992: 20), gdyż osoby o piśmie rozchwianym są niestabilne emocjonalnie. Człowiek skrywa w sobie wiele tajemnic. Potrzeba odkrywania tego, co ukryte wyrosła nie tylko ze sfery nauki, polityki czy 
„Pismo jest jak obraz” - zapiski Marii Więckowskiej. Interpretacja wybranych fragmentów z elementami grafologicznej analizy pisma

sztuki, ale codziennych relacji międzyludzkich. Nie budzi zdumienia fakt, że już od dawien dawna próbowano „odczytać człowieka”, jego myśli, intencje, to kim jest, ale przede wszystkim jaki jest. Uczeń Arystotelesa i Teofrasta z Eresos - Demetriusz z Faleronu stwierdził, że „Pismo wyraża duszę człowieka” (Hill 1992: 20). Podwaliną myślenia w kategorii związku między tym, co zewnętrzne, czyli ciałem a tym, co ukryte (dusza) wydaje się być traktat przypisywany Arystotelesowi „Fizjognomika”, w którym to zawarł myśl, iż psyche i fizis wzajemnie od siebie zależą. Nastój człowieka znajduje odzwierciedlenie w powierzchowności, a to, co dolega ciału ma wpływ na stan ducha (Arystoteles 1993: 321). Starożytni filozofowie powszechnie wyrażali przekonanie, że charakter pisma pozwala na wniknięcie w duszę człowieka i poznanie jego najskrytszych marzeń, pragnień czy cech charakteru. Pierwszą ze znanych prac wzbogaconych o rys grafologiczny była kronika Swetoniusza Trankwillusa. Badając pismo cesarza Augusta, Swetoniusz doszedł do wniosku, że cesarz był człowiekiem racjonalnym, logicznie myślącym (Hill 1992: 20). I choć historia pokazuje, że zainteresowanie badaniem pisma wygasło na kilka wieków -przyczyny tego zjawiska upatrywano w analfabetyzmie (często nawet władcy byli niepiśmienni) - uznawano tę metodę poznawania człowieka za rodzaj wróżbiarstwa, niemającego nic wspólnego z nauką. Paradoksalnie, kilka stuleci później, to właśnie za sprawą jezuity Flandrina (XVIII w.) odkrywanie tajników pisma przeżywało czas rozkwitu. Jednak przełomem w tej dziedzinie była monografia pt. „Tajniki charakteru pisma” (1872), którą napisał francuski ksiądz Jean-Hyppolyte Michon. Jego spojrzenie oparte na wątkach z notatek Flandrina, stało się fundamentem „grafologicznej metody kartezjańskiej” (Kartezjusz 2019: 32 $)^{1}$, w pewnym stopniu wykorzystywanej również współcześnie. Metoda ta zdaje się nawiązywać do teorii poznania, której podstawą było wątpienie („Mam argumenty, by wątpić, gdy nie posiadam wystarczające pewnych postaw, żeby nie wątpić" (Gottfried 2007: 17)), prowadzące do opracowania uniwersalnej metody poznania, której fundament stanowiły na jasność i wyraźność. Ustalenia Michona były wynikiem wieloletnich analiz setek próbek charakterów pism, pochodzących z przełomu wieków, tak, aby stworzyć zasady obiektywne, dalekie od spekulacji i domysłów, by rozwiać wątpliwości i mieć pewność. W analizie pisma badacz brał pod uwagę ,szybkość pisania, nacisk, kształt, kierunek i wielkość liter, ciągłość wiersza i porządek" (Hill 1992: 22). Michon został uznany za protoplastę grafologii, której to

\footnotetext{
${ }^{1}$ Cyt: „1. Nie przyjmować nigdy żadnej rzeczy za prawdziwą, zanim jej nie poznam z całą oczywistością jako takiej: tzn. unikać starannie pośpiechu i uprzedzeń i nie obejmować swoim sądem niczego poza tym co się przedstawi memu umysłowi tak jasno i wyraźnie, iż nie miałbym żadnego powodu podania tego w wątpliwość. 2. Podzielić każde z rozpatrywanych zagadnień na tyle cząstek na ile się da i ile będzie tego wymagać lepsze rozwiązanie. 3. Prowadzić myśli po porządku, zaczynając od przedmiotów najprostszych i najłatwiejszych do poznania, aby następnie wnosić się pomału, jak gdyby po stopniach, aż do poznania bardziej złożonych; należy się przy tym domniemywać prawidłowych związków nawet między tymi, które nie tworzą naturalnego szeregu. 4. Czynić wszędzie wyszczególnienia tak dokładnie i przeglądy tak ogólne, abym był pewny, iż nic nie opuściłem”.
} 
nazwę w takim brzmieniu nadał. Słowo „grafologia” pochodzi od grapho- (gr. $\gamma \rho \alpha \varphi \eta ́$, „zapis”) oraz logos (gr. $\lambda$ óyos, który odnosi się do słowa i umysłu). Czytanie człowieka na podstawie jego charakteru pisma, zatem przestało być jedynie metaforą, magiczną sztuczką chiromantów, za których brano grafologów. Interpretowanie pisma w 1925 roku zyskało miano nauki akademickiej na Sorbonie w 1925 r.

Polska grafologia nie doczekała się zbyt dużych osiągnięć wśród badaczy. Być może ze względu na postrzeganie jej, jako swoistej zabawy opartej na spekulacji, a nie naukowej metody. Często stawiana była na równi $\mathrm{z}$ astrologią, chiromancją czy wróżbiarstwem. Warto, jednak wymienić pracę Henryka Kwiecińskiego - „Grafologia sądowa” czy „Grafologia w zarysie, czyli tajemnice piszącej ręki” (1938) Ludwiki Bidermann. Badaczka ta wykształcenie z zakresu poznawaniu tajników pisma zdobyła w Niemczech, kolebce biegłych grafologów. Bidermann tak napisała o motywacji do powstania tej książki: „W książce mojej o grafologii wykluczam z góry wszelkie metafizyczne i mistyczne podstawy - postępuję ściśle według metody badawczej, wypróbowanej w długoletnim doświadczeniu. Pracą moją chciałabym dać impuls do badań grafologicznych, podnieść poziom tej nauki, wykazać, jakie ona przynosi korzyści wychowania, prawnikom itd." (Bidermann 1938: 5).

Wśród specjalistów wysoko cenieni byli niemieccy badacze tajników pisma. W 1896 roku założyli Niemieckie Towarzystwo Grafologiczne. Rozliczne przeprowadzone ekspertyzy ręcznego pisma pozwoliły na postawienie tezy, że stan psychiczny, przeżywane w danym momencie emocje oddziałują na ruchy ręki, co w konsekwencji ma wpływ na ostateczny kształt pisma, na który się składa wiele elementów, wymagających wiedzy i obserwacji badacza. „Współczesna analiza nie ogranicza się do ogólników: określa się tempo pisania, konstrukcję, rozmach, czytelność, nachylenie liter, spójność, intensywność i wyrazistość nacisków, konfigurację, kształt wierszy i odległość między nimi, rozmieszczenie znaków, przekreślenia, kropki, sposób zwijania pętli, a także kompozycję i styl narracji, gramatykę i ortografię (...) Bada się również specyficzne cechy dokumentu, jak plamy, kleksy (...)" (Hill 1992: 113). Istotnym elementem w ocenie grafologów jest narzędzie użyte do pisania, gdyż jego wybór jest warunkowany podświadomością autora tekstu. Przykładem mogą być osoby, wybierające pióro wieczne, które wymaga pewnego wysiłku od piszącego, zwolnienia tempa pisania. Piszący tym narzędziem postrzegają kartkę, na którą przelewają swoje myśli, jako partnera tego specyficznego dialogu. Wybór pióra wiecznego, jako środka piśmienniczego (pióro wieczne) świadczyć też może o waleczności i odważnym stawianiu czoła problemom. Natomiast najważniejszą cechą indywidualną rękopisu i jednocześnie jedną $\mathrm{z}$ najtrudniejszych cech do wychwycenia jest rytm, jak stwierdził Ludwig Klages (1872-1959) uważany za 
najwybitniejszego niemieckiego grafopsychologa, badającego zależności między mową, mimiką a pismem. Grafolodzy badają tę cechę poprzez określenie, m.in. odstępów między słowami czy poszczególnymi wersami tekstu. Przykładowo skokowe, pogrubione pismo z dużymi odstępami dowodzi ogromnej emocjonalności i istnienia w piszącym podmiocie wewnętrznych napięć (Hill 1992: 47).

Forma graficzna pisma podkreśla niepowtarzalność jego autora. Stanowi wypadkową czynników sytuacyjnych, psychologicznych, ale to biologicznie zdeterminowany temperament jest odpowiedzialny za gest graficzny (Gawda 2006: 13). Analogiczną zależność zauważam w procesie twórczym. Otóż człowiek w procesie stwarzania jest źródłem pomysłu i stanowi narzędzie jego realizacji. W nim dokonuje się przemiana bodźców wynikających ze świata zewnętrznego, z natury, a także, a może przede wszystkim, z jego psychicznych uwarunkowań. Niepodważalne znaczenie osobowości i jej podmiotowości w procesie twórczym podkreślił Andrzej Osęka: „Nie to ma znaczenie, co robi artysta, ale to, czym jest (Osęka 1975: 7)". W odniesieniu do twórczości Marii Więckowskiej pytanie o człowieka jest niezwykle ważne w procesie, w którym spełnia on rolę wytwórcy. Dzieła artystki implikują jej doświadczenia, stając się wypadkową bodźców płynących ze świata zewnętrznego, ale i podróży w głąb siebie, eksploracji własnej natury i nieuświadomionych przesłanek podświadomości. Obrazy, wiersze stają się, więc jak linie papilarne na opuszkach palców, wyjątkowe w swoim rodzaju i przynależne tylko jednemu człowiekowi. Styl jest wynikiem nie tylko nurtu obowiązującego w danym momencie historycznym, to wypadkowa talentu, pracy, charakteru, siły ekspresji itd. Bliska temu założeniu - bo zakładająca stan nieskończoności i niepoznawalności psychologii artysty - wydaje się teoria Focillona, który wyobraźnię, pamięć, wrażliwość określa jako cudowną moc duchową, co zakłada niemożność zgłębienia i odkrycia tajemnic duszy. Zakłada jednocześnie, że szczegóły egzystencji nie są istotne, ważne jest tworzenie, przejawy geniuszu zmaterializowane w formie (Osęka 1975: 17). Człowiek jako istota myśląca, twórcza podejmuje różne działania, ażeby dać upust swym myślom. Realizuje potrzebę kreatywności, która jest wpisana $\mathrm{w}$ istotę człowieczeństwa. Twórca dzięki swojemu intelektowi opracowuje plan, który poprzez odpowiedni dobór tworzywa realizuje idee, by w ten sposób powstało dzieło. Czesław Stanisław Bartnik w swych rozważaniach stwierdził, że pracą są wszelkie działania, które zmierzają do rozwoju życia ludzkiego zarówno w aspekcie duchowym, jak i cielesnym. Stwierdził również, że „w pracę wkładana jest osobowość człowieka, uzewnętrznia się poprzez akty działania, wytwory pracy. Kiedy w pracę włożymy oprócz skrupulatności, rzetelności swoiste piękno, w którym dochodzi do głosu jakiś blask życia osobowego, wówczas to piękno można uznać za sztukę" (Bartnik 1977: 15). 
Celem moich rozważań jest ukazanie, że metody odczytywania formy graficznej pisma czy analizy rysunku w zakresie proponowanym przez grafologów znajdują zastosowanie w odkodowywaniu płaszczyzn wizualnych, pogłębiają ich interpretacje, odkrywają sensy nieuświadomione przez ich autorów, pozwalają na poszerzenie zakresu interpretacji cech typograficznych. David Crystal wyodrębnia kilka znaczeniowo dystynktywnych właściwości typograficznych, jak: „styl czcionki (kursywa, pogrubienie/wytłuszczenie etc.), zastosowanie wielkiej i małej litery (...), zastosowanie określonego kroju czcionki, np. o łamanych konturach (tzw. pismo gotyckie) oraz rozmieszczenie elementów na stronie czy też określonej powierzchni” (Antos, Spitzmüller 2015: 198).

Grafologia jest nauką odnoszącą się do aktu pisania, zastosowanych środków i efektów graficznych. Fascynacja tą dziedziną wynika z chęci poznania człowieka, wniknięcia w jego myśli i osobowość. Wynika z założenia, że to, co człowiek reprezentuje na zewnątrz (ruchy ciała, mimika, gesty) jest obrazem intrapsychicznych cech. Przyjmuje także, że ręczne pismo jest formą zapisanej gestykulacji, obrazem niosącym za sobą informacje, dotyczące często nieuświadomionych stanów emocjonalnych piszącego, a także utrwalonych i zmiennych cech osobowości. Z punktu widzenia medycznego pisanie jest procesem fizjologicznym. Czwarte i szóste pole Brockmana zarządza ruchami mięśni szkieletowych zależnych od woli człowieka. Kora motoryczna mózgu szlakami piramidowymi po przełączeniu na poziomie rogów przednich rdzenia przesyła impulsy elektryczne nerwami obwodowymi do połączeń synaptycznych mięśni (efektorów). Wydzielanie acetoholiny w synapsach skutkuje wyładowaniem elektrycznym w błonach mięśniowych, otwarciem kanałów wapniowych i skurczem białek kurczliwych (aktywnej mienzyny) jednostek motorycznych mięśni. W ten sposób procesy zachodzące w mózgu decydują o akcie pisania, którego cechy są zindywidualizowane, jak linie papilarne. Zważywszy na swoistość graficznego kształtu pisma przynależną jego autorowi, grafologia coraz częściej jest wykorzystywana przez psychologów i psychiatrów, którzy lokują przydatność tej wiedzy na równi z testem kleksu Rorschacha (interpretacja czarnobiałych plam atramentowych) (Amend, Stansbury 2006:11). Ręczny zapis zaliczany jest do testów projekcyjnych, co jest słusznym stanowiskiem, ponieważ prace plastyczne uznane są za nośniki informacji o autorze, tym samym nie sposób odmówić tego prawa również pismu, będącego formą obrazu. Sztuki plastyczne, jak i pismo są formą autoekspresji, ukazują sposób postrzegania rzeczywistości przez autora, jak czytamy: „Grafizm jest formą ekspresji, na którą przeniesione zostały elementy osobowości autora tego grafizmu. Pismo jest ponadto obrazem projekcyjnym (...) gest graficzny jest pod bezpośrednim wpływem mózgu (...) Indywidualizacja pisma jest konsekwencją 
„Pismo jest jak obraz” - zapiski Marii Więckowskiej. Interpretacja wybranych fragmentów z elementami grafologicznej analizy pisma

indywidualności psychosomatycznej człowieka" (Gawda 1999: 123). Mówiąc za autorytetem wśród grafologów G. Moriettim, gest, mowa ciała obrazują stan psychosomatyczny człowieka, a pismo jest jednym z gestów (Gawda 1999: 48). Stanowisko o holistycznym podejściu do człowieka i psychosomatycznych zależnościach popiera współczesna medycyna i psychologia.

Niniejsza praca wynika z założenia, że pismo jest determinowane osobowością autora. Odnosi się do aktualnego nurtu w psychoanalizie nazywanego symbolizmem przestrzeni, a także klasyfikacji cech pisma i odpowiadających im cech charakteru. Poddałam już analizie rysunki i bazgroły z rękopisów Marii Więckowskiej (Kunda 2021: 21-32), krakowskiej malarki i poetki. Kolejnym krokiem w odkrywaniu sensów nieuświadomionych jej ekspresji twórczej będzie ujawnienie cech pisma przy wykorzystaniu narzędzi z zakresu grafologii.

Prawidła do analizy pisma są takie same, jak przy analizie rysunku. Graficzny zapis traktowany jest jak obraz. Założenie to zostało również zaanektowane przez badaczy komunikatów plastycznych. Gunther Kres i Theo van Leeuwen kategoryzując i waloryzując narzędzia czytania ustrukturyzowanych płaszczyzn wizualnych przyjęli, że czysty obraz i czysty język nie istnieją. Jak możemy przeczytać w ich pracy badawczej:

„Tekst mówiony jest nie tylko werbalny, ale także wizualny, łącząc się $\mathrm{z}$ trybami takimi jak mimika, gest, postawa i inne formy autoprezentacji. Podobnie tekst pisany obejmuje coś więcej niż język: jest napisany na czymś, na jakimś materiale (papier, drewno, kamień, metal, kamień itp.) I jest napisany czymś (złoto, atrament, ryciny, kropki farby itp.); z literami uformowanymi jako rodzaje czcionek, na które wpływ mają względy estetyczne, psychologiczne, pragmatyczne i inne; oraz $\mathrm{z}$ układem nałożonym na substancję, czy to na stronie, na ekranie komputera, czy na wypolerowanej mosiężnej tabliczce" (Kress, Leeuwen 2006: 44-45).

Przywołana teoria potwierdza słuszność odczytywania pisma jako obrazu i zastosowania narzędzi lingwistyki obrazu, a także uzasadnia przekonanie o naukowości grafologii, która znajduje zastosowanie w różnych dziedzinach badawczych. Można dostrzec analogię w gramatyce obrazu proponowanej przez badaczy Koła Semiotycznego Sydney a symbolizmem przestrzennym pisma wywodzącym się z psychoanalizy opracowanym przez Maxa Pulvera. Przyjął on założenie, że pismo to nieświadomy rysunek odzwierciedlający indywidualne cechy osoby.

Przywołane metody odkodowywania komunikatów wizualnych można ująć w planie krzyża (rys. 1), na który nałożyłam dwa spojrzenia. Świat ideału, to świat 
naszych marzeń, aspiracji, tęsknot. Przestrzeń given odnosi się do naszej wiedzy, przeszłości, którą znamy. Ukierunkowuje nas na - new - czyli dążenia, działania, ku przyszłości. Centrum to nasze ego, któremu podporządkowujemy rozumienie rzeczywistości, patrzymy przez pryzmat naszego ja. Sfera - real - to rzeczywistość, profanum, biologizm. Zatem widzimy, że czytanie człowieka, jego osobowości jest bliskie sposobowi odczytywania wytworów jego umysłu w postaci ekspresji twórczej.

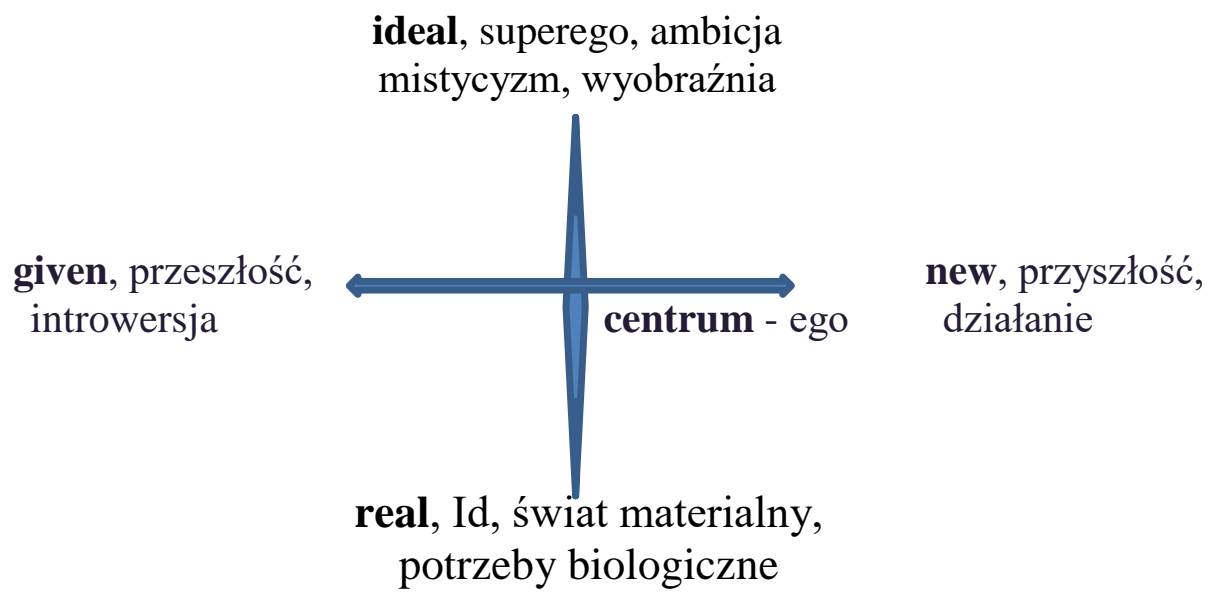

„Pismo symbolizuje naturę człowieka” (Gawda 1999: 42), jako świadomy wyuczony i zautomatyzowany akt jest projekcją osobowości człowieka. Jego zapis graficzny odsyła nas do kondycji fizycznej i psychicznej autora. Chcąc podkreślić naukowość grafologii i wiarygodność psychoanalizy pisma, trzeba wskazać na precyzyjność pomiarów poprzez zastosowanie analiz ilościowych. Analizy te ukształtowały się grafometrię reprezentowaną przez cenioną badaczkę psychologii pisma - Thea Stein-Lewinson, która wykorzystuje 22 parametry graficzne zgrupowane w cztery skale - są to cechy formy pisma, jego poziome i pionowe właściwości oraz cechy głębi. Najważniejszym założeniem w badaniach grafizmu jest stwierdzenie, że pojedyncza cecha pisma nie może być podstawą do określenia osobowości człowieka. Trójpodział liter w ich pionowym wymiarze odnosi się do symbolizmu przestrzeni w ujęciu Freuda, a także trójpodziału sylwetki człowieka. Mianowicie strefa górna (nadlinijna), odpowiada superego. Dotyczy procesów myślowych, rozumu, odpowiada za wyobraźnię, inteligencję i zdolności twórcze. Wstęga (dukt, część środkowa) odnosi się do ego. Odnosi się do też teraźniejszości, życia codziennego. Strefa podlinijna pisma jest równoznaczna $\mathrm{z}$ id, to również płciowość, instynkty, materializm (Amend, Stansbury 2006: 25). Istotne są proporcje zachowane pomiędzy trzema strefami. Dominacja, którejś z nich wskazuje na rozbudowane potrzeby przynależne do „symbolizmu przestrzeni”. 


\section{Cechy graficzne pisma i interpretacja tekstów Marii Więckowskiej}

Badając rękopisy Marii Więckowskiej ustaliłam, że artystka posługuje się różnymi narzędziami pisarskimi. Niekiedy jest to wieczne pióro, które jest dość wymagającym narzędziem, ponieważ nie ślizga się po papierze w odróżnieniu od długopisu. Posługiwanie się wiecznym piórem wskazuje na cechy uczuciowości i marzycielstwa, ale również na sposób odnoszenia się do trudności życiowych - oznacza odwagę i chęć stawiania czoła problemom. Pojawiają się w zeszytach również teksty napisane ołówkiem, jednak biorąc pod uwagę, że było to narzędzie jej pracy, często rysowała szkice, to naturalnym było również pisanie nim. Kolor niebieski wybieranego tuszu również nie jest brany pod uwagę, jako czynnik znaczący. Grafolog uznaje to za normę.

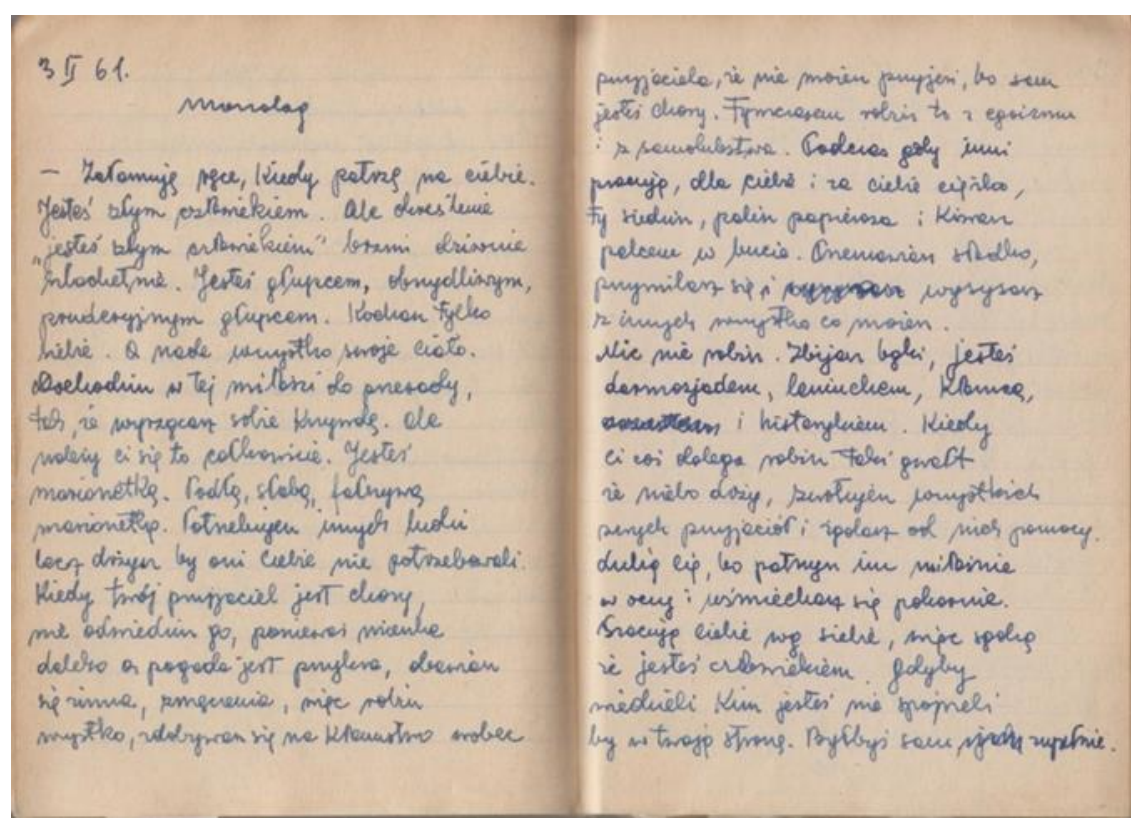

Maria Więckowska, rękopis, 1961, zbiory prywatne

Podobnie, jak przy czytaniu obrazów ważne jest rozmieszczenie tekstu na kartce. Marginesy z lewej strony (norma 1,5-2,5 cm) według francuskiej grafolog Surany świadczy o stosunku autora do matki, prawy (norma $1-1,5 \mathrm{~cm}$ ) o relacjach z ojcem, górny (norma 2,5-3 cm) mówi o postrzeganiu autorytetów, władzy. Dolny margines (miejsce na jeden wers) odzwierciedla nasze działanie i relacje z otoczeniem (Hill 1992: 45). W przypadku zapisków Marii Więckowskiej najczęściej występuje brak lewego marginesu, co oznacza przywiązanie do matki, o czym też świadczą słowa z 11 kwietnia 1961 roku: „U mamusi czułam się naprawdę dobrze, a tu? Ginę chyba”2. Pisząc o matce Więckowska często stosowała deminutywy: mama, mamusia. Silna więź matki z córką,

\footnotetext{
${ }^{2}$ Fragmenty tekstów Marii Więckowskiej pochodzą z nieskatalogowanych rękopisów, znajdujących się w zbiorach prywatnych.
} 
to $\mathrm{w}$ dużej mierze wynik straty ojca we wczesnym dzieciństwie. O relacjach z Franciszką Więckowską najwięcej dowiadujemy się $\mathrm{z}$ nagrań, będących retrospektywnym przywołaniem wspomnień o matce: „Mama była osobą bardzo skromną, pełną prostoty, prostolinijną $(\ldots)^{3 "}$.

Jednocześnie brak lewego marginesu, to brak zaufania, ostrożność, poczucie zagrożenia. Towarzyszący artystce lęk ujawniał się równie często w mocno zaczernionej, zapętlonej kresce w rysunkach. „Lęk” to słowo najczęściej pojawiające się w jej zapiskach:

„Sobota. III. 61. „Samotność i męka. Lęk. Jest mi strasznie źle. Chcę iść gdzieś, ale nie mam siły. Przez ten lęk.

- Nie możesz poddawać się lękowi, bo zaczniesz się bać wszystkiego. Zwalczaj lęk"4.

Natomiast nierówny prawy margines mówi o zmienności nastrojów, nieprzewidywalnych czynach i reakcjach (Amend, Stansbury 2006: 78). Górny i dolny margines w zapiskach Marii nie przekracza linii wydrukowanych na kartce, zatem pozostaje grafologiczną normą.

Odzwierciedlenie jej ambiwalentnych emocji, o których dowiadujemy się z graficznej analizy notatek, można znaleźć w pamiętnikach artystki: „Czwartek 9 lutego 1961 roku. Wczoraj wieczorem było mi nagle dobrze. Spokojnie i dobrze. Aż ogarnął mnie lęk; żeby to była cisza przed burzą. I okazało się, że tak. Że drobna rzecz właściwie wytrąciła mnie $\mathrm{z}$ równowagi. Nie spałam całą noc. Męczyłam się makabrycznie. Dlaczego takie głupstwo potrafiło mnie zatruć?"5. Bliskie jej osoby mówiły o niepohamowanej nerwowości i nagłych wybuchach niezadowolenia. Drażniły ją hałasy, ostre światło czy nawet gołębie i ostentacyjnie dawała temu wyraz. W monologu z 3 lutego 1961 Maria Więckowska opisuje sytuację, które nader często zdarzały się w jej życiu: "Kiedy coś ci dolega robisz Taki gwałt, że niebo drży, zwołujesz wszystkich swoich przyjaciół i żądasz od nich pomocy"' . W zapisie tego fragmentu odnajdujemy bardzo wyrazistą i często występującą cechę w charakterze pisma malarki, tzw. podpórki (,kreski rozpoczynające pierwszą literę słowa” (Amend, Stansbury 2006: 122)) w literach „m”, „n”. Interpretuję je w powiązaniu z innymi

\footnotetext{
${ }^{3}$ Nagrania zostały wykonane przez samą autorkę tekstów, Marię Więckowską. Obecnie znajdują się w zbiorach siostrzenicy artystki, Grażyny Szczurkowskiej.

${ }^{4}$ Maria Więckowska, rękopisy nieskatalogowane; zbiory prywatne.

${ }^{5}$ Ibidem.

${ }^{6}$ Ibidem.
} 
cechami pisma, jako silne uzależnienie od drugiej osoby (Amend, Stansbury 2006: 189), poszukiwanie wsparcia, poczucie własnej bezradności i zranienia emocjonalnego.

Szczególną również uwagę zwraca podwójne przekreślenie w głosce „t”, co można odczytać jako chęć zatuszowania czegoś wstydliwego, nieuczciwego, jako wyraz poczucia winy. Wyjaśnienia możemy szukać w kolejnych fragmentach monologu. Czytamy: „Jesteś marionetką, podłą słabą, fałszywą marionetką. Potrzebujesz innych ludzi, lecz drżysz by oni Ciebie nie potrzebowali" ${ }^{\text {"7 }}$. Motyw marionetki może sugerować poczucie zależności od innych, braku wpływu na własne życie. Niewykluczone, jednak że jest celowym kreowaniem siebie na osobę potrzebującą wsparcia, by zwolnić się z odpowiedzialności i konieczności realizacji przyziemnych obowiązków. Z drugiej strony amplituda emocji, chwiejność uczuć, rozedrganie myśli wprowadzało Marię na drogę bycia bezwolną marionetką poddaną silnym, wręcz dramatycznym wewnętrznym napięciom. Emocje przejmowały kontrolę nad jej postępowaniem do tego stopnia, że dopuszczała się nieuczciwych manipulacji, by wzbudzić zainteresowanie i współczucie otoczenia. W „Monologu” z 1961 roku wyznaje przed światem winy, wykorzystując zabieg wewnętrznego dialogu. Zwraca się do siebie w drugiej osobie w rodzaju męskim, dokonując projekcji własnych wad charakteru na swego rozmówcę: "Zdobywasz się na kłamstwo wobec przyjaciela, że nie możesz przyjść, bo sam jesteś chory. Tymczasem robisz to z egoizmu i z samolubstwa" ". Pierwiastek męski, odczytywany pejoratywnie, zdaje się współtworzyć osobę wypowiadającą się w tekście.

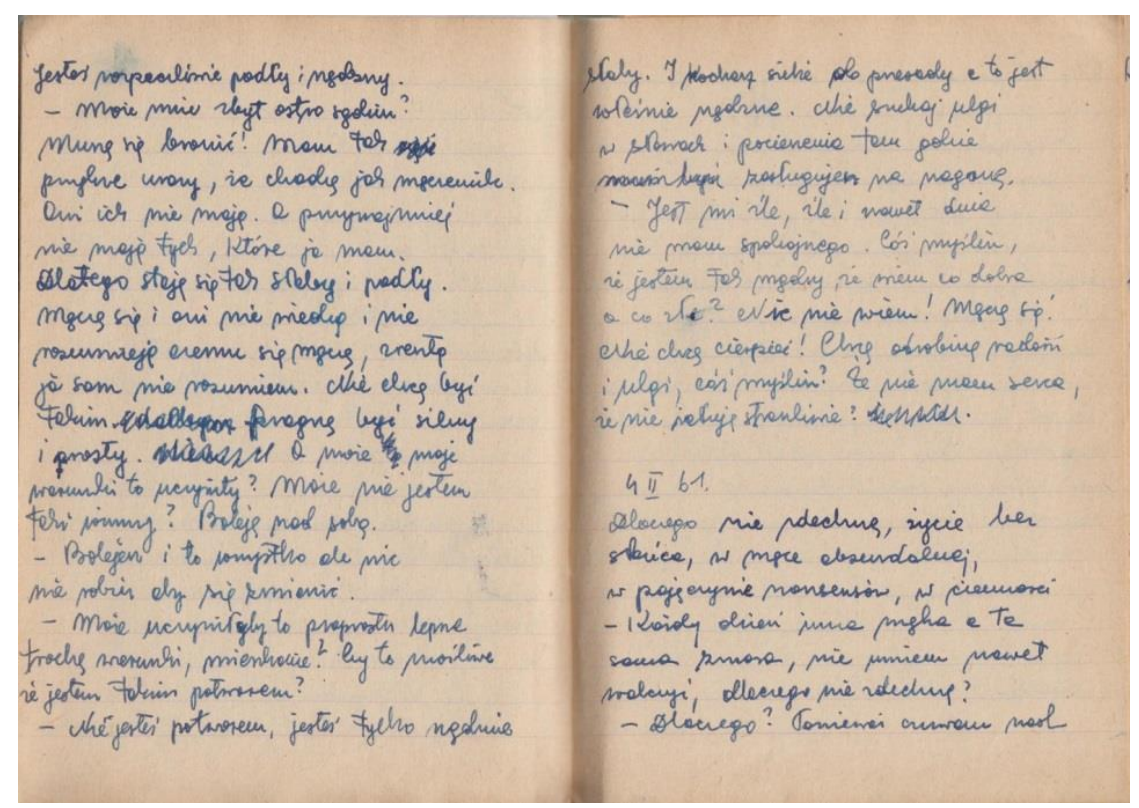

Maria Więckowska, rękopis, 1961, zbiory prywatne

\footnotetext{
${ }^{7}$ Maria Więckowska, rękopisy nieskatalogowane; zbiory prywatne.

${ }^{8}$ Ibidem.
} 
Artystka czuła się winna, ponieważ postrzegała siebie, jako osobę przepełnioną egoizmem. Zbytnio koncentrowała się na sobie, dbała o własną wygodę, co więcej świadomie dopuszczała się manipulacji wobec innych. Chęć bycia w centrum uwagi, a jednocześnie wyrzuty sumienia $\mathrm{z}$ tego powodu zawarła w dalszej części przytaczanego tekstu: „Kiedy twój przyjaciel jest chory, nie odwiedzisz go, ponieważ mieszka daleko a pogoda jest przykra (...) ,, by dalej stwierdzić: „Lubią cię, bo patrzysz im miłośnie w oczy i uśmiechasz się pokornie. Szacują Ciebie wg siebie, więc sądzą, że jesteś człowiekiem" ". Cechą pisma, która jest widoczna w tym fragmencie, to finezyjne pętlice zwłaszcza w zaimkach rzeczownych „cię”, „ciebie”. Pętlice są wyrazem emocji (Amend, Stansbury 2006: 105), które być może wynikają ze stosunku do swego intrapsychicznego rozmówcy. Dialog prowadzony $\mathrm{z}$ wewnętrznym głosem jest typowym zabiegiem stylistycznym, pojawiającym się w zapiskach Więckowskiej. Owe ,ja” tzw. społeczności umysłu pojawia się w dwojakiej naturze: krytyka - pewnego rodzaju Daimonion, negującego ujemne cechy charakteru, postawy wobec zastanej rzeczywistości i „Przyjaciela” (cyt. „Przyjacielu, mój przyjacielu, męczę się bardzo”10), który kształtuje właściwe postawy moralne, dodaje otuchy, wiary, zapewnia o miłości, nakłania do wytrwałości, jest wsparciem. Przyjaciel jest postacią bardziej skonkretyzowaną przez dookreślenia występujące w tekście: „20 luty 1961. Ukochany, czemu to żyję lękiem, kiedy Ty jak światło roztaczasz nade mną swój wzrok?" ${ }^{11}$.Zapiski te budują narrację na wzór psalmów błagalnych pełnych żalu i próśb o zmiłowanie. Autorka zastosowała apostrofy („Ukochany”, „Przyjacielu”, Świetle”), zaimki dzierżawcze, wskazujące zapisane dużą literą, co wskazuje na zwrot do bóstwa, Boga, kogoś szczególnie umiłowanego.

Amplituda uczuć względem drugiego człowieka, jak i siebie samej podlegała skrajnym zmianom, o czym można przeczytać w liście do nieznajomego: „Czasem się pragnie ludzi, a czasem ucieka przed nimi" ${ }^{12}$. Prostopadłe pismo, jakim posługuje się Więckowska, świadczy o ostrożności, ale również takie osoby bywają obdarzone dużym urokiem osobistym i ciętym dowcipem, co w moim przekonaniu potwierdzają jej teksty literackie, jakich przykładem jest „Facet jest taki sam, jak jego twarz” (Więckowska 2015: 50). Koncept utworu polega na wykreowaniu świata przedstawionego wokół tematu wiodącego, czyli „kościuszkowskiego nosa”, który stał się pretekstem do opisu mężczyzny o imieniu Staszek. Narrator manifestuje swoją obecność, wypowiadając się w pierwszej osobie. Jest jednocześnie bohaterem świata przedstawionego, o czym świadczą słowa: ,(...) myślałam patrząc na siedzącego vis-á-vis przy sąsiednim stoliku

\footnotetext{
${ }^{9}$ Maria Więckowska, rękopisy nieskatalogowane; zbiory prywatne.

${ }^{10}$ Ibidem.

${ }^{11}$ Ibidem.

${ }^{12}$ Maria Więckowska, rękopisy nieskatalogowane; zbiory prywatne.
} 
„Pismo jest jak obraz” - zapiski Marii Więckowskiej. Interpretacja wybranych fragmentów z elementami grafologicznej analizy pisma

mężczyznę" (Więckowska 2015: 50), stąd też możemy mówić o narracji pamiętnikarskiej. Tekst ten odnajdziemy także na kartach intymnych zapisków Marii Więckowskiej. Ponadto nie sposób odrzucić wrażenie, że narrator przejawia cechy właściwe osobowości autorki. Opis jest wyrazem wnikliwego oka malarza oraz poczucia humoru ze szczyptą ironii. Wydaje się cieniem epizodu związanego z występami Marii Więckowskiej w „Piwnicy pod Baranami” za namową Piotra Skrzyneckiego. Charakterystyka Staszka pokazuje, że Maria Więckowska była portrecistką, posiadającą rzadko spotykaną umiejętność wydobywania głębi osobowości, nie idealizując, ale dążąc do uchwycenia prawdy, jej prawdy. Ujmująca szczerość, wnikliwe spojrzenie, gorycz i ironia - zaskakująca wyobraźnia. Sama uwikłana w pajęczynę uczuć potrafiła z ich delikatnej formy stworzyć zachwycające obrazy, te na płótnie i na papierze. Liczne powtórzenia, paralele składniowe („Mieć taki nos i taką minę, do takiego nosa nie można mieć innej miny - do głupiego nosa, głupia mina, idiotyczna mina" (Więckowska 2015: 50)), przekształcenia semantyczne na styku z neologizmami (,wydmuchany" w znaczeniu pusty), porównania wprowadzające elementy obrazowe jak i sugestie emocjonalne („Pusty, jak makówka”, nieciekawy, jak stary, nudny, kawał”, ,patrzy w przestrzeń, jak niewidomy” (Więckowska 2015: 50)) bogactwo środków stylistycznych oprócz malarskiej formy tekstu wprowadzają charakter monodramu, w którym występuje tylko jeden wypowiadający, a jego monolog stanowi jakby szereg replik wyimaginowanego dialogu z nieistniejącym rozmówcą (Głowiński i in. 1991: 407).

Przywołałam dwa utwory Marii Więckowskiej, będących przykładami jednej $\mathrm{z}$ technik zastosowania strumienia świadomości nazywany soliloquium (Humphrey 1970: 264). W pierwszym przypadku tekst stanowi swoisty dialog (rozmowę z samym sobą), którego interlokutorem jest wewnętrzne ,ja”, kiedy to wypowiadający go bohater próbuje uformować własną postawę względem rozgrywających się w jego życiu zdarzeń; drugim przykładem jest monolog, będący wyrazem ironicznej dramaturgii skonstruowanej wokół Staszka i jego „kościuszkowskiego nosa”. Oba pełnią funkcją emotywną, choć emocje jakie przekazują są zgoła odmienne. Jedynie cechy ikoniczne pisma zdradzają tego samego autora. Co więcej ujawniają dychotomię jego osobowości - siłę i chęć zmagania się z przeciwnościami, a jednocześnie potrzebę wsparcia innych osób; strach przed samotnością i ucieczkę w samotność; smutek, samokrytykę i świadomość własnej wyjątkowości. 


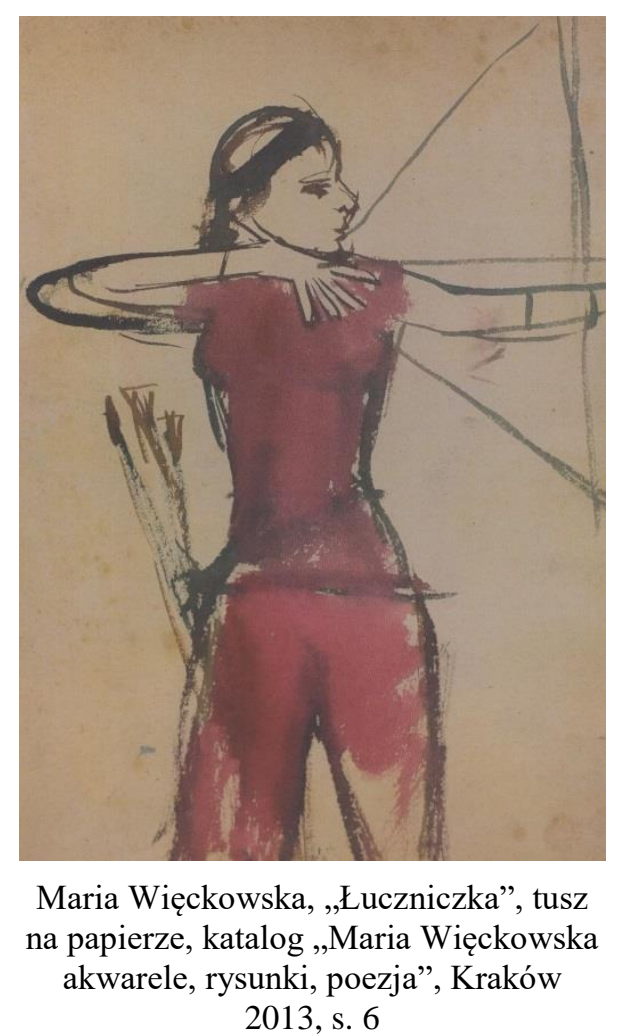

Potwierdzenie dwoistości natury znajdziemy również w jej pracach plastycznych. Kobiecość tytułowej łuczniczki podkreśliła talią, subtelnie zarysowanym biustem i szerokimi biodrami, wydającymi się mocno osądzającymi postać na ziemi. Jednak pierwsze wrażenie nie jest do końca słuszne, bo przecież kobieta jest ukazana w zbliżonym planie bez stóp wspierających się o ziemię. Tło jest tylko pustą przestrzenią. Nie jesteśmy w stanie określić gdzie się znajduje. Podobnie jest z dłońmi, jedna z nich naciąga cięciwę, co mówi nam o zdecydowanym działaniu, by osiągnąć cel, a jednocześnie nie widzimy co nim jest. Strzały w kołczanie są przygotowaną bronią, może stanowią pewne atuty, które mają pomóc w realizacji aspiracji. Twarz skierowana $\mathrm{W}$ stronę strzały, mającej być wypuszczoną $\mathrm{z}$ naprężonego łuku. W psychoprzestrzeni prawa strona odnosi się do podjęcia działań, wyzwań, otwarcie się na doświadczenia i taką postawę można dostrzec w sylwetce kobiety. Jednocześnie zaczerniony łokieć mówi o lęku z bliżej nieokreślonych powodów, ponieważ nie widzimy realnego zagrożenia w przedstawionej kompozycji. Brak lewej dłoni, tej przynależnej do psychologicznej sfery kobiecości również odnoszącej się do matki, świadczy o bezradności, braku poczucia bezpieczeństwa, które zapewniała autorce pracy obecność matki, o czym też wielokrotnie pisała. Przełożenie postaw, obaw, emocji na kreowane postaci w plastycznych wytworach tworzą swoisty profil psychologiczny Więckowskiej, tworząc w ten sposób zbiór specyficznych autoportretów. Sposób przedstawienia łuczniczki mocno koresponduje z zapiskami, których w podobnym 
charakterze jest bardzo dużo. Dwoistość natury, strach i potrzeba walki ujawnia się między innymi w tekście z 15 marca 1961 roku:

„15 marca 1961. Wczoraj nie umiałam walczyć. Byłam zdenerwowana, niespokojna i przerażona (...) Boję się czegoś nieokreślonego, jakiegoś załamania, rozpaczy.

- Jeżeli zaufasz Mnie, nie będziesz obawiać się rozpaczy.

- Wczoraj dzień był taki niedobry.

- Nie myśl o tym

- Powraca samo, nie wiem, jak się bronić.

- Pomyśl o malarstwie (...)"13.

Malarstwo, potrzeba zaspokojenia ambicji i odniesienia sukcesu artystycznego wydaje się być celem, którego nie widzimy przed kobietą strzelającą z łuku. Tak też łuczniczka może stać się autoportretem, mówiącym o niedefiniowalnych stanach emocjonalnych, w których dominowało poczucie zagrożenia i walce w realizowaniu własnych aspiracji. O tym też nieustannie pisała Więckowska: „Wiesz czym jest życie ludzkie. Wiesz jak niepewne"14.

Treści tekstów wyraźnie korespondują i dookreślają informacje zakodowane w pracach malarskich, zaś analiza grafologiczna dopełniła postawione wnioski interpretacyjne, wskazując wysoki stopień zależności między autorem, jego osobowością kształtowaną przez doświadczenia a treścią ekspresji twórczej. „Życie malarza przecież istnieje w jego obrazach" (Lorenc 1969: 17) - w słowach z biografii Czesława Rzepińskiego (profesor ASP, do jego pracowni uczęszczała Maria Więckowska) wybrzmiewa wskazówka odczytywania twórczości nie tylko Marii Więckowskiej. Zamykając ogólną charakterystykę pisma Więckowskiej - ponieważ skupiłam się na cechach wyrazistych, by uniknąć domniemań - chciałabym zwrócić uwagę na jego harmonijny wygląd. Żadna $\mathrm{z}$ trzech sfer (nadlinijna - wstęga podlinijna) nie dominuje. Pętlice $w$ górnej i dolnej strefie mieszczą się w normie, co świadczy o wewnętrznej równowadze autora, ale nie należy tego mylić z brakiem uczuciowości (Amend, Stansbury 2006: 105). Ponadto w piśmie widać duży stopień łączliwości liter, co jest oznaką kreatywności, wysokiej inteligencji. Wyczuwalny artyzm z subtelną dozą finezji ujawnia się w oryginalnym łączeniu „„” lub „," z głoskami następującymi. Elastyczne, staranne formy liter potwierdzają dużą umiejętność posługiwania się kreską malarską.

\footnotetext{
${ }^{13}$ Maria Więckowska, rękopisy nieskatalogowane; zbiory prywatne.

${ }^{14}$ Ibidem. 
$\mathrm{Na}$ podstawie literki „t” możemy określić cele autora, jego aspiracje. W przypadku Więckowskiej linia włosowata jest umieszczona wysoko, a niekiedy na wierzchołu laseczki, co świadczy o pragnieniu niemożliwego, skłonności do fantazjowania, oderwania od rzeczywistości. Takie same wnioski wysnuć można z wysoko stawianych kropek nad ,i” - świadczy to o intelekcie i aspiracji, wyobraźni i entuzjazmie ((Amend, Stansbury 2006: 143-148). Maria była osobą bardzo pracowitą, szukającą zajęcia. Z determinacją walczyła ze skłonnością do zatapiania się w zadumę: „Maluj drapieżnie, brutalnie, odważnie (...) wykonaj zamiar”, „Codziennie coś trzeba robić” - nieustanie napominała samą siebie - „Spieszyć się trzeba nie w pracy, ale w momentach marnowania czasu" ${ }^{15}$.

Dzięki tym cechom powstało wiele prac malarskich, ale także dziesiątki zapisanych staranną kaligrafią zeszytów. Uzdolnienia literackie, artyzm czytamy w sposobie zapisu literki ,g”, która kształtem przypomina cyfrę 8 (Amend, Stansbury 2006: 166). Była artystką wszechstronną, wytrawnie posługującą się rzemiosłem malarskim. Jako absolwentka ASP wielokrotnie była wyróżniana za pracę twórczą. Aktywnie brała udział w najważniejszych wystawach w latach 1957-1980. Jako poetka wyrażała się w różnych formach literackich, poezji, intymnych zapiskach, opowiadaniach, będących wyrazem romantycznej frenezji, filozoficznej natury z nutą mistycyzmu.

W piśmie przeważa forma arkadowa, co może świadczyć o zdystansowaniu wręcz tajemniczości, ukryciu się przed światem, a także sporej dozie ostrożności w nawiązywaniu przyjaźni, bliższych relacji. Podobne sensy niesie za sobą literka „k”. Kreski się nie stykają, co również interpretujemy jako budowanie dystansu (Amend, Stansbury 2006: 163), ale również świadczy o przedsiębiorczości. Te cechy odczytywane przez pryzmat grafologii ujawniły się dość radykalnie po roku 1980, kiedy to Maria Więckowska całkowicie wycofała się z publicznej działalności artystycznej pozostała w ukryciu własnej pracowni przy ul. Szerokiej w Krakowie. W 1996 roku napisała wiersz, a w nim słowa: ,jestem ptakiem wysokoniebnym/ uwięzionym w klatce"16. Wyraziła własną sytuację w metaforze utworzonej ze złożenia „wysokoniebny” (compositia - wyraz utworzony ze dwóch słów (Głowiński i in. 1999: 108)) i rzeczownika ,ptak”, precyzując związek przysłówka z rzeczownikiem pozwala na zakwalifikowanie tropu jako epitetu metaforycznego na określenie skrzydlatego stworzenia, które archetypicznie kojarzone jest z tym, co przebywa w sferze nieba. Określenie „wysokoniebny” można odczytywać jako hiperbolę wznoszenia się, ponieważ stwarza wrażenie lotu ponad inne ptaki, ponad błękit bezkresnego nieba.

\footnotetext{
${ }^{15}$ Maria Więckowska, rękopisy nieskatalogowane; zbiory prywatne.

${ }^{16}$ Maria Więckowska, rękopisy nieskatalogowane; zbiory prywatne.
} 
„Pismo jest jak obraz” - zapiski Marii Więckowskiej. Interpretacja wybranych fragmentów z elementami grafologicznej analizy pisma

Dramatyczne napięcie pojawia się w przywołanym wierszu, kiedy poetycki obraz wolnego ptaka unoszącego się $\mathrm{w}$ przestworzach zostaje zestawiony $\mathrm{z}$ uwięzieniem w klatce, by w kolejnym wersie przeczytać słowa: „moje cierpienia są inne” ${ }^{17}$ - będące jakby wyrzutem podmiotu lirycznego sformułowanym wobec otoczenia, mówiącym o braku zrozumienia, może odrzuceniu, czy poczuciu obcości wynikającej ze świadomości własnej wyjątkowości. Nieprzeciętna wyobraźnia kształtowana przez wrażliwość optyczną i emocjonalną zbudowała klatkę, z której nie ma ucieczki, bo jak odrzucić własną osobowość, zapanować nad wybujałą uczuciowością? Wyobraźnia, uczuciowość jako więzienie - może zbyt daleko posunięty oksymoron, ponieważ „skrzydła wyobraźni” powinny dawać wolność, możliwość przekraczania granic przyziemnej rzeczywistości, a jednak czytając teksty Więckowskiej nie sposób odrzucić intensywnych i dramatycznych sprzeczności demonizujących jej sposób odczuwania własnego bytu. Przywołane teksty ikoniczno-lingwistyczne, bo takimi też można nazwać rękopisy, w swej tematyce, podejmowanych problemach, wątkach autobiograficznych, przynagleniach kierowanych do interlokutora wewnętrznych dialogów wraz grafologiczną analizą konstruują portret artystki wzajemnie się oświetlając i wskazując kierunki interpretacyjne. Grafologia i psychoanaliza wydają się być narzędziami wzbogacającymi wnioski i pozwalającymi w większym stopniu sprostać wyzwaniom, jakie stawia sztuka.

Zasadnym wydaje się założenie, że interdyscyplinarność jest właściwym kierunkiem działań artystyczno-naukowych, pozwalających na świadome odniesienie się do najnowszych kierunków w humanistyce, mówiących o multiomodalności, która definiowana jest jako kombinacja różnych kategorii semiotycznych (Bucher 2015: 88). Nie można $\mathrm{w}$ takim wypadku mówić o czystym języku, ani czystym obrazie, co predestynuje określenia hybrydowe „obraz języka” czy ,język obrazu” do znormatyzowania. Natomiast postawione wnioski odnośnie przywołanych przykładów twórczości Marii Więckowskiej wskazują, iż grafologia jest nauką, którą można wykorzystywać w badaniach nad ekspresją twórczą czy odkodowywaniem płaszczyzn wizualnych jako ważnego elementu typograficznego.

\section{Summary}

The word in this article is considered to be arbitrary, but also iconic. Hence the desire to interpret texts in interaction with the visual aspect of them. When reading manuscripts, graphology has become an important source of knowledge to discover the

\footnotetext{
${ }^{17}$ Ibidem.
} 
meanings between the author and graphic shape of his writing, which models and significantly influences the overtone of the message.

\section{Literatura}

Amend, K. K., Stansbury Ruiz, M. Analiza pisma ręcznego. Twoje pismo mówi, jaki jesteś. Warszawa: KDC Warszawa, 2006.

Antos, G., Spitzmüller, J. Jakie znaczenie ma design tekstu? Rozważania o teorii wiedzy typograficznej. In: Opiłowski, R., Jarosz, J., Staniewski, P. (eds.) Lingwistyka mediów. Antologia tłumaczeń. Wrocław-Dresden: ATUT/Neisse Verlag 2015, s. 183-195.

Arystoteles. Fizjognomika. In: Dzieła wszystkie. Tłum. Regner, L.,Warszawa: PWN, 1993.

Assmann, A. i in. Schrift und Gedächtins. T. 1. München: Fink, 1983.

Bartnik, C. S. Teologia pracy ludzkiej. Warszawa: Instytut Wydawniczy PAX, 1977.

Bidermann, L. Grafologia w zarysie, czyli tajemnice piszacej ręki. Warszawa: Skarbczyk Domowy Ksiegarni św. Wojciecha, 1938.

Gawda, B. Grafizm jako forma ekspresji. Lublin: UMCS, 2006.

Glowiński, M., Okopień-Sławińska, A., Sławiński, J. Zarys teorii literatury. Warszawa: WSiP 1991.

Gottfried, G. Teoria poznania od Kartezjusza do Wittgensteina. Kraków: WAM, 2007.

Hill, B. Tajniki pisma. Warszawa: Wydawnictwo Tetris, 1992.

Humphrey, R. Strumień świadomości - techniki. Pamiętnik Literacki LXI. 1970 (4), s. $255-283$.

Kartezjusz. Rozprawa o metodzie. Gliwice: Onepress, 2019.

Klaffke, C. Mit jedem Greis stribt eine Bibliothek. In: Assmann, A. i in. Schrift und Gedächtins. T. 1. München: Fink, 1983.

Kress, G., Van Leeuwen, T. Reading images. The grammar of visual design. London and New York: Routlege, 2006.

Kuckenburg, M. Pierwsze słowo. Warszawa: Państwowy Instytut Wydawniczy, 2006.

Kunda, A. Psychoanaliza rysunku jako istotne narzędzie interpretacji płaszczyzn wizualnych na przykładach prac plastycznych Marii Więckowskiej. In: Rusakow, 
S. S., Możgin, W. (eds.) Gumanitarnij Korpus. T. 2. Kijów: Vinntysia „TVORY”, 2021, s. 21-32.

Kunda, A. Słowo-wizja-obraz. Między religią a sztuką. In: Karapuda, A., Włoczewska, A. (eds.) Wyrażanie niewyrażalnego. Mistycyzm w sztuce, literaturze, malarstwie, muzyce w 100-lecie śmierci Leona Bloy. Warszawa: ASP, Instytut Romanistyki UW, 2018, s. 147-158.

Lorenc, W. Czesław Rzepiński. Kraków: Wydawnictwo Literackie, 1969.

Osęka, A. Mitologie artysty. Warszawa: Państwowy Instytut wydawniczy, 1975. 


\section{STATUS HISTORICKÉHO ROMÁNU V DIELE ČARODEJNICA Z FLORENCIE OD SALMANA RUSHDIEHO}

\section{Status of the Historical Novel in The Enchantress of Florence by Salman Rushdie}

\section{Keywords: historical novel, romance, postmodernism}

Contact: Univerzita Pavla Jozefa Šafárika v Košiciach; onuskova.gabriela@gmail.com

Salman Rushdie je britský spisovatel' indického pôvodu. Prepojenie európskej a indickej kultúry je neodmyslitel'nou súčast'ou jeho tvorby. Podobne je tomu aj v knihe Čarodejnica z Florencie, ktorá vyšla v roku 2008. Román opisuje Florenciu a indické mesto Síkrí v 16. storočí. Ústrednou postavou Čarodejnice z Florencie je Mogor dell'Amore (Mogul lásky), ktorý prepája krajiny, resp. mestá na dvoch svetadieloch v období renesancie. Na pozadí celého príbehu sú sny a predstavy o najkrajšej, najdokonalejšej žene na svete, ktorú chcú všetci muži milovat', hoci je nepolapitel'ná $\mathrm{v}$ čase a priestore.

Americký literárny kritik, Michael Dirda označil Čarodejnicu z Florencie za text, ktorý prezentuje romantiku krásy a moci $\mathrm{v}$ Taliansku a Indii. Je to podl'a neho romantický príbeh, v ktorom sa prelína nádhera a sila vládnutia. Dirda píše, že je to prekrásna romanca predstavujúca renesančnú mágiu a úžas (Dirda 2008: online). Polemizujeme však s týmto tvrdením, lebo nepovažujeme Rushdieho knihu za úplne totožnú s romancou, skôr sa prikláňame $\mathrm{k}$ názoru, že Čarodejnica z Florencie je historický román. A hoci jeden z ústredných motívov - opis a hl'adanie vel'kej lásky - priam vábi čitatel'a, považovat' knihu za historickú romancu, my v prípade tohto diela dávame prednost' označeniu historický román.

Historický text môžeme definovat' ako akýkol'vek útvar, ktorý má charakter celku a prináša informácie o historickej skutočnosti takým spôsobom a v takom rozsahu, že ponúka priestor na interpretáciu (Beneš 1995: 83). Postavy v historickom románe musia mat špecifickú historickú črtu: „odvodenie zvláštnosti konajúcich postáv z historickej osobitosti ich čias“ (Lukács 1957: 23). Pri postavách Akbara Vel'kého či Niccolu il Machia pozorujeme aj prvky fikcie, ale zároveň je tam výrazná spätost’s ich reálnymi ,predlohami““. 
Ladislav Nagy uvádza $\mathrm{v}$ knihe Od romance $k$ románu niekol'ko názorov teoretikov na historický román: Avron Fleishman považuje historický román za román, ktorý je pevne zakotvený vo svojej prítomnosti, z ktorej smeruje k nejakej minulosti, k jej historicite a zároveň odkazuje na historicitu samotnú. Historický román podl'a Fleishmana potrebuje mat' historický rozmer, v ktorom je aktívna prítomnost' konceptu dejín ako utvárajúcej sily. David Carr poukazuje na to, že naratív historického románu vychádza $\mathrm{z}$ nejakého historického záznamu, podobne ako dokumenty vznikajú na základe niektorých udalostí. R. G. Collingwood si myslí, že autor historického románu zostavuje koherentný obraz histórie, tak, aby ju čitatel’ovi lepšie priblížil a začala mu dávat' zmysel. W. B. Gallie tvrdí, že historickému románu môžeme porozumiet' prostredníctvom jeho naratívnej povahy s nazeraním na rušenie rozdielu medzi sujetom a fabulou, kronikou a príbehom (Nagy 2019: 68-77).

Z predchádzajúcich definícii vyplýva, že Čarodejnica z Florencie inklinuje k historickým románom. Pomocou textu spoznávame spoločenské pomery a kultúru renesancie v Indii a vo Florencii. Dielo odkazuje na historické osobnosti, udalosti, či miesta a to, že Rushdie skutočne čerpal z historických poznatkov, dokazuje aj súpis bibliografie, ktorý uvádza v závere knihy. Mogor dell 'Amore sa spätne vracia do minulosti, aby opísal život svojich predkov a zároveň presvedčil Akbara, že je jeho strýko. Hoci Mogul lásky rozpráva príbeh na dvore cisára pár dní, rozpráva mu udalosti, ktoré sa odohrávali desiatky rokov. V diele môžeme rozdelit čas na čas rozprávaný a čas rozprávania. Mogor dell'Amore sprítomňuje udalosti, ktoré jeho poslucháč (Akbar) dovtedy nevnímal. „Rozlišuje sa tu fakt „rozprávania“ a „rozprávaná“ vec. Ide teda o fenomenologické rozlíšenie, ktoré spôsobuje, že každé (vy)rozprávanie je aktom (vy)rozprávania čoho, ktorý nie je rozprávaním“ (Ricoeur 2004: 118).

Mogor dell'Amore prichádza na dvor cisára Akbara Vel'kého, aby mu vyrozprával svoj životný príbeh, $\mathrm{v}$ ktorom panovníkovi odhal'uje tajomstvo o mughalskej princeznej - Kara Köz (Čiernooká) a zároveň sa mu priznáva, že je jeho strýko. Prostredníctvom Mogora dell'Amore spoznávame renesančnú Florenciu, do ktorej Rushdie zahrnul významné osobnosti tej doby. V tomto kontexte sa zameriame na konkrétne významné postavy dejín, ktoré boli Mogorovi dell’Amore najbližšie.

Salman Rushdie sa raz vyslovil o svojej poetike nasledovne: „Můj př́běh, má fiktívní země existuje - stejně jako já sám - v mírném náklonku ke skutečnosti“ (Nagy 2016: 141). V problematike rozlišovania fikcie od historických faktov, vychádzame z teórií Lubomíra Doležela. V Heterocosmice tvrdí, že fikčné jednotliviny pomocou mimetickej funkcie môžu zobrazovat' skutočnú jednotlivinu alebo skutočnú všeobecninu (Doležel 2003: 22). V našom prípade fikčnú jednotlivinu, ktorá predstavuje skutočné osobnosti, v diele zastupujú napríklad postavy, ako sú Niccoló il Machia, 
Agostino Vespucci, Andrea Doria, Lorenzo de Medici či Akbar Vel'ký. Sú to fikčné subjekty, ktorým dokážeme nájst' v skutočnom svete reálne náprotivky. Vymenované postavy sa pohybujú $\mathrm{v}$ rovnakom priestore a majú rovnaké mená ako ich reálne „,predlohy“, ku ktorým referujú v literárnom diele.

Niccoló il Machia predstavuje renesančného filozofa Niccola Macchiavelliho. Rushdie podčiarkuje ich spojitost' nielen rovnakým prostredím a podobným životným štýlom, ale aj tým, že literárna postava často vyslovuje známy výrok filozofa: „Účel svätí prostriedky“، Agostina Vespucciho by sme mohli automaticky spojit' s moreplavcom Amerigom Vespuccim, ktorý je $\mathrm{v}$ diele jeho bratrancom. Reálny Agostino bol skutočne bratranec Ameriga a zároveň asistentom Macchiavelliho (AmesLewis 2008: online). V románe sa tiež doplaví k „novému kontinentu“ ako Amerigo Vespucci. Kým literárny Agostino je priatel'om Macchiavelliho, reálny bol jeho asistentom. Andrea Doria je náprotivkom skutočného Andreu Doria, ktorý je taktiež ako jeho „literárny odraz“ taliansky námorník a admirál, ktorý bojoval s Francúzskom (Britannica, online). Lorenzo de Medici v Čarodejnici z Florencie vládol Florencii a zomrel na syfilis rovnako ako skutočný Lorenzo de Medici. Akbara Vel'kého Rushdie opisuje ako cisára, ktorý založil Síkrí s vel’kolepými palácmi, bádal vo filozofii a náboženstvách, nariad'oval obyvatel'om kedy smeli byt' ticho alebo rozprávat', mal hárem a jednu imaginárnu manželku Džódhu, ktorú miloval zo všetkého na svete najviac. Reálny Akbar Vel'ký bol takisto ako jeho literárny náprotivok mughalským cisárom, zakladatel'om Síkrí, a zaujímal sa o filozofiu (Ballhatchet 2018: online). O Akbarovi Vel'kom je v dejinách známe aj to, že sa zaujímal aj o krest’anstvo a európsku kultúru, preto pozýval do Indie Jezuitov. Práve Jezuitský rád bol prvou európskou inštitúciou, ktorá vytvorila systematickú štúdiu o indickej kultúre a vzdelanosti (Budil 2002: 76). Ríšu mughalského panovníka opisoval aj francúzsky cestovatel' Francoise Bernier, ktorý tvrdil, že panovníci vlastnia stovky vojnových slonov a po celej krajine sa rozprestierajú vel'kolepé mramorové sídla (Budil 2002: 73).

Postava, ktorá úzko súvisí s hlavnou dejovou líniou, je Antonino Argalia, ale na rozdiel od predchádzajúcich charakterov, povedané jazykom Doleželovej Heterocosmicy, to nie je fikčná jednotlivina, ktorá má v skutočnom svete reálnu jednotlivinu, ale predstavuje reálnu všeobecninu. Takýto typ fikčného subjektu je spojený s historickými, sociologickými, politickými či kultúrnymi kategóriami (Doležel 2003: 23). Antonino Argalia sa rozhodne ujst' z krest'anskej Florencie a stane sa pravou rukou osmanského sultána. Jeho čin je zhodný s mnohými vtedajšími osobnost’ami, ktoré ušli z Florencie. V 15. storočí sa mnohí pridávali na stranu Turkov, pričom to považovali za rovnaký politický krok ako spojenie sa s európskymi krajinami. Týmto 
krokom sa zároveň začali objavovat’ aj „trhliny“ v západnom svete krest’anstva (Burckhardt 2013: 73-74).

Pri zakladaní mesta Síkrí, resp. Fatehpur Sikri, Akbar Vel'ký dohliadal na každý detail, čo spôsobilo aj ornamentálnost' architektúry (prevažne z červeného pieskovca), no i napriek exkluzivite palácov, skutočným drahokamom pre obyvatel'ov Síkrí bola voda (Tajmahal.gov.in, online). Na vzácnost' vody v meste poukazuje aj Rushdie v románe, ked’ píše: „Aj cisár sa raz-dva obráti na prach, ak nemá vodu. Skutočným vládcom je voda a my všetci sme jej otroci“ (Rushdie 2009: 16). Vzhl’ad renesančnej Indie spoznávame v románe prostredníctvom Síkrí, kde sa do popredia dostávalo bohatstvo a rozmary panovníka s vel'kolepost'ou palácov mesta. „Na svitaní vyzerali strašidelné pieskovcové paláce nového vít’azného mesta Akbara Vel'kého ako stvorené z červeného dymu. Väčšina miest začne pôsobit' dojmom večnosti takmer hned' po svojom vzniku, no Síkrí vždy vyzeralo ako fatamorgána. (...) horúčava tu zmazávala hranicu medzi rojčením a blúznením, medzi fantáziou a skutočnost'ou“ (Rushdie 2009: $35)$.

Akbar Vel'ký musel opustit' Síkrí pre nedostatočné zásoby vody, podobne ako aj „románový Akbar“ v závere knihy: „Musí opustit' Síkrí, musí odíst' z milovaného červeného mesta z tieňa a dymu, nechat' ho osamotené na mieste, ktoré náhle vyschlo, aby ostalo na večné veky symbolom pominutel'nosti a náhlych zmien, ktoré môžu postihnút' aj tých najmocnejších“ (Rushdie 2009: 334). Voda symbolizuje podvedomie a je považovaná za prvotný prúd všetkého živého. Voda všetko vytvára alebo naopak ničí (Biedermann 1992: 335-337). V Akbarovom podvedomí existovala jeho imaginárna manželka Džódha, ktorú považoval za skutočnejšiu než jeho reálne manželky. Dokonca v závere sa mu v podvedomí zjavuje aj Kara Köz a až ked' Akbar pochopí, čím všetkým si v živote prešla a kto to je naozaj, až vtedy sa mu z predstavy zhmotní, vystúpi z jeho podvedomia. Voda sa spája so ženskostou už od čias antiky, ked' tento živel odkazoval na telesnost' žien a súvisel aj s vtedajšími ženskými božstvami. V starovekom Grécku bol rozšírený názor, že ženské telo obsahuje väčší podiel vody ako telo mužov. Súvislost' medzi ženou a vodou predstavuje niečo plynúce, nestále, čosi, čo neustále uniká a zároveň niečo, čo sa formuje, modifikuje a odohráva v čase (Kalnická 2000: 39-45). Postava Kary Köz unikala mužom, času a ich vedomiu. Bola nepolapitel'ná, nikomu nepatrila, nik ju poriadne nevidel a nepoznal, hoci o nej všetci snívali a neustále sa objavovala v ich vedomí. Kara Köz o sebe samej tvrdila, že jej mysel' je nestála a stále v nej niečo plynie. V jej mysli prebiehal príbeh, ktorý Mogul lásky rozprával cisárovi, $\mathrm{v}$ jej hlave človek videl minulost' aj budúcnost'. Sama o sebe hovorila ako o „Paláci spomienok“, čo by sme mohli považovat' za Rushdieho nepriamy odkaz na jeho dielo Hárún a more príbehov. 
Historický román popisuje jednotlivé udalosti a entity prostredníctvom minulosti. Zdôrazňuje subjektivizmus historických naratívov, dodržiava historický mod, aby bol román, čo najautentickejší (Nagy 2019: 14). Dejiny v historickom románe by sme mohli vnímat' aj ako produkt palimpsestu, pričom Brooke-Roseová vymedzuje jeho pät' rozličných podôb (Brooke-Roseová 1995: 124). Prvou podobou je realistický historický román. Druhý typ predstavuje vymyslený príbeh, ktorý sa odohráva v historickom období a zasahuje doň magickost'. Tretí typ je podobný druhému, nemá však v sebe magickost', ale za to je nasýtený filozofickými, teologickými a literárnymi odkazmi. Štvrtý typ dejín v palimspestovom prevedení predstavujú romány nám bližšieho, resp. nám známejšieho obdobia alebo udalosti, so zjavnou magickost’ou, ktorá je spôsobená halucináciou. Piaty typ poukazuje na palimpsestové dejiny národa a viery, pre ktoré je magickost' takmer prirodzená, ba až nepodstatná v komparácii $\mathrm{s}$ absurdnost'ou l'udí, opisovaných realisticky. Posledný typ je takisto výrazne spätý s imaginatívnost'ou. Ak by sme Čarodejnicu z Florencie vnímali ako výsledok palimsestu, priradili by sme ju $\mathrm{k}$ piatemu typu, lebo Rushdie istým spôsobom modifikoval dejiny tým, že nám na výsek z historickej reality ponúkol d’alší možný pohl’ad. Napríklad v dejinách je známe, že Síkrí malo problém s vodou, čo bolo hlavnou príčinou odchodu cisára, ale Rushdie vyschnutie jazera v meste pripísal hlavne tomu, že Mogul lásky uvalil na Akbara a mesto kliatbu, lebo ho neprijali medzi seba a neuverili mu jeho príbeh.

Umberto Eco delil historický román do troch kategórií. Prvá kategória predstavuje tzv. romancu, v ktorej ani nie je podstatná história ani jej pravdivost', len sa neodohráva $\mathrm{v}$ súčasnosti, je to fabulačná konštrukcia, $\mathrm{v}$ ktorej predstavivost' dostáva vol’ný rozlet. Druhú kategóriu prezentujú dumasovské romány „kepeňa a meča“. Do reálne spoznatel'nej minulosti vloží autor postavy, podl'a ktorých tú minulost' spoznávame a o ktorých hovoria aj encyklopédie, ale pripíše im niektoré činy, ktoré sa v žiadnej odbornej literatúre nepíšu no zároveň historickým faktom neprotirečia. Do tretej kategórie patria romány, ktorých postavy nie sú známe z encyklopédií, ale ich konanie slúži na lepšie pochopenie dejín, na pochopenie toho, čo sa stalo. Udalosti aj postavy sú vymyslené, ale hovoria nám o aktivitách a o prostrediach také veci, ktoré sa nedozvieme v žiadnej inej literatúre (Eco 2004: 577-578). V prípade tohto delenia, môžeme o Čarodejnici z Florencie uvažovat' ako o historickom románe „kepeňa a meča“. To, že cisár Akbar existoval, nevylučuje fakt, že mal aj imaginárnu manželku alebo Vespucci a Machia mohli mat' pokojne priatel'ský vzt'ah, nielen pracovný.

Ďalšie dôvody, prečo je Čarodejnica z Florencie historickým románom a nie romancou, vysvetl'ujeme na ich kontrastom postavení v literatúre. Romanca je vnímaná ako nenáročné čítanie a stojí v priamom protiklade $\mathrm{k}$ historickému románu, ktorý má priniest' čitatel'ovi zážitok a ešte ho aj vzdelávat'. Historický román si na rozdiel od 
romance nárokuje aj na istý status pravdivosti, lebo reprezentuje to, čo sa stalo. Je vierohodný a čitatel' dokáže identifikovat', o aké historické postavy alebo prostredie $\mathrm{v}$ dejinách ide. Romanca je chvíl'kové čítanie a je vel'mi málo pravdepodobné, aby sme našli identické miesta a osoby v minulosti, o ktorých v nej čítame (Nagy 2019: 21). Historický román mieša fikciu so skutočnostou, kým romanca je celá fikčná. Reevová (podl'a Nagya) hovorí, že romanca popisuje nereálne bájne osoby a veci, kým historický román zobrazuje skutočné udalosti minulosti a zachytáva dobovú kultúru a mravy, o ktorých sa v ňom píše.

Romanca alebo idylický román podl’a Northropa Fryea vychádza zo stredovekého rytierskeho románu, v ktorom hlavný hrdina bojuje za vel'ké ideály, aby získal ruku vznešenej dámy (podl'a Macura - Jedličková 2012: 258). K znakom romance patrí aj dobrodružstvo a podl'a nás je to aj jediný aspekt, ktorý sa spája s Rushdieho Čarodejnicou z Florencie. Mogul lásky precestoval vel’a krajín a vo svojom rozprávaní opisuje, čo všetko prežila Kara Köz na cestách, ked' musela neustále unikat' pred hroziacim nebezpečenstvom. Tento atribút však nepovažujeme za dostatočný na to, aby sme jednoznačne označili Rushdieho román za romancu.

Pri vysvetl'ovaní, prečo nie je Čarodejnica z Florencie romancou, sme zohl'adnili charakter fikčných postáv a miest, ktoré sú odrazom historických osôb a oblastí a takisto aj dôležitý fakt, že historické romány majú status pravdivosti, možnosti overenia fikčných entít. Taktiež sme pri vyhodnocovaní opozície romanca - historický román brali do úvahy aj naratívnu stránku Čarodejnice z Florencie. Kým pri romanci nie sú sujet a fabula v kontraste, pri historickom románe môžu byt' (Nagy 2019: 131). Pre postmoderné romány, ako aj pre poetiku Rushdieho próz, je typické, že sujet a fabula sú $\mathrm{v}$ dielach doslova prepletené a čitatel' musí knihu čítat' vel'mi pozorne, aby sa v diele „nestratill“.

Za prelomový okamih v písaní historického románu je považované práve obdobie postmodernizmu, ked' sa tento žáner začal rehabilitovat' (Nagy 2019: 145). V Rushdieho postmoderných románoch je prítomná aj tzv. naratívna autorita. Znamená to, že do svojich príbehov vkladá samého seba. Prináša zážitky a aspekty, ktoré súvisia priamo s ním, s jeho osobou (Nagy 2016: 144). Podobne je tomu aj v Čarodejnici z Florencie, kde Salman Ruhdie opisuje indické dejiny a kultúru. Dokonca pri strete svetov západ - východ, Indiu opisuje ako lepšie miesto na život než Európu: „Na Východe muži a ženy tvrdo pracovali, (...), žili úplne normálne. No títo bájni l'udia zo západných krajín, boli, ako sa zdalo, náchylní k hystérii (...)“ (Rushdie 2009: 319). Rovnako nelichotivo rozpráva o vtedy novom objavenom území - Amerike a jej domorodých obyvatel’och, ktorých Európania nazvali Indiánmi, lebo verili, že našli cestu do Indie. „Nazvat' týchto l'udí Indiánmi bolo podl'a Akbarovho hlbokého 
presvedčenia pre vznešených mužov a ženy Hindustanu urážlivé“" (Rushdie 2009: 320). Postmoderné beletristické texty obsahujú komentáre a vyjadrujú často názor autora na podmienky rekonštrukcie minulosti (Doležel 2008: 112).

Z uvedených argumentov považujeme za správne označit' Čarodejnicu z Florencie za historický román nie romancu. Avšak, ak by sme chceli pristúpit' ku kompromisu v tejto problematike, mohli by sme povedat', že dielo je historickým románom, ale vzhl'adom na postmodernú tvorbu, pre ktorú je príznačná medzižánrová hybridita a flexibilita, môžeme Čarodejnica z Florencie označit’ za historický román s prvkom romance (dobrodružnost').

Postmoderné historické romány dávajú do popredia čas a priestor, aby poukázali na to, že človek už nemusí byt' stredom diania a opisujú hypotetické udalosti medzi historickými osobami a miestami. Preto sa v Čarodejnici z Florencie prelína India s Talianskom, minulý a prítomný čas, sen a skutočnost' a stretávajú sa osoby z Východu s európskou spoločnost'ou.

\section{Summary}

The article describes why The Enchantress of Florence by Salman Rushdie is a historical novel, not a romance. We defend this statement through the definitions and features of the historical novel and romance. The only thing that connects the historical novel and the romance in this novel is adventure. Based on the theoriesmentioned above, especially by Doležel and Nagy, we conclude that the work is a historical novel and may contain elements of romance, but it is not exclusively a historical romance.

\section{Literatúra}

Rushdie, S. Čarodejnica z Florencie. Bratislava: Slovart, 2009.

Beneš, Z. Historický text a historická kultura. Praha: Karolinum, 1995.

Biedermann, H. Lexikón symbolov. Bratislava: Obzor, 1992.

Budil, I. Od prvotního jazyka k rase. Praha: Academia, 2002.

Burckhardt, J. Kultura renesance v Itálii. Praha: Rybka Publishers. 2013.

Doležel, L. Heterocosmica (Fikce a možné světy). Praha: Karolinum, 2003.

Doležel. L. Fikce a historie v obdobi postmoderny. Praha: Academie, 2008.

Eco, U. Meno ruže. Bratislava: Petit Press. 2004. 
Lukács, G. Historický román. Bratislava: Tatran, 1957.

Macura, V., Jedličková, A. Průvodce po světové literární teorii 20. století. Brno: Host, 2012.

Nagy, L. Palimpsesty, heterotopie a krajiny. Praha: Karolinum, 2016.

Nagy, L. Od romance k románu a zase zpět. Praha: Argo, 2019.

Ricoeur, P. Čas a literárne rozprávanie. Bratislava: Iris. 2004.

Welsch, W. Estetické myslenie. Bratislava: Archa, 1993.

Brooke-Roseová, Ch. Dejiny ako palimpsest. In: Collini, S. (ed.) Interpretácia a nadinterpretácia. Bratislava: Archa, 1995, s. 122-134.

Kalnická, Z. Obraz vody. In: Kiczková, Z. (ed.) Otázky rodovej identity vo výtvarnom umení, architektúre, filme a literatúre. Bratislava: Univerzita Komenského, 2000, s. 38-54.

\section{Elektronické zdroje}

Ames-Lewis, F. Agostino Vespucci's Marginal Note about Leonardo da Vinci in Heidelberg. Leonardo da Vinci Society Newsletter. 2008. Dostupné z: https://www.academia.edu/384690/Agostino_Vespucci_s_Marginal_Note_abou t_Leonardo_da_Vinci_in_Heidelberg (2021-02-22).

Andrea Doria. Encyclopedia Britannica. Dostupné z: https://www.britannica.com/ biography/Andrea-Doria-Genoese-statesman (2021-02-22).

Ballhatchet, K. Akbar. Encyclopedia Britannica. 2018. Dostupné z: https://www.britannica.com/biography/Akbar (2021-02-22).

Dirda, M. A romance of beauty and power from Italy to India. The Washington Post. 2008. Dostupné z: https://www.washingtonpost.com/wp-dyn/content/article/ 2008/05/22/AR2008052203533_pf.html (2021-02-22).

Fatehpur Sikri. Taj Mahal. Dostupné z: https://www.tajmahal.gov.in/fatehpursikri.aspx (2021-02-22). 


\section{CHARAKTER A POSTAVENIE KOMIKSU V LITERATÚRE A VO FILME}

\section{Character and Position of Comics in Literature and Film}

Keywords: comics, comic book, literature, film, popculture

Contact: Univerzita Pavla Jozefa Šafárika v Košiciach; basapetrova@gmail.com

Komiksová kultúra je neoddelitel'ne spájaná s popkultúrou. Hoci popkultúrne diskurzy sú v súčasnosti na vzostupe a disponujú vlastným terminologickým slovníkom, svoje miesto $\mathrm{v}$ akademickom prostredí si našli približne v 30 . rokoch 20. storočia, inšpirované slovníkom frankfurtskej školy. Komiksy dnes vnímame ako moderné, zväčša súčasné texty, väčšinou prinášajúce príbeh o nejakom superhrdinovi.

\section{Historický vývoj komiksu}

Súvislosti s komiksami môžeme nájst' už v komunikačných systémoch ranej podoby civilizácie, kedy ešte neexistovalo písmo $\mathrm{v}$ takej forme, $\mathrm{v}$ akej ho poznáme dnes. „Možná jsme nedospěli k rozhodnutí, kam vlastně datovat vznik comicsu, ale můžeme $\mathrm{s}$ jistotou ř́ci, že pokusy vyprávět př́běhy prostřednictvím obrazu a textu se táhnou lidskou historií jako červená nit už od počátku věkưu“ (Kruml 2007: 16). Dôležité je datovanie miesta a času vzniku komiksov, rovnako ako ideológie, ktoré v danom období prevládali.

Počiatky komiksu môžeme zaznamenat' pri pravekých mal'bách. Na stenách španielskej jaskyne Altamira a v jaskynnom komplexe Lascaux vo Francúzsku môžeme vidiet' namal'ované lovecké príbehy. Nemajú však premyslenú sekvenčnú štruktúru, nie sú usporiadané $\mathrm{v}$ priestorovej juxtapozícii, rovnako im chýba časová postupnost'. Za predobraz komiksov tiež považujeme kombináciu egyptského obrázkového písma (hieroglyfy) a malieb, ktoré zaznamenávajú životy faraónov v chronologickej, časovej postupnosti (cca 1300 pr. Kr.). Hieroglyfy, rovnako ako naša abeceda, iba zastupujú znaky, samé o sebe nehovoria nič, preto samotné hieroglyfy nepovažujeme 
za predchodcov komiksu. „Skutečným potomkem hieroglyfů je písmo, nikoly komiks“ (McCloud 2008: 13).

Trajánov stíp, pomník postavený $\mathrm{v}$ Ríme $\mathrm{v}$ druhom storočí, je nielen jednou z najslávnejších starovekých sochárskych pamiatok. Ako prvá obrazová pamiatka určená verejnosti (200 metrov dlhá obrazová špirála), je historickým medzníkom aj v ponímaní komiksu. Ďalšou z historických, tentokrát stredovekých pamiatok, ktorá $\mathrm{v}$ sebe nesie jeho prvky, je Tapiséria z Bayeux, ktorá podrobne zobrazuje normandskú inváziu do Anglicka z roku 1066. Tento sedemdesiat metrov dlhý gobelín predstavuje jedinečný obrazový dokument, ktorý dopíňajú latinské texty. Jedinečnost’ diela spočíva vo využití celostranovej kompozície, ktorú tvorí celkom 58 obrazov. Túto kompozíciu ako jeden z mála autorov do dnešného dňa využíva komiksový autor Will Eisner (McCloud 2008: 12).

Rozvoju sekvenčného umenia v stredoveku napomáhalo rozšírené používanie symbolov. Negramotnost' väčšiny obyvatel'stva a prioritné postavenie cirkvi $\mathrm{v}$ spoločnosti prispeli $\mathrm{k}$ novému fenoménu, a to mal'ovaniu křest'anských výjavov následne vylepovaných $\mathrm{v}$ kostoloch. Módne bolo tiež zaznamenávanie života odsúdencov na plagáty, ktoré si bolo možné pri poprave kúpit', najmä v 14. a 15. storočí. Vd’aka týmto príkladom z histórie od staroveku po stredovek sme si vymedzili rôzne znaky, ktoré ovplyvnili súčasný tvar komiksu.

\section{Súvislosti s literatúrou}

Ďalším medzníkom nielen pre počiatok novoveku, ale aj pre vývoj komiksu a jeho súvislost' s literatúrou, je vynájdenie kníhtlače v 15. storočí, ktorá prispela k šíreniu písomnej kultúry všetkým vrstvám obyvatel’stva. Stále pretrvávalo ponímanie dvoch typov literatúry, rozlišujeme literatúru vysokú a nízku. Na toto delenie nemusíme nazerat' ako na výsledok delenia zhl'adiska estetických kritérií, môže íst' o výraz společenského poriadku alebo sociálneho usporiadania. To je mnohokrát dôsledok toho, že literatúra popisujúca nižšie vrstvy bola práve tou literatúrou, ktorou vyššie vrstvy opovrhovali.

Obrázkové príbehy dosiahli nový vrchol v 18. storočí, kedy karikaturista Wiliam Hogarth preferoval názor, že zavádzanie nových obsahov si vyžaduje aj nové formy. Jeho farebná a detailná kresba vtedajšej reality v kombinácii so zaznamenávaním textu do bublín spôsobila, že: „vytvořil žánr, který můžeme označit jako obrazový cyklus“ (Kruml 2007: 15). V diele s názvom Dráha pobehlice zobrazil na šiestich obrázkoch životný príbeh prostitútky pomocou sekvencie obrázkov. Jeho diela boli vystavované ako série obrazov a predávané ako sekvenčné súbory rytín. Týmto autorom 
sa inšpirovali aj d’alší, napríklad Thomas Rowlandson alebo James Gilray. So zdokonal'ovaním kníhtlače sa spája aj vznik prvých humoristických a satirických časopisov, medzi inými napríklad Le Caricature, Le Charivari vo Francúzsku, El Sol a Don Quijote v Španielsku, Punch vo Vel'kej Británii alebo Humoristické listy v Čechách.

Devätnáste storočie je pre komiks obdobím novátorských pokusov, medzi inými ohraničenie jednotlivých obrázkov a vzájomné prepájanie slov a obrázkov, ktoré pripisujeme Rodolpheovi Töpfferovi. Scott McCloud o ňom hovorí ako o „otcovi moderného komiksu“ (McCloud 2008: 17). Zásadné dielo v dejinách formovania komiksu vzniklo $\mathrm{v}$ roku 1895, kedy Richard Felton Outcalt zverejňoval príbehy o det'och z ulice New Yorku v časopise Truth, ktorý sa stal medzi čitatel'mi vel'mi populárny. Komiks mal názov The Yellow Kid a zo začiatku vychádzal bez textu, neskôr bol text napísaný na košeli hlavnej postavy. Postupom času sa ustanovila podoba písania do bublín. Tento komiks považujú odborníci za karikatúru. Tú od komiksu dôrazne odlišuje Mario Saraceni, ked' hovorí, že komiksy sú tvorené radom panelov tak, aby medzi každým d’alším panelom zostal prázdny biely priestor. To považuje za zásadný rozdiel medzi komiksami a karikatúrami, ktoré sú tvorené iba jedným panelom (Saraceni 2003: vol'ný preklad).

Prvým komiksovým hrdinom, ktorého považujeme za periodickú postavu zobrazovanú v komiksoch, je postava Ally Sloper, archetyp intrigána s červeným nosom, ktorého vytvoril anglický spisovatel' Charles Henry Ross. Už v tomto období sa začali ozývat' hlasy proti komiksom, ktoré prezentovali rôzni pedagógovia a moralisti. To zapríčinilo, že mnoho autorov prerobilo alebo úplne zrušilo svoje postavy.

Dvadsiate storočie je obdobím, ktoré pre komiks znamenalo zlatý vek, ale aj úpadok. Autori kreovali nové komiksové postavy, s ktorými sa snažili prerazit' $\mathrm{v}$ novinách. Inšpiráciami pre ich témy boli mnohokrát príbehy reálnych detí z ulice (ako v prípade The Yellow Kid), neskôr v komiksoch začali vyobrazovat' zvieratá. Samostatnou kapitolou je zobrazovanie žien v komiksoch. V tomto období hovoríme o prvých komiksových hrdinoch, ktorí si našli svoje stále publikum. Patria medzi nich napríklad Popeye, The Phantom alebo Mickey Mouse. S obdobím Druhej svetovej vojny a hospodárskej krízy sa spája obdobie, kedy vznikali prvé superhrdinské postavy ako Superman, Batman, Wonder Woman a pod. Ich popularita vrcholila počas trvania vojny, ich predaj sa neskôr čiastočne znížil kvôli publikácii amerického psychiatra Fredrica Werthama. Ten vo svojom diele Seduction of Innocent (Zvádzanie nevinných) ostro kritizoval komiksy, ktoré považoval za negatívnu formu populárnej kultúry a vážnou príčinou kriminality mladistvých. Kniha sa stala bestsellerom a podnietila kampaň v boji za cenzúru. 
Malá encyklopédia žurnalistiky z roku 1982 predstavuje pojem „comics, pôv. comic strips ako sled kresieb, ktoré majú nenáročný, zväčša komický dej, sprevádzaný najnevyhnutejším textom $\mathrm{v}$ podobe dialógu, resp. rozprávania a uverejňovaný ako súčast' seriálu“ (Jacz 1982: 59). Na základe tejto definície môžeme napríklad pozorovat' "vzt'ah" bývalého režimu ku komiksu, ktorý na neho nazeral ako na menejcenný žáner $\mathrm{s}$ banálnym obsahom určený predovšetkým pre čitatel’ov neschopných čítat' prozaické diela. Obrázkové znázornenia mali byt' akýmsi pomocníkom na porozumenie textu. Súčasný Slovník súčasného slovenského jazyka hovorí, že komiks je „synkretický žáner spájajúci výtvarné, literárne, dramatické a filmové prvky a postupy“ (Avramovová 2011: 235). Vnímanie komiksu ako literárneho žánru napomáhalo komunistickým ideológiám poukazovat’ na jeho chabú literárnu hodnotu.

Medzi znaky komiksu patrí hlavne sekvenčnost', ktorej komiks je hlavným zdrojom. Jeho vnímaniu ako súčasti literatúry predchádzajú dva znaky: komiks rozpráva príbeh a obsahuje verbálny text. Komiksový teoretik McCloud rozširuje jeho definíciu, ked' ho vytyčuje ako „záměrnou juxtaponovanou sekvenci kreslených a jiných obrazů, určenú ke sdělování informací nebo k vyvolání estetického prožitku“ (McCloud 2008: 9). Niektoré teórie komiks uvádzajú ako žáner epiky, oponenti ho kritizujú a nazývajú ho hybridom zložených z kresieb a krátkych textov v bublinách. Podl’a Eduarda Petrů má literatúra tri funkcie: „informatívnu, estetickú a formatívnu“ (Petrů 2000: 13). Informatívna funkcia umožňuje vidiet' istý súbor sémantických informácií o javoch alebo faktoch, ktoré sú predmetom literárnej reflexie. Formatívnou funkciou rozumieme vplyv literárneho diela na formovanie vzt’ahu percipienta $\mathrm{k}$ nemu. Nakoniec funkcia estetická, ktorá je z hladiska histórie najdôležitejšia, vytvára predpoklady a priestor pre estetický prežitok literatúry. Komiks spíňa všetky tri základné funkcie literatúry. Svoje miesto si našiel okrem iného predovšetkým v populárnej literatúre a v literatúre pre deti a mládež.

Sústavne zvyšujúca sa popularita komiksu je spájaná s mnohými spoločenskými, psychologickými, ale aj literárnymi aspektmi, pokial' sa do spoločenského kreovania tohto média nezapájajú ideológie. Komiks si vytvára svoje prostriedky a hranice, preberá prvky z jednotlivých umeleckých žánrov, nemožno ho preto posudzovat' iba z jedného hl'adiska. Pokial' nazeráme na komiks a na literatúru, môžeme komiks považovat' za primitívny (text je jednoduchý a neobsahuje vel'ké množstvo slovnej zásoby). Ich spoločným znakom je napriek nezrovnalostiam prítomnost' rozprávača, ktorý je sprostredkovatel'om príbehu a dotvára komiks. Kto je rozprávačom v komikse? Mario Saranceni v knihe The Language of Comics uvádza, že v určitých prípadoch sa hlas rozprávača stáva rušivým a napáda reč postáv. Podl'a neho je niekedy zložité 
oddel'ovat' rozprávača a reč postáv (Saraceni 2003: vol'ný preklad). Komiks úzko súvisí s populárnou kultúrou, v tomto prípade s populárnou literatúrou. Vyniká dejovost'ou, vyvoláva účinok a komunikačný dosah. Príbehy v sebe zahŕňajú ponaučenie, výrazne vyniká emocionálna stránka, prítomné je napätie a vzrušenie. Ďalším zo znakov komiksu je, že nie sú zasadené do minulého času, ako to býva pri iných literárnych žánroch. Repliky sú písané v prítomnom čase, teda prekračujú sa hranice epiky a dochádza k dramatizácii deja. Tu sa dostávame k d'alšiemu odvetviu, s ktorým má komiks množstvo spoločných znakov.

\section{Súvislosti s filmom}

Vznik komiksu a filmu odborníci datujú do roku 1895. Odvtedy prešli obe médiá značným vývojom, ale tento rok sa pripisuje tak bratom Lumiérovcom, ktorí 28. decembra 1895 v Paríži premietli svoje prvé filmy, ako aj komiksu, konkrétnejšie 5. február 1895, kedy prvá komiksová postava - The Yellow Kid - dostala svoje meno. Rad odborníkov považuje za zrod komiksu až 25. október 1896, kedy jeden obrázok nahradilo viac obrázkov a reč postáv bola prvýkrát zobrazovaná v bublinách, nie na oblečení kreslených postáv (Kruml 2007).

Mnohé spoločné vlastnosti má komiks s filmom, podobá sa mu. Recipientovi je predložený komiksový príbeh v súčasnosti. Prebieha pred ním rovnako ako dej $\mathrm{v}$ divadle, filme alebo $\mathrm{v}$ televízii. Recipient vníma vizuálnu stránku diela, následne zvuk (vo filme) a text (v komikse). Na základe toho ho môžeme definovat' ako vizuálno - verbálne umenie.

Súvislosti medzi komiksami a filmami si predostrieme na príklade z histórie a koreláciou s filmovou produkciou. Vo filmovej tvorbe sa odrážajú napríklad významy v hieroglyfických grafických záznamoch. Nové možnosti významu nám dávajú princípy montáže izolovaných elementov a ich konfrontácia. „Film nekopíruje «objektivně», naturalisticky nebo kontinuálně nějakou realitu, jež se mu předkládá: ve filmu se oddělují sekvence, izolují se záběry a prostřednictvím nové montáže se znovu kombinují. Film nereprodukuje věci: manipuluje s nimi, uspořádává je, strukturuje je. A jeho elementy dostávají smysl pouze $\mathrm{v}$ nové struktuře získané jejich montáži‘ (Kristeva 1999: 47). Vo filme Krížnik Potemkin režiséra Ejzenštejna vidíme tri rôzne sochy leva izolované od ostatných záberov a usporiadané jedna za druhou, čím vytvárajú filmovú výpoved'. Kristeva hovorí, že film podl'a Ejzenštejna musí byt': „hieroglyfickým textem, jehož každý izolovaný element má smysl jen v kontextuální kombinatorice a v závislosti na svém místě ve struktuře“ (Kristeva 1999: 47). $\mathrm{Na}$ základe hieroglyfov si všímame spoločný znak filmu a komiksu, ktorým je 
sekvenčnost' alebo oddel'ovanie záberov. Zároveň je to jednou zo základných definícií komiksu: komiks je hlavným zdrojom sekvenčného umenia (Eisner 1985). Ako hlavný znak poukazuje na sekvenciu minimálne dvoch obrázkov. Tu sa môžeme pozriet' na súvis medzi animovanými filmami a komiksom. Sekvencia pri animácii prebieha $\mathrm{v}$ čase, zatial' čo sekvencia pri komiksoch prebieha v priestore. Film sa premieta na ten istý priestor (plátno alebo obrazovka), zatial' čo pri komikse má každý panel svoje miesto. „V komiksu hraje prostor právě tú roli, kterou u filmu hraje čas“ (McCloud 2008: 7). Obraz nemá prevládat' nad textom, prevládat' má naratívna a estetická funkcia. Sekvencia pri animácii prebieha $\mathrm{v}$ čase, zatial' čo sekvencia pri komiksoch prebieha v priestore. Film sa premieta na ten istý priestor (plátno alebo obrazovka), zatial' čo pri komikse má každý panel svoje miesto.

D. Kokeš sa vo svojej knihe zaoberá výkladovou pružnost'ou komiksového formátu, ked' hovorí o možnom vplyve umeleckej formy komiksu na systém filmového diela. Na príklade filmu Kdo chce zabít Jessii hovorí o nesúlade filmových a komiksových postupov, kedy prenikanie komiksovej estetiky je skôr umeleckým nástrojom ako cielom. Využitím rôznych komiksových princípov vo filme docielili vznik diela, ktoré bolo rovnomerne odsudzované a prijímané. Poetika komiksu sa vo filme uskutočňuje $v$ troch rovinách:

1. rovina rozprávania;

2. rovina fiktívneho světa;

3. rovina štylistických postupov.

Film obsahuje dva komiksové postupy, konkrétne prácu s namal'ovanými statickými obrazmi a prácu s mizanscénou. Kritiky ho označovali ako paródiu na komiks a ironickou zábavou, zatial’ čo autori tvrdili, že paródiou je maximálne z tridsiatich percent (Kokeš 2015: 129-131).

\section{Superhrdina a popkultúrny hrdina}

Literárny, filmový, ale aj komiksový hrdina má svoje špecifiká. V článku sa zaoberáme rozdielmi medzi hrdinom, superhrdinom a popkultúrnym hrdinom. Práve hrdina je subjektom, ktorého identifikáciou môžeme vidiet' odlišnosti medzi literatúrou, filmom a komiksami. „Superhrdina disponuje na rozdiel od hrdinu nielen mimoriadnymi osobnými vlastnost’ami, nútiacimi $\mathrm{v}$ hraničných situáciách správat' sa $\mathrm{z}$ hl'adiska morálneho kódexu v súlade sideálom, ale aj schopnost’ami, prirodzenými či nadprirodzenými, reálne prekračujúcimi medze uveritel'nosti, hranicu medzi akože a naozaj“ (Malíček 2008: 16). Malíček d’alej hovorí o popkultúrnom hrdinovi, ktorého 
definuje ako samotára, nositel'a vlastného morálneho kódexu, d’alej ako schizofrenika, ktorý je na jednej strane hrdinom a na strane druhej civilnou bytost'ou. Popkultúrny hrdina podl'a Malička nemá bohatý vnútorný život (na rozdiel od jeho civilného alter ega), nedochádza u neho k osobnostným zmenám a nemá vel'a priatel’ov. Medzi typický a univerzálny znak zarad'uje to, že každý popkultúrny hrdina je budovatel'om a nositel'om vlastného mýtu (Malíček 2008: 16-17). Považujeme komiks za umelecký výtvor? Prostredníctvom citátu od Malíčka sa vrátime k jeho umiestneniu do oblasti filmu alebo literatúry. „Pravým domovom popkultúrneho hrdinu nie je domovský popkultúrny artefakt, ale vedomie, mysel', fantázia, celkom konkrétnych recipientov, čitatel'ov a divákov..." (Malíček 2008: 25). Toto tvrdenie môžeme transformovat' na vnímanie komiksu $\mathrm{v}$ dnešnej spoločnosti, ktorého pravým domovom je rovnako mysel', fantázia a vedomie recipienta. Svoje miesto vo svete literatúry, filmu alebo všeobecne umenia, si komiks postupne nachádza aj napriek odlišným konštrukciám diskurzu.

\section{Záver}

Obsah čítania a vnímania komiksu je totožný ako pri čítaní literárnych diel a pozeraní filmov (alebo seriálov). Naratívna funkcia zobrazuje plynutie času v nazeraní do minulosti alebo do budúcnosti, čo je rovnaké v prípade literatúry aj filmu. Komiks preto $\mathrm{v}$ dnešnej dobe naberá $\mathrm{v}$ akademickom prostredí vážnost'. Niektorí odborníci ho už považujú za samostatné, tzv. „,deviate umenie“, teda za nezávislú umeleckú formu. Odmietajú ho dávat' do súvislostí s literatúrou, filmami alebo žánrami. Kanadský teoretik médií Marshall McLuhan dokonca zaradil komiks medzi samostatné médiá, pretože definoval odlišnosti komiksu z viacerých hl'adísk na úrovni narácie. Primárnym kódom v literatúre je jazyk, zatial' čo komiks kladie rovnaký dôraz aj na obraz, preto nedáva do súvislostí komiks ani so žánrami. Preto za opodstatnený posun považuje adaptácie komiksových diel (McLuhan 1991: 159-160).

\section{Summary}

European comics scholar Thierry Groensteen explains that the rich diversity that is attributed to comics makes it almost impossible to set any defining criteria that would be universally valid. In line with this assumption, we can see that the criteria determining the general status and classification of comics have not been clearly established. There have been different approaches to comics in varied studies. Some theorists regard comics as a medium whereas others define it as a hybrid genre. This paper attempts to explore comics in a broader context of literature and film. We have detected some 
common features of all these industries which then provided us with a sound foundation for establishing the status of comics among them, which we demonstrate on individual examples.

\section{Literatúra}

Avramovová, M. et al. Slovník súčasného slovenského jazyka. Bratislava: Veda, 2011.

Eisner, W. Comics \& Sequential Art. Florida: Poorhouse Press, 1985.

Groensteen, T. Stavba komiksu. Brno: Host, 2015.

Jacz, L. et al. Malá encyklopédia žurnalistiky. Bratislava: Obzor, 1982.

Kristeva, J. Slovo, dialog a román: Texty o sémiotice. Praha: Sofis - Pastelka, 1999.

Kokeš, R. D. Rozbor filmu. Brno: Filozofická fakulta Masarykovy univerzity, 2015.

Kruml, M. Comics: Stručné dějiny. Praha: Martin Trojan, 2007.

Malíček, J. Hl'a, popkultúrny hrdina (Typológia popkultúrneho hrdinu). In: Malíček, J. (ed.) Zbornik o populárnej kultúre. Nitra: Univerzita Konštantína Filozofa v Nitre, 2008, s. 16.

McCloud, S. Jak rozumět komiksu. Praha: BB/art., 2008.

McLuhan, M. Jak rozumět médiim. Praha: Odeon, 1991.

Petrů, E. Úvod do studia literární vědy. Olomouc: Rubico, 2000.

Saraceni, M. The Language of Comics. London: Routledge, 2003. 


\title{
RECENZIA V 21. STOROČÍ
}

\author{
A Book Review in $21^{\text {st }}$ Century
}

Keywords: literacy criticism, book review, internet, mass media communication, social networks, annotation, customer review, literature

Contact: Univerzita Komenského v Bratislave; maria.stankova@uniba.sk

\section{Úvod}

Hodnotenie umenia a informovanie o dianí voblasti kultúry patrí k základným funkciám žurnalistiky. Aj to je dôvod, prečo je žáner recenzie a celkovo kultúrna publicistika pravidelnou súčast’ou masmediálnej komunikácie. V súčasnosti však vidno trend rozširovania pol'a pôsobnosti recenzistiky. Tak ako v druhej polovici 20. storočia platilo, že kritika sa presúvala zo stránok odborných časopisov (zameraných na konkrétne druhy umenia, teda literárnych, divadelných, filmových, hudobných či výtvarných periodík) do denníkov a časopisov bez zamerania, v súčasnosti sú recenzie čoraz pravidelnejšími textmi publikovanými aj v rámci sociálnych sietí. Tento aspekt predstavuje len jednu z tendencií, ktorým treba venovat' zvýšenú pozornost', či už sa bavíme o umenovednom, alebo masmediálnom prístupe. Na druhej strane sa recenzia, resp. hodnotenie umeleckých textov $\mathrm{v}$ tom najširšom slova zmysle, udomáč̌uje aj v platformách, ktoré s literárnou kritikou nesúvisia. Mám tu na mysli najmä internetové stránky, ktorých primárnou funkciou je predaj, čiže v prípade literárnych recenzií sa bavíme najmä o e-shopoch vydavatel'stiev a kníhkupectiev. Všetky spomenuté informácie sa priamo podiel'ajú na transformácii recenzie ako žánru v 21. storočí. Prekladaná štúdia si kladie za ciel' popísat' tieto zmeny na výsledkoch doterajších bádaní s využitím literárnovedných a žánrologických informácií. Teoretické základy predkladaného textu stoja najmä na heslách zo slovníkov, literárnovedných či žánrologických učebníc, rovnako ako aj na vybraných vedeckých a odborných štúdiách. Vnímanie recenzií a vo všeobecnosti prístup ku kultúrnej publicistike, do ktorej možno kritiku a recenzistiku zaradit', priblížim aj na základe výsledkov kvantitatívneho výskumu dotazníkovou metódou. 


\section{Recenzia}

Recenzia je v rovnakej miere súčast’ou masmediálnej komunikácie a umeleckej komunikácie. (Obr. 1) Prvá menovaná jej poskytuje priestor a ovplyvňuje jej formálnu aj obsahovú stránku, druhá menovaná jej zase poskytuje základné teoretické východiská, terminológiu a metódy prístupu k hodnotenému dielu (napríklad analýza, interpretácia).

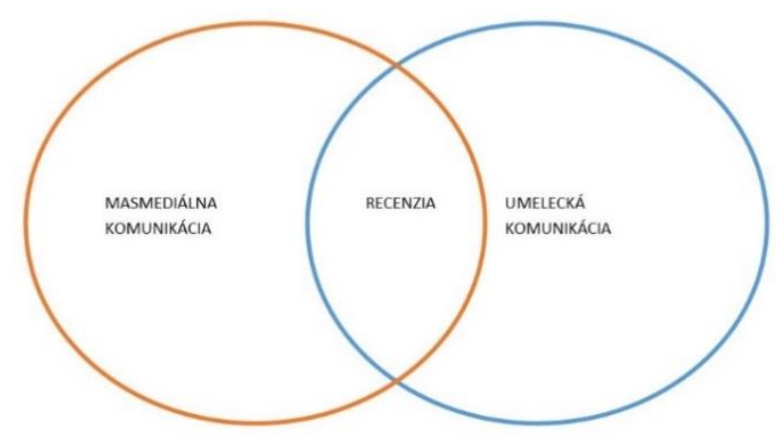

Obr. 1: Recenzia ako prienik masmediálnej komunikácie a umeleckej komunikácie

Názov žánru recenzia pochádza z latinského slova recensere, ktoré znamená „,konat' prehliadku“ či „prehliadat', uvažovat““ (Ondrejovič 2000: 198). Ked’že ide o žáner, ktorý sa formuje a existuje na pomedzí viacerých vedeckých disciplín, informácie o nej možno nájst' ako v štylistických, tak i v novinovedných či umenovedných publikáciách. Lingvista Jozef Mistrík recenziu definoval ako „zhodnotenie hotového, publikovaného diela, ktoré stojí medzi potenciálne neznámou prácou a zvedavým záujemcom o túto prácu“ (Mistrík 1997: 447). Novinovedkyňa Jana Čeňková recenziu vníma ako ,kriticky zameraný druh publicistiky alebo odborného textu, ktorý predstavuje nové dielo umeleckého charakteru“ (Čeňková 2017: 198).

Recenzia je žáner kultúrnej publicistiky, ktorý predstavuje, hodnotí, analyzuje, opisuje a interpretuje aktuálne umelecké dielo, napr. film, divadelné predstavenie, knihu, hudobné či výtvarné diela. Pri aspekte aktuálnosti treba zdôraznit' význam, ktorý recenzistika má. Recenzent býva spravidla prvým človekom, ktorý poskytuje prijímatel'ovi základné informácie o novom umeleckom diele. Aj preto je význam recenzistiky a kritiky všeobecne dôležitý z aspektu d'alšieho bádania. Ako príklad môže poslúžit' literárna veda - ak sa literárny vedec rozhodne venovat' konkrétnym dielam konkrétneho autora, sú to práve dobové recenzie, ktoré mu poskytnú základné a prvotné informácie o ňom. Časový aspekt je teda pri recenziách kruciálny, v súčasnosti je to prvý hodnotiaci text, $v$ budúcnosti môže poslúžit' ako podklad pre hlbšie bádanie daného diela. Práve tieto fakty negujú vnímanie recenzie ako efemérneho textu - recenzie sú 
nielen súčast'ou masmediálnej komunikácie, ale aj súčast'ou štruktúry daného umeleckého odvetvia a následne odborných vedeckých textov, ktoré sa týmto umením zaoberajú. Aj to je dôvod, prečo by recenzent mal disponovat' istými kvalitami - od vzdelania cez skúsenosti až po problematický aspekt vkusu.

Jedna z novších žánrologických monografií zdôrazňuje vzt'ah medzi recenziou a knižnou anotáciou: „Recenzia patrí medzi najstaršie publicistické žánre - vznikla z anotačnej poznámky $\mathrm{v}$ knihovníctve a $\mathrm{z}$ potreby určitým spôsobom klasifikovat' rozmáhajúcu sa knižnú produkciu v období osvietenstva“ (Bučková - Rusňáková 2017: 52). Tento prístup súvisí s potrebou „poriadku“, teda zjednodušenia orientácie $\mathrm{v}$ umeleckom svete - recenzia by mala prispiet' nielen k všeobecnému zaradeniu hodnoteného diela do sústavy ostatných diel, ale využit' aj hodnotiaci aspekt - označit' dielo za „kvalitné“ či menej kvalitné, a naznačit’ tak jeho postavenie v systéme všetkých ostatných diel. Práve pri textoch, ktoré majú charakter anotácie, badat' tendenciu nehodnotit', ale bud' len knihu opísat', predstavit', alebo propagovat'. Tento aspekt je priamo ovplyvnený spoločenskou situáciou a situáciou knižného trhu, ktorý možno charakterizovat' nadprodukciou. Podl'a J. Čenkovej ,,zrychlená digitální doba přinesla snůšku anotací, tzv. PR-recenzí, v denním tisku, které jsou spíše produktem managementu a nakladatelských strategií““(Čeňková 2017: 198).

Recenzia je žáner, ktorý sa vyznačuje intertextualitou. Každá recenzia je metatextom, ktorý odkazuje na prototext. To je jeden aspekt. Ďalší rozmer tejto problematiky naznačuje umiestnenie recenzie v sústave d'alších recenzií o tom istom prototexte, či na podobné typy textov. Tretí rozmer intertextuality recenzií v súčasnosti prezentujú najmä internet a sociálne siete, ked’že texty publikované na týchto platformách sú prejavom intertextuality par excellance. Predstavme si situáciu, že na internete hl'adáme ohlasy na konkrétnu knihu. Vyhl'adávač nás odkáže na stránky kníhkupectiev, možno stránky autora či autorky, stránku vydavatel'stva, na weby jednotlivých médií, ktoré danú knihu reflektovali, ale aj na rôzne blogy, vlogy, či príspevky na sociálnych siet’ach. Recenzia teda v súčasnosti existuje v sieti iných textov, pričom práve toto slovné spojenie (,siet' iných textov“) vel'mi jasne a zároveň výstižne definuje intertextualitu. Ak budeme pokračovat' v opísanej situácii, predstavme si, že sa rozhodneme prečítat' si recenziu na knižnom blogu. Je pravdepodobné, že text bude obsahovat' hypertextové prepojenia na iné webové stránky, ktoré o knihe informujú (weby vydavatel'stva, kníhkupectva, možno web autora či prekladatel'a), rovnako ako aj prepojenia na sociálne siete - či už recenzenta - blogera, alebo autora, vydavatel'a a podobne. Takýmto spôsobom, ktorý nás v každodennom živote nijakým spôsobom neprekvapí, lebo je jeho normálnou súčast'ou, sa tiež realizujte intertextuálny potenciál recenzie. 


\section{Recenzia v kontexte internetu a sociálnych sietí}

V súčasnosti, $\mathrm{v}$ časoch sociálnych sietí a online nakupovania, badat' v prípade pojmu recenzia zaujímavý sémantický posun. Upozornili ma na to okrem iného aj výsledky kvantitatívneho výskumu dotazníkovou metódou ${ }^{1}$, v ktorom 63,3\% respondentov odpovedalo negatívne na otázku, či čitajú literárnokritické texty (recenzie, glosy, úvahy, eseje...) a zároveň $65,7 \%$ respondentov reagovalo pozitívne na nasledujúcu otázku (Kúpili ste si niekedy knihu na základe recenzie?) $)^{2}$ (Obr. 2)
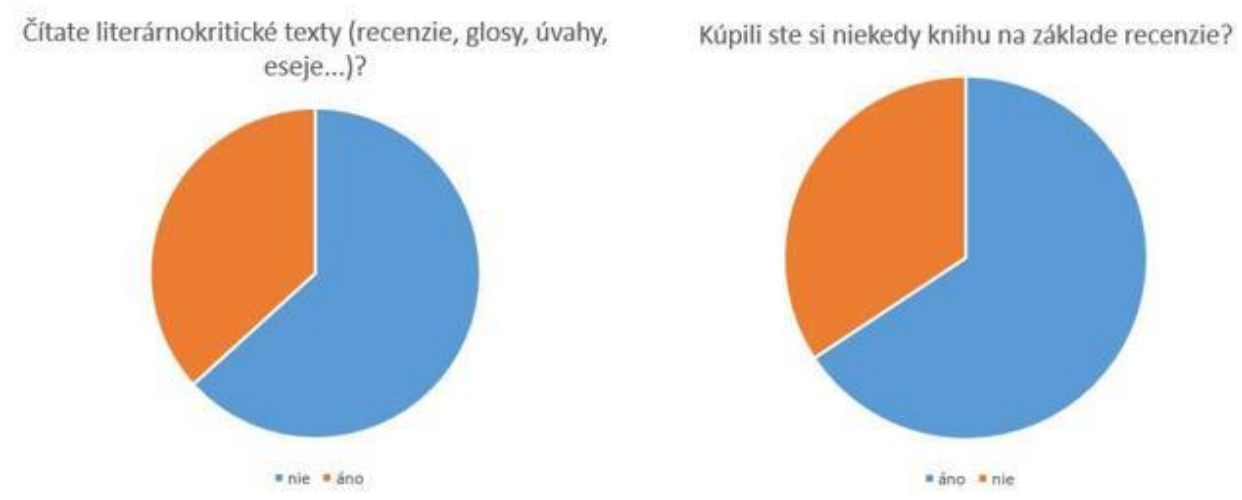

Obr. 2: Vzt'ah respondentov $\mathrm{k}$ recenzii

Na základe uvedených dát vidno diskrepanciu, ktorá nesúvisí s neznalost’ou terminológie, ani s nespol'ahlivost'ou respondentov. Treba ju vnímat' ako prejav rozširovania sémantiky pojmu recenzia, najmä vplyvom internetu a sociálnych sietí, pretože v každodennom živote začína slovo recenzia označovat' akúkol'vek reakciu človeka (zákazníka) na produkt, ktorý si kúpil alebo získal (v našom prípade na knihu, ktorú si prečíal). Takéto reakcie poznáme napríklad pod názvami užívatel'ská recenzia či zákaznícka recenzia. Táto skutočnost' ukazuje na fakt, že recenzia sa posúva z hodnotenia umeleckého diela kvalifikovaným recenzentom na vyjadrenie používatel'a (zákazníka) k produktu, s ktorým má nejakú skúsenost', resp. zážitok. Tento sémantický posun je spôsobený najmä tzv. zákazníckymi recenziami ${ }^{3}$, ktorých začiatok v prípade hodnotenia literatúry možno spájat' s prvým významným online knižným obchodom, ktorý ovplyvnil celosvetový knižný trh - s Amazonom. Potvrdzuje to napríklad Jiř̌́ Trávníček, český literárny vedec a kritik, ktorý je autorom viacerých kníh reflektujúcich správanie českých čitatel’ov. Ten charakterizuje vzt’ah medzi „kamennými“ a online kníhkupectvami takto: „Dokonce v prvních letech obchodování přses sít' internet výrazně

\footnotetext{
${ }^{1}$ Dotazník, ktorý vyplnilo 985 vysokoškolských študentov, bol súčastou výskumu literárnej kritiky, ktorý som opísala v monografii Literárna kritika v slovenských médiách včera, dnes a... (Stanková 2021: 137-151, 212243).

${ }^{2}$ Viac informácií o vzt’ahu súčasných mladých čitatel’ov k recenzii: Stanková 2021: 145-150.

${ }^{3} \mathrm{Z}$ anglického customer review.
} 
pomáhal klasickým (kamenným) knihkupectvím. Lidé si našli např́íklad na Amazonu informaci o knížce a šli si ji koupit do knihkupectví kamenného v místě svého bydliště. Našli zde i názor jiných kupujících, který v jejich volbě hrál daleko větší roli než autoritativní hlas kritiky či médií'“ (Trávníček 2011:29).

V kontexte spomínaného kvantitatívneho výskumu tento výklad výsledkov potvrdila aj otvorená otázka, v ktorej mali respondenti uviest' recenziu, ktorú nedávno čítali, resp. takú, ktorá im utkvela v pamäti. Zo 135 slovných odpovedí, 7 odkazovalo na informácie o knihách z webovej stránky kníhkupectva Martinus. (Stanková 2021: 147-148). V kontexte všetkých odpovedí v dotazníku sa toto kníhkupectvo vyskytlo 55krát. Tento stav reprezentuje napríklad odpoved’ 21-ročnej študentky: „Recenzie čítam len na martinuse/pantharei pod knihou, o ktorej premýšl'am.“

Ciel'om predkladanej štúdie nie je hodnotit' kvalitatívne rozdiely medzi klasickou (t. j. časopiseckou či novinárskou) recenziou a recenziou ${ }^{4}$, ktorá sa realizuje primárne v online prostredí (na sociálnych siet’ach, na blogoch, v podcastoch, či vo forme tzv. booktube), ale poukázat' na zásadné tendencie, ktoré prispeli k tomu, že aj recenzia, a teda aj literárna kritika a kultúrna publicistika všeobecne, boli a sú značne reformované (či deformované) konvergenciou médií ${ }^{5}$.

Recenzia by mala knihu hodnotit' a svojho čitatel'a nielen informovat' a zaujat', ale i vzdelávat'. Tieto aspekty sú pri rôznych variáciách literárnokritických textov na internete zrejme najkritickejšie. Na jednej strane recenzie ohrozujú marketingovo ladené anotácie, ktoré sú určené primárne na propagáciu a informovanie. Takéto texty niekedy nebývajú na rozoznanie od recenzií - a často sa stáva, že jediným indikátorom je rozsah textu6 . Propagačné texty, ktoré napísali zamestnanci vydavatel'stiev, kníhkupectiev, prekladatelia, redaktori, či autori samotní, sú viac reklamou než návodom ako čítat' $\mathrm{knihu}^{7}$. Na druhej strane je hodnotiaca funkcia recenzií ohrozovaná príspevkami na sociálnych siet'ach - ich používatelia zdiel'ajú príspevky o svojom živote, ktorého súčast'ou neraz býva aj literatúra. Niektoré účty na sociálnych siet'ach možno vnímat' ako online verzie čitatel'ských denníkov. Takéto príspevky na sociálnych siet'ach majú tiež propagačný charakter - niekedy sú výsledkom spolupráce medzi

\footnotetext{
${ }^{4}$ Tejto téme som sa venovala vo viacerých textoch zameraných na súčasnú podobu literárnej kritiky (Stanková 209: 64-75; Stanková 2019b: 763-768; Stanková 2019c: 180-191; Stanková 2019d: 428-437; Stanková 2020: 12-136).

${ }^{5}$ Mediálna filozofka Anna Sámelová konvergenciu médií definuje ako „,spoločensko-technologický fenomén, ktorý vstúpil do života bežného človeka v posledných dvoch dekádach 20. storočia. Jeho podstatou je fakt, že spotrebitel' (konzument) mediálnych obsahov, textových, zvukových aj obrazových, sa môže dostat' k rovnakým obsahom na jednom mieste." (Sámelová 2018: 28)

${ }^{6}$ Porovnaj napríklad anotáciu a recenziu na www.pravda.sk. Anotácia (https://kultura.pravda.sk/kniha/clanok/ 545741-sally-rooney-normalni-ludia/) a recenzia (https://kultura.pravda.sk/kniha/clanok/551749-sally-rooneynormalni-ludia/).

${ }^{7}$ Návod ako čítat' knihu možno tiež vnímat’ ako jednu z možných definícií recenzie.
} 
vydavatel'stvom/kníhkupectvom a influencerom, inokedy zase propagujú viac svojho autora, jeho osobnost', názory, zál'uby... V prípade sociálnych sietí je dôraz kladený na subjektívnost' (vlastný čitatel'ský zážitok, vlastná perspektíva) a pragmatickost' komunikácie (vo forme snahy oslovit' čo najväčšie publikum).

Dá sa povedat', že niekde medzi týmito dvoma tendenciami sa nachádza tzv. zákaznícka recenzia, s akou sa stretávame napríklad na weboch vydavatel'stiev. Tá neprechádza schval'ovacím redakčným procesom, nikto ju nekontroluje po formálnej, ani obsahovej stránke. Jej autor je často nepodpísaný, resp. využíva pseudonym. Toto všetko vedie $\mathrm{k}$ skutočnosti, že subjektívnost' a perspektíva autora sú väčšinou nadradené všetkým ostatným aspektom textu - negatívne čitatel'ské skúsenosti bývajú nezriedka prezentované nevyberanou lexikou, ktorá obsahuje aj vulgarizmy. Zároveň majú mnohé z týchto zákazníckych recenzií polylogický charakter, predstavujú reakcie na podobné texty uverejnené na tej istej stránke predtým, niektoré možno vnímat' dokonca ako akési repliky rozsiahlej výmeny názorov a čitatel'ských skúseností. Zákaznícke recenzie sú subjektívne, sú otvorené, sú intertextuálne a najmä nie sú ničím obmedzované - ani časom, ani pravidlami a postupmi redakčnej práce. Tieto recenzie predstavujú rovnaké riziko ako anotácie - na weboch kníhkupectiev a vydavatel'stiev sú zverejnené aj anotácie, ktoré ani v tomto prípade nie je l'ahké rozoznat' od reakcií čitatel'ov. Nezriedka sa stáva, že známi autorov alebo autori samotní pridávajú pozitívne reakcie na svoje vlastné knihy. V̌̌etky spomenuté skutočnosti naznačujú, že hodnotenie kníh nebýva v prípade nových variantov recenzie primárne. Rovnako nie je dôležitá ani vzdelávacia funkcia recenzií, pretože len malé množstvo textov na sociálnych siet’ach či zákazníckych recenzií svojho čitatel’a vzdeláva - dôraz sa nekladie na percepciu textu, na kritické myslenie a používanie argumentov, ktoré podporia názor autora recenzie. Dôraz sa kladie na autorovo ja, na jeho vlastný čitatel'ský zážitok a často na emócie, ktoré nahrádzajú v online textoch argumenty.

$\mathrm{Na}$ druhej strane platí, že rôzne online varianty recenzií majú ovel’a väčší dosah ako literárna kritika v klasických médiách. Spájajú čitatel’ov, ktorým ponúkajú jasné a zrozumitel'né informácie - a pre množstvo potenciálnych čitatel’ov je zrejme dôležitejšie vytvorit' si názor na knihu či autora pomocou človeka s podobným vkusom, vzdelaním, vekom, skúsenost'ami... Online varianty recenzií pomaly ale isto búrajú výsostné postavenie kritika ako najvyššieho sudcu v literárnej komunikácii. Ruší sa tak isté autoritárstvo, na ktoré sme boli pri kritike zvyknutí a do popredia sa dostáva čitatel'ská skúsenost' a čitatel' samotný. 


\section{Záver}

Rôzne varianty recenzií, s ktorými sa stretávame v online prostredí, kritike umožňujú zasiahnut' a ovplyvnit' väčší počet adresátov. Navyše, adresáti sú dôvod, prečo takéto recenzie vznikajú a sú čoraz populárnejšie - nedôvera v autority sa prejavuje v tom, že potenciálny čitatel’ si radšej prečíta zákaznícku recenziu alebo post na sociálnej sieti, pretože takéto názory sú mu bližšie, ako názory erudovaného kritika - vyštudovaného literárneho vedca. Zároveň treba zdôraznit', že pri rôznych online recenziách sa vyzdvihuje čitatel'ská skúsenost' a čitatel' samotný, kniha často nebýva hlavnou témou takýchto textov - pointa spočíva v čitatel’ovi, jeho zážitkoch, pocitoch, názoroch.

Možno konštatovat', že recenzia ako žáner je internetom a sociálnymi siet’ami zasiahnutá presne tak ako mnohé iné žurnalistické žánre - na jednej strane platí, že získala nový priestor a násobne väčšie publikum, na druhej strane však vieme, že to ovplyvnilo však jej kvality, pretože sa novému priestoru a násobne väčšiemu publiku musela prispôsobit'.

\section{Summary}

The paper focuses at current aspects of a book review. The mass media communication is nowadays influnced by internet and social networks. This text provides a basic characteristics of book review, its qualities and functions. The aim of this text is to outline shifts in the perception of word „review“. The research is focused at reviews in traditional media (dailies, journals) and in online reviews (mainly at online bookshops). This text provides basic information about relationship of book review and readers review.

\section{Literatura}

Bučková, Z., Rusňáková, L. Publicistika v periodickej tlači. Trnava: Univerzita sv. Cyrila a Metoda v Trnave, 2017.

Čeňková, J. Recenze. In: Halada, J., Osvaldová, B. (eds.) Výklad pojmů a teorie oboru. Praha: Karolinum, 2017, s. 198-199.

Mistrík, J. Štylistika. Bratislava: SPN, 1997.

Onrejovič, O. Recenzia a jej žánrovo-kompozičné charakteristiky. Kultúra slova. 2000 (34/4), s. 198-203. 
Sámelová, A. Konvergencia médií. In: Hacek, J., Sámelová, A., Stanková, M. (zost.) Novinárska prvouka. Slovnik základných pojmov žurnalistiky. Bratislava: Katedra žurnalistiky FiF UK v Bratislave, 2018, s. 26-30.

Stanková, M. Fenomén literárnej kritiky v 21. storočí. In: Magnanimitas (ed.): MMK 2019. Hradec Králové: Magnanimitas akademické sdružení, 2019b, s. 763-768.

Stanková, M. Fenomén literárnej kritiky v 21. storočí. In: Sámelová, A., Stanková, M., Hacek, J. (zost.) Fenomén 2019. Súčasná profesionálna žurnalistika a jej reflexie. Bratislava: Univerzita Komenského, 2019, s. 64-75.

Stanková, M. Literárna kritika v slovenských médiách včera, dnes a... Bratislava: Univerzita Komenského, 2020.

Stanková, M. Vzdelávacia funkcia literárnej kritiky v 21. storočí. In: Linczényi, M. (ed.) Výchova a vzdelávanie $k$ demokratickému občianstvu $v$ Slovenskej republike. Trenčín: Trenčianska univerzita Alexandra Dubčeka v Trenčíne, 2019c, s. 180-191.

Stanková, M. Vzt’ah marketingovej a vzdelávacej funkcie literárnej kritiky v 21. storočí. In: Bučková, Z., Kačincová Predmerská, A., Rusňáková, L. (eds.) Megatrendy a médiá 2019: Digital Universe. Trnava : Fakulta masmediálnej komunikácie, 2019d, s. 428-437.

Stanková, M. Z „kritického“ parnasu $\mathrm{k}$ influencerom (Literárna kritika $\mathrm{v}$ čase sociálnych sietí). In: Sámelová, A., Stanková, M., Hacek, J. (zost.): Fenomén 2020. Komunita v mediálnom priestore. Bratislava : Univerzita Komenského, 2020, s. 124-136.

Trávníček, J. Čtenáři a internauti. Brno: HOST, 2011.

\section{Elektronické zdroje}

Dostupné z: https://kultura.pravda.sk/kniha/clanok/545741-sally-rooney-normalniludia/ (2021-04-29).

Dostupné z: https://kultura.pravda.sk/kniha/clanok/551749-sally-rooney-normalniludia/ (2021-04-29). 
TRANSLATOLOGIE

/ TRANSLATOLOGIA

/ ПЕРЕВОДОВЕДЕНИЕ 



\section{OBRAZ ROSJANINA W REPORTAŻU JACKA HUGO-BADERA „BIALA GORĄCZKA” I JEGO ROSYJSKIM PRZEKŁADZIE}

\section{The Picture of Russian in the Reportage of Jacek Hugo-Bander "Biata Goraczka" and its Russian Translation}

Keywords: Polish literature of journey, Russian's picture, reportage, Jacek Hugo-Bader

Contact: Uniwersytet Śląskiw Katowicach; adamczyk.dawid93@gmail.com

Postrzeganie Rosjan stanowi jeden z bardziej skomplikowanych aspektów polskiej tożsamości narodowej, co jest związane z naznaczoną dramatycznymi wydarzeniami historią stosunków polsko-rosyjskich (m. in. rozbiorami Rzeczpospolitej, II wojną światową czy sposobem funkcjonowania i upadkiem Związku Radzieckiego). Stosunki te w znacznym stopniu przyczyniły się do powstania negatywnych i niezmiennych od dziesięcioleci stereotypów na temat przedstawicieli narodu rosyjskiego. Tendecja ta wydaje się nieodwracalna nawet w obliczu udziału nowych pokoleń w kształtowaniu opinii społecznej. Wyniki badań przeprowadzonych w XXI wieku wskazują jedynie na kilka pozytywnych cech, jakie Polacy utożsamiają z Rosjanami (gościnność, wesołość, dobroć, skłonność do rozrywek), w zestawieniu z szerokim wachlarzem negatywnych (np. pijaństwo, nieschludność, niegospodarność, niezdyscyplinowanie, zacofanie, nieuczciwość, niemoralność) (Błuszkowski 2003: 150-152). Stanowi to tylko niewielkie przesunięcie w porównaniu do powojennego obrazu Rosjan, uważanych wówczas za niemożliwy do zatrzymania, bezwzględny i niszczycielski żywioł, wśród którego można odnaleźć przyjazne jednostki (Korczyński 2017: 36).

Podobne portrety Rosjan odnajdujemy w polskiej literaturze poprzednich wieków. Już w tekstach renesansowych pisarzy Rosjanie są przedstawiani jako carscy niewolnicy, a ich państwo jako zagrożenie. Intesyfikację takiego podejścia można zaobserwować w tekstach epoki romantyzmu, która przypada na początku 123-letniego okresu, podczas którego Polska nie istnieje na mapie Europy. Czas ten był naznaczony twórczością „ku pokrzepieniu serc“, często będącą apelem o niepodległościowy zryw i podejmującą próbę kształtowania polskiej tożsamości narodowej. Jednak w tekstach nasławniejszego polskiego wieszcza - Adama Mickiewicza, zauważalne jest 
oddzielenie obrazu rosyjskiego aparatu władzy (charakteryzującego się wręcz zwięrzęcą nienawiścią w stosunku do Polaków) od obrazu Rosjanina - przyjaznego i dobrego człowieka (http://www.mysl-polska.pl/777).

Władza państwowa i aktywność polityczna - te dwa apsekty najbardziej niepokoją Polaków, dla których Rosjanie, „gdyby nie mieli państwa, a tylko kulturę, byliby najbardziej ulubioną nacją“ (de Lazari 2006: 6). Z jednej strony pozytywne postrzeganie Rosjan przez Polaków ma swoje źródło w wspólnym słowiańskim korzeniu obu kultur narodowych. $\mathrm{Z}$ drugiej jednak strony, krytyka w stosunku do państwa rosyjskiego nierzadko opiera się na przekonaniu o jego przynależności do obcego, z polskiego punktu widzenia, kulturowego kręgu Wschodu.

Za kolejny istotny czynnik, sprzyjający zakorzenieniu i usprawiedliwieniu w polskiej świadomości zbiorowej przedstawionego wcześniej negatywnego streotypowego obrazu Rosjan należy uznać informacje na temat ich państwa, przekazywane i publikowane $\mathrm{w}$ środkach masowego przekazu. Po skandalu dopingowym z udziałem rosyjskich sportowców i zajęciu Krymu, które było szeroko komentowane, obecnie media skupiają się na sprawie Aleksieja Nawalnego i rosyjskiej aktywności militarnej wzdłuż granicy z Ukrainą, a także niekorzystnej z perspektywy polskiej racji stanu budowie gazociągu Nord Stream 2. Nie zwraca się przy tym uwagi na działalność organizacji zajmujących się wspieraniem przyjaznych kontaktów pomiędzy Polską i Rosją. Prowadzi to do postrzegania Rosjan przez Polaków prawie wyłącznie przez pryzmat rosyjskiej polityki, działającej z rozkazów Kremla, w związku z czym wizurek państwa nie zostaje oddzielony od wizerunku jego mieszkańców (Korzeniowska-Berczyńska 2003: 127).

Opisane powyżej determinanty nie tylko odcisnęły piętno na portrecie Rosji i Rosjan, ale stały się także przyczynkiem do licznych dyskusji w przestrzeni polskiej opinii publicznej. Pomimo dużej popularności, temat „Rosja” nadal pozostaje aktualny. Za przejaw takiego stanu rzeczy można uznać chociażby szeroki wybór reportaży literackich opisujących rosyjską rzeczywistość. Wśród nich odnajdujemy także teksty przetłumaczone na język rosyjski.

Jednym z bardziej wyrazistych pisarzy, który zmierzyli się niejednokrotnie ze wspomnianym zagadnieniem jest Jacek Hugo-Bader, od lat 90. związany z „Gazetą Wyborczą”. Jego „Dzienniki Kołymskie”, „W rajskiej dolinie wśród zielska” i „Biała gorączka" do dziś cieszą się popularnością wśród polskich czytelników za sprawą przyjętej przez pisarza strategii $\mathrm{w}$ przedstawianiu Rosji jako obiektu badań, zapewniającego emocjonujące przeżycia i adrenalinę. Strategia ta pozwoliła skupić się na tym, co niezrozumiałe, niezwykłe, szczególne, inne czy kontrowersyjne. Hugo-Bader 
przydaje Rosji pewną egzotyczność, co osiąga dzięki m. in. wyborowi trasy czy informatorów, wśród których odnajdujemy hipisów, raperów, narkomanów, członków sekty, krewnych postaci historycznych, czy przedstawicieli mniejszości narodowych (Собчак, Вуйчак 2019: 47).

Niestety, jego książki nie doczekały się przekładu na język rosyjski. Wyjątek stanowi tytułowy reportaż jednej z nich - „Biała gorączka”, który, przetłumaczony przez Jurija Czajnikowa, ukazał się w czasopiśmie literackim „Zvezda”. W tekście tym pisarz skupił się na historii opowiedzianej z punktu widzenia przedstawicieli mniejszości narodowej Ewenków. Dotyczy ona grupy pasterzy, którzy zginęli z powodu syndromu poalkoholowego nazwanego białą gorączką. Ludy północy nie tolerują napojów alkoholowych w związku z dietą opartą prawie wyłącznie na mięsie. Ten sposób odżywiania zmienił ich metabolizm do tego stopnia, że niewielka ilość alkoholu wywołuje stan upojenia, a syndrom odstawienia równa się bardzo silnej psychozie, która może doprowadzić do zachowań autodestrukcyjny.

W przywołanym reportażu uwagę zwracają przede wszystkim określenia dotyczące Rosjan i sposób ich oddania w przekładzie:

Szamanka na oczach wszystkich zmienia się w stuletnią staruszkę. Zarzuca garb na plecy, nogi wykrzywiaja się jej w pałak, a słowa skrzypia jak wieko trumny, przykazuje, żeby Lena spisała wszystko czego potrzebuje od duchów.

Lena zaczyna więc tak: „Szanowny Sowoki. W pierwszych słowach mojego listu zwracam się do Ciebie z uprzejma prośba, żeby te Ruski oddali nasze ziemie..." (Hugo-Bader 2011: 153).

Шаманка на глазах всех присутствующих превратилась в столетнюю старуху. На спине вырос горб, ноги согнулись дугой, голос заскрипел, как крыика гроба. Приказала Лене написать все, чего та хочет от духов.

Послание Лены начинается так: «Уважаемый Совоки. В первых строках моего письма обращзаюсь к Тебе с убедительной просьбой, чтобы русские вернули нам наши земли...» (https://zvezdaspb.ru/index.php?page=8\&nput=1285).

Z perspektywy języka wyjściowego słowo Ruski dla określenia Rosjan nie budzi wątpliwości co do interpretacji. Jest to potoczna i bardziej negatywnie nacechowana forma słowa Ruscy (Лешкова 2018: 167). W języku rosyjskim nie znajdziemy ekwiwalentów wyrażających negatywny stosunek do przedstawicieli kultury języka docelowego. Istnieje określenie pyсак, ma ono jednak pozytywne znaczenie: 'człowiek 
z cechami rosyjskiego charakteru; prosty, dobry rosyjski człowiek' (https://dic.academic.ru/dic.nsf/ushakov/1012746).

Na uwagę zasługuje również użycie w oryginale zaimka wskazującego te, który nie został oddany $\mathrm{w}$ przekładzie. Zabieg ten wzmacnia negatywny obraz Rosjan: te Ruski - w domyśle ci, którzy zabrali nasze ziemie i są odpowiedzialni za nasz los. O ile w przypadku nominacji Ruski można mówić o nieprzekładalności, to umieszczenie rosyjskiego zaimka эmu mogłoby w pewnym stopniu oddać ekspresywność listu eweńskiej kobiety. Zamiast tego, można stwierdzić, że fragment ten został zneutralizowany przez tłumacza.

Dalej także napotykamy różnice w podejściu do określeń przedstawicieli narodowości rosyjskiej:

- Renifery zawsze ciela się w tym samym miejscu (...) Sto lat do tytu albo $i$ więcej wybrały sobie rzeke Jałte, a oni tam zaczęli kopać złoto (...)

- A Rusek wszystko zamorduje, żeby się nażreć mięsa (...) udaja, że nie odróżniaja dzikich reniferów od naszych...

- To mój Dima idzie do nich - ciagnie Masza i ttumaczy-żeby nie ubijali tych naszych matek, bo one moga tylko tam, a oni śmieja się, a ten ich naczelnik, taki potężny, wstrętny ruski chlop, mówi, że niczego nie im możemy zabronić, bo to ruska ziemia, a nie nasza (Hugo-Bader 2011: 172).

- Олени всегда телятся в одном и том же месте (...) Сто или больше лет тому назад выбрали себе реку Ялду, а они там золото начали кonamb.

- Русский все убьет, лишь бы мяса нажраться, - подключается ее муж. - Прикидьваются, что не различают диких оленей от наших...

- Вот и идет мой Дима к ним, - продолжсает Маша, - и объясняет, даже просит, чтобы не убивали этих наших маток, потому что они могут рожать только там, а они смеются, а этот их начальник, толстый такой, противный русский мужни, говорит, что мьл ничего не можем им запретить, потому что это русская земля, а не наша (https://zvezdaspb.ru/index.php?page=8\&nput=1285).

Ponownie należy przyjrzeć się określeniu Rosjanina - Rusek - które jest bardziej negatywną formą określenia Ruski dla nazwania męskiego przedstawiciela narodu rosyjskiego (Лешкова 2018: 166). Wątpliwości wzbudza pominięcie w tłumaczeniu partykuły $a$, która pełni funkcję ograniczającą i przeciwstawiającą (wszyscy rozumieją, tylko Rosjanin tak czyni), co wzmacnia ujętą przez autora wypowiedź Ewenki. W tym 
przypadku mamy jednak do czynienia z kompensacją utraconych znaczeń poprzez wprowadzenie do rosyjskiej wersji reportażu spójnika лишь бы - podkreślenie celu, dla osiągnięcia którego subiekt jest gotowy dołożyć maksymalnych starań (https://www.efremova.info/word/lish_by.html). Transformacja ta wzmacnia negatywny obraz Rosjanina, pozbawiając ewentualnych wątpliwości co do interpretacji jego działań.

Warto przyjrzeć się także nominacji ruski chłop. W języku polskim użyty przymiotnik, nawiązujący do przynależności narodowej jest również nacechowany negatywnie. Neutralnym określeniem jest przymiotnik rosyjski. Kolejny raz wskazuje to na brak ekwiwalentu w kulturze docelowej.

Za dobrą decyzję translatorską można uznać przekład wyrażenia ruska ziemia, a піе nasza - потому что это русская земля, а не нама. Użyty w tłumaczeniu przymiotnik tym razem $w$ pełni oddaje znaczenie oryginału. Wiążę się to z rozgraniczeniem w języku rosyjskim znaczeń słów русский (odnoszący się do narodu i jego kultury, np. русский менталитет, русская кухня, русская литература) і российский (odnoszący się do państwowości, np. Российская Федераиия, российское законодательство, российская территория). Na uwagę zasługuje fakt, że w polszczyźnie istnieje różnica semantyczna obejmująca omawiane przymiotniki, ale ma ona swoje źródło w etnonimie Rusin - ogólnej nazwie stosowanej dawniej przez Polaków w stosunku do Wschodnich Słowian, następnie do realiów ukraińskiej i białoruskiej kultury, a w czasie międzywojnia oznaczającej narodowość ukraińską (Лазари 2005: 1-7). Zastosowanie przymiotnika русская w tych okolicznościach w pełni oddaje artykułowaną przez Ewenkę kwestię - traktowanie przez przedstawiciela władz terytorium zamieszkałego przez mniejszość jako rdzennie rosyjskiej ziemi i potwierdza interlingwalne kompetencje thumacza.

Rosjanie wszystkich niestowiańskich mieszkańców Syberii nazywaja pogardliwie cziurkami. Wymyślają na ich temat niezliczone kawaly, tak jak my wymyślamy kawaly o mieszkańcach Wąchocka, a Amerykanie o glupich Polaczkach. Piloci nie chca latać nad Czukotka, bo miejscowi lubia wsiadać $\boldsymbol{i}$ wysiadać w biegu. Jak większość kawatów także i te wzięty się z obserwacji życia codzienniego - w tym przypadku pijaków (HugoBader 2011: 153).

Всех неславянских жителей Сибири русские презрительно называют чурками. Создают о них бесчисленные анекдоты, вроде тех, что мы придумываем о жителях Вонхоцка, а американцы - о глупых полячишках. Как и большинство анекдотов, эти тоже взяты из наблюдений за повседневной жизнью, в данном случае - за жизнью пьянии (https://zvezdaspb.ru/index.php?page=8\&nput=1285). 
Ostatni przywołany fragment jest przykładem złagodzenia treści reportażu w języku docelowym. Autor sugeruje, że kształtowanie się negatywnych stereotypów na temat grup etnicznych jest powszechną praktyką. W tym celu zestawia żarty na temat Polaków o mieszkańcach prowincji oraz kawały Amerykanów o Polaczkach z dowcipami na temat mniejszości w granicach Państwa Rosyjskiego.

Wprost do rosyjskiej wersji reportażu zostało przeniesione określenie cziurki, gdyż ukształtowało się ono w ruszczyźnie od słowa чурка (rzadziej чурак). Dosłownie oznacza ono krótki, okrągły kawałek pnia lub korony drzewa przed obróbką (https://dic.academic.ru/dic.nsf/efremova/266928). Przenośny sens tego określania ma negatywny, a nawet wulgarny wydźwięk, odnoszący się do człowieka o odmiennej niż rosyjska przynależności etnicznej i kulturowej (najczęściej przedstawicieli narodowości obszaru Kaukazu) jako osoby niezdolnej do odczuwania emocji, okrutnej, nie potrafiącego współczuć (https://dic.academic.ru/dic.nsf/efremova/266928), również o obniżonych zdolnościach intelektualnych (https://slovar.cc/sleng/vor/2492346.html). O pogardzie, którą jest naznaczone to słowo świadczą związane z nim powiedzenia, np. чурка с глазами 'głupi człowiek' (Мокиенко, Никитина 2007: 743) і жить за чурку ‘być nikomu niepotrzebnym’ (Мокиенко, Никитина 2007: 743).

Dalsza część fragmentu jest z kolei przykładem opuszczenia i neutralizowania przez tłumacza kontrowersyjnych z perspektywy kultury docelowej stwierdzeń. Odnosi się to do opuszczenia w rosyjskim przekładzie fragmentu Piloci nie chca latać nad Czukotka, bo miejscowi lubia wsiadać i wysiadać w biegu. Mowa tutaj o rosyjskich pilotach.

W „Białej gorączce” odnajdujemy kolejny negatywny wizerunek Rosjan, którzy zostali przedstawieni w roli kolonizatorów uciskających mniejszość etniczną. Spoglądając na użyte w autorskim zapisie wypowiedzi Ewenków określenia nazywające Rosjan, można je uznać za nieprzekładalne. Bez wątpienia autor reportażu, wykorzystując możliwości języka polskiego, nadał tłumaczonym przez siebie wypowiedziom, przytoczonym w pierwszym i drugim fragmencie, większą ekspresywność. Z punktu widzenia tłumacza określenia te okazały się niemożliwe do oddania, gdyż język rosyjski jest w tym wypadku narzędziem komunikacji kolonizatorów i nie istnieją w nim nacechowane w podobny sposób określenia.

Ciekawą z perspektywy rosyjskiej recepcji „Białej gorączki” jest decyzja tłumacza o opuszczeniu kontrowersyjnego żartu o pilotach latających nad Czukotką. W zestawieniu $\mathrm{z}$ wywodem autora o powszechnej naturze kawałów na temat określonych grup wspomniane pominięcie ogranicza negatywny obraz Rosjan, którzy jak zostało to ujęte w Białej gorączce skolonizowali ziemie Ewenków, przywieźli ze 
sobą zabójczą wódkę, nie liczą się z potrzebami mniejszości, nazywają jej przedstawicieli pogardliwie cziurkami, a jeszcze mieliby żartować na ich temat. W związku z powyższym można uznać, że wizerunek Rosjan w przypadku tego reportażu został złagodzony $\mathrm{w}$ procesie tłumaczenia nie tylko z powodu nieprzekładalności, ale także poprzez zamierzoną ingerencję tłumacza.

\section{Summary}

The following paper features the issue of Russians picture in the reportage of Jacek Hugo-Bader "Biała gorączka" In the theoretical part there were presented the main stereotypes concerning Russians which exist in Polish public awareness and there was characterized the specificity of the author's creation. In the analytical part the attention was turned to unique author's methods of the picture of Russians, which were confronted with Russian version of reportage.

\section{Literatura}

Błuszkowski, J. Stereotypy narodowe w świadomości Polaków. Warszawa: Elipsa, 2003.

de Lazari, A. Wzajemne uprzedzenia Polaków i Rosjan. In: de Lazari, A. (ed.) Katalog wzajemnych uprzedzeń Polaków i Rosjan. Warszawa: Polski Instytut Spraw Międzynarodowych, 2006, s. 4-13.

Hugo-Bader, J. Biała goraczka. Wołowiec: Wydawnictwo Czarne, 2011.

Korczyński, T. M. Wizerunek Rosjanina w Polsce. Socjologiczna analiza zjawiska stereotypu narodowego w paradygmacie socjologii. Journal of Modern Science. 2017 (32), s. 29-44.

Korzeniowska-Berczyńska, J. Obraz Włodzimierza Putina ze stereotypami Rosji w tle. In: Paradowski, R., Ossowski, Sz. Polska w Rosji - Rosja w Polsce. Stosunki polityczne. Poznań: Wyd. Naukowe INPiDz UAM, 2003, s 31-41.

Лазари, А. Русскость, советскость и российскость в польской культурной запрограммированности. Зарисовнка вопроса. In: Шылежкова, С.Г. (ред.) Россия-Польша: Филологический и историко-культрный дискурс. Магнитогорск: Издательство Магнитогорского государственного университета, 2005, с. 1-7. 
Лешкова, О.O. «Ruski, rosyjski, radziecki, sowiecki...»: к вопросу о семантической и прагматической эволюции лексем. In: Ремнева, М.Л., Ананьева, Н.Е., Васильева, В.Ф., Изотов, А.И., Ковтун, Е.Н., Лифанов, К.В., Останчук, О.А. (ред.) Славянский мир. Язык, литература, культура. Москва: Макс Пресс, c. $164-167$.

Мокиенко, В.М., Никитина, Т.Г. Большой словарь русских поговорок. Москва: Олма Медия Групп, 2007.

Собчак, Б., Вуйчак, М. Образы России: стратегии представления России в современном польском репортаже. Вестник Северного (Арктического) федерального университета. Серия «Гуманитарные и соииальные науки». 2019 (3), c. 41-54.

\section{Źródła elektroniczne}

Dostęp z: http://www.mysl-polska.pl/777 (2021-04-29).

Dostęp z: https://zvezdaspb.ru/index.php?page=8\&nput=1285 (2021-04-29).

Dostęp z: https://dic.academic.ru/dic.nsf/ushakov/1012746 (2021-04-29).

Dostęp z: https://www.efremova.info/word/lish_by.html (2021-04-29).

Dostęp z: https://dic.academic.ru/dic.nsf/efremova/266928 (2021-04-29).

Dostęp z: https://slovar.cc/sleng/vor/2492346.html (2021-04-29). 


\section{ARANŻACJA PIOSENKI A JEJ WPLYW TLUMACZENIE I JEGO RECEPCJE (NA MATERIALE UTWORÓW WLODZIMIERZA WYSOCKIEGO W PRZEKŁADACH MACIEJA MALEŃCZUKA)}

\section{The Arrangement of the Song and its Influence on the Translation and its Reception (Based on the Material of Vladimir Vysotsky's Songs Translated by Maciej Maleńczuk)}

Keywords: translation, Maleńczuk, Vysotsky, bards, song, poetry, author song, shanson Contact: Uniwersytet Śląśki w Katowicach; szymonbryzek@gmail.com

Wśród utworów muzycznych piosenka jest jedną z najbardziej rozpowszechnionych i pojemnych stylistycznie form. Obejmuje ona rozmaite gatunki i podgatunki muzyczne - od muzyki rockowej, punkowej, hip-hopowej przez gospel, blues, country - aż po poezję śpiewaną. Autor Słowniczka muzycznego Jerzy Habela charakteryzuje piosenkę następującymi słowami:

Pieśń - krótki utwór wokalny do tekstu poetyckiego (na głos solo, na głos z towarzyszeniem instrumentu lub orkiestry, na wokalny zespół kameralny, na chór). (2) pieśń popularna (masowa, taneczna), zazwyczaj o tematyce popularnej, aktualnej, odznacza się również prostą budową, często zwrotkową z refrenem (Habela 1998: 143).

Również Anna Barańczak, polska uczona badająca relacje języka i muzyki, dostrzega i podkreśla jej powszechny charakter ukierunkowany na zdobycia masowego słuchacza:

Piosenka, będąc typowym obiektem kultury masowej, nastawiona jest przede wszystkim na uczestniczenie w masowym obiegu, a więc na maksymalną popularność. Popularność tę zdobywa - jeśli pominąć wpływ czynników zewnętrznych - przede wszystkim dzięki posługiwaniu się dobrze przyswojonymi konwencjami, które umożliwiają odbiorcy pozostawanie w ramach znanych mu rozwiązań, nie „narażają” go na nadmierne angażowanie się poznawcze, refleksyjne czy interpretacyjne w proces odbioru (Barańczak 1983: 65). 
Powszechność i łatwość w odbiorze, podkreślane w cytowanych powyżej definicjach, są szczególnie interesujące w kontekście wyjątkowego typu piosenki, jakim jest poezja śpiewana, zwana również piosenką poetycką lub też, w ujęciu interesującej nas twórczości Włodzimierza Wysockiego - piosenką autorską, bardowską, szansonem ${ }^{1}$. Synkretyczny gatunek piosenki autorskiej, którą Большая российская энщиклопедия definiuje jako gatunek związany przede wszystkim z okresem radzieckim i kulturą miejską, wyróżnia się dominacją warstwy tekstowej (poetyckiej) nad nieskomplikowaną warstwą muzyczną (sprowadzającą się zazwyczaj do śpiewu pod gitarę). Mimo swej pozornej prostoty jednak może ona stanowić wyzwanie dla tłumacza. Wynika ono przede wszystkim z polifonicznej konstrukcji każdego utworu słowno-muzycznego, który jest organizowany przez warstwę muzyczną i tekstową estetycznym komunikatem. Konstrukcja ta wymusza na thumaczu refleksję nad tym, w jaki sposób i czy w ogóle przetransferować tę polifoniczność do utworu docelowego. Jak podkreśla Anna Barańczak: „Piosenka jest przekazem wielokodowym, korzysta mianowicie z kodu słownego, muzycznego, ewentualnie również gestycznego i innych" (Barańczak 1983: 5). Obecność warstwy muzycznej jest niewątpliwie cechą konstytutywną każdego utworu muzycznego. Aranżacja instrumentalna, wykonanie wokalne pozwalają nam stwierdzić, że mamy do czynienia z piosenką, ma także niebagatelny wpływ na odbiór utworu.

Roman Lewicki w rozważaniach nad istotą i definicją przekładu zawartych w Zagadnieniach lingwistyki przekładu zadaje pytanie - „(...) Co właściwie podlega tłumaczeniu? Czy tłumaczeniu podlega język? Czy tłumaczeniu podlega tekst? Czy może thumaczeniu podlega znaczenie tekstu? A jego forma - czy ona także? (...)" (Lewicki 2017: 75). W pytaniu tym pobrzmiewają echa dialogu tego badacza z Krzysztofem Hejwowskim i jego krytyką tekstualizmu, zawartą w Kognitywnokomunikacyjnej teorii przekładu. Dla nas jednak podjęta przez Lewickiego kwestia istotna jest w kontekście dwuwarstwowej budowy komunikatu, jakim jest piosenka, i hierarchii tych warstw (lub może jej braku?) w procesie tłumaczenia. Odpowiedź na te wątpliwości można odnaleźć w pracach Anny Bednarczyk poświęconych problematyce przekładu. Badaczka wprowadza bowiem pojęcie dominanty translatorskiej, którą definiuje jako „ten element struktury utworu tłumaczonego, który trzeba przełożyć (odtworzyć) w utworze docelowym, aby zachować całokształt jego subiektywnie istotnych cech" (Bednarczyk 1999: 19). Jedną z takich cech, w zależności od podjętej przez thumacza decyzji, może być warstwa muzyczna, której recepcję umożliwia

\footnotetext{
${ }^{1}$ Zarówno w tekstach polskich, jak i rosyjski nazwy te używane są wymiennie, co prowadzi do jeszcze większej nieostrości w klasyfikacji gatunkowej.
} 
i determinuje aranżacja muzyczna, pozostająca jednak często poza sferą tłumaczeniowego rzemiosła i analizy.

Kolejnym czynnikiem wyróżniającym warstwę muzyczną, który wydaje się istotny z punktu widzenia przekładu, jest fakt jej wpływu na organizację rytmiczną tekstu. Jak bowiem zauważa Anna Barańczak - warstwa melorytmiczna tekstu zmienia się w zależności od warstwy muzycznej, z którą jest niejako zlepiona (Barańczak 1983: 66).

W przekładzie artystycznym materiałem podlegającym naukowej analizie i refleksji jest zazwyczaj tekst, rozumiany (między innymi) jako realizacja funkcji komunikacyjnej języka (de Beaugrande, Dressler 1990: 11). To właśnie tekst stanowi przedmiot transferu międzyjęzykowego, na co zwraca uwagę Gideon Toury: „Jest on [przekład] przeprowadzany na tekstach i produkuje teksty; inaczej mówiąc, jest on raczej intertekstualny niż interlingwalny, dotyczy bowiem par tekstów i jedynie przez implikacje - par języków" (Toury 1981: 253). Obecność warstwy muzycznej w przekładzie piosenki bywa często przemilczana, gdyż tłumacze (co zrozumiałe) wyodrębniają z utworu muzycznego sam tekst i dokonują jego transferu do kultury docelowej. Nie inaczej jest z przekładami piosenek Włodzimierza Wysockiego, które na polskim rynku wydawniczym funkcjonują przede wszystkim jako zbiory tekstów z przekładami barda ${ }^{3}$, zbliżając się w swojej konwencji do tomików poetyckich. Zabieg ten $\mathrm{z}$ jednej strony ułatwia polskiemu odbiorcy recepcję utworów, ale jednocześnie pozbawia go komunikatu zawartego w warstwie muzycznej, której polski odbiorca może nie znać ze względu na zanurzenie twórczości Wysockiego w kulturze samizdatu, co ograniczało jej masową dostępność.

W niniejszym artykule przyjrzymy się aranżacji muzycznej w kontekście przekładu. Jako materiał egzemplifikacyjny wykorzystane zostaną najnowsze tłumaczenia utworów Włodzimierza Wysockiego autorstwa polskiego muzyka Macieja Maleńczuka, któremu polscy fani nadali przydomek „,barda Krakowa” (Sawala 1997: 135). Przekłady te są nietypowe, bowiem oprócz transferu warstwy tekstowej Maleńczuk, dzięki formule albumu muzycznego, mógł pozwolić sobie na transfer oraz swego rodzaju trawestację warstwy muzycznej. Odbiorca obcuje nie z tekstem, ale $\mathrm{z}$ albumem muzycznym, który umożliwił Maleńczukowi reinterpretację Wysockiego również $\mathrm{w}$ kategoriach muzyki. W związku z powyższym interesować nas będą

\footnotetext{
${ }^{2}$,It (the translation) is exerted on texts and produced texts; In other words, it is intertextual rather than interlingual, involving pairs of texts, and only by implication - pairs of languages“.

${ }^{3}$ Do najpopularniejszych należy zaliczyć m.in.: zbiór tekstów w przekładach Michała B. Jagiełly - Nie ma mnie oraz 14 piosenek w przekładach Ziemowita Fedeckiego.
} 
najbardziej charakterystyczne cechy aranżacji utworów Wysockiego oraz to, czy ich transfer lub neutralizacja w przekładzie będą mieć wpływ na recepcję thumaczenia.

Warstwa tekstowa utworów Wysockiego spotyka się $\mathrm{z}$ szerokim zainteresowaniem badaczy. Pewne zdziwienie budzi więc fakt, że głębokiej refleksji nie została poddana muzyczna strona jego twórczości, a jeśli już - to zazwyczaj w kontekście krytyki jej formy - niewyszukanej kompozycji, opartej na „trzech przebrzmiałych akordach" lub odwrotnie - w kontekście zachwytu nad prostotą i spójnością aranżacji (Томенчук 1990: 154). Oryginalne aranżacje piosenek radzieckiego barda, wykonywane za jego życia podczas nieoficjalnych koncertów, cechują się minimalizmem formy muzycznej (Drawicz 2007: 578-579). Minimalizm ten wpływa na instrumentarium, które $\mathrm{w}$ większości nagranych za życia poety i dystrybuowanych w samizdacie zapisach koncertów ograniczone zostało do siedmiostrunowej gitary akustycznej. Mimo, że w latach 70. zaczynają się pojawiać gramofonowe płyty z nagraniami utworów Wysockiego, w których występuje on z profesjonalnymi muzykami, a nawet całymi orkiestrami, to w świadomości masowego odbiorcy Wysocki jawi się jako bard z gitarą. Trafnie obrazuje to Olga Szylina, analizująca muzyczny aspekt jego twórczości:

Конечно, «классическим» вариантом исполнения песен Высоцкого общепризнанно считается авторское пение под гитару. Но существует множество записей, где Высоцкий поет в сопровождении нескольких гитар или даже целого оркестра. Высоцкий признавался, что его часто упрекают в том, что в песнях, записанных на пластинки, он изменил гитаре (Шилина 2008: 16).

Wysocki, wykonywał swoje utwory na siedmiostrunowej gitarze strojonej zazwyczaj w tonacji d-h-g-d-H-G-D lub obniżonej o cały ton lub półtora całego ton. Taki zabieg nadaje gitarze charakterystyczne brzmienie słyszalne zwłaszcza nagraniach pirackich nagraniach koncertowych. Strój ten jest typowy dla rosyjskiej piosenki autorskiej i pozwala na wykonywanie utworów w sposób silnie podkreślający basową linię i linię melodyczną. Większość utwór grana jest w tonacjach molowych - zazwyczaj c-mol lub a-mol z wykorzystaniem od trzech do siedmiu akordów, wydobywanych za pomocą palców, bez użycia plektronu. Umożliwia to wykorzystanie techniki grania linii basowej kciukiem przy jednoczesnym wygrywaniu pełnego akordu pozostałymi palcami na strunach wiolinowych. Dodatkową charakterystyczną cechą aranżacji Wysockiego jest niedostrojona gitara, która, wraz z jakością samizdatowych nagrań i często knajacką tematyką utworów, tworzy konglomerat wrażeń wzbudzających poczucie obcowania z muzyką nietypową, niszową i w jakiś sposób alternatywną. 
Stylistyka muzyczna utworów jest silnie związana z ich tematyką, warstwą liryczną. Jest to świadomy zabieg twórczy, o którym sam Wysocki wypowiada się następująco:

Я пишу стишки, придумывая на них мелодию. Это для того, чтобы больше усилить впечатление от стихов. Это такая манера - петь свои стихи, чтобы еще лучше донести их до публики. Я всегда пытаюсь придумывать такие мелодии, чтобы они не мешали слушать смысла. Они всегда простые и легкие для запоминания (Высоцкий 2000: 156157).

Anna Bednarczyk, badaczka twórczości barda, wskazuje, jakie tematy są najbardziej typowe dla Wysockiego, a więc: блатныл, poruszające tematykę okołokryminalną, ,sportowe”, satyryczno-obyczajowe, społeczno-polityczne, wojenne i liryczne (Bednarczyk 1995: 10). Dostosowanie aranżacji do tekstu szczególnie widoczne jest w tekstach o tematyce kryminalnej - Wysocki gra melodię w stylu блатной песни z szybkim rwanym rytmem, wywołującym u odbiorcy rosyjskiego określone konotacje. Kolejnym istotnym czynnikiem jest wariantywność tekstów i aranżacji muzycznych utworów Wysockiego. Piosenki Wysockiego nie nabierały nigdy ostatecznego skończonego kształtu, zmieniały się podczas występów na scenie zarówno w warstwie tekstowej, którą Wysocki modyfikował, grał nią z odbiorcą, dostosowywał do jego reakcji, wykorzystując warsztat nabyty podczas pracy w teatrze, jak i w warstwie muzycznej, w której zmianie ulegała tonacja, tempo i metrum. Zbiór wyżej omówionych cech tworzy kompilację formalnych wyróżników twórczości Wysockiego, które są oczywiste dla odbiorców mających możliwość obcowania $\mathrm{z}$ dziełami barda $\mathrm{w}$ oryginale.

Maleńczuk w swoich tłumaczeniach Wysockiego zawartych na albumie Wysocki Maleńczuka decyduje się na tzw. uprowadzenia komunikatu wyjściowego i przepuszczenie go przez filtr własnych metod autorskich (Bryzek 2020: 476). Czyni to zarówno w warstwie tekstowej, jak i muzycznej. Aranżacje muzyczne wszystkich tłumaczeń, które Maleńczuk zawarł na płycie Wysocki Maleńczuka, utrzymane są w stylistyce dalekiej od stylu typowego dla utworów Wysockiego. Przede wszystkim - poszerzone zostało instrumentarium - pojawia się gitara elektryczna (strojona w standardowym stroju E-A-D-G-H-E), perkusja, gitara basowa, mandolina, bandżo oraz syntezatory. Opracowanie przekładu w formie kompilacji utworów na albumie studyjnym, pozbawia odbiorcę samizdatowej jakości oryginałów, co stanowiło część jego kodu estetycznego (Barańczak 1983: 7). Z tego samego powodu zanika element wariantywności aranżacji i tekstów. Krakowski muzyk decyduje się na aranżacje 
utrzymane w różnych stylach muzycznych, grając konwencjami muzycznymi od country-grass, przez blues po thrash metal. Warto też podkreślić, że aranżacje muzyczne korespondują z tekstem, tak jak ma to miejsce w oryginale, choć na innych poziomach stylistycznych. Można tu więc mówić o pewnej formie adekwatności aranżacji. Jako przykład można przytoczyć utwór Czerwone, zielone, który w oryginalnych aranżacjach Wysockiego utrzymany jest w stylistyce блатной песни, zaś na płycie Maleńczuka został nagrany w dynamicznej bluegrassowej aranżacji, która choć odległa od блатной песни, posiada tak samo wyraźne i dynamiczne metrum, co może wzbudzać skojarzenia $\mathrm{z}$ oryginałem. Podobnie rzecz ma się z thumaczeniem Песни о сентиментальном боксере - zostało ono nagrane w stylistyce muzyki punk-rock, co również można traktować jako odniesienie do tekstu będącego opisem walki bokserskiej.

Zjawisko reorganizacji warstwy brzmieniowej utworów muzycznych nie jest badaczom przekładu obce. Opisuje je Anna Bednarczyk, podkreślając, korzyści płynące z tej strategii:

Sposób aranżacji i wykonanie przekładu może wynikać z osadzenia thumacza w konkretnym środowisku kulturowym lub z wyznaczenia przez niego celu, który winno spełnić dane tłumaczenie (i wykonanie). Ciekawe na przykład, że w przypadku piosenki zatarcie elementów kultury źródłowej, podobnie jak wprowadzenie elementów kultury docelowej, często sprzyja popularyzacji danego utworu w innej kulturze. Dotyczy to obu tkanek piosenki - słownej i muzycznej (Bednarczyk 2008: 91-92).

Refleksję Bednarczyk zdają się potwierdzać słowa krytyków muzycznych. Mirosław Pęczak, w recenzji dla tygodnika Polityka, nie tylko akceptuje strategię Maleńczuka, ale wręcz ją chwali:

Starzy fani Włodzimierza Wysockiego pewnie się obrażą. Wszak Maleńczuk używa ich idola bezczelnie po swojemu. Wysocki zdaje się tu raczej pretekstem niż celem. Żadna z prezentowanych na płycie piosenek nie przypomina oryginału. Ale, wbrew temu, co mogą pomyśleć obrażalscy, na tym właśnie Maleńczuk wygrywa. Bez czołobitności, za to z autorskim pomysłem pokazuje, jak można dziś przywoływać ducha rosyjskiego śpiewającego poety (Pęczak 2011: 63).

Szereg podjętych przez tłumacza i jednoczesnego aranżera decyzji w kwestii aranżacji utworów ma swój wpływ na recepcję. Słuchacze zaznajomieni z twórczością barda nie będą mieli problemów, żeby przebić się przez filtr autorskiej poetyki i stylu muzycznego Maleńczuka. Natomiast osoby mające nadzieję na wierny transfer zarówno treści, jak i formy utworów Wysockiego, mogą zderzyć się z poczuciem obcości 
zarówno tekstów, jak i muzyki. Już sam tytuł płyty Wysocki Maleńczuka sugeruje bliską relację na linii autor - thumacz oraz przyjęty przez tłumacza cel. Maleńczuk, nawet jeśli stawia sobie za cel przybliżenie twórczości Wysockiego, to mocno tę twórczość filtruje i adaptuje do swoich potrzeb. To z kolei niewątpliwie wpływa na odbiór całości albumu.

\section{Summary}

The aim of the article was to analyze the influence of musical arrangement on the reception of translations. The music album Wysocki Maleńczuka was used as an exemplification material, which is also the source of the newest Polish translations of Vysotsky's songs. The work analyzes the rearrangement of songs and its impact on the reception of the album

\section{Literatura}

Barańczak, A. Stowo w piosence - poetyka wspótczesnej piosenki estradowej. Wrocław: Wydawnictwo PAN, 1983.

Bednarczyk, A. W poszukiwainu dominanty translatorskiej. Warszawa: Wydawnictwo Naukowe PWN, 2008.

Bednarczyk, A. Wybory translatorskie. Modyfikacje tekstu literackiego w przektadzie i kontekst asocjacyjny. Łódź: Wydawnictwo Uniwersytetu Łódzkiego, 2008.

Bednarczyk, A. Wysocki po polsku. Łódź: Wydawnictwo UŁ, 1995.

de Beaugrande, R., Dressler, W. Wstęp do lingwistyki tekstu. Tłum. Szwedek, A. Warszawa: PWN, 1990.

Drawicz, A. Władimir Wysocki. In: Drawicz, A. (ed.) Historia literatury rosyjskiej XX wieku. Warszawa: Wydawnictwo Naukowe PWN, 2007, s. 578-579.

Habela, J. Stowniczek muzyczny. Warszawa: PWM 1968.

Hejwowski, K. Kognitywno-komunikacyjna teoria przektadu. Warszawa: Wydawnictwo Naukowe PWN, 2004.

Lewicki, R. Zagadnienia lingwistyki przektadu. Lublin: Wydawnictwo Uniwersytetu Marii Skłodowskiej-Curie, 2017.

Pęczak, M. Jak Wysocki. Polityka. 19. 2011 (2806), s. 63.

Sawala, K. Maciej Maleńczuk. In: Jakubowski, M., Szalbierz, M. (eds.) Encyklopedia Muzyki Popularnej - Blues w Polsce. Poznań: Atena, 1997, s. 135-136. 
Toury, G. Contrastive Linguistic and Translation Studies. In: Kühlwein, W., Thome, G., Wills, W. (eds.) Kontrastive Linguistik und Übersetzungwissenschaft. München, 1981, s. 253.

Брызек, Ш. Высоцкий Маленьчука. Сколько Маленьчука в переводах песен Высоцкого. In: Mizerová, S., Plesník, L. (eds.) SLAVICA IUVENUM XXI - Sborník př́spěvkĩ z mezinárodní vědecké konference Slavica iuvenum 2020. Ostrava: Ostravská Univerzita, 2020, s. 473-482.

Высоцкий, В. Монолог со сиены. Москва: АСТ, Фолио, 2000.

Томенчук, Л. О музыкальных особенностях песен В.С. Выссоикого. In: Андреев, Ю.А., Мущенко, Е. (ред.) В.С. Высоикий: исследования и материальл. Воронеж: Издательство Воронеж, 1990, с. 154.

Шилина, О. Владимир Высочкий и музыка «Я изучил все ноты от и до ...». СанктПетербург: Композитор, 2008. 


\section{O PRZEKŁADZIE OPISÓW ILUSTRACJI W CYKLU „BRUDERSZAFT ZE ŚMIERCIĄ” BORISA AKUNINA}

\section{On the Translation of the Descriptions of the Illustrations in the Series “Bruderschaft with Death" by Boris Akunin}

Keywords: Boris Akunin, translation, descriptions, illustrations, series, Bruderschaft with Death, Russian literature

Contact: Uniwersytet Śląskiw Katowicach; lukasz.geborek22@gmail.com

Grigorij Szałwowicz Czchartiszwili (ros. Григорий Шалвович Чхартишвили) to prawdziwe nazwisko pochodzącego z Gruzji rosyjskiego pisarza, który szerokiej publiczności zarówno w Rosji, Polsce jak i innych krajach, znany jest przede wszystkim jako Boris Akunin. Jest to jeden z jego wielu pseudonimów, którego używa, wydając swoje powieści. Do pozostałych należą: Anna Borisowa (książka „Vremena goda"1 wydana także w polskim tłumaczeniu jako „Pory roku” przez wydawnictwo Znak Literanova) czy Anatolij Brusnikin (Lubocha-Kruglik, Małysa 2004: 91-93) (książki: «Девятый Спас» сzy też «Герой иного времени»). Grigorij Czchartiszwili jako Boris Akunin jest autorem kryminałów, a do najpopularniejszych z nich należą:

- cykl o Eraście Fandorinie (ros. «Новый детективъ»);

- cykl o mniszce Pelagii (ros. «Провинціальный детективъ»);

- analizowany w niniejszym artykule cykl „Bruderszaft ze śmiercią” (ros. «Смерть на брудершафт»).

Wyjściowym terminem dla przeprowadzenia analizy jest pojęcie 'ilustracja', pochodzące od łacińskiego wyrażenia 'illustratio', które oznacza 'oświetlenie', 'wizualizacja'. W ślad za Janiną Wiercińską uznaję, że:

„Ilustracja (...) to utwór rysunkowy, malarski, graficzny, a nawet fotograficzny, umieszczony w rękopisie, lub jakimkolwiek druku. Zadaniem jej jest objaśnianie, uzupełnianie, interpretowanie lub dopowiadanie tekstu; ewokowanie pewnych stanów uczuciowych, wzmagających działanie utworu. O ilustracji - w tym znaczeniu - można

\footnotetext{
${ }^{1}$ Oryginalny zapis z okładki książki, będący łacińską transliteracją z cyrylicy.
} 
mówić tylko i wyłącznie wówczas, gdy (...) temu tekstowi towarzyszy. Decyduje bowiem o tym funkcja, dla której została powołana do życia, funkcja w sposób zasadniczy uzależniona od słowa, od tekstu" (Wiercińska 1986: 37).

Ewa Rutkiewicz w artykule „Wokół problemów ilustracji” przytacza klasyfikację funkcji, jakie mogą pełnić ilustracje w różnego rodzaju tekstach. Należą do nich (Rutkiewicz 2010):

- funkcja zdobnicza ilustracji jako estetycznego uzupełnienia książki/tekstu;

- funkcja interpretacyjna, czyli taka, która wyjaśnia jakąś treść (funkcja ta używana jest przede wszystkim w słownikach, encyklopediach, skryptach naukowych czy podręcznikach);

- ilustracja ekspresywna (pojawiająca się w utworach fabularnych);

- ilustracja dokumentalna (w której skład wchodzą różnego rodzaju ikonografie);

- ilustracja autoteliczna, która to zastępuje tekst wobec jego niewystarczalności. Ewa Rutkiewicz jako przykład podaje obrazy świata, tzw. „nieskończonych małości” (Rutkiewicz 2010).

Ilustracje, które pojawiają się zarówno na okładce, jak i wewnątrz książki wchodzą w skład paratekstów. Termin paratekst wprowadził w 1987 roku do dyskursu naukowego Gerard Genette, pochodzący z Francji teoretyk literatury (Лиходкина 2018: 110). Pojęcie to dość dokładnie wyjaśnia autorka artykułu pt. «Заглавие как важный компонент паратекста и специфика его перевода» Irina Lichodkina:

«паратекст - это то, что позволяет тексту превратиться в книгу и в качестве таковой предложить его читателю и, в более общем смысле, широкому кругу лиц. Это не ограничение или закрытая граница, а порог - или слово, которое Борхес применил по отношению к предисловию - “вестибюль”, предлагающий каждому войти или уйти прочь» (Лиходкина 2018: 110).

Iwona Loewe w książce „Gatunki paratekstowe w komunikacji medialnej” zwraca uwagę na to, że sam Gennette określa paratekst terminem 'akompaniament' ze względu na fakt, że żaden tekst nie może się obejść bez niego: począwszy od informacji na okładce - nazwiska autora czy tytułu książki, poprzez nazwy rozdziałów, dedykacji, a kończąc na wykresach, tabelach, indeksach czy innych zestawieniach (Loewe 2007: 12-13), które uzupełniają całość, zawartą między przednią i tylną okładką.

Tłumaczenie cyklu Borisa Akunina pod tytułem „Bruderszaft ze Śmiercią”, który został wydany w Polsce nakładem wydawnictwa „Replika” zawdzięczamy Piotrowi 
Fastowi. Składa się na niego dziesięć filmów (w ten sposób autor określa każdą z powieści) umieszczonych w pięciu książkach - po dwa 'filmy' w każdej z nich.

Ilustracje, które widzimy w powieściach cyklu „Bruderszaft ze Śmiercią”, można podzielić na trzy podstawowe grupy:

- ilustracje na okładce i stronie tytułowej powieści (swoim wyglądem przypominają one plakaty filmowe). Przykład może stanowić strona tytułowa powieści «Мука разбитого сердца» (pol. „Cierpienie złamanego serca”), na której w wersji oryginalnej widzimy słowa pisane zgodnie z zasadami ortograficznymi sprzed reformy języka rosyjskiego z 1917-1918 roku.

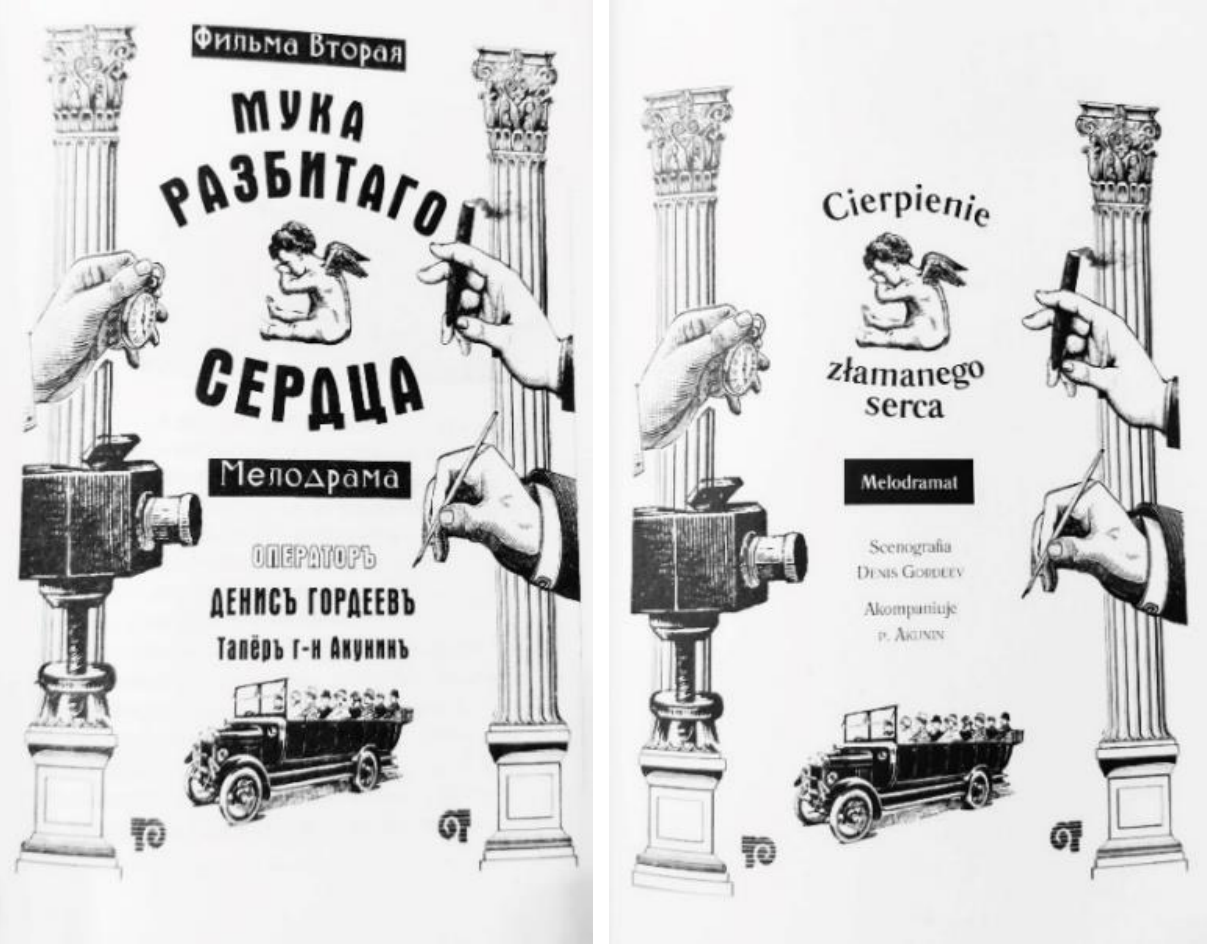

- ilustracje, odzwierciedlające określony fragment fabuły powieści. Należy zaznaczyć, że pod ilustracjami zawsze znajdują się cytaty w postaci fragmentów pieśni czy wierszy (w tym znanych nie tylko w Rosji, ale i na świecie autorów, do których należą: Afanasij Fiet, Aleksandr Siergieewicz Puszkin czy Johann Wolfgang Goethe). Cytaty te wpisują się swoją treścią zarówno do fragmentu powieści, jak i opisywanej ilustracji. Ponadto, w zależności od potrzeb, na przykład w przypadku nawiązania do muzycznego gatunku filmu, jak w powieści „Dzieci Księżyca” (ros. Дети Луны), której gatunek został określony jako etiuda dekadencka (ros. декадентский этюд), dodatkowo pojawia się nazwisko 
kompozytora. Jego muzyka powinna towarzyszyć określonemu fragmentowi filmu (niniejszy aspekt zostanie poruszony w dalszej części artykułu).

- ilustracje (są to przede wszystkim fotografie), umieszczone na końcu każdego filmu w postaci kroniki zdjęciowej. Odzwierciedla ona wydarzenia, postaci lub ważne przedmioty $\mathrm{z}$ historii, które były wspomniane w powieści.

W artykule szczególna uwaga zostanie poświęcona opisom, pojawiającym się na końcu każdego filmu w kronice zdjęciowej. Należy podkreślić, że zarówno zdjęcia, jak i znajdujące się pod nimi opisy pełnią w książce funkcję informacyjną.

W przedstawionej poniżej klasyfikacji zostaną zestawione grupy opisów, w których tekst oryginału (język rosyjski) porównany będzie z przekładem na język polski:

- opisy miejsc: Здание Жандармского корпуса на Фурштатской (Акунин 2008: 365) - Budynek Korpusu Żandarmerii przy ulicy Frusztadzkiej (Akunin 2016: 321) lub Полевой аэродром (Акунин 2008: 157) - Lotnisko polowe (Akunin 2016: 157),

- nazwy urządzeń: вошебойка (Акунин 2011: 219) - urządzenie do likwidacji wszy (Akunin 2017: 345);

- określenia maszyn latających z okresu Pierwszej Wojny Światowej: «Илья Муромец» (Акунин 2008: 171) - Ilja Muromiec (Akunin 2016: 153), «Ньюпоры» (Акунин 2008: 174) - Nieuporty (Akunin 2016: 155), или «Таубе» (Акунин 2008: 174) - Taube (Akunin 2016: 155);

- określenia ludzi oraz ich działalności: Украинки в австро-венгерской армии (Акунин 2011: 220) - Ukrainki w armii austro-węgierskiej (Akunin 2017: 346), Русские прапорщики (Акунин 2011: 221) - Rosyjscy chorążowie (Akunin 2017: 347);

- przedstawione na fotografiach wydarzenia: Совещание главкомов (Акунин 2011: 211) - Odprawa naczelnych dowódców (Akunin 2017: 337), Богатыря выкатывают из ангара (Акунин 2008: 180) - Kolos wyjeżdża z hangaru (Akunin 2016: 161).

Opisy te nie stwarzają większych problemów w procesie ich przekładu na język polski, ponieważ każdy $\mathrm{z}$ analizowanych języków w swoim zasobie ma jednostki leksykalne odnośnie do tego, co zostało przedstawione na fotografiach. Przykład mogą stanowić nazwy zilustrowanych samolotów: «Ньюпоры» - Nieuporty czy «Таубе» Taube. 

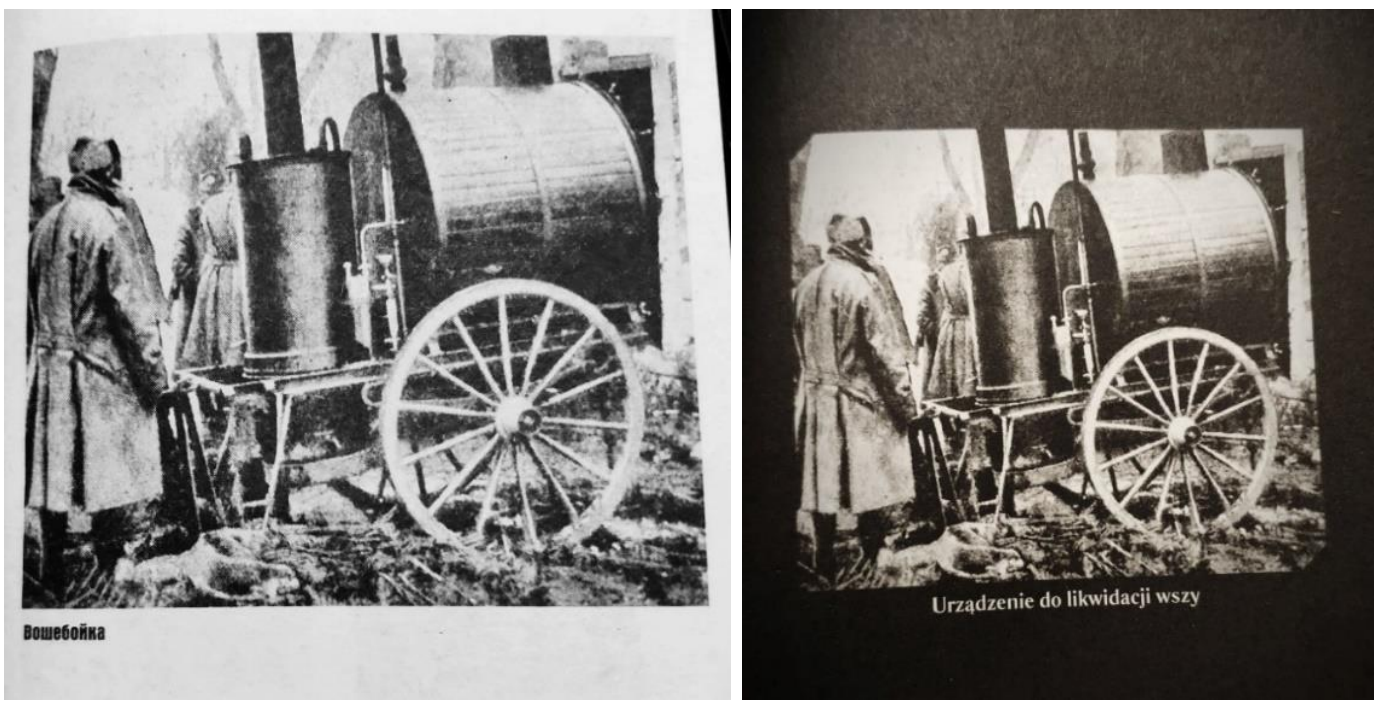

W przeciwnym razie tłumacz może zastosować ekwiwalent opisowy, co można zauważyć w przekładzie wyrazu «вошебойка» jako „urządzenie do likwidacji wszy”.

Szczególną uwagę należy jednak zwrócić na słowa realia, które są związane z kulturą rosyjską przez co zakorzenione przede wszystkim w rosyjskiej świadomości językowej. Wyjściowemu odbiorcy tekstu mogą one przekazać znacznie więcej informacji dodatkowych, niż odbiorcy przekładu.

Jako przykład może posłużyć fotografia i podpis samolotu, którego rosyjska nazwa brzmi «Илья Муромец»:
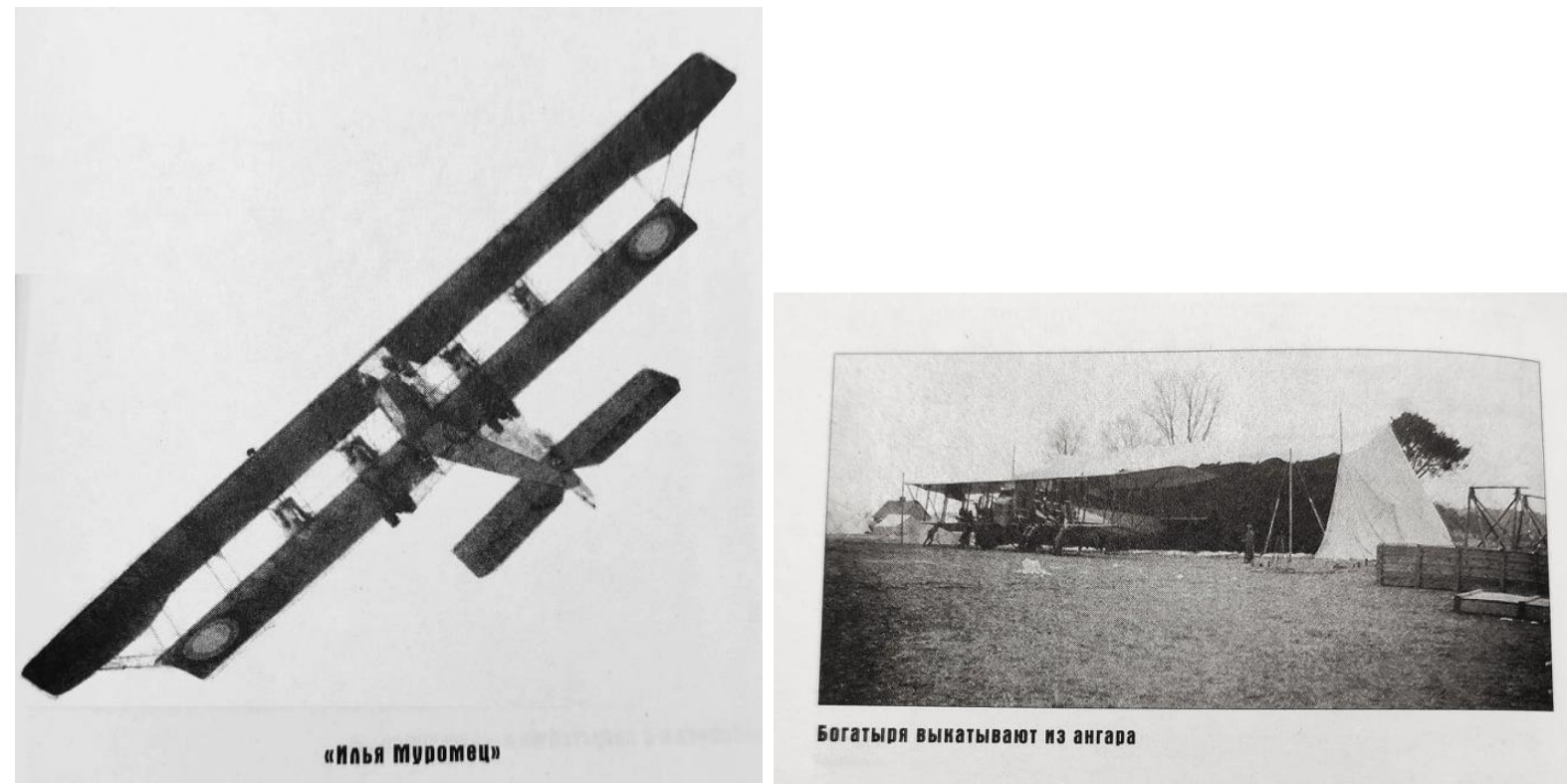

Богатыря выкатывают из ангара 
Fakt, że nazwa latającej maszyny „Ilja Muromiec” pochodzi od imienia i nazwiska jednego z bohaterów, związanych z epoką Rusi Kijowskiej, nie będzie czymś zadziwiającym. Jednak w dalszej części kroniki można przeczytać następujący opis do zdjęcia, na którym widnieje dokładnie ta sama maszyna: «Богатыря выкатывают из ангара» (iz.ru...), które zostało przetłumaczone w następujący sposób: „Kolos wyjeżdża $\mathrm{z}$ hangaru".

Docelowemu odbiorcy thumacz zaproponował ekwiwalent „kolos” jako odpowiednik nazwy dla przedmiotu/urządzenia ogromnych rozmiarów ( $w$ danym przypadku - samolotu). Jak już było zauważone, w rosyjskim wariancie został użyty leksem 'Богатырь', który w języku rosyjskim ma nie tylko znaczenie dosłowne, czyli ‘мускулистый человек' или 'силач' (slovarozhegova.ru...), (pol. 'siłacz' lub 'muskularny człowiek'). Dosyć często wyraz ten był używany także na określenie parowozów, fregat, krążowników z przełomu XIX oraz XX wieku (militera.lib.ru...). Odpowiada to także czasowi akcji powieści Borisa Akunina, która toczy się w okresie Pierwszej Wojny Światowej. Co więcej, 'богатырь', to też określenie bohatera ruskich bylin lub legend, który odznaczał się szczególnymi cechami: wielką siłą i odwagą (slovarozhegova.ru...). Przykładem takiego bohatera jest bez wątpienia Ilja Muromiec.

Podsumowując, Ilja Murimiec to ogromnych rozmiarów samolot, który $\mathrm{w}$ dalszym fragmencie tekstu wyjściowego został określony rzeczownikiem 'Богатырь'. Zostało to przełożone na język polski poprzez zamianę leksemu i użycie rzeczownika 'kolos', co w pewnym sensie odzwierciedla zamysł Borisa Akunina. Bez względu na fakt, że polski ekwiwalent 'kolos' swoim znaczeniem nie jest związany $\mathrm{z}$ bohaterem Ilją Muromcem, należy podkreślić, że język docelowy nie ma w zasobie słów określenia, które mogłoby $\mathrm{w}$ swoim wielowymiarowym znaczeniu połączyć wszystkie wspomniane powyżej konotacje - wyrażone jednym, rosyjskim wyrazem ‘богатырь'. W danym przypadku należy uznać decyzję translatorską za uzasadnioną i trafną.

W innym opisie - 'Совещание главкомов' - można odnaleźć interesujący leksem w dopełniaczu liczby mnogiej - 'главком', które jest skróconą formą rzeczownika 'главнокомандующий' (со na język polski tłumaczono jest jako 'główny/naczelny dowódca'). Takie skrócone wersje słów w języku rosyjskim pojawiają się dosyć często, jednak już w języku polskim są one rzadszym zjawiskiem. W związku z tym thumacz zmuszony był do użycia opisowego analogu wyrażenia w postaci 'naczelni dowódcy', które bez wątpienia należy uznać za najlepszy z możliwych ekwiwalentów tłumaczeniowych. 

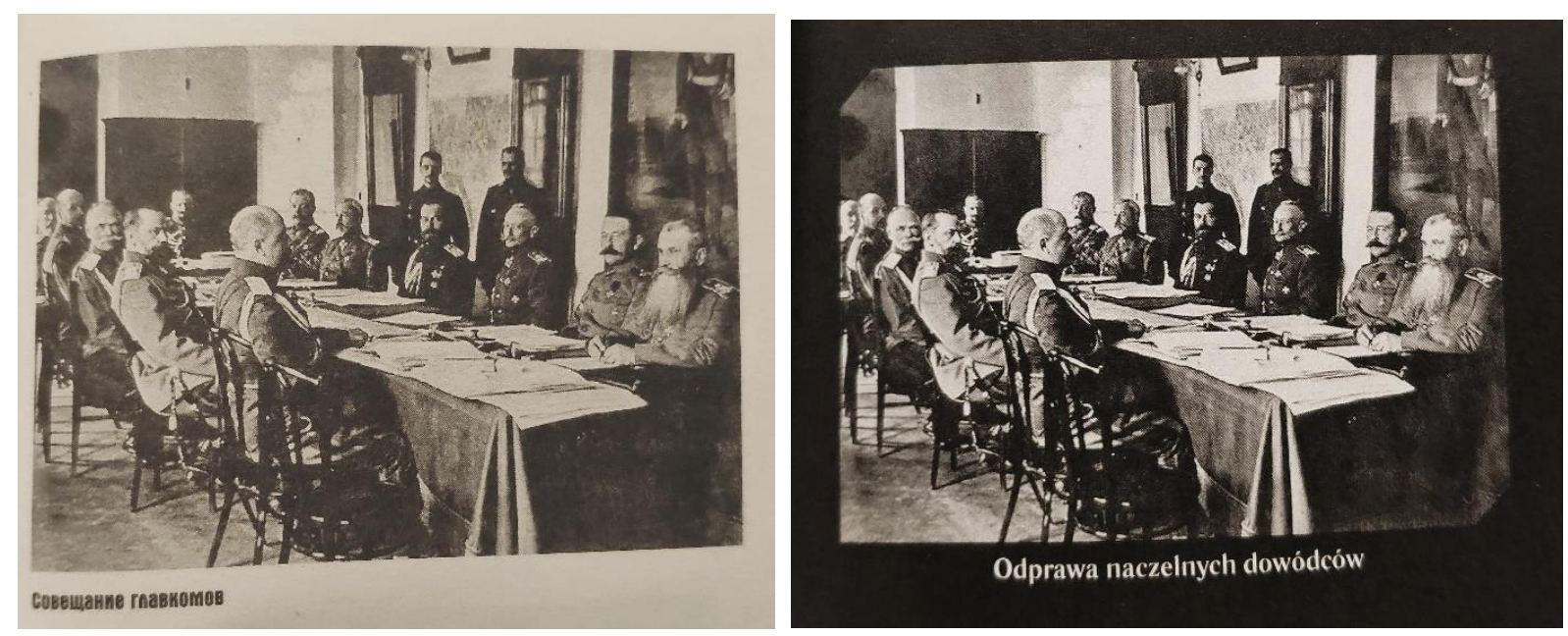

Kolejny element analizy stanowią opisy grafik, odzwierciedlających treść powieści. Aby skupić się na wszystkich elementach, pojawiających się w tego typu paratekstach, użyta zostanie grafika z treścią, które pochodzą z muzycznego gatunku „,etiuda dekadencka”, reprezentowanego przez powieść „Dzieci Księżyca”.

Przedstawiony poniżej fragment został zilustrowany na rysunkach:

«- Караул! На помощь!

Грабителей было не трое, а больше. Поодаль в темноте прятались по меньшей мере еще двое. Они растопырили руки, пытаясь схватить беглянку, но Люба увернулась и от одного, и от другого.

(...)

Не по зубам разбойникам оказался и человек-змея. Он изогнулся, обхватил усатого налетчика за голову и с резким выходом швырнул через себя. Тот смачно приложился о камни и в данейших событиях не участвовал» (Акунин 2011: 279-281).

,--Bandyci! Na pomoc!

Jak się okazało, napastników było więcej. Nieopodal w ciemności schowało się jeszcze przynajmniej dwóch. Rozłożyli ręce, próbując zatrzymać uciekinierkę, lecz Luba wymknęła się i jednemu, i drugiemu.

(...)

- Pomocy! Tu-uta-a-aj!

Rozbójnicy nie dali sobie także rady z człowiekiem-wężem. Wygiął się, chwycił wąsatego napastnika za głowę i z głośnym stęknięciem przerzucił go przez siebie" (Akunin 2016: 246). 

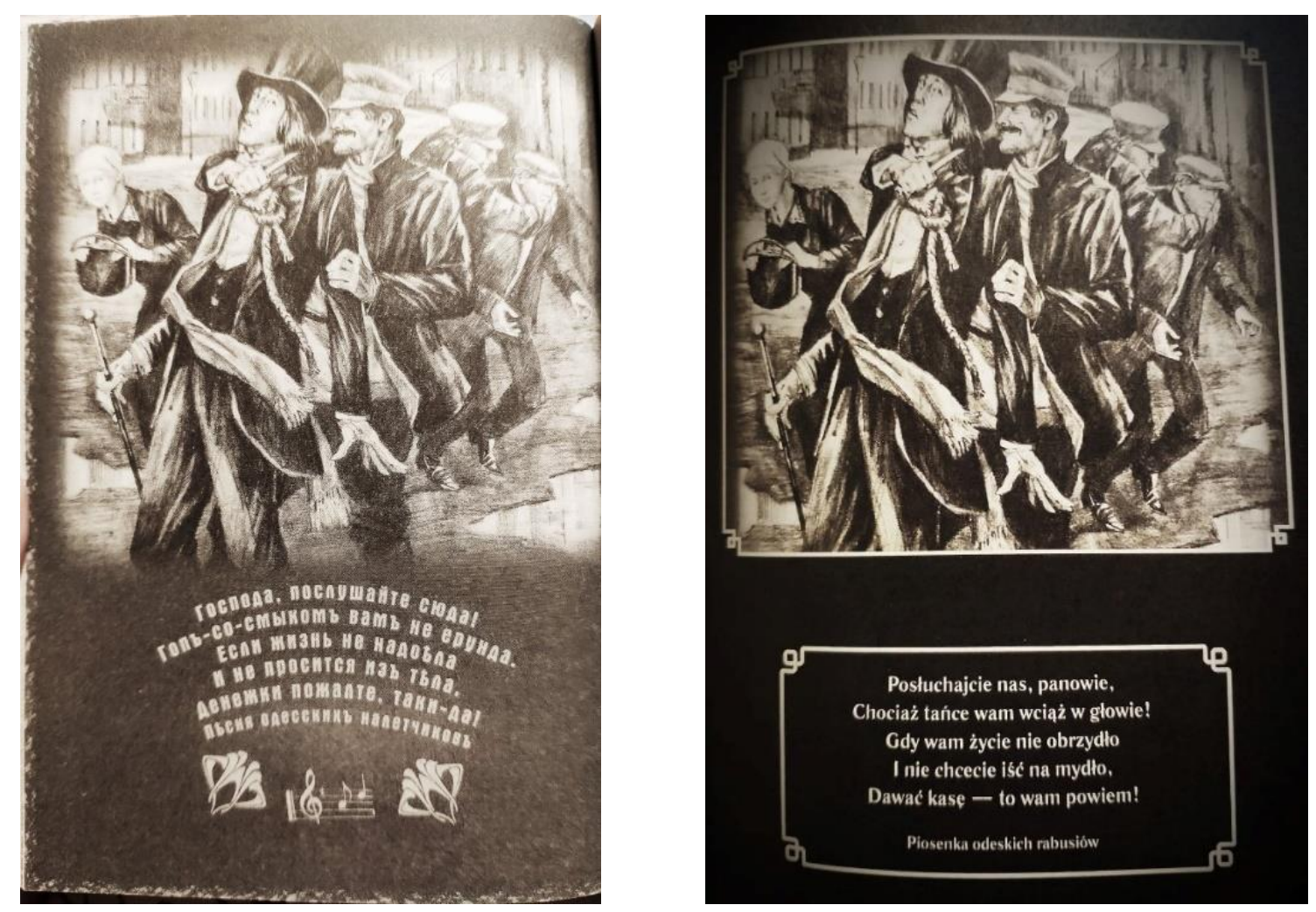

W przypadku opisu ilustracji zauważamy, że utwór w przekładzie nazwany jest „Piosenką odeskich rabusiów”, natomiast w tekście oryginału jego tytuł brzmi «Пњсня одесскихъ налетчиковъ».

Stylizacja języka rosyjskiego poprzez użycie litery jać oraz jera tylnego na końcu wyrazów po twardej spółgłosce nie została zachowana w języku docelowym zarówno w nazwie utworu jak i samej jego treści, ze względu na brak takiego czy podobnego zjawiska w języku polskim.

Najważniejszym może okazać się jednak fakt, że wydźwięk cytatu jest identyczny poprzez zachowanie parzystych (sąsiadujących) rymów AABB, bez względu na to, że w rosyjskim oryginale wersy 1, 3, 4 mają po osiem sylab, 2 i 5 - po dziewięć, kiedy w polskim tłumaczeniu każdy wers ma równo po osiem sylab. Rymy «сюда - едунда» przekazane zostały ekwiwalentem ,,panowie - głowie”, а «надођла - тела» poprzez parę tłumaczeniową „obrzydło - mydło”.

Odnośnie do graficznego przedstawienia fragmentu utworu, można zauważyć, że polskie tłumaczenie przedstawione jest w minimalistycznie ozdobionej ramce, natomiast tekst rosyjski tworzy łuk, pod którym znajdują się trzy obrazki. Środkowa grafika z kluczem wiolinowym i nutami kolejny raz wskazuje na muzyczny charakter 
utworu, czego również zabrakło w polskim wydaniu powieści. Nie wpływa to jednak w znaczącym stopniu na odbiór całości przez docelowego odbiorcę przekładu.

\section{Zakończenie}

Przedstawiona powyżej analiza stanowi próbę wprowadzenia do dalszych badań poświęconych analizie przekładu na język polski opisów ilustracji w cyklu „Bruderszaft ze Śmiercią" rosyjskiego pisarza Borisa Akunina. W trakcie przeprowadzonego badania zostało zauważone, że przekład wspomnianych opisów ilustracji w funkcji informacyjnej w większości przypadków nie powoduje problemów translacyjnych. Wyjątkiem mogą być słowa realia, które dysponują wielością znaczeń czy bagażem skojarzeń i konotacji, często czytelnych wyłącznie dla odbiorcy tekstu wyjściowego, natomiast dokładny i pełny przekaz na inne języki jest utrudniony lub wręcz niemożliwy. Należy jednak podkreślić, że tłumaczenie na język polski dokonane przez Piotra Fasta można uznać za w pełni udane, ponieważ polskiemu czytelnikowi nie tylko oferowana jest wystarczająca ilość informacji dla zrozumienia tekstu przekładu (w porównaniu z oryginałem), ale także w warstwie artystycznej nie dają się zauważyć straty wartościowe (o czym świadczy m.in. przekład fragmentu „Piosenki odeskich rabusiów").

\section{Summary}

The following paper constitutes an attempt to present the problem of illustration classification which appear in the film-stories of the cycle titled „Bruderschaft with death" by the Russian writer Boris Akunin. Author presented a comparative analysis on the basis of two languages - Russian (the language of the original) and Polish (the language of translation). In the stories the illustrations play an important role but the descriptions which appear together with them play different function what depends on the needs of their usage.

\section{Literatura}

Akunin, B. Cykl „Bruderszaft ze Śmiercia”. Dziwny człowiek. Grzmijcie, fanfary zwycięstwa! Zakrzewo: Replika, 2017.

Akunin, B. Cykl „Bruderszaft ze Śmiercią”. Latający Słoń. Dzieci Księżyca. Zakrzewo: Replika, 2016. 
Loewe, I. Gatunki paratekstowe w komunikacji medialnej. Katowice: Wydawnictwo Uniwersytetu Śląskiego, 2007.

Lubocha-Kruglik, J., Małysa, O. Potyczki z przekładem, czyli Akunin po polsku. In: Fast, P. (ed.) Kultura popularna a przeklad. Katowice: Wydawnictwo „Śląsk”, 2004, s. 91-102.

Rutkiewicz, E. Wokół problemów ilustracji. Biuletyn EBIB. 2010 (9/118), dokument elektroniczny.

Wiercińska, J. Sztuka i książka. Warszawa: Państwowe Wydawnictwo Naukowe, 1986.

Акунин, Б. Роман-кино. Смерть на брудершафт. Фильма третья, фильма четвертая. Летающий слон. Дети Луны. Москва: АСТ Москва, 2008.

Акунин, Б. Роман-кино. Смерть на брудершафт. Фильма шестая. Гром победы, раздавайся! Москва: АСТ Астрель, 2011.

Лиходкина, И.А. Заглавие как важный компонент паратекста и специфика его перевода. Филологические науки. Вопросы теории и практики. 2018 (80/2), c. $110-113$.

Режим доступа: https://iz.ru/news/660242 (2021-04-20).

Режим доступа: http://militera.lib.ru/h/shirokorad_ab2/04.html (2021-04-20).

Режим доступа: https://slovarozhegova.ru/word.php?wordid=1889 (2021-04-20). 


\title{
К ВОПРОСУ О ПЕРЕВОДЕ НАЗВАНИЙ КВЕСТОВ В КОМПЬЮТЕРНЫХ ИГРАХ (НА ПРИМЕРЕ ИГРЫ «DRAGON AGE: INQUISITION»)
}

\author{
On the Translation of Quest Names in Computer Games \\ (on the Example of the Game "Dragon Age: Inquisition")
}

Keywords: translation, computer games, language localisation, fantasy, Dragon Age Contact: Uniwersytet Śląskiw Katowicach; ziel97@tlen.pl

«Квест» (англ. quest) является термином из области компьютерных игр. С его помощью называем задания в мире игры, которые должен выполнять персонаж игрока с целью получить определенную награду. Квесты составляют один из самых важных компонентов компьютерной ролевой игры; на их основе строится весь игровой процесс (так наз. геймплей). Можно их разделить на главные, связанные с основной сюжетной линией игры, завершение которых требуется для ее окончания, и побочные, не оказывающие значительного влияния на ход игры. Каждый квест имеет отдельное название, которое обычно каким-то образом намекает на его суть или содержание; особенно в компьютерных ролевых играх (англ. RPG) замечается такая тенденция. В настоящей статье мы сосредоточимся именно на этого типа названиях квестов и рассмотрим их русские и польские соответствия. Материал для анализа был почерпнут из игры «Dragon Age: Inquisition», являющейся довольно популярным представителем жанра игр RPG.

«Dragon Age: Inquisition» - это компьютерная ролевая игра, разработанная канадской студией BioWare, премьера которой произошла в 2014 году. Она является продолжением двух предыдущих игр серии: «Dragon Age: Origins» и «Dragon Age II». Персонаж, в которого воплощается игрок - это лидер заглавной Инквизиции, т.е. организации, созданной для разрешения споров на земле Тедаса (континента в мире игры), а также преодоления демонических сил, угрожающих человечеству. Игра, аналогично предыдущим частям серии, относится к жанру фэнтези; ее сюжет сильно сфокусирован на мотиве борьбы со злом, а представленный мир полон магии. Геймплей игры построен на основе 
открытого мира: игрок имеет возможность путешествовать по различным землям на территории Тедаса и завершать многие, связанные с ними задания. Учитывая главные и побочные квесты, квесты спутников, задания ставки командования, стол заявок, коллекции (в том числе те, принадлежащие к загружаемому контенту), «Dragon Age: Inquisition» включает в себя почти 800 квестов. Мы проанализируем лишь некоторые примеры, являющиеся, на наш взгляд, особо интересными.

Однако, прежде чем перейти к предмету настоящей статьи, следует уделить некоторое внимание вопросу языковой локализации, чтобы подчеркнуть, какое значение имеет соответствующий перевод в компьютерных играх. Суть локализации игр - сохранить игровой процесс для целевых игроков таким образом, как будто игра оригинально была разработана на их языке, и доставить удовольствие, эквивалентное тому, которое испытывают игроки оригинальной версии (Mangiron, O’Hagan 2006: 14-15). Элементы геймплея, подвергающиеся переводу (такие как интерактивные диалоги персонажей, кат-сцены, т.е. внутриигровое видео, содержание журнала квестов, содержимое инвентаря, древо навыков, а также названия предметов или других элементов, связанных с взаимодействием персонажа с окружающей средой в игровом мире и т.д. $\left.{ }^{1}\right)$ чаще всего выполняют информативную (но не только) функцию. Они позволяют расширить знания игрока об игровом контенте, но и подчеркнуть созданный авторами внутриигровой сеттинг (т.е. уникальную вселенную игры). Стоит здесь упомянуть о явлении иммерсии. Иммерсия представляет собой ощущение погружения в представленный в игре мир. Она составляет довольно важный аспект игрового процесса, поскольку самое главное в приеме игры - это переживание сюжета таким образом, чтобы игрок «слился» со своим персонажем и чувствовал себя участником происходящих на экране событий (Mäyrä 2008: 108-110). Не подлежит сомнению утверждение, что соответствующая локализация игры способствует также явлению иммерсии, т.е. усиливает потенциальный прием игры.

Осознавая все существенные для нас теоретические моменты, мы перейдем к практической части статьи. Сравним оригинальную английскую версию названий квестов из игры «Dragon Age: Inquisition» с их переводами на русский и польский языки. Данные названия мы классифицировали по их структуре.

\footnotetext{
${ }^{1}$ О специфике перевода разных элементов в компьютерных играх см. больше: Drab 2017: 103-105. 


\section{Группа I}

В первую группу включаются названия, структура которых основывается на предлоге of, передающем значение русского и польского родительного падежа:

The Wrath of Heaven - Небесный гнев; Gniew niebios;

The Loss of a Friend - Погибший друг; Strata przyjaciela;

The Spoils of Desecration - Кошунство и святотатство; Zdobycze profanacji;

Memories of the Grey - B память о Cmражах; Szare wspomnienia.

В случае первых двух примеров, замечается тенденция русского переводчика строить названия на основе прилагательного в качестве определения существительного (Небесный гнев, Погибший друг). В третьем примере произошла модификация: употребляются здесь два синонимических существительных (Кощунство и святотатство). Польский переводчик, в свою очередь, принял решение передать эти названия с помощью несогласованного определения (Gniew niebios, Strata przyjaciela, Zdobycze profanacji). Интересным кажется перевод последнего примера на оба языка. Grey относится к полному названию древнего ордена - Grey Wardens (рус. Cерые Cтражи, польск. Szara Straż). Данный квест состоит в обнаружении артефактов в старых лагерях и форпостах Стражей. Русский переводчик решил здесь уточнить содержащийся намек, употребляя название $B$ память о Стражах. Польский же - вместо аналогичной оригиналу форме несогласованного определения применил присущее членам этого ордена прилагательное szary в качестве определения признанного эквивалента английского memories, т.e. wspomnienia.

The Heart of the Still Ruins - Сердие Безветренных руин; W sercu

Nieruchomych Ruin;

The Corruption of Sahrnia - Заражение Cарнии; Zepsucie w Sahrni;

The Vault of Valammar-Валаммарское хранилище; Skarbiec

$w$ Valammarze.

По всей видимости, и в русской версии отмечаем перевод анализируемой нами структуры с использованием несогласованного определения (Сердие Безветренных руин, Заражение Сарнии), хотя в случае последнего примера снова появляется прилагательное как определение существительного (Валаммарское хранилище). Касательно польского перевода, - учитывая, что все вышеприведенные примеры содержат название какой-то локализации, - добавлен здесь предлог w (W sercu Nieruchomych Ruin, Zepsucie w Sahrni, Skarbiec $w$ Valammarze). 


\section{Группа II}

Одной из составляющих названий второй группы является притяжательная форма существительного:

The Magister's Birthright - Право первородства; Rodowód magistra; My Lover's Phylactery - Амулет любимой; Filakterium mojej kochanki; A Lover's Promise - Обещание влюбленного; Obietnica kochanki; The Knights' Tomb - Рыщарская гробница; Grobowiec rycerza; A Father's Guidance - Отиовские указания; Wskazówki ojca; A Father's Name - Отиовское имя; Nazwisko ojca; Mата's Ring - Мамино кольцо; Pierścień mamy.

Относительно этой структуры замечаем отчетливые тенденции. В польской версии, без исключений, используются несогласованные определения. На русский язык они переводятся либо так же, как на польский (Право первородства, Амулет любимой, Обещание влюбленного), либо с помощью прилагательного (Рыцарская гробница, Отиовские указания, Отцовское имя, Мамино кольио). Кроме того, мы хотим уделить дополнительное внимание трем первым примерам. Во вселенной Dragon Age титул Magister (рус. магистр, польск. magister) относится к магам-членам Сената одной из Империй Тедаса. В русском переводе квеста The Magister's Birthright этот элемент опущен. В польском он присутствует в сочетании с лексемой rodowód, обладающей сходным, но не идентичным значением, что лексема birthright. По поводу названий, компонентом которых является слово lover, следует подчеркнуть, что, в связи с присутствием категории рода в русском и польском языках, пришлось здесь определить, касается ли оно женщины либо мужчины. Сомнения вызывает пример A Lover's Promise, в котором пол различается на языках перевода. Ознакомившись с содержанием квеста (юноша в письме предлагает любимой встретиться, чтобы сбежать вместе), становится ясным, что в этом случае русский вариант оказался правильным.

\section{Группа III}

К третьей группе принадлежат названия, компонентом которых выступает имя прилагательное в качестве определения существительного:

A Dalish Perspective - Взгляд долийщев; Dalijski punkt widzenia;

Tough Love - Любовь по-кунарийски; Madra mitość;

Rocky Rescue - Спасение среди камней; Ratunek wśród skat;

Avvar Allies - Aввары-союзники; Awarscy sojusznicy;

Strange Bedfellows - Необычный дуэт; Niecodzienni towarzysze;

Guily Pleasures - Тайное увлечение; Wstydliwa lektura. 
Как видим, в русской версии названия, построенные аналогично оригиналу на основе прилагательное + существительное, появляются лишь в двух выбранных нами примерах (Необычный дуэт, Тайное увлечение). Остальные переведены описательно (Взгляд долийцев, Спасение среди камней) или как сложные существительные (Аввары-союзники). В польской версии замечаем тенденцию переводить аналогично подлиннику, т.е. с помощью прилагательного и существительного, но появился и описательный перевод (Ratunek wśród skat). Стоит обратить внимание на модификацию названия квеста Tough Love, связанного с романом со спутником - представителем расы Кунари. Русский переводчик уточнил здесь содержание задания (Любовь по-кунарийски), польский - использовал другое, чем в оригинале прилагательное (Mądra miłość). Интересным является также польский перевод последнего примера. Данный квест касается одной из спутниц, которая втайне читает любовные романы. Польский признанный эквивалент фразы guilty pleasure - это «grzeszna przyjemność». Однако, слово grzeszny могло бы вызывать здесь нежелательные религиозные коннотации и, вероятно, поэтому переводчик решил отнестись к элементу сюжета.

A Superior Tower - Bсе выше, выще и выше; Lepsza wież;

A Greener Garden - Oü, в моем садочке; Zieleńszy ogród.

Вышеприведенные квесты касаются улучшения крепости главного героя и именно поэтому в их названиях появились прилагательные в сравнительной степени. На польский язык они были переведены буквально. Русский переводчик проявил более творческий подход к этому вопросу.

Noble Deeds, Noble Heart - Благородство в сердие и делах;

Szlachetne czyny i serce;

Wicked Eyes and Wicked Hearts - Злье глаза и злье сердиа; Oczy i serca przebiegte;

Another Side, Another Story - Другая история; Inna strona, inna historia.

Данные названия построены на основе повторения прилагательного по отношению к разным существительным. В переводах эта особая структура отображена лишь в случае двух примеров: Злье глаза и злье сердия и Inna strona, inna historia. Остальные переводы опираются либо на опущение повторяемого элемента (Szlachetne czyny i serce, Oczy i serca przebiegłe) или фрагмента названия (Другая история), либо строятся совсем по-другому (Благородство в сердие и делах). 


\section{Группа IV}

В четвертую группу входят названия, содержащие в оригинале сказуемое:

Here Lies the Abbys - Там лежит Бездна; Oto jest otchtan';

The Threat Remains - Опасность не миновала; Nieustajace zagrożenie;

This Water Tastes Funny - Забавный вкус у этой воды; Ta woda dziwnie smakuje;

These Demons Are Clever - Хитрые демоны; Sprytne sa te demony;

It Remains to be Seen - Время покажет; Dostrzec niewidoczne;

They Came From Somewhere Else - Все было не так; Przybyli skadinad;

They Shall Not Pass - Bpaz не nройdem!; Ani kroku dalej;

Not Everyone's Free - Невольники вольных; Nie każdy jest wolny.

Сравнивая переводы, легко отметить, что в большинстве случаев также присутствует сказуемое. Некоторые из них переведены довольно буквальным образом, иногда с небольшими модификациями (Там лежит Бездна, Забавный вкус у этой водьг; Oto jest otchtań, Ta woda dziwnie smakuje, Sprytne sa te demony, Przybyli skadinad, Nie każdy jest wolny). В русской версии встречается и пример антонимического перевода (Опасность не миновала). Остальные названия отличаются на уровне формы, но они все равно передают смысл подлинника, относясь к содержанию квеста (Время покажет, Все было не так, Враг не nройdem!; Dostrzec niewidoczne). Исключениями от анализируемых нами названий, содержащих сказуемое, являются примеры перевода с помощью структур, которые мы рассматривали в предыдущей части этой статьи (Nieustajace zagrożenie; Хитрые демоны; Невольники вольных).

Bring Me the Heart of Snow White - Сердие снежного виверна;

Przynieś mi serce Śnieżki;

Sit in Judgement - Cyd uдеm; Weź udziat w rozprawie;

Know Thy Enemy - Знай врага своего; Znaj swego wroga.

Есть и названия, содержащие глаголы в повелительном наклонении. Они переводятся на польский язык буквально (Przynieś mi serce Śnieżki; Znaj swego wroga) или описательно (Weź udziat w rozprawie). В русской версии лишь один пример построен аналогичным оригиналу образом (Знай врага своего). Стоит отметить, что в русском переводе названия Bring Me the Heart of Snow White имя Snow White (рус. Белоснежка, польск. Śnieżka) заменено определением вида ящероподобного животного, приобретение сердца которого является целью этого квеста. Достойным внимания является также вопрос устаревшего наполнения местоимения thy в названии квеста Know Thy Enemy, которое русский переводчик отобразил на уровне синтаксиса (Знай врага своего). Польский, в свою очередь, применил местоимение swego, характерное для высокого, литературного стиля. 
Seeing Red - В красных тонах; Wszystko na czerwono;

Weeding Out Bandits - Долой сорняки; Wyrywanie chwastów;

Throwing Away Monеy - Деньги в воду; Utopione pieniadze;

Passing Notes - Передача записей; Pożegnalne notatki.

К этой группе принадлежат также названия, компонентом которых является глагол в неличной форме, так наз. герундий. Вопрос их перевода кажется нам интересным прежде всего вследствие того, что как в русском, так и польском языках эквивалента герундию не существует. Как могло бы показаться, самой близкой ему формой является отглагольное существительное, но в переводе оно появляется лишь в одном примере (Wyrywanie chwastów). Итак, в первом названии переводчики решили подчеркнуть красный цвет, который является ключевым элементом в данном задании. Во втором - отмечаем опущенный элемент bandits. Внимание обращается на глагол weeding out, а упомянутые бандиты считаются сорняками. Суть квеста Throwing Away Money заключается в том, чтобы бросать специальные монетки в фонтан; в обоих переводах находим ссылку именно на это действие. Что касается последнего названия, наблюдаем здесь разные подходы переводчиков. Слово passing можно воспринимать либо как отглагольное существительное от передавать, либо как прилагательное, связанное с умиранием. Итак, здесь каждый переводчик выбрал другой вариант. Тем не менее, зная содержание данного квеста, оба названия подходят.

\section{Группа V}

В последнюю группу мы включили названия, содержащие предлог. Он находится либо в их начале, либо посередине. Начнем с первых:

In Hushed Whispers - По секрету; Szeptem;

In the Elements - Во власти стихий; Wśród żywiołów;

By the Grace of the Dalish - Долийское снисхождение; Z łaski

Dalijczyków;

Under Her Skin - Пристальное внимание; Zaleźć jej za skórę;

Of Somewhat Fallen Fortune - Злой рок; Los spotkat ich smutny.

Снова проявляется здесь тенденция русского переводчика передавать названия с помощью существительного и определяющего его прилагательного (Долийское снисхождение, Пристальное внимание, Злой рок). На примере двух последних названий можно заметить, что перевод не относится к оригиналу, но содержит ссылку на содержание квеста. Что касается остальных примеров, они также переведены с использованием предлогов, передавая основной смысл (По секрету, Во власти стихий). В польской версии буквально переведено одно из 
приведенных названий (Z taski Dalijczyków). Остальные из них переданы недословным образом. Из-за языковых различий они приняли форму наречия (Szeptem), содержат другой предлог (Wśród żywiołów), инфинитив (Zaleźć jej za skórę) либо глагол в личной форме (Los spotkat ich smutny). Хотим подчеркнуть особый перевод последнего примера. Касающийся его квест связан с неблагоприятным положением семьи одной из советниц главного героя. Итак, в очередной раз переводчики полностью изменили название задания, опираясь на знания о его содержании.

Someone to Lose - Ecmь кого терять; Bliska osoba; Something to Prove - Показать и доказать; Coś do udowodnienia; A Bear to Cross - Размедвеживание; Uwaga na niedźwiedzia;

Beasts at Bay - Защита om зверей; Odstraszanie dzikich zwierząt; Doom Upon All the World - Дивитесь же совериенству; Zagłada na caly świat.

Учитывая также предыдущие примеры, следует признать, что названия из этой группы являются наиболее разнообразными с точки зрения перевода. Видно здесь, что переводчики руководствовались нуждой передать смысл подлинника максимально адекватно, но также воспользовались знаниями о содержании квестов. В русской версии замечаем здесь глагольные формы (Есть кого терять, Показать и доказать, Дивитесь же совершенству), появляется также шутливый неологизм (Размедвежсиване). Название Beasts at Bay на обоих языках передает информацию о потенциальной охоте на зверей. Однако, наше удивление вызывает русский вариант последнего примера (финального квеста игры), который кажется не иметь отношения к исходному названию и не намекать на содержание задания. Что касается польской версии, то замечаем два буквальных перевода (Coś do udowodnienia, Zagłada na caly świat); остальные названия позволяют игроку догадаться, с чем связан данный квест.

Наконец, уже вне нашей категоризации, хотим обратить внимание на пример, который мы решили рассмотреть отдельно: All New, Faded for Her. Этот квест одного из спутников имеет довольно загадочное название. Как оказывается, это анаграмма от «Dread Wolf, Fen'Harel», образующая скрытую личность нашего компаньона. Переводчики не отразили этой детали в переводе, лишь отнеслись к содержанию задания. Русское соответствие это Вне родной стихии, польское Piękna, nowa Pustka (причем Pustka является неким местом в мире игры). 


\section{Итоги}

Подводя итоги, можно заметить определенные тенденции переводчиков относительно конкретных структур названий квестов. Однако, от них бывают многие исключения, поэтому здесь нет возможности четко назвать правила, которыми руководствовались переводчики в ходе перевода. Стоит подчеркнуть, что они часто пользовались знаниями о содержании того или иного квеста, которые иногда влияли на их окончательное решение. Тем не менее, следует признать, что большинство проанализированных нами названий передает смысл и информацию, содержащиеся в оригинале и хорошо вписывается в сеттинг внутриигрового мира.

\section{Summary}

The above article oscillates around the topic of translating quest names in computer games. The issue has been presented on the basis of the exemplification material taken from the computer role-playing game "Dragon Age: Inquisition". The analysis shows the Russian and Polish translators' different tendencies regarding variously constructed names of in-game missions.

\section{Литература}

Domaciuk-Czarny, I. Uwagi o nazwach własnych w tekstach gier komputerowych z gatunku fantasy. Prace Językoznawcze. 2016 (18/3), c. 19-29.

Drab, E. Gry wideo a przekład: nowe pole badań w obrębie tłumaczenia audiowizualnego. Rocznik Przekładoznawczy. 2017 (9), c. 101-114.

Inglot, K. Nazwy własne a lokalizacja gier elektronicznych fantasy - o potrzebie przekładu oraz wybranych tendencjach w tłumaczeniu gier anglojęzycznych na rynek polski i niemiecki. Homo Ludens. 2013 (5/1), c. 73-81.

Mangiron, C., O’Hagan, M. Game Localisation: Unleashing Imagination with 'Restricted' Translation. The Journal of Specialised Translation. 2006 (6), c. $10-21$.

Mäyrä, F. An Introduction to Game Studies. London: SAGE Publications, 2008. 


Simona Mizerová, Lukáš Plesník (eds.)

\section{SLAVICA IUVENUM XXII}

Sborník př́íspěvků z mezinárodní vědecké konference Slavica iuvenum 2021

Vydavatel:

Ostravská univerzita, Dvořákova 7, 70103 Ostrava

Technická redakce:

PhDr. Simona Mizerová, Ph.D.

Mgr. Lukáš Plesník, Ph.D.

Jazyková redakce:

PhDr. Simona Mizerová, Ph.D.

Mgr. Lukáš Plesník, Ph.D.

Návrh obálky:

MgA. Helena Hankeová

Vydání:

první

Místo a rok vydání:

Ostrava 2021

ISBN 978-80-7599-244-4 (print)

ISBN 978-80-7599-245-1 (online)

Informace o nabídce titulů vydaných Ostravskou univerzitou:

http://knihkupectvi.osu.cz 
Sborník SLAVICA IUVENUM XXII je publikačním výstupem z mezinárodní vědecké konference Slavica iuvenum 2021. Představený sborník prezentuje 34 vědeckých prací mladých slavistů, kterí zde publikuji dílči výstupy svého lingvistického, literárněvědného a translatologického bádání. Př́spěvky z oblasti lingvistiky jsou zastoupeny 16 odbornými články, které se mj. dotýkaji problematiky etymologie, odborné terminologie či vybraných témat morfologicko-lexikální roviny jazyka. Oblast literární vědy je představena 14 odbornými texty, z nichž některé zkoumajî konkrétní literární díla vybraných autorů, jiné se zaměřuji na literárněvědnou analýzu obecnějšího charakteru. Translatologická část sborníku je zastoupena 4 odbornými pracemi, které analyzuji problematiku překladu na základě vybraných děl nejen umělecké literatury, ale i textů virtuálního prostoru. 